\title{
CIDADES OUTRAS
}

pobreza, moradia e mediações em trajetórias urbanas liminares 



\section{CIDADES OUTRAS}

pobreza, moradia e mediações em trajetórias urbanas liminares

Tese apresentada ao Programa de Pós-Graduação em Arquitetura e Urbanismo do Instituto de Arquitetura e Urbanismo da Universidade de São Paulo, como parte dos requisitos para a obtenção do título de Doutora em Arquitetura e Urbanismo

orientação | Profa. Drä. Cibele Saliba Rizek 
AUTORIZO A REPRODUÇÃO TOTAL OU PARCIAL DESTE TRABALHO, POR QUALQUER MEIO CONVENCIONAL OU ELETRÔNICO, PARA FINS DE ESTUDO E PESQUISA, DESDE QUE CITADA A FONTE.

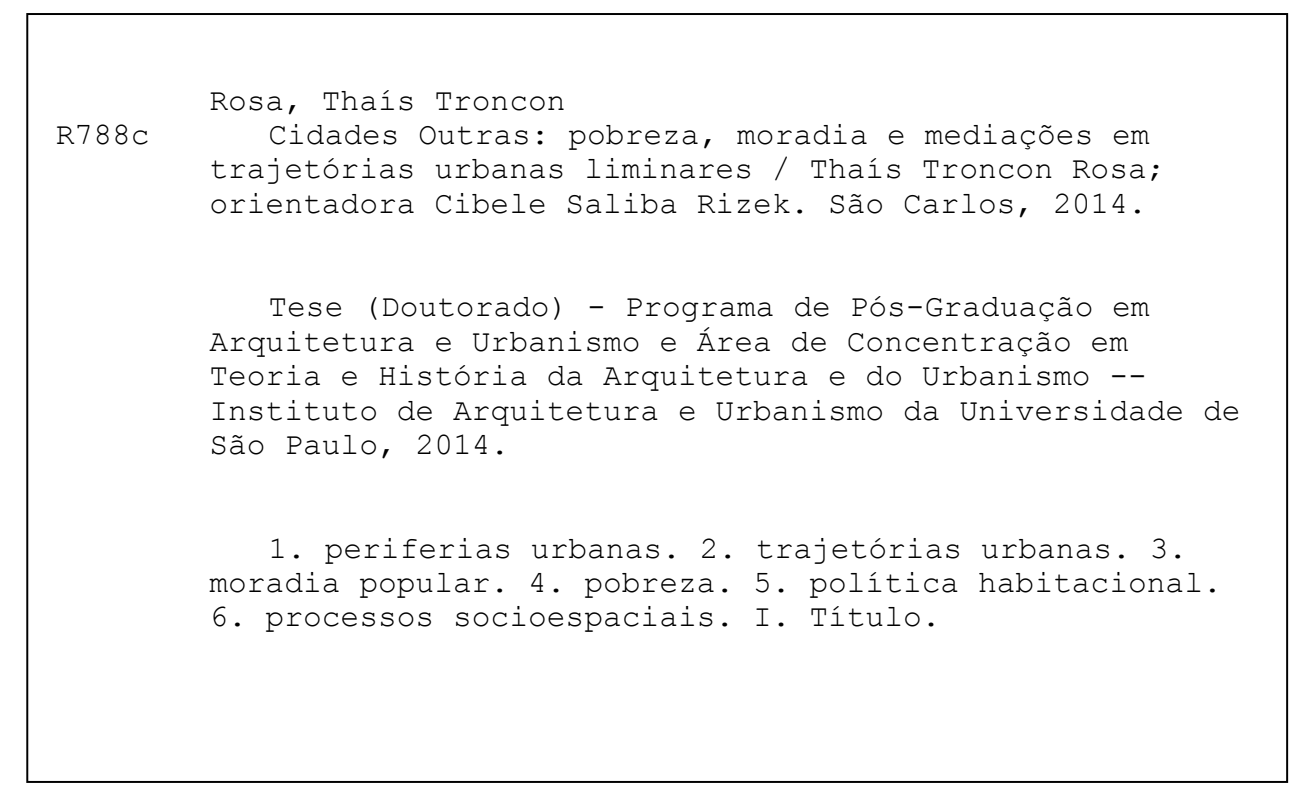




\section{FOLHA DE JULGAMENTO}

Candidata: Arquiteta e Urbanista Thais Troncon Rosa

Título da tese: "Cidades outras: pobreza, moradia e mediações em trajetórias urbanas liminares"

Data da defesa: 25/11/2014

Comissão Julgadora:

Profa. Dra. Cibele Saliba Rizek (Orientadora)

(Instituto de Arquitetura e Urbanismo - USP)

Prof. Dr. Caio Santo Amore de Carvalho

(Peabiru - Trabalhos Comunitários e Ambientais)

Profa. Dra. Mariana Cavalcanti Rocha dos Santos

(Fundação Getulio Vargas - FGV)

Profa. Dra. Isabel Pauline Hildegard Georges

(Institut de Recherche pour le Développement)

Prof. Dr. Ruy Sardinha Lopes

(Instituto de Arquitetura e Urbanismo - USP)
Resultado:

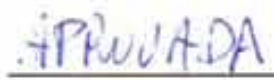

$\triangle P R O V D D \triangle$

APROVADA

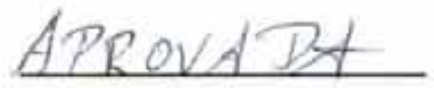

Coordenador e Presidente da Comissão de Pós-Graduação do Programa de PósGraduação em Arquitetura e Urbanismo: Prof. Dr. Márcio Minto Fabrício 
para caio e nuno, que me trouxeram outros sentidos de vida, e de cidade. para daniel, pelos mundos compartilhados, sonhados e transformados de todo dia. 



\section{agradecimentos •}

Concluindo este doutorado, faço as pazes com minha formação, minhas opções profissionais, meus rumos acadêmicos. No fim da graduação, deixei a universidade incerta de que regressaria; ansiava por experiências práticas, por um "corpo a corpo com o real". Quase quinze anos depois, tendo construído uma intensa atividade prático-profissional, passado por um enriquecedor mestrado em história, iniciado uma desafiadora atividade docente, e encerrado o percurso acadêmico e intelectual que o doutorado representa (e que se abre agora a novas possibilidades), lanço um olhar generoso à minha própria trajetória e vejo que suas várias tramas se entrelaçam na indissociabilidade entre questões sociais e urbanas que desde então já julgava importantes.

Nessa trajetória e, mais especificamente, nos últimos - e intensos - quatro anos e meio em que estive imersa nesta pesquisa de doutorado, me fiz acompanhar de pessoas que, de perto ou de longe, foram fundamentais para que esse momento, enfim, chegasse. Assim, longe de ser uma formalidade, estes agradecimentos são também um registro do percurso (entre prazeroso e sofrido) que resulta nesta tese, que, sem os tantos apoios, incentivos, ensinamentos, contribuições que recebi, certamente não teria se concretizado. É com alegria e gratidão, portanto, que encerro essa etapa e abro esta tese.

Cibele Rizek já me acompanha, ora mais próxima, ora mais distante, desde os primeiros dias no curso de arquitetura e urbanismo: devo a ela, certamente, o "olhar para o social" que desde então se fez presente em mim. Foi ela quem me ampliou as perspectivas sobre espaços, cidades, urbanidades, me mostrando seus complexos imbricamentos com as dinâmicas sociais. Sua participação em minha banca de mestrado foi decisiva para que eu decidisse regressar ao "campo da arquitetura e do urbanismo"; somente sob sua arguta orientação me seria possível empreender a experiência em que se configurou esta pesquisa. Durante estes anos de doutorado, Cibele foi, a um só tempo, orientadora e amiga; ofereceume inspiração e interlocução; acreditou em minhas ideias, em alguns momentos, mais do eu mesma, tendo paciência e delicadeza com minhas (muitas) crises de insegurança. Além de ler, questionar, comentar, criticar e elogiar tudo que escrevi, Cibele ainda me forneceu o exemplo de uma vida dedicada à universidade. Palavras são pouco para Ihe agradecer.

Ainda no mestrado, ter tido as oportunidades de ser orientada por Silvana Rubino e de estabelecer um diálogo com Heitor Frugoli Jr. foi decisivo nos rumos que este doutorado tomaria: agradeço por me abrirem os caminhos da interlocução junto à antropologia urbana, e por terem me ensinado a "prática restrita da interdisciplinaridade", nos moldes de Lepetit.

Ao lado de Cibele, outras duas pessoas foram fundamentais para que eu conseguisse delinear minhas questões de pesquisa e, principalmente, colocá-las em prática no trabalho de campo, auxiliando esta urbanista a se aventurar pela etnografia. Isabel Georges, ofereceu, com Cibele, um curso precioso no PPGAU-IAU/USP, a partir do qual nasceu uma frutífera interlocução. Seu interesse por mim, por minha pesquisa, por minhas questões foram de uma generosidade inestimável: entre cafezinhos e almoços, iluminou momentos encruados do trabalho. Agradeço ainda o convite para participar do Grupo de Estudos sobre Trabalho, Políticas Sociais, Participação e Gênero, na UFSCar. Gabriel Feltran, antes de se tornar professor e referência bibliográfica, era já um querido amigo: dessa somatória decorre o 
privilégio ímpar de não apenas ter cursado sua enriquecedora disciplina de sociologia urbana, participado dos seminários internos do Na Margem - núcleo de pesquisas urbanas, ou conseguido 'brechas' em sua disputada agenda para dialogar e me orientar sobre esta pesquisa, como também de poder "tomar cerveja com a bibliografia", falando de periferias e vendo nossas crianças brincarem juntas. Gabriel leu e comentou a estrutura prévia da tese, e me ajudou a ir mais a fundo na reflexão indutiva tão cara à perspectiva etnográfica.

Ronaldo Almeida e Ruy Sardinha Lopes compuseram a banca de qualificação, e não é exagero dizer que suas arguições - brilhantes e complementares - foram um divisor de águas na estrutura e nos rumos deste trabalho, abrindo mesmo horizontes de reflexão que vão muito além desta pesquisa. Mariana Cavalcanti e Caio Santo Amore compuseram, ao lado de Ruy, Isabel e Cibele a banca examinadora desta tese, a quem agradeço não apenas pelas leituras interessadas, pelas arguições estimulantes e pelo frutífero diálogo ali iniciado, mas também pelo privilégio de ter sido avaliada por professores cuja postura e comprometimento serão sempre exemplos daqui em diante.

A todos os colegas de pesquisa do LEAUC - Laboratório de Estudos do Ambiente Urbano Contemporâneo devo não apenas diálogos sobre meu trabalho, mas o aprendizado de debater outros temas e interesses sobre a cidade contemporânea. Destaco a amizade que o grupo fez nascer com Camila Moreno, Huana Carvalho, Maísa Fonseca e Rakel Bozza Gomes, além de Bianca Habib Silva e Magaly Pulhez, amigas também de outras paragens. Ao grupo agradeço, ainda, o suporte físico e material para a finalização da pesquisa: sem a "salinha" eu - mãe de duas crianças pequenas - não teria tido a concentração necessária para escrever boa parte desta tese. Um agradecimento especial dedico ao professor Manoel Rodrigues Alves, coordenador do grupo ao lado de Cibele, pelo acolhimento e, mais, pelo constante incentivo ao meu trabalho.

A Manoel devo, ainda, a oportunidade de realizar um estágio na ETSAS - Escuela Tecnica Superior de Arquitectura de Sevilla, junto ao grupo OUT_arquias, que me abriu horizontes acadêmicos e trouxe decisivas contribuições teórico-metodológicas à elaboração da tese. Aos professores do grupo OUT_arquias, Carlos Tapia Martín e Carmen Guerra de Hoyos, agradeço a receptividade, o apoio e a disposição em dialogar. Agradeço imensamente a Mariano Perez Humanes, querido supervisor espanhol, que em pleno fim de ano letivo se organizou para me receber, me orientar, me ensinar sobre Sevilla, me levar para visitar barriadas e viviendas de proteción social e ainda me introduzir ao delicioso caldinho de caracoles! Os meses que passei acompanhando-o em suas disciplinas também me instruíram muito sobre o ensino da arquitetura e do urbanismo, inspirando-me na minha vez de ser professora. De Sevilla agradeço, ainda, a Pepe Muñoz, anfitrião exemplar; a Glenda di Muro, compatriota que generosamente me introduziu às "situações periféricas" daquela cidade; a Maria Prieto, professora da ETSAS cuja investigação de doutorado muito me inspirou, e a quem devo uma percepção mais territorial e multiescalar de meu campo empírico; e a Santiago Cirugeda, pela disponibilidade em dialogar sobre outras arquiteturas.

Agradeço ainda aos professores e funcionários do Instituto de Arquitetura e Urbanismo, pela oportunidade do desenvolvimento desta pesquisa, pelas disciplinas cursadas que tanto me estimularam, pelo apoio técnico necessário. Registro também meu agradecimento à Capes e à Fapesp, pelos financiamentos que permitiram que eu me dedicasse profissionalmente exclusivamente a este trabalho a partir do final do primeiro ano de doutorado. 
A concretização da pesquisa de campo só foi possível porque encontrei interlocutores dispostos a dela participar, que me abriram suas casas, me receberam junto a suas famílias e vizinhanças, me permitiram conhecer suas histórias e experiências, se dispuseram a narrálas, me descortinaram 'cidades outras'. Dando-me muito mais do que eu teria a oferecer em troca, a Núbia, Jimmy, Joana, Ryan, Jefferson, Beatriz, Marielen, Jairo - e a todas as outras pessoas com as quais tive contato e que observei em campo - não tenho como agradecer, senão acreditar no estatuto político que um trabalho intelectual de viés etnográfico como este pode ter frente a sociedades e cidades tão desiguais.

Sem os parceiros e amigos, de longe e de perto, de antes e de agora, esse período teria sido mais árduo e menos prazeroso. Alguns, como Regina Oliveira e Rosamaria Giatti talvez nem tenham se dado conta do quanto, por vezes, um simples conselho, o comentário de um esboço, ou a leitura atenta de um capítulo me indicaram caminhos e reforçaram minha autoconfiança. Rosamaria é, além de amiga, parente, sendo portanto uma raridade: alguém com quem compartilho o cotidiano e o extraordinário, as agruras da vida e os ideais políticos, as fofocas e as reflexões intelectuais. Lucia Shimbo generosamente me forneceu textos e informações sobre o Programa Minha Casa Minha Vida, e me despertou a vontade de novos rumos de pesquisa.

Outros, de todo dia, para qualquer hora, que são cúmplices de vida e de trabalho, com quem compartilho incertezas e rumos, e a quem agradeço por estarem sempre por perto (mesmo quando estão longe!): Aldo Ometto, Chico Simões, Du Araújo, Lu Ceron, Mariano Maudet, Elke Cliquet, Marcelo Simões, Lis Almeida, Vivian Parreira, Juliana Pfeifer, Vânia Shwenke, Cristiana Barroso... A João Marcos Lopes devo meu 'mergulho' definitivo, há quinze anos, no universo de favelas e periferias. Magaly Pulhez se refez em presença importante no dia-adia, entre filhos, escritas e aulas, e me ofereceu ajudas cruciais na etapa de finalização da tese. Seu apoio se soma a outras três presenças femininas em minha vida, sem as quais eu teria certamente desabado neste último ano: Bianca Habib, Manuela Souza e Renata Peres. Amigas de uma vida, sem o suporte físico e afetivo dessas mulheres eu, mãe de duas crianças pequenas, finalizando a tese e iniciando uma atividade docente, jamais teria chegado até aqui. A todas elas agradeço pelo inestimável apoio e carinho com as crianças, e mais: a Manu, pelas palavras sempre carinhosas e animadoras, pela comida deliciosa e pelas festas que renovaram minha energia nesse período; a Bianca por seu apoio inconteste, por nossa afinidade que tanto me alimenta e, como se não bastasse, por ter ainda feito os mapas que acompanham a tese; a Re, pela história que construímos juntas e que nossos filhos seguem construindo, por nunca me deixar cair, por infinitas vezes me fazer recobrar a autoconfiança e por me aguentar, durante esse último ano, falando quase que exclusivamente da tese.

Agradeço também à nova geração da Teia - casa de criação, organização que me orgulho muito de ter fundado e que foi crucial em minha formação profissional, e da qual pude me afastar sem dor, na certeza da continuidade - ainda que por outros rumos - do trabalho ali desenvolvido.

Como não poderia deixar de ser, registro aqui minha imensa gratidão aos professores e funcionários da Creche e Pré-escola USP - São Carlos: a entrada de meus filhos nessa escola incrivel foi das grandes oportunidades que este doutorado me brindou, não apenas porque, com isso, eu pude trabalhar tranquila, mas principalmente porque em nenhuma outra escola da cidade eles teriam a formação e o afeto que ali lhes foi oferecido. 
Agradeço, ainda, à Ju Santos por topar cuidar das crianças quando comecei a dar aulas à noite, e por tornar essa ausência mais fácil para eles; e à Lu Silva por ser minha fiel escudeira em casa, pelo cuidado com minha família e pelo exemplo de vida que me dá.

A Nadya e Lumumba, talvez não fossem necessárias palavras, mas faço questão de registrálas: obrigada por ajudarem a me reencontrar com o sagrado do mundo, e por cuidarem de mim, independente da distância física.

Chegando ao fim desta longa seção, a imensa gratidão aos familiares, que tanto sentiram o impacto deste último ano imersa na tese. Aos meus sogros Marli e Afonso agradeço o acolhimento, o carinho, o incentivo; agradeço ainda às tantas vezes que cuidaram de meus pequenos, para a "mamãe poder trabalhar". À Marli devo, ainda, um agradecimento mais que especial: afinal, que outra sogra se disporia a passar um mês fora do país, para que a nora pudesse manter os planos de realização do estágio-sanduíche, porque o marido teria um compromisso profissional no primeiro mês da viagem?

A meus pais, Sergio e Maria Inês, tanto já agradeci, tanto tenho ainda a agradecer! Pela vida, pelo exemplo, pela liberdade, pelas oportunidades; por ser quem sou, por ter sempre com quem contar, pelo amor incondicional que dedicam a mim e a meus filhos. Por entenderem minhas ausências, por me acalentarem em minhas crises, por me socorrerem com as crianças. Por acreditarem no meu trabalho, mesmo nem sempre entendendo meus caminhos e escolhas e, mais, por me apoiarem também nisso: mãe, obrigada pelas horas dedicadas à revisão a um só tempo primorosa e respeitosa desta tese! Às minhas irmãs Sílvia e Flávia agradeço por, mesmo distantes fisicamente, serem sempre parte do que sou, e estarem sempre na torcida.

Aos amores da minha vida, a quem dediquei esta tese: Daniel, companheiro de uma vida, Caio e Nuno, nossos filhos, só vocês sabem o quão sofrido foi chegar até aqui. As palavras não dão conta de expressar toda a gratidão que sinto por vocês, e talvez diminuam a imensidão do que fizeram por mim nesse período, e que fazem todos os dias. A Daniel agradeço, acima de tudo, por me fazer ir até o fim neste percurso, e não desistir de me acompanhar mesmo nos períodos mais cinzentos. Agradeço ainda por ter cuidado das coisas da vida e do cotidiano e, principalmente, das crianças nos últimos tempos, deixando de lado suas próprias atividades profissionais e pessoais para que eu pudesse concluir a tese. Sei bem o quanto são raros os companheiros que se dispõem a isso, e isso me faz te admirar ainda mais. Pela vida, pela casa e pelos sonhos compartilhados, e pela possibilidade de sempre recomeçarmos. E, como se fosse pouco, ainda há mais: pelas estimulantes reflexões, por ser meu leitor e crítico, pelas tantas sugestões e incentivos a este trabalho, que carrega, também parte dos ideais que desde sempre nos uniram.

Caio, Nuno: quando penso em vocês, nesse momento, lágrimas me caem dos olhos... Nestes anos do doutorado, Caio deixou de ser bebê e se tornou um pequeno-grande companheiro; Nuno nasceu e me inundou de ainda mais amor, completando nossa família. Só nós sabemos o quanto minhas ausências, nesses últimos meses, nos custaram... Agradeço a vocês por terem esperado (nem sempre pacientemente!) a mamãe finalmente terminar "esse doutorado", que vocês tanto queriam saber o que era: Caio estava, já, em contagem regressiva para a entrega! Agradeço pelos sorrisos, carinhos, abraços e beijinhos quando eu mais precisava... pelas brincadeiras fora de hora, que me traziam de volta à vida nos períodos mais desgastantes. Agradeço, enfim, por existirem: vocês dão um sentido maior a este trabalho, às minhas perspectivas, à minha vida. 
Claro calar sobre uma cidade sem ruínas

(Ruinogramas) | Paulo Leminski

\author{
Em Brasilia, admirei. \\ Não a niemeyer lei, \\ a vida das pessoas \\ penetrando nos esquemas \\ como a tinta sangue \\ no mata borrão, \\ crescendo o vermelho gente, \\ entre pedra e pedra, \\ pela terra a dentro. \\ Em Brasília, admirei. \\ $O$ pequeno restaurante clandestino, \\ criminoso por estar \\ fora da quadra permitida. \\ Sim, Brasilia. \\ Admirei o tempo \\ que já cobre de anos \\ tuas impecáveis matemáticas. \\ Adeus, Cidade. \\ O erro, claro, não a lei. \\ Muito me admirastes, \\ muito te admirei.
}





\section{resumo}

ROSA, Thaís Troncon. Cidades outras: pobreza, moradia e mediações em trajetórias urbanas liminares. Tese de doutorado. São Carlos: Instituto de Arquitetura e Urbanismo - USP, 2014.

Inserindo-se nos debates sobre pobreza e cidade no Brasil, a pesquisa aborda os nexos entre deslocamentos habitacionais, mobilidades socioespaciais, dinâmicas familiares e políticas urbanas nos processos recentes de produção do espaço urbano. A tese parte do argumento de que, em um contexto de reconfiguração do mundo social e ressignificação das categorias fundadoras dos territórios periféricos, em curso no país nas últimas décadas, também o espaço urbano se reconfigura: nesse sentido, direciona-se a refletir, de modo articulado, sobre as dimensões sociais e territoriais dessas mudanças e permanências. Tomando como base a realização de uma pesquisa de campo de caráter etnográfico na cidade de São Carlos - SP, são investigadas trajetórias urbanas de moradores de periferias que, nas últimas décadas, transitaram pela cidade em busca de moradia, bem como os cruzamentos, tangenciamentos ou desencontros com as políticas urbanas e habitacionais empreendidas nesse mesmo período. Tais trajetórias são encaradas como uma entrada privilegiada para o estudo das dinâmicas socioespaciais envolvidas em processos situados de produção, apropriação e significação das periferias urbanas, ao permitir apreender tais processos nas injunções entre espaço e sociedade. A tese delineia uma cartografia espaço-temporal de territorialidades e experiências urbanas ditas marginais ou periféricas, revelando cidades outras: cidades feitas de desenraizamentos, vulnerabilidades e ajustes, mas também de relações, simbolizações e projetos, cuja multiplicidade de dimensões históricas, concepções em ato ou devires possíveis somente se dão a apreender a partir das práticas e narrativas dos sujeitos. Estabelece, assim, um diálogo sobre as dobras que configuram, simultaneamente, territórios, subjetividades e sensibilidades; percursos, narrativas e espaços; pobreza, experiência urbana e cidades; produção de conhecimento e produção do espaço.

Palavras-chave: periferias urbanas, trajetórias urbanas, moradia popular, pobreza, política habitacional, processos socioespaciais 



\section{abstract .}

ROSA, Thaís Troncon. Other cities: poverty, housing and mediations in liminar urban trajectories. Tese de doutorado. São Carlos: Instituto de Arquitetura e Urbanismo - USP, 2014.

Being inserted in debates about poverty and cities in Brazil, the research deals with the links among housing displacements, socio-spatial mobility, family dynamics and urban policies in recent processes of urban space production. The dissertation starts from the argument that, in the context of reconfiguration of the social world and re-signification of the founding categories of surrounding territories, in progress in the country in recent decades, the urban space is also reconfigured: in this sense, it is directed to reflect, in an articulated way, about social and territorial dimensions of these changes and continuities. Based on the completion of an ethnographic field research in the city of São Carlos - SP, it investigates urban trajectories of residents of surrounding areas who, over the last decades, passed through the city in search of housing, as well as the crossings, tangents or divergences with the urban and housing policies undertaken during the same period. Such trajectories are faced as a prime input for the study of socio-spatial dynamics involved in situated processes of production, appropriation and significance of urban surrounding areas, while allowing for apprehending such processes in the injunctions between space and society. The dissertation outlines a spatio-temporal cartography of urban territorialities and experiences considered marginal or peripheral, revealing other cities: cities made out of uprooting, vulnerabilities and adjustments, but also of relationships, symbolizations and projects, whose multiplicity of historical dimensions, conceptions in act or possible future ones, take place just to be apprehended as from the practices and narratives of the subjects. A dialogue is thus established on the folds that simultaneously shape territories, subjectivities and sensibilities; pathways, narratives and spaces; poverty, urban experience and cities; production of knowledge and production of space.

Key words: urban surrounding areas, urban trajectory, affordable housing, poverty, housing policy, socio-spatial processes. 



\section{OS MEANDROS DO ACESSO À MORADIA: redes, mercados, políticas}

Casa de patroas, vida de aluguel, coabitação: moradia e gênero, primeiro ato $\mathbf{5 1}$

Anos 1990: ocupações como condição de permanência no centro $\quad 63$

Uma trégua na praga de cigano: a fixação em uma ocupação periférica $\quad 75$

De lugar tranquilo a lugar pesado: novas dinâmicas socioespaciais $\quad 83$

Uma (breve) aproximação à moradia como direito $\quad 91$

De volta à vida de aluguel, nas fronteiras da cidade $\quad 106$

$\begin{array}{ll}\text { Políticas habitacionais (e sua reconversão em mercado popular) } & 123\end{array}$

[ENTREMEIO I] Política habitacional e mercado imobiliário informal: 137 imbricamentos

\section{NOVAS POBREZAS, NOVAS PERIFERIAS?}

Dinâmicas familiares e deslocamentos habitacionais até a conquista da "casa própria"

Parque Novo Mundo e Jardim Zavaglia: novos territórios tão próximos e tão distantes

Processos movediços: entre fixação e novos deslocamentos

[ENTREMEIO II] O urbano em ato: territorialização da pobreza e produção de uma 'centralidade periférica'

\section{PARA ALÉM DA MORADIA E DA POBREZA: vulnerabilidades territorializadas}

Deslocamentos habitacionais: moradia e gênero, segundo ato

Uma experiência urbana entre a fixação espacial e os trânsitos sociais

Dinâmicas socioespaciais fronteiriças: mediações de uma mãe de bandido

Saberes e lógicas territoriais

A casa manjada e as reconfigurações na relação com o bairro

[ENTREMEIO III] Expansão urbana, classificações socioespaciais e linhas de clivagens nos territórios populares 

Cada aldeia, vila ou cidade não é somente um lugar no espaço, mas um drama no tempo. | Patrick Geddes 



\title{
INTRODUÇÃO .
}

\begin{abstract}
Seria então necessário recuperar como alvo e objeto de reflexão e como possibilidade de pensar e nomear os territórios do indeterminado, da suspensão, da hesitação, do tatear, contra as classificações apressadas. Recuperar a possibilidade de pensar devagar, pela prática do desvio, sem os resultados rápidos da linha reta, do dado objetivo, das contagens, das categorias e das taxonomias. Pensar reconhecendo a concretude irredutível das coisas e dos corpos. | Cibele Rizek
\end{abstract}

Esta pesquisa trata de cidades ${ }^{1}$, ainda que seu campo empírico tenha se concentrado em uma única cidade, tal como se cristaliza em unidades territoriais, governamentais ou conceituais. Uma questão de fundo, quase filosófica, a orienta: o que é 'a cidade' 2 ? De que é feita, por quem e para quem e, principalmente, como se faz ou se deixa fazer? ${ }^{3}$

Tal questionamento decorre de um olhar para a cidade a partir de suas margens ${ }^{4}$, anterior e fundador de toda minha trajetória como urbanista e pesquisadora: refletir

1 Vale remeter, aqui, à feliz abordagem de Fortuna e Leite (2009:7 - grifos no original): "Plural de cidade são as cidades que existem dentro da cidade. Não é um conjunto diverso de cidades, nem uma questão de geografia. Plural de cidade são os territórios díspares que fazem a cidade, as políticas sóciourbanas e a sua ausência, o atropelo aos direitos e as paisagens de privilégio, as formas de segregação e ostentação, a cultura, a saúde, o emprego, o dinheiro, o futuro e, ao mesmo tempo, a falta de todos eles. Plural de cidade é a conjugação destas cidades numa só. E em todas elas."

2 Ao longo da tese, serão utilizados os seguintes critérios gráficos: termos ou expressões êmicas serão indicados em itálicos; quando se tratar da reprodução de um trecho mais longo no corpo do texto, este constará ainda entre aspas. Palavras, expressões ou citações entre aspas e não em itálicos referem-se a conceitos, categorias, fontes bibliográficas ou outras fontes documentais escritas (jornais, atas etc) e virão acompanhadas das respectivas referências. Palavras ou expressões minhas, sem grifo especial e entre aspas simples, indicam destaque, problematização, coloquialidade, suspeita ou ironia.

3 Questões que me levaram às reflexões de Agier (1999, 2011). Para uma abordagem do pensamento filosófico sobre as cidades, ver Ansay (1998). Questionamento semelhante, de certa forma, acompanhou minha formação em arquitetura e urbanismo e meu mestrado em história (Rosa, 2008), desde então atenta às relações imbricadas entre espaço e sociedade, a outros aspectos do espaço urbano que não somente os físicos, às relações estabelecidas - não sem conflitos - entre "teorias" e "técnicas" de produção desse espaço e as práticas e sociabilidades que o constroem, experienciam e disputam cotidianamente.

4 Agier (2011); Telles (2013). Esta pesquisa pensa a noção de "margens" com Das e Poole (2008), Perlongher (1987), Feltran et al (2011), Cunha e Feltran (2013), para citar algumas abordagens de referência. A retomada contemporânea da noção de "margens" para pensar as periferias urbanas (ou, de um modo mais amplo, as "situações periféricas" urbanas, como propõem Almeida et al, 2009) distancia-se em tudo daquela articulação entre a "teoria da marginalidade social" (Quijano, 1973) e a ideia de uma "cultura da pobreza" (Lewis,1959) a partir da qual se fizeram as primeiras reflexões acadêmicas sobre as favelas no Brasil, em que tais espaços foram interpretados como a mais típica manifestação da não-integração de amplos segmentos da sociedade urbana (Vekemans e Venegas, 
sobre os espaços de moradia dos pobres nas cidades foi mote de pesquisas de iniciação científica, aprimoramento e mestrado, além de toda uma atuação profissional extra-acadêmica. Os fenômenos urbanos denominados "favelas" e "periferias" estiveram no centro dessas investigações e atuações, dentre as quais a formulação analítica mais acabada se deu quando da produção de minha dissertação de mestrado, não por acaso realizada em um programa de pós-graduação em história, pois que se propunha a refletir sobre tais fenômenos a partir da consideração da historicidade que seria própria à produção e à apropriação processual de seus espaços. ${ }^{5}$

Ancorada na crítica à perspectiva totalizante de "cidade"6 que orientaria as concepções originárias - e seus desdobramentos contemporâneos - de "favela" e "periferia" e as abordagens dicotômicas sobre as cidades dela decorrentes (calcadas

1966). Em sentido contrário, tais reflexões contemporâneas recusam-se a pensar as margens na chave da "ausência" ou da "exclusão", pensando-as relacionalmente: as "franjas" (sociais, urbanas) são encaradas em sua relação intrínseca com o "centro" (Feltran et al, 2011:6), são os "supostos necessários" do estado (Das \& Poole, 2008:20), da sociedade, da cidade.

5 Rosa (2008). A pesquisa enfocou a trajetória do espaço urbano conhecido como Gonzaga, em São Carlos - SP, perscrutando os tortuosos caminhos da produção e apropriação desse espaço, que se origina como uma pequena ocupação irregular de terra, em meio a loteamentos de periferia, na década de 1970; adensa-se progressivamente e passa a ser representado socialmente como uma "favela" (Favela do Gonzaga), configurando-se como o principal "problema social e urbano" da cidade, na década de 1980; após uma série de intervenções públicas (ora pontuais, ora remocionistas, ora urbanizadoras) transforma-se oficialmente em um "bairro de periferia" (Jardim Gonzaga), na década de 1990 - o que não o impediria de dar lugar a novos núcleos favelizados e tornar-se regionalmente representado como um dos redutos do tráfico de drogas e da violência na cidade; e, nos anos 2000, torna-se alvo, mais uma vez, de uma ampla e modelar intervenção urbanizadora.

6 Trata-se de questionar uma abordagem essencialista da cidade, na qual o conceito se apresenta como universal, naturalizado, e tudo o que escapa de ser englobado por ele configura-se em seu avesso, ou sua ausência. Evitando partir de "totalidades inacessíveis de um ponto de vista empírico a 'grande cidade', o 'urbano global', a 'metrópole', a 'urbanização desterritorializada'" (Cordeiro e Frugoli, 2011:19), o esforço intelectual daí decorrente se faz, entretanto, no sentido de não deslizar para uma perspectiva fragmentária, da cidade como "mosaico", ou reduzida a "localismos", como alerta Smith (2002). Refletindo sobre o espaço geográfico de forma mais ampla, o autor, partindo da crítica a uma abordagem da diferença como totalidade (que se reduziria à "diversidade") e dialogando com a proposição de Lefevbre da cidade como "espaço das diferenças", conduz a reflexão em termos de uma concepção relacional do espaço (aí incluída a cidade), a partir de uma concepção também relacional das escalas espaciais. Tal concepção será retomada adiante. Alerta semelhante faz Magnani (2002:19, 20): "renunciar a esse tipo de totalidade não significa embarcar no extremo oposto: um mergulho na fragmentação. Se não se pode delimitar uma única ordem, isso não significa que não há nenhuma; há ordenamentos particularizados, setorizados; há ordenamentos, regularidades." O autor, discorrendo sobre algumas características da "totalidade como pressuposto da etnografia", aponta que "uma totalidade consistente em termos da etnografia é aquela que, experimentada e reconhecida pelos atores sociais, é identificada pelo investigador, podendo ser descrita em seus aspectos categoriais: para os primeiros, é o contexto da experiência; para o segundo, chave de inteligibilidade e princípio explicativo. Posto que não se pode contar com uma totalidade dada a priori, postula-se uma a ser construída a partir da experiência dos atores e com a ajuda de hipóteses de trabalho e escolhas teóricas, como condição para que se possa dizer algo mais que generalidades a respeito do objeto de estudo." 
em categorias como "cidade informal" ou "cidade ilegal")7, os questionamentos despertados por tal trilha investigativa foram também o ponto de partida do projeto inicial desta pesquisa de doutorado 8 :

Ao delimitar teoricamente fronteiras demasiado rígidas entre duas formas de produção da cidade - uma "formal", legalizada e exposta à sociedade e outra "informal", "ilegal" e, no mais das vezes, considerada "periférica" - tais abordagens não deixariam escapar a complexidade de relações que caracterizam, na prática, tais fronteiras? Em que medida as abordagens dicotômicas sobre os espaços de moradia dos pobres têm dado conta de apreender a diversidade de contextos urbanos no país (para além das metrópoles) e a crescente diferenciação dos espaços de moradia dos pobres nesses contextos? Seria possível superar essas dualidades através das quais os espaços de moradia dos pobres nas cidades foram lidos durante décadas? De que forma e até onde seria possível desconstruí-las?

Acima de tudo, havia - e ainda há - a crítica à perspectiva etnocêntrica, que encara tais configurações urbanas exclusivamente pela chave da "ausência" e que culminaria em proclamá-las "o avesso da cidade".

Mas, afinal, que cidade é essa que não estaria presente nos inúmeros espaços de moradia dos pobres? Não seria a mesma cidade que os produz e que é também produzida por eles? E o que dizer da enorme parcela da sociedade que vive nesses espaços, das práticas, relações, disputas que os produzem e lhes dão sentido cotidianamente? Não seriam estes outros aspectos a serem considerados como forma - sim - de produção da cidade?

Munido desses questionamentos, o projeto de pesquisa de doutorado tencionava inserir-se nos debates contemporâneos sobre pobreza e produção do espaço urbano no Brasil ${ }^{9}$. Tais debates dão conta do quanto as mudanças em curso na economia e na sociedade, desde pelo menos o final dos anos 1980 e intensificadas a partir da segunda metade dos anos 1990, vêm desestruturando o "diagrama de relações" entre trabalho, cidade e política, a partir do qual se formularam as reflexões pioneiras sobre a "questão urbana" no Brasil ${ }^{10}$, embaralhando os pares conceituais que a pautavam e evidenciando uma "ampliada e crescente zona de indiferenciação entre o lícito e o ilícito, o direito e o não-direito, entre o público e o privado, a norma e a exceção". Nesse contexto, diversos autores chamavam a atenção para a necessidade

7 Desenvolvi reflexão aprofundada sobre tais questões, que não caberia retomar aqui, em Rosa (2008, 2009).

8 As duas próximas citações foram extraídas do projeto de pesquisa que originou a presente tese.

9 Tais debates emergiram no país nos anos 1970, tendo por referência paradigmática o trabalho de Oliveira (1972), que influenciou significativamente os estudos subsequentes sobre pobreza e espaço urbano, introduzindo no debate as noções de periferia e de urbanização periférica. Destacam-se alguns trabalhos pioneiros, como: Kowarick e Brant (1975); Sampaio e Lemos (1978); Kowarik (1979); Bonduki e Rolnik (1979); Maricato (1979); Valladares (1980), entre outros, muitos deles levados a cabo por toda uma geração de arquitetos e urbanistas.

10 Rizek (2003). 
de se apreenderem as "realidades urbanas em mutação", uma vez que, a despeito da inegável existência das desigualdades e diferenças e de seu significativo aumento nos últimos anos, já há algum tempo elas vêm se condensando em espaços múltiplos, redesenhados a partir de práticas, circuitos e relações que não cabem "nas dualidades supostas nos estudos anteriores" ${ }^{\prime 11}$.

Em especial a partir dos anos 2000, uma gama diversificada de trabalhos passou a introduzir questionamentos àquelas explicações gerais sobre "a crise urbana", bem como às definições categoriais de "pobreza", "exclusão" ou "segregação". Desde então, esforços de reinterpretação dos espaços de moradia dos pobres nas cidades vêm sendo empreendidos, mobilizando e articulando disciplinas, fontes, métodos os mais variados. Se, por um lado, reatam-se criticamente fios das importantes abordagens produzidas nas décadas de 1970 e 80, por outro, busca-se construir novos parâmetros do debate sobre esses fenômenos urbanos. ${ }^{12}$

Contudo, nesse contexto de renovação acadêmica sobre a questão urbana brasileira, tendo como foco privilegiado de atenção os fenômenos urbanos das favelas e periferias, instigava-me a ainda pouca atenção destinada a apreender tais processos para além dos circuitos metropolitanos. Acreditando ser premente a necessidade de introduzir maior capacidade comparativa aos debates em curso, propus direcionar (novamente) meu olhar para a cidade de São Carlos - SP, enquanto campo ampliado da pesquisa empírica. A intenção, então, era produzir uma reflexão em termos de 'contextos urbanos não metropolitanos'.

Assim, o objetivo geral da pesquisa foi formulado: investigar, a título de hipótese, os nexos entre mobilidades socioespaciais, deslocamentos habitacionais, dinâmicas familiares e políticas urbanas nos processos de produção e apropriação dos espaços de moradia dos pobres em contextos urbanos não-metropolitanos.

\section{O projeto propôs, ainda, como objetivos específicos:}

- Identificar e investigar trajetórias urbanas de famílias em situação de pobreza que, nas últimas décadas, venham transitando pela cidade de São Carlos - SP em busca de moradia, procurando apreender as diversas dinâmicas - locais e extralocais, conjunturais e estruturais - envolvidas nesses trânsitos. Pretendia, assim, reconstruir

11 Telles (2006:49, 53, 61).

12 No primeiro capítulo de minha dissertação de mestrado (Rosa, 2008), bem como em alguns artigos (Rosa, 2006, 2009), desenvolvi revisões bibliográficas, percorrendo, de forma panorâmica, alguns dos caminhos tomados pelos estudos de favelas e periferias urbanas no Brasil, desde sua 'descoberta' social e acadêmica até a primeira metade dos anos 2000: a intenção foi recuperar alguns dos principais debates sobre tais fenômenos no âmbito dos estudos urbanos, desde sua construção enquanto problemas sociais, categorias, campos ou objetos de estudos. Para outras excelentes revisões e reflexões sobre tal produção, remeto a Frugoli (2005); Telles (2006); Marques e Torres (2005). 
histórias dos processos de produção dos espaços de moradia dos pobres nesta cidade, buscando compreendê-los a partir das práticas espaciais de seus agentes e das disputas que elas engendram;

- Verificar a articulação entre as dinâmicas socioespaciais apreendidas por meio das trajetórias e as políticas urbanas e habitacionais empreendidas na cidade de São Carlos (ou a ausência delas) nas últimas décadas ${ }^{13}$, procurando desvelar as relações estabelecidas entre moradores e poderes públicos, perscrutar os modos como tais relações foram, ao longo do tempo, constituindo espacialidades e, ainda, examinar os processos enfocados a partir das conexões que simultaneamente atualizam e transcendem o seu caráter local;

- Reconhecer e analisar modulações específicas das configurações socioespaciais denominadas genericamente "favela", "periferia", "cidade ilegal”, "cidade informal", bem como singularidades dos processos de produção dos espaços de moradia dos pobres em contextos urbanos não-metropolitanos, como o de São Carlos. Ao buscar compreender a produção de tais espaços para além dos circuitos metropolitanos, objetivava, ainda, produzir novas referências empíricas e analíticas acerca dos constructos de conceituação, categorização e representação social dos mesmos.

De modo geral, os objetivos da pesquisa se mantiveram, com algumas alterações mais significativas referentes ao delineamento do campo empírico-analítico em termos de "espaços de moradia dos pobres" e "contextos urbanos nãometropolitanos". De fato, tais categorias, essencialmente descritivas, foram adotadas na elaboração do projeto visando justamente a escapar às categorizações a priori, que poderiam obscurecer a construção de meu objeto de pesquisa, como, por exemplo, as noções de "periferia" e de "cidades médias". Mesmo considerando que também as categorias adotadas pudessem ter problemas, a necessidade de circunscrever, em palavras, os fenômenos e contextos urbanos a serem investigados levou a tais opções descritivas: uma escolha, portanto, e nada fortuita.

No entanto, como conceitos e categorias não são inócuos e, levados a sério, dialogam continuamente com a empiria e instruem as construções analíticas dela decorrentes, as questões suscitadas pelo campo da pesquisa passaram a inquirir tais noções ${ }^{14}$, não em caráter meramente retórico, mas justamente em seu potencial analítico.

13 O recorte temporal definido, então, para precisar a intersecção entre objeto, campo e método de pesquisa considerou o período entre as décadas de 1970 e 2010, ou seja, desde o "boom" de reprodução do dito "padrão periférico de produção do espaço urbano" para as cidades do interior do estado de São Paulo (Devescovi, 1987; Fernandes, 2004; Rosa, 2007), como é o caso de São Carlos, até os dias atuais.

14 Cf. Veyne (1998:11): "a experiência mostra que a indiferença pela discussão sobre termos é, frequentemente, acompanhada por uma confusão de ideias sobre a própria coisa". 
Comecemos com a expressão "espaços de moradia dos pobres" (a qual se relacionava diretamente com a nomeação dos sujeitos da pesquisa como famílias ou indivíduos "em situação de pobreza"). A inserção em campo - e, a partir dele, o diálogo com a literatura - despertaram muitos questionamentos acerca da concepção mesma de "pobreza"15, tanto em termos das inúmeras transformações nos marcadores e limiares que a definiam, a partir dos anos 2000, com as gestões do Partido dos Trabalhadores no governo federal e as políticas sociais e "de combate à pobreza" então implementadas, quanto em termos da orientação metodológica da pesquisa, que pressupunha extrair do próprio campo certas definições e conceituações: de pobres mesmo a classe média, passando por menos favorecidos, mais carentes ou classe média baixa, meus interlocutores se veem de formas bastante distintas em termos da hierarquia social. E, além do mais, tal hierarquia, desde o ponto de vista deles, demonstrou ser nem um pouco estática e possuir gradações bastante sutis ${ }^{16}$. Tais alterações da "pobreza" - e suas nomeações - estão conectadas às já mencionadas transformações sociais, econômicas e políticas ocorridas nas últimas

15 Embora já fosse alvo de reflexões e análises científicas sistematizadas desde o século XIX, o século $X X$ verá proliferar uma multiplicidade de abordagens sobre a pobreza (de sua conceituação à sua mensuração), seja pela generalização do fenômeno, seja por sua associação aos processos de urbanização dos então "países subdesenvolvidos" (Santos, 2009). A partir da década de 1970, terão início tentativas de universalização do conceito, em especial por organismos multilaterais como a ONU ou a OIT, tendo em vista a formulação de "políticas de erradicação" (Rocha, 2010). Dentre a multiplicidade de estudos sobre a questão da pobreza no país, destaco os de Telles (2001) e Ivo (2001; 2003; 2008).

16 Em diálogo com Ivo (2008:107), para quem noções como pobreza, desigualdades, exclusão e vulnerabilidade social "impõem normas de percepção do próprio objeto, em seu processo de apropriação, que se inscrevem como realidade, conformando a prática dos sujeitos sociais", depreende-se que as formas de nomeação dos "pobres" estão imbricadas, em grande medida, às formas como estes sujeitos também acabam se vendo/representando/diferenciando, e que orientam projetos de mobilidade socioespacial, elaboração de fronteiras simbólicas e linhas de clivagem internas, e produção de sentidos sobre a cidade, como veremos. De fato, quando recorri aos meus interlocutores, minha visão era homogeneizada sob uma ideia genérica de "pobreza", e o que encontrei em campo, em grande medida, foi uma situação não apenas muito diferente do que eu imaginava, mas, sobretudo, do que eles já viveram um dia, em um passado não tão distante. Mesmo os que se definiam como pobres não se viam como completamente destituídos, particularmente numa perspectiva comparada com seu próprio passado, ou o de sua família, ou o de seus supostamente iguais - havia, quase sempre, uma ideia e um horizonte de melhoria nessas autorrepresentações (tema a que retornarei e que dialoga com reflexões de Cavalcanti, 2007, 2009). Nesse sentido, e tendo em conta o vasto debate nas Ciências Sociais sobre tal questão (dentre os trabalhos me vali, especialmente, dos de Paoli e Sader, 1986; Paoli, Sader e Telles, 1983; Zaluar, 1985; Ivo, 2008; Duarte e Gomes; 2008), optei pelo uso da noção de "camadas populares", considerando tanto a heterogeneidade da pobreza (e de suas nomeações), como a inegável constatação de uma experiência urbana comum a uma vasta camada da sociedade brasileira, cujo "campo de possibilidades" (Velho, 1987; 1994) não se configura da mesma forma que para as "camadas médias" e "altas" (também heterogêneas), e que se encontra submetida - ainda que, em alguns casos, mais, em outros, menos ao que Kowarick denominou "vulnerabilidades socioeconômicas e civis" (ver nota 20). 
décadas no país, e ecoam com cada vez mais força nas figurações públicas (aí incluídas também muitas representações 'nativas') das camadas populares, as quais têm se pautado, a um só tempo, pela exacerbação de sua criminalização e pela saudação de sua financeirização: a emergência da "classe C", ou "nova classe média"17, representaria, mesmo, "os efeitos positivos do desenvolvimento econômico e da consolidação institucional do país"18. Há, portanto, toda uma reconfiguração das desigualdades, nesse contexto de "heterogeneidade da pobreza", que se tornam ainda menos legíveis: a pobreza, hoje, sobretudo mediante a popularização do crédito (e a consequente desvinculação entre consumo e renda), está no cerne da "cultura do novo capitalismo"19 e, no jogo das visibilidades e invisibilidades a que sempre esteve condicionada, a face de sua mercantilização e financeirização se sobrepõe, cada vez mais em tais figurações públicas, à de sua vulnerabilidade. ${ }^{20}$

Sem a pretensão de aprofundar-se nos meandros das discussões teóricas e conceituais acerca das "novas pobrezas" ou da "nova classe média"21, um dos motes desta pesquisa foi justamente pensar todas essas mudanças também em termos do espaço urbano, de modo a articular as reflexões sobre os horizontes sociais e territoriais das camadas populares no país. Sendo assim, optou-se pela retomada da concepção de "periferias", no plural, de modo a circunscrever os meandros socioespaciais das trajetórias urbanas de meus interlocutores no que têm de regularidade e multiplicidade, considerando a inteligibilidade proporcionada pela

17 Neri (2008, 2011). Conforme apontam Feltran et al (2011:11): “Dos últimos quarenta anos, vivemos na segunda metade dos anos 2000 o período de maior expectativa de ascensão social entre os trabalhadores pobres urbanos. A década atual se inicia em plena marcha dessa esperança (a de um Brasil sem pobreza, conforme o slogan oficial)".

18 Feltran et al (2011:11).

19 Sennet (2006).

20 As reflexões propostas na tese ancoram-se na concepção ampliada de "vulnerabilidades socioeconômicas e civis", tal como proposta por Kowarick (2009:19): "Refere-se à situação de desproteção a que vastas camadas pobres encontram-se submetidas no que concerne às garantias de trabalho, saúde, saneamento, educação e outros componentes que caracterizam os direitos sociais básicos de cidadania. Entre eles, destaca-se a questão habitacional, que não pode ser reduzida apenas à qualidade da moradia, aspecto importante, mas não único, pois implica também a sua localização e os serviços existentes no bairro em que se localiza. (...) Esse é o lado socioeconômico da vulnerabilidade. O outro lado, a vulnerabilidade civil, refere-se à integridade física das pessoas, ou seja, ao fato de vastos segmentos da população estarem desprotegidos da violência praticada por bandidos e pela polícia".

21 O que, por si só, daria uma outra tese (como a que vem sendo empreendida de forma bastante instigante por Kopper, 2014) e para o que remeto a trabalhos contemporâneos que vêm debatendo a (polêmica) questão: além do já mencionado estudo de Neri $(2008,2011)$, responsável, em grande medida, por cunhar e popularizar a expressão, destaco, em especial, as abordagens críticas que então se seguiram, como as de Pochman $(2012,2014)$ ou as de Souza $(2009,2010)$. 
recorrência de tal concepção tanto na literatura, quanto nas narrativas dos sujeitos, ainda que não unívoca em seus significados ${ }^{22}$.

Em se tratando das reflexões sobre favelas e periferias urbanas no Brasil, desde sua emergência como questão a instruir os estudos urbanos no país, já na década de 197023 , até a já mencionada renovação analítica da questão urbana brasileira (na qual tais fenômenos urbanos têm lugar de destaque) promovida no fim dos anos $1990 \mathrm{e}$ início dos anos $2000^{24}$, a bibliografia é vasta e vem sendo alvo de leituras e sistematizações desde meu mestrado. Há, ainda, uma bibliografia bastante recente e diversa, resultado de uma apuração coletiva desse processo de renovação, com a qual me mantive permanentemente em contato. ${ }^{25}$

Considerando-se a vasta gama de estudos produzidos até o início dos anos 1990 cujos enfoques perpassavam questões como migração, família operária,

22 Tendo em vista que a definição de "pobreza" tem se tornado tão ou mais complexa do que a própria noção de "periferia" e, tomando em conta que tenho procurado inferir conceitos e categorias da empiria, não há porque fugir desta última noção, que se mostrou, no correr da pesquisa, a mais adequada (ou menos inadequada), ainda que eu continue reconhecendo todos os problemas aí enfrentados (em especial sua concepção dicotômica em relação ao "centro", ou à "cidade", como já mencionado; mas, também, as já clássicas concepções da periferia como "expressão territorial" seja das desigualdades, seja do "modo de vida" das populações pobres; e, sobretudo, aquela mais recente, que a lê como mera territorialização da criminalidade violenta: todas elas remetendo, de alguma forma, a uma série de estigmas socioespaciais). Admitindo a polissemia da noção, atesto, com Birman (2013:7) - em prefácio à coletânea de artigos organizada por Cunha e Feltran (2013), intitulada "Sobre Periferias" - o "desafio de tratar de 'periferias', considerando os lugares construídos como 'periféricos', mas sem buscar fixá-los a priori (por meio de atributos sociais, pelo estatuto de seus habitantes ou outros exames que desconsideram as formas variadas de inserção nesses espaços)", ao que eu acrescentaria, também, as formas variadas de produção e apropriação dos mesmos. Destacando o processo coletivo, em curso, de "elaboração rica de um campo analítico, cuja complexidade se deve ao reconhecimento de que as fronteiras das periferias estão longe de se constituírem por coordenadas somente ou primordialmente espaciais", a autora evoca (em diálogo com os artigos da coletânea) a já mencionada noção de "margens", enfatizando que estas podem ser "políticas, religiosas, sociais, administrativas, culturais - sem que se recubram de forma a criar espaços fixos, homogêneos, unificados e submetidos às mesmas clivagens".

23 Cf. trabalhos pioneiros produzidos na década de 1970, destacados à nota 9. Já nos anos 1980, predominariam os trabalhos produzidos no âmbito da antropologia - como os de Caldeira (1984), Magnani (1984), Zaluar (1985), Durham (1986), Sarti (1985), entre outros. Mais ao final da década de 1980, serão produzidos diversos trabalhos gerados por uma maior aproximação entre a sociologia urbana e a ciência política, decorrente da emergência de novos atores políticos que se faziam ver através das "lutas urbanas", dentre os quais destaca-se o trabalho fundamental de Sader (1988).

24 Veja-se, por exemplo: Marques e Bichir (2001; 2001a); Torres e Marques (2001); Lago (2003); Valladares (2005); Preteceille e Valladares (2000; 1999); Taschner (2002); Torres et al (2003); Saraiva e Marques (2004); Caldeira (2000); Kowarick (2002); Ferreira (2003); Telles e Cabannes (2006); Hirata (2005); Silva (2006); Feltran (2005); Freire (2005); Piccolo (2006); Rizek (2006); Cavalcanti (2007); Pandolfi e Grynzpan (2003); Zaluar e Alvito (2003); Zaluar (2004); Rosa (2006); Misse (2006); Abramo (2003).

25 Veja-se, por exemplo: Feltran (2008; 2010; 2011); Feltran e Cunha (2013); Telles (2009a, 2009b, 2010); Kowarick (2009); Kessler e Telles (2010); Hirata (2010); Cavalcanti (2008; 2010); Biondi (2010); Lyra (2010); Rizek (2010); Rosa (2008, 2009); Abramo (2009); Almeida et al (2009); Cabanes et al (2011); Cunha e Feltran (2013); Ivo (2010), para citar apenas alguns. 
autoconstrução, "sonho da casa própria", loteamentos clandestinos, seguidos depois pela abordagem dos processos de politização da pobreza e dos movimentos sociais e aqueles decorrentes dos deslocamentos ocorridos desde então - os quais, a partir dos anos 2000, vêm refletindo sobre as novas tramas da articulação entre cidade, moradia e trabalho e apontando para a "ressignificação recente das categorias fundadoras do território [periférico], como família, trabalho, religião e projeto de ascensão social”26, as quais coexistem com a presença do tráfico de drogas ilícitas e da "sociabilidade violenta"27, além das inúmeras estratégias políticas de gestão da pobreza urbana -, há todo um referencial bibliográfico de peso, com o qual a pesquisa empírica dialogou permanentemente.

Evidencia-se, na visão de conjunto dessa literatura, um percurso que contempla quatro décadas de transformações profundas nas dinâmicas socioespaciais das periferias urbanas brasileiras, bem como a guinada necessária àqueles que se propõem ao seu estudo ainda hoje:

Para o analista das periferias, migra-se de um ambiente em que se encontrava um padrão estável de organização (familiar, social e político, centrado no projeto operário e em seus desdobramentos diretos) para uma experiência social em que esse padrão, em crise, cede espaço e coexiste, às vezes na mesma casa, com alternativas de vida muito mais individualizadas e heterogêneas. Os parâmetros de análise também são forçados a se deslocar, dadas as transformações. Não é à toa que, no período recente, há tantas tentativas renovadas de interpretação das periferias urbanas. (Feltran, 2011:34)

E se há toda essa reconfiguração do mundo social e ressignificação das categorias fundadoras dos territórios periféricos, argumenta-se que também o espaço urbano se altera, a partir de dinâmicas socioespaciais novas e velhas, persistentes ou reconfiguradas: nesse contexto, um dos enfoques aqui propostos direciona-se a pensar, de modo articulado, as dimensões sociais e territoriais dessas mudanças e permanências; em outras palavras (mais afeitas ao linguajar urbanístico ou geográfico), pensar suas dimensões espacializadas a partir da relação entre formas e conteúdos das periferias urbanas.

No que tange à noção de "contextos urbanos não-metropolitanos", devo dizer que se trata de uma espécie de 'calo' em minha trajetória de pesquisadora formada e atuante fora dos circuitos metropolitanos. Já há algum tempo tenho me dedicado a refletir sobre os efeitos que o foco quase que exclusivo dos estudos urbanos nas

26 Cf. Feltran (2011:19).

27 Machado da Silva (2008). 
grandes metrópoles (em especial São Paulo e Rio de Janeiro), mais especificamente aqueles centrados nos fenômenos das favelas e periferias, poderia ter sobre a construção da chamada "questão urbana" brasileira: tendo em vista a multiplicidade de contextos urbanos no país, em grande medida aqueles - os não-metropolitanos acabariam por permanecer invisibilizados nos debates acadêmicos, ou tornar-se objetos de estudos a reboque das referências metropolitanas, reproduzindo suas categorias e matrizes explicativas. A importância de se ampliarem e diversificarem tais estudos para além das metrópoles tornou-se praticamente uma 'bandeira' acadêmica: parecia-me imperativa a necessidade de apreender as semelhanças e diferenças entre as lógicas de produção dos espaços de moradia dos pobres nesses variados contextos e, em consequência, ampliar o panorama empírico, teórico e conceitual sobre esses fenômenos urbanos no país, evitando tipificá-los ou esvaziálos de seus significados.

Tendo essa 'bandeira' em conta ao propor o projeto de pesquisa de doutorado, a questão do campo ampliado a ser enfocado empiricamente - no caso, São Carlos/SP - trazia consigo a dificuldade de nomeá-lo, já que não se pretendia incorporar nomeações aprioristicamente vinculadas a uma escala populacional ou territorial como "cidades médias" ou "cidades de porte médio", ambas objeto de intensos debates nos campos da economia, demografia e geografia28. A opção por "contextos urbanos não-metropolitanos" decorreu da intenção de diferenciá-lo, descritivamente, tanto dessas categorias quanto dos contextos metropolitanos. Entretanto, desde o início, tal nomeação causou desconforto, fosse pela reposição do caráter 'etnocêntrico' que ela carrega, mantendo a "metrópole" como contraponto em negativo, fosse pela dificuldade em encontrar interlocuções com outras abordagens no âmbito dos estudos urbanos, já que a quase totalidade dos estudos produzidos fora dos circuitos metropolitanos remetem à categoria "cidades médias" 29 (e uma minoria a "cidades do interior", que também é pouco elucidativa, considerando-se que, no interior do Estado de São Paulo, também há regiões metropolitanas).

Se tal desconforto já existia antes da incursão ao campo da pesquisa, pouco tempo depois dela iniciada, os próprios achados de campo me conduziram a rever tal abordagem: de um lado, não haveria por que evitar a noção mesma de cidade, uma

28 Veja-se, por exemplo: Sposito et al (2006); Sposito (2007); Araújo et al (2010). Segundo Sposito (2004), o conceito de "cidades médias" estaria diretamente relacionado ao tamanho demográfico das cidades, enquanto o conceito de "cidades de porte médio" diria respeito, de forma mais específica, às cidades que "além de terem tamanho demográfico correspondente a este porte, desempenham claros papéis intermediários entre a(s) metrópole(s) e as cidades pequenas que compõem uma rede urbana".

29 É o caso, por exemplo, dos estudos articulados em torno da RECIME - Rede de Pesquisadores sobre Cidades Médias (www.recime.org - último acesso em julho de 2014). 
vez que, como apontado no início deste texto, é justamente em torno dessa noção que se originam minhas questões de pesquisa; acima de tudo, as trajetórias urbanas perscrutadas nesta pesquisa evocam indubitavelmente cidades, que adquiriram centralidade nas reflexões desenvolvidas na tese. De outro, aquela construção pela negação parecia entrar em choque já com os primeiros achados da pesquisa: entre a esperada apreensão de modulações específicas e singularidades dos espaços periféricos de uma cidade como São Carlos e a inevitável constatação da conexão e regularidade de diversos aspectos desses espaços e suas dinâmicas socioespaciais em relação a processos ampliados identificados pioneiramente nas periferias metropolitanas (e não apenas no Brasil) há todo um leque de mediações e matizes que se faz necessário compreender e que decorre do tipo de olhar lançado aos próprios campo e objeto de pesquisa.

Não é que não se trate de uma questão de escala; porém, ao propor investigar processos, trajetórias, fluxos e deslocamentos urbanos, fez-se necessário trabalhar a partir da perspectiva de sua variação. A escala urbana importa, mas de maneira relacional e não etnocêntrica (metrópole/não-metrópole ou cidades médias) - a pesquisa trata de cidades, sem adjetivações a priori. A busca por modulações situacionais persistiu, mas também conduziu a abordagens multiescalares. Nesse sentido, inferiu-se, a partir do diálogo com os dados empíricos, que a escala urbana poderia ser pensada em dois vieses: na perspectiva do sujeito e da experiência urbana do deslocamento, essa escala parece fazer toda diferença; já na perspectiva das dimensões estruturantes que atravessam a produção do espaço urbano e suas configurações periféricas, talvez não o faça tanto. E por aí poderíamos prosseguir, como num atravessar de espelhos: da perspectiva ampliada das políticas públicas (em especial as urbanas e habitacionais) tal escala é praticamente ignorada (visto que quase sempre se pautam efetivamente pelas metrópoles); já nas formas de tratamento local dessas dimensões estruturantes, nas práticas municipalizadas de regulação estatal, nas formas cotidianas de gestão propriamente dita, a escala faz novamente diferença.

A variação de escala é aqui considerada, portanto, uma operação analítica, que pressupõe um "jogo de escalas" para além de uma taxonomia do urbano. $E$, nessa perspectiva, dialogamos com Revel (1998) e Lepetit (2001) ${ }^{30}$, além de Smith (2002),

30 A questão da mudança de escala também é objeto de profícua reflexão de historiadores: considerada, sobretudo, como recurso de conhecimento, ela implica não apenas o aumento ou diminuição do objeto a ser estudado, mas principalmente o alcance de aspectos e variáveis que se dariam a ver. Vejam-se, por exemplo, as abordagens de Revel (1998:20): “variar a objetiva não significa apenas aumentar (ou diminuir) o tamanho do objeto no visor, significa modificar sua forma e sua trama"; Lepetit (2001:225, 226): "Esse movimento, de aproximação ou de distanciamento regular, sem solução de continuidade, não tem por efeito apenas fazer passar do grande ao pequeno ou vice-versa numa série contínua. A acomodação progressiva da óptica revela elementos que não são homólogos, 
para quem a escala é um processo ativo: "os diferentes processos sociais estão envolvidos na mediação e construção de escalas diferentes da atividade social". O vínculo entre relações de escala (e seus processos de construção social) e relações de poder é recorrente nas reflexões de tais autores, os quais invocam a desnaturalização da escala e a incorporação de uma perspectiva crítica sobre ela nos estudos urbanos $^{31}$.

Em abordagem sobre a questão da variação de escala no estudo do urbano pelo viés histórico, Lepetit (2001:137) propõe que se considerem, ainda, as relações entre escalas de tempo e espaço nas cidades, analisando seu desenvolvimento a partir das "interações entre a escala microscópica dos comportamentos individuais e a escala macroscópica das configurações urbanas, entre a dinâmica veloz da conjuntura e a dinâmica lenta das estruturas". A presente pesquisa aponta para temporalidades e espacialidades distintas em um mesmo objeto, a partir de um mesmo campo, complexificando ainda mais qualquer tentativa de circunscrevê-las em uma cidade tipológica ou escalarmente definida.

Dessa perspectiva, argumento que pensar as periferias é, portanto, pensar as cidades $^{32}$, e São Carlos, mais do que uma abstração escalar e categorial, é o posto de observação de onde as relações, processos e trânsitos são observados, atentando para o que têm de "local" e de "global" e, mais, encarando como procedimento relevante de conhecimento a própria classificação das mediações entre o local e o global. ${ }^{33}$

A proposta metodológica de seguir etnograficamente trajetórias urbanas, apresentada em mais detalhes em seção seguinte desta Introdução, mostrou-se

mas cuja natureza difere: o jardim é sucessivamente, à medida que dele nos aproximamos, parreiral, cacho, bago de uva etc."; ou Levi (1998:203): "Escolher uma escala de observação significa escolher um instrumento analítico que não é neutro, (...) a escala dos fenômenos não está inscrita na realidade. A escala não é um dado preestabelecido, mas resulta de uma escolha estratégica que envolve a própria significação da pesquisa: o que vemos é aquilo que escolhemos fazer ver".

31 Cf. Smith (2002:141): "Las diferentes sociedades no sólo producen el espacio, como Lefebvre nos ha enseñado, ellas también producen la escala. La producción de la escala puede ser la diferenciación más elemental del espacio geográfico y es en toda su extensión un proceso social. No hay nada ontologicamente dado sobre la división tradicional entre hogar y localidad, escala urbana y regional, nacional y global. La diferenciación de las escalas geográficas establece y se establece a través de la estrutura geográfica de interacciones sociales. Con un concepto de escala como producido, es posible evitar por una parte el relativismo que trata la diferenciación espacial como un mosaico, y por outra evita la reificación y la acrítica división de escalas que reitera un fetichismo del espacio."

32 São inspiração nesse sentido as abordagens de Das e Poole $(2004,2008)$; Das $(1999,2007,2011)$; Agier (2011); Telles (2006; 2013).

33 Cf. Marcus (2001:116): “Un diseño de investigación basado en yuxtaposiciones, en cual lo global se colapsa en, y es vuelto parte integral de, situaciones locales paralelas y vinculadas entre si, más que como algo monolítico o externo a ellas." Inevitável estabelecer, neste ponto, conexões com as abordagens de Lefevbre $(1974,2008)$ sobre a "ordem próxima" e a "ordem distante". 
bastante profícua no sentido de permitir flagrar essa transitividade, essa translocalidade, e desestabilizar distinções (e as fronteiras delas decorrentes) préestabelecidas entre "localidades" e "sistema mundo", nos termos de Marcus $(2001)^{34}$.

Considera-se que as trajetórias urbanas permitem apreender os pontos de inflexão da produção do espaço e da experiência urbana recente; situá-los pressupõe "reter a cidade como plano de referência" - não como 'cenário' ou 'reflexo', mas evidenciando dimensões, a um só tempo, de sua história urbana e das "linhas de atualidade" que colocam as questões observadas em São Carlos em diálogo com os processos em curso no mundo contemporâneo, "trabalhando as transversalidades e ressonâncias de uma experiência que faz da cidade, efetivamente, um campo de batalha, mas também um campo de experimentação histórica na qual estamos todos envolvidos". ${ }^{35}$

\title{
- Trajetórias urbanas: aproximações teórico-metodológicas
}

\author{
"Não sou eu que mudo a história, é a história que muda todo dia". Assim Marielen 36 , \\ procurou justificar, quase sem graça, o fato de que, a cada nosso novo encontro de \\ pesquisa, a narrativa recente de sua trajetória e de sua família se alterava: nesse \\ momento, o envolvimento de seu filho mais velho com o mundo do crime foi \\ identificado por ela como o elemento central a operar essa transformação cotidiana \\ nos planos, rumos e certezas de suas trajetórias urbanas e nas narrativas sobre ela.
}

34 O autor aponta a "etnografia móvil" como uma ainda emergente modalidade que, ao passo que "investiga y construye etnograficamente los mundos de vida de vários sujetos situados, también construye etnograficamente aspectos del sistema en sí mismo, a través de conexiones y asociaciones que aparecen sugeridas em las localidades." Ao sustentar que qualquer etnografia de uma formação cultural inserida no "sistema mundo" é também uma etnografia do próprio sistema, destaca que: "Para a etnografia, entonces, no existe lo global en el contraste local-global tan frecuentemente evocado em estos tempos. Lo global es una dimensión emergente en la discusión sobre la conexión entre lugares en la etnografia multilocal". (Marcus, 2001:112, 113)

35 Telles (2013:359,371).

36 Os nomes de todos os sujeitos da pesquisa, bem como de pessoas por eles referidas, foram alterados, na tentativa de preservar sua identidade. Ainda restam, entretanto, "dilemas éticos e políticos da etnografia 'em casa'”, na esteira das reflexões desenvolvidas por Fonseca (2005), tendo em vista que não alterei os nomes de bairros, por exemplo, e exponho informações que podem oferecer algum risco aos informantes: "todos nós reconhecemos que o uso de nomes fictícios não garante o anonimato aos informantes. Justamente porque a descrição densa depende da riqueza dos detalhes contextuais - tanto do local, quanto do indivíduo - não é difícil para qualquer pessoa próxima aos nossos sites etnográficos reconhecer cada personagem, que seja nomeado ou não. (Posso mudar o nome oficial do bairro, mas não vou deixar fora o apelido que é tão pertinente ao meu texto e à própria visão do mundo dos moradores: a 'Vila do Cachorro Sentado', por exemplo, ou o 'Morro das Guampas'). O pesquisador anda numa corda bamba, procurando garantir a riqueza de detalhes que mantém fidelidade ao texto etnográfico, ao mesmo tempo que exerce uma vigilância constante aos limites éticos de sua ousadia." 
Entretanto, esta seria apenas mais uma dentre muitas. Mobilidade, instabilidade, deslocamento: assim se trama, em grande medida, a cidade de Marielen e, nela, sua própria história. E sua justificativa envergonhada, se levada a sério, pode ser o fio condutor de um emaranhado socioespacial tecido cotidianamente nas cidades, fornecendo pistas importantes dos modos como espaços, trajetórias, narrativas e experiências urbanas se constituem mutua e dinamicamente.

Estruturando-se como uma exploração etnográfica a partir de encontros com integrantes de famílias moradoras atualmente das chamadas periferias de São Carlos, a pesquisa propôs apreender o espaço urbano a partir de trajetórias urbanas e suas narrativas, em diálogo com a ideia de uma "cidade transumante", como delineada por Michel de Certeau (2003). Também em diálogo com este autor, a ideia de trajetória é aqui acionada como um "movimento temporal no espaço"37: as trajetórias urbanas, por sua vez, "supõem uma espacialização demarcada pelas temporalidades urbanas corporificadas nos espaços e territórios da cidade", conforme proposição de Telles (2006a:70).

A condensação de práticas espaciais cotidianas ${ }^{38}$ dos indivíduos e de suas famílias, as quais se constituem tanto por meio do diálogo permanente entre passado e presente, como por justaposição das dimensões qualitativamente heterogêneas de tempo e espaço (Certeau, 2003), seria uma das dimensões essenciais das trajetórias urbanas, cuja persecução, tal como proposta por Telles $(2006,2006 a)$ e adotada nesta pesquisa, invoca percursos habitacionais e ocupacionais, além dos deslocamentos cotidianos que se realizam no espaço urbano. Trata-se, portanto, de uma abordagem que possibilita uma mudança na escala de compreensão das já bastante debatidas relações entre pobreza e espaço urbano no Brasil, a qual se distancia de designações genéricas para se aproximar dos fluxos, dos trânsitos e, fundamentalmente, das narrativas que produzem não configurações urbanas à parte da cidade, senão a própria cidade.

E, se a articulação entre temporalidades (tempos biográficos, geracionais, sociais e históricos) e espacialidades (marcos espaciais, referências urbanas, pontos de condensação dos deslocamentos) é constitutiva da análise de trajetórias urbanas, um terceiro aspecto se entrelaça a elas e faz-se crucial para a abordagem adotada pela pesquisa: os "eventos políticos" que as atravessam (políticas urbanas, programas habitacionais, conflitos sociais, formas de ação coletiva, práticas de tutelagem), ao operarem como vetores concretos na produção do espaço urbano. E aqui vale

37 Certeau (2003:98).

38 Certeau (2003). Para o autor, “as práticas do espaço tecem, com efeito, as condições determinantes da vida social” (p.175). 
registrar a formulação completa de Telles (2006a), fundamental para a orientação da presente pesquisa:

Poderíamos, então, dizer que as mobilidades urbanas são demarcadas e compassadas por eventos atravessados por três linhas de intensidade. A linha vertical das cronologias, em que os tempos biográficos se sucedem em compasso com o tempo social-histórico. No âmbito interno das famílias, a sucessão das gerações com suas linhas de continuidade e rupturas, heranças familiares transmitidas, redefinidas ou reinterpretadas conforme mudanças nos agenciamentos cotidianos e nas hierarquias internas. A linha horizontal das espacialidades, em que os tempos se efetuam: as práticas urbanas deixam suas marcas no espaço e estas se objetivam, ganham forma e constroem referências que permitem entrecruzamentos com outras histórias, outros percursos, outros eventos que pontilham a história urbana - não a linha das filiações familiares, mas a das comunicações transversais que fazem conexões com outros pontos de referência do social (e da cidade). Atravessando tudo isso em uma linha perpendicular, os eventos políticos que ganham forma e também operam como referências práticas que compõem os territórios urbanos: a cronologia dos investimentos públicos, os descaminhos da moradia popular, os conflitos sociais e suas derivações, práticas de tutelagem e clientelismo, que vêm de muito tempo e persistem entrelaçadas com as mediações democráticas de representação política, formas de ação coletiva e de solidariedade, que se alimentam de fontes diversas e também vêm de tempos diferentes, aberturas e retrocessos políticos que se sucedem aos calendários eleitorais. Eventos e situações que podem ser tomados como vetores que conectam espaços e territórios com os tempos políticos da cidade. (Telles, 2006a:70,71)

Nessa perspectiva, as dinâmicas de produção do espaço urbano se fazem ver por meio das trajetórias urbanas: do cruzamento entre elas, de seus múltiplos pontos de conexão e condensação é possível apreender os sujeitos em jogo nas disputas pelo espaço e suas representações, suas variadas posições e deslocamentos ${ }^{39}$, as temporalidades urbanas coexistentes, as tramas relacionais de caráter e extensão variada. Trata-se, além do mais, de por meio delas acessar a "experiência espacial" 40 dos sujeitos da pesquisa, perscrutando como os sucessivos deslocamentos e as

39 Bourdieu (1998:189), em crítica à abordagem biográfica como sucessão longitudinal e coerente de acontecimentos, invoca, como contraponto, a noção de trajetória "como série de posições sucessivamente ocupadas por um mesmo agente (ou um mesmo grupo) num espaço que é ele próprio um devir, estando sujeito a incessantes transformações". Por sua vez, algumas críticas à tal perspectiva questionam o fato de que, para o autor, o que interessaria apreender sociologicamente sobre um indivíduo seria tão somente seu deslocamento no espaço social, nas estruturas objetivas, desconsiderando aspectos subjetivos e, principalmente, o lugar das temporalidades em tal deslocamento (Kofes, 2004). Em Grafmeyer (1995), as noções de biografia e trajetória são reaproximadas, uma vez que, conforme apresenta Frúgoli (2009:61), o autor propõe a primeira "não apenas como sucessão regrada de posições ao longo da vida, mas um mapeamento das rupturas nos pertencimentos, das reorganizações nas atitudes e comportamentos e das mudanças de espaço da vida, levando, por conseguinte, a trajetórias situadas simultaneamente no tempo e no espaço - esse último, simultaneamente registro particular da vida social, mediação e unidade de observação."

40 Merleau-Ponty (1999). Sem intenção prévia de aprofundar-me nas dimensões fenomenológicas sobre o espaço, acerquei-me delas através das proposições de Certeau (2003) e Lindón (2005; 2006). 
experiências de constantemente refazer relações e espacialidades cotidianas vão dar sentido a escolhas e modos de apreender e vivenciar a cidade, o bairro, a casa. Que cidades se delineiam a partir desse enfoque?

Por meio das trajetórias urbanas nos aproximamos, portanto, da ideia de um "espaço praticado", tal como proposto por Michel de Certeau. Distinguindo "cidade", enquanto conceito normativo, da "vida urbana" propriamente dita, a qual se constitui a partir de "práticas de espaço", Certeau (2003:172) irá relacionar tais práticas a uma ideia de "mobilidade opaca e cega" que seria constituinte da "cidade habitada": o autor a define como uma "cidade transumante", a se insinuar cotidianamente em meio à "cidade planejada e visível". Essa ideia de mobilidade, de transumância inerente às práticas de espaço é o que interessa aqui apreender, uma vez que se vincula à ideia de percursos urbanos e suas enunciações ("enunciações pedestres") e conforma as relações entre o que Certeau denomina "lugar" e "espaço".

Sem avançar muito nessa distinção promovida pelo autor, caberia ao menos apresentá-la, destacando a profunda correlação entre sua concepção de espaço e a perspectiva das trajetórias urbanas. Para Certeau, "lugar" associa-se à ideia de estabilidade, de imobilidade, de ordem, de propriedade, de hierarquia, de poder; já o "espaço" seria caracterizado pela mobilidade, pela ação, pela multiplicidade de possibilidades que abarca - "um lugar praticado".

Existe espaço sempre que se tomam em conta vetores de direção, quantidades de velocidade e a variável tempo. $O$ espaço é um cruzamento de móveis. É de certo modo animado pelo conjunto de movimentos que aí se desdobram. Espaço é o efeito produzido pelas operações que o orientam, o circunstanciam, o temporalizam e o levam a funcionar em unidade polivalente de programas conflituais ou de proximidades contratuais. (...) Diversamente do lugar, não tem portanto nem a univocidade nem a estabilidade de um "próprio". (Certeau, 2003:202)

A memória seria um elemento fundamental na relação entre espaços e lugares, efetuando um trabalho constante de transformação de lugares em espaços e viceversa. Os espaços - lugares vividos - são vistos por Certeau como "presenças de ausências": por meio da lembrança, movimento de passagem da memória, conferem ao visível sua "invisível identidade". A memória funciona aí como um elo de comunicação - mas não necessariamente de continuidade - entre distintas temporalidades e espacialidades, uma "prática significante" dos lugares, "prática 
inventora de espaços", trazendo à tona suas "simbolizações enquistadas na dor ou no prazer do corpo". ${ }^{41}$

Entretanto, para Certeau, a memória, essa "arte de lembrar", é indissociável de uma "arte de dizer" - o relato, um discurso que é memória e prática simultaneamente, produto de trocas sutis entre as "astúcias da história vivida" e aquelas da "história narrada". Mais do que fixar uma realidade pela descrição, o relato cria, fabrica, funda outros tempos e espaços. Configura-se como "um gesto equilibrista em que participam a circunstância (lugar e tempo) e o próprio locutor, uma maneira de saber, manipular, arranjar e 'colocar' um dito deslocando um conjunto". 42

Assim, os movimentos-deslocamentos-caminhos-percursos, entendidos como "ações de sujeitos históricos", seriam responsáveis pela constituição de espaços: "parece que um movimento sempre condiciona a produção de um espaço e o associa a uma história". De fato, para o autor, ainda que os percursos não sejam passíveis de fixação, eles produziriam o efeito de espacializar, de "fazer efetivamente a cidade". Isso se daria a partir da associação entre os percursos - "práticas de espaço" - e o que denomina "relatos de espaço", uma perspectiva que valoriza a descrição da cidade como "fundadora de espaços", trazendo à tona a relação entre tais práticas de espaço e a "ordem construída". ${ }^{43}$

Os relatos seriam, portanto, mais do que uma das condições essenciais de apreensão das trajetórias - são a própria "feitura dos espaços" por onde as trajetórias fluem e se condensam: "os relatos cotidianos contam aquilo que, apesar de tudo, se pode aí fabricar e fazer". Essa indissociabilidade entre percurso e relato vincula-se à ideia mesma de um "espaço praticado", um espaço topológico, o qual pressupõe, por seu caráter relacional e móvel, a articulação com os tempos urbanos e os corpos (em movimento) dos atores, que delimitam e organizam espaços: trata-se, segundo o autor, da "inscrição do corpo no texto da ordem". ${ }^{44}$

A errância, multiplicada e reunida pela cidade, faz dela uma imensa experiência social de privação de lugar - uma experiência, é verdade, esfarelada em deportações inumeráveis e ínfimas (deslocamentos e caminhadas), compensada pelas relações e os cruzamentos desses êxodos que se entrelaçam, criando um tecido urbano, e posta sob o signo do que deveria ser, enfim, o lugar, mas é apenas um nome, a Cidade. (Certeau, 2003:183)

41 Certeau (2003: 189).

42 Certeau (2003: 153).

43 Certeau (2003:203, 207).

44 Certeau (2003: 215-217). 
Tais abordagens dialogam diretamente com a proposta de Telles e Cabanes (2006:15) de encarar as trajetórias urbanas como trilhas que permitem descrever a cidade: "Ao seguir os traçados dos percursos urbanos de indivíduos e suas famílias, é a própria cidade que vai se perfilando."

As inflexões de tais fluxos e mobilidades no tempo e no espaço traduziriam, na escala dos destinos individuais, a dinâmica mais ampla dos destinos sociais e transformações urbanas. É no diálogo com tal proposta que as abordagens de Certeau acerca da distinção entre lugares e espaços, da articulação entre percurso e relato e, principalmente, da persistente conformação da cidade transumante - uma cidade feita de deslocamentos e ausências, mas também de relações e conexões fundamentais - podem ser úteis para apreender as múltiplas dimensões, em relações de força e tensão, presentes em tais trajetórias.

Ao articular espaços e tempos urbanos diferenciados, as abordagens centradas em "formas de mobilidade"45 - fluxos migratórios, deslocamentos habitacionais, percursos ocupacionais, trânsitos cotidianos de indivíduos e suas famílias pela cidade - estariam se configurando, tal como aponta Telles (2006:63), como perspectiva renovada aos pesquisadores urbanos, em especial aqueles inseridos nos já mencionados debates sobre pobreza e espaço urbano, uma vez que a atenção aos trânsitos sociais e espaciais das camadas populares na cidade permitiria captar a complexidade das novas realidades urbanas, bem como os deslocamentos, processos e práticas dos sujeitos, superando muitas das limitações de noções, categorias e parâmetros estabelecidos para medir e caracterizar a segregação urbana.

\section{- Trajetórias e cartografias: dinâmicas de produção e apreensão do espaço urbano}

Em se tratando do trabalho com trajetórias urbanas de moradores de periferias, tais abordagens se mostraram muito profícuas no sentido de possibilitar cartografar (espacial e temporalmente) experiências urbanas ditas "marginais"46 ou "periféricas"47, revelando 'cidades outras': cidades feitas de deslocamentos, desenraizamentos, ajustes e ausências, mas também de relações, mediações, projetos e afetos, cuja multiplicidade de dimensões históricas, concepções em ato ou devires possíveis somente se dão a apreender a partir das narrativas dos sujeitos.

As trajetórias urbanas foram encaradas como uma entrada privilegiada para o estudo das dinâmicas socioespaciais envolvidas em processos situados de produção, apropriação e significação dos espaços de moradia das camadas populares, objeto

\footnotetext{
45 Grafmeyer (1995).

46 Feltran et al (2012).

47 Almeida et al (2009).
} 
dinâmico de estudo, ao permitir apreender tais processos para além das associações imediatas entre espaço e sociedade ${ }^{48}$, trazendo à tona a via de mão dupla pela qual os fluxos urbanos estruturam trajetórias de vida, mas também o próprio espaço da cidade (e vice-versa). Tratou-se, portanto, de construir estratégias metodológicas centradas nesses fluxos, nos trânsitos urbanos, e a exploração etnográfica demonstrou grande potencial no estudo de tais deslocamentos ${ }^{49}$.

Para a apreensão das trajetórias urbanas em toda sua complexidade, a pesquisa de campo, de caráter qualitativo e com preocupação descritiva, ancorou-se em procedimentos já consagrados em etnografias urbanas ${ }^{50}$, privilegiando a realização de entrevistas semiestruturadas (e sua combinação com entrevistas abertas e conversas informais), além de visitas de observação reflexiva de atividades cotidianas, bem como coleta de documentação de interesse da pesquisa. Explorouse, ainda, o acompanhamento de alguns deslocamentos (cotidianos, mas não somente) dos interlocutores pela cidade. A elaboração de um caderno de campo foi valorizada como técnica de pesquisa e prática reflexiva imprescindível para os objetivos pretendidos ${ }^{51}$ : mais do que mera ferramenta de coleta e registro, o caderno

48 Lepetit (2001).

49 Veja-se, nesse sentido, os trabalhos de Cunha (2002); Ferreira (2003); Telles e Cabanes (2006); Silva (2006a) e Feltran (2011).

50 Destaco, aqui, o diálogo com a proposição de Magnani $(2002: 15,16,18,25)$ acerca do que denomina "olhar de perto e de dentro": uma perspectiva etnográfica que permitiria "captar determinados aspectos da dinâmica urbana que passariam despercebidos, se enquadrados exclusivamente pelo enfoque das visões macro e dos grandes números". Esse enfoque é acionado pelo autor como forma de considerar os arranjos dos próprios atores sociais, seus trânsitos, deslocamentos, apropriações, encontros e trocas no espaço urbano, entendido não como mero "cenário", mas como parte constitutiva fundamental das práticas sociais e, consequentemente, do recorte de análise.

51 Metodologicamente, o caderno de campo desta pesquisa estruturou-se tendo por inspiração as cinco dimensões estabelecidas por Bruno Latour (a partir de comunicação pessoal com Gabriel Feltran, que participou do curso Exercices de métaphysique empirique com o autor, em 2007, no Centre Culturel International de Cerisy-la-Salle, a quem muito agradeço a orientação): 1) cronologias e mapas - marcos temporais e espaciais do dia em campo; 2) descrição densa - situações, diálogos, deslocamentos, atividades (onde aparecem as várias perspectivas encontradas em campo); 3) insights analíticos - obtidos a partir de observações de campo; 4) ideias reprimidas - senso comum, coisas aparentemente desconectadas da pesquisa em si etc.; 5) diário íntimo - sensações, emoções, pessoalidades. Vale retomar, aqui, a concepção de "descrição densa", cunhada por Gilbert Ryle e consagrada com Geertz (1978:20): “O ponto a enfocar agora é somente que a etnografia é uma descrição densa. O que o etnógrafo enfrenta, de fato - a não ser quando (como deve fazer, naturalmente) está seguindo as rotinas mais automatizadas de coletar dados - é uma multiplicidade de estruturas conceptuais complexas, muitas delas sobrepostas ou amarradas umas às outras, que são simultaneamente estranhas, irregulares e inexplícitas, e que ele tem que, de alguma forma, primeiro apreender e depois apresentar. E isso é verdade em todos os níveis de atividade do seu trabalho de campo, mesmo o mais rotineiro: entrevistar informantes, observar rituais, deduzir os termos de parentesco, traçar as linhas de propriedade, fazer o censo doméstico... escrever seu diário. Fazer a etnografia é como tentar ler (no sentido de 'construir uma leitura de') um manuscrito estranho, desbotado, cheio de elipses, incoerências, emendas suspeitas e comentários tendenciosos, escrito não com os sinais convencionais do som, mas com exemplos transitórios de comportamento modelado." 
de campo foi encarado como produtor de dados da investigação, por meio do qual se tornou possível estabelecer relações e mediações entre a prática da pesquisa e o aporte teórico e conceitual.

As entrevistas e conversas foram realizadas sempre com mais de um integrante de cada família: esta é a unidade empírica central, uma vez que os arranjos internos a ela são determinantes das trajetórias urbanas a serem analisadas ${ }^{52}$. 0 acompanhamento de uma mesma família possibilita a aproximação a uma variedade de atores (diferentes faixas etárias, gêneros, graus de escolaridade, tipos de ocupação etc.) e de trânsitos pela cidade, garantindo a diversidade de trajetórias urbanas: segui-los ao longo do tempo e articular vários relatos internos a uma mesma família é recurso científico já clássico no sentido de fazer emergirem narrativas simultaneamente individuais e coletivas ${ }^{53}$. Além disso, tal opção metodológica favorece a apreensão dos modos como os arranjos familiares atravessam o espaço urbano e as relações com moradia e trabalho, possibilitando circunscrever alguns circuitos urbanos ${ }^{54}$ por meio das histórias e trajetórias familiares e evidenciando os possíveis cortes geracionais.

Não há, portanto, um - e apenas um - recorte espacial específico, uma vez que a persecução das trajetórias urbanas é que guiou a pesquisa pelos espaços a serem considerados na análise ${ }^{55}$ : foram privilegiados, como ponto de partida da investigação, simultaneamente trajetórias e espaços urbanos periféricos que permitissem abarcar situações diversificadas no que diz respeito, por exemplo, a condições e propriedade da moradia, tempo de permanência e vinculação ao processo histórico de produção dos espaços em questão, inserção em programas públicos de provisão ou melhoria habitacional e urbana, trânsitos anteriores pelo espaço urbano de São Carlos, entre outros critérios de delimitação do universo empírico elaborados durante a pesquisa.

A sistematização e a análise das trajetórias tatearam a composição de cartografias espaço-temporais das mesmas: uma vez que a pesquisa não se propôs estudar um

52 Referência fundamental para o estudo de famílias e suas trajetórias urbanas são os trabalhos de Cabanes $(2006,2011)$.

53 Becker (1994); Grafmeyer (1995).

54 Neste ponto, valeria destacar as conexões entre a perspectiva de trabalho com trajetórias urbanas e as categorias etnográficas desenvolvidas também por Magnani (2002, 2005): pedaço, trajeto, mancha, pórtico, circuito - mais especificamente as de trajeto e circuito, justamente por permitirem apreender as mobilidades, fluxos e conexões recorrentes estabelecidas para além da delimitação apriorística de espaços circunscritos ou contíguos. A articulação entre tais categorias possibilita apreender trânsitos e passagens por entre dinâmicas e produções socioespaciais variadas, permitindo levar em conta as diversas escalas das cidades e seus diferentes planos de análise (Magnani, 2002:26), contribuindo significativamente para o desenho metodológico da investigação.

55 Trata-se de uma proposta de pesquisa que resulta de procedimentos de construção experimental de seu próprio objeto, cujos recortes e contornos específicos vão se delineando ao longo de seu próprio curso, cf. Lepetit (2001). 
objeto circunscrito em si mesmo, mas, antes, tratou de investigar dinâmicas e relações envolvidas na produção cotidiana de espaços e experiências urbanas 'periféricos', a concepção de cartografia tal qual desenvolvida por Deleuze e Guattari (1996) e desdobrada por Rolnik (1989) e Guattari e Rolnik (2000) ofereceu pontos de referência importantes nesse sentido.

Nessa concepção, a cartografia trata de acompanhar deslocamentos não apenas físicos, espaciais, mas também nas próprias narrativas, nas significações e, em última instância, nas subjetividades e experiências a elas emaranhadas ${ }^{56}$. Nas palavras de Rolnik (1989:29), uma cartografia "acompanha e se faz ao mesmo tempo que o desmanchamento de certos mundos - sua perda de sentido - e a formação de outros". Em se tratando de prospectar processos simultâneos de constituição de territorialidades, subjetividades e experiências urbanas ${ }^{57}$ de moradores de periferias, parece ser pertinente seguir as indicações da autora acerca de duas dimensões coexistentes em tal concepção de cartografia: aquela que se propõe a rastrear as "linhas duras", as estruturas, o plano de organização dos territórios vigentes, bem como a que persegue as "linhas de fuga", as desterritorializações, os movimentos e deslocamentos.

Destaca-se, ainda, a distinção promovida pela autora entre a cartografia - "desenho que acompanha e se faz ao mesmo tempo que os movimentos de transformação da

56 Veja-se, por exemplo, a abordagem de Braidotti (2000) acerca das "figurações nômades do sujeito". O desdobramento de tal concepção de cartografia, tal qual explicitado por esta autora, também interessa a esta pesquisa: "Una cartografía es basada en la teoría y marcada por la política. En este sentido, responde a mis dos exigencias primordiales, a saber, dar cuenta de la propia localización tanto en términos espaciales (dimensión geopolítica o ecológica) como temporales (dimensión histórica o genealógica) y proporcionar figuraciones alternativas o esquemas de representación para esas mismas localizaciones en términos de poder en su sentido restrictivo, pero también en su sentido potenciador o afirmativo." Agradeço a Rosamaria Giatti Carneiro pela indicação.

57 A pesquisa, desde o início, orientou-se pelo argumento da produção simultânea de territorialidades e subjetividades, direcionando seu foco para uma "experiência urbana possível" (Rosa, 2012b) de meus interlocutores, buscando iluminar simultaneamente os modos como essas experiências produzem o espaço urbano, conformam cidades, e como a produção do espaço urbano afeta e se traduz também em tais experiências. O potencial heurístico da polissêmica noção de "experiência" foi explorado por mim ao longo da pesquisa (Rosa, 2012b), e orientou as abordagens aqui desenvolvidas, sem no entanto ancorá-las especificamente em uma única definição conceitual, valendo-me de diferentes facetas ali apreendidas. No que tange aos imbricamentos entre territorialidades e subjetividades, inspiro-me em algumas proposições de Deleuze e Guattari (2002), de cuja obra se depreende a "territorialidade" como sendo produzida processualmente na relação entre espaços e sujeitos (em recíproca construção), em movimentos de "desterritorialização" e "reterritorialização". Haesbaert $(2004 ; 2005)$ propõe a concepção de "multiterritorialidade" como "uma resposta a esse processo identificado por muitos como 'desterritorialização': mais do que a perda ou o desaparecimento dos territórios, propomos discutir a complexidade dos processos de (re)territorialização em que estamos envolvidos, construindo territórios muito mais múltiplos ou, de forma mais adequada, tornando muito mais complexa nossa multiterritorialidade." Sem pretender aprofundar-me nos meandros desse debate, de resto já bastante avançado em especial no campo da geografia, indico a excelente revisão crítica promovida pelo autor acerca das concepções de território (e, por conseguinte, de territorialidade), no segundo capítulo de Haesbaert (2004). 
paisagem" - e o mapa - "representação de um todo estático" 58 -, distinção esta que nos aproxima novamente das abordagens de Certeau acerca do percurso e do relato como "fundadores de espaços". O autor estabelece uma distinção bastante incisiva entre, de um lado, os "mapas" ("sistema tecnológico de um espaço coerente e totalizador") e, de outro, as práticas, percursos e relatos ("figuras ambulatórias") 59 : o primeiro estaria para a ideia de "Iugar" (fixação de um próprio, instituição de uma ordem), enquanto os últimos, para a noção de "espaço" (operações, movimentos, relações). Sua proposição de um mapeamento dinâmico do espaço por meio dos relatos $^{60}$, em contraponto à fixação e rigidez dos mapas permite estabelecer um diálogo com aquela concepção de cartografia, pois também ela propõe delinear traçados heterogêneos, móveis, com múltiplas direções, entradas, pontos de condensação.

Tratando, portanto, de valorizar e dar crédito científico aos "nexos entre relações sociais, experiências reais e o investimento imaginário na operação narrativa como criando a vida" 61 e os espaços onde ela transcorre, a investigação etnográfica das trajetórias urbanas e a perspectiva de composição de uma cartografia espaçotemporal da cidade transumante que elas permitem descortinar são, assim, mais do que opções metodológicas, estratégias de conhecimento que privilegiam trajetórias e narrativas (percursos e relatos) como formas de produção e apreensão do urbano.

\section{- Notas sobre o campo, a escrita e a organização da tese}

Esta pesquisa, como visto, estruturou-se como uma exploração etnográfica pautada em encontros com moradores de periferias urbanas, realizados ao longo de pouco mais de dois anos (entre 2011 e 2013), a partir dos quais se obteve a matéria para o desenvolvimento das reflexões aqui apresentadas: relatos, narrativas, trajetórias e todos os seus ditos, não-ditos e interditos, gestos e afetos. Entrevistas e caderno de campo compõem seu extrato bruto, cujas sistematização e análise passaram por inúmeras fases, ao longo de dois períodos que totalizaram cerca de quinze meses, até que finalmente se tornassem uma tese.

58 Rolnik (1989:29). A questão da cartografia Para uma reflexão aprofundada acerca da concepção de cartografia, suas distinções em relação aos mapas e sua relação com as produções de subjetividades e territorialidades, ver também as coletâneas organizadas por Torres et al (2011) e Acselrad (2008), bem como os trabalhos de Fonseca (2010, 2011).

59 Diz o autor sobre os "mapas urbanos": "o traço vem substituir a prática"; ou, ainda: "Onde o mapa demarca, o relato faz uma travessia" (Certeau, 2003: 176;182).

60 Certeau (2003:208) pontua os relatos - "narração oral que não cessa, trabalho interminável, de compor espaços, verificar, confrontar e deslocar suas fronteiras" como "campo muito rico à análise da espacialidade".

61 Kofes (2004:12). 
A pesquisa de campo contou com uma fase exploratória inicial indispensável no sentido de favorecer uma aproximação gradativa ao campo da pesquisa, bem como um rico embate teórico-metodológico entre, de um lado, as leituras e o planejamento para a coleta de dados efetuados e, de outro, a prática da pesquisa propriamente dita, ampliando seu horizonte analítico e dando forma à perspectiva relacional que se pretendeu adotar frente ao campo empírico. Essa fase possibilitou ampla prospecção acerca do campo, das questões e dos objetivos da pesquisa, bem como o mapeamento preliminar de espaços e trajetórias urbanas de interesse desta (a partir de redes de relações estabelecidas em trabalhos e pesquisas anteriores), resultando na definição das quatro famílias cujas trajetórias seriam investigadas em profundidade.

Feitas as escolhas metodológicas apresentadas na seção anterior, pus-me a campo. Já os contatos iniciais, informais, e, em seguida, as primeiras entrevistas gravadas com meus primeiros interlocutores (além de observações e registros em diário de campo) forneceram as bases para as acomodações necessárias entre intenção e gesto na pesquisa de campo: se, no início, eu estava preocupada em construir o guia para as entrevistas semiestruturadas ${ }^{62}$, que pudesse 'dar conta' das principais questões que me interessariam abordar, pouco a pouco, tal guia perdeu centralidade, funcionando mais como um horizonte de questões de interesse ao qual eu eventualmente recorria a título de verificar se algum ponto importante estaria carente de abordagem. A construção da reciprocidade com os interlocutores, o contato com suas famílias, a inserção em suas casas foram questões que demandaram maior cuidado nesse período, bem como a articulação, através dos primeiros interlocutores, com os próximos sujeitos e famílias a serem inseridos na pesquisa ${ }^{63}$.

62 O guia de entrevista (mais aberto que um roteiro propriamente dito) estruturou-se de modo a contemplar, inicialmente, os seguintes eixos de interesse: trajetória residencial (moradia), trajetória ocupacional (trabalho), deslocamentos cotidianos (usos da cidade), rotina e arranjos familiares, práticas espaciais, marcos temporais, marcos espaciais, eventos políticos/associativos. Entende-se, com Duarte (2002:150), que este é um "instrumento flexível para orientar a condução da entrevista e precisa ser periodicamente revisto para que se possa avaliar se ainda atende os objetivos definidos para aquela investigação". Além disso, antes de cada entrevista, este guia era repensado de acordo com o perfil do entrevistado: assim, a partir de um índice comum, o guia-base foi inicialmente personalizado para cada caso, com especial atenção para as entradas que favorecessem, a cada um dos interlocutores, permitirem-se narrar. Tal como ensina Bourdieu (2008:700), uma "interrogação atenta a seus próprios resultados" somente se faz possível a partir de uma "representação adequada da situação da pessoa interrogada".

63 Desde o início, considerou-se fundamental que a rede de interlocutores da pesquisa se estruturasse, primeiramente, a partir de famílias com as quais eu já possuísse algum contato ou que pertencessem a redes de relações destas, de modo a garantir um conhecimento prévio de sua realidade. Tal opção metodológica ancora-se na concepção de que a realização das entrevistas necessita de um período de intermediação, a partir do qual se desdobra para a abordagem de questões de interesse a serem trabalhadas, se possível, em mais de uma entrevista, havendo uma espécie de hierarquia entre elas (em termos de graus de profundidade alcançada), em função das condições de aproximação e do estabelecimento (ou não) dos "encontros de pesquisa", nas palavras de Feltran 
O desenvolvimento subsequente da pesquisa de campo se articulou em torno de quatro famílias - Núbia e Jimmy; Jefferson e Beatriz; Joana e Ryan; Marielen, Jeison e Jairo $^{64}$-, de suas casas e dos territórios periféricos onde vivem (quatro bairros distintos: Cidade Aracy, Parque Novo Mundo, Santa Felícia, Jardim Zavaglia ${ }^{65}$ ). É importante dizer que, uma vez que o campo ampliado da pesquisa coincide com a cidade onde vivo há dezenove anos, as dinâmicas da pesquisa de campo são distintas daqueles casos em que o pesquisador necessita realizar deslocamentos significativos para estar em campo: de fato, não houve um ou mais períodos de imersão, mas uma espécie de periodicidade continuada - em alguns momentos, com maior frequência e permanência; em outros, de forma mais espaçada e pontual.

A despeito dessa familiaridade com o campo ampliado e com as realidades das periferias urbanas, uma nova inserção em campo é sempre produtora de certo "estranhamento"66, tanto pela reconfiguração do olhar que cada investigação exige, quanto pelas opções teórico-metodológicas adotadas. Neste caso específico, isso se deu, ainda, em decorrência das significativas mudanças ocorridas nas últimas décadas nos territórios por onde a pesquisa circulou: embora eu conhecesse previamente as periferias de São Carlos, desde o início da pesquisa - e cada vez mais, à medida que esta se desenvolvia - todo um novo universo foi se abrindo para mim, a partir da aproximação às trajetórias urbanas de meus interlocutores e, acima de tudo, às 'cidades outras' que elas evocam. Tal processo foi algo impactante, talvez por confrontar-se com um suposto saber que eu julgava deter sobre as periferias, mas, sobretudo, por tensionar minha própria experiência nessa cidade.

De um lado, houve a inserção em novos territórios (novos não apenas para mim, mas em termos de sua produção concreta na cidade), em certa medida distintos das já conhecidas configurações urbanas das periferias são-carlenses: decorrentes dos investimentos do Programa Minha Casa Minha Vida, o Parque Novo Mundo e o Jardim Zavaglia foram os locais onde essa inserção gerou em mim maior

(2011), ou da "relação de pesquisa", nas palavras de Bourdieu (2008), entre pesquisador e interlocutor.

64 Durante a fase exploratória, dois interlocutores foram selecionados para aproximação inicial às suas famílias: Jimmy e Marielen. Sem interrupção entre esta fase e a continuidade da pesquisa de campo, através de Jimmy, iniciei os contatos com sua mãe, Núbia, bem como retomei antigos contatos com Jefferson, cuja família, recém-mudada para o Parque Novo Mundo, já havia sido identificada como de interesse para a pesquisa (também sua esposa, Beatriz, tornou-se desde então uma interlocutora importante). Através de Marielen, estabeleci meus primeiros contatos com Joana, cuja família havia sido contemplada há alguns meses, em sorteio, com uma casa no conjunto habitacional Jardim Zavaglia.

65 Ver mapas no Anexo 1.

66 Da Matta (1978); Velho (1978). Ou, ainda, como apontam Pedrosian e Latierro (20013:8): "el extrañamiento como actitud y actividad de des-obviar para aceder a las dinâmicas de producción y reproducción de lo existente, actividad cognoscente primordial en la práctica etnográfica". 
"estranhamento" (e, possivelmente, também na vizinhança, uma vez que são os territórios mais desconectados da malha urbana e por onde não é comum ver pessoas de fora circulando). De outro, houve a retomada da visitação (ou apenas a passagem) frequente a outros bairros e regiões das periferias por onde eu há alguns anos não circulava com tal assiduidade: a constatação empírica das transformações anunciadas pela bibliografia desde o início dos anos 2000, algumas já evidenciadas quando da pesquisa de mestrado, se fez de forma gritante nesse momento, em termos da expansão dos limites da malha urbana, do espraiamento da infraestrutura e dos serviços urbanos, do adensamento e da consolidação habitacional e, principalmente, da expansão do consumo nessas regiões, atestado não apenas internamente às famílias e suas moradias, mas, acima de tudo, na paisagem urbana, agora repleta de pequenos e grandes empreendimentos comerciais.

Há, ainda, o "estranhamento" decorrente da inserção nas casas - e nas vidas - dos interlocutores, em especial nos primeiros momentos em campo: ainda que eu já tivesse contatos prévios com três das quatro famílias participantes da pesquisa, nossos "abismos cotidianos" 67 foram inevitavelmente evidenciados nesse processo inicial de pesquisa, tendo sido necessário muita paciência, sensibilidade e disponibilidade para deixar de ser uma 'intrusa' ou uma 'visita' e aproximar-me, tanto quanto possível, do cotidiano das famílias e dos indivíduos envolvidos nessa relação. A aceitação do pesquisador em campo (e as relações de troca que aí se estabelecem) é um processo que interfere diretamente, portanto, na qualidade dos dados obtidos.

A sensação de intimidade percebida, o crescente 'desejo de narrar' e contribuir com a pesquisa e, principalmente, as dimensões progressivamente permitidas de serem narradas foram meus principais indicadores do estabelecimento da relação de reciprocidade com os interlocutores e suas famílias, configurando propriamente o que considero serem "encontros de pesquisa": espaços de diálogo e reflexão conjunta ${ }^{68}$ que, a meu ver, conferem, mesmo, estatuto político a uma pesquisa de campo como a aqui proposta69. É a partir dessa reciprocidade que os "abismos

67 Feltran (2004). O autor tece uma importante reflexão sobre a experiência, enquanto pesquisador, em lidar com a constante reposição das desigualdades e diferenças que apartam nossos mundos sociais, apesar dos inúmeros pontos de conexão e aproximação, num exercício constante de relação com a alteridade, bem como de reflexão sobre ela.

68 Nesse sentido, é importante destacar que as trajetórias, tal qual apresentadas aqui, não pretendem ser tratadas como dados objetivos, portadores de realidade em si mesmos; essas trajetórias remetem, necessariamente, ao meu encontro de pesquisa com elas. Sua construção narrativa e as questões problematizadas a partir delas são apenas as decorrentes desse encontro: constituem-se, portanto, no espaço entre o pesquisador e os sujeitos da pesquisa.

69 Nas belas palavras de Feltran (no prelo): "uma causa, ao mesmo tempo intelectual e política, de compreender para habitar um mundo comum". 
cotidianos" se atualizam em uma "recuperação positiva da alteridade" 70 na relação de pesquisa, possibilitando que se estabeleça efetivamente uma comunicação.

Neste ponto, caberia aprofundar-me um pouco: se as famílias, os indivíduos, as trajetórias e os territórios pesquisados se mostraram teórica e empiricamente heterogêneos, não seria diferente em termos da comunicação entre pesquisador e sujeitos da pesquisa. Para além do estatuto do estabelecimento possível da comunicação na alteridade, como mencionado, a comunicação mediante toda essa heterogeneidade requer ainda mais que reciprocidade, sendo mesmo necessário ao pesquisador encarar um contínuo processo de "negociação de identidades", nos termos de Marcus (2001). No jogo de compreender e ser compreendido, não se trata de mimetizar linguagens e comportamentos dos interlocutores, mas de permitir-se aproximar de seu universo também a partir da linguagem. Isso demandou uma atenção, em campo e fora dele, para os 'nós' dessa comunicação, sejam gírias e expressões, sejam referências a personagens, lugares e meios de comunicação locais, tidos pelos interlocutores como algo corriqueiro, mas que para mim carecia de explicação: não me furtar a pedi-la, quando o momento permitia, mostrou-se uma estratégia positiva tanto no que se refere à reflexividade produzida conjuntamente entre nós, quanto à própria construção da reciprocidade acima referida. Em outros momentos, e conforme a pesquisa avançava, a observação e a documentação atenta desses 'nós' permitiram que eu os decifrasse por mim mesma e os incorporasse em nossas conversas, aproximando-nos também por meio da linguagem. De todo modo, para além das dinâmicas de compreensão mútua no ato mesmo dos encontros de pesquisa, a atenção a esses 'nós' tem também valor heurístico, ao permitir acessar outros aspectos do objeto que, de outra forma, talvez permanecessem velados ${ }^{71}$.

Dessa reflexão se infere, portanto, o quanto a coleta e a análise dos dados estão imbricados em uma pesquisa como esta, ainda que, com tal afirmação, não se desprezem necessárias delimitações em cada uma dessas etapas. Ao contrário, mesmo que sem grande rigor disciplinar, realizei pequenos intervalos sistemáticos ao longo de todo o período em campo para o processamento dos dados - transcrição e leitura das entrevistas, mapeamento de novas questões acerca das trajetórias urbanas em foco -, aos quais se seguia uma preparação para reingressar ao campo; isso garantiu um aprofundamento contínuo da pesquisa empírica. Além desses pequenos intervalos, foram dois os momentos de paralisação do trabalho de campo: o primeiro, quando da elaboração do memorial de qualificação, e o segundo, quando do início da escrita da tese, no fim de 2013, quando o dei por encerrado. Esses dois

70 Godoi (1999).

71 Remeto aqui ao excelente capítulo metodológico da tese de doutorado de Diogo Lyra (2010), cujas reflexões me foram bastante inspiradoras. 
momentos - sofridos, diga-se - foram fundamentais não apenas para que pudesse estabelecer algum distanciamento do campo, mas também para imergir propriamente nos dados coletados, dando início a um processo de organização, sistematização e análise das informações obtidas.

Foram realizadas vinte e cinco entrevistas em profundidade, todas integralmente transcritas por terceiros e revisadas tão minuciosamente quanto possível por mim (a partir das gravações em áudio), de modo a preservar ao máximo o contexto em que foram produzidas. Com as mais de novecentas páginas devidamente impressas, iniciei um intenso período de imersão: todas as entrevistas foram lidas, sequencialmente; além delas, também o caderno de campo foi revisitado. A partir da leitura do conjunto, passei a inúmeras releituras, identificando questões, temas, categorias e classificações que emergissem do próprio material empírico, em diálogo com minhas próprias questões e objetivos de pesquisa. Sistematizações preliminares foram feitas, principalmente procurando pinçar os elementos norteadores dos relatos, de modo a reconstruir em narrativas etnográficas as trajetórias urbanas de meus interlocutores para a etapa intermediária da qualificação. Tais reconstruções foram parte da experimentação de um método de investigação, um modo de organizar dados e informações, de apreendê-los, orientando sua análise. A partir delas (e em diálogo com a literatura) procedi a um refinamento de categorizações, cruzamentos de dados, hierarquizações temáticas e analíticas, e, durante algum tempo, me vi paralisada, sem saber como, a partir daquela profusão de dados, proceder à estruturação e escrita da tese. Como bem sintetizou Bourdieu (2008:11), "os lugares ditos 'difíceis' (...) são, primeiramente, difíceis de descrever e de pensar", sobretudo quando se pretende distanciar das "imagens simplistas e unilaterais", oferecendo uma "representação complexa e múltipla".

Uma vez que, como visto, o percurso da pesquisa foi também o percurso de (re)construção de suas questões e delineamento de seu objeto ${ }^{72}$, o campo não se configurou, portanto, em algo meramente ilustrativo, ou em um lugar onde se comprovariam hipóteses; ao contrário, o esforço foi no sentido de produzir minhas reflexões a partir da relação entre tudo aquilo que ouvi, vi, senti, compartilhei em campo e as teorias acadêmicas que foram se entrelaçando, em momentos diferentes da pesquisa e da escrita, às minhas questões. O mestrado em história, bem como minha insistente interlocução junto à antropologia urbana, já há algum tempo me ensinaram que os "dados" não são algo objetivo e inócuo, sendo mesmo indissociáveis da forma subjetiva com que o pesquisador os acessa (e mesmo - por que não dizer? - os produz).

72 Cf. Lepetit (2001). 
Nesse sentido, posso dizer que literalmente me deixei levar pelo campo e pelas questões que ele suscitou, quase numa 'deriva' (processo de todo muito angustiante, mas muito enriquecedor). A estrutura e a escrita da tese, como se verá, resultam desse processo, desse caráter indutivo da reflexão: as trajetórias urbanas são seu marco de referência, tanto analítico quanto descritivo; elas fornecem o enredo para sua construção. O modo de exposição dos dados está, assim, diretamente ligado a esse enfrentamento experimental do campo da pesquisa, ao modo de construção processual de seu objeto. A estratégia de orientar a escrita da tese pelo marco das trajetórias decorre, sobretudo, da intenção de expressar, na escrita, o caráter dinâmico do objeto delineado pela pesquisa, um universo em constante movimento.

Dessa opção metodológica deriva a multiplicidade de temas e questões pelos quais a tese transita ${ }^{73}$ : não se tratou de elencar, a priori, um ou mais temas centrais a partir dos quais se daria toda a pesquisa e análise (como, por exemplo, o "mercado informal de habitação", o Programa Minha Casa Minha Vida, o mundo do crime); antes, das trajetórias emergiram os temas a serem tratados, que não foram abordados em si mesmos, mas a partir das questões que eles permitiam iluminar, em diálogo com os objetivos da pesquisa (o mesmo critério foi utilizado para silenciar outros temas que, também emergindo das trajetórias, não trariam contribuições nesse sentido). A tese resulta, então, simultaneamente panorâmica (ao permitir apreender linhas de força mais gerais sobre a produção de territorialidades e experiências urbanas atravessadas, em algum sentido, por dimensões de pobreza) e aprofundada (ao esmiuçar etnograficamente as trajetórias e fazer emergir uma tal multiplicidade de questões sobre as 'cidades outras' nelas cravadas).

A teoria, nesse sentido, é incorporada em diálogo e tensão com o campo, e viceversa, procurando encará-la de forma menos 'utilitária' ou 'demonstrativa': a partir das trajetórias, buscou-se estabelecer os nexos entre teoria e empiria, daí a inexistência do convencional "capítulo teórico". Não há, de fato, um autor ou uma teoria a sustentar todo o trabalho; ao contrário, as interlocuções e construções teóricas perpassaram todo o processo de elaboração da tese, e diversos autores o instruíram em diferentes aspectos e momentos. Desse modo, há todo um diálogo possível com estudos já clássicos e com outros contemporâneos acerca de temáticas

73 E, nesse sentido, alinho-me a todo um debate acadêmico em curso em torno da questão das "periferias", como bem expressou Birman (2013:7): "Pesquisadores de diferentes gerações e tradições acadêmicas abordam as periferias por intermédio de análises que valorizam certa transversalidade de campos temáticos fundamentais. Não é suficiente, pois, saber que família, trabalho, religião e gênero, entre outros domínios sociais, andam juntos e se entrelaçam nas práticas sociais mais diversas. É preciso direcionar o foco e valorizar os nexos que permitem destacar certas relações de sentido que hoje se disseminam, como entre trabalho ilegal e legal, entre evangélicos e criminalidade, entre mediação feminina e políticas públicas etc. Valorizar nexos quer dizer, em muitos casos, perceber como trazem inovações na vida social". 
como: pobreza; produção do espaço urbano; experiência urbana; a casa e os modos de habitar; relações entre espaço público e privado; família, gênero e geração na pobreza; políticas sociais, urbanas e habitacionais; acesso à moradia; "ideologia da casa própria"; mercantilização da habitação popular; "mercado imobiliário informal"; relações moradia - trabalho - cidade; "ilegalismos urbanos", tráficos, violências; para citar alguns dos quais as proposições da tese se acercaram e cujos debates foram evocados na medida em que os argumentos os suscitavam.

Postura semelhante foi adotada quanto ao lugar a ser ocupado pela cidade de São Carlos na tese, resultando que também esta não se apresenta de forma apriorística: optou-se, deliberadamente, por não fazer uma seção ou um capítulo à parte, cujo objetivo seria apresentar São Carlos como "contexto". E aqui retomo a reflexão anterior sobre a questão da "variação da escala" proposta, e dialogo com Revel (1998:27), para quem a noção de "contexto" seria usada, muitas vezes, de forma "cômoda" nas ciências sociais, seja visando a produzir um "efeito de realidade" em torno do objeto da pesquisa, ou a apresentar as condições gerais nas quais uma realidade particular encontra seu lugar, ou, ainda, a extrair do contexto as razões gerais que permitiriam explicar situações particulares. As opções teóricometodológicas e analíticas da pesquisa, como visto, caminham justamente na contramão desses usos do "contexto" e justificam a inexistência dessa apresentação panorâmica sobre a cidade que configura o campo ampliado da pesquisa: uma vez que estou propondo alcançar 'cidades outras', ainda que a partir de uma única cidade normalizada (que, neste caso, é São Carlos, mas poderia ser Araraquara, Rio Claro ou Bauru, por exemplo), fazer o caminho inverso - apresentar São Carlos como totalidade, como contexto estruturante, para só depois introduzir as trajetórias contrariava a inversão epistemológica proposta, bem como a própria argumentação da tese.

A radicalização de uma postura epistemológica que se pauta efetivamente pelas trajetórias e pelas experiências urbanas dos interlocutores é a mesma, portanto, que faz refutar tal abordagem genérica da São Carlos 'oficial' ou 'unidade territorial total': a pesquisa enfoca a cidade de São Carlos tal como vivenciada, experimentada e narrada pelos sujeitos da pesquisa, e, nesse sentido, ela aparece simultaneamente em sua unicidade e diversidade, podendo ser lida em várias escalas e tempos, como já dito anteriormente. Entretanto, considera-se importante situar o leitor em relação a esta cidade que é o posto de observação de onde se investigam as trajetórias, e, para tanto, a estratégia adotada foi introduzir dados e informações sobre ela entremeados às trajetórias e às análises delas decorrentes, conforme os dados etnográficos os demandassem, e sempre que pudessem esclarecer (contextualmente, e disso não vejo como fugir) as situações e questões trabalhadas. Como se verá, a tese extrai, das próprias trajetórias, as temporalidades urbanas que 
pautam a apresentação e a análise dos dados, e é a partir delas que se buscou promover o diálogo entre campo empírico e informações mais gerais sobre a cidade. Desse modo, tencionou-se que São Carlos aparecesse menos como contexto e mais como "o local como tensão"74, ou seja, justamente na relação entre o que é geral, estruturante, que reverbera em outras realidades e aquilo que é singular, localizado.

Caberia ainda apontar que, nesse sentido, a tese, ao mencionar os vários bairros, localidades, territórios situados que emergem das trajetórias, mais do que apenas oferecer elementos para uma história urbana de São Carlos (o que, de certo modo, também o faz), ou ambicionar uma caracterização aprofundada de cada um desses espaços, teve a intenção de enfatizar sua recorrência e as dinâmicas escalares atreladas aos deslocamentos de meus interlocutores no espaço urbano, as cidades que tais deslocamentos e suas narrativas compõem, a complementaridade ou oposição em suas representações, de modo que, com o auxílio dos mapas em anexo, fosse possível apreender escalas, interconexões, transformações nessas 'cidades outras' aqui apresentadas.

Dito isso, a escrita da tese e o modo como o texto se organiza espelham o caráter experimental e as dimensões exploratórias que a metodologia adotada imprimiu à pesquisa e, portanto, o próprio modo como as problemáticas aqui enfrentadas foram sendo elaboradas, e o objeto, delineado, ao longo desses quatro anos e meio de trabalho. É, nesse sentido, ela própria também um exercício de experimentação, que caberá ao leitor julgar se frutífero ou não.

Além desta Introdução, a tese se estrutura 'horizontalmente' em três longos Capítulos, simultaneamente descritivos e analíticos, cada um deles elaborado a partir de determinadas trajetórias e dos aspectos mais significativos que cada uma delas possibilitava melhor iluminar frente aos objetivos e questões da pesquisa ${ }^{75}$. Fugindo

74 Formulação que devo à minha orientadora Cibele Rizek, a quem mais uma vez agradeço.

75 Aqui, duas ressalvas quanto a estratégias textuais adotadas. Uma delas refere-se à mobilização de muitos trechos (por vezes, mesmo, longos) de relatos dos interlocutores, não apenas porque são o extrato bruto da pesquisa, muito menos em caráter meramente ilustrativo, mas no sentido de evidenciar sua potência expressiva e cognitiva - heurística, portanto - e possibilitar ao leitor transportar-se, em alguma medida, ao lugar de onde falam meus interlocutores. Enfim, para que suas trajetórias, suas dinâmicas, suas experiências - e, em última instância, suas cidades - possam ser compreendidas também a partir de uma aproximação a seus pontos de vista. Para, como ensina Bourdieu (2008:701), "tentar compreender ao mesmo tempo na sua unicidade e generalidade os dramas de uma existência”. A outra refere-se à opção de articular a discussão bibliográfica, ao longo dos capítulos, nas notas de rodapé: a intenção, com isso, foi construir, a um só tempo, um eixo narrativo principal a partir das trajetórias, e outro, quase em paralelo, em que se evidenciam suas conexões, diálogos e discussões com a literatura (e, sempre que possível, com outras realidades urbanas nelas evocadas), bem como os trânsitos escalares decorrentes desses enfrentamentos, de modo a evitar que estes últimos resultassem numa apreensão truncada das primeiras. 
à praxe acadêmica, os Capítulos são transpassados 'verticalmente' por três breves Entremeios - pensados, a um só tempo, como intervalos e costuras entre os Capítulos (e suas trajetórias correspondentes) -, em que se apontam algumas questões tramadas a partir de tangenciamentos, cruzamentos, justaposições entre as várias trajetórias e observações em campo e que, recorrentes, se mostraram mesmo dimensões transversais - quiçá estruturantes - das cidades e experiências urbanas que os Capítulos vão dando a ver.

No Capítulo 1, através das trajetórias de Núbia e seu filho Jimmy, o leitor é introduzido ao universo empírico-analítico da pesquisa, tendo como enfoque central a questão do acesso à moradia. Tais trajetórias permitem entrever uma ampla envergadura de dimensões relativas a esta problemática: se a tônica da trajetória de Núbia são os deslocamentos em busca de moradia ao longo dos últimos quarenta anos (e uma forte dimensão de gênero implicada nesses deslocamentos), o entrelaçamento com a de Jimmy evidencia cortes geracionais e políticos frente à produção e à experiência da cidade, permitindo cartografar as transformações nas formas de acesso à moradia e nos destinos dos deslocamentos nesse período. Fazendo emergirem os imbricamentos entre trajetórias e dimensões da história urbana recente de São Carlos que permearão toda a tese - a partir de cruzamentos entre cronologias urbanas, políticas, biográficas e geracionais (e, inevitavelmente, também as cronologias do tráfico de drogas e da violência) ${ }^{76}$-, o capítulo configurase, sobretudo, como um esforço por dotar de historicidade os processos e dinâmicas socioespaciais investigados. Nesse sentido, introduz, a partir de como isso se evidencia em meu universo empírico, as transformações das últimas décadas no âmbito da "pobreza" e de seus territórios na cidade, nas dinâmicas socioespaciais das periferias, nas políticas públicas destinadas aos "pobres" e nas formas de acesso à moradia pelas camadas populares.

Em diálogo com a reflexão, introduzida no Capítulo 1, do quanto as políticas habitacionais são parte fundamental da construção (histórica) de "toda uma forma de conceber a gestão das diferenças sociais na cidade"77, o Entremeio I esboça uma genealogia dos imbricamentos entre tais políticas e a movimentação de todo um "mercado imobiliário informal" - e, em alguns casos, também ilegal - vigente entre as camadas populares na cidade, o qual se articula a potentes mecanismos de produção de demanda para tais políticas, bem como de "gestão dos ilegalismos" a elas associados. Trata, nesse sentido, de problematizá-las - a partir das representações tecidas entre meus interlocutores - como parte fundamental das

76 Telles (2006; 2006a).

77 Rui (2012:196). 
relações entre legalidade e ilegalidade que atravessam diversas dimensões das trajetórias e experiências urbanas investigadas.

O Capítulo 2 pretende iluminar, a partir do material empírico, a relação entre a conformação do que vem sendo considerada uma "nova pobreza" (ou, em sentido inverso, uma "nova classe média") e a constituição de 'novas periferias' produzidas recentemente no âmbito do Programa Minha Casa Minha Vida (PMCMV). O Capítulo estrutura-se em torno das trajetórias urbanas de integrantes de duas famílias, cujos deslocamentos habitacionais desembocaram, simultaneamente (em 2011), em dois empreendimentos vinculados ao PMCMV em uma mesma região periférica da cidade, produzidos sob duas modalidades distintas desse Programa, mas que acabaram atingindo 'públicos' semelhantes: no caso de Beatriz e Jefferson, pela via da aquisição privada, em que se evidencia uma perspectiva de integração urbana e social pelo consumo mercantil da casa (financiada); no caso de Joana, através do modelo em que mais se evidencia a articulação política pública/mercado, pela via da consecução da casa por meio de sorteio promovido por órgão público municipal. Trata-se, portanto, de descrever e analisar, a partir das trajetórias, as semelhanças e distinções nos dois modelos de intervenção urbana e promoção habitacional, nos projetos familiares a eles vinculados, nas concepções de sociedade e cidade que deles emergem e nos territórios e dinâmicas socioespaciais que aí se produzem, atentando especialmente para os longos processos de fixação nesses novos territórios e para as dinâmicas movediças aí implicadas. Implementado no país a partir de 2009, o Programa Minha Casa Minha Vida emerge em meu campo como nova, absolutamente central e praticamente única forma de acesso à "casa própria", na cidade, para as camadas populares atualmente: quais os efeitos dessa atual 'política habitacional' nas trajetórias urbanas investigadas e nos territórios onde elas têm seus pontos de condensação?

Essa questão - em cujo bojo estão as continuidades e rupturas na produção de territórios e dinâmicas socioespaciais nas periferias das cidades brasileiras contemporâneas (observadas, na tese, a partir da realidade de São Carlos) - orienta também as reflexões delineadas no Entremeio II, estruturadas em três argumentos entrelaçados. $O$ primeiro ressalta a existência de uma experiência anterior - comum a todos os meus interlocutores - de acompanhar o urbano a se fazer, processualmente, a embasar a confiança numa inescapável conformação de urbanidade nesses novos territórios. Disso decorre o segundo argumento, que aponta para uma espécie de "imaginação urbana" e uma figuração de desenvolvimento dos bairros, que orientam a construção - concreta e simbólica - de 'novas centralidades periféricas'. Por fim, observando o processo de reconfiguração de uma "fronteira urbana" em uma 'centralidade periférica' e sua articulação à produção dessas novas periferias no âmbito do PMCMV, indago pelos efeitos de tal 
processo, como o acirramento da territorialização da pobreza e a consolidação da diferença social inerente à consolidação do território periférico em foco.

No Capítulo 3, a trajetória de Marielen (e seus dois filhos) permite apreender, para além dos meandros do acesso à moradia e de uma concepção de pobreza stricto sensu (ou reconfigurada em "nova classe média"), algumas dinâmicas socioespaciais e vulnerabilidades vinculadas à expansão do mundo do crime nas periferias, e o lugar da casa e do território nesse contexto. Sendo a única trajetória cuja fixação em uma casa e um território (por vieses bastante específicos e, mais uma vez, atrelados a dimensões de gênero) se encontrava já relativamente consolidada quando do início da pesquisa, o capítulo evidencia o quanto a consecução de uma casa - a experiência de ter um pé fixo -, embora tenha representado uma salvação (econômica, social, familiar, simbólica) no contexto de sua trajetória, não significou, em definitivo, a eliminação de outras dimensões de vulnerabilidade que a atravessariam desde então, trazendo à tona uma miríade de outros trânsitos e deslocamentos socioespaciais para além daqueles atrelados ao acesso à moradia, cujos efeitos desestabilizariam, inclusive, tal fixação, o enraizamento em uma casa, uma vizinhança, um território conquistados a duras penas. Nesse sentido, o capítulo arremata questões construídas ao longo dos capítulos anteriores, introduzindo outras dimensões ao contexto de velhas e novas pobrezas/periferias/vulnerabilidades/dinâmicas socioespaciais perscrutadas na tese.

O Entremeio III estrutura-se a partir da constatação empírica de que se, por um lado, a despeito da já mencionada heterogeneidade que configura as camadas populares e seus territórios, as dimensões estruturantes que a tese permite entrever delineiam uma inegável experiência urbana comum, por outro, os moradores de periferias se percebem, classificam e relacionam internamente como grupos sociais distintos. Tal constatação decorreu de uma recorrente emergência em campo: a relação entre a dinâmica processual de produção do urbano apreendida através das trajetórias e a constante produção e reconfiguração de classificações e hierarquizações não apenas sociais, mas sobretudo espaciais, pelos próprios moradores das periferias. Explorando analiticamente o que chamei de sistemas classificatórios êmicos e as disputas internas acerca das representações dos territórios da cidade homogeneizados sob categorias como "periferias" ou "bairros populares" que eles evidenciam, este Entremeio propôs refletir, mesmo que brevemente, sobre a produção simultânea de territórios periféricos e de linhas de clivagem internas às camadas populares, atentando para algumas das categorias que pautam tais classificações, perguntando por seus parâmetros e sentidos, bem como suas reverberações simultâneas nas trajetórias urbanas investigadas e nos processos de produção e apropriação dos espaços a que se referem. 
Arrematando tudo isso, a tese se encerra com Considerações Finais, nas quais se recobram apenas alguns dos muitos fios analíticos que as trajetórias permitiram evidenciar ao longo dos Capítulos e Entremeios e que, em conjunto, permitem tecer reflexões sobre as 'cidades outras' de que trata a tese. Mais do que conclusões propriamente, trata-se de um mapeamento de dimensões - e, sobretudo, indagações - pulsantes a partir do exposto ao longo da tese, o qual articula-se a considerações sobre o que uma exploração etnográfica a partir de trajetórias urbanas permite dizer sobre a produção das cidades em suas margens, sobre que cidades são essas e sobre a dimensão de alteridade que elas evocam.

É, portanto, sobre as dobras que configuram, simultaneamente, territórios, subjetividades e sensibilidades; percursos, narrativas e espaços; pobreza, experiência urbana e cidades; produção de conhecimento e produção do espaço que a tese se propõe a dialogar.

Como se verá, a escrita da tese procurou evidenciar a densidade vivida da cidade $^{78}$ : das trajetórias emergem temporalidades, trânsitos, mediações, deslocamentos, representações, políticas, gestões, classificações e os pontos de condensação disso tudo (entrelaçados a suas motivações diversas), que acabam por estriar o espaço urbano, fazendo-o muito mais complexo. São, portanto, e como anteriormente anunciado, a entrada da pesquisa para as 'cidades outras' do título. Entremos, pois.

78 Ou, conforme as palavras de Joseph (1999), "reintegrar a ação e a linguagem" na observação e análise dos processos de produção de cidades e experiências urbanas aqui enfocados. 


\section{OS MEANDROS DO ACESSO À MORADIA: redes, mercados, políticas}

Eu acho muito ruim essa história de muda pra lá, muda pra cá, vai de um bairro pro outro, é muito difícil. Mas eu tenho praga de cigano! | Núbia

\section{- Casa de patroas, vida de aluguel, coabitação: moradia e gênero, primeiro ato}

Núbia chegou a São Carlos, cidade do interior do estado de São Paulo, em 1973. Aos dezoito anos, era já a quarta ruptura em sua ainda breve trajetória, a primeira com alguma dimensão de escolha própria. Antes disso, fora abandonada pela mãe, em Valença-RJ, tendo ficado aos cuidados da tia, que vivia em um sítio na área rural com o marido, dois filhos e três filhas, os quais se tornariam os pais e irmãos adotivos de Núbia. O trabalho como empregada doméstica, iniciado aos nove anos de idade, e a distinção paterna - por vezes violenta - em relação a ela dão a tônica das memórias dessa infância rural. No fim dos anos 1960, contrariando a vontade das mulheres da família, que desejavam permanecer próximas aos demais familiares, o pai imporia a mudança para Pirassununga - SP, acompanhando a transferência dos irmãos mais velhos, militares: passaram, então, a viver na cidade, em uma casa inacabada alugada em um bairro afastado, com um grande quintal onde os pais podiam manter algumas práticas rurais, como o cultivo de alimentos para subsistência e a criação de animais. Núbia tinha apenas doze anos, e o pai, após a mudança, não mais permitiu que voltasse a estudar, para poder trabalhar em tempo integral como doméstica. Aos dezesseis, sob alegação de tratamento de uma tuberculose, o pai internou-a em um hospital psiquiátrico em Araraquara, onde permaneceria por quase um ano. A internação foi sentida por Núbia como punição pelo fato de que ela, já adolescente, vinha enfrentando o pai nas investidas, cada vez mais violentas, dele contra a mãe, guardando no corpo e na memória as marcas doloridas desse período.

É no retorno a Pirassununga que uma oportunidade de trabalho transformaria todo o curso seguinte de sua trajetória. Sabendo da dificuldade de Núbia e suas irmãs em 
conseguir empregos na cidade, em função da dificuldade também em estabelecer redes de relações ${ }^{1}$ naqueles primeiros anos ali, uma vizinha ofertou a duas delas um emprego fora da cidade, como domésticas na casa de uma senhora, onde elas deveriam, inclusive, residir. O emprego vinha a calhar, não apenas pelo salário bastante melhor do que os que conseguiam em Pirassununga, mas, sobretudo, pela possibilidade de tentar uma nova vida, longe das agressões do pai. Núbia se viu dividida entre partir para esta nova vida ou ficar e cuidar da mãe, cujo estado de saúde se deteriorara a olhos vistos desde a saída de Valença, visando, inclusive, a protegê-la das agressões do pai; entretanto, a própria mãe a encorajou a aproveitar o aval fornecido pelo pai para sair de casa (motivado, segundo ela, apenas pela possibilidade de acréscimo na renda familiar, já que ela e a irmã permaneceriam enviando dinheiro para ele). Decisão tomada, o pai mandou chamar a futura patroa para ter certeza de que o emprego existia realmente: no mesmo dia, ela e a irmã chegariam a São Carlos, empregadas domésticas importadas pessoalmente pela patroa.

Estamos no início dos anos 1970, e a São Carlos de então, em razão da crescente e progressivamente descentralizada industrialização do estado de São Paulo, começava a tornar-se destino migratório tanto de famílias excluídas do campo pelo processo de mecanização da agricultura, como de outras vindas da metrópole paulistana, de demais cidades do próprio estado e do país, em busca de emprego. Núbia e sua irmã, embora possam incluir-se nas estatísticas desse período, tinham por motivação central livrar-se dos maus tratos do pai, ainda que a consecução de um emprego na cidade tenha sido crucial para tanto.

1 A expressão "redes de relações" teve, a princípio, emprego eminentemente descritivo, como forma de nomear as muitas e variadas articulações referidas com frequência pelos interlocutores e de enfatizar uma abordagem relacional das trajetórias, para além do foco exclusivamente no indivíduo. Dada a recorrência de sua presença ao longo da escrita da tese, tornou-se, em certo sentido, um conceito importante a balizar interpretações e análises. Há, entretanto, um vasto debate, nas ciências sociais, pautado na concepção de "redes sociais" sobre o qual não caberia, dados os objetivos da tese, aprofundar-me sobremaneira. Sugiro, nesse sentido, as revisões sobre o conceito de rede nas teorias sociais promovidas por Enne (2004) e Portugal (2007), de quem destaco, para os fins deste trabalho, a constatação de que a atenção às redes de relações sociais permitiria apreender como "as trajetórias sociais dos indivíduos não são determinadas integralmente nem pelas suas posições estruturais, nem pelas suas decisões individuais" (p. 12). Uma importante reflexão sobre as origens e desdobramentos do conceito e seus usos no pensamento antropológico sobre as cidades e o urbanismo encontra-se em Hannerz (1980:163-201). Sem pretender realizar uma "análise de redes sociais", ancoro-me nas abordagens seminais desenvolvidas no âmbito da antropologia social por Barnes (1954; 1987) e Bott (1976[1957]), nas quais, a partir do enfoque sobre as relações dos indivíduos na sua vida cotidiana e em múltiplos contextos, emergiu a concepção de "redes sociais" para delinear relações interpessoais mutáveis, cruzadas, por vezes contraditórias em termos de pertencimento a categorias sociais ou grupos formalmente instituídos; nas palavras de Barnes (1987), "processos sociais que envolvem conexões que transpassam os limites de grupos e categorias". 
Com pouco mais de 76.500 habitantes, São Carlos encontrava-se em um considerável movimento de expansão urbana, tendo em ampliado quatro vezes seu perímetro urbano entre os anos de 1960 e 1975, sobretudo em direção àquelas áreas onde, desde pelo menos meados dos anos 1940/50, já vinham se concentrando os locais de moradia dos trabalhadores, na região sul da cidade, para além da linha férrea². Antigas vilas operárias, bairros de trabalhadores, loteamentos populares: naquele momento, esses eram os destinos da grande maioria daqueles que conseguiam se inserir nos postos de trabalho do crescente polo industrial local. Os que não tinham a mesma sorte, passaram, nessa década, a contar com a possibilidade de construir um barraco na primeira ocupação favelizada da cidade, a chamada Favela do Gonzaga $^{3}$. Ao longo de toda a década de 1970, serão frequentes, nos jornais locais e nas sessões da Câmara Municipal de Vereadores, as discussões sobre a "carência de moradia popular na cidade" ou os "aluguéis abusivos", além dos inúmeros "problemas dos bairros de periferia" e a abertura de "loteamentos irregulares e clandestinos" ${ }^{\prime \prime}$. No caso de Núbia e sua irmã, a condição de residirem no trabalho eliminou, momentaneamente, a preocupação com moradia. Mas trazia outros níveis de dificuldades, um deles associado justamente à perspectiva de "morar de favor em casa de patroa", vendo a vida reduzida ao trabalho, sem outros vínculos sociais na cidade e sem nenhuma liberdade.

Eu sei que é difícil, viu Thaís, no começo foi muito difícil. Porque a gente era de fora, morava em um emprego, tinha uma folga só por mês, sabe, a gente não tinha todo fim de semana de folga.. Muitas vezes coincidia de, no domingo, eu querer visitar minha mãe, e eu não podia ir porque eu tinha que estar trabalhando, e tudo isso complicava muito. Me deixava bem para baixo, mexia muito com a minha cabeça. (...) Então, por um lado, vir pra cá foi muito bom, porque eu acabei me livrando dos maus tratos [do pai adotivo]. Esse foi o lado bom da situação. Mas, por outro lado, eu tinha essa preocupação com minha mãe, e morar no trabalho não era fácil... essa era a pior parte. (...) Eu lembro que, no começo, eu estranhei bastante, porque era uma cidade que eu não conhecia, não tinha amigos, morava no serviço. Então o primeiro ano foi muito difícil. Eu ficava mais no trabalho, porque não conhecia ninguém, eu não sabia, por exemplo, como sair de Estância Suíça [bairro onde se localizava a casa da patroa] e chegar na Avenida [São Carlos, principal eixo viário da cidade], sabe, porque eu trabalhava o dia todo, morava no serviço e... Não tinha aquele tempo de sair, né? ${ }^{5}$ [Núbia]

2 Para uma reflexão sobre o processo de urbanização de São Carlos e os locais de moradia dos trabalhadores pobres até o início dos anos 1980, ver Devescovi (1987).

3 Rosa (2008).

4 Cf. pesquisa documental realizada durante o mestrado, para a elaboração de Rosa (2008). A década de 1970 assistiu à intensificação do processo de periferização da expansão urbana de São Carlos, com a abertura de setenta e seis novos loteamentos, ao menos treze deles de forma irregular (PMSC, 2010).

5 Nas citações de trechos das entrevistas gravadas e transcritas ou conversas registradas em diário de campo, seguindo Bourdieu (2008:697,710), optei por "aliviar o texto", omitindo "frases confusas, redundâncias verbais ou de tiques de linguagem" (os excessos de bom, né, sabe, ou mesmo conversas paralelas que por vezes ocorriam, com a chegada de um filho ou um vizinho), bem como alguns "sinais 
Foram alguns anos nesta situação: trabalhando para ajudar no sustento da mãe, angustiada, dividindo-se entre construir uma vida na nova cidade - com todas as limitações que morar no emprego e ter apenas uma folga por mês lhe impunham - e manter os mínimos vínculos que a ligavam à família. Obviamente, apesar dos maus bocados enfrentados, nem só de sofrimento e trabalho se fizeram seus primeiros tempos na cidade de São Carlos: jovens, solteiras, sem filhos e livres da marcação mais que cerrada do pai, após cerca de um ano na cidade, Núbia e sua irmã já circulariam com um pouco mais de desenvoltura pela região central (onde a patroa residia), divertindo-se em bailes e concursos de dança promovidos em espaços culturais historicamente frequentados por negros na cidade de São Carlos (em especial o Grêmio Recreativo Flor de Maio ${ }^{6}$ ). Foram nesses primeiros poucos "circuitos"7 de lazer dos negros na cidade que se teceram suas primeiras relações sociais, fundamentais quando elas decidiram deixar de morar no emprego:

Eu falei pra minha irmã: 'quer saber de uma coisa? Não quero mais morar em emprego não, vou procurar um canto!' Eu queria muito deixar de morar no emprego, não aguentava mais aquela falta de liberdade, porque, por mais conforto que a gente tenha, não é como estar na casa da gente, entendeu? Fica aquela coisa meio fora, dá um certo incômodo, não pode receber ninguém, não tem liberdade. Daí a gente saiu procurando, pedindo ajuda pros poucos conhecidos que a gente tinha... pergunta pra um, pergunta pra outro e, aí, uma conhecida que trabalhava ali perto me indicou pra uma mulher, que tinha um cômodo e um banheiro desocupados, pra alugar. Aí ela me indicou, a mulher aceitou, e assim acabamos arrumando uma casinha. [Núbia]

Com o salário reduzido após deixar de morar no emprego, ainda assim ela e a irmã conseguiram alugar um cômodo em um bairro limítrofe ao centro, no perímetro máximo da cidade que ela conhecera até então": "naquela época, aluguel no centro não era como hoje. Dava pra pagar." Elas mantinham a dinâmica de, periodicamente, visitar a mãe internada, até que um dia, em uma dessas visitas, receberam a notícia de que a mãe já havia morrido há mais de uma semana. Depois disso, Núbia romperia definitivamente os vínculos com a família, com exceção da irmã que ainda vivia com ela em São Carlos.

Era final dos anos 1970, e esse foi um período muito difícil para Núbia, que tinha pouco mais de vinte anos: ela se afundou na bebida; sua irmã se envolveu com drogas; ambas perderam o emprego, passando a realizar alguns bicos como diaristas. Núbia engravidou de seu namorado e perdeu sua primeira filha três meses após o

verbais" ("sinais de feedback") de minhas interações com o entrevistado (como, por exemplo: Hum hum, entendi, certo, claro, me fale mais disso), que poderiam prejudicar o entendimento do relato.

6 Fundado na década de 1920, é um dos mais antigos clubes sociais negros na região, sendo referenciado em diversos relatos de meus interlocutores. O local permanece em atividade ainda hoje.

7 Cf. "família de categorias" proposta por Magnani (2002, 2005).

8 Nos Anexos encontra-se um mapa de referência espacial da trajetória habitacional de Núbia. 
parto; logo depois, engravidou novamente e, pouco antes de o filho nascer, ela e a irmã tiveram que deixar a casa onde viviam, por não conseguirem mais arcar com o custo do aluguel. Seu companheiro, morador da cidade há um pouco mais de tempo ${ }^{9}$ e já escolado em viver de aluguel na cidade com a mãe e o irmão, conseguiu um cômodo em um beco na região central da cidade, onde viveram, por um tempo, ela, ele, o filho (Jimmy) e a irmã, que logo se mudaria para São Paulo, envolvida com tráfico de drogas ${ }^{10}$. Por volta de 1983, a irmã seria presa em São Paulo - para onde Núbia fora uma única vez na esperança de vê-la, sem sucesso. Rompia-se seu último elo com a família, ao passo que também sua relação com o companheiro se desfazia: ele a traía há tempos, e ela finalmente o expulsou de casa, ficando sozinha com o filho. É dessa época, também, uma disputa informal com a avó do menino pela guarda da criança, que acabou permanecendo com ela. E, como se não bastasse, ainda teria de mudar-se novamente de casa:

Tive que mudar porque o dono faleceu. Ele era amasiado com uma mulher há muitos anos e faleceu. Aí deu um rolo danado na justiça, porque a irmã queria tomar posse, a mulher não queria entregar... Eu sei que virou um rolo danado! E eu e mais outros inquilinos no meio, porque era um quintal com várias casas. Eu falei: 'antes que o despejo sobra, né'... Porque o advogado já tinha alertado, então eu pensei 'deixa eu caçar rumo de sair fora'. Aí eu mudei de lá. [Núbia]

Seria o início de uma vasta trajetória de deslocamentos habitacionais pela cidade, na qual se mostrariam de suma importância as redes de relações ${ }^{11}$, estabelecidas progressivamente. Após a prisão da irmã e a ruptura com o companheiro, Núbia, agora mãe solteira, se virou como podia na cidade, caçando rumo ${ }^{12}$ entre casas ou cômodos de aluguel em quintais e becos nos quais habitavam outras famílias pobres,

9 A mãe dele (avó de Jimmy, o primeiro filho de Núbia) também havia migrado para São Carlos, sozinha e com dois filhos, em busca de emprego, no início dos anos 1970. Ela conseguiu se inserir em uma das indústrias locais, chegando a, posteriormente, construir uma casa própria no bairro Jardim Medeiros.

10 Cf. pesquisa documental realizada durante o mestrado, é no início dos anos 1980 que aparece pela primeira vez nas atas da Câmara Municipal de São Carlos a questão do "tráfico de tóxicos" e da "criminalidade" na cidade, que, a partir de então, passa a ser tema cada vez mais recorrente nas mesmas.

11 Vale dizer, desde já, que não se trata daquelas já bastante estudadas "redes extensas de solidariedade e ajuda mútua" articuladas como "estratégia de sobrevivência nas situações de extrema penúria" (Chalhoub, 2005:228): são, antes, conexões situacionais, "reciprocidades episódicas" (Joseph, 1999), que se articulam e se desfazem na medida dos intensos deslocamentos habitacionais experimentados por Núbia. Esse aspecto recobrará importância no Capítulo 3.

12 A ideia de caçar rumo é bastante recorrente nas narrativas de Núbia e parece sintetizar sua condição durante grande parte de sua trajetória, associando-se a constatação de "ter que se virar sozinha", em tudo distante tanto dos direitos como das tutelagens sociais. Essa ideia passa a aparecer nesse contexto de ruptura completa com os vínculos familiares e construção de novas redes de relações (centradas na concepção de ajuda mútua), em grande medida mediadas por seu novo papel de mãe. Essa ideia de caçar rumo também aponta para uma introjeção da dimensão do acesso a moradia como dever privado, algo que depende exclusivamente dela, individualmente e/ou articulada a suas redes. 
e empregos intermitentes como doméstica ou diarista. Seus relatos dão conta da existência de um dinâmico mercado informal de alugue ${ }^{13}$ no centro da cidade, nas décadas de 1970 e 1980, ainda acessível às camadas populares e cujos modos de operação, sobretudo a necessidade de indicação prévia de alguém para conseguir alugar um imóvel, seriam muito semelhantes aos encontrados mais recentemente nas periferias, como veremos adiante.

Conseguia as casas sempre por indicação de alguém. Quando precisava de uma... eu falava: 'nossa, eu preciso mudar, preciso entregar a casa', qualquer coisa desse gênero... porque eu já tinha criança na creche, tinha mais conhecimento, né, então era sempre por indicação de alguém. (...) Aquela época, no centro, era fácil, né, Thaís, não era... Por exemplo, você tava procurando casa, e alguém indicava. la lá e a pessoa alugava. Não era esse fervo de imobiliária que é hoje! Antigamente, a maioria dos contratos era no boca a boca. Um que conhecia, que indicava... as pessoas não exigiam tanto fiador como hoje, então... era bem mais fácil. [Núbia]

Embora desde os anos 1940/50 tenha se dado, em São Carlos, a progressiva periferização dos espaços de moradia dos trabalhadores pobres na cidade e, a partir dos anos 1960, tenha se instaurado um "processo de sensíveis alterações no panorama urbano", com a intensificação do uso dos espaços centrais da cidade por comércio e serviços de elite (como a instalação de agências bancárias) e a consequente demolição de antigas residências - processo que se amplificaria ainda mais nas décadas de 1970 e 80, sobretudo em termos de verticalização de novas edificações (a partir do qual a região central e suas adjacências passaram a ser ocupados prioritariamente por camadas médias da população) ${ }^{14}$-, a trajetória de Núbia deixa entrever os movimentos daqueles mais pobres que insistiam em ali permanecer, oferecendo, de alguma maneira, entraves à univocidade desse processo durante os anos 1980 e 1990.

13 A temática dos "mercados informais de solo" (aí envolvidas transações de bens fundiários e imobiliários), vem sendo pesquisada de forma sistemática, no Brasil, sobretudo por Abramo (2003, 2007,2009 ). O enfoque de tais pesquisas (que acabaram por se articular em uma importante rede de pesquisadores - Rede Infosolo), entretanto, esteve mais centrado no funcionamento de tais mercados no âmbito de favelas, ou, de modo mais genérico, "assentamentos informais" (Cf. Abramo, 2009: "a sua base territorial, por definição, é uma propriedade que não respeita os preceitos do direito de propriedade e/ou urbanístico, e assim assume uma dimensão de informalidade urbana"). Não encontrei bibliografia referente especificamente a mercados informais em regiões centrais, como é o caso da dinâmica que a trajetória de Núbia permite entrever; mesmo estudos sobre tal mercado em bairros periféricos são escassos. Além disso, predominam os estudos dos mercados informais de compra e venda de imóveis residenciais em favelas, sendo o mercado informal de locação tema ainda relativamente pouco estudado. Voltarei a essas questões adiante, mas vale reter, aqui, que a trajetória de Núbia permite entrever a continuidade de uma mesma lógica de mercado informal de moradia que existia no centro e se desloca para a periferia da cidade, e que é invisibilizada do ponto de vista dos estudos sobre o tema.

14 Devescovi (1988:185); Dozena (2001). 
Se, inicialmente, Núbia conseguiu manter-se empregada (ainda que com períodos de intermitência) e sustentar individualmente a vida de aluguel no centro da cidade, em pouco tempo os simultâneos processos de pauperização das camadas populares no país e de intensificação das mudanças na organização socioespacial da cidade (com a crescente valorização imobiliária da região central e seus bairros contíguos), associados ao maior estabelecimento de redes de relações a partir de sua condição de mãe, vinculada sobretudo à creche onde seu filho passava o dia, levou-a às suas primeiras experiências de coabitação sem relação de parentesco, dividindo os custos de moradia com outras mulheres em condições semelhantes às dela.

Esse ponto da trajetória de Núbia permite apreender que motivos diversos, não apenas e nem sempre de ordem econômica, mobilizam os deslocamentos habitacionais e sua amplitude, que são, em grande medida, regidos pelos movimentos também nas redes de relações. Inicialmente concentradas basicamente na região central, até meados dos anos 1980 tais redes ainda não a haviam levado como era o caso de tantas outras famílias com as quais travei contato em minhas pesquisas - nem aos loteamentos periféricos em franco processo de expansão e consolidação (destino certo daqueles que, vindo em busca de empregos nas indústrias locais e, uma vez exitosos, logravam consolidar o "projeto operário", no qual a autoconstrução de moradia própria em loteamentos periféricos configurava pilar fundamental); nem à crescente Favela do Gonzaga (destino daqueles que não conseguiam lograr tal "projeto" e, estando já situados nos "bairros de trabalhadores" na região sul, acabavam recorrendo àquela ocupação como forma de permanecer na cidade); nem, ainda, aos históricos locais de moradia dos negros na cidade desde o pós-abolição, então ainda significativos e já integrados à malha urbana. ${ }^{15}$

\footnotetext{
É, era aquele negócio, eu trabalhava, tinha as crianças pra cuidar, não tinha muito tempo de sair pra procurar, então o que aparecia eu pegava. E como eu já tava por ali, pelo centro, conhecia as pessoas que tavam por ali, acabava aparecendo por ali mesmo e eu ficava, assim, por ser uma coisa que apareceu primeiro. Porque eu fazia assim ó: era assim, falava com um, falava com outro, e a primeira opção que aparecia eu ia, então... como meus conhecidos tavam por aqui, no começo aparecia mais aqui pelo centro mesmo. Quando começou a aparecer nos bairros, eu fui também. Mas pra mim, de certa forma, era bom morar no centro, porque eu tinha mais facilidade para as crianças irem para a escola e levar os pequenos pra creche. [Núbia]
}

Em 1984, Núbia engravidaria novamente, de um novo companheiro, irmão de suas primeiras amigas na cidade, Dália e Benê, conhecidas naquele já mencionado circuito de lazer dos negros na cidade. Núbia chegou a morar por pouco tempo com esse rapaz, mas o relacionamento também não durou. Ainda assim, ali se iniciaria uma

15 Cf. Devescovi (1987); Rosa (2008); TEIA (2005); Oliveira (2012). 
primeira aproximação à família extensa das amigas Dália e Benedita, que, em momento posterior, se tornará referência fundamental em sua trajetória.

Novamente sozinha, agora com dois filhos para criar e desempregada após o nascimento do segundo filho, a coabitação seria, mais uma vez, sua salvação: uma mãe conhecida na creche, recém-separada do marido e sabedora da situação de Núbia, ofereceu a ela um cômodo em sua casa para morar com os dois filhos, em troca de cuidar de seus quatro filhos enquanto ela trabalhava. Pouco tempo depois, a mulher partiria para São Paulo, deixando os filhos aos cuidados de Núbia. Ela, então, passaria quase cinco anos sem trabalhar, apenas cuidando de seus filhos e dessas crianças, cujo pai arcava com as despesas básicas de manutenção, incluindo o aluguel da casa. Sem condições, porém, de seguir arcando com dois aluguéis, o pai das crianças os leva, a todos, para sua casa alugada no bairro Jardim Botafogo, até que, por volta de 1988, transferido no emprego para outra cidade, muda-se com os filhos, deixando a casa alugada e mobiliada com Núbia.

O período em que Núbia viveu com essa família foi o primeiro momento em que ela morou fora da região central, em bairros periféricos em dois extremos da cidade à época. Com a partida da família, Núbia volta à vida de aluguel e, nesse mesmo ano, ela e os dois filhos mudam-se mais duas vezes, no próprio Jardim Botafogo, então o limite sudoeste da malha urbana ${ }^{16}$. Suas narrativas evidenciam que, diferente do que ela conhecera na região central, o mercado de aluguel nos bairros periféricos se configurava então, mormente, como uma espécie de híbrido entre coabitação e mercado informal de aluguel, no qual famílias disponibilizavam cômodos construídos no quintal de suas próprias casas, como forma de incrementar a renda doméstica, e apontam para as adversidades, vicissitudes e violências simbólicas latentes a que estava sujeita ao depender desse mercado para obter uma moradia, sobretudo sendo mulher, sendo negra, sendo jovem, sendo mãe solteira:

A casa da dona Julieta eu saí porque... o marido dela era folgado. Ela tinha dois cômodos e um banheiro no fundo que era para alugar. Mas como na época eu era sozinha com os dois meninos, o marido dela perturbava muito, sabe? Ele ia bater na porta de noite, batia na janela, queria ter caso comigo... Falei: 'isso aqui não vai dar certo, não vai prestar!' Porque, no fim, a filha dela começou a invocar comigo, porque achava que eu dava em cima do pai dela... Aí eu falei 'não'... resolvi sair. [Núbia]

16 Conforme as lembranças de Jimmy, filho mais velho de Núbia: “Tipo, eu lembro de São Carlos bem antes da minha adolescência, assim, sabe? Quando eu ainda era criança, a gente pegava, é... o bairro mais longe aqui era o Cruzeiro do Sul, não tinha nem o Monte Carlo direito, a gente morava lá no Botafogo, tem uma igreja lá, que acho que é São Nicolau, daquela igreja pra baixo, não tinha nada, não tinha [o conjunto habitacional] Romeu Santini, não tinha os predinhos [conjunto promovido pela $\mathrm{COHAB}$, não tinha o [bairro Jardim] Medeiros, não tinha nada, era tudo mato, ali no Botafogo era o fim da cidade." 
Após o período vivido com essa família, Núbia enfrentaria grandes dificuldades ao ter de voltar à vida de aluguel, pois estava desempregada, e os filhos, de três e oito anos, necessitando maiores cuidados e gastos: "Eu tava com dificuldade, sabe, eu não tava dando conta de me manter sozinha com as crianças, com os dois. Fiquei desesperada". Tendo conseguido um emprego de doméstica numa casa onde ela poderia, inclusive, morar (mas sem os filhos), Núbia tomaria a difícil decisão de deixálos, temporariamente, em um abrigo para menores ${ }^{17}$. Entretanto, apenas William, de 3 anos, acabaria tendo esse destino, já que Jimmy, por insistência de sua avó, foi interceptado pelo pai, com quem viveria, por quase dois anos, nas cidades de Matão e São Paulo. Foi o primeiro momento em que as dificuldades financeiras e de acesso à moradia resultariam em interferências mais drásticas em suas dinâmicas familiares, sobretudo relativas à criação dos filhos: nesse caso, ela - mulher, jovem, negra, mãe solteira -, para continuar sobrevivendo na cidade (nessa cidade que ela conhecia então, cujas redes de relações ainda não a levavam para outras alternativas de moradia, como as ocupações), acabou por abdicar, temporariamente, da guarda dos filhos, acreditando que, em breve, ela teria melhores condições financeiras e habitacionais e poderia reavê-los.

O emprego conseguido junto a essa família (aqui denominada família D.) e, sobretudo, a relação estabelecida com a patroa foram recorrentemente destacados por ela como de grande importância em sua trajetória desde então: seriam mais de vinte anos, entre idas e vindas, trabalhando nas mais diversas funções - faxineira, arrumadeira, babá, cozinheira, balconista de padaria, atendente de açougue -, mas, prioritariamente, como empregada doméstica ${ }^{18}$. Apesar de os patrões viverem na

17 Essa atitude parece corroborar a inconsistência de redes de relações a ampará-la na cidade nesse momento, já que, como diversos estudos apontam - incluindo minhas próprias pesquisas de campo em casos onde redes sociais de parentesco, amizade ou vizinhança encontram-se minimamente consolidadas, a "circulação de crianças" passa a compor um conjunto de obrigações morais (Fonseca, 1995; Guedes, 2008, ancoradas nos "deveres de reciprocidade" (Chalhoub, 2005). Nesse caso, sem tais redes, a alternativa foi recorrer a uma prática relativamente comum entre os mais pobres até a promulgação do Estatuto da Criança e do Adolescente, em 1990: a de encaminhar crianças para instituições assistenciais conveniadas com a então Fundação Estatal de Bem Estar do Menor - FEBEM, cujo público majoritário era composto pelos chamados "menores carentes e abandonados" (Mallart, 2011). Cf. Fonseca (2007:4): “Había una infinita cantidad de razones por las cuales una mujer querría institucionalizar a un niño: por ejemplo, si estaba pasando por un período financiero particularmente malo (lo que era usual), si estaba sin hogar, si se había casado nuevamente y su pareja actual se negaba a sustentar a niños de uniones anteriores. (...)De cualquier forma, las madres que conocí, que habían institucionalizado a un hijo o a una hija, generalmente consideraban que era un arreglo transitorio y esperaban traerlos a casa 'tan pronto como las cosas mejorasen'".

18 A vinculação de Núbia a essa patroa, que, tendo oferecido suporte material e simbólico em diferentes "momentos difíceis" da trajetória de Núbia, é sempre referida por ela como uma "mãe", é característica da ambivalência das relações entre patroas e empregadas, em que coexistem desigualdade e afetividade, lealdade, paternalismo e lógicas de mercado, e nas quais o intercâmbio de bens materiais e simbólicos ocupa lugar central (Preuss, 1997; Vidal, 2009; Georges, 2009; Dantas, 2013). Sobre a "ambiguidade afetiva" (Brites, 2007) que seria constitutiva de tais relações, este trecho dos relatos de Núbia é significativo: "ela era uma pessoa que não era uma patroa, ela era uma mãe, 
região central da cidade, as redes de relações de Núbia, a essa altura, já se concentravam cada vez mais nas periferias da cidade, sobretudo no Jardim Botafogo, onde vivera nos últimos anos. Lá, ela engravidou de um rapaz do bairro, com quem há anos mantinha um relacionamento. Mas, mesmo após o nascimento de sua terceira filha, Diana, em 1989, Núbia permaneceu morando na casa da patroa. Nesse período, conseguiu reaver a guarda parcial do filho William, que passaria a ficar com ela nos finais de semana e nas férias, na casa dos patrões; para lá também retornaria Jimmy, o filho mais velho, após a temporada com o pai. Empregada, e sem os custos da moradia, a vida parecia voltar a melhorar.

Em 1991, Núbia engravidaria novamente (do mesmo pai de sua filha Diana), tornando-se, agora, inviável permanecer morando na casa da patroa (e, após o nascimento do filho, até mesmo permanecer trabalhando ali, já que não era registrada e não conseguiria creche para o filho tão cedo). Após uma tentativa frustrada de morar com o pai de seus filhos mais novos, Núbia rompeu definitivamente com ele e foi acolhida por Dália e sua família, que, então, já se tornara sua familia são-carlense ${ }^{19}$, dividindo com ela o aluguel de uma edícula nos fundos de uma casa na Vila Jacobucci, bairro às margens da rodovia Washington Luís, na extremidade leste da cidade à época: "era muita criança junta! Porque os meus eram pequenos, os dela eram pequenos... uma criançada! E a gente trabalhava fora e se ajudava". Dali, elas e os respectivos filhos (totalizando sete crianças) mudaramse para uma casa cedida a Dália por uma antiga patroa, em um lugar bastante privilegiado na região central da cidade, o que facilitaria a elas a busca de emprego e a organização das dinâmicas cotidianas com os filhos, que passavam o dia entre a creche e uma instituição evangélica onde participavam de projeto social.

O expediente de morar junto a conhecidas, acionado diversas vezes em sua trajetória, representa, nesse momento, não apenas um alívio nos custos de moradia, mas

sabe? Porque eu trabalhava bastante, verdade, mas ela me recompensava de outra forma. Porque, por exemplo, meus filhos precisavam de escola, ela corria atrás. Quando... chegava a época do começo das aulas, ela falava assim: 'não precisa ficar preocupada com material de escola, que eu vou atrás...' Ela fazia tudo para mim. Então, ela sempre me deu um suporte muito grande. Era uma relação de troca, porque tanto funcionava bem para mim, quanto para ela também... e com isso, eu praticamente criei todos os meus filhos lá, trabalhando lá. Sabe e... foi muito bom". Esse tema será retomado no capítulo 3, pela centralidade na trajetória ali investigada.

19 A antropologia social acumula já vasto repertório de estudos sobre as famílias populares e suas articulações a redes sociais nas quais o idioma do parentesco aplicado a relações densas que não envolvem consanguinidade (compadrio, amizade, vizinhança, religião), o denominado "parentesco por consideração", desempenha papel fundamental. Nesse sentido, me foram esclarecedores os trabalhos de Marcelin (1999), Guedes (1998, 2008), Duarte e Gomes (2008) e McCallum e Bustamante (2012), justamente por apontarem os imbricamentos entre tais relações e as concepções de casa e vizinhança daí decorrentes. A relação de Núbia com essa família “por consideração" será determinante nos rumos futuros de seus deslocamentos habitacionais, bem como de sua experiência urbana, como veremos. 
também um suporte fundamental nos cuidados e dinâmicas cotidianas com os filhos. $E$, se foi responsável por seus primeiros deslocamentos habitacionais rumo às periferias da cidade, foi também, em grande medida, o que permitiu que ela vivesse tanto tempo no centro da cidade ${ }^{20}$.

Era tudo junto, a gente morava tudo junto, mas por exemplo, a gente dividia, porque naquela situação, eu trabalhava e a outra pessoa também. Então por exemplo, a gente chegava em casa tarde, se eu ia pro tanque lavar roupa, eu ia lavar roupa e ia cuidando da janta da cambada, a outra ia cuidar da limpeza da casa e dar banho na criançada, então a gente ia sempre dividindo, pra uma não ficar mais sobrecarregada do que a outra, então é um esquema assim, que sempre funcionou bem. Me ajudou bastante, igual, a Dália mesmo, quando a gente morava junto ela tinha as crianças pequenas, então a gente fazia assim, não vamos sobrecarregar demais uma a outra, por exemplo, se eu levava pra creche de manhã, a tarde a Dália pegava, assim não cansava demais nem eu, nem ela. [Núbia]

Nesse contexto, ela decide reaver definitivamente a guarda de seu filho William, não sem muita dificuldade ${ }^{21}$ : a assistente social queria encaminhá-lo para adoção por um casal de italianos, sob a justificativa de que Núbia não teria condições - estrutura familiar, residência e emprego fixos e, sobretudo, "adequados" - de criar o filho. Foi necessário que Núbia comprovasse que estava morando em uma casa decente, que estava empregada e que já tinha garantido a vaga do filho em creche e projeto socioeducativo para que conseguisse reaver definitivamente sua guarda. Não seria a primeira nem a última vez que a ausência de moradia (ou, sobretudo, o argumento

20 Chalhoub (2005), em seu já clássico estudo sobre o cotidiano dos trabalhadores nas últimas décadas do século XIX e primeiras do século XX na então capital da República, o Rio de Janeiro, detecta a coabitação não apenas entre parentes, mas também entre conhecidos e até entre casais com poucos vínculos, como esforço individual "ingente" decorrente dos "ajustes e estratégias de sobrevivência praticados pelos populares com o objetivo de contornar o problema da habitação" que se intensificava sobremaneira no contexto das reformas "civilizatórias" promovidas por Pereira Passos, tornando-se tal prática em um dos grandes focos de tensão e violência entre os trabalhadores. Oitenta anos depois, em um contexto em que o problema da moradia não chegou a ser tão grave como aquele, vemos ainda a mesma prática em vigência, não mais entre casais pauperizados, mas entre mulheres pobres, mães solteiras. Interessante notar que, progressivamente, essa opção deixará de existir para Núbia (e, sobretudo, não será sequer alternativa cogitada por seus filhos), apontando para uma transformação importante nos imbricamentos recentes entre redes de relações, dinâmicas familiares e modos de habitar entre os populares.

21 Cf. Fonseca (2007): “Aquellas mujeres, que un tiempo después aparecían en el orfanato listas para asumir su maternidad, en algunos casos tras de años de ausencia, quedaban estupefactas cuando les informaban que sus hijos habían sido declarados "abandonados" y dados en adopción. Incluso aquellas que firmaban um papel consintiendo la adopción de sus hijos, parecían no comprender la idea de que habían sido desligadas permanentemente de la maternidad y que sus hijos habían desaparecido para siempre. Desde su punto de vista, habían dejado a sus hijos al cuidado de la institución, con el mismo espíritu con el que lo hubieran dejado con una abuela o una vecina. (...) En el enfrentamiento de la madre biológica con las autoridades del Estado, el choque de racionalidades diferentes era completamente evidente." 
de autoridade sobre a ausência de "moradia adequada") quase a impediria de criar os próprios filhos 22 .

Surgida a necessidade de deixarem a casa cedida, que estava em juízo por problemas familiares, a amiga Dália consegue um cômodo na então recente ocupação de um antigo orfanato, nos limites do bairro Monte Carlo (na região sul da cidade), e, sendo ele muito pequeno para abrigar as duas famílias e não havendo outro barraco disponível ("na época não tinha mais nada vago no Orfanato, já tava entupido"), Núbia - que havia voltado a trabalhar para a família D. - permanece na região central, alugando uma das várias casas de aluguel mantidas em uma espécie de chácara urbana por um conhecido personagem são-carlense proprietário de terras, denominado Juca Miséria. Porém, a precariedade da casa e o alto custo do aluguel a levariam a sair de lá e, mais uma vez, seguir em direção à periferia, para alugar um cômodo nos fundos de uma casa no bairro Monte Carlo, nos arredores da ocupação do antigo orfanato, conseguida por intermédio de Dália. Entretanto, a localização distante $^{23}$ e aspectos subjetivos da sua relação com a proprietária, que morava na casa da frente, fizeram com que passasse pouco tempo ali:

Era muito distante pro que eu precisava, trabalhando, com as crianças... Sem contar que ela bebia muito, mexia com droga e dava trabalho, entrava na casa que era nossa, eu sozinha com as crianças... E no centro, pra mim, era melhor, era mais fácil pra trabalhar e levar as crianças nas escolas, nos projetos. [Núbia]

A isso se somava a dificuldade em seguir arcando, sozinha, com os custos de aluguel, mesmo na periferia, e a opção foi buscar alguma forma de voltar a morar no centro: "A gente não aguentou pagar o aluguel e voltou pro centro, pra tentar se virar" [Jimmy].

22 Ao narrar este acontecimento, ela se lembra de diversas conhecidas que passaram por situação semelhante e que, ao contrário dela, não conseguiram reaver a guarda dos filhos por esses mesmos motivos, entre os quais, a ausência de "moradia adequada" ocupava peso considerável. Nesse sentido, também uma passagem da trajetória de um ex-interno da Febem reconstituída por Mallart (2011:47) chama a atenção para essa questão: a mãe do rapaz, que entregara os três filhos para a instituição, após anos consegue readquirir a guarda dos filhos ao comprovar estabilidade financeira (emprego formal) e a aquisição de uma casa própria, apontando para uma experiência comum, em que gênero e pobreza se articulam em termos da impossibilidade de vida digna para as mães solteiras e pobres na cidade, onde a questão da moradia desempenha papel fundamental.

23 Vale chamar a atenção, aqui, para o jogo de perspectivas sobre a cidade que se opera na trajetória de Núbia, conforme suas experiências urbanas vão se transformando: nesse momento, em que sua principal referência ainda era o centro, ela considerava esse novo lugar de moradia distante; depois de chegar a viver muito tempo na ocupação do antigo orfanato (situada nessa mesma região), e, em seguida, no bairro Cidade Aracy (ainda mais distante), o mesmo local passou a ser considerado bem perto do centro, já que a referência de lugar distante passaria a ser o Cidade Aracy, como veremos adiante. Também Jimmy dá conta desse jogo de perspectivas, como neste trecho: "Quando eu morava no Botafogo, depois no Monte Carlo, a gente pegava ônibus ali e pra gente era uma vida pra chegar no centro, na época. Depois que morei no Orfanato, que eu ia a pé pro centro, e mesmo hoje, que chego a ir a pé daqui do Aracy até lá, acho uma piada." 


\section{- Anos 1990: ocupações como condição de permanência no centro}

Após essas duas tentativas renovadas de voltar a viver de aluguel, os relatos de Núbia e Jimmy dão conta do quanto, desde meados dos anos 1980, tal condição tornou-se cada vez mais difícil, sobretudo na região central da cidade ${ }^{24}$, onde ela insistia em permanecer em função de minimizar os deslocamentos cotidianos na difícil logística de conciliar o trabalho como empregada doméstica e os cuidados com os quatro filhos.

É, morar no centro me facilitava bastante. Então eu também acabava ficando, voltando, por causa disso, mais pela facilidade também de serviço, de creche, de escola, né, porque todos eles passaram pela creche ali. Igual, quando voltei a morar no centro, quem ficava na creche era a Diana e o Jaelson, e eu, era aquele negócio, eu tinha horário pra entrar no trabalho, mas eu não tinha horário pra sair. Então, normalmente, pegava as crianças das 17 h00 às $17 \mathrm{~h} 30$, mas nunca que cinco horas da tarde eu estava desocupada pra ir embora pra casa, sabe, eu tava de serviço até o pescoço. Né, então era aquele negócio, às vezes trabalhava doze, quinze horas por dia, eu saía de casa 6 h30 da manhã e ia entrar em casa 21h30, 22 h00 da noite. / Thaís: E aí, as crianças? / E aí é aquele negócio, o Jimmy foi crescendo e eu fui ensinando, 'ó você faz arroz assim, você cozinha o feijão assim, você tempera o arroz assim, tempera carne assim'... fui ensinando, pra ele poder se virar com os irmãos na hora que eu não tivesse em casa. Porque às vezes eu chegava e fazia comida, muitas vezes eu chegava cansada e não fazia, deitava e dormia. E ainda era aquele negócio, chegava, tomava banho, deitava e dormia, no outro dia levantava, fazia café, tomava café, mandava pra creche, mandava pra escola... / Thaís: Claro. E aí o fato de vocês estarem ali facilitava pra ele também... / É, pra ele fazer essas caminhada pra mim. Tinha dia que eu levantava correndo, ele falava pra mim: 'não, mãe, pode ir trabalhar tranquilo, só troca as crianças, que eu levo na creche'. Então ele descia na creche, levava as crianças, depois subia correndo, porque ele estudava por ali também, aí ele ia pra escola. Quando chegava à tarde, ele passava lá no meu serviço e: 'ó mãe, pode ficar tranquila, que eu tô indo buscar as crianças'. [Núbia]

Ela iniciaria, então, um significativo itinerário por casas cedidas ou invadidas: os deslocamentos habitacionais, nessa primeira metade da década de 1990 , não são mais em busca do menor aluguel, mas da possibilidade de viver sem ele. A primeira delas foi um casarão cedido por sua patroa, pertencente à tia desta e que se encontrava desocupado: ela moraria ali sem custos em troca de cuidar da casa, justamente para preservá-la de invasões (dando indícios de uma prática então recorrente no centro da cidade e que, por ironia do destino, seria justamente o

24 Nessa mesma época, registros nas Atas da Câmara Municipal dão conta de uma "grave crise habitacional" e de um "crescimento vertiginoso" do déficit habitacional na cidade, enfatizando a necessária atuação da PROHAB - Progresso e Habitação São Carlos, empresa mista destinada a operacionalizar as políticas habitacionais no município, constituída em 1985, sobre a qual voltarei a falar adiante. De fato, se ao longo da década de 1970 e até a constituição da empresa o número de moradias produzidas no município de que se tem notícia não alcançavam 300 unidades, a década de 1980 assistirá à construção de pouco mais de 1000 moradias na cidade, todas em áreas periféricas da cidade, envolvendo órgãos como PROHAB, COHABs - Companhias de Habitação (Bauru e Ribeirão Preto) e CDH - Companhia de Desenvolvimento Habitacional do Estado de São Paulo. 
caminho seguinte de Núbia). Após pouco mais de um ano, com a morte da proprietária, os demais filhos decidiram pôr a casa à venda, e Núbia teria que "caçar rumo" novamente.

Foi quando ela partiu para sua primeira ocupação: uma conhecida, que trabalhara com ela na casa dessa mesma patroa, havia invadido uma casa na mesma região e a convidou para ir morar lá também. Em questão de meses, porém, elas foram expulsas pelo proprietário, e Núbia viu-se novamente na urgência de ter que arrumar outro lugar para morar com os filhos. Mais uma vez, faz funcionar suas redes de relações prioritariamente femininas (mães da creche, professoras, colegas de profissão) -, através das quais ela toma conhecimento de outra ocupação, próxima dali, conhecida como casarão 2020, que seria o endereço da família durante quase dois anos, entre 1993 e $1994^{25}$.

Boa parte do período em que viveu nesse casarão coincide com mais um dos períodos de intermitência em relação ao seu trabalho para a família D. Após um tempo desempregada, Núbia consegue, através de sua já mencionada amiga Dália, um emprego em obras de casas populares em dois bairros periféricos da cidade (primeiro, no Jardim Santa Felícia e, depois, no Jardim Botafogo, onde ela mesma já havia morado): ela e outras colegas iniciaram trabalhando como faxineiras, fazendo a limpeza das casas que já estavam finalizadas, e, ao fim das obras, já estavam trabalhando como serventes de pedreiro e fazendo tudo o mais que fosse necessário. É desse momento seu conhecimento da existência da PROHAB e das políticas habitacionais implementadas na cidade, que depois assumirão papel importante em sua trajetória: apesar de trabalhar na produção dos conjuntos habitacionais, a perspectiva de acessar uma casa própria não se fazia presente para ela nesse momento, talvez por acreditar que "aquelas casas não eram pro nosso bico, a gente era pobre demais" 26 .

Pra você ver, trabalhei como servente nas casas da Prohab. E, naquela época, eu era mais cabeça fresca, nem pensei em fazer inscrição, nada. Até então, eu nem sabia que existia isso, essas casinhas. Foi meu primeiro contato. Na realidade, eu, uma tia dos meninos, a avó deles e mais uma amiga, nós fomos trabalhar lá

25 Sobre tais ocupações na região central, as narrativas de Núbia e Jimmy evidenciam que, no início dos anos 1990, essas práticas não eram tão residuais, sendo mesmo recorrentes: acompanhando a articulação entre os deslocamentos habitacionais e as redes de relações de Núbia, apreendem-se circuitos de moradia dos pobres na região central, envolvendo mercados informais de aluguel, coabitação, moradias cedidas, ocupações... Nota-se a existência de uma rede de populares que viviam nessa região e que se pautavam por essas práticas, configurando tramas de arranjos habitacionais para continuar vivendo ali.

26 Em geral, os interlocutores da pesquisa referem-se a órgãos como COHAB e PROHAB como sendo uma coisa só, e às políticas habitacionais promovidas na cidade como sendo destinadas para camadas médias da população, e não para os então "pobres como a gente era", associando-as à necessidade de possuir emprego formal e uma renda mínima para consegui-las. Voltarei a tais representações no Entremeio I. 
pra limpar as casas. Que já estavam prontas, né? Que tinha, assim, que tirar a sujeira do vidro, do chão, essas coisas, nós fomos trabalhar lá fazendo esse trabalho. Aí, no fim, nós acabamos virando servente! [risos]. Eu aprendi bastante coisa lá, sabe? Aprendi colocar telha, aprendi colocar peças de banheiro, rebocar a parede, um pouco de pintura, então eu posso dizer que eu aprendi de tudo um pouquinho. Mas, naquela época, nem pensei em tentar uma casa pra mim. Depois, com o passar do tempo, foi que eu... Que eu comecei a pensar. [Núbia]

Contudo, apesar de estar empregada, além de atrasos no pagamento do salário acontecerem com frequência, nem sempre o dinheiro durava até o fim do mês e, nesse momento, seus filhos mais velhos (com doze e sete anos), entre escola e projetos sociais, passaram a fazer correrias para ajudar a mãe: permanecer morando no centro era fundamental nesse sentido. Eles olhavam carros, limpavam quintais, conseguiam restos de comida em restaurantes, pediam esmolas nos semáforos, ganhavam pão e leite nas padarias da região. Núbia passava o dia todo fora, trabalhando, mas faz questão de valorizar, ao longo dos relatos, seu papel de mãe, manifesto nos seus deslocamentos cotidianos intensos para conciliar o trabalho e o cuidado com os filhos:

Eu saía de lá, eu vinha aqui na baixada do Botafogo trabalhar, passava na creche, deixava eles, vinha trabalhar, na hora de almoço eu ia no maior pique lá em casa almoçar, e eu ia lá para almoçar, porque o Jimmy e o William vinham da escola, porque eles estudavam no Sebastião. No que eles vinham da escola, passavam em casa, guardavam a mochila para ir para a Casa da Criança. Sabe? Então, eu fazia isso, era a maior corrida, todo dia! Vai e volta. E a pé, porque se eu fosse bancar o ônibus eu não ia ter salário no fim do mês. (...) porque era assim: chegar em casa, fazer comida, comer e sair correndo para não atrasar. Eu descia, deixava os meninos na Casa da Criança e vinha embora pro Botafogo. [Núbia]

O casarão 2020, como ela e Jimmy se referem à ocupação, era um casarão já bastante antigo, abandonado, cuja edícula de três cômodos, ao fundo, fora ocupada inicialmente por uma família (uma senhora e quatro filhas) que transformaria o local em um "ponto de venda de drogas e prostituição". O casarão em si seria ocupado em seguida, após negociação com essa senhora, pela família de Núbia e mais outras três: Núbia e uma conhecida sua ocuparam um cômodo cada uma na parte da frente e compartilhavam um banheiro para as duas famílias. A cozinha, a lavanderia, as áreas de circulação e o quintal eram compartilhados entre todas as famílias moradoras (todas compostas por mulheres e seus filhos), embora este último fosse reduto dos programas e negócios realizados pelas meninas moradoras do fundo do casarão. A casa estava com o fornecimento de energia elétrica interrompido, tendo Núbia e sua família vivido ali por cerca de um ano e meio sem luz. Em seus relatos, essa experiência será constantemente referida como "a primeira vez que morei assim, 
nessa coisa assim meio cortiço ${ }^{27}$, vamos dizer assim", sempre em comparação com as experiências anteriores e posteriores de moradia.

A gente morou ali, onde hoje é o estacionamento da Wizard, era um casarão chamado 2020, que era o número do casarão. Ficou famoso, infelizmente, por causa de uma família que morava no fundo, e era todo mundo envolvido com os negócio, né? Inclusive foi um lugar que a gente morou, assim... era um casarão enorme, e as famílias se apropriaram. Então, por exemplo, lá no fundo eles se apropriaram de uma parte da casa. Na frente morava mais 3, 4 famílias. / Thaís: Mas era uma negociação entre as famílias ou tinha um dono? / Não, não. Era uma negociação entre as famílias. Era área invadida mesmo. A casa tava abandonada há anos e foi invadida mesmo. Inclusive a gente morou ali sem energia elétrica, sabe? Só tinha água... E por causa dessas palhaçadas do povo lá do fundo, lá, teve vezes assim que a gente, como a gente morava num cômodo que a janela já dava pra rua, direto, quantas vezes a gente não escuta barulho, põe a cara pra fora, os cara apontando revolver na nossa cara? [Jimmy]

Será morando nesse casarão que a família enfrentará, pela primeira vez, uma vivência cotidiana próxima ao crime ${ }^{28}$ e tráfico de drogas ${ }^{29}$, em função das práticas da família pioneira da ocupação, o que acarretava invasões policiais e agressões a todos os moradores do local, sem distinção: "ali no 2020 a violência era grande, porque por ser uma casa no centro da cidade, era uma coisa muito chamativa o que as meninas faziam! Os vizinhos olhavam lá e já viam a 'casa mal assombrada', só tinha monstro lá morando, né. E mandavam a polícia em cima da gente!" [Jimmy]

27 Chama a atenção a existência dessa espécie de cortiço no centro da cidade nos anos 1990, bastante invisibilizados do ponto de vista das políticas e debates públicos (em pesquisa anterior em atas da Câmara Municipal e jornais locais do período, não encontrei nenhuma menção a este tipo de moradia na cidade). Forma de habitação comum, também em São Carlos, entre os mais pobres nas primeiras décadas dos anos 1900, em grande medida como moradia de aluguel (e não como ocupação), os cortiços situavam-se principalmente nos arredores de indústrias, nos bairros operários e no entorno da linha férrea que demarca a fronteira entre o centro e a região sul da cidade, embora haja registros de cortiços também na região central (Devescovi, 1988), inclusive já no pós-abolição (Oliveira, 2012). Proibidos por legislação municipal desde o final dos anos 1920, os cortiços, na década de 1940, ainda eram o principal "problema" urbano local, quando passou a ter lugar a abertura de loteamentos em áreas periféricas, bem como o estímulo municipal à construção de "casas populares" para venda "à prestação" (cf. notícias de jornal dos anos 1940 analisadas por Devescovi, 1987).

28 A noção de crime foi bastante utilizada por Jimmy - e um pouco menos por Núbia - para nomear genericamente práticas ilícitas/criminalizadas diversas com as quais tiveram contato ao longo de suas trajetórias, como o tráfico de drogas, roubos, assaltos, estelionato, prostituição. A expressão êmica mundo do crime, bastante recorrente em campo e já alvo de inúmeros estudos - à qual abordarei nos próximos capítulos -, foi entretanto utilizada apenas por Jimmy (e nunca por Núbia) e com menos frequência, sempre para referir-se a um período histórico mais recente (após os anos 2000), em abordagens que não foram utilizadas na elaboração deste Capítulo. Por esta razão, optei por introduzir a noção de "mundo do crime" em outro momento da tese, já que pautada por sua utilização nativa.

29 Jimmy relata que, em meados dos anos 1990, havia já um dinâmico mercado de drogas ilícitas no centro da cidade, com alguns pontos de venda definidos, como o do casarão 2020. Ele menciona a venda de maconha, cocaína e mesmo crack: "o crack mesmo eu conheci em 94, vendo as meninas lá do casarão usando o negócio. Já tinha, já tinha crack, nego fala que não, mas tinha, eu via, eu lembro bem. Se você perguntar pro William, ele lembra também de ver as mina fritando o negócio na latinha." 
Mas eu vou te contar, Thaís, o que rolava de bebida e droga naquele fundo... era impressionante! E as meninas, eram quatro moças, elas não queriam saber se tinha criança, se tinha adolescente... elas usavam assim, à vontade. Sabe? Sem interrupção nenhuma. E era difícil, porque elas tanto usavam, quanto vendiam drogas, se envolviam em roubo, em assaltos... Então, quando a gente... o duro de lá é que, quando a gente pensava que estava sossegado, a gente se deparava com a invasão da polícia! A Diana hoje tem vinte anos, e até hoje ela tem um verdadeiro horror de polícia. Ah, ela era pequenininha, sabe, e de tanto que via... E é aquele negócio, eu me lembro que fazia pouco tempo que eu morava na casa, a Diana ficava na creche. Mas ela tinha um problema de ouvido que, virava e mexia, estava com infeç̧ão no ouvido. Então eu marquei uma consulta para ela e ia saindo com ela para ir na consulta... eu morava na parte da frente, então... a porta da lavanderia da casa era do outro lado, então a gente saía pela lavanderia, dava a volta assim, pegava o corredor e saía na frente da casa. No que eu faço essa volta, que eu vou saindo eu dou de cara com o batalhão da DISE ${ }^{30}$. Eles são tudo uns hominho pequenininho, da DISE, né (risos)! Thaís, eu nunca esqueço a cara daquele $R$., da DIG. Que ele não tem uma mão, que eu falo que a mão dele é uma pá de lixo, ele abriu a mão, ele fez assim no meu peito, eu bati na parede, eu quiquei na parede, eu arregalei o olho assim, ele apontou o revólver para mim... 'quem é você? O que você está fazendo aqui? Onde você vai?' Olhei para ele assim, 'ô moço, eu moro aqui, só que eu moro do outro lado'. 'Você mora aqui?' Eu falei: 'eu moro aqui'. Ele: 'mão na parede, deixa eu ver o que tem nessa bolsa', não sei o quê... a Diana olhando para mim assim, né, eu tive que voltar para trás e trocar ela. Porque o susto dela foi tão grande, que ela não teve reação de chorar. Ela fez xixi! Aí, depois de muito custo, conversando, mostrei documento, falei para ele que estava trabalhando na firma que está construindo as casas populares do Botafogo, 'eu pedi dispensa agora depois do almoço, para mim levar minha filha no médico, que está doente, olha aqui o papel da consulta', que não sei o quê... falei, falei, falei, falei, falei, até me cansou... e foi difícil de convencer ele de que eu não tinha nada a ver. Que ele achou, no trajeto que eu vinha saindo da casa, ele achou que eu tinha ido lá no fundo comprar droga. Sabe? Aí eu conversei com ele, tudo, expliquei, aí foram chegando os outros, eu lembro que o menorzinho da turma veio com uma $12 \mathrm{na}$ mão e queria bater em mim de qualquer jeito [risos]. Eu lembro que eles falavam... Que eles são meio pesado, né? Eu lembro que eles falavam: 'ah negona folgada, estamos doidos para dar umas porradas nessa vagabunda'. E a Diana assim, ó, ouvindo tudo... [Núbia]

Os relatos de Núbia sobre o período vivido nesse casarão são pontuados por situações como essa, em que além de ela própria sofrer a violência policial, também seus filhos estavam expostos às agressões, ameaças e abusos de todo tipo. Será somente após um bom tempo passando por isso que, tendo deixado o trabalho nas casas populares e tornado a ser funcionária na casa da família D., em uma dessas

30 A partir desse momento em sua trajetória, suas narrativas serão perpassadas, em vários momentos, por menções às forças policiais, tanto civis quanto militares. As menções mais detalhadas, ao lembrar de episódios em que esteve diretamente envolvida, são todas relativas ao fato de, desde então, ter morado e convivido cotidianamente junto a pontos e circuitos do crime, com forte presença do tráfico de drogas: nesses momentos, faz questão de demonstrar conhecimento dos órgãos e instituições com que estaria lidando, especificando-os. Nesse sentido, a DISE - Delegacia de Investigação Sobre Entorpecentes - e a DIG - Delegacia de Investigações Gerais - são mencionadas diversas vezes, inclusive de maneiras sobrepostas, como nesse trecho citado, incluindo menções, pelo nome, a delegados e policiais envolvidos nas operações. 
batidas da polícia à ocupação, ela acionará o vínculo com os patrões e conseguirá uma espécie de imunidade em relação às invasões e agressões policiais durante o resto do período em que permaneceu morando ali.

Gente, mas era um sofrimento! Eles já chegavam enfiando a mão na orelha de qualquer um. Quem tivesse na frente, ih, batiam lindo, sem dó. Até que uma vez, esse $R$. da DIG teve a cara de pau de me levar na porta da casa da dona Leda D., que eu falei que tava trabalhando lá, eles eram uma família conhecida, tinham muito comércio ali. Aí, a finada Leda falou pra ele: 'cês num põe a mão na minha funcionária, porque aquela ali é minha funcionária, é a mulher de confiança da minha casa. Ela tá ali por acidente do destino, mas nós vamos dar um jeito de tirar ela dali, cês não me põe a mão nela e nos filhos dela, hein?' Aí, depois disso, o que aconteceu? Quando eles iam dar batida lá, sempre um deles batia na minha janela, que a minha janela ficava de frente pra calçada. Aí eles perguntavam, sabe? Se eu... 'É, seus filhos tá aí?' Eu falava: 'tá. Eles tão lá fora, tão brincando no quintal'. 'Então põe pra dentro'. [Núbia]

Mesmo após acionada sua identidade de trabalhadora ${ }^{31}$ como espécie de imunização em relação à violência policial, as dinâmicas a que seguia sujeita por morar ali - "era um transtorno, quando pensava que tava dormindo em paz a polícia tava na porta. Muitas vezes eu acordava, o policial olhando na minha cara, pra ver se tinha alguém escondido ali" - conformam as memórias desse tempo vivido no casarão como tendo sido o pior lugar onde já viveram - "Ah, ali foi péssimo!" - em que a tais violências sofridas se associam as próprias condições de moradia, as dificuldades financeiras e, sobretudo, o risco iminente de perder os filhos, que ela vivenciou enquanto esteve ali, novamente sob a justificativa do local e das "condições de moradia inadequadas" em que vivia.

Aí bateu na porta. E a colega que era a minha vizinha, que morava na porta da frente, sempre muito bocuda, 'a gente não pode nem almoçar em paz, né, Núbia!' Eu sei que ela abriu a porta, conversou, conversou, conversou e eu lá no meu quarto trocando o William para levar para a Casa da Criança. 'Ô Núbia!', 'Que foi? Que que está doendo?' Eu sempre tive essa mania. Sabe? De brincar assim... mas nesse dia, eu fiquei com tanta vergonha, Thaís! (risos) Ela falou: 'mas que caralho! Tem gente aqui na porta!' E eu falei: 'legal, dá um quilo desse negócio que você falou ai.' Porque eu costumava brincar com ela desse jeito, ela falava palavrão e eu falava, dá um quilo! (rindo) E ela: 'A assistente social do Fórum está te chamando. Está aqui e disse que vai recolher todas nossas crianças!' Eu nem pus a cara na porta. Ó como eu também dou minhas mancadas! De lá eu gritei, 'vai recolher o caramba, as vagabundas moram no fundo, eu não tenho nada a ver com peixe! Meu, ela não vai levar nenhum, porque se ela levar, ela vai ter que passar por cima de mim viva, porque morta qualquer um passa'. 'Não, Núbia, o juiz mandou'... 'o juiz mandou o caralho

31 Zaluar (1985:132) foi pioneira ao discutir as implicações do acionamento da "identidade de trabalhador" que se constrói simultaneamente em oposição e em relação a "bandidos e vagabundos que não trabalham". Mais recentemente, Feltran (2011) refletiu sobre as transformações dessas complexas relações entre "trabalhadores" e "bandidos", captando desde os trânsitos e distensões entre tais identidades, práticas e representações, até sua coexistência contemporânea no interior de famílias de camadas populares. 
(rindo), ele mandou o caralho, ele manda nas negas dele, na casa dele. Ele não dá comida, não dá roupa, ele não dá remédio pros meus filhos, então ele não manda nada. Aqui ele não manda nada. Na minha casa, quem manda sou eu'. 'Núbia, você está falando demais, vem aqui'... 'Ô minha filha, eu tenho trabalho, não tenho tempo para perder com assistente social não. Ela ganha a vida no macio, e eu tenho que dar murro em ponta de faca'. Thaís do céu, quando eu chego na porta (risos), estava assim ó, uma rempa de advogado, assistente social, a psicóloga do fórum e o juiz! O doutor João Galhardo tinha acabado de assumir o posto aqui em São Carlos naquela época. Ele era o juiz de menor. Núbia, vem aqui na porta conversar com o juiz. Cheguei na porta falei: 'olha doutor, já não tenho mais o que falar, porque o que eu tinha para falar o senhor já escutou, é a minha opinião' (risos). Ele olhou assim para mim, de cima em baixo, e falou: 'o que a senhora faz? A senhora trabalha?' 'Trabalho. Por isso eu me arrepio quando falam que vão levar meus filhos. Que eu não aceito. Eu não sou prostituta, eu não roubo nada de ninguém, eu dou murro em ponta de faca para criar meus filhos'. 'Mas enquanto a senhora trabalha, onde fica seus filhos?' Eu falei: 'olha, tem os dois maiores que vão pra escola Sebastião, agora eu desço e deixo eles na Casa da Criança. Os outros tá na creche até sete horas'. 'E porque que a senhora está morando aqui nesse covil?' Eu falei: 'porque eu precisei de mudar com urgência, não tinha outro lugar e nem dinheiro na mão na hora pra mim alugar uma casa, porque eu dependia de pagar um aluguel adiantado. Por isso eu vim parar aqui'. 'Quem são seus filhos?' Falei: 'tenho esses dois, e tenho mais dois que está na creche'. 'Só pra saber'. Mas ele falou assim para mim, 'só pra saber' com aquela cara de quem diz 'eu vou mandar recolher'. Falei pra ele: 'bom doutor, o senhor já viu que o que eu tenho pra falar, eu não costumo pensar e também não mando recado não. Se o senhor tá pensando em esperar eu virar as costas pra recolher os meus filhos, o senhor recolhe já. Não é uma ameaça, estou conversando com o senhor. Se o senhor recolher os meus filhos enquanto eu estiver trabalhando, eu coloco fogo no fórum. Eu meto fogo no fórum'. Ele olhou assim, pensou... 'a senhora é muito topetuda, sabia?' 'Claro! Quem que dá murro em ponta de faca? Quem que luta pela educação deles? Sou eu. Então, ninguém vai pegar meus filhos e levar de mão beijada. $O$ senhor vai recolher? $O$ senhor acha que o ambiente não é bom, no momento eu não tenho situação para oferecer melhor. Agora, se for para o senhor esperar eu virar as costas e recolher, eu viro bicho'. Ele falou: 'não, eu não vou recolher seus filhos, a única coisa que eu vou falar é pra a senhora arrumar uma outra casa o mais rápido que a senhora puder, porque aqui não dá para ficar. Porque aqui, a nossa ordem aqui é uma só: recolher todas as crianças'. Tanto é que do pessoal que morava no fundo, recolheram, os meus e os da outra moça não recolheram. Porque eles tinham escola e creche pra ficar. Aí ele não recolheu. [Núbia]

Essa seria a primeira de uma sequência de incursões de técnicos jurídico-sociais vinculados ao Juizado da Infância e Juventude então recém-implantado na cidade, que, sob a justificativa de proteger as crianças e os adolescentes que ali viviam, contribuiria para desmantelar a ocupação ${ }^{32}$. "Esse não é lugar para se criar filho": não seria a primeira nem a última vez que Núbia ouviria esse tipo de julgamento frente a suas condições de moradia. Após a intimidação que tais incursões promoveram junto

32 As narrativas de Jimmy e Núbia evidenciam a intensa atuação das 'forças da ordem e da lei' (policiais, delegados, juízes, assistentes sociais) na legitimação da distinção socioespacial da qual decorrerá a expulsão dos pobres que, como Núbia, insistiam em permanecer morando no centro da cidade. 
às mães que ali viviam e com a ameaça de desocupação iminente feita pela polícia, ela e a colega com quem dividia a parte frontal do casarão 2020 deixam o local e ocupam outra casa abandonada, ainda na região central, onde ficam poucos meses (sofrendo um novo despejo).

A partir daí, sua trajetória habitacional rumará em direção à periferia sul da cidade, em um caminho sem volta que desembocará no que, até muito pouco tempo atrás, era a periferia extrema da cidade - o bairro Cidade Aracy - onde vive atualmente, como veremos adiante. Em um primeiro momento, ela volta a morar com a conhecida que a tinha iniciado nas ocupações na região central, sublocando um cômodo nos fundos de sua casa alugada na Vila Prado; em seguida ela retorna ao Jardim Botafogo, alugando uma edícula na casa de outra conhecida: é nesse retorno ao bairro que ela engravida novamente, de seu filho mais novo (Thiago). Ao contrário dos demais companheiros, com os quais ela sempre fez questão de dizer que, bem ou mal, ela vivera, entre idas e vindas, quase uma década com cada um, esse relacionamento teria sido um tropeço do destino, pelo fato de o rapaz ser envolvido com coisas mais pesadas - ele foi preso antes mesmo do filho nascer, vindo a conhecê-lo apenas quando ele já estava com dez anos de idade ${ }^{33}$.

Nesse movimento em direção à periferia, uma situação se tornaria um grande marco em sua trajetória e na de Jimmy: este, que sempre fora o braço direito de Núbia nos cuidados domésticos e com os irmãos, acaba saindo de casa para morar na rua, em função de uma série de acusações que ele e o irmão passaram a sofrer quando ainda viviam no centro da cidade ${ }^{34}$ (sendo constantemente acionados como suspeitos de

33 É interessante notar que, a despeito de todos os seus relacionamentos anteriores não terem vingado, apenas este é desconsiderado por Núbia, não apenas pelo fato de o rapaz ser envolvido com o crime, mas sobretudo pelo fato de que eles nem sequer tentaram estabelecer um relacionamento duradouro, como teria acontecido com os demais pais de seus filhos (mesmo quando a tentativa fracassou já no início). Sua trajetória e as narrativas sobre ela apontam para uma tentativa sempre renovada (e sempre frustrada) de reconstituir uma família nuclear conjugal, sempre destacando que, com cada companheiro, permaneceu durante anos (mesmo quando isso se deu de forma intermitente). Tal busca contínua por viabilizar o ideal modelar da família nuclear foi analisada por Neves (1984) como estando na origem do fenômeno conhecido como matrifocalidade (uma mulher com vários filhos, em geral de mais de um pai): “As exigências referentes aos papéis sociais masculinos, de dificílima realização para os trabalhadores, conduzem a rompimentos sucessivos, mas não à desistência de recomposição do núcleo familiar conjugal" (Guedes, 2008:5).

34 Jimmy expressa com muita clareza o gradativo processo de expulsão dos pobres para as periferias que a trajetória de sua família encarna, sobretudo das diferenças geracionais entre sua experiência urbana e de moradia e as vividas por sua mãe: para sua geração, não existiu nem a possibilidade de viver de aluguel na região central, muito menos a perspectiva de ocupações ali. E, ainda que o mercado informal de aluguel tenha se configurado também para ele como principal forma de acesso à moradia, esta também aparece reconfigurada, sobretudo territorialmente, em relação àquele presente em grande parte da trajetória de Núbia. "Naquela época não tinha essa diferença que começou a ter, que tem hoje; na época que minha mãe viveu de aluguel no centro não tinha esse negócio de preto e pobre na periferia, dos moradores do centro não quererem ter um vizinho preto... Foi a partir dos anos 90 isso daí, a coisa ficou absurda. Na época, a droga que mais tinha aqui era a maconha. (...) Daí, nessa época, eu adolescente, quando eu comecei a sair, antes de eu conhecer a maconha eu já tomava blitz 
pequenos furtos e incidentes nas vizinhanças da ocupação seguinte à do casarão 2020) e das consequentes agressões direcionadas pela mãe a eles.

Era uma época que já tava pegando pesado esse negócio de droga na cidade, e o centro era 'o' lugar. E a gente, preto, pobre, ali no centro, eu e meu irmão, a gente era muito visado pela polícia, os vizinhos tavam sempre denunciando coisas que a gente nem fazia. Preconceito do pessoal, fala: 'preto é tudo igual'. E nessa época, a gente chegou a ser castigado pela minha mãe sem dever, por quê? Os outro falava, e ela, na intenção de controlar pra gente não se perder, descia a mão sem dó. Então foi uma época, assim, muita briga com a minha mãe, foi um ano muito difícil, e eu acabei saindo de casa. (...) Eu fiquei um ano na rua, por opção minha. /Thaís: Morando na rua mesmo? / Morador de rua. Mas assim, opção minha, minha mãe nunca me botou pra fora de casa em dado momento, nunca! Foi opção minha mesmo. E nessa eu aprendi que, primeiramente, dentro de casa é sempre melhor. Segundo, eu fiquei bem mais malandro, porque eu era muito devagar, né? Aí cê apanha da vida...Tive que aprender a me virar, saca? Eu guardo algumas coisas boas desse período, aprendi a lidar com certas situações na rua. A rua ensina bastante coisa pra gente. [Jimmy]

Nos relatos de Jimmy, esse período é rememorado como fruto de uma escolha, da qual teria, simultaneamente, obtido muitos aprendizados e vivenciado de forma ainda mais intensa a violência policial, fortemente direcionada aos pobres no centro da cidade àquela época. Destaca-se, sobretudo, a possibilidade de ter tido maior contato com o hip-hop, que então chegava à cidade e cujos praticantes se reuniam na Praça Coronel Salles, no centro da cidade, bem como o conhecimento socioespacial dessa região central, que a experiência proporcionou:

E, assim, o que eu mais gostei é que, na época, eu tive mais proximidade ainda com o hip hop, que tava começando na cidade. Ali fiz várias amizades. Então eu ficava ali na praça vendo o pessoal dançar, naquela época, era mais a dança. $E$ era ali na praça, no centro, pra você ver! Então, nessa época que eu morei na rua contribuiu ainda mais pra eu dominar tudo aqui, o centro da cidade. Eu conheço isso aqui como a palma da minha mão. Eu passei minha infância e juventude aqui, e ainda mais quando morei na rua, aqui era meu território, então eu consigo descrever tudo aqui, consigo descrever com perfeição o que era ${ }^{35}$, e até hoje tem pessoas ali que eu passo e me conhecem: 'ô neguinho, cê mudou de vida, hein!' (risos). [Jimmy]

Já nas narrativas de Núbia, tal período representa o primeiro momento em que aparece a dimensão do medo em sua trajetória (a partir de então cada vez mais frequente), associado à preocupação com o rumo que o filho mais velho tomava

no centro por causa dela! Já tava começando essa associação, por eu ser preto, ser pobre... e, detalhe, eu nem usava roupa larga na época! (risos)"

35 Vale destacar, nos relatos de Núbia e do filho Jimmy, as referências às casas e aos espaços centrais da cidade por onde ela e os filhos circulavam: todas as casas foram demolidas, assim como grande parte dos marcos que permeiam as memórias da vida nessa região central na cidade. As referências são sempre no passado, ou pautam-se pelos novos usos que os locais adquiriram - 'onde fica hoje aquele estacionamento', 'agora ali é aquela escola de inglês', 'ali onde virou aquele escritório' - dando conta das transformações sofridas pelo centro da cidade nesses mais de vinte anos, em especial no que diz respeito a usos cotidianos e espaços de moradia dos pobres. 
morando na rua, fazendo parte de uma banca de molecada ${ }^{36}$ que se tornaria visada pela polícia por envolvimento em roubos e uso de drogas no centro da cidade.

Quando eu vi que não, o Jimmy estava para a rua. Encontrava o Jimmy na rua, parecia um mendigo, Thaís. Sujo, descabelado, cabelo imenso, sabe, sem banho... Era irreconhecivel! A gente olhava, a gente via um bermudão imundo (risos), a camisa pior ainda, o pé da cor do asfalto. E a vida deles era praça e fliperama. Praça e fliperama. E começou a juntar com essa turma e começou a aprontar... quando via o Jimmy entrar dentro de casa, tinha problema. Aí ele ficava com aquela carinha de anjo caído, sabe? Aí começou a fase de dar trabalho de verdade, né? E adolescente é bicho que não presta, né? Não pensa. Aí aprontava pela rua, a polícia pegava. Virava e mexia, tomava uns cascudos da polícia... Sabe, eu acho que por umas duas vezes eu fui buscar ele lá no Primeiro DP. Aí quando eu vi que a coisa estava ficando feia... que eu não tinha controle... / Thaís: Mas ele ficava morando na rua mesmo? / Na rua. Não voltava para casa. Ele voltava para casa a cada dez, quinze dias, porque ele entrava, tomava banho, trocava de roupa, 'mãe, eu vou ali' e ó... sumia de novo. Aí quando eu vi que ele estava dando trabalho além do limite... que tinha um menino que andava na turma deles que....imagina, um menino de quinze anos, naquela época, roubava carro que nem louco. Aí, eu comecei a ficar com medo. E levava ele para casa, conversava e tal, mas era entrar por aqui e sair por aqui. Aí eu fiquei pensando, pensando, pensando, pensando... me veio a ideia de levar ele para conversar com o juiz. [Núbia]

É interessante notar que, em nenhum momento de suas narrativas, ela emitiu juízo de valor sobre a opção do filho de morar na rua, decidindo interferir somente quando percebeu que iria perder o controle sobre a situação e passou a temer pelo futuro do filho. Até então, ela procurava apenas se manter informada sobre onde ele estava, o que andava fazendo, levava-o, por vezes, para tomar banho e comer, dava-lhe algum dinheiro, tendo chegado, inclusive, a interceder junto a policiais conhecidos seus, visando a amenizar as violências sofridas por ele nesse período ${ }^{37}$.

Até hoje, tem uns cara da antiga aí, uns policiais, que nem o P. mesmo, eu num posso nem ver ele na frente. Foi um cara que, toda vez que me enquadrava, me batia, à toa. Ele nunca me pegou em nenhuma ocorrência, mas sempre fazia questão de me bater. Pior que eu sabia quem ele era, porque ele é negrão, frequentava o Flor de Maio e era amigo da minha mãe. O dia que minha mãe descobriu que era ele que sempre me batia... minha mãe foi lá na casa dele! Não achou, trombou ele no centro e falou um monte: 'a próxima vez que cê pôr a mão no meu filho, você some da cidade'. Nossa, ele ficou sem graça! Ele me via na rua e virava a cara, nunca mais ele me enquadrou, nunca mais. Às vezes, assim, na

36 Sobre as dinâmicas e arranjos urbanos dos moradores de rua em São Carlos, e sua organização territorial, dentre outras, em bancas, indico o trabalho de Martinez (2011).

37 Durante o período vivido no centro (sobretudo na ocupação do casarão 2020), Núbia começou a construir, ao lado de suas redes de relações, um conjunto de saberes na relação com as polícias e os técnicos e instituições judiciais e assistenciais que lhe será útil tanto nesse período em que Jimmy morou na rua, bem como no tempo em que viveu na ocupação do antigo orfanato, como veremos. Destaca-se, nesse sentido, a dimensão da escala da cidade, que possibilita a ela o conhecimento dos policiais, delegados e técnicos pelo nome, bem como o aprendizado de invocar sua identidade de trabalhadora como forma de compensar os supostos desajustes em termos familiares e habitacionais dos quais fora recorrentemente acusada. 
blitz da madrugada, a gente de rolê, eu com os moleques, ele enquadrava, ele apavorava todo mundo. E eu, ele deixava de lado, ele só me dava a blitz e: 'ó, cê fica ali'. [Jimmy]

Será a crescente violência policial dispensada à banca e o medo daí decorrente que levarão Jimmy a deixar a rua, não sem mediações oficiais. De fato, também em sua narrativa o medo foi mobilizado, mas como um freio que teria colocado limites às suas aventuras na rua, circunscrevendo em uma espécie de flerte seu contato com as drogas e os roubos e evitando, de certa forma, que seu destino fosse, como o de outros companheiros de banca, a internação na então FEBEM ou mesmo "a morte em uma emboscada".

Foi um período mais de aventura do que qualquer outra coisa, né, meu? Porque quando a gente não ficava perambulando pra rua a gente achava uma casa - que aqui em São Carlos até hoje no centro tem " $n$ " casas abandonadas -, a gente entrava dentro e dormia lá, né? Teve até uma casa que a dona cedeu a garagem lá pra gente dormir. E em troca a gente cuidava da casa pra ela, entre aspas, né? Então a gente morou junto em muito mocó, sabe, que era casa abandonada que a gente entrava só pra dormir. E, fora isso, ficava perambulando pelo centro, tentava ganhar uma grana... A nossa vida era essa, perambular. (...) E nessas, várias vezes rodei na mão da polícia. Aos poucos fui ficando com medo, medo mesmo. Esta é a parte que eu não gosto de lembrar, o fato de ter apanhado muito da polícia e o desgosto que dei pra minha mãe e meu irmão William, que a gente era muito apegado. Que foi uma época que, tipo, aconteceu um incidente com nós, os moleques, e a polícia, e os caras me ameaçaram de morte, né? Aí eu fiquei com medo. / Thaís: Como foi isso? / Eu e mais um fomos acusados de um crime que não cometemos e, pra liberar a gente, eles queriam que a gente caguetasse uma par de ladrão na cidade. E a gente deu um jeito lá, inventamos uns nomes e endereços frios e conseguimos ser liberados. Na época a gente morava numa casa abandonada lá na rua sete. Aí, a gente voltando pra casa, minha mãe tava até junto com a gente que ela tinha ido assinar lá o papel pra liberar a gente, quando chegamos, a casa tava toda bagunçada e um bilhete desse tamanho na parede. Os cara tinham ido lá, quebrou as poucas coisas que a gente tinha lá... e um bilhete desse tamanho na parede ameaçando a gente de morte. Minha mãe começou a tremer, chorar: 'filho, volta pra casa pelo amor de Deus'. Fiquei com aquilo na cabeça, aquele medo, pensei: 'se tá nesse nível, é pra mim parar, vou morrer por causa de coisa que eu nem fiz?' A gente procurou $o$ juizado, aí o juiz encaminhou a gente pro Educandário. Só que como a gente já tinha mais de 14 a gente num podia ficar lá. A gente tinha que ficar no pensionato. Aí resolvi trabalhar: melhor suar a camisa que suar sangue, né? E, depois de um tempo, fui condenado a fazer serviços na comunidade, por causa de outros delitos. [Jimmy]

Tal episódio seria decisivo para sua saída da rua: a iminência de ser encaminhado para a FEBEM, a ameaça de morte e o desespero da mãe e do irmão mais novo são apontados como os principais motivos que o levaram a essa decisão. Entretanto, ela somente se concretizou quando Núbia, incentivada pela patroa, tomou uma atitude considerada por ela decisiva para o futuro do filho: procurar o juizado da vara da infância e da adolescência (onde já corriam processos em nome de Jimmy, decorrentes das vezes em que fora pego pela polícia). o juiz o encaminhou para o 
Educandário São Carlos $^{38}$, que mantinha, no centro da cidade, um pensionato para abrigar jovens acima de quatorze anos. Nesse período, Jimmy começou a trabalhar como jardineiro em uma casa de família, passando o dia no emprego e as noites no pensionato.

A tentativa de levar o filho para morar novamente com ela inviabilizou-se, pois a proprietária do cômodo por ela alugado recusou a presença do jovem ali, por sua fama de menino de rua; indignada, Núbia começou a mobilizar suas redes de relações para encontrar um novo local para morar. Foi quando tomou conhecimento, através de Dália, de que uma de suas vizinhas na ocupação do antigo orfanato estava se separando do marido e iria vender seu barraco imediatamente. Núbia, que estava mais uma vez grávida e desempregada, não teria condições de fazer o negócio naquele momento, e seria Jimmy a "decidir o destino da família" (numa atitude decisiva também para o seu próprio destino): para tanto, ele optaria por pedir a conta no emprego e, com o dinheiro do mês que ainda tinha por receber, compraria o barraco para a família, no valor de $\mathrm{R} \$ 40,00$.

Estamos no ano de 1995, e São Carlos, a essa altura, já contava com cerca de 175.000 habitantes: o significativo aumento populacional teria sido decorrente da "reversão da tendência migratória no estado de São Paulo, no período de 1980 a 1991" 39. Nesse contexto de combinação entre novas dinâmicas de migração e pauperização das camadas populares no país, a cidade viverá uma espécie de 'boom' de ocupações favelizadas em suas periferias, bem como o adensamento exponencial de loteamentos populares abertos irregularmente na década anterior no extremo sul da cidade, que se tornarão "problemas urbanos" recorrentes em notícias de jornais locais e atas da Câmara Municipal nos anos 1990. Mais especificamente, nesse mesmo ano de 1995, em várias sessões da Câmara, discutia-se a respeito de “invasões indiscriminadas de áreas públicas na cidade", com especial destaque para o fato de que "o prefeito estimula[ria] invasões", não apenas autorizando-as, como favorecendo suas condições através da instalação de pontos de água e luz nos limites

38 Instituição fundada originalmente como abrigo para menores carentes do sexo masculino, posteriormente encampada pela Congregação Salesiana no Brasil, a qual, após a aprovação do Estatuto da Criança e do Adolescente no país, tornou-se a entidade responsável pela implementação, em parceria com a Vara da Infância e da Adolescência e com a Prefeitura Municipal, das medidas socioeducativas em meio aberto na cidade de São Carlos.

39 Dozena (2001:48). Laisner (1999:56) afirma que, no mesmo período, “42\% do crescimento populacional de São Carlos se deu devido ao saldo migratório", cujo crescimento teria se mantido até o final dos anos 1990. Dados referentes a esse período apontam para uma intensificação da pobreza na cidade (NPD/UFSCar, 1994) e sua já bastante significativa concentração no extremo sul. 
das ocupações ${ }^{40}$ : de fato, ao longo de duas gestões municipais nos anos $1990^{41}$ se formarão e/ou consolidarão pelo menos cinco áreas de ocupações favelizadas na cidade (dentre as quais a do antigo orfanato), tendo havido também uma nova ocupação no então recém- "urbanizado" Jardim Gonzaga (que, também por isso, persistiu sendo conhecido como Favela do Gonzaga).

Núbia, que passara ao largo da realidade de tais ocupações favelizadas nas periferias da cidade até esse momento (e aqui reitero a conexão, já apontada, entre os deslocamentos habitacionais e as redes de relações até então estabelecidas, bem como a constante intervenção de dimensões subjetivas e não apenas de ordem econômica nos agenciamentos aí implicados), em meados de 1995 muda-se para o antigo orfanato, onde viveria por mais de uma década: "Eu vim morar no orfanato, eu tava grávida do Thiago. Quando eu saí de lá, ele já tava com treze anos. É... [risos]. Uma vida. Ele aprendeu andar, falar, tudo ali".

\section{- Uma trégua na praga de cigano: a fixação em uma ocupação periférica}

O antigo orfanato originou-se a partir da ocupação das ruínas das obras do que seria um orfanato, cuja construção foi embargada sob justificativa de localizar-se em área imprópria para edificações. As obras, abandonadas já há alguns anos quando a ocupação se deu (por volta de 1990), compreendiam um edifício principal inacabado, térreo e comprido, sem piso e sem cobertura, do qual restavam algumas paredes externas e algumas subdivisões internas (uma parte das paredes havia sido derrubada, outras encontravam-se esburacadas, outras haviam sido paralisadas pela metade) e, a alguns metros desse edifício, quatro pequenas casas, cuja construção se encontrava em estágio mais avançado, com todas as paredes e o piso concluídos, cobertas com laje inclinada, mas sem portas, janelas, instalações ou acabamentos. Essas casas foram as primeiras a ser ocupadas, geralmente coabitadas por duas ou mais famílias, que subdividiam os cômodos e improvisavam as vedações que faltavam. Em seguida, também o edifício passou a ser ocupado por várias famílias, que, a partir das paredes existentes, delimitavam os cômodos destinados a cada uma

40 Adotada anteriormente pelo mesmo político Rubens Massucio em meados dos anos 1980, quando vice-prefeito, na então Favela do Gonzaga, a instalação pontual, pelo poder público, de torneiras coletivas em ocupações favelizadas não era prática exclusiva de São Carlos: diversos estudos, sobretudo cariocas, irão mencionar essa prática política, que se tornou conhecida como "política da bica d'água". Veja-se, por exemplo, De Paoli (2000); Pandolfi e Grynzpan (2002).

41 Gestões municipais de 1993-1996 e 1997-2000, nas quais Rubens Massucio e Dagnone de Mello (ambos do Partido Trabalhista Brasileiro - PTB) se alternaram no cargo de prefeito, e Henriqueta Garcia e seu filho Airton Garcia (proprietário de terras responsável pela abertura de inúmeros loteamentos irregulares na periferia de São Carlos, dentre eles o Cidade Aracy, como veremos adiante) no de vice-prefeito. 
delas, completando a moradia com restos de materiais de construção, papelões, plásticos, pedaços de madeira ${ }^{42}$. Quando a amiga Dália mudou-se para lá, por volta de 1991, a ocupação dos edifícios pré-existentes já estava adensada, a ponto de não haver lugar para Núbia e seus filhos, como visto. A própria família de Dália (ela, sua mãe e quatro filhos) conseguiu um único cômodo no edifício subdividido, ao qual depois de um tempo anexou outro pequeno cômodo de madeira, para dividir o que seria a sua casa e a casa de sua mãe.

Quando Núbia e seus filhos chegaram ao antigo orfanato, em 1995, seriam uma das primeiras famílias a comprar um barraco no local, que contava, então, com algo em torno de vinte famílias ali vivendo, ainda nos limites das ruínas das obras, com um ou outro 'anexo' construído com madeira e materiais de descarte. Pouco antes, atendendo a reivindicações dos moradores, a prefeitura acabara por instalar um ponto de água nos limites da ocupação ${ }^{43}$ com o bairro Monte Carlo, a partir do qual os moradores improvisavam formas de levar água aos barracos. Entretanto, no local ainda não havia energia elétrica, sendo a iluminação à base de velas e candeeiros ${ }^{44}$.

A chegada de Núbia à ocupação marca a maior inflexão em sua trajetória (e também na de Jimmy) em termos familiares, ocupacionais, habitacionais, financeiros, para citar alguns aspectos em que tal inflexão se evidencia. Destaca-se, nesse sentido, o fato de ter sido a primeira - e até hoje única - vez em que a família viveu em uma casa com algum sentido de propriedade, ainda que também decorrente de uma ocupação: para todos os efeitos, eles haviam comprado o barraco, e isso era vivido como uma grande vitória familiar. Por outro lado, além de ser o local mais distante da região central em que até então tinham vivido, era também a primeira vez que moravam em um lugar tipo favela, como eles, por vezes, qualificavam a ocupação daí referirem-se à casa como barraco, apesar de ser de alvenaria:

Thaís: Era barraco de madeira?/ Não, não. / Thaís: Vocês chamam de barraco por quê? / Ah, porque era área invadida. E a casa que a gente tava eles [os moradores anteriores] tinham derrubado um cômodo da construção, então os cômodos que sobraram a gente ocupou, né? Era tudo meio improvisado, por isso também... A porta era mó comédia! (risos) Então a gente chamava de barraco, virou costume. Todo mundo chamava de barraco, acho que pouquíssimas pessoas lá falavam que tinham casa. 'Não, tenho meu barraco lá'. Às vezes, quando eu falava 'minha casa' ou até 'minha propriedade', pra zuar mesmo, os

42 Informações sobre a ocupação do antigo orfanato foram obtidas através não apenas da pesquisa de campo, mas também de minha experiência profissional anterior nas periferias da cidade, e dos trabalhos de Carneiro (2008) e TEIA (2005).

43 Cf. a já mencionada "política da bica d’água" levada a cabo na cidade nesse período, a qual, através de intervenções como essa, contribuiu para o crescimento desta e de outras ocupações na cidade.

44 Há relatos de incêndios ocorridos na ocupação nessa época, como o próprio caso de Dália, que teve seu cômodo de madeira destruído e voltou a viver com os quatro filhos no barraco da mãe. 
caras até riam, por causa do preço que eu paguei no negócio lá, e eu ria junto, porque a situação era engraçada mesmo, sabe? [Jimmy]

É que ali... o espaço físico da casa era ruim. / Thaís: Era ruim por quê? / Porque era assim, muita gente numa casa pequena, sabe? E era uma coisa assim, que não era terminada, entendeu? Tinha pouco espaço, não era uma casa terminada, muito pelo contrário, tinha buraco até não sei onde... [Núbia]

O barraco adquirido tinha dois cômodos, subdivididos (com os poucos móveis que possuíam e algumas cortinas herdadas da antiga patroa) em sala, cozinha e quarto "era até grandinho, e nós conseguimos dividir bem, sabe?". Sem banheiro, a família, inicialmente, compartilhava o existente no barraco de Dália, "depois Jimmy improvisou um lá fora, de madeira, sabe, que deu para ir quebrando um galho" [Núbia]. Para solucionar a ausência de janelas nos cômodos, Núbia abriu buracos nas paredes, e cortinas plásticas faziam as vezes de vedação; sobre o chão de terra batida, estendeu um grande carpete (também herdado da patroa) para aliviar o poeirão.

É interessante observar que esta é a casa que tanto Núbia quanto Jimmy mais descreveram espacialmente e, embora caracterizada como barraco e como um espaço físico ruim, é a mais associada a memórias positivas. É, sobretudo, o primeiro lugar (e talvez único) que ela considerou propriamente como sua casa - "o lugar que me fez sentir melhor no sentido casa foi o orfanato" -, instigando a uma reflexão sobre a relação estabelecida por ela (mas também por Jimmy) com essa casa, menos no sentido de propriedade material - já que sempre permeada pela insegurança da posse: "eu sabia que uma hora ou outra a gente ia precisar sair de lá, né? Pelo fato de ser uma área invadida, então a gente tinha essa noção" -, mas talvez numa dimensão mais antropológica de "bem", pelos significados simbólicos a ela associados, diretamente ligados ao fato de ser sua primeira experiência (em quarenta anos!) de efetiva fixação em uma casa e um território (de onde decorre sua concepção de vizinhança, abordada a seguir). Assim, embora ela faça uma clara distinção entre essa experiência da casa no antigo orfanato e das demais casas em que viveu antes e depois (com exceção do casarão 2020), cujo enfoque recai para o fato de que as outras eram casas sozinhas ou casas normais, a vivência desta casa como um "bem" (material e simbólico) despertará em Núbia, pela primeira vez, o desejo de ter uma casa própria. E, mais, trazendo consigo a dimensão de que "uma casa representa[ria] segurança" para ela e seus filhos, os treze anos vividos nessa mesma casa suscitarão em Núbia o que chamarei aqui, em diálogo com Guedes (1998) e Duarte e Gomes (2008), de um “desejo de quintal"45: o sonho de possuir

45 A categoria "quintal" refere-se aos "conjuntos de casas que foram construídas ao longo do tempo num mesmo lote ou terreno, a partir de uma casa inicial, em que o proprietário realiza ele mesmo ou permite a realização de novas construções. Podem apresentar-se em densidade variável: há quintais com três, quatro ou cinco casas e muito disponível, há outros em que mais de dez casas encontramse lado a lado, outros ainda que cresceram verticalmente em direções dificilmente imagináveis, compondo uma arquitetura surpreendente" (Guedes, 1998:9). Nesse sentido, “os 'quintais' 
uma casa com um espaço melhor, um espaço maior para que os filhos pudessem permanecer morando junto com ela, mesmo após tornarem-se adultos e necessitarem de um espaço próprio.

Então foi a partir desse tempo que vivi no orfanato que comecei a pensar em ter uma casa própria, um lugar em que eu sei que vou ficar tranquila, onde ninguém vai falar comigo: 'ah, amanhã você precisa mudar porque eu preciso do local', entendeu? Porque até então eu não pensava muito nisso. Meu grande sonho passou a ser eu poder, eu conseguir ter a minha casinha, com espaço pra caber todos os filhos, os netos... que eu fui vendo meus filhos crescendo, e o meu maior sonho era ter um espaço maior pra eles... [Núbia]

Mas lá no antigo orfanato eu já tinha um pouco esse sentimento de casa própria, né? Porque a gente não pagava aluguel, não pagava nada. E meu sonho lá, até então, era ter um serviço decente, eu, minha mãe, e meu irmão crescendo, nós ter um serviço decente pra gente aumentar o que a gente já tinha, e fazer... meu, a gente tava com vários projetos, fazer um quarto pra cada um, sabe, crescer mesmo a casa... Umas coisas bem ousadas, mas aí não rolou ${ }^{46}$. Não rolou de fazer isso, e aí... ficou esse sonho, esse desejo.... [Jimmy]

Após a mudança da família para o barraco comprado por ele no antigo orfanato é que Jimmy, prestes a completar dezesseis anos, voltaria definitivamente a morar com a mãe e os irmãos, passando a trabalhar para ajudar financeiramente Núbia, que enfrentava mais um período de desemprego após o nascimento de seu quinto e último filho. O processo junto à Vara da Infância e da Juventude resultou no encaminhamento de Jimmy para a prestação de serviços comunitários ${ }^{47}$ na creche onde seus irmãos mais novos passavam o dia. Foi também o momento em que ele começou a se envolver efetivamente no circuito hip-hop da cidade, fundando um dos primeiros grupos de rap da cidade, em 1996.

Aos quarenta anos e com cinco filhos, dos quais apenas Jimmy contribuía um pouco com a renda familiar, esse período é relatado por Núbia como aquele em que ela teria enfrentado suas maiores dificuldades financeiras, por ter vivido ali seus maiores períodos de desemprego 48: "emprego de doméstica foi ficando cada vez mais difícil,

constituem um modelo representativo de organização e reprodução das relações familiares presentes nas camadas populares. (...) Há uma conciliação do modelo nuclear e conjugal de família com o modelo de família extensa, imerso nas relações de vizinhança, compadrio e parentesco." (Duarte e Gomes, 2008:171). Desde então, esse "desejo de quintal", de possuir uma moradia que pudesse ir se desdobrando em outras para abrigar os novos núcleos familiares de seus filhos, sem que isso represente uma desconexão em termos da família ampliada, se fará presente para Núbia, repercutindo também nos posteriores arranjos familiares e modos de habitar, mesmo em moradias de aluguel, quando deixaram a ocupação para viver no bairro Cidade Aracy, como veremos.

46 O declínio da concretização desse desejo no próprio orfanato será decorrente de diversos fatores, desde o fato de a namorada de Jimmy engravidar e ele deixar a ocupação, até o processo de intervenção sofrido pela ocupação, apresentado a seguir.

47 Uma das medidas socioeducativas em meio aberto que passou a vigorar legalmente após a aprovação do Estatuto da Criança e do Adolescente. Ver também nota 31 do Capítulo 3.

48 A situação de Núbia coaduna-se com a situação geral das camadas populares no país nesse período. Em São Carlos, nos anos 1980 e, sobretudo, nos anos 1990, a temática do desemprego é 
e em fábrica, então, nem se fale". Ela acabou conseguindo um trabalho bastante diferente do que ela já havia feito até então, como catadora de frango terceirizada para uma indústria de carne local ${ }^{49}$, descrito por ela como tendo sido o pior que já realizara, pelo nível de precariedade e privação enfrentado, sobretudo o fato de ter de passar semanas inteiras fora de casa, deixando as crianças - inclusive o filho mais novo, ainda bebê - aos cuidados do mais velho e das vizinhas. Foram oito anos nesse trabalho (sem nenhum tipo de garantia trabalhista), o qual, apesar do sacrifício, representou sua tábua de salvação para a manutenção da casa e dos filhos nesse período e do qual ela só saiu por problemas de saúde (decorrentes do próprio serviço, como dores nas costas e uma sinusite crônica). Depois disso, sem conseguir novos empregos, ela se tornaria catadora de reciclagem por um bom tempo, até ser chamada para trabalhar novamente junto à família D.

A despeito de passar boa parte do seu tempo fora de casa, ao longo dos primeiros oito anos em que viveu no antigo orfanato, Núbia fez grandes amizades ali, além de ter fortalecido ainda mais os vínculos com a sua família são-carlense (tendo seus filhos e os de Dália crescido juntos, até hoje se considerando como primos), o que fez com que, mesmo associando aquele território ao ápice das dificuldades e precariedades vivenciadas até hoje, ela estabelecesse com o lugar uma vinculação extremamente forte e afetiva: "Era maravilhoso, no início. Olha, eu vou ser sincera, Thaís, eu nunca tive tanta saudade de um lugar que eu morei como eu tenho do orfanato".

O Orfanato era um lugar gostoso quando eu fui morar lá. Porque era um lugar sossegado, era calmo. Igual... Não tinha a luz, mas, à noite, o pessoal fazia fogueira, a criançada brincava, os meninos ficavam tocando pagode... Sabe? Todo mundo lá se conhecia... Todo mundo conhecido, sabe? Ali era aquele lugar assim, que... a campanha da boa vizinhança funcionava muito bem! (risos) Todo mundo se ajudava. $O$ pessoal era amigo... Era amigo... e era tranquilo assim. [Núbia]

É nesse ponto das narrativas de Núbia que aparece, pela primeira vez, a referência a uma ideia de vizinhança, cujo sentido tornou-se tão caro a ela desde então. Depois de duas décadas de trânsito intenso pela cidade, em que as relações se faziam e se desfaziam ao sabor das vicissitudes e necessidades do momento, sem tempo-espaço hábeis para se consolidarem, ela vivenciaria, no antigo orfanato, a experiência de construir relações duradouras a partir da fixação em um território (com as tensões e conflitos também aí implicados), cuja posterior ruptura seria vivida com grande

recorrente nas atas da Câmara Municipal, com destaque para a amplitude de demissões nas indústrias e empresas na cidade e a queda na oferta de empregos em geral. Cf. Atas da Câmara Municipal de São Carlos, consultadas quando da realização do mestrado (Rosa, 2008).

49 Trabalho esse compartilhado com diversos outros moradores do orfanato, havendo, inclusive, um ônibus da empresa que buscava os trabalhadores na entrada da ocupação, atestando-a como lócus de fornecimento de mão-de-obra barata e desqualificada. 
sofrimento. Aquela dimensão simbólica de casa ali experimentada é por ela associada diretamente a essa dimensão de vizinhança, de uma boa vizinhança. Tal dimensão expressaria, mesmo, uma espécie de síntese entre casa e território (que não chegou a ser considerado por eles como um bairro, sendo expresso em termos de uma comunidade):

Olha, Thais, pra mim, uma casa representa segurança, mas junto com essa segurança, vem assim, a boa convivência com os vizinhos, e no orfanato a gente tinha muito isso, sabe? No Orfanato era assim, como se diz, um por todos e todos por um, entendeu? A gente dividia muito as coisas, compartilhava muito. Eu acho que essa boa convivência, boa amizade com os vizinhos, faz falta. Então, ali, foi a melhor casa, o melhor lugar que eu morei, por causa disso. A gente, ainda esses dias atrás, eu e o Jimmy estávamos lembrando, você sabe que era assim, um lugar muito carente, é verdade, mas também muito divertido, tinha lá as diversões, sabe? Onde as famílias eram bastante unidas, um lugar onde a criançada podia crescer à vontade, tranquilo, sem problemas. E era aquele negócio assim, por exemplo, levantava de manhã, se eu não tinha café em casa, ia tomar na casa do vizinho; se o vizinho não tinha na casa dele, vinha tomar na minha casa. Às vezes um tinha o pão, o outro não tinha o açúcar, o outro tinha manteiga mas não tinha o pão. (...) Então, por isso que pra mim uma casa é mais... uma casa tem a ver com aquele quê assim da convivência geral, digamos assim, de uma meia comunidade. / Thaís: Mas pra você isso importa mais que a casa em si, isso é mais importante? / Não, mais importante não, mas junto, junto. O espaço físico da casa também tem que ser viável, mas a vizinhança... é assim, aquela coisa que faz falta. Um quê a mais, uma coisa que falta. [Núbia]

Nesse sentido, ainda que, ao longo do período anterior de trânsitos e deslocamentos habitacionais, no qual a coabitação teve lugar fundamental em sua trajetória, se evidencie já a construção de um sentido bastante elástico de família - e, consequentemente, de casa - será a experiência de vizinhança vivida no orfanato (preponderando aí a relação com aquela considerada sua família são-carlense) a orientar toda sua posterior experiência urbana e as dinâmicas habitacionais, tornando-se sua referência no que tange a essa associação entre casa e vizinhança (que não havia aparecido em nenhum momento em seus relatos sobre o período vivido anteriormente no centro ou em outros bairros). Sua casa articulava-se a pelo menos outras três de sua família são carlense, cujos espaços eram intercambiáveis (a família de Núbia usava o banheiro de Dália; a família de Benedita usava a cozinha de Núbia...) e por onde circulavam pessoas, afetos, bens materiais e simbólicos. Essa concepção alargada e relacional de casa, "espaço moral" que "pode se estender por metros ou quilômetros" ${ }^{50}$, também foi expressa em diversos momentos por Jimmy:

50 Cf. proposição de Duarte e Gomes (2008:170) em estudo sobre "três redes familiares de classe popular na área do Grande Rio de Janeiro" (p.9), em que apreendem as íntimas imbricações entre casa, família, vizinhança e localidade como aspecto central nas dinâmicas de "manutenção e reprodução da família popular" (p. 169). Tal concepção ampliada de casa como "espaço moral" se estabelece em diálogo com a proposição de Marcelin (1999:37) sobre "configurações de casas", elaborada a partir de pesquisa junto a três bairros periféricos da cidade de Cachoeira, no Recôncavo 
A situação de comunidade, aquela união, aquela unidade, a segurança que a gente tinha ali, as coisas que a gente fazia entre a vizinhança, de relação entre as casas, de todo mundo dormir com a porta aberta, e o outro já ir entrando, começar a conversar, fazer um café... é umas coisas assim que, se você for fazer isso hoje, num bairro comum, tipo Aracy [onde eles vivem atualmente] ou mesmo o bairro que você mora, vai ser incomum, porque tá todo mundo acostumado a estar dentro da sua casa, mas no antigo orfanato era assim, era normal, era normal, parecia uma familia só o negócio, era como se fosse uma casa só. Tinha aquela proximidade afetiva mesmo, sabe? [Jimmy]

Tal concepção de casa e sua intrínseca relação com aquela de vizinhança relacionase, portanto, com a possibilidade de construção de redes de relações no tempo e no espaço, não tão episódicas como antes, a partir das quais se configuraria uma experiência urbana traduzida nas categorias êmicas ser conhecido e ter conhecimento. Tais dimensões referem-se, simultaneamente, às pessoas e ao espaço, de forma imbricada: ser conhecido significaria estar imerso em redes de relações sociais que implicam necessariamente algum tipo de vinculação ao território, seja pelo fato de ser nascido e criado ou, ao menos, morador antigo em um determinado lugar ("aqui todo mundo me conhece"; "aqui, onde eu vou tenho um conhecido"; "aqui todo mundo sabe minha índole"), opondo-se àqueles considerados estranhos; de forma complementar, ter conhecimento expressa o outro lado da balança, reunindo tanto os contatos e boas relações cultivadas no tempo e no espaço, quanto o domínio físico e simbólico sobre um território ("eu conheço esse lugar como a palma da minha mão"; "conheço cada buraquinho aqui"; "aqui eu sei quem é quem"; "aqui eu sei onde encontrar ajuda"). ${ }^{51}$

Baiano, e que se mostrou muito profícua para a reflexão sobre os modos de habitar e as experiências urbanas de Núbia e sua família a partir da experiência da ocupação no antigo orfanato, motivo pelo qual vale registrar a longa citação: "A casa não é somente um bem individual transmissível, uma coisa, um bem familiar, uma ideologia. Ela é uma prática, uma construção estratégica na produção da domesticidade. Ela também não é uma entidade isolada, voltada para si mesma. A casa só existe no contexto de uma rede de unidades domésticas. Ela é pensada e vivida em inter-relação com as outras casas que participam de sua construção - no sentido simbólico e concreto. Ela faz parte de uma configuração. (...) A configuração de casas não se refere a um conjunto imediatamente localizável. Ela não corresponde ao conceito de "família extensa". Trata-se de uma conceitualização, por meio da categoria cultural "casa", de processos relacionais entre agentes familiares originários de várias casas. Uma configuração não se revela ao pesquisador de um momento para o outro; nesse sentido ela não tem seus fundamentos em valores exclusivamente holísticos. Da mesma maneira que a casa cria em si mecanismos de regulação do individualismo de seus agentes, expressos em seu espaço interior que organiza o comunitário e o individual, a configuração de casas dá conta de um espaço cujas fronteiras são paradoxalmente confusas (do ponto de vista do observador) e nítidas (do ponto de vista dos agentes), no qual se dá um processo contínuo de criação e recriação de laços de cooperação e de troca entre entidades autônomas (as casas)."

51 Embora as categorias ser conhecido e ter conhecimento e sua apreensão como fonte de segurança frente a um território apareçam aqui vinculadas à experiência de Núbia e Jimmy na ocupação do antigo orfanato, elas foram recorrentes ao longo de toda a pesquisa de campo, em grande medida vinculadas a uma concepção de bairro, e reaparecerão em outros momentos da tese, inclusive acrescentando outros aspectos das mesmas. A delimitação simbólica de um território sobre o qual se tem conhecimento socioespacial e no qual se é reconhecido - justamente o que Mayol (1996) define como 
O interconhecimento, a familiaridade entre as pessoas e destas com aquele espaço e, sobretudo, as dimensões complementares de pertencimento e segurança daí advindas conformariam a caracterização essencial do antigo orfanato para Núbia e Jimmy, que se tornaria o cerne das memórias saudosas do lugar ${ }^{52}$ e referencial sempre acionado de casa e vizinhança, sintetizado na categoria lugar tranquilo ${ }^{53}$.

O antigo orfanato eu falo que foi o melhor pelo lugar mesmo, sabe? Porque, apesar de a gente não ter um saneamento básico, uma estrutura básica, a gente tinha aquela tranquilidade, que é uma tranquilidade de ter os vizinhos, que sempre abraçavam qualquer causa com a gente. Era tão assim próximo, que um vizinho fazia uma festa ia lá e falava: 'olha, tô fazendo uma festinha ali que é pra comemorar o aniversário do meu filho, a gente vai esticar o som até tal hora, não tem problema? E olha, vocês tão convidados, se quiser vir'. Sabe, era umas coisas assim bem combinadas, não tinha problema desse tipo lá, a gente se acordava. Porque ali todo mundo se conhecia, todas as casas ficavam com a porta aberta 24 horas por dia, era um lugar tranquilo, super sossegado. [Jimmy]

Se, por um lado, a noção de lugar tranquilo está diretamente associada a um lugar onde se é conhecido e se tem conhecimento, por outro, trata-se de uma construção a posteriori e absolutamente relacional: um lugar só é considerado tranquilo em comparação a outro, ou, como no caso do antigo orfanato, a ele próprio, em outro tempo (ver também Entremeio III). O fato é que o antigo orfanato tornou-se, progressivamente, um lugar pesado: um lugar que passou a ser ocupado por outras pessoas, onde o número de desconhecidos passou a crescer progressivamente ${ }^{54}$; e

bairro - também será apreendida como "fonte de segurança" por Segura (2007; 2009:67), em investigações sobre a periferia de La Plata, as quais "remarcan acerca del barrio las dimensiones del conocimiento del territorio y el reconocimiento de la persona, construidos a partir de la práctica cotidiana del espacio barrial, como fuentes de seguridad (lo que no supone la ausencia de conflitos)". Tais dinâmicas socioespaciais e construções simbólicas que permitem vivenciar estes territórios como "lugares seguros", mesmo em casos de convívio cotidiano com o crime, o tráfico e a violência policial (como veremos no próprio caso do orfanato, mas em outras situações abordadas nos capítulos seguintes), podem ser apreendidas - seguindo proposições analíticas de Rocha $(2008,2009)$, Machado da Silva e Leite (2007) e Fridman (2008) - como estratagemas para manutenção de uma "segurança ontológica", como definida por Giddens (1991:95): "crença que a maioria das pessoas têm na continuidade de sua auto-identidade e na constância dos ambientes de ação social e material circundantes".

52 Diversos estudos fazem referência a essas memórias saudosas de períodos vividos em condições socioespaciais de extrema privação de direitos (eu mesma encontrei diversos relatos semelhantes em minha pesquisa de mestrado sobre a favela do Gonzaga - Rosa, 2008), associando-as à intensa solidariedade e ajuda-mútua experimentada em tais contextos (Feltran, 2005). Não se trata, aqui, de avaliar o quão idealizadas ou efetivamente próximas da realidade vivida são tais narrativas, mas, sim, considerá-las como o caldo que passou a compor a experiência urbana de Núbia e Jimmy, informar seus imaginários de casa e cidade desde então, tendo na categoria êmica (também extremamente recorrente em campo) lugar tranquilo sua expressão máxima.

53 Veja-se o que aponta Guedes (2008:8), cuja aproximação com as dimensões aqui destacadas são inevitáveis: "as relações de vizinhança expressam-se também em avaliações discursivas frequentes conectando a tranquilidade do lugar e a vizinhança".

54 Inevitável destacar, aqui, que eles próprios foram alguns dos primeiros "outros" a aportarem no local, quando uma das famílias pioneiras decidiu vender seu barraco no local; entretanto, foram 
alguns desses outros, desconhecidos, seriam os responsáveis por acabar com a paz do Orfanato, ao instalarem ali bocas ${ }^{55}$, fazendo do lugar ponto de venda de drogas.

\section{- De lugar tranquilo a lugar pesado: novas dinâmicas socioespaciais}

A transformação do antigo orfanato de lugar tranquilo em lugar pesado é apreendida por Núbia e Jimmy como decorrência de um contexto mais amplo, em que se associam várias transformações socioespaciais, produtos e produtoras da expansão da ocupação. A primeira delas foi a chegada de asfalto e iluminação pública até o limite entre a ocupação e o bairro Monte Carlo, onde a mesma se situava: embora a sequência de postes fosse interrompida na curva da via que demarcava materialmente tal limite, possibilitou aos moradores improvisar, eles próprios, um poste de iluminação na entrada da ocupação, a partir do qual em pouco tempo os moradores passaram a fazer ligações diretas, o popular gato, estendendo a energia elétrica para todos os barracos do orfanato, permanecendo apenas as áreas coletivas sem iluminação.

No orfanato, não tinha iluminação pública; quando chegava no final das ruas, acabava, ai naquele, naquela curva que emendava as duas ruas ali no orfanato, não tinha iluminação nenhuma. Sabe como que teve iluminação? Que nós metemos o louco, erguemos dois caibros lá, tudo emendados, emendamos dois caibros assim um no outro, acho que deu uns três metros, fizemos dois modelo disso, erguemos e botamos uma lâmpada amarela lá mesmo, pra ter o mínimo. (...) depois que descobriram que dava pra fazer ligação direta na força, haha, pra que escuridão? Começou com uma casa, um mês depois já tinha quatro, aí, quando deu uns três meses, tava todas as casas com força elétrica. [Jimmy]

Apesar das dificuldades, era incrivel, eu lembro até hoje. A gente era bem feliz lá. Agora olha que loco que foi ficando o negócio: a infraestrutura melhorou, mas a segurança caiu, né, véio? Foi depois da iluminação que mudou tudo... [Jimmy]

Se a chegada da iluminação elétrica melhoraria significativamente a vida no local, também despertaria o interesse de novas famílias em se instalar ali. Além disso, no mesmo ano (certamente não por coincidência, já que a ocupação tornava-se mais visibilizada e começava a crescer), haverá o que foi considerado pelos moradores como uma intervenção da prefeitura no local, ocorrida na gestão do prefeito Dagnone de Melo (1997 - 2000), através da qual se pretenderia eliminar a ocupação através da distribuição de lotes no bairro Antenor Garcia (de propriedade do então vice-prefeito). Embora não haja nenhum tipo de registro oficial dessa 'intervenção' 56 ,

trazidos por moradores conhecidos, eram considerados parte da família desses antigos moradores, e isso fazia toda a diferença.

55 Boca ou biqueira são alguns dos nomes dados aos pontos de venda de drogas no varejo.

56 Fica evidente, aí, o embaralhamento intencional entre as figuras políticas do prefeito e seu vice e os interesses privados deste último, proprietário dos loteamentos Cidade Aracy, Presidente Collor e Antenor Garcia: as terras doadas não eram públicas, nem a intervenção, oficial; tratava-se, 
ela não ficou apenas na memória de Núbia e Jimmy: diversos moradores chegaram a se mudar para os lotes doados, alguns vivendo no local até hoje, como é o caso da mãe de Dália. Tais moradores teriam cedido, alugado ou vendido seus barracos no orfanato a novos moradores, instaurando um mercado informal bastante dinâmico no local, a partir do qual ocorreria um movimento de intensa renovação de moradores, reconfigurando boa parte da vizinhança.

Teve gente que comprou lá, na época, por um dinheiro, sei lá, dois, três conto [mil reais] assim, eu falei: 'nossa mano, eu tive sorte', porque nós pagamos bem mais barato no nosso barraquinho! E outro até tirava: 'e nós, mano, que não pagamos!', que eles ocuparam primeiro, foi bem diferente. [Jimmy]

Entretanto, uma parte dos lotes doados no Antenor Garcia (inclusive o de Núbia, que não se mudou para lá não apenas pela falta de condições de construir um novo barraco naquele momento, mas sobretudo pelo fato de que o local "era distante demais, ia dificultar mais ainda a minha vida"57) literalmente afundou na lama pouco tempo após a doação, em um período de chuvas mais intensas no início de $1999^{58}$. Em consequência, embora não tenham sido todos a regressar para o orfanato, uma parte deles voltou, reavendo seus barracos alugados (e, com isso, as famílias que os haviam alugado acabavam dando um jeito de ficar por ali, construindo novos barracos); no caso daqueles que os haviam vendido, a alternativa foi construir um novo barraco nas áreas livres da ocupação.

Na mesma época de chuva, uma parte das ruínas do edifício ocupado desabou, tendo algumas famílias ficado desabrigadas e, no processo de reconstrução de um barraco no local, acabaram também contribuindo para expandir a ocupação para além dos limites das antigas construções, abrindo caminho para que novos moradores passassem a construir barracos até as margens da encosta que circunda toda a parte alta dessa periferia ao sul da cidade. ${ }^{59}$

simultaneamente, de mais uma estratégia do loteador para ocupar o loteamento (que, aberto irregularmente em torno de 1993, nessa época contava com menos de $50 \%$ dos lotes ocupados e encontrava-se ainda absolutamente sem infraestrutura e irregular do ponto de vista fundiário, cf. Gaspar, 2000) e garantir clientela política para as próximas eleições.

57 A amiga Dália também não teria deixado o orfanato pelos mesmos motivos; contudo, o terreno ganho por ela localizava-se em um local que não chegou a ser afetado pelas erosões e, mais recentemente, após alguns imbróglios com outros moradores locais, a mesma conseguiu reavê-lo e pretende construir uma casa lá. "Ali no Antenor mora muita gente que era do Orfanato! A mãe da Dália era do orfanato, foi pra lá nessa ocasião, tem muitas famílias ali que eram do Orfanato, que ganharam esses terrenos."

58 A significativa erosão ocorrida nesse local, bem como o consequente desmoronamento de moradias, foram alvo de estudos acadêmicos e de inúmeras notícias nos jornais locais. Cf. Gaspar (2000).

59 Os relatos apontam para a chegada de migrantes nordestinos na ocupação nesse momento, corroborando com dados de outros trabalhos que detectaram a chegada desses migrantes, nesse mesmo período, em outros locais da cidade considerados, então, como "bolsões de pobreza" 
Assim, a somatória desses fatores teria não apenas ampliado o vulto da ocupação, como também "dado a brecha para chegada de novos moradores, inclusive traficantes" [Jimmy], pondo fim ao equilíbrio tênue da boa vizinhança e à tranquilidade do lugar, ancorada na segurança da reciprocidade inerente às dinâmicas complementares de ser conhecido/ter conhecimento. É nesse contexto que, a partir de meados dos anos 2000, o orfanato se tornaria gradativamente um lugar pesado:

Foi chegando outras pessoas, alguns antigos foram embora. Aí o bicho pegou lá quando virou boca memo, tsc, aí a paz acabou. Virou ponto de drogas. /Thaís: $\mathrm{E}$ como foi isso? / É, chegou um figurão lá, foi lá na favela [do Gonzaga], buscou umas paradas e montou uma filialzinha dos caras lá. A gente só ficou sabendo que ele tinha se instalado ali, não tem como, né, a gente bater de frente. Tipo, os caras andam armados, nunca são sozinhos. A gente podia até bater de frente com ele, mas depois ia vim uma renca em cima da gente. Ficamos na nossa, porque tava ficando pesado ali. [Jimmy]

Depois, com o passar do tempo que mudou um e outro, a turminha da pesada, acabou acontecendo fatos violentos, morte, essas coisas... / Thaís: Turminha da pesada você fala envolvida com droga, crime? / Isso. É, tinha tráfico também. Teve duas mortes, né? Virou um lugar pesado. [Núbia]

Crescendo progressivamente, a ocupação chegou a contar com pouco mais de sessenta famílias em meados dos anos $2000^{60}$ e, segundo Jimmy, chegou ao ápice de quatro bocas de tráfico de drogas naquele que era "um espaço muito pequeno", o que alterou significativamente as dinâmicas socioespaciais locais: foi deixando de ser seguro manter as casas tão abertas, as crianças já não deveriam circular em determinados pedaços da ocupação, passou a ser frequente o trânsito de estranhos no local, a violência tornou-se a tônica entre uma parcela dos novos moradores, o convívio cotidiano com o tráfico de drogas tornou-se inescapável.

E no orfanato, eu acho que... Eu gostava do orfanato, sempre gostei muito de lá, sabe, Thaís? Mas os últimos anos tava muito pesado. Porque era assim: aqui tinha uma casa que o cara era traficante, aqui minha casa e o daqui também era traficante [risos]. Então a minha casa ficava no meio. E eles não se bicavam. Então, por exemplo, se alguém vinha nessa casa aqui pra comprar, esse cara aqui não tinha, ele tinha que fazer uma volta assim pra chegar no outro. Ele não dava essa volta, passava por dentro do meu quintal. Às vezes, eu tava na cozinha fazendo comida, alguém esticava o rosto na porta: ' 0 , o cheiro tá gostoso, viu dona?' [risos]. Era alguém que tava indo lá comprar, dava uma paradinha ali. 'ô dona, a senhora não me arruma um copo d'água?' [risos]. 'Ô dona, o café tá cheirando gostoso, a senhora não me dá um golinho?'. Era mais ou menos assim. Ainda quando era isso, assim, menos mal; o duro quando saía briga. Saía muita briga. (...) Eram grupos diferentes, sabe? Era aquele negócio: um vendia pó, outro vendia maconha, outro vendia crack, outro vendia não sei o quê, o outro já

(NPD/UFSCar, 1994): Jardim Gonzaga (Rosa, 2008); Cidade Aracy (Silva, 2006); Antenor Garcia (Ávila, 2006).

60 Cf. Carneiro (2008). 
vendia de tudo e todos num lugarzinho só, ali era pequeno... então, a briga era por quê? Era por disputa de lugar. Pra ver quem vendia mais. [Núbia]

E, se até então a ocupação passara ao largo das investidas policiais já frequentes na relativamente próxima Favela do Gonzaga (o que corrobora na representação dos primeiros tempos do orfanato como lugar tranquilo: "Num ia polícia no antigo orfanato, pra você ter uma ideia, os caras não iam lá. Porque eles sabiam que lá não tinha nada, eles sabiam, eles tavam cientes disso. Era um lugar assim totalmente tranquilo, tranquilo" - Jimmy), entre essas novas dinâmicas cotidianas decorrentes da "bagunça da droga e do tráfico" estaria a progressiva inserção do orfanato nas rotas de patrulhamento policial na região, sendo cada vez mais frequente a presença de viaturas a espreitar o local.

Thaís: E o que mudou? / Por exemplo, aquela segurança lá não tinha mais. / Thaís: Porque? / Porque muitas vezes acontecia alguma coisa. Por exemplo, a polícia ia lá invadir... e dependendo da situação os caras chegavam lá atirando ${ }^{61}$. / Thaís: Antes num tinha isso? / Num tinha, a polícia num ia lá. Não ia. Era incrivel, a gente tava lá, ficava lá quando não tinha luz, a gente fazia fogueira. Que nem, nessa época fria? A gente fazia umas fogueira gigantona lá, os cara passava, nem olhava pra gente, nem ligava. Era como se a gente nem existisse. Depois que foi esse pessoal pra lá era polícia lá direto. Teve duas vezes que os caras chegou atirando lá, a gente tinha que colocar as crianças correndo pra dentro de casa, deitar no chão. Era negócio de favela memo. Virou aquele negócio de morro, pesado, sabe? Ficou insustentável o negócio. Era muito gostoso morar lá, mas aí desandou o molho, ficou muito inseguro. [Jimmy]

Em 2003, ocorreria ali a primeira morte violenta, decorrente de disputas entre os traficantes, a qual seria presenciada à distância por Jaelson, filho de Núbia, na época com dez anos. A ocupação do orfanato ganhava as mídias locais. É esse episódio que demarca, para ela, a transformação em lugar pesado; a partir dele tornou-se constante a presença de policiais na ocupação, da qual decorreriam invasões nos barracos e pancadarias nos moradores. Núbia teve seu barraco invadido algumas vezes pela polícia, à procura de traficantes, drogas e armas ${ }^{62}$; à humilhação e ao sofrimento, seguiu-se a naturalização63: "Bom, a polícia andar por lá de noite,

61 A insegurança associada a maior presença policial no território foi tema recorrente em campo, sendo aspecto retomado em outros momentos da tese.

62 Porém, em que pese ter convivido com aumento da criminalidade violenta e, consequentemente, com a violência policial nos últimos tempos em que viveu no orfanato (já nos anos 2000), nos relatos de Núbia (e de seu filho Jimmy), é o casarão 2020 que aparece como o lugar mais pesado em que viveram, pelo fato de a violência policial vivenciada ter sido maior, o que eles associam justamente à sua localização central: "Núbia: Ah, mas no 2020 a violência era maior que no orfanato. / Jimmy: Era, porque... por ser uma casa no centro da cidade (...)/ Núbia: É aquele negócio, Thaís, por ser no centro, aquele bando de pessoas de periferia morando num casarão daquele, isso aguçou a atenção do pessoal. Então... não se podia respirar ali, que a polícia já tava invadindo". Essa é a primeira passagem, nos relatos de Núbia, em que a distinção centro/periferia aparece verbalizada explicitamente, associando-os à periferia, apesar de, na época, viverem no centro.

63 Também compreendida como estratégia de manutenção de um mínimo de "segurança ontológica", como exposto por Machado da Silva e Leite $(2007: 576,577)$ para o caso das favelas 

mais, sabe? Acabou acostumando".

Quando você pensava que tava sossegado, a polícia tava chegando, e era uma pancadaria sem namoro. No fim, eu lembro que a gente não tinha sossego. Eu lembro que no barraco do orfanato num tinha janela e, como era muito abafado, eu fiz um quadrado na parede, um buraco. Pra arejar o quarto. E quantas vezes? Eu sempre tive mania de dormir no chão, então essa mania não é de agora, é véia. Então, quantas vezes eu tava dormindo, eu sentia a luz no meu rosto, eu olhava pro lado e jogavam ofarolete no meu rosto. Aí eles viam que eu acordava e perguntavam: 'Quem tá aí com você?' 'Meus filhos'. Às vezes, eles me mandavam abrir a porta pra verificar quem tava e quem não tava, mas era direto! [Núbia]

Núbia: E teve uma ou outra vez, assim, que eles invadiram mesmo em casa... A primeira foi a pior... Lembra Jimmy, daquele cara de Ibaté, parece que matou polícia, num lembro mais do nome do cara. / Jimmy: Quem? / Núbia: O cara que era de Ibaté, matou um polícia, lembra? Que veio até helicóptero procurar o cara, falaram que ele tava no orfanato? / Jimmy: Ah, como é que é o nome dele, meu Deus? Eu num vou lembrar, era um barbudo. / Thaís: Chegou helicóptero no orfanato? / Núbia: Ô, ele rodava em cima do orfanato, porque o cara matou um polícia em Ibaté, mas falaram que o cara tava escondido no lá. Então a polícia... Mas num teve uma casa naquele orfanato que a polícia num entrou. Num foi só na minha casa, foi em todas! Na cabeça deles, acharam que eles iam achar droga também. Eles esparramaram mantimento, tinha acabado de limpar a casa, Thaís... Eles chegaram no meu guarda-roupa, que era um grandão que eu tinha, eles jogaram tudo pro chão. Tinha caixa de brinquedos dos meninos em cima do guarda-roupa, jogaram tudo no chão. Aí eu tinha uma pecinha pequenininha onde guardava as roupas da Diana. O PM começou a abrir as gavetas, falei pra ele: 'a última gaveta é roupa íntima da minha filha', aí foi lá mesmo que ele virou tudo no chão. Mas depois eu chorava tanto pra arrumar tudo aquilo no lugar! $E$ andaram daqui pro meio do mato, helicóptero rondando, no fim acharam o cara na beirada do rio aqui embaixo, no Aracy. / Jimmy: Detalhe: meteram bale nele e puseram uma arma fria na mão do defunto. [Núbia e Jimmy]

As memórias desse cotidiano que foi se alterando com a presença do crime, embora oscilem entre suplantar as narrativas saudosistas sobre a vida no local e serem minimizadas por elas, permitem entrever rearranjos nas relações de vizinhança, que passaram a incorporar também os novos elementos: por um lado, evidencia-se a construção conflituosa desse convívio ${ }^{64}$ (já bastante diferente do enfrentado

cariocas, mas que parece expressar igualmente o vivenciado por Núbia no contexto do orfanato: "a experiência prática e imediata de uma ordem rotineira estável (aquilo que permite 'continuar', como diz Giddens) que fornece tais garantias, orientando os moradores sobre como ajustar suas condutas às situações de violência, perigo e insegurança. (...) tais garantias são representadas por rotinas suficientemente estabilizadas, capazes de incorporar a possibilidade de 'prosseguir' em situações extraordinárias, que passam a ser cognitiva e moralmente manipuladas como 'riscos' e não como bloqueio das condições 'objetivas' (isto é, da organização das rotinas) para 'continuar'."

64 Jimmy destaca que houve momentos de tensão entre ele, os primos, os jovens que já viviam na ocupação e os rapazes que instalaram as bocas no orfanato, já que estes teriam, inicialmente, forçado a barra para envolvê-los no negócio. Teria sido a proximidade dele e dos demais garotos com os traficantes da favela (do Gonzaga) - com os quais já tinham relações estabelecidas por terem estudado juntos, jogado futebol no campão da favela, compartilhado a iniciação no hip-hop - a induzir os novos 
anteriormente no casarão $2020^{65}$ ), definida por diversos interlocutores como o aprendizado de "um modo de viver na periferia" (que envolve a lei do silêncio ${ }^{66}$, mas também o estabelecimento de uma espécie de reciprocidade ${ }^{67}$, na forma de proteção mútua); por outro, sua naturalização, a partir desse próprio convívio, de modo que, embora a referência à perda de segurança seja frequente (associada tanto à presença do crime, quanto da polícia, como visto), a dimensão do medo só apareceria em um momento bem específico da trajetória, ao qual voltarei adiante: "Nessa época eu ainda não tinha medo. Eu não tinha. Sabe, por mais que eles brigassem lá entre eles, não mexia com a gente, não tinha problema com a gente." [Núbia].

Jimmy: É aquele negócio, como é que eu vou te dizer? É um lugar pra cada coisa, cada coisa no seu lugar. É aquele negócio: teve sim os problemas deles, vendeu droga, mas pra gente que era vizinho, na maior parte do tempo, eles não incomodavam. Eles acabavam incomodando os de fora. / Núbia: Cê entendeu? A

traficantes a um maior respeito no convívio cotidiano com os moradores locais, de modo que compreenderam que "aquele não era o nosso negócio, e sim, o hip-hop". A partir daí, as relações teriam se tornado melhores, a ponto destes novos traficantes terem sido incorporados às dinâmicas sociais integradas desses jovens de ambos os territórios do orfanato e do Gonzaga: "aí eles não faziam mais nada pra gente. Começamos a jogar bola direto, até trabalhamos junto na laranja... e eles eram umas moças, se você fizer amizade com os caras, você não fala que esses caras são capaz de cortar a cabeça de alguém como se corta um pão".

65 Esse convívio no orfanato teria sido bastante diferente daquele experimentado, quase dez anos antes, no casarão 2020, seja porque, ali, uma única família era responsável pelo negócio, não havendo disputas violentas, e se estabelecera entre eles e a matriarca da família uma relação bastante afetuosa, seja pelo fato de que eram todas jovens mulheres e não faziam uso de violência, nem eram armadas, ou pelo fato de estarem no centro e as dinâmicas serem um tanto mais veladas do que no orfanato, que, segundo Jimmy, era um dos "pontos de venda e uso de drogas" mais ostensivos que ele já conhecera (seu maior parâmetro é sempre a favela do Gonzaga), sem respeitar vizinhos e crianças.

66 Poucas vezes assim nomeada por meus interlocutores, a chamada "lei do silêncio", conhecido dispositivo de submissão e autoproteção "que impede os moradores de favela de construir discursos sobre sua submissão ao tráfico de drogas por medo de represálias" (Rocha, 2008) esteve por diversas vezes em pauta nos encontros de pesquisa: "É sempre aquele negócio, tudo o que acontece a gente sabe quem foi, mas não pode fazer nada, não pode falar nada. A gente fica à mercê dos caras" [Jimmy].

67 Aqui entendida mais no contexto de "deveres de obrigação" (Chalhoub, 2005) ou, como querem Almeida e D’Andrea (2004:104), "circuitos de reciprocidade negativa". Fonseca (2004:19-22), em estudo em uma favela em Porto Alegre nas décadas de 1980 e 1990, irá observar que, apesar das diferenças entre a maioria dos moradores e aqueles identificados como "bandidos", "tanto o isolamento imposto pela sociedade circundante quanto a necessidade de uma ajuda mútua cotidiana obriga[ria] os moradores da vila a agilizar um código de interação que permite o desenrolar das atividades rotineiras." Chama a atenção da autora o fato de "que as pessoas entrevistadas dividiamse em duas categorias: as que têm medo e se queixam dos "bandidos" da vila e as que se dizem tranquilas. Estas sentem-se 'respeitadas', as outras não." Buscando desvelar o que diferenciaria tais relações, a autora conclui "que a intimidade dos habitantes e sua interdependência constantes são regidas por um código de honra, onde a proteção e a homenagem são as principais moedas de troca": os moradores "respeitados" eram, em geral, aqueles que "prestavam homenagem", bem como cediam pequenos serviços e bens materiais (roupa, comida, cigarros) aos "bandidos". Veja-se também o apontamento de Alvito (1998:202) que, embora refira-se às favelas cariocas, parece explicitar bem algumas situações enfrentadas por meus interlocutores em diferentes contextos, como veremos: "há um entrecruzamento de lealdades, solidariedades e pertencimentos que torna extremamente espinhosa a questão de perceber até onde vai a amizade, até onde vai a vizinhança e onde começa o medo e/ou interesse". 
gente, eu mesmo, as crianças, nunca fizeram nada, nunca me faltaram o respeito, sabe? Muito pelo contrário, eles conversavam: 'Dona Núbia, tá tudo bem? A senhora tá precisando de alguma coisa? Se alguém incomodar, faltar respeito com a senhora ou com as crianças, só a senhora falar, e a gente dá um jeito'. A gente tinha essa relação, então, pra mim... Com as crianças, pra todo mundo lá - a não ser pr'aqueles que eram envolvidos com a droga, que tinham dívida ou disputavam - eles nunca fizeram nada. Mas aí, quando começou briga daqui, facada de lá, tiro de lá e facãozada de lá, até chegar no caso que o Thiago viu... Aí já mexeu comigo, me amedrontou ${ }^{68}$. [Núbia e Jimmy]

Chama a atenção aí, inclusive, a distinção entre essa boa relação que teria se estabelecido entre os antigos moradores e os novos traficantes (sobretudo os primeiros a chegar) e o fato de que "eles acabavam incomodando os de fora", promovendo um acirramento das fronteiras da ocupação, que se tornaria um dos lugares mais estigmatizados da cidade (ao lado da antiga Favela do Gonzaga): "então, o principal problema foi que a partir daí, todos os moradores do orfanato viraram bandidos" [Jimmy].

\begin{abstract}
Jimmy: O pessoal do bairro reclamava muito do orfanato. Já reclamava antes, depois que virou boca, então... As mulher ali da rua Paulo VI falava na maldade, quando a gente passava: 'isso daí, ó, traficantezinho já'. / Núbia: Mas, por quê? Porque o antigo orfanato era considerado favela. Quer dizer, da ponta da rua que tinha asfalto pra cima eram pessoas de bem. Onde acabava o asfalto, que era bem na frente do antigo orfanato, era favelado. / Jimmy: Era escola pra traficante, estuprador, tudo de ruim. / Núbia: Ladrão, tudo de ruim. /Jimmy: Só que, graças a Deus, eu, meus primos, a gente nunca foi pra essa vida aí, a gente teve nossas experiências, mas depois da gente ter um grupo de rap, a gente se apaixonou de um jeito pelo negócio, que a gente não queria saber de coisa errada, a gente queria fazer um rap. Só que hoje cê vai lá, e das molecada que cresceu com nós ali, que teoricamente era de fora do orfanato, era do bairro, a maioria usa droga, tem moleque lá que trafica, tem que é alcoólatra. (...)/ Núbia: É, porque... Eu acho que não só ali, mas acho que na maioria dos bairros é assim, existe essa separação. Nos bairros sempre tem assim, um lugar mais pobre, que o resto do bairro separa, assim, igual faziam com a gente ali no orfanato. Porque você vê uma coisa, eu já ouvi comentários assim, mais ou menos assim: Poxa, Núbia, nem parece que seus filhos cresceram no antigo orfanato, são meninos maravilhosos, educados, trabalhadores.' / Thaís: Como se o lugar que eles cresceram... / Núbia: Né? Num tem problema com polícia, tal... Essas pessoas não entendem que a droga, ela existe em todo e qualquer lugar: na favela, no bairro médio, no bom. Ela existe. Não adianta, ela tá em todo e qualquer lugar. [Núbia e Jimmy]
\end{abstract}

Nesse sentido, depois dessa transformação em lugar pesado e a consequente maior visibilidade pública da ocupação, o orfanato se tornaria não apenas estigmatizado mas, sobretudo, criminalizado. Núbia destaca, em sua narrativa, que a partir de então ela enfrentaria, como nunca antes, o preconceito relacionado ao local de moradia, manifesto na dificuldade em conseguir empregos e até mesmo em matricular as crianças na escola por morar no orfanato.

68 Voltarei a esse episódio adiante. 
Eu tinha que falar que morava no Cruzeiro, no Monte Carlo... se falasse que morava no orfanato não conseguia nada. E mesmo depois que conseguia o emprego, já aconteceu de a pessoa descobrir que eu morava lá e me mandar embora, por preconceito, medo... Eu antes não tinha passado por isso. E depois vivi isso aqui [no Cidade Aracy], aqui tem esse mesmo preconceito. [Núbia]

Pra arrumar escola pras crianças também. As diretoras não queriam aceitar matrícula, quando falava que era do orfanato. Diziam assim: 'ah, criançada que mora no orfanato não gosta de vir na escola, fazem a matrícula e não vêm, querem só ficar pela rua'. [Núbia]

O ápice desse processo de estigmatização e criminalização da ocupação e de seus moradores, para Núbia, teria sido o episódio em que Jimmy e os primos foram acusados, na porta de seus barracos, de um crime ocorrido em outra região da cidade, no qual se evidencia que a ocupação (como já acontecia há décadas com a Favela do Gonzaga) se tornava alvo da produção de suspeição pelas forças policiais locais.

Nessa época, que começou a pegar fogo lá, que os caras [a polícia] começou a ir frequentemente lá, aconteceu um episódio uma vez, a gente costumava sair de casa logo cedo, porque de manhã minha mãe xingava até umas hora, eu já levantava e num lavava nem o rosto. Já saía a milhão lá pra cima, ia pra casa da tia Dália e ficava eu, meus primos... Sei que nós ficava numa turma de uns quinze moleques assim sentados. Aí encostou umas três viaturas lá, e os caras começou a dar geral em nós. Só que, aí, os caras encanou comigo e com um primo meu, né? 'Ah, esses dois aí memo, esses dois aí memo, ó a roupa, e num sei o quê'. Os caras enfiou nós na viatura e não falaram nada. Aí, minha mãe veio, né? Veio minha mãe e minha tia Dália aos berros: 'Tira a mão deles!'. Aquele escândalo. Aí, o sargento falou assim: 'Eu vou levar eles, e o primeiro que falar alguma coisa aqui, eu vou enfiar a mão na cara'. Nossa, mas minha mãe partiu pra cima desse cara, mas deu uma dor de cabeça: 'Então você vai enfiar a mão na minha cara, mas o meu filho e meu sobrinho vocês não vai levar sem falar nada. Aqui mora gente, num mora burro não, cês tão de brincadeira?' Aí, já juntou tudo o povo ali na frente, os caras viu que a pressão tava demais, e ele falou: 'Ó, eles vão ser levados lá pra avenida Morumbi, que teve um assalto a um ônibus lá. Aí minha mãe falou: 'só que eu vou junto, do meu filho e do meu sobrinho vocês não vão judiar não'. 'Não, a senhora não pode ir'. 'Eu vou e quero ver se vocês vão me impedir'. Aí, o outro deu uma ideia e falou: 'deixa ela ir'. Aí foi ela e minha tia junto. Chegou lá, o cobrador: 'não esses caras aí eu conheço. Eles moram lá no antigo orfanato', o cobrador conhecia nós. Era o Jão: 'Pelo amor de deus, esses menino aí num mexe com nada não, num é esses daí não'. Então, no fim, hoje é até engraçado, porque os cara num perguntou nada, chegou na nossa casa, deu geral, pá. E o pior é que, depois disso, os vizinhos do bairro falaram mais ainda: 'ah lá, num falei, é os filho da Núbia, da Dália'. Aí minha mãe já mandou todo mundo tomar num lugar bem legal (risos). [Jimmy]

É nesse contexto de expansão, transformação e consequente maior visibilidade da ocupação, em que o local passa a ser representado socialmente como favela, ponto de venda de drogas, antro de marginais, que se configura uma aproximação da nova gestão municipal, a partir da qual a ocupação passará a ser considerada também como área de risco, tornando-se alvo de intervenção urbanística. 


\section{- Uma (breve) aproximação à moradia como direito}

Se os anos 2000 trariam muitas mudanças para o país, a cidade e o antigo prfanato, também o trariam para Núbia: depois de anos, ela encontraria um novo companheiro, Cleiton (morador justamente do bairro vizinho), que se muda para o seu barraco em 2001 e, alguns anos depois, expulso de lá por Núbia, compra outro barraco no local; seus dois filhos mais velhos, Jimmy e William, que já trabalhavam (na maior parte do tempo em serviços na roça) e ajudavam nas despesas familiares, saem de casa, reduzindo drasticamente os ganhos familiares (Jimmy se muda para o Cidade Aracy para morar com a namorada, que havia engravidado, e William se desentende com o novo companheiro da mãe e vai morar primeiro com Dália e, em seguida, com o irmão). Sem o auxílio dos filhos, com problemas de saúde e sofrendo o preconceito por morar no orfanato, Núbia enfrentaria, a partir de 2003, suas maiores dificuldades financeiras, passando por um grande período de desemprego, após o qual se tornaria catadora de recicláveis.

A mudança de gestão governamental em escala municipal e nacional repercutiria na chegada de políticas sociais e habitacionais ao orfanato. Em 2002, é feita a primeira incursão da nova gestão municipal ao local (gestão Newton Lima/Partido dos Trabalhadores - 2001-2004), na qual foram realizadas algumas reuniões com moradores e levantamentos físicos da ocupação: tais ações incluíam-se em uma sequência de levantamentos realizada pela Secretaria Municipal de Habitação e Desenvolvimento Urbano e pela já mencionada $\mathrm{PROHAB}^{69}$ em várias regiões da cidade, com vistas a identificar situações habitacionais e urbanas consideradas "problemas" na cidade, as quais sofreriam intervenções durante a gestão. Nesse início dos anos 2000, São Carlos, com 197.187 habitantes, era uma cidade com uma periferia já bastante consolidada, onde se situavam ao menos oito núcleos de "invasão" e/ou "áreas de risco" (consideradas pequenas favelas, como o próprio Orfanato), além de uma miríade de "áreas irregulares" do ponto de vista fundiário. A postura da nova gestão já fora evidenciada um ano antes, logo no início do mandato, quando, após fortes chuvas, foram removidas dezenove famílias de uma área considerada "de risco" no Jardim Gonzaga para o Loteamento Social Santa

69 Com atuação bastante intermitente desde sua fundação, em 1986, até o início dos anos 2000, a PROHAB terá novo fôlego a partir dessa primeira gestão do Partido dos Trabalhadores na prefeitura municipal, a qual, a partir de 2003 (com o início da gestão Lula/PT - 2003-2010 - no governo federal) estará em diálogo com as políticas nacionais em curso (criação do Ministério das Cidades, realização das Conferências das Cidades, aprovação da Política Nacional de Habitação, para citar alguns exemplos). Uma reflexão um pouco mais detida sobre a PROHAB e as representações populares das políticas habitacionais no município será esboçada no Entremeio I. De forma complementar, sugiro as análises sobre a atuação do órgão encontradas em Rosa (2008; 2012) e PMSC (2010). 
Angelina, e tiveram início algumas intervenções pontuais em outras "áreas críticas" do bairro. A partir de 2002, o mesmo bairro seria alvo de um "projeto de reurbanização" no âmbito do Programa Habitar Brasil Bid, através do qual novas remoções de "áreas de risco" seriam realizadas, desta vez para uma área no bairro Monte Carlo, próxima ao Jardim Gonzaga ${ }^{70}$.

Ainda em 2002, quando da incursão da prefeitura ao antigo orfanato, as memórias de Jimmy e Núbia corroboram com outros registros de que, nessas primeiras reuniões com os moradores, a negociação teria ficado no ar entre uma proposta de reassentamento dos moradores no próprio local da ocupação, uma proposta em que os moradores poderiam ter acesso a um lote urbanizado para autoconstrução em outros bairros da cidade e uma proposta de remoção integral da ocupação, ainda sem destino definido ${ }^{71}$. Mesmo sem uma definição concreta sobre a intervenção, já nesse momento, as famílias teriam sido cadastradas, e os barracos, selados: essa prática, recorrente em intervenções urbanísticas em áreas de ocupação, expressa a tentativa de "congelar" a mesma, evitando novas ocupações. No entanto, independente da selagem, a perspectiva de conseguir uma casa própria através da inserção no mutirão atraiu ainda mais moradores para o local.

O misto de euforia e insegurança inicial em relação à perspectiva de intervenção daria lugar à descrença e ao desânimo entre os moradores: quase dois anos se passariam sem que a mesma se concretizasse. Nesse meio tempo, assistentes sociais da prefeitura cadastraram os moradores do local para o recebimento do novo benefício concedido pelo governo federal, o Bolsa-Família, que Núbia receberia até novembro de 2011, quando seu filho mais novo deixou de frequentar a escola por um semestre. Ela faz questão de destacar o modo como tomou conhecimento de sua inclusão no programa, e o relato, se associado aos momentos em que ela menciona episódios relativos a suas aproximações às políticas habitacionais da cidade, indica um modo descrente (e por vezes crítico) de encarar as políticas públicas e, principalmente, a maneira desencontrada como estas (ou as informações sobre elas) chegam aos chamados "beneficiários" (aspecto, que, veremos, será recorrente em sua trajetória

70 Cf. Carneiro(2008); PMSC (2002, 2003, 2005, 2010); TEIA (2001, 2002).

71 Carneiro (2008); Shimbo (2009). Tais "rodadas" de levantamentos pela cidade, cuja efetivação em ações políticas levaria um bom tempo, seriam posteriormente invocadas como signo do caráter democrático adotado pela gestão para o tratamento dos problemas urbanos e habitacionais no município, permitindo aos "invasores" optar por alguns dos programas oferecidos pela PROHAB, em parceria com a CEF, em basicamente dois locais de destino: os loteamentos sociais Santa Angelina e São Carlos VIII (cf. diversas notícias no site http://www.saocarlos.sp.gov.br/). No caso do orfanato, entretanto, tal caráter democrático parece não ter sido efetivado, como captou Carneiro (2008) e como as narrativas de Núbia e Jimmy permitem apreender. 
daqui por diante), que, em sua maioria, têm, como Núbia, uma grande dificuldade em lidar com essas papeladas ${ }^{72}$.

Uma vez, eu morava lá no orfanato ainda, aí passou um pessoal lá fazendo o cadastro do Bolsa-Família, mas eu nem sabia, sabe? Fazendo perguntas, quantas pessoas eram na casa, tal. E passou... muito tempo, ih! Passou meses! Aí, um dia, foi até uma época que a gente tava numa situação feia! [risos]. Acabou meu gás. Aí eu fui na assistente social pra elas me darem um gás. Falei: 'Ai... porque tempo de chuva sem gás em casa não dá.' Aí que ela falou: 'mas a senhora não recebe o Bolsa Família?'. Falei: 'Eu não! Nunca recebi não.' 'Não, a senhora recebe sim. Tá aqui na ficha da senhora, tá constando como...' Falei: 'Não, mas eu nunca recebi um tostão desse Bolsa Família! Eu lembro que foi falado uma vez, passaram em casa tal, mas não recebi comunicado nenhum! Então eu nunca recebi.' Aí que ela foi verificar e tava depositado o Bolsa Família pra mim, já fazia oito meses. E eu não sabia! Aí, naquela época, eu pude sacar só dois meses. O... porque, quando vem e a gente não saca, volta, né? Volta, é. A gente não recebe. Mas eu consegui sacar dois meses ainda. / Thaís: Aí já deu um alívio... / Nossa, e como deu, porque eu lembro que tava numa semana de chuva! Aquela época, eu catava papelão, não tinha como trabalhar com tempo de chuva! E acabou meu gás, nossa, que sufoco! Fazer comida na espiriteira de álcool... [Núbia]

Apenas em 2004, no último ano da primeira gestão municipal do PT, seria retomada a pauta da intervenção no local. Após aquele processo de selagem, devido à intensa dinâmica de saída e chegada de moradores (inclusive estimulada pela incerteza da intervenção), foi realizado um recadastramento das famílias. Nessa altura, Jimmy (que, desde o início de 2003, morava no Cidade Aracy com a esposa e o primeiro filho e acabara de ter o segundo) e Cleiton (o companheiro de Núbia, que agora morava em um barraco próprio) foram cadastrados como outros dois núcleos familiares.

A proposta fora definida unilateralmente pela PROHAB: remoção integral através da realização de mutirão no loteamento social São Carlos VIII, promovido pela empresa e situado no outro extremo da cidade, bastante distante do orfanato. No local, onde além dos lotes sociais a empresa mista implementou outros programas habitacionais ${ }^{73}$, seria construído o conjunto habitacional, posteriormente denominado Dom Constantino Amstalden, com duzentos e vinte e quatro unidades habitacionais distribuídas entre edifícios de dois pavimentos e algumas casas térreas: para lá seriam removidos não apenas os moradores da ocupação do antigo orfanato, mas também de outras duas "áreas de risco" da cidade, identificadas naqueles

72 Tanto pela questão dos estudos incompletos, quanto pela ausência de um endereço fixo, através do qual teriam acesso a comunicados e documentos referentes às políticas.

73 Cf. Carneiro (2008); PMSC (2010). Loteamento social criado pela PROHAB em 1998, com 1456 lotes. No local, foram construídas, através de políticas habitacionais, entre 2001 e 2012, 535 moradias, vinculadas aos programas Imóvel na Planta Individual, Imóvel na Planta - Operações Coletivas (mutirão), Programa de Arrendamento Residencial (PAR) e Pró-Moradia. Segundo informações divulgadas no site da prefeitura, os programas habitacionais implantados no local receberam mais de R\$ 15 milhões em investimentos em moradia, envolvendo recursos da Prefeitura, do Governo Federal e da Caixa (www. saocarlos.sp.gov.br). 
primeiros levantamentos de 2002 (localizadas nos bairros Santa Maria e Santa Felícia). Sendo o número de unidades maior que o número de famílias dessas ocupações, o conjunto também atenderia outras "famílias de baixa renda" a partir do cadastro de demanda habitacional da PROHAB, por meio de sorteio.

Embora a versão oficial tenha dado conta de que os próprios moradores teriam optado pela remoção e realização do mutirão, os relatos de Núbia e Jimmy evidenciam um processo um tanto conflituoso, já captado por Carneiro (2008) em estudo sobre a intervenção. Além do fato de diversos moradores desejarem permanecer no local (como era o caso de Núbia e sua família ${ }^{74}$ ), um dos aspectos a gerarem grandes conflitos foi a localização do conjunto habitacional, extremamente distante do Orfanato, do centro da cidade e em uma região então desprovida de infraestrutura, equipamentos públicos, serviços e comércio.

Muitas vezes o governo tira uma comunidade de um lugar, por exemplo, uma área invadida. Que nem o antigo orfanato, era perto de escola, posto, mercado, pa pa pa, pa pa pa. Jogaram o povo lá no São Carlos VIII, lá onde o Judas perdeu as botas e a esperança também, sem creche, sem escola, sem posto de saúde, sem nada, agora que tão fazendo. Quer dizer, eles tiram o povo como se o gueto fosse obrigado de ficar longe de tudo. Você num tem o direito de morar perto do seu emprego, você não tem o direito a morar ali perto de um supermercado, de um hipermercado, fazer uma compra mais barata, você não tem direito a morar mais perto de um hospital, você tem sempre que tá se ferrando. [Jimmy]

Por outro lado, como também apreendeu Carneiro (2008), Núbia e Jimmy associam a política habitacional levada a cabo pela $\mathrm{PROHAB}$ na cidade e a intervenção no orfanato dela decorrente como mais um fator a desestabilizar a vizinhança, a comunidade: seja porque uma parte dos moradores, após a primeira incursão da prefeitura ao local e posterior demora no início da intervenção, acabaram vendendo seus barracos e mudando-se para outros bairros; seja porque, como descreverei a seguir, um tempo após o início do mutirão os moradores do antigo orfanato foram divididos em dois grupos de mutirantes, de modo que a sociabilidade no local ficou prejudicada (não apenas porque enquanto um grupo trabalhava nas obras, o outro permanecia na ocupação, desencontrando inclusive os momentos de remoção de

74 Ambos mencionaram, diversas vezes, que gostariam que a prefeitura os tivesse mantido no mesmo local da ocupação, urbanizando-a ou realizando o mutirão ali mesmo, e não no São Carlos 8. "Ali era pra ser um condomínio, igual do CDHU [Companhia de Desenvolvimento Habitacional e Urbano], e a gente podia tá morando lá até hoje, com uma infraestrutura completa. / Thaís: Mas se fizessem isso, vocês continuariam morando lá? / Núbia: Tranquilamente. / Jimmy: Nós e a maioria continuaria". Nesse contexto, Jimmy opõe-se à visão de antigos moradores que, tendo deixado o local, referem-se a ele com negatividade, em função da presença do tráfico de drogas e da violência enfrentada nos últimos tempos vivendo ali, distinguindo claramente o espaço dessas relações sociais ali instauradas: "Eu vou ser bem sincero aqui, teve gente que saiu lá do antigo orfanato e falou: 'ó, nunca mais eu volto aqui nesse lugar desgraçado'. Usaram essa palavra sobre o lugar! Então, é o que eu falei, num é o lugar que é desgraçado. O lugar em si, uma casa vai fazer o quê pra alguém? O pessoal num entende isso, e acha que o lugar que é o problema". 
cada família, mas, sobretudo, porque alguns teriam se aproximado mais do que outros dos técnicos e políticos da PROHAB, contribuindo para a construção de posições hierárquicas no processo do mutirão ${ }^{75}$ ); seja, ainda, porque a inserção em um grupo bastante mais amplo, com pessoas oriundas de diversas regiões da cidade, e os conflitos daí decorrentes já no próprio processo do mutirão lhes dava a tônica de que, no novo local de moradia, as relações de vizinhança estabelecidas no orfanato não seriam mais as mesmas, ali se amplificando sobremaneira as dimensões que vinham caracterizando o orfanato como um lugar pesado.

As duas falas de Jimmy reproduzidas a seguir sintetizam todos esses aspectos e chamam a atenção para a não estanqueidade das dimensões lugar tranquilo e lugar pesado: mesmo após todas as transformações anteriormente relatadas nas dinâmicas locais, ainda se mantiveram (e se intensificaram) as relações de amizade entre os moradores antigos que ali permaneceram (como eles e as tias, os primos, entre outros), que faziam persistir esse sentimento de vizinhança e comunidade mesmo em meio ao lugar pesado; por outro lado, com os traficantes locais eles haviam aprendido a conviver, teriam estabelecido (mesmo involuntariamente) aquela espécie de reciprocidade necessária para garantir sua "segurança ontológica", como visto, que eles percebiam - já no canteiro de obras do mutirão - que também não se reproduziria no São Carlos VIII, desde então apreendido como uma panela de pressão, tema aprofundado adiante.

A gente gostava de morar ali [no orfanato], apesar de tudo. A gente tinha planos ali... quando a prefeitura chegou lá e veio com as ideia de tirar a gente de lá... Ah, foi triste. Não só pelas nossas ideias pra casa, mas porque ia se desfazer toda aquela comunidade, sabe? Toda aquela união, toda aquela parceria, porque, sei lá cara, quando a gente se desloca é uma coisa né, fica diferente, já não é mais a mesma coisa, sabe? A gente já ia morar num bairro onde não ia ter só o nosso pessoal, então já não ia ser mais a mesma coisa né, alguma coisa ia mudar. Então, pra gente, foi muito cabuloso assim, foi decepcionante também por causa disso, né? Porque a gente tava realmente assim com ideias mirabolantes, de aumentar, sabe? A gente pensava que, depois daquele tempo todo, poderia rolar o usocapião ali... / Thaís: E por que você acha que não rolou o usocapião ali? / É, balaio de gato, com certeza, porque ali tinha usocapião. / Thaís: E ninguém tentou? / Não ia dar nada, a prefeitura tava pau a pau com o cara, não ia dar nada pra nós, a gente entendeu que a gente tinha perdido aquilo lá. Infelizmente, quando a gente fala do usocapião, se tem um poder público federal junto, nos apoiando, aí a gente ia, mas tava tudo do lado do cara! Aí eu falei: 'meu, é a gente ir e tomar pau. Vamos aceitar isso que eles tão oferecendo porque, se a gente colocar no prazo, nem isso eles vão querer, pá'. / Thaís: Que era o mutirão? / É... E no fim eu acabei ficando também, no mutirão, sabe? Mas aí eu fui vendo: no fim, os caras iam tirar a gente de um "conforto" pra colocar em uma caixa de sardinhas, sabe? Pra gente estourar todo mundo lá dentro e foda-se, espalha sangue. / Thaís: $O$ conforto que você fala é a situação que vocês viviam ali? / A situação de comunidade, aquela união, aquela unidade, a segurança que a gente 
tinha ali, porque o lugar já tava pesado, né, mas até então a gente ainda tinha nosso meio domínio ali, tinha a relação estabilizada com os caras... mas no São Carlos VIII, já no mutirão tava virando uma panela de pressão... [Jimmy]

Um ano depois que eu saí [do orfanato] começou o mutirão. Eu até entrei no programa, consegui me cadastrar quando ainda morava lá, meu filho já tinha nascido. Eu cheguei a entrar, entre aspas. / Thaís: Por que entre aspas? / Porque, na verdade, num era pra eu ter entrado, porque eu já tinha saído de lá. Assim, meio que no esquema, eu acabei entrando, só que eu fui desencanando, talvez fosse um pensamento até meio errado, porque hoje eu podia ter algo no meu nome. Mas depois, vendo assim com o tempo, falei: 'não, num é, eu fiz o certo'. Assim, eu tinha essa preocupação de criar... na época eu tinha só o meu mais velho, eu num posso criar meu menino num clima desse, saca? Eu tinha essa preocupação. E lá no São Carlos VIII, juntou: Santa Maria II, antigo orfanato, Santa Felícia, uma parte lá, não sei, acho que era irregular, Jacobucci, uma parte do Gonzaga que morava em área de risco, vários lugares. Os caras, no mutirão, eles tavam brigando pra ver quem ia ser o dono da boca. Eu fiquei pensando nisso, falei: 'como é que eu vou morar num lugar onde eu não vou poder soltar meu moleque pra brincar numa pracinha?' / Thaís: Durante o mutirão já tava tendo essa disputa? / Já tava, já tava. Mas, fora isso, muita coisa errada rolou naquele mutirão, muita coisa errada por parte da PROHAB. A PROHAB não soube organizar aquele negócio, tanto que eu trabalhei lá durante tanto tempo... E o tempo que eu não trabalhei eu paguei o meu irmão pra ir no meu lugar, eles não marcaram nada! Então, ficou como se eu tivesse inadimplente todos os dias, todos os horários. Aí eu acabei desistindo mesmo. / Thaís: Então, no fim, você trabalhou lá, sua mãe trabalhou lá... / Meu irmão trabalhou. O Cleiton, que era o companheiro da minha mãe, trabalhou. Meus primos, minhas tias... Todo mundo trabalhou, todo mundo. Só que a galera foi desencanando, sabe? Foi todo mundo desencanando. [Jimmy]

Iniciado no próprio ano de 2004 - com recursos próprios da PROHAB, enquanto os trâmites para viabilização do conjunto através do Programa Imóvel na Planta Operações Coletivas, operacionalizado pela Caixa Econômica Federal (CEF), ainda não haviam sido finalizados -, o cronograma inicial de realização do mutirão previa vinte e quatro meses de obras ${ }^{76}$. Núbia, Jimmy, Cleiton, Dália e os demais moradores que aceitaram a condição de remoção para o mutirão passaram a trabalhar aos finais de semana, junto aos moradores da ocupação no bairro Santa Maria (localizado ao lado do São Carlos VIII) e, durante um ano e meio, construiriam as fundações de todas as edificações do conjunto. Núbia contaria ainda com a ajuda de outros dois filhos (Jaelson e Diana, então adolescentes entre treze e quinze anos). Em algumas ocasiões, a inserção deles também representou a possibilidade de obter recursos extras para a família, já que alguns moradores que não conseguiam ir todos os finais de semana pagavam outros para trabalharem em seu lugar ${ }^{77}$.

76 As informações complementares referentes a aspectos operacionais da intervenção foram obtidas junto a Carneiro (2008) e Shimbo (2009).

77 Já que a diária paga a um conhecido poderia ser menor do que a "multa" de R\$ 20,00 estipulada pela PROHAB para cobrir faltas não justificadas. 
Finalizadas as fundações em meados de 2005 (já na segunda gestão Newton Lima/PT - 2005-2008) e ainda sem a aprovação do financiamento pela CEF, a PROHAB decidiu dar continuidade às obras, mas apenas parcialmente, o que gerou uma divisão dos mutirantes em dois turnos: um (composto pelos moradores da ocupação do Santa Maria e uma parcela dos moradores do orfanato), que daria continuidade às obras de setenta e duas unidades habitacionais, e outro (composto pelos demais moradores do orfanato, os moradores da ocupação do Santa Felícia e os demais sorteados do cadastro da PROHAB), que retomaria o trabalho após a assinatura do contrato com a CEF, construindo as cento e cinquenta e duas unidades restantes. Com a mudança de gestão, embora o prefeito tenha sido reeleito, a diretoria da PROHAB foi recomposta e, com ela, uma parte da equipe técnica responsável pelo mutirão. O contrato com a CEF seria assinado apenas em agosto de $2006^{78}$. Em 2007, ocorreria uma nova mudança na diretoria e equipe, e teria início o segundo turno do mutirão.

A rápida reconstituição desses fatos tem por objetivo iluminar o quão confuso foi todo o processo de realização do mutirão, que, com todos esses contratempos ${ }^{79}$, levaria quase seis anos para ser concluído. A desinformação (e a descrença) sobre os rumos do processo entre os moradores do antigo orfanato fez com que muitos parassem de trabalhar, após mais de dois anos de participação no mutirão, e acabassem excluídos do Programa. Jimmy foi o primeiro a abandonar o barco: com dois filhos pequenos e trabalhando em uma empresa com apenas uma folga por semana, a participação no mutirão ficou cada vez mais difícil, mesmo pagando os irmãos para cobrirem suas faltas. Some-se a isso o desencontro de informações decorrente de tantas mudanças na equipe técnica e política e o desgosto com os rumos que a situação no canteiro de obras tomava (com a progressiva hierarquização entre os mutirantes, o que, aos olhos dos demais, soava como privilégio e produzia ainda mais descrença em relação à atuação da $P R O H A B^{80}$ ), bem como a visualização mais concreta não apenas do espaço físico dos apartamentos e do conjunto como um todo, mas também das relações sociais conflituosas que já se estabeleciam ali, como já mencionado. Por tudo isso, Jimmy destaca que foi uma escolha deixar de participar

78 O contrato assinado por Núbia, do qual obtive cópia junto à Prohab, está datado de 11 de agosto de 2006.

79 Além de muitos outros, como a ausência de materiais disponíveis todos os finais de semana, desentendimentos entre os mutirantes e destes com as equipes técnicas, alterações nos regimentos do mutirão, para citar alguns (cf. tb. Carneiro, 2008; Shimbo, 2009). Vale dizer que não é meu objetivo analisar a problemática do mutirão em si, mas apenas fornecer elementos para a compreensão dos efeitos que tal política terá nos rumos futuros da trajetória de Núbia e que, articulados, dão uma dimensão das violências inerentes à implementação de políticas habitacionais em escala local.

80 Que, de resto, já não gozava de boa fama entre os populares, tema ao qual retornarei no Entremeio I. 
do mutirão (o que não diminui sua sensação de injustiça pelo tempo e mão de obra ali empregados, nunca recompensados):

Eu fui porque minha mãe pediu pra me inscrever, pra família voltar a ficar toda junta, e eu achei que ela tava certa. Eu fui, me inscrevi, mas já quando eu cheguei lá e vi o projeto, eu falei: 'nossa, não era isso que eu tinha em mente ${ }^{81}$. É uma coisa muito junta, tudo colado, e não era isso que eu tinha em mente, eu queria algo um pouco mais confortável e privativo que isso, porque fica tudo em cima, os murinho tudo meia altura, e eu falei: 'meu, isso aí não dá certo, nunca'! Mas aí, assim, se tem que começar, vamo lá, essa parte eu consegui relevar, mas aí tava acontecendo esses negócios que eu falei pra você, aí eu já fui murchando... Lá tava rolando, assim, algumas pessoas, por ser puxa-sacos do sistema, começaram a ter umas prioridades, de não ir trabalhar, de ficar lá só mandando na turma, e eu não achei que aquilo era justo, não pelo fato de a pessoa tá lá no outro cargo no mutirão, mas de ser só aquela pessoa. Tem muita gente inteligente ali. / Thaís: Pessoas do orfanato mesmo, ou não? / Não, pessoas do Santa Maria 2. E isso deu uma brigaiada lá, certa vez, que só por Deus viu! Nego quase saiu na mão lá por causa de nada! Só que ai eu entendi o lado do povo, falei: 'meu, eles tão pegando meia dúzia de pessoas que fica em cima dos outros, cuidando da vida dos outros, fofocando da vida dos outros, entregando os outros, pra mandarem nas pessoas'. As pessoas ficaram revoltadas, então, aí eu já vi, é foda, sabe, aí falaram assim 'quem não perder dia vai poder escolher a sua casa', foi uma época que eu comecei a ir direto assim, direto, só que no dia de escolher a casa, olhamos na lista lá, meu nome não tava na lista, nem o da minha mãe... Aí eu desanimei, falei: 'ó, não acredito'. Ficou aquele negócio, assim, parece que a gente sempre tá tomando uma rasteira. Aí, depois, caiu a ficha que ia Santa Maria II, tinha o orfanato, Santa Angelina e Jardim Gonzaga, brigar pra ver quem ia ser dono da boca no lugar, falei: 'pronto, não é pra mim isso.' De jeito nenhum, meu filho vai estar brincando ali, meus filhos gostam de correr pra todo lugar, imagina se um retardado dá um tiro de lá pra cá me acerta um filho meu, um filho de um vizinho meu, não dá, não dá. (...)... Então, foi uma decisão, uma escolha, falei: 'infelizmente eu vou ter que esperar mais um pouco', não dá, não é pra eu criar meus filhos ali. Num quero criar minha família numa panela de pressão, que eu num sei o que vai acontecer daqui 10 minutos... [Jimmy]

Evidencia-se nos relatos de Jimmy a caracterização do conjunto habitacional como uma panela de pressão ${ }^{82}$, da qual os conflitos no mutirão eram apenas uma amostra, e cuja condição ele associa diretamente às dimensões físicas do mesmo:

Aquele conjunto habitacional, no meu ponto de... Eu não sou arquiteto, eu não sou engenheiro, mas no meu ponto de vista como um cidadão comum, eu já vejo que aquilo lá é um erro, é terrível aquele projeto, é um projeto errado e tipo assim, começaram a reunir todas as pessoas que moravam em área de risco e: 'taca pra lá'. É tipo assi:, 'ah, joga aquele pessoal pra lá e deixa que eles se matem por lá', dá essa impressão, sabe? [Jimmy]

81 Veja-se depoimento de uma então moradora do orfanato e mutirante apresentado em Carneiro (2008:111): "através de um telão eles apresentaram um projeto pra nós. A planta da casa e a casa já feita. (...) então, a casa de vocês pronta vai ficar assim. Então eles tiravam da planta e punham numa imagem da casa pronta. Então, lógico, pra quem mora aqui todo mundo ficava babando na casa pronta no telão, entendeu? Mas não tem nada a ver, nada, nada, nada, nada."

82 Representação essa bastante recorrente em campo no que tange a conjuntos habitacionais, que merecerá uma análise mais detida no Entremeio III. 
A representação do conjunto habitacional como uma panela de pressão evoca três dimensões percebidas como negativas por meus interlocutores: a mistura de moradores "vindos de tudo quanto era área de risco na cidade", o que era sentido como algo que dificultaria o estabelecimento de boas relações de vizinhança; a junção, nesse contexto, de traficantes dessas várias localidades que, "se de longe já não se bicavam, imagine morando vizinho", apreendida como fonte certeira de guerra e violência; e a escala e as características materiais do espaço produzido, que, sendo "um espaço muito pequeno e fechado", composto por predinhos cujos apartamentos eram muito próximos uns dos outros, com uma viela central que os conectava ainda mais e, além disso, "com falta de espaços mais abertos" ou quintais onde as crianças pudessem brincar e os adultos relacionar-se mais livremente, eram o invólucro a, simultaneamente, potencializar tal pressão, gerar insegurança e impelir os moradores ao "convívio com violência, briga, morte, esse tipo de situação, muito de perto".

É um conjunto habitacional com umas casinhas que foram planejadas para serem uma grudada na outra, tudo meia parede, então, por exemplo, se tiver, no meio de um pavilhão, uma briga, aquela briga vai acabar, querendo ou não, atingindo as outras famílias, sabe? Que não têm nada a ver com nada, como, por exemplo, sai um tiroteio lá e claro, não é isso que eu quero, mas se sai um tiroteio lá entre um cara que tá sendo procurado e a polícia, meu, quantas crianças não vão ser feridas? Quantas pessoas não vão ser feridas de tabela? São Carlos 8 é uma bomba, cara. Pelo jeito que o espaço foi organizado. [...] Imagina um CDHU, os apartamentos do CDHU, só que tudo um grudado no outro, enfileirado direto, num pavilhão só, aí tem a ruelazinha assim, um calçadão no meio, na frente das casas, que as casas não tem nem quintal, sacou? É um lugar muito espremido pra muita gente, então qualquer coisinha lá pode afetar segundos e terceiros que não têm nada a ver... [jimmy]

Eu fiz inscrição e ia pro mutirão mas eu preferi num ir por causa do meu filho, eu num queria criar ele naquele ambiente. / Thaís: No Aracy, você não vê isso, essa questão do tráfico, da violência, não interfere? / Mas olha a diferença do tamanho do Cidade Aracy pros predinhos do São Carlos VIII, onde a gente poderia morar de frente, entende? Que ali é dois apartamentos por andar, o convívio seria inevitável. A gente ia pegar apartamento, não as casinhas, no chão. Aí, por exemplo, suponhamos que, na porta da frente... Porque é assim: você abre a sua porta e tem a porta do vizinho na frente já. Suponhamos que seja uma biqueira. Uma criança conviver tão perto assim de um bagulho desse, é foda. É muito diferente de você tá aqui numa casa, e essa daqui é uma casa e do lado tem a biqueira. Que ali, você, a criança, lá dentro ela num tá de frente com o bagulho. /Thaís: Entendi. Ela não vai conviver diretamente. / Ela tem um quintal só dela, sabe? E ali eu achei foda, e outra, muita palhaçada daquele mutirão, que não por acaso era o Cotrim que era o presidente da PROHAB [quando foi iniciado o mutirão], ele, mano, manipulou demais aquilo lá! E eu achei muito foda, eu trabalhei muitas horas lá, essas horas não foram registradas. Paguei muitas vezes o meu irmão pra ir no meu lugar, porque eu não podia por causa dos horários que eu trabalhava. Gastei dinheiro, e no fim, eu falei: 'quer saber de uma coisa? Deixa pra lá isso aí. [Jimmy]

Embora Núbia compartilhasse da mesma percepção - "Mas aí aquele negócio: ajuntou meia dúzia que era da pesada, que era do orfanato, mais uma meia dúzia que 
já morava no Santa Maria, mais meia dúzia de outros bairros... aquilo foi virando um transtorno" -, ela ainda seguiu trabalhando no mutirão, tendo sido excluída do mesmo em 2007, em condições bastante nebulosas, cuja tentativa de reconstituição, aqui, importa tanto pela elucidação de mecanismos de funcionamento das políticas habitacionais em escala local, quanto para o entendimento da reverberação que tal processo terá em momento mais recente da trajetória de Núbia, tratado adiante.

Quando inventaram aquele mutirão no São Carlos VIII, eu só fiz trabalhar, viu, Thaís... trabalhei igual a uma camela naquilo lá, pra no fim ficar de fora! / Thaís: E como foi isso? / Ah, eu não fui excluída do programa? A gente foi trabalhando, foi trabalhando. Nós íamos todo fim de semana, de sábado e domingo. Às vezes, quando eu não podia ir, o Jaelson ia, a Diana ia, sabe... Foi passando o tempo, e eu continuei trabalhando. Aí, quando chegou a hora da entrega das casas, eu tinha sido excluída. (...) E tem mais gente, não fomos só nós dois, não! Tem um monte! Não é justo. [Núbia]

As memórias de Núbia dão conta de mais de dois anos de trabalho (entre 2004 e 2007), em que ela e seus filhos se dedicaram muito; de períodos em que ela teve problemas de saúde, mas cujas faltas teriam sido supridas em parte pelos filhos, pelos sobrinhos ou mesmo por Cleiton, seu companheiro; de diversas pessoas que acabaram na mesma situação que ela, "sem casa nenhuma, nem no orfanato e nem no mutirão". A divisão em dois turnos de obra, as muitas mudanças de gestão e equipe da PROHAB, as alterações no regimento do mutirão, tudo isso foi registrado por ela nos termos de que "a PROHAB tinha lá os rolos deles, e a gente que pagou o pato": a incompreensão acerca da exclusão amplifica o sentimento de engodo e injustiça pelos anos de trabalho desperdiçado e de frustração das expectativas de acessar uma moradia após tanto esforço.

Durante a pesquisa de campo, já quase em sua etapa final, tive a oportunidade de ter acesso à documentação arquivada sobre a situação de Núbia na PROHAB. A documentação, embora pouca, revelou nuances sobre o contexto de sua exclusão do mutirão, corroborando aspectos que, para Núbia, restavam como incompreensíveis. Em sua pasta, constavam cartões de ponto que, apesar de bastante confusos, pude depreender serem dos meses de abril a setembro de 2007, os quais não contavam com assinatura de nenhum responsável pelo mutirão e nem sequer dela própria (ou do mutirante que poderia tê-la substituído em algum daqueles dias). Esses cartões registravam quatro dias de falta em maio (e a anotação a lápis "fazer plano de reposição"), sete dias de falta em junho (ao lado das quais havia a anotação "tem atestado médico") e presença completa até dia 15 de julho (dia seguinte ao recebimento de duas advertências, descritas adiante); depois disso, e até setembro, os cartões registravam apenas faltas.

Constava ainda, desse arquivo, um "informativo de exclusão" datado de 13 de junho de 2007, assinado pela então presidente da Prohab (mas sem nenhum atestado de 
recebimento por parte de Núbia, sem nem sequer mencionar seu nome), no qual se lê:

O processo construtivo do Programa Imóvel na Planta_Operações Coletivas (Mutirão São Carlos VIII), referente ao grupo da 2a etapa teve início no dia 14 de abril de 2007. Verificou-se que até o dia 03/06/2007 o(a) Sr.(a) não compareceu no Canteiro de Obras para contribuir no processo construtivo e nem na PROHAB S.A. para fazer plano de reposição de faltas ou assinar termo de desistência, portanto encontra-se com um total de 16 (dezesseis) faltas. Considerando o exposto, serve a presente para NOTIFICÁ-LO(A) que com base no Regulamento do Canteiro de Obras item 3 o(a) Sr.(a) encontra-se EXCLUÍDO(A). Ressaltamos que o Sr.(a) assinou contrato com a CEF e com a PROHAB S.A. em 11 de agosto de 2006 o qual gerou financiamento em seu nome. Para encerramento do mesmo o Sr.(a) deverá comparecer nesta Empresa para assinar documentação específica referente ao cancelamento do Contrato e consequentemente do financiamento solicitado.

Em primeiro lugar, chama a atenção tratar-se de uma carta padrão, endereçada genericamente aos mutirantes que não teriam se apresentado para o trabalho após o início da segunda fase do mutirão, dando indícios de que haveria diversas pessoas nessa mesma situação. Em seguida, nota-se que Núbia estaria, portanto, associada aos mutirantes do segundo turno, os quais, após a conclusão das fundações, teriam ficado parados até segunda ordem. Entretanto, segundo os relatos de Núbia, de seus filhos e de seu antigo companheiro eles todos teriam trabalhado também durante 0 período referente à primeira fase, fato que parece se confirmar em três advertências (curiosamente recebidas após a data desse comunicado de exclusão), nas quais se lê “Mutirante do Programa Mutirão São Carlos VIII - 1a Fase". Ainda com relação a essa carta, também é mencionado o fato de que ela não teria comparecido a nenhum dia de trabalho desde 14 de abril de 2007, o que também é contraditório com os registros dos cartões de ponto.

Para completar a confusão, havia ainda as três advertências mencionadas, posteriores àquela carta: uma, datada de 07 de julho de 2007, em que o espaço destinado para a justificativa da advertência encontrava-se em branco e cujo recebimento foi assinado por seu filho Jaelson (então com 15 anos), em um dos dias em que o mesmo atuou como "mutirante substituto"; as outras duas advertências foram entregues na mesma data (14 de julho de 2007): em uma depreende-se, apesar da anotação incompleta, que o motivo são as faltas dos dias 12, 19 e 26 de maio e, na outra, as dos dias 02, 04, 10 e 27 de junho (faltas que, no cartão de ponto, estavam acompanhadas da anotação "tem atestado médico", como visto). Ambas foram assinadas por seu companheiro, Cleiton.

Por fim, havia ainda outro "informativo de exclusão", novamente assinado pela diretora-presidente da PROHAB, datado de 05 de setembro de 2007, e agora endereçado efetivamente a Núbia, no qual se lê: 
Identificamos no controle de presença número de faltas superior ao admitido no Regulamento de Obras, sendo que sua exclusão será registrada na Assembléia de 09 de setembro de 2007 às $11 \mathrm{~h} 00 \mathrm{~min}$. Registramos aqui oportunidade para sua manifestação sobre suas faltas na Assembléia, caso contrário sua exclusão do Programa Imóvel na Planta Operações Coletivas (Mutirão São Carlos VIII) será efetivada.

Este foi o único documento cujo recebimento foi assinado por Núbia. Na pasta não constam cópias do referido Regulamento de Obras, nem tampouco das atas da mencionada assembleia, às quais não nos foi permitido acesso. De todo modo, os documentos evidenciam que Núbia e Jimmy não estão equivocados em ver maracutaias no processo de exclusão de uma parcela dos moradores: a precariedade dos registros de presença e a ambiguidade presente nos documentos emitidos pela empresa ratificam tal impressão, embora não se trate aqui de analisar a fundo a implementação dessa política, nem de avaliar os meios adotados pelas diversas equipes técnicas frente às dificuldades decorrentes de um mutirão que se estendeu por tanto tempo.

O fato é que Núbia estava oficialmente excluída do mutirão, como vários moradores do orfanato. Sua postura, na época, assim como a de Dália e outros, foi deixar no gelo: alguns deles acreditavam que, ao não assinarem o termo de desistência, ainda poderiam ser contemplados quando da entrega das $\operatorname{casas}^{83}$, mas não foi o que aconteceu.

Teve bastante gente que desistiu, que nem o Jimmy mesmo, mas eles também deixaram de entregar a casa pra muita gente. Pra mim, pra Dália, pra irmã dela, teve um monte de gente. Resumindo, acabou ficando casas vazias lá, e está até hoje na justiça, porque foi invadida. (...) Foi um monte de gente que ficou de fora, sem aviso direito, só chegaram e falaram: 'você foi excluída'. / Thaís: E vocês? / Eu já não queria ir mesmo... aí deixei no gelo. Depois aconteceu aquele fato que já te contei, aí que larguei mão mesmo. [Núbia]

As primeiras setenta e duas casas do mutirão (referentes à primeira fase) começariam a ser entregues apenas em setembro de 2008 (já no final da segunda gestão Newton Lima), aos poucos, conforme as casas iam ficando prontas $^{84}$.

83 Veja-se, nesse sentido, o depoimento de uma mutirante excluída apresentado em Carneiro (2008:118): “me mandaram essa carta falando que eu tava excluída e tal, e que... era pra mim comparecer na PROHAB, e eu não fui. Eu já sabia que era pra mim ir lá, assinar uma desistência e ir na Caixa assinar uma desistência também. Porque, segundo a informação que eu tive, eu preciso assinar essa desistência, porque é assim: a casa vai sair no meu nome, está lá, meu nome está lá, e eu preciso assinar essa desistência porque a próxima pessoa que pegar a casa pegue no nome dela, e não no meu. Então eu não vou assinar porque eu não desisti, não fui eu que desisti."

84 No mesmo ano, houve a invasão de algumas casas que, prontas, permaneceram desocupadas. As outras cento e cinquenta e duas casas ainda continuariam em obras por mais quase dois anos, tendo os mutirantes enfrentado mais uma mudança de gestão na prefeitura municipal (gestão Oswaldo Barba/PT - 2009 -2012) e na diretoria e equipe da PROHAB. Houve inclusive mudanças no programa de financiamento (uma parte das casas passou a ser financiada pelo programa municipal Morar Legal, através de recursos do FNHIS - Fundo Nacional de Habitação de Interesse Social), além de contar 
Entretanto, antes disso (em fevereiro de 2008) aconteceria no antigo orfanato um episódio violento envolvendo indiretamente a família de Núbia, que faria com que ela abrisse mão por completo tanto de sua casa na ocupação, quanto de tentar batalhar por seu direito a uma moradia no conjunto ainda em obras no São Carlos VIII.

A aproximação da prefeitura municipal e o consequente desenvolvimento do mutirão foram, como visto, quase simultâneos à transformação do orfanato em um lugar pesado, a partir da intensificação da presença do tráfico de drogas no local. Após aquela primeira morte ocorrida ali, ainda que tenha se instaurado uma sociabilidade violenta entre os envolvidos no crime, o convívio cotidiano nesse contexto não é rememorado em termos de medo, como já mencionado, sendo possível entrever inclusive que, após os primeiros momentos de disputa pelos pontos de venda de drogas no local, teria havido um período sem tantas brigas e episódios violentos (havendo algumas referências à presença do Primeiro Comando da Capital - PCC no local a partir da segunda metade dos anos 2000, que teria sido responsável por "dar uma acalmada na violência" ${ }^{85}$ ). A dimensão de medo e o desejo de deixar a ocupação se farão presentes para Núbia apenas a partir de fevereiro de 2008, quando aconteceu uma segunda morte violenta no local, presenciada de perto por seu filho mais novo, Thiago. A intensidade da narrativa justifica a longa citação, que apresenta em detalhes a situação vivida e seus efeitos na trajetória de Núbia e sua família:

E principalmente, o que me levou a não correr atrás [de tentar reaver seu direito a uma moradia no conjunto habitacional], a perder de vez o interesse é que um

também com injeção de verbas municipais e contratação de construtoras para auxiliar na finalização da obra. Vale destacar que, nos registros encontrados acerca da remoção das famílias do orfanato, os números apresentados pela prefeitura giram em torno de quarenta famílias, denotando que ao menos vinte e quatro famílias que viviam no local em 2005 tenham desistido ou sido excluídas ao longo do processo.

85 Corroboradas pelo estudo de Carneiro (2008). PCC - Primeiro Comando da Capital é a principal denominação de um coletivo originado nas prisões paulistas nos anos 1990, após o que ficou conhecido como Massacre do Carandiru, no contexto de processos políticos que alteraram significativamente o universo prisional do estado, como o crescimento exponencial da população carcerária e sua desconcentração, através da construção de presídios nas cidades do interior ou em regiões mais afastadas da grande São Paulo (Biondi, 2009). Inicialmente concentrado nas instituições penais, sua abrangência atualmente as extrapola, fazendo-se presente nas periferias urbanas de diversas cidades do estado (Feltran, 2007; 2009), em muitas das quais passou a ser acionado como uma espécie de "marca do 'genérico' crime", para além da facção em si (Malvasi, 2011). Sobre a hipótese de que tal espraiamento do PCC teria sido responsável pela redução nos homicídios no estado de São Paulo, regulando o uso indiscriminado da violência nas periferias, ver, dentre outros, Feltran (2010, 2012) e Hirata (2010). Veja-se também o que diz a pesquisadora Camila Caldeira Nunes: "Ao alcançar hegemonia no universo criminal paulista, o PCC teve êxito em se constituir como instância central de regulação e mediação de conflitos, dentro e fora das prisões. Isso teve um impacto importante na redução dos homicídios no estado, sobretudo nos homicídios vinculados às disputas envolvendo o comércio de drogas e outras atividades ilícitas." (cf. entrevista com a pesquisadora Camila Caldeira Nunes, publicada em http://institutoavantebrasil.com.br/entrevista-com-a-prof\%C2\%AA-camila-caldeira-nunes-dias-pcc-e-violencia/, última consulta em julho/2014). 
dos assassinos da Geísa mora lá. Ele era do orfanato e... ele mora lá. / Thaís: Ele construiu casa lá também pelo mutirão? / [Faz que sim com a cabeça] Então, $o$ que me levou a desistir de vez do mutirão, do orfanato, foi isso... Que no dia que mataram a Geísa... a Geísa era uma pessoa que não era chegada a criança, não, ela não gostava de criança. Mas ela tinha um carinho muito grande pelo Thiago. E, onde ela ia, esse Thiago estava a tiracolo. E coincidiu dela mudar de lá para o Antenor. O dia que mataram ela, ela tinha ido lá visitar. E ele viu ela chegar de carro, foi abraçar ela e ficaram conversando. Que era a única criança que chegava perto da Geísa, abraçava e beijava. E aí, nisso, os caras já fechou. / Thaís: Mataram ela como? / Deram cacetada, deram paulada, deram facada, facãozada, martelada, tudo... / Thaís: Mas o que ela tinha feito? / Ah, ela... Ela era uma traficante pesada [fala baixo]. Ela era uma traficante pesada. E ela desafiava os caras. E eu passei muitos, muitos, muitos dias, que esse menino não dormia... Ele era bem adolescente, sabe? Ele não dormia. Ele deitava para dormir, ele gritava 'não!', sabe? E aconteceu o crime, toda aquela parafernália, e ele urrava! Eu tava dentro de casa e ouvi os gritos dele, e como lá no orfanato a gente morava numa baixada, tinha que subir uma rampinha. Eu subi a rampa e só ouvia os gritos dele, mas não via ele. Que eu olhei assim na esquina, ele tava na esquina. Mas assim, pensa numa pessoa transtornada. Era ele. Aí eu fui correndo de encontro com ele, ele me abraçou e só gritava, só gritava: 'Ai mãe, ai mãe'. Abracei ele assim, sabe, segurei ele, tentando acalmar ele, chacoalhando ele e ele gritava muito... E eu sem entender o que tava acontecendo, e aquele monte de gente na frente do carro... E aí veio o rapaz, juntou ele assim pela camiseta, com uma mão ele puxava e com a outra ele estava com o facão assim para dar nele. Eu acho que ele pensou: 'a única pessoa que viu de perto, detalhadamente, foi ele, então tem que calar a boca'. E isso me deu um medo, mas um medo... / Thaís: E gente que vocês conheciam ali. / Gente conhecida. Ali, no fim, eu abracei o Thiago assim, o rapaz puxava de um lado, e eu puxava do outro. Até que eu falei: 'ai meu Deus, o que eu vou fazer?' Aí eu empurrei com uma mão e segurei com a outra, eu empurrei ele e falei: 'ô velho, que que é? É o Thiago, pô, tá ficando louco?' 'Ô Dona Núbia, desculpe, desculpe!' Mas daquele dia eu peguei um medo do rapaz... Pra falar a verdade, Thaís, até hoje eu tenho medo. Tanto é que o Thiago tem bastante coleguinha que mora lá, os meninos liga... mas eu não gosto que ele vá lá. Eu não gosto que ele vá lá. Que eu tenho medo. Sabe, porque eu falo, o tempo passou, mas... as pessoas quando tem esses problemas assim não esquece. (...) Sabe, eu fiquei... eu tenho medo. Eu tenho medo. Porque na época, os caras pesados da favela me chamaram para conversar... Pediram pra levar ele... / Thaís: Espera aí, calma, os caras pesados de onde? Do Gonzaga? / É, que são os chamados irmãos ${ }^{86}$ [fala baixo]. Chamaram ele para conversar, só para conversar. Porque ele tinha visto. Então, eles queria saber o que ele tinha visto. Esses caras me encostaram na parede. 'Não, você sabe, você viu, você morava lá'... 'Eu não sei, porque na hora do fato'.../Thaís: Eles queriam saber quem tinha feito. E você levou? / Não levei. Falei: 'não vou trazer ele aqui, porque ele está tão traumatizado que ele não pode nem ouvir falar no nome da finada. Vocês vão arrumar outra pessoa pra testemunhar'./ Thaís: Eles queriam tipo poder fazer a justiça lá. Era isso?/ É, porque o que me passaram, na época, era mais ou menos assim, que ela estava pesada. Ela estava pedindo para morrer. Mas só que não tinha ordem do comando [o PCC] para matarem ela. Então, quem matou, errou. Lá no... na regra deles estava errado, então eles queriam saber quem foi. E eu falava pra ele na época, até hoje eu falo, seja quem for que te perguntar, fala que você não sabe,

86 Os irmãos são os membros batizados do PCC, cuja entrada "só pode ser feita mediante convite e indicação de dois irmãos" (Biondi, 2010:99 - grifos no original). 
você não viu. Fala que você não lembra, alguma coisa. Então foi uma coisa... Depois desse fato aí que eu não vou mesmo! [para o São Carlos VIII]... porque esse cara, ele falava assim... que ele pegou um apartamento numa esquina... ele falava assim: 'quando eu morar lá em cima eu não vou nem descer a escada, vou vender maconha no anzol. O cara lá embaixo me pede, eu jogo o anzol, eu jogo a maconha e pego o dinheiro. Neguinho abusou comigo eu busco de lá da minha janela, pow!'. Eu pensava, 'eu, heim, uma hora esse cara está muito louco, dá um tiro nas costas de qualquer um aqui de casa, e aí?' Aí eu desisti mesmo. Aquela coisa, eu já não tinha vontade de ir mesmo. Porque eu não sei o que eu vi naquele lugar, que era assim, aquele lugar, eu não gostei. Eu não queria ir. Aí esse fato foi a gota d'água. Foi decisivo, eu falei: 'não, não vou'. [Núbia]

Assim, na medida em que uma situação violenta envolveu, de alguma maneira, a ela e a seu filho, a dimensão do medo passou a aparecer como elemento estruturante em sua narrativa (fazendo ruir aquela "segurança ontológica"), como uma interferência direta em sua relação com aquele espaço, bem como nos rumos posteriores da trajetória dela e de sua família, a ponto de abrir mão da possibilidade de acessar uma moradia no loteamento social São Carlos VIII - fosse reivindicando seu direito por ter trabalhado um longo período no mutirão, fosse mudando-se para a casa do companheiro (que ainda permanecia trabalhando no mutirão ${ }^{87}$ ) - em função desse medo, de não querer se arriscar a seguir convivendo com os traficantes que teriam assassinado Geísa e ameaçado seu filho e que seriam removidos do orfanato para o conjunto habitacional.

E eu vou te contar, eu passei um mau bocado nessa época. Aí foi quando eu falei pros meninos: 'Não, o negócio é sair daqui porque...', aí eu fiquei com medo. $\mathrm{Na}$ hora eu saí de lá, vim aqui pra baixo, falei: 'pô, não têm condições'. Aí eu falei: 'Bom... eu já não queria ficar, agora eu não fico mais de jeito nenhum!' Tinha que sair do orfanato. Aí eu optei por pagar o aluguel, né? Aí foi onde eu vim pra cá, e aqui, graças à Deus, a gente... nunca tive problemas assim, sabe? [Núbia]

Imediatamente após tal episódio, ela repassaria seu barraco a uma amiga que estava se separando do marido e se mudaria para o bairro Cidade Aracy, onde o filho Jimmy já vivia desde 2003. Uma parcela dos barracos do antigo orfanato seria demolida no final de 2008, logo após a remoção de algumas famílias para as primeiras casas finalizadas do conjunto. A ocupação seria demolida por completo apenas em 2010, quando foram entregues as últimas casas do mutirão. Sua amiga, assim como outros moradores mais recentes do orfanato, seria contemplada com uma casa no conjunto

87 Conforme relato de Cleiton, seu companheiro (em participação em uma das entrevistas realizadas com Núbia), ele teria abrido mão de continuar participando do mutirão após a constatação de que ela não se mudaria para o conjunto habitacional de maneira nenhuma, em função de o traficante que ameaçou seu filho ter sido removido para lá na primeira entrega de casas: "Teve um fato que ela olhou para mim... eu lembro até hoje, não esqueço... ela falou assim: 'eu não vou morar ali em cima. Se você quiser ir, você vai'. Eu falei assim, 'você não vai, nega, também não vou'. Aí abrimos mão. Eu perdi a minha também". Posteriormente, ele se arrependeria de ter desistido da casa, por ter concluído que, mesmo não se mudando para lá, poderia ter negociado a casa, como tantos conhecidos deles fizeram. À época, ele não julgava que isso seria possível, dadas as regras da PROHAB e da CEF. 
habitacional construído no São Carlos VIII ${ }^{88}$. Núbia voltaria à vida de aluguel, após mais de uma década vivendo no orfanato.

\title{
- De volta à vida de aluguel, nas fronteiras da cidade: novas dinâmicas familiares e habitacionais
}

A mudança de Jimmy para o Cidade Aracy em 2003, que acabaria influenciando a posterior mudança de toda a família para o bairro, é vista por ele como tendo três principais motivações, articuladas entre si: o nascimento de seu primeiro filho e o fato de que sua companheira já vivia naquele bairro com os pais; a dificuldade em acomodar mais um núcleo familiar no barraco da mãe no antigo orfanato; as relações sociais que ele já possuía no Cidade Aracy, em grande medida decorrentes de sua atuação como rapper, construídas ao longo do tempo em que viveu no orfanato.

Quando sua namorada engravidou, em 2001, Jimmy - então com 22 anos e sem emprego formal -viu-se dividido entre trazê-la para morar com sua família (como queria Núbia), ir morar na casa dos sogros (como queria sua namorada) ou abrir mão do relacionamento e da criança, cedendo a guarda para a sogra (como queriam os pais da moça). Núbia não queria que Jimmy, seu braço direito, saísse de casa. Além disso, a perspectiva de seu filho mais velho configurar um novo núcleo familiar despertou nela, pela primeira vez, como visto, o desejo de ter uma casa própria, onde a família pudesse crescer próxima a ela (o já mencionado "desejo de quintal"):

\begin{abstract}
Pela minha mãe, eu vou ser bem sincero, num sei se ela já falou isso pra você, eu nunca teria saído de casa. Mesmo com mulher e filho. É uma coisa assim, eu nunca teria saído de casa. Eu saí porque eu não achei justo morar com a minha mãe com mulher e filho. /Thaís: Você levar a mulher e o filho pra lá. / É, por ela eu levava de boa. Minha mãe nunca quis que eu saísse de casa, nunca quis que nenhum de nós saíssemos de casa, nunca quis. Porque minha mãe tem medo que todo mundo casa, sai fora, e ela fica sozinha. Que ela já é bem sozinha desde a época dos pais, que é aquele problema com meu avô, com a minha finada avó. As irmãs dela e os irmãos dela não tá nem aí pra chorra nenhuma, cada um foi prum canto, e dane-se quem ficou. Então minha mãe tem esse medo, e ela quer fazer diferente do que aconteceu com ela, ela quer a gente junto. E eu entendo o lado dela, eu também não queria sair, mas eu não acharia justo numa casa que nem aquela, que era pequena, eu levar mulher e filho lá... já ia sobrecarregar, já ia ficar difícil, e ela [a ex-esposa] é muito difícil de conviver. É uma pessoa que chora miséria por nada, minha mãe não gosta de gente assim, e lá a gente vivia daquele jeito, né? E outra coisa que eu acho que ia dar uma guerra feia entre as
\end{abstract}

88 Em notícia divulgada pela prefeitura em 2009, quando da entrega das primeiras casas no conjunto, lê-se a seguinte informação: "Uma das pessoas beneficiadas é a família de Antônio Lima da Cruz. Ele morou por um ano e três meses no antigo orfanato", evidenciando que moradores recém-chegados à ocupação teriam sido contemplados com uma moradia no conjunto, enquanto Núbia e pelo menos outras vinte e três famílias, após tanto tempo de trabalho, permaneceriam sem moradia. (Cf. site consultado em fevereiro de 2014: http://www.saocarlos.sp.gov.br/index.php/noticias/2009/15526740-familias-recebem-casa-no-sao-carlos-8.html) 
duas, que já deu, mesmo morando em casa separada: as crianças. Então eu já sabia que não ia dar certo. Mas pela minha mãe eu iria pra lá, com ela, com o menino e tudo, ela falou: 'não, vem pra cá, depois a gente faz um outro barraco aí atrás' e não sei o quê. [Jimmy]

Embora desestimulado tanto por sua mãe quanto pela mãe de sua namorada a constituir um novo núcleo familiar, esta foi a opção de Jimmy, mesmo ciente das dificuldades que enfrentaria, sobretudo vinculadas à saída do orfanato, ao afastamento da família ampliada, à constituição de um novo núcleo familiar e ao início de sua própria vida de aluguel.

Foi uma coisa difícil essa mudança, por ter que pagar aluguel, porque mesmo que eu já tinha passado por isso com a minha mãe, assim, de acompanhar minha mãe chorando porque naquele mês não tinha dinheiro e tal, então eu já sabia que ia ser difícil, eu já tava preparado pra esse nível de dificuldade, de desafio, na verdade. Mas mesmo assim foi difícil, ainda mais por ter que me afastar da minha mãe, dos meus irmãos e de todo mundo lá em cima, isso foi a parte mais difícil. [Jimmy]

Cerca de seis meses depois do nascimento de seu primeiro filho, quando Jimmy já estava com um emprego fixo e sua companheira encontrou uma casa para alugarem, ele se mudou para o bairro Cidade Aracy I, já bastante conhecido seu desde sua chegada ao antigo orfanato, fato que amenizaria a ruptura sentida com a mudança.

Na verdade, Aracy sempre foi uma segunda casa pra mim. / Thaís: Você tinha conhecidos, amigos? / É, a gente descia do antigo orfanato pra lá direto, pra ir nos showzinhos que tinha no bairro. Tinha um clube lá chamado Risca Faca que a gente ia muito. / Thaís: O que é o Risca Faca? Nunca ouvi falar... / Era aquele salão que dava de tudo, forró, música eletrônica, rap, reggae... a gente ia lá, pra num precisar vim até o centro, a gente tava meio a pampa de vir até o centro, a gente ia lá, sabe? Então, a gente descia, passava no cemitério e ia lá, na época podia passar pelo cemitério. Eu vivia no Aracy, vivia, então eu conheço o bairro desde aquela época. [Jimmy]

O loteamento, aberto irregularmente vinte anos antes (por volta de 1983), já era um bairro relativamente estruturado quando Jimmy se mudou para lá: desde meados dos anos 1990 (cujas gestões municipais tiveram a mãe do proprietário do loteamento e ele próprio como vice-prefeitos da cidade), o bairro Cidade Aracy I vinha recebendo, progressivamente, investimentos em infraestrutura urbana básica e equipamentos públicos, bem como passou a ser um pouco melhor atendido por transporte público ${ }^{89}$. Naquela época, bailes populares e shows de rap eram frequentes no bairro e já atraíam jovens de mais baixa renda da região (como moradores do Orfanato e do Gonzaga), que viam, ali, alternativa de lazer mais econômica que no centro ou nos bairros mais consolidados da Zona Sul. Além disso, entre os meninos que começavam a se envolver com o hip-hop na cidade (como era

89 Tendo em vista a centralidade física e simbólica fundamental do bairro Cidade Aracy em todas as trajetórias, alguns aspectos de sua história urbana serão recompostos nos capítulos seguintes. 
o caso de Jimmy e seus primos quando moravam no Orfanato), o bairro materializava a territorialização da cidade dualizada entre Zona Sul e Zona Norte, o que orientava a produção local de rap (inspirada nos raps paulistanos e norte-americanos) ${ }^{90}$. Os relatos de Jimmy trazem à tona uma certa fluidez de trânsitos e redes de relações entre o orfanato, o Jardim Gonzaga e o Cidade Aracy àquela época, principalmente em função do hip-hop, mas não apenas: "são lugares parecidos, as ideias batem". Essa relação anterior de Jimmy com o Cidade Aracy já dá indícios de uma espécie de centralidade que o bairro foi adquirindo em relação à Zona Sul da cidade, sobretudo no que diz respeito à sociabilidade dos jovens da região, mas não apenas (algo que aparecerá, também, nos relatos de outros interlocutores da pesquisa). Se, para Jimmy, a experiência de morar no orfanato e aproximar-se do universo hip-hop configurara uma percepção distinta da territorialidade da cidade (até então muito fundada na vida no centro), a dimensão de morar na favela o aproximara não apenas daqueles que viviam na mesma condição que ele (no orfanato e na Favela do Gonzaga), mas também daqueles que viviam na quebrada, na periferia - o Cidade Aracy, espécie de destino certo para ele, nesse sentido.

Eu sempre tive essa proximidade com o Cidade Aracy, sabe? Tinha amigos ali, vivia ali, os cara sempre falavam: 'meu, cê ainda vai morar aqui, cê tem tudo a ver com esse lugar'. Então, eu até falei pra minha mãe esses tempos atrás, falei: 'meu, morar no Aracy era uma questão de tempo', porque eu saí e foi natural eu vir pra cá, e minha mãe ainda ficou no antigo orfanato. Mas depois, quando zicou e teve que sair todo mundo, ela veio aqui pra baixo, foi direto. Já tinha minha avó morando no Antenor também, depois minhas tias [refere-se à família de Dália]. É que minha mãe seguiu botando fé naquele mutirão, que, por mim, eu tinha trazido ela pra cá há muito tempo. Na época que eu saí, eu saí doído, sabe? Dolorido, que eu queria tirar minha mãe de lá, já. [Jimmy]

Desde que Jimmy se mudara para o Cidade Aracy, havia a preocupação pela mãe e os irmãos, no contexto de transformação do antigo orfanato em lugar pesado; contudo, seu desejo de trazer a mãe pra baixo ${ }^{91}$ se materializaria somente em 2008, após a exclusão de Núbia do mutirão e o episódio violento em que a mãe e seu irmão mais

90 "Antigamente, no rap, a gente dividia a cidade por zonas. Antigamente sim, hoje não mais. / Thaís: E como era isso? / Ah, a gente pegou os pontos cardeais mesmo da cidade, né? Santa Felícia era Zona Norte, e Aracy era Zona Sul, mesmo a gente tendo noção que era sudoeste, a gente fala que é Zona Sul. Num primeiro momento tinha uma rivalidade e tals, e eu era só Zona Sul, Zona Sul, só Aracy, Aracy... mas depois não, se as ideia batessem, não tinha mais essa de Zona Sul e Zona Norte." Essa abordagem do território diferencia-se tanto da participação anterior de Jimmy em disputas territoriais (de quando morava na rua e acompanhava disputas entre espécies de gangues de bairros, todos na zona sul, que brigavam em torno de questões como "qual bairro era mais foda" ou "qual bairro tinha mais estrutura, rua asfaltada, num sei o quê" ou "qual bairro era pior, tinha mais biqueira, coisas assim, ignorância mesmo"), quanto da realidade atual que ele descreve, de conexões entre os diversos bairros periféricos da cidade através do hip-hop.

91 Pelo fato do Cidade Aracy situar-se geograficamente bastante abaixo do restante da cidade, conectando-se aos outros bairros da chamada Zona Sul por uma serra bastante íngreme, é comum a referência ao Cidade Aracy e seu entorno como "lá embaixo" ou "aqui pra baixo", sendo o restante da Zona Sul referenciado como "lá em cima". 
novo se viram envolvidos. Jimmy já tinha dois filhos e estava na segunda casa alugada - dois cômodos no fundo da casa dos proprietários -, na qual abrigaria, temporariamente, a mãe e os irmãos, quando estes decidiram sair às pressas do orfanato e se mudaram para o bairro.

Embora a mudança para o Cidade Aracy tenha se dado nesse contexto, Núbia a elaborou como tendo sido uma escolha, na qual pesou não apenas o valor dos aluguéis (menor em comparação com outros bairros da cidade), mas sobretudo a perspectiva de morar próxima ao filho e aos netos, além das relações sociais que ela e os outros filhos também já tinham na região ${ }^{92}$ (já que, além daqueles moradores que haviam se mudado para o Antenor Garcia quando da mencionada doação de lotes - caso de parte da família de Dália -, diversos moradores do Orfanato que desistiram ou foram excluídos do mutirão acabaram mudando-se lá pra baixo). Ainda assim, seus relatos evidenciam o quanto a mudança foi vivida como sofrimento: pela dupla ruptura representada pela exclusão do mutirão e pelo episódio violento que maculou sua relação afetiva com o Orfanato; por ter sido a experiência de viver no Cidade Aracy marcada, por um bom tempo, pela ausência de relações de vizinhança (devido à dificuldade de estabelecê-las, em virtude da volta à transitoriedade da vida de aluguel); pela vivência ainda mais acentuada do preconceito em relação ao local de moradia (uma vez que o Cidade Aracy encarna, nas representações locais dominantes, "a periferia", "o bolsão de pobreza" da cidade) e - principal aspecto destacado por ela ao tratar dessa dimensão de ruptura associada à mudança - pela questão das dificuldades de circulação pela cidade, em razão da completa dependência do transporte público, enfrentadas então pela primeira vez: "a primeira vez que eu senti essa dificuldade [para se locomover na cidade] foi aqui mesmo. Antes não tinha sentido, porque os outros bairros, mesmo sendo mais distantes do centro, não eram como aqui, dava pra ir a pé. Então, foi só aqui que eu tive essa dificuldade. E no começo foi bem difícil"

Acho que o que mais me incomodou na época, que hoje eu já acostumei, foi a distância, que aqui era distante de tudo, que, na época, aqui pra baixo não tinha farmácia, então, se precisasse de uma farmácia, tinha que ir lá em cima, sabe? Mercado tinha bastante, mas outras coisas não tinham, então o que mais me pegou mesmo foi distância, também pra trabalhar, sabe, pra um monte de coisa. Então, o que mais me incomodou nessa época foi essa distância e a falta de amizades. / Thaís: E a distância ,como você fazia? / la de ônibus, e aí era mais um gasto, né. Porque daqui, eu já caminhei muito, hoje já não aguento caminhar, pra ir a pé daqui no centro, é só o Jimmy viu? [Jimmy ainda hoje se desloca do

92 Caberia destacar, uma vez mais, como a cidade que Núbia conhece, por onde transita e onde vai morar varia conforme as dinâmicas de suas redes de relações: num primeiro momento, restringe-se ao centro e seu entorno imediato, e depois vai, progressivamente, em direção às periferias, ainda mantendo-se com em idas e vindas ao centro, para depois direcionar-se definitivamente à periferia extrema da cidade, sendo que, hoje, suas redes de relações atravessam os diversos bairros populares, tanto onde já morou, quanto em outros para onde se deslocaram conhecidos. 
Cidade Aracy para o centro a pé, muitas vezes, por falta de recursos] / Thaís: Mas, quando você mudou pra cá, você ia a pé? / Ah, às vezes acontecia de precisar ir e não ter passe... Tinha que ir né? E era coisa de necessidade, tinha que ir...

E mais: após treze anos de alguma estabilidade em sua trajetória habitacional, ela retomaria - agora bastante distante do centro da cidade - o ciclo de deslocamentos decorrente de viver de aluguel, revivendo algumas das vicissitudes já muito enfrentadas por ela anteriormente, como visto, ligadas ao mercado informal de alugue ${ }^{93}$.

A primeira casa no Cidade Aracy - "uma casa que não tava terminada"94 - foi conseguida através de contatos na própria vizinhança de seu filho Jimmy, pouco tempo após a mudança para o bairro:

O filho da mulher morava vizinho lá da casa do Jimmy, eu conversando, ele falou que a mãe dele tinha casa pra alugar, sabe? Aí eu fui, conversei com ela, fiquei lá um ano. Ah, era uma casa que não tava terminada, então, na verdade, eram dois cômodos que eram, assim, um quarto, uma cozinha e um banheiro, mas não tava terminado. Dormia tudo no mesmo quarto, não tinha como fazer separação,

93 Como já apontado anteriormente (ver nota 13), o "mercado imobiliário informal", embora seja hoje já campo consolidado de estudos no país (cf. Abramo, 2003, 2007, 2009; Baltrusis, 2000, 2005, 2010), tem sua abordagem ainda bastante focada na comercialização de imóveis em favelas situadas em regiões metropolitanas. Tanto o crescente mercado informal de aluguel, quanto a realidade destes mercados informais em loteamentos populares periféricos (inclusive aqueles ditos "formais") têm sido ainda pouco estudados. Davis (2006:52) chama a atenção para essa ausência de estudos sobre o "mercado de locação de baixa renda", destacando que este teria se tornado "muito mais comum do que se costuma admitir na periferia das cidades latino-americanas, sul-africanas e no Oriente Médio". No Brasil, ainda que mantendo-se concentrados nas favelas, algumas pesquisas, mais recentemente, vêm se debruçando sobre esse mercado informal de aluguel, dentre as quais, destacam-se os estudos conduzidos por Norma Lacerda e demais pesquisadores sobre a região metropolitana de Recife, no âmbito do Grupo de Estudos sobre o Mercado Fundiário e Imobiliário (GEMFI/UFPE), como: Lacerda (2011); Lacerda et al (2010; 2009); Anjos (2013); Anjos e Lacerda (2012); Silva (2013). Sobre tal mercado em favelas no Rio de Janeiro, ver Magalhães et al (2013) e Gonçalves (2012); para o caso de Florianópolis, ver Lonardoni (2007). Ainda que não seja objetivo desta pesquisa esmiuçar o funcionamento de tal mercado no contexto estudado, interessa-me a abordagem proposta por Cavalcanti (2010:23) de "uma leitura do mercado imobiliário como fenômeno social, em que cálculos econômicos se interconectam com a produção de valores mais subjetivos, da ordem dos afetos e da trajetória pessoal de sujeitos sociais localizados e singulares."

94 A julgar pelos depoimentos de meus interlocutores e por minhas observações em campo, o mercado informal de aluguel, no bairro, compõe-se, em grande medida, de casas inacabadas, muitas delas construídas, inicialmente, para morar, mas, em função de dinâmicas familiares cambiantes, acabam sendo inseridas no mercado informal de aluguel sem nunca ter sido ocupada pela família proprietária, como neste tipo de situação: não são poucos os casos encontrados de casais que iniciam a construção de uma casa, separam-se, um deles (ou mesmo os dois) deixa o bairro (e, muitas vezes, a cidade, em casos de migrantes, voltando para os locais de origem) e colocam a casa para alugar; por vezes, uma das partes volta e decide retomar a construção, retirando os inquilinos. Mesmo no caso de casas construídas especificamente para aluguel, estas, várias vezes, foram definidas como inacabadas por meus interlocutores, seja pela ausência de acabamentos, de vedações (sobretudo portas internas e janelas nos banheiros), de laje ou de portões, seja pela incompletude de instalações infraestruturais, para citar alguns exemplos mencionados por eles e observados por mim. 
porque o quarto era pequeno. Eu pagava $R \$ 180,00$, e a água e a luz, como ela ainda não tinha posto o relógio, era gambiarra. Era gato. [Núbia]

Embora, relatado dessa forma, possa parecer relativamente fácil conseguir uma casa para alugar através desse mercado informal no bairro, na prática, a situação é bastante mais complexa e envolve uma miríade de relações, mediações e negociações que tornavam corriqueiro escutar, em campo, que um conhecido "teve muita sorte em conseguir alugar aquela casa" ou "consegui alugar uma casa até que rápido", evidenciando que uma série de dificuldades permeiam as dinâmicas desse mercado: além da demanda ser intensa, há a necessidade de ser indicado por alguém, ou possuir algum nível de relação com o proprietário; por vezes exige-se o pagamento de um ou mais aluguéis adiantados, quando não um fiador, o que parece ser cada vez mais comum ${ }^{95}$. Núbia, por exemplo, só conseguiu alugar essa primeira casa, sem fiador, porque a proprietária já conhecia Jimmy há alguns anos e porque concordou em pagar um aluguel adiantado.

Tais dificuldades podem ser mais ou menos acentuadas conforme cada uma das duas diferentes modalidades desse mercado informal, que pude apreender a partir das trajetórias analisadas: o contrato de boca (ou boca-a-boca), no qual se estabelece um acordo verbal entre as partes, e o contrato de gaveta, em que as partes assinam uma espécie de contrato que, embora informal, estabelece alguns direitos e deveres de ambas as partes. A essas modalidades contratuais parecem estar relacionados, ainda, distintos perfis de proprietário: faz diferença alugar uma casa cujo proprietário é morador (ou ex-morador) do bairro e tem uma ou mais casas para alugar (aqui, vale mais a rede de relações, as indicações, o contrato de boca; a já mencionada dimensão de ser conhecido e ter conhecimento é, nesse caso, fundamental para que o inquilino tenha maior ou menor dificuldade em alugar uma casa no bairro), ou uma em que o proprietário não é morador local (situação cada vez mais frequente ali, na última década sobretudo), mas que, aproveitando-se dos baixos custos dos terrenos e da alta demanda por moradia de aluguel na região, constrói moradias especificamente para esse fim (neste caso, as redes de relações têm pouca influência, predominando o contrato de gaveta e a necessidade de um fiador).

95 Sobre a intensidade de tal demanda, veja-se o que diz Beatriz, cuja trajetória será abordada no capítulo 2: "Alugar, na Aracy, é terrível! Casas pra alugar, é um caminhão saindo com a mudança, e o outro chegando. É muito disputado! Aluguel é mais barato, sabe, mora muita gente. Então, quando vêm pessoas de fora, os parentes já moram aqui, entendeu? Daí já arruma a casa de aluguel. / Thaís: Tem muita casa de aluguel no Aracy? / Assim, pra alugar, sim. Mas quando você quer, você não acha. Porque tá tudo ocupado." Sobre outras dificuldades enfrentadas, mesmo nesse mercado informal, é Núbia quem as explicita: "A dificuldade de alugar casa tá em preço e fiador. Porque é difícil a gente alugar uma casa, assim, com contrato particular, entendeu? É bastante difícil. E eu consegui um contrato particular, sem fiador. Direto com o proprietário. Mas ela me exigiu um mês de aluguel adiantado. Então, pra quem num tem sobrando, como eu... fica difícil." (Núbia) 
E, como se não bastassem essas dificuldades inerentes à consecução de casas para alugar, há que se lidar, ainda, com vicissitudes e instabilidades de tal mercado decorrentes, também, de movimentos nas trajetórias dos proprietários - sobretudo nos casos em que estes são moradores (ou ex-moradores) do bairro: um filho que se separa e precisa da casa; brigas entre parentes que são coproprietários do imóvel; necessidade de vender a casa em função de uma situação de desemprego ou de mudança de cidade, para citar alguns exemplos encontrados em campo ${ }^{96}$. Quando iniciei a pesquisa, Núbia estava já em sua quarta casa alugada no bairro em pouco mais de três anos: de cada uma delas teve que sair por um motivo diferente, apontando, mais uma vez, para as dinâmicas simultaneamente subjetivas e objetivas que regem esses deslocamentos e para o constante nível de incertezas e inseguranças a que está sujeita, ao depender desse mercado informal de aluguel.

Aí acabou coincidindo de eu ter achado essa casa lá embaixo e eu fui morar ali. Aí, depois, eu mudei ali perto do posto, onde eu morei.../Thaís: E você mudou por que de uma para a outra? Por causa do aluguel? / Aqui embaixo, é porque a mulher era um transtorno. A dona da casa. Ela usa droga... então, todo dia a mulher batia na porta querendo dinheiro. Eu teria que plantar um pé de dinheiro para a mulher. Aí eu acabei arrumando a casa aqui em cima. Morei. Aí a mulher me alugou a casa, e a casa tinha problema na justiça. Ah, não, tenho praga de cigano! (risos) Aí eu tive que arrumar... depois de um ano e pouco que eu estava na casa, tal, que foram me contar a história da casa, a mulher não podia ter alugado a casa. Aí eu fui e aluguei a casa da vizinha, morei acho que um ano na casa, aí a mulher precisou vender, vendeu a casa... foi onde eu mudei pra cá. Faz um ano e pouco. [Núbia]

É principalmente assim, quando a gente vive de aluguel, você está tranquila na casa, igual como já aconteceu comigo, aqui nessa rua de trás mesmo, quando eu achei que eu estava tranquila, tudo, a mulher vendeu a casa. Quando eu penso que não, o novo proprietário da casa chega: 'ai eu preciso da casa pra daqui a uma semana'. Aíme deixou louca, eu falei: 'mas como?' 'Não, porque eu negociei a casa, porque eu comprei a casa e eu preciso mudar de onde eu estou, então em uma semana eu quero a casa'. Isso me deixou, sabe, transtornada... Porque achar, a gente até acha uma casa, rapidinho, pra alugar, o problema é que nem sempre tá no orçamento da gente, ou num se acerta com o proprietário... Então isso me chateou bastante, foi uma época que eu passei muito nervoso, muito perreio, sabe? Eu vivia de cabeça quente... / Thaís: Procurando assim? / Procurando, e o grande problema do proprietário é esse, que normalmente, quando é imobiliária não, mas quando é contrato particular, principalmente se for de boca, eles fazem assim, por exemplo, se a dona da casa chega aqui hoje e fala 'eu tô precisando da casa, eu te dou um mês pra você mudar', só que todo dia tá aqui na porta: 'você já achou casa?'... Isso vai dando um nervoso na gente, que parece que tem hora que a gente quer explodir. Sabe, isso acaba com a gente, e foi isso que aconteceu comigo ali, todo dia o homem vinha 'a senhora já arrumou casa?' 'não moço, me dá mais um tempo', 'tá, então dou mais uma semana', até que eu consegui achar aquela lá embaixo. Na verdade não foi nem

96 Por outro lado, justamente por ser dinâmico e flexível, tal mercado se molda muito bem às dinâmicas familiares (e financeiras) cambiantes e seus rearranjos constantes nas trajetórias dos inquilinos. 
achar, a minha comadre morava lá, tava pra mudar, e falou 'olha Núbia, qualquer coisa eu passo a casa pra você e o Juca fica de fiador, você aceita?' eu falei: 'bom, se o preço tiver dentro da minha situação eu aceito, eu não tenho opção né? E daí foi isso que aconteceu... / Thaís: Ela tava saindo da casa? / Ela tava saindo da casa. Ela mudou lá pro Jardim Paulistano, que lá fica mais perto do trabalho do marido dela. Porque aqui dependia de condução, tinha que fazer integração, uma coisa e outra, daí preferiu mudar, porque lá é mais fácil pra ele ${ }^{97}$. Aí eu fiquei com a casa, aqui funciona assim. [Núbia]

Os relatos de Núbia, Jimmy e outros interlocutores da pesquisa evidenciam, também, uma outra faceta, ainda mais perversa, da dependência desse mercado para obtenção de moradia, decorrente justamente de seu caráter informal: a promiscuidade que se estabelece nas relações entre inquilino e proprietário, sobretudo nesses casos em que este último é morador do bairro, muitas vezes vizinho ou até mesmo morador de uma casa agregada à alugada, gerando situações de cobranças que extrapolam os acordos pré-estabelecidos (como no caso da proprietária usuária de drogas narrado por Núbia) ou de invasão de privacidade (como num caso narrado por Jimmy, em que a proprietária da casa em que ele vivia com a mulher e os filhos era sua vizinha e, a cada discussão do casal, invadia a casa deles para tomar satisfações), para citar alguns exemplos, que, embora não tenham chegado a esse extremo nas trajetórias aqui analisadas, podem inclusive ter desfechos violentos (tanto entre inquilinos e proprietários, quanto entre dois inquilinos de um mesmo proprietário, já que muitas vezes existem duas ou três casas alugadas no mesmo terreno).

O pior caso é o proprietário que é vizinho, ou mora na casa da frente, porque daí a pessoa entende que ela tem um poder sobre você, de alguma forma ou de outra, algum poder de te persuadir, ela acha que te comanda, porque você tá morando na casa dela, mas ela esquece que você tá pagando pra ela por isso, pra que ela seja a primeira pessoa a dar paz pra você. Mas as pessoas não entendem assim, 'não, você tá morando na minha casa, então eu posso falar pra você, posso me intrometer na sua vida', sabe? E tem isso, então, morar de aluguel é complicado mesmo. No caso do aluguel, o que começa a ficar mais chato é tipo morar de fundo, nossa, ai é chato, porque por exemplo, eu tenho filho, se meu filho fizer qualquer coisa e o filho do vizinho da frente fizer igual, aí começa a brigaiada entre os adultos, 'ah, porque o seu filho incentivou o meu', ele não vai procurar ver, eu já tive esses casos já, sabe? E tem esse tipo de problema, que pode dar até briga feia também. [Jimmy]

Mas, se por um lado, para Núbia, a mudança do orfanato para o Cidade Aracy representaria enfrentar novamente as vicissitudes de viver de aluguel, por outro foi encarado por ela (e também por Jimmy) como a possibilidade de voltar a morar em uma casa normal (por oposição à ideia de barraco e a ausência de saneamento básico), de não ser mais aquela bagunça (referindo-se à organização espacial das

97 Vale notar que, em campo, tive contato com poucos casos como esse, em que o deslocamento habitacional se deve à localização do emprego (como era corrente há algumas décadas). 
casas no Orfanato, "uma quase por cima da outra") e, sobretudo, de voltar a "agir dentro da lei", evidenciando não apenas uma certa introjeção dos estigmas e da criminalização sofridos durante o período vivido na ocupação do antigo orfanato, mas também os anseios relativos a concepções de moradia e condições urbanas que aquela experiência, por mais saudosa que seja, fez emergirem.

De fato, a possibilidade de, após tantos anos, deixar de viver ilegal seria o grande aspecto valorizado por eles nessa retomada do viver de aluguel no Cidade Aracy, sempre em comparação com as experiências anteriores de moradia no casarão 2020 e no Antigo Orfanato. Na gradação por eles promovida entre tais experiências, embora haja, como visto, uma aproximação entre ambas (que se vincula não só ao tipo de casa - "uma coisa tipo favela, meio cortiço" -, mas principalmente com a dimensão pesada a elas associada - convívio próximo ao tráfico, violência policial), o casarão seria claramente considerado o pior lugar em que já viveram, pela somatória de todas essas dimensões às dificuldades materiais, financeiras e familiares vividas ali; o orfanato é considerado o melhor, por conta das memórias saudosas do sentido ampliado de casa, de vizinhança, de comunidade; já o Cidade Aracy seria valorizado pelo retorno à "legalidade", à "normalidade" (ainda que através do mercado informal de aluguel), apontando para um relevante jogo de perspectivas sobre a cidade, que se monta a partir da contraposição de experiências urbanas, relativizando a própria hierarquização centro/periferia: não se trata apenas da casa ou de sua localização; são as memórias que ficaram dos tempos vividos em cada lugar que compõem essas experiências urbanas que vão se acumulando e virando referencial em relação às novas casas, aos novos bairros, às novas vizinhanças e à ideia de cidade que, a partir delas, se constitui, de maneira dinâmica. Ainda nesse sentido, Núbia destaca, como uma das principais vantagens da mudança para o Cidade Aracy, o fato de nunca mais ter tido problemas com a polícia, evidenciando, mais uma vez, essa perspectiva relacional sobre a cidade ${ }^{98}$ : "essa é a melhor parte de tudo, porque é horrível, você

98 Para Núbia, apesar da região do Cidade Aracy ser um dos principais alvos policiais locais (como se depreende da leitura dos noticiários policiais), o fato de não sofrerem mais invasões policiais em casa representou um aspecto positivo da mudança para o bairro. Já para Jimmy, tal aspecto positivo seria suplantado, inicialmente, pelo fato de ter se acentuado aquela dimensão, já experimentada anteriormente, de ser um suspeito em potencial, em seu próprio território: na época em que se mudou para o bairro, este ainda era alvo de abordagens de rotina da polícia, ou seja, rondas sistemáticas para mapear (e produzir) suspeitos. Jimmy foi por diversas vezes "pego de quebrada, andando no bairro à noite" e teria sofrido assédios policiais violentos. A partir do espraiamento do PCC, tal situação teria mudado: "Agora já não tem mais isso, como antigamente. Eu percebi que parou esse negócio de abordagem de rotina, parou esse negócio. Os caras sabem muito bem quem é quem, sabem muito bem que eu não uso nada, sabem muito bem quem usa, quem vende. Eles não querem mais saber quem usa e quem deixa de usar, como antigamente, querem saber de outros BO's, maiores, que rendam mais pra eles." Ver também capítulo 3. 
acorda e sua casa tá cheia de PM! Então, graças a Deus que, de quando eu mudei pra cá, eu nunca mais tive esse problema."

Deixar de viver ilegal, entretanto, teria seus custos, e voltar a pagar aluguel (e, eventualmente, a depender da casa alugada, também contas de água e luz), depois de tanto tempo, não foi nada fácil para Núbia, já que, então, apenas ela trabalhava para sustentar a casa. Logo a filha começou a trabalhar também, "mas o salário dela mal dava pra ela. Então era só eu mesmo". O primeiro ano (2008/2009) teria sido bem difícil: "foi um ano assim de bastante aperto, sabe? Aí depois, quando o Jaelson começou a trabalhar, que começou a ajudar mais um pouco, que foi dando uma melhorada". Em 2010, Jimmy se separaria da mulher (após ter oficializado a relação e tido a terceira filha) e voltaria a morar com a mãe, passando a contribuir novamente com a renda familiar. No mesmo ano, Diana teria sua primeira filha, e Núbia deixaria de trabalhar para cuidar da neta.

Quando iniciei a pesquisa de campo, no fim de 2011, esta era a configuração familiar abrigada na já quarta casa alugada no bairro Cidade Aracy: nela viviam Núbia, quatro de seus cinco filhos - Jimmy, Diana, Jaelson e Thiago - e uma neta, filha de Diana. Apenas William não morava mais com a família, vivendo com a esposa e a filha em uma casa alugada no bairro Cruzeiro do Sul. Além disso, mais três netos, filhos de Jimmy, passavam os finais de semana na casa, às vezes permanecendo durante toda a semana. A despeito da bagunça que tanta gente morando junto estabeleça na casa - "Ah, fim de semana essa casa vira um auê! (risos)" -, morar junto com os filhos já adultos garantia a Núbia uma vida um pouco menos instável financeiramente, pois todos os filhos empregados contribuíam com as despesas da casa, tendo permitido a ela, inclusive, ficar mais de um ano sem sair para trabalhar, a fim de ajudar a cuidar da neta, só retomando, gradativamente, alguns serviços como faxineira em 2012.

Hoje em dia, Thaís, eu tô numa situação bem melhor! Porque não passo necessidade. Porque eu já passei muita, mas muita necessidade mesmo, sabe? Até mesmo por questão de saúde, questão de desemprego... mas hoje em dia, graças a Deus não. Como eu tenho o suporte dos filhos, né, então eu já não passo mais necessidade... cê vê, hoje, eles tão grande, tudo. Eles trabalham, todos eles me ajuda muito. (...) só o Thiago que, por enquanto, não trabalha. E a gente divide as contas, né? Então, a gente... como é que eu posso dizer? Não falta, sabe? Não tem de sobra, mas também não falta, como antigamente.

A casa onde viviam então fora conseguida por indicação dos padrinhos de William, que a haviam alugado anteriormente e, ao saírem de lá, repassaram o aluguel a Núbia, comprometendo-se com o proprietário a serem seus fiadores - só assim foi possível a ela alugar uma casa um pouco maior (em que coubesse toda a família) e, 
consequentemente, mais cara ${ }^{99}$, porque, também nesses casos, a existência de um fiador parece ser uma condicionante do aluguel. A casa de quatro cômodos (dois quartos, uma sala, uma cozinha) e um banheiro, embora grande, se comparada com a maioria das casas onde Núbia morou anteriormente e, especialmente, com o barraco no orfanato (onde ela e os cinco filhos dividiam dois cômodos e um banheiro improvisado), era já considerada pequena pelos filhos, sobretudo porque o único banheiro da casa ficava dentro de um dos quartos e porque a sala era também usada como quarto por Thiago, Diana e sua filha, dificultando seu uso coletivo quando a pequena estivesse dormindo em seu berço, ali instalado. Tal percepção se agravou quando Júlia, a nova companheira de Jimmy, veio de sua cidade para morar ali com ele, reconfigurando todo o arranjo espacial da casa: o quarto que antes era compartilhado por Jimmy e Jaelson passou a ser de Jimmy e Júlia (que fizeram uma divisão, utilizando um dos guarda-roupas, para ter mais privacidade, uma vez que todos os demais moradores teriam de entrar no quarto quando fossem usar o banheiro); Jaelson passou a dormir na sala, e Thiago mudou-se para o quarto da mãe.

Essa reconfiguração, entretanto, não foi novidade, já que, antes mesmo da chegada de Júlia, eu presenciara pelo menos duas alterações nesse sentido. Por ser a casa alugada, uma maneira de conferir a ela algum sentido de pertencimento é o constante rearranjo dos poucos mobiliários ${ }^{100}$, sobretudo nas áreas comuns (por diversas vezes, em campo, registrei falas como essas entre meus vários interlocutores: "ah, já que a casa não é nossa, o jeito é deixar ela com nossa cara, por isso tô sempre mexendo nos móveis" ou "já que a gente não pode mexer nas paredes, nem prego pode pôr, o jeito é ir mudando os móveis de lugar"). Além disso, relacionase com a já mencionada dimensão plástica conferida à casa, vinculada às dinâmicas familiares cambiantes: mesmo alugada e sem a possibilidade de alterações materiais (como no caso de uma casa própria autoconstruída e as constantes reformas e "puxadinhos"), a casa é vivida como eterno processo: mudam arranjos de pessoas, cômodos e móveis o tempo todo.

De fato, ao longo dos dois anos da pesquisa de campo, a configuração de moradores e espaços da casa mudou muito: já no fim de 2012, a filha Diana havia engravidado novamente e estava indecisa entre permanecer morando na casa da mãe com os dois

99 Localizada nos fundos de um meio-lote, onde o proprietário possuía ainda outras três casas alugadas (duas na frente - uma em cima e outra embaixo - e uma ao lado da de Núbia), a família pagava por ela, no final de 2011, R\$350,00 de aluguel, que, segundo Núbia e outros moradores locais, seria um valor padrão, na região, para uma casa do tamanho da sua. No final de 2013, a mesma casa já custava R\$ 480,00.

100 A casa tem poucos móveis, decorrência não apenas da ausência de recursos financeiros para tanto (o que denota, também, a ausência de acesso ao crédito, aspecto importante na caracterização desta família frente às demais participantes da pesquisa, apresentadas nos capítulos seguintes), mas também da transitoriedade da vida de aluguel, cujas mudanças constantes implicam perdas materiais. 
filhos ou casar-se, indo morar com o namorado em uma casa alugada no mesmo bairro; também a namorada de Jaelson engravidaria nesse período, e uma das opções para quando o filho nascesse era morarem por um tempo na casa de Núbia; durante alguns meses, o filho mais velho de Jimmy passou a morar ali e, quando o filho do meio desejou mudar-se também, voltaram todos para a casa da mãe.

E quando, após um tempo distante do campo, voltei, em meados de 2013, tudo havia mudado novamente, e muito. A família, que antes habitava a mesma casa, estava agora distribuída em três casas, todas no mesmo bairro: Jaelson foi o primeiro a se mudar, após o nascimento do filho, tendo morado por um tempo na casa da sogra no bairro Cruzeiro do Sul e, pouco tempo depois, alugado um cômodo no Cidade Aracy II; Diana permaneceu um tempo ainda na casa de Núbia após o nascimento do segundo filho, mas acabara se mudando para uma casa alugada pelo companheiro, também no Cidade Aracy II, próxima à casa da mãe; por um tempo, permaneceram na antiga casa Núbia, Thiago (o filho mais novo), Jimmy e sua companheira Júlia. Por fim, Núbia e o filho mais novo foram morar na casa de Diana; Jimmy e Julia ficaram com a casa, que imediatamente deixou de ser a casa de Núbia, para se tornar a casa de Jimmy.

O contexto dessa mudança de Núbia para a casa da filha contém elementos de interesse para a compreensão desses imbricamentos entre dinâmicas familiares cambiantes, rearranjos habitacionais, o sentido plástico de casa e sua articulação com certos modos de produção e apropriação da cidade. Com a saída dos outros filhos, a manutenção das contas da casa ficou mais difícil, recaindo em grande medida sobre Jimmy, o que a deixava desconfortável em permanecer ali, ainda mais devido à condição de recém-casado do filho (Jimmy oficializara a relação com a nova companheira em meados de 2013) e à posição, ainda que bastante discreta, de Júlia de que quem casa quer casa (não compartilhando da espécie de "ética do quintal" presente na família). Por outro lado, a demanda constante de Diana pela presença da mãe em sua nova casa, para ajudar com as crianças, tornava sua presença ali cada vez mais frequente, inclusive passando várias noites a pedido da neta, que não se acostumara com a mudança e a distância da avó. Some-se a isso um fato que tornaria a vida na antiga casa de Núbia bastante dificultada, em razão justamente dos imbróglios característicos desse mercado informal de aluguel: em função de atrasos no pagamento da conta de luz da moradia, o abastecimento fora cortado pela companhia, e, mesmo após o pagamento dessas contas, o fornecimento de energia não foi restabelecido, por haver uma dívida de 2007 (referente a outro inquilino, anterior ainda aos compadres de Núbia), que totalizava quase $\mathrm{R} \$ 3.000,00$, em função de multas e correções. Iniciou-se um processo de negociação com o proprietário, e foi nesse meio tempo que Núbia e Thiago se mudaram de vez para a casa de Diana. 
Nessa dinâmica de rearranjos familiares e habitacionais, tanto Núbia quanto Jimmy ficaram submetidos a condições mais precárias: Núbia porque, apesar de a casa de Diana ser maior que sua antiga casa (com sala, cozinha, três quartos e um banheiro), passou a habitar um quarto bastante pequeno, úmido e sem ventilação, com apenas um colchão no chão, sem lugar sequer para guardar suas roupas, além de ter voltado a morar de favor numa casa mantida pelo companheiro da filha (não tendo nem mais uma casa alugada para chamar de sua $\left.{ }^{101}\right)$. Jimmy e Júlia, por sua vez, passariam meses morando numa casa sem energia elétrica (e, durante alguns períodos, também sem água, devido ao insuficiente abastecimento do bairro).

Tais condições (que, de resto, não eram novidade para eles) eram amenizadas pela articulação que se configuraria entre as três casas, remontando àquela concepção alargada de casa como "espaço moral" que extrapola os limites de cada uma, conectando-as, anteriormente vivida no orfanato: Núbia e Thiago mantinham pertences e usos cotidianos na casa de Jimmy; este e Júlia iam quase todos os dias tomar banho quente na casa de Diana e, quando a água acabava, iam todos para a casa de Jaelson (já que na região onde se situava sua casa os cortes de água eram menos frequentes); as seis crianças (filhos de Jimmy, Diana e Jaelson) circulavam pelas três casas, de acordo com os cuidadores disponíveis; aos finais de semana e finais de tarde, todos acabavam se encontrando na casa de Diana. Estes intercâmbios atestam que, mesmo sem uma casa para chamar de sua, ainda era em torno de Núbia que se articulava a nova configuração familiar e sua decorrente "configuração de casas". Na ausência da casa própria e do desejado "quintal" onde a família e a casa pudessem se ampliar em novos núcleos mas mantendo a proximidade e a ajuda mútua da família ampliada, a articulação entre as três casas alugadas no mesmo bairro acabou se construindo como alternativa nesse sentido, como núcleo reconfigurado (agora tripartite), a partir do qual novas configurações também decorreriam.

Mas se, bem ou mal, as dinâmicas cotidianas se ajustavam nessa articulação entre as casas, a situação de Jimmy e Júlia envolvia uma relação comercial - informal, é verdade - mas cuja resolução ficara a encargo deles, já que eles é que viviam na casa quando tudo aconteceu. Essa situação vivenciada pelo casal tanto reitera as vicissitudes a que estão sujeitos por dependerem do mercado informal de aluguel,

101 Nesse sentido, vale registrar um exemplo dessa despossessão, que não é apenas material, senão simbólica: o fato de a casa da filha ter-se tornado, por um período, uma célula feminina da igreja batista que ela e os filhos frequentavam intermitentemente (com exceção de Wiliam e Thiago, este último inclusive objetivando tornar-se pastor). Considerando-os, talvez, muito desgarrados, eu já presenciara diversas investidas da coordenadora da célula sobre Núbia, que se livrara de todas, inclusive a de fazer de sua casa uma célula. Em poucos meses da mudança de Diana para sua própria casa, onde ela passaria a viver também, Núbia teria de se sujeitar a receber a célula na casa em que vivia, que agora não era a sua. 
quanto evidencia também o proveito que podem tirar dele, demonstrando como tal mercado, apesar de tudo, se ajusta bem a essas dinâmicas familiares cambiantes e às instabilidades financeiras a que estão sujeitas as famílias de baixa renda. Ao descobrir o problema com a companhia fornecedora de energia elétrica, Jimmy informou o proprietário, que se prontificou a verificar a situação, sem nunca dar um retorno a eles. E por que, então, eles permaneceriam na casa, nessas condições, sem geladeira, sem banho quente, sem iluminação? Se se tratava de uma relação comercial informal, a ausência de solução para o problema da luz não seria razão suficiente para encerrarem tal relação, procurando outra casa? O fato é que também alguns aluguéis estavam atrasados, e eles não poderiam simplesmente deixar a casa sem pagá-los. Além disso, na situação financeira em que se encontravam (Jimmy com recebimentos intermitentes, Júlia desempregada), a melhor opção era permanecerem na casa enquanto pudessem, mesmo sem luz, empurrando a dívida do aluguel até que a situação financeira melhorasse. Para o proprietário, por sua vez, a não resolução do problema da luz seria uma forma de dificultar a permanência do casal na casa, sem ter que partir para um enfrentamento, embora todo mês ele fosse até lá para cobrálos: "ele tá no meu pé pra receber os aluguéis, mas eu não tenho o dinheiro pra dar todo de uma vez, então vô levando ele" [Jimmy].

A inesperada solução veio, mais uma vez, das redes de relações estabelecidas no bairro. Jimmy, já há algum tempo, vinha se interessando pela possibilidade de adquirir uma casa própria, inicialmente para "tirar a mãe do aluguel", incentivado por alguns conhecidos seus que estavam financiando uma casa pelo então recémcriado Programa Minha Casa Minha Vida ${ }^{102}$; entretanto, à época, seus rendimentos eram insuficientes (tratava-se de financiamentos para chamada "Faixa 2" do Programa, então destinados a famílias entre 3 e 10 salários mínimos), além de as opções serem todas distantes do Cidade Aracy e consideradas por Jimmy extremamente desestruturadas (sem acesso a equipamentos, serviços e transporte públicos, distantes de comércios). Já casado com Júlia, buscando aluguéis mais baratos para tentar sair da casa em que estavam, Jimmy identificou várias casinhas sendo construídas ao longo do bairro, para financiamento pelo mesmo Programa ${ }^{103}$. Foi quando descobriu que um conhecido seu estava construindo algumas, tendo Jimmy, inclusive, feito uns bicos como vigia noturno das obras para conseguir uma renda extra (ocasiões em que, para não dormir sozinha na casa sem luz, Júlia passava as noites na casa de Diana). Esse conhecido, sabendo de sua situação, passou a

102 O Programa Minha Casa Minha Vida, implementado no país a partir de 2009, será tratado com mais atenção no capítulo 2, a partir de seus efeitos nas trajetórias e nos espaços ali tratados.

103 Trata-se da modalidade "Carta de Crédito Individual". Encontrei um único estudo sobre tal modalidade (Ramos e Cardoso, 2011), que tem-se feito muito presente nas periferias da cidade de São Carlos, sobretudo no bairro Cidade Aracy. 
estimulá-lo a financiar uma de suas casas; entretanto, seria um longo caminho a percorrer para dar conta de toda a burocracia. Desesperado para deixar a casa em que vivia, acordou com o tal conhecido que ficaria com a casa, mas precisava cair pra dentro imediatamente, antes mesmo de iniciado todo o processo junto à Caixa Econômica Federal.

\begin{abstract}
A PROHAB era o único meio de a gente conseguir na época; aí rolou tudo que rolou, eu nunca fui sorteado. O lance da PROHAB é que eu continuei inscrito lá, já vai pra seis anos, só que eu nunca fui sorteado, esse que foi o porém. (...) E, assim, eu nunca tinha encarado financiar diretamente uma casa assim, porque não tinha essa facilidade que tem hoje, né? Era muito diferente desse Minha Casa Minha Vida, um financiamento fora disso é coisa que... Muita gente fala: 'realiza seu sonho de ter a casa própria', mas, quando você chega lá pra fazer uma simulação fora do programa Minha Casa Minha Vida, você sai de lá rindo, fala: 'meu, vocês tão contando uma piada pra mim, não é possível.' E pra mim não dava. Os salários que eu ganhava eram sempre poucos né? A Júlia mesmo, quando tava na Faber, ela ganhava um salário de mil e poucos reais; a pessoa que ganha mil e poucos reais, ela não vai ter condição de dar $R \$$ 700,00 em uma casa! Só vai sobrar $R \$ 300,00$ pra ela, ela vai fazer o quê? Pagou água e luz, acabou, não come, não tem mais nada, não faz mais nada da vida. Se acabar o gás no meio do mês, tá perdido. Umas coisas que não dá pra entender, parece que aquilo nunca tá ao nosso alcance. Eu sei porque eu já fiz umas simulações, sabe? / Thaís: Você já tinha tentado outras vezes? / Já, já, eu fui lá na MRV, saí de lá transtornadíssimo! Aí, logo na sequência, descobri que esse meu camarada tava fazendo aqui, né? Aí que ele explicou pra mim, pela primeira vez, a situação. Daí ele falou: 'fica esperto mano, pode sobrar uma pra você ai'. A primeira vez que ele falou isso, eu fiquei com medo, por causa daquela simulação que eu fiz. Sabe? Falei: 'putz, pra mim não dá velho, pra eu entrar numa dessa agora assim não dá, tem que ser uma coisa bem certeira mesmo'. Aí, quando ele levou pra mim as condições, me levou na Caixa pra fazer simulação, eu falei: 'putz cara, totalmente outras ideias, né, ai dá pra gente fazer'. Aí eu animei. [Jimmy]
\end{abstract}

Com a possibilidade de mudar de casa sem ter de comprometer-se com um novo aluguel, o problema da dívida com o proprietário da casa alugada ficava mais fácil de ser solucionado. Quanto ao financiamento, tratava-se quase de uma aposta e, sendo um tanto incerta, ele e Júlia mal comemoraram a notícia de que se mudariam para uma casa que, em teoria, seria deles. Mas a ideia era resolver um problema de cada vez.

Então eu já tava pensando nesse negócio, porque tá uma febre esse negócio [o Minha Casa Minha Vida]. Mas talvez eu não estaria aqui [na casa] ainda, por quê? Esse cara me possibilitou uma coisa que só tendo amizade e confiança pra obter. Ele falou: 'olha, eu conheço você, conheço sua família, vou te possibilitar entrar na casa, se você tiver certeza que você tá na pegada de encarar isso mesmo, porque você vai estar saindo do aluguel, mas você vai ter uma conta pra pagar todo mês, depois que sair o financiamento'. Eu falei assim: 'mano, antes eu pagar um pouco mais em uma coisa que é minha do que eu ficar de aluguel a vida inteira. Vamo pra cima'. [Jimmy]

Enquanto se preparavam para a mudança, que pude acompanhar, Jimmy me disse que ainda não tinha informado ao proprietário da casa alugada que sairiam já no dia seguinte. Quando o questionei se isso não lhe causaria problemas, ele me respondeu, 
tranquilo: "não, só preciso negociar direitinho, ele tá com medo que um dia desses eu saia sem pagar. Então, vou propor a ele pagar um aluguel agora e, depois, um aluguel por mês até quitar os dez meses que tô devendo. Não vai ter erro." E, de fato, não teve: naquele mesmo dia, o proprietário apareceu (mais uma vez para cobrá-los), Jimmy e ele ficaram por um bom tempo na calçada em frente à casa negociando, e então ele voltou, dizendo que estava tudo resolvido, que o proprietário aceitara sua proposta e ficara até aliviado por saber que eles honrariam a dívida e sairiam no dia seguinte, pois já teria outros inquilinos interessados na casa. A informalidade da relação, a meus olhos, atingira o ápice - uma negociação na calçada, um acordo de boca para o pagamento de dez meses de aluguel atrasados (algo em torno de $\mathrm{R} \$$ $4.500,00$ ) e a liberação imediata da casa. Jimmy estava extremamente aliviado, não apenas por ter encaminhado a solução do problema, mas também por acreditar que, a partir de então, estaria livre dessa vida de aluguel.

Bom, vamo começar assim, compartilhar a casa com uma família, porque, na verdade, a maioria das vezes a gente morou de favor mesmo, lá na casa da pessoa. Liberdade zero, privacidade zero e vírgula zero, não tem como, porque a gente tem que se adaptar no cotidiano da pessoa, pra não deixar essa pessoa desconfortável a ponto dela pedir pra gente sair. Então é um ponto que é terrivel, mas, na época, minha mãe sozinha, na época em que a moeda não era o real, era tudo mais difícil, era tudo caro, não dava, não tinha jeito, minha mãe chorava pelos cantos, não tinha jeito. Ocupação, ocupação, hoje em dia, tem trilhões de leis aí que apoiam, de alguma forma, uma ocupação, mas antes não tinha, então a gente estava sempre desconfortável na questão, era um risco que a gente sempre tava correndo então, sabe? Porque a gente sabia que a casa não era nossa, e também tem a questão de pelo fato de a casa ainda não ser nossa, a gente não podia fazer qualquer alteração na casa, qualquer alteração, não tinha como, porque era fazer e perder, não tinha jeito. Casa alugada, casa alugada é, eu que já morei com minha esposa, com a minha mãe, é outros quinhentos, você tá pagando pra viver dentro daquela casa. Mas só que também tem a questão material, você, por exemplo, eu não queria que essa janela fosse aí, se a casa fosse alugada eu não podia tirar essa janela daí, se o dono não concordasse, $e$ muitos donos não concordam. Hoje em dia, hoje em dia não, sempre foi assim, é clássico do aluguel: o dono quer que você utilize a casa dele, mas ele quer que a casa dele fique daquele jeito. Entendeu? Você pode pagar um milhão de dólares pro cara e não vai fazer o cara mudar, é caçar briga e perder, né? A única coisa boa que eu lembro da casa de aluguel é que isso criou em mim o sonho de ter a minha casa, sabe? Isso criou o sonho, e mais do que ter a minha casa, sempre sonhei em minha mãe ter a dela, que eu acompanhei minha mãe, eu e o William, a gente acompanhou a minha mãe no processo mais duro da vida dela assim com a gente, a gente via ela chorando, a gente chorava junto com ela, sabe? Era uma coisa que eu sempre quis, assim, a minha mãe ter o cantinho dela, sabe? Quando a gente fosse visitar, assim, tá tudo mundo reunido, junto com ela, com ela feliz. Então morar de aluguel pra mim foi um desafio, mas, ao mesmo tempo, alimentou esse sonho. [Jimmy]

Algum tempo após a mudança de Jimmy, apesar de ainda sutil, já era possível notar mais um rearranjo em curso nas dinâmicas familiares e habitacionais, agora naquela que se estabelecera a partir da "configuração de casas". A casa de Jimmy, pouco a pouco, tornava-se também a casa de Júlia, que, desempregada e passando a maior 
parte do tempo ali, acabou dando a tônica da gradativa redução da participação do casal e de sua casa nessa configuração, favorecendo o nucleamento da experiência familiar e da casa em curso: o futuro próximo de Jimmy como proprietário de uma casa trouxe à tona as distensões entre positividades e conflitos inerentes à dimensão da família ampliada e ao ideal introduzido por Júlia (e reforçado pela possibilidade da casa própria) da família nuclear e independente. Jimmy, entretanto, que por diversas vezes criticara a postura do irmão William sobre sua distância em relação à família ampliada, por se preocupar apenas com seu próprio núcleo e, nesse contexto, renegar o Cidade Aracy como possibilidade de moradia, encarava sua própria escolha em permanecer no bairro como uma estratégia para manter-se vinculado à família ampliada, num visível esforço para, sem conflitar com sua companheira, ainda manter sua casa como parte daquela configuração por onde a mãe e as crianças circulam, o que dificilmente aconteceria se sua futura casa própria se situasse fora do bairro ${ }^{104}$.

\begin{abstract}
A gente tem uma mentalidade um pouco diferente, eu e meu irmão. Eu sempre fui de pensar em mim, na minha mãe e todos os meus irmãos. Aí foi nascendo meus filhos... Eu sempre penso no coletivo, tanto que uma parte de mim tá incomodada, porque eu tô na minha casa, mas e meus irmãos? Tão aonde? Minha mãe? Que agora a gente tá correndo atrás desse esquema da minha mãe, porque eu tô super ansioso que isso saia e minha mãe esteja no lugar dela. Sabe? Eu sou super preocupado com essa situação, isso aí às vezes até me atrapalha, porque às vezes eu tô num rolê que é pra eu me concentrar naquilo, na minha família, eu não consigo, porque fico pensando neles. [Jimmy]
\end{abstract}

Se a perspectiva de conquista da casa própria por Jimmy induzia a uma nova organização familiar, a experiência anterior da família seguia orientando sua perspectiva no sentido da manutenção da "configuração de casas", da permanência de sua casa como parte do "espaço moral" que conectava os agora três núcleos estabelecidos no bairro, bem como do ideal de que sua mãe e irmãos também pudessem, em breve, acessar uma casa própria no bairro.

Aí, só que assim, falando de economia, o Brasil era diferente, né? Falar em financiar uma casa há uns quatro anos atrás, era, assim, pra mim, pra muitos outros aí, era impossivel né, era meio que impossivel, porque era uma caminhada muito difícil. Aí, eu ficava meio que com esse negócio na cabeça, né? Vai demorar muito pra eu ter minha casa... Porque é muita coisa, tinha que pagar aluguel,

104 Este trecho de Marcelin (1999:38) é interessante para compreensão desse movimento que se instaura a partir do reposicionamento de Jimmy na rede familiar e das tensões e ajustes daí decorrentes: "[a configuração de casas] se constrói numa estrutura de tensão entre a hierarquia e a autonomia, entre o coletivismo e o individualismo, entre os mecanismos tradicionais de socialização e o élan pós-moderno de modos individuais de consumo." O conflito entre relacionalidade e individualização (Duarte e Gomes, 2008; McCallum e Bustamante, 2012) que parece se instaurar aí talvez decorra, também, desse modo de acessar a casa pronta, via financiamento individual, de forma desconectada das relações que sempre regeram a consecução da moradia pela família ampliada. Trata-se de uma hipótese que, longe de se pretender comprovar (já que isso demandaria novos estudos), exploro também no Capítulo 2. 
não sei o quê, pagar um monte de conta, cuidar das crianças. Mas eu nunca deixei de acreditar que um dia eu teria uma casa. Nunca, nunca passou pela minha cabeça assim: 'desisto, vou viver de aluguel e dane-se', sabe? Eu nunca desisti, e junto com esse sonho, nunca passou pela minha cabeça desistir da minha familia, como um todo. A gente entende, quando a gente casa, a gente tá formando uma nova família, a gente tem que sair da casa de nossos pais, porque o que eles fizeram, já tá feito. Mas não que a gente tá tipo abandonando, né? Então eu sempre tive isso na cabeça: 'não, um dia eu vou ter minha casa, minha mãe vai ter uma casa, meus irmãos vão ter a casa deles', sabe? Sempre tive isso na cabeça. E agora chegou o momento. [Jimmy]

\section{- Políticas habitacionais (e sua reconversão em mercado popular): a casa própria como miragem}

Logo que iniciei a pesquisa com Núbia, intrigou-me sua recorrente menção ao fato de que ela havia sido sorteada, pela PROHAB, para uma das casas no Jardim Zavaglia (primeiro conjunto habitacional promovido no âmbito do Programa Minha Casa Minha Vida na cidade, voltado para famílias de 0 a 3 salários mínimos, como apresentado em mais detalhes no Capítulo 2), e, alguns meses depois, excluída do programa. Custei a entender o que havia acontecido, até mesmo a compreender que era algo então recente, pois sempre que a conversa chegava a esse ponto - fosse espontaneamente através dela, fosse por alguma deixa dada por mim - o assunto automaticamente se misturava com as lembranças da exclusão do mutirão, e o enfoque recaía sobre sua frustração, seu sofrimento e o caráter injusto das políticas habitacionais levadas a cabo pela PROHAB na cidade.

Primeiro, foi a época do mutirão. Depois houve uma troca do pessoal lá, não sei que rolo que deu. Eu sei que eu e mais um monte de gente foi excluída. Depois de dois anos de serviço, que eu queria bater no Cotrim [presidente da PROHAB que fez o acordo inicial com os moradores do orfanato] a qualquer preço! Porque não é justo. Olha, durante mais de dois anos, a gente perdia sábado, domingo, feriado, ia pra lá, trabalhava o dia todo. Quando tava chegando perto da época do sorteio, tiraram nós! E não foi só eu. Tiraram um monte de gente! Aí passou, aí, quando surgiu a inscrição pro Zavaglia, eu fiz a inscrição. Fui sorteada, tudo, e eu fui excluída de novo! É muita injustiça. [Núbia]

Embora, como visto, ter uma casa própria não tenha sido propriamente um "sonho" ao longo de boa parte da vida de Núbia, isso foi se tornando uma perspectiva cada vez mais presente desde a experiência de viver na ocupação do antigo orfanato, acentuando-se ao ver os filhos formando novos núcleos e saindo de casa, devido à inexistência de uma "casa-matriz"105 a partir da qual pudessem construir suas próprias casas, e, sobretudo, ao ver-se com mais idade, com menos condições físicas para o trabalho e temendo depender dos filhos por não ter mais as mesmas condições de antigamente para seguir caçando rumo e vivendo de aluguel: "Ah, eu ainda quero

105 Duarte e Gomes (2008). 
ter minha casinha, né, pra mim e pro Thiago, uma casinha pequenininha tá de bom tamanho, não precisa ser grande. Só o suficiente pra me tirar do aluguel e do pé dos outros (risos)". Foi, inclusive, um dos filhos que a levou a cadastrar-se novamente na PROHAB, já que ela trazia consigo a frustração de ter sido excluída do mutirão e a descrença nas ações da instituição:

Eu já tinha largado mão. Quando foi no último dia do sorteio, o William me ligou: 'mãe, a senhora foi na Prohab?' Eu: 'não fui e não vou. Num acredito mais nesse negócio de PROHAB'. Aí ele veio em casa e me levou: 'Ah, a senhora vai sim, que a mãe merece uma casa'. E não é que eu fui sorteada? Só que não levei... [Núbia]

Era fevereiro de 2011, e a inscrição referia-se a uma espécie de sorteio de 'repescagem' de cerca de trezentos e cinquenta das mil casas do referido conjunto (uma vez que o primeiro sorteio acontecera um ano antes, e uma parcela significativa dos sorteados não tivera seus cadastros aprovados pela CEF). Núbia compareceu ao sorteio, e qual não foi sua surpresa ao ouvir seu nome ao microfone: ela havia sido sorteada e mal podia acreditar. Interpelada por funcionários da PROHAB, foi instruída sobre os aspectos que a impediriam de assumir a casa: ela não poderia residir na cidade a menos de três anos, deveria ter família constituída, a renda da família não deveria ultrapassar $\mathrm{R} \$ 1.395,00$ e, sobretudo, ela não poderia ter nenhum imóvel em seu nome ${ }^{106}$. "Eu falei: 'moço, eu pago aluguel, eu estou pagando um aluguel que eu estou sofrendo, porque é pesado para mim pagar o aluguel. Essa casa vai me chegar em boa hora. Em uma ótima hora. Quê! Estou esperando. Estou na fila faz tempo'." Núbia se enquadrava tranquilamente em todos os critérios e, após entregar toda a documentação solicitada na PROHAB, passou a "sonhar com a casinha".

É que, por exemplo, uma casa que a gente ocupa, a gente tá sempre na expectativa, que a gente sabe que uma hora alguém vai requerer aquilo. A casa alugada, a gente sabe que, se a gente não cumprir aquele aluguel, a gente vai ter problema, muitas vezes o proprietário é chato, sabe? Ou, às vezes, o espaço físico da casa não é tão bom, mas ele pediu aquele preço, e a gente tá na necessidade de mudar, a gente acaba ficando, entendeu? Então, e chegar até onde eu cheguei, com o sonho de ter a casa própria, pra mim foi assim, sabe? Porque chegou uma época que eu pensava tanto, que eu sonhava que tava dormindo na minha casa, sabe? Porque a partir do momento em que aconteceu tudo aquilo, que eu fui excluída do mutirão... Então, nossa, quando eu fui sorteada eu me senti assim, eu falava: 'meu Deus, até que enfim eu vou ter o meu cantinho, a minha casa própria, vou poder arrumar do jeito que eu quiser, fazer do jeito quiser, porque é minha e ninguém vai implicar'. [Núbia]

106 Requisitos determinados por meio da Lei Municipal no 12.117/99, que "estabelece critérios para a distribuição de casas e lotes urbanizados no Município de São Carlos e dá outras providências". Adaptada, desde o primeiro sorteio realizado em 2010, às exigências do PMCMV (como a inclusão de beneficiários com renda entre 0 e 1 salário mínimo, destinação de porcentagens para moradores de áreas de risco, portadores de necessidades especiais, idosos etc), em 2012 seria aprovado um projeto de lei incorporando-as à legislação vigente. 
Oito meses depois do sorteio, Núbia receberia uma carta da PROHAB. Sua primeira reação foi ficar feliz da vida, acreditando que chegara a hora de tomar posse da casa. Ao abrir o envelope, porém, ela descobriria que a notícia era a contrária: de tudo o que a carta dizia, ela só registrou que havia sido excluída do Programa Minha Casa Minha Vida ${ }^{107}$. A decepção foi terrível, dias e dias chorando, inconformada. Mais uma vez ela esteve perto de conseguir uma casinha; mais uma vez ela fora excluída sem maiores explicações.

Esse negócio de Prohab é só enrolação, viu Thaís? É só enrolação. Porque olha, igual lá, quando saiu o mutirão do São Carlos VIII, eu fiquei anos nessa esperança! Nossa, quando eu fui sorteada pro Zavaglia eu não sabia se eu ria, se eu chorava, se eu pulava, o que que eu fazia. Porque eu fiquei super feliz! Mas na hora eu peguei o telefone, liguei pros meninos, sabe? Aí, quando chegou a carta, o carteiro bateu, fui atender, que eu olhei no envelope vi: Prohab, nossa! Eu vim pulando de lá de fora até aqui dentro de casa: 'chegou carta da PROHAB, chegou carta da PROHAB'! No que eu sento, que eu abro a carta, nossa! Foi a mesma coisa que me jogar um tonel de água gelada na cabeça. Nossa! Porque, olha, eu estava numa esperança, numa certeza que eu ia receber essa casa... Eu sentei, mas chorei, mas chorei! Chorei, chorei, chorei o resto do dia! A Diana chegou aqui eu tava num choro só, na hora que ela chegou do serviço. Ela falou: 'Ué, mãe, o que que aconteceu?', falei: 'Ah, não deu certo o negócio da casa da Prohab de novo!' Ela falou: 'Ah, mãe. Mais pra frente a mãe vai e tenta de novo, porque teve gente que ficou anos tentando até conseguir.' Falei: 'Ah, não. Tentei uma não deu certo, tentei duas não deu certo...' Agora o porquê? / Thaís: Que coisa estranha, Núbia... E você não foi atrás ver o que tinha acontecido? / Ah... Eu fiquei tão decepcionada, que eu vou falar uma coisa para você, eu passei uns três dias chorando de raiva. E depois eu num podia nem pensar no assunto, que senão eu desabava. / Thaís: Será que não foi porque você participou do mutirão? / Mas eu não recebi a casa. Esse é o problema. Eu não recebi a casa. / Thaís: Então até hoje você não sabe o porquê?/ Não! Fiquei com tanta raiva, Thaís, que eu nem fui atrás. Ainda, acho que faz coisa de uns quinze dias, eles tavam fazendo inscrição de novo. Aí a Diana falou assim pra mim: 'Vamo, mãe?' Falei: 'Não vô! Não quero mais nem saber de Prohab mais... [risos] tô até as tampa com a Prohab, não vô fazer mais!'. Ela fez, o Jaelson também fez, sabe? Mas eu falei: 'Não, eu não vou mais.' Eu não quis. / Thaís: Por que, da outra vez você se inscreveu direto pro sorteio do Zavaglia? Cê não tava inscrita na Prohab há mais tempo? / Eu já tinha feito a inscrição a primeira vez praquelas casas do mutirão... Aí passou. Aí, quando surgiu pro Zavaglia, eu fui lá na Prohab, e eles falaram: 'Não, aquela que foi feita pro São Carlos VIII não serve mais, a senhora tem que ir fazer de novo.' Aí eu fui e fiz de novo, sabe? Aí não deu certo, falei: 'Não! agora não quero mais'. [Núbia]

Como se não bastasse uma vida inteira de deslocamentos em busca de moradia, ela ainda teria que conviver com o sofrimento decorrente de, por três vezes, ter se

107 Posteriormente, pude ter acesso à tal carta, cujo conteúdo efetivamente não trazia maiores explicações: "De acordo com o resultado do relatório SITAH apresentado pela Caixa Econômica Federal, após processo de pesquisa realizado em Brasília com base nas informações constantes no Cadastro único, V. Sa. obteve status incompatível com o Programa Minha Casa Minha Vida. Diante do exposto acima, V. Sa. encontra-se excluído(a) do programa Minha Casa Minha Vida por não possuir os requisitos exigidos pelo Governo Federal." 
aproximado da possibilidade de acessar efetivamente uma moradia, a partir de três dinâmicas distintas das políticas públicas municipais. Essa constatação seria retomada por ela em diversos momentos, como espécie de justificativa por seu descrédito frente à PROHAB principalmente, bem como por sua consciente inércia perante a sequência de injustiças que teria sofrido.

\begin{abstract}
Ah, é meio difícil, sabe? Que assim, de primeiro momento, a gente fica mega feliz né? 'Vou ter meu cantinho!' Aí, de repente, muda, então, na verdade, a gente se sente impotente, sabe? Sem ter muito assim o que fazer. Bom, o terreno do Antenor eu ganhei, mas, coisa de três meses depois, deu um temporal muito forte e o terreno virou uma cratera, e o pessoal da prefeitura falou pra eu desistir, que ali não tem condições de construir nada, por causa de ser muito arenoso... Aí veio a casa do mutirão, mas daquele jeito, veio e foi, também sem muita explicação. E depois a casa do Zavaglia. Me fala, cê acha que eu tinha força pra brigar? É tanta injustiça, que a gente fica traumatizado, fica impotente mesmo. [Núbia]
\end{abstract}

Foi nesse momento que a conheci, quando, após a renovada frustração frente à possibilidade de acessar uma casa própria pela via das políticas públicas, o "sonho da casa própria" havia deixado de existir para Núbia: "já desisti, porque nunca que eu vou ter condição de comprar um terreno, guardar dinheiro e construir uma casa a essa altura da vida... Não tive até agora...". Em verdade, durante os quase dois anos de pesquisa de campo, tive a impressão que este era uma espécie de 'tema-tabu' na família, em função desse histórico de expectativas e frustrações frente às políticas habitacionais na cidade. No entanto, pude acompanhar de perto quando a inesperada mobilização de Jimmy em torno da aquisição de uma casa, a ser financiada através do PMCMV, trouxe essa pauta de volta à vida da família: enquanto Jaelson e Diana, agora com novos núcleos familiares, se cadastraram na PROHAB para um novo sorteio também vinculado ao PMCMV e insistiram muito para que ela se cadastrasse novamente (ao que ela se recusou veementemente), foi Jimmy quem decidiu finalmente investigar os motivos por que Núbia fora impedida de tomar posse da casa sorteada em seu nome, pedindo minha ajuda: "Eu guardei a carta, mas eu não tinha forças pra correr atrás, eu fiquei muito decepcionada, muito! E, na época, o Jimmy falou para mim: 'mãe, não joga essa carta fora, porque nós ainda vamos lá na PROHAB saber o que aconteceu, por que a mãe não pôde receber a casa'”.

Passados quase dois anos desde o recebimento da fatídica carta, entramos em contato com a PROHAB, para verificar os motivos que levaram Núbia a ser excluída do Programa Minha Casa Minha Vida. A resposta inicial foi a seguinte:

Atendendo à sua solicitação, informamos que a senhora Núbia consta no CADMUT (Cadastro Nacional dos Mutuários) como beneficiada por uma unidade no São Carlos VIII (Mutirão), por isso está impedida de um novo financiamento. Favor procurar pessoalmente o setor Administrativo/Jurídico da PROHAB para esclarecimentos, acompanhada da Sra. Núbia.

Em contatos posteriores (quando conseguimos ter acesso ao já mencionado arquivo do cadastro de Núbia na empresa), tivemos a confirmação: sua situação seria a 
mesma de mais de uma dezena de pessoas que participaram do mutirão, que, após terem assinado o contrato com a CEF, acabaram sendo expulsas ou desistindo no meio do processo, mas não tiveram seus contratos encerrados pela Prohab, de modo que as casas foram repassadas a outros moradores, mas permaneceram em nome dos primeiros mutirantes. Assim, no CADMUT (e, portanto, para efeito de toda e qualquer política habitacional no país), Núbia consta como proprietária de um imóvel (sem que nem ela própria soubesse disso), estando, por isso, impedida de acessar qualquer política ou financiamento público, razão pela qual ela foi excluída do Programa Minha Casa Minha Vida. Soubemos, ainda, que um ou outro ex-mutirante do São Carlos VIII que se descobriu na mesma situação já havia procurado a PROHAB anteriormente, a qual, ao contatar a CEF para tentar solucionar o problema, teria sido informada de que, uma vez encerrado aquele convênio com a empresa e tendo sido toda a documentação encaminhada a contento, não haveria por que a CEF reabrir tal processo em função de "erros cometidos pela diretora da Prohab na época" (nos termos dos funcionários da empresa contatados). Por sua vez, a PROHAB nos informou de que também não teria como solucionar o problema, e que os outros casos semelhantes tinham sido encaminhados da seguinte maneira: instruindo aos reclamantes que fossem por conta própria ao cartório fazer um documento de compra e venda do imóvel (situação em que, além de arcar com os custos legais, ainda permanecerão impedidos de acessar outras políticas ou financiamentos habitacionais, pois sempre constarão como já tendo sido beneficiados uma vez).

De posse da documentação constante na PROHAB, acompanhei Núbia e Jimmy ao cartório de registro de imóveis. Ambos ficaram perplexos com a confirmação de que o apartamento estava ainda em nome de Núbia: "quer dizer que tô há cinco anos sofrendo, pagando aluguel, e tem alguém morando numa casa que tá no meu nome?" E mais: com a constatação de que novamente, os rolos da PROHAB ao longo do mutirão a teriam impedido, pela segunda vez, de acessar uma casa própria (sorteada em seu nome!) pela via das políticas habitacionais.

Incitados por familiares e amigos, por funcionários da própria empresa (e por mim) a batalharem por seus direitos, eles fizeram uma primeira consulta à defensoria pública, na qual a opção apresentada como mais exequível foi tentar reaver a casa em seu nome. Núbia e Jimmy demonstraram cautela, invocando a experiência conflituosa de participação no mutirão, o caráter de panela de pressão do conjunto habitacional e, sobretudo, o episódio vivenciado nos últimos tempos do orfanato como lugar pesado. A intenção era, primeiramente, descobrir quem estaria de posse do apartamento em nome de Núbia, para depois decidir como proceder: "vai que a gente descobre que é justamente aquele sujeito, envolvido no assassinato da Geísa? Eu que não quero rolo com esse cara, prefiro ficar sem casa." Além disso, havia uma outra preocupação: "eu não quero tirar a casa de ninguém pobre como eu. A pessoa 
não tem culpa, quem tem culpa é a Prohab. Senão vai virar uma briga de pobre contra pobre, e eu não quero isso". Mais uma vez, a despeito da necessidade, não seria a qualquer custo que ela teria uma casa própria, trazendo à tona aquele mesmo misto de medo e alguma dimensão de escolha que já pautara os rumos de sua trajetória habitacional, quando de sua exclusão do mutirão.

Acompanhei-os em incursão ao conjunto habitacional, no loteamento social São Carlos VIII, em busca de descobrir qual seria o apartamento em nome de Núbia (do qual só tínhamos a indicação extraída do registro do imóvel) e qual a sua situação atual. Andando pelo local, Núbia rememorou, entre orgulhosa e triste, todo o trabalho ali desempenhado ("tá vendo aqui, Thaís, daqui até lá embaixo a gente cavou tudo os buraco aqui pras fundação, a gente cavou tudo isso aqui! Assentei muito tijolo aqui!"). Ela e Jimmy encontraram antigos vizinhos do orfanato e, acima de tudo, reafirmaram o acerto da decisão de não terem insistido em conseguir uma casa ali ("você entendeu o que eu te falava da panela de pressão? Aqui não tem quintal, os espaços livres são esses aí que você tá vendo, é totalmente diferente de uma rua, de um bairro, onde você tem espaço e o que acontecer de ruim não vai ser tão próximo de você, da porta da sua casa. Então, não tinha condição da gente vir pra cá. Demorou, mas agora eu vou conseguir minha casinha, que é pequena, mas perto dessas daqui é um palácio. Valeu a pena esperar" - Jimmy). Quando finalmente conseguimos encontrar o apartamento que estaria em nome de Núbia, a atual moradora lhe informou tê-lo alugado, e entrou em contato com o proprietário, para que viesse conversar com Núbia.

Em lugar do proprietário, entretanto, apareceu uma mulher, falando em um celular com um fone de ouvido e querendo saber o que estava acontecendo. A inquilina apontou, do andar de cima, para Núbia, que, apreensiva, tentou explicar sua situação. Jimmy ainda procurou amenizar a tensão, dizendo que conhecia a tal mulher de algum lugar, mas ela não deu continuidade à conversa, dizendo logo que "a casa é dos meninos, tô só ajudando os amigos". Enquanto Núbia falava mais uma vez, procurando deixar claro que não pretendia tomar a casa, mas apenas saber se era aquela mesmo em seu nome e a situação em que se encontrava, a mulher recolocou um fone no ouvido e continuou a falar com alguém que a aguardava no celular, contando resumidamente a história para a pessoa do outro lado da linha e concluindo: "aí, o que ela quer é ir lá na Caixa resolver a situação dela, tirar o nome dela da história. Ela tá no direito dela, não vai te prejudicar." Ao desligar, ela informou que os tais meninos proprietários do apartamento estavam na praia, e que Núbia poderia conversar com eles no início da outra semana.

Encerrada nossa incursão, enquanto seguíamos para o carro, notei que eles estavam transtornados, já que o desfecho fora justamente o que eles mais temiam: tendo pertencido a pelo menos outros dois proprietários (a suplente que assumira a casa 
no lugar de Núbia e mais um), o apartamento, atualmente, pertenceria a um menino que eles concluíram ser do crime. Pergunto por que chegaram a essa conclusão, e Jimmy diz que reconheceu a mulher, "ela é filha de uma envolvida bem conhecida, que é dona de vários bares de prostituição lá embaixo [no Aracy], tem envolvimento com o crime". E, com isso, Núbia concluiu: "se for essa mesma situação que tá parecendo, eu não vou querer essa casa de jeito nenhum; vou mais é partir pra briga com a Prohab pra tentar conseguir outra casa". Depois desse dia, eles não voltaram mais ao bairro, e Núbia deu entrada em processos junto à CEF e à Justiça Federal (por indicação da Defensoria Pública), cujos desfechos poderiam ser desde a retirada de seu nome do CADMUT pela CEF até a compensação material, pela PROHAB, da sequência de injustiças sofridas.

Em paralelo, Jimmy, para quem a perspectiva da casa própria era narrada como algo bastante longínquo quando iniciei a pesquisa, em menos de dois anos tinha nela sua prioridade absoluta. Já instalado em seu palácio, como ele passou a se referir à casa que tentava financiar pelo Programa Minha Casa Minha Vida, tratava agora de "correr atrás da papelada" para que ela pudesse tornar-se efetivamente sua. Logo de início, a descoberta do imbróglio sobre a situação de sua mãe na PROHAB o apavorou: se ele estivesse nas mesmas condições, não poderia realizar o financiamento. A primeira providência foi verificar seu caso: descobriu que nem sequer tinha um cadastro arquivado na PROHAB, denotando que sua participação no mutirão não ficara registrada, nem tampouco a (re)inscrição no cadastro que efetivara nos primeiros tempos de casado, por insistência da primeira esposa ${ }^{108}$.

A alegria de Jimmy por descobrir que não estaria inviabilizado (como sua mãe) de concretizar o financiamento da casa em que já estava vivendo levou-me a refletir um pouco mais sobre o lugar do "sonho da casa própria" na trajetória não apenas de Jimmy, mas também de Núbia. Tais trajetórias permitem relativizar tanto a generalidade de tal "sonho" quanto seu caráter meramente "ideológico"109,

108 Uma deteç̧ão sobre a situação caótica dos arquivos de dados e do cadastro da PROHAB, que dão margem para questionamentos sobre seus modos de operação e embasam a imagem negativa do órgão entre os populares, foi realizada em PMSC (2010). Voltarei a esta questão no Entremeio 1.

109 "Evidentemente que não se trata apenas de um fenômeno ideológico. A casa própria é percebida e vivida pelas camadas populares como verdadeiro bastião da sobrevivência familiar, ainda mais em tempos de crise e de instabilidade crescente no mundo do trabalho. A casa própria, no Brasil, representa a garantia de uma velhice "com-teto", na ausência ou insuficiência da previdência social, ou seja, é vista como a única garantia para um fim de vida com o mínimo de segurança e dignidade. Para os jovens casais com filhos ou mães chefes-de-família, a casa própria é a garantia de uma estabilidade em vários níveis, em relação à escola dos filhos, aos laços de solidariedade de bairro, à segurança real e simbólica de não ser ameaçados ou vitimados pelo despejo em caso de desemprego. Nesse sentido, a casa própria cumpre um papel de amortecedor diante da incompletude dos sistemas de proteção social e da ausência de uma industrialização com pleno emprego e é, por isso, o "sonho número um dos brasileiros" (Arantes e Fix, 2009). Em maior diálogo com as questões trazidas pelo campo desta pesquisa está a reflexão sobre a casa própria como "mito", produzida por Lindón (2005), 
evidenciando que este não se configurou como um objetivo em si e a priori, mas construiu-se histórica e geracionalmente no contexto de inseguranças, instabilidades e violências que não ter casa acarretou em ambas as trajetórias. Jimmy, em particular, traz à luz outros sentidos conferidos à perspectiva de conquista da casa própria, ao apreendê-la como uma materialização da vitória do projeto sobre o destino $^{110:}$

Tinham pessoas na época [em que a família viveu no orfanato], assim, que encaravam minha mãe e a gente como uma família destinada a desandar e fazer merda na vida. Principalmente porque eu morei na rua, tive meus problemas. $E$ agora, eu conseguindo minha casa própria... é um cala boca pra essa gente. Era como se eu devesse isso pra minha mãe. [Jimmy]

Então, eu fui construindo esses projetos, primeiro o sonho meu de produção musical, depois de ter uma casa. Pros que pensavam que meu destino era ser mais um traficantezinho, FEBEM, cadeia, eu tô dando a prova do contrário. Nada vai inibir esses projetos meus, os dois concretizando juntos agora são a minha prioridade. A produção musical já tá rolando, e agora a casa. [Jimmy]

Mesmo sem ter dado início ao processo de financiamento, a simples perspectiva de sua viabilização foi suficiente para a mobilização desse futuro-próximo de concretização da conquista não apenas por Jimmy, mas por Núbia e mesmo por seus irmãos: apesar das injustiças da PROHAB, depois de "tanta luta, sofrimento e necessidade", finalmente alguém da família teria uma casa. Entre seus conhecidos, pude ouvir comentários como "ê, Jimmy, quem diria, hein, você de casa nova!" ou ainda "O Jimmy nunca deu essa ideia, levei até um susto quando ele contou que ia financiar uma casa. Pô, fiquei feliz por ele, porque achava que ele ia ficar naquela, de que só porque é pobre tem que viver de aluguel, andando a pé...", apontando para uma espécie de "economia moral da casa própria"111 a partir da qual sua aquisição

em que este é pensado no quadro de uma "subjetividad espacial", em articulação com "trayectorias de vida marcadas por la alta movilidad espacial" e com as heterogêneas "formas de habitar" a "periferia pauperizada". A autora aponta para a complexidade inerente à incorporação e reconstrução de tal "mito" pelas camadas populares (que "às vezes se desdibuja y otras se potencia"), decorrente de um vasto "entramado de sentidos espaciales em torno a la casa própria".

110 Jimmy, por diversas vezes, referiu-se às ideias de destino (associado à trajetória de sua mãe, à pobreza, à vida na rua e à experiência próxima ao crime e à violência vivida no casarão 2020 e na ocupação do antigo orfanato) e projeto (associado inicialmente ao sonho de ganhar a vida atuando profissionalmente com o rap e a produção musical e, mais recentemente, à perspectiva de financiar uma casa), sempre enfatizando as dificuldades para alguém na sua condição (referindo-se ao fato de ser negro e pobre, bem como às dificuldades financeiras, aos estudos incompletos e à necessidade de aceitar trabalhos braçais e mal remunerados para sobreviver) conseguir concretizar um projeto. Inevitável pensar, aqui, nas reflexões de Velho $(1987,1994)$ sobre a noção de "projeto" e sua articulação à existência de um "campo de possibilidades", referente às margens de escolha e iniciativa "construídas dentro do processo sócio-histórico e com o potencial interpretativo do mundo simbólico da cultura" (1994:28), cuja delimitação corresponderia ao espaço para formular e viabilizar projetos. A apreensão da casa própria como um projeto, nesse sentido, auxiliará também nas reflexões constantes do capítulo 2.

111 Kopper $(2013,2014)$, em investigação etnográfica ainda em curso sobre a chamada "nova classe média" a partir do mercado da casa própria, irá propor uma abordagem centrada na ideia de uma 
pode ser apreendida atrelada a um conjunto de classificações sociais e distinções morais em operação nas camadas populares: "o povo que muitas vezes me julgou hoje me vê com outros olhos". Ainda que a conquista ${ }^{112}$ da casa própria não represente necessariamente mobilidade social (e, no caso de Jimmy, não tenha nem sequer resultado desse objetivo, como é o caso de uma das trajetórias analisadas no Capítulo 2), ela (re)encarna essa potência ${ }^{113}$, configurando quase que automaticamente um novo lugar entre os supostamente iguais e podendo ser apreendida mesmo como um modo de minimizar uma das principais marcas associadas por meus interlocutores à ideia de pobreza - o "não ter casa"114.

\footnotetext{
"economia moral da casa própria" que me parece extremamente fértil, em termos analíticos, para a compreensão das dinâmicas engendradas a partir da implementação do Programa Minha Casa Minha Vida, como as aqui introduzidas por meio da trajetória de Jimmy e mais aprofundadas através das trajetórias analisadas no capítulo 2 .
}

112 A ideia de conquista da casa própria, tal como referida por Jimmy, embora remeta ao aspecto simbólico de uma batalha travada para tanto (na qual se incluem a um só tempo as dificuldades presentes na trajetória de sua mãe e na sua própria), carrega significados bastante distintos da noção de "luta", expressão das dificuldades cotidianas enfrentadas no árduo processo de construir um lugar para viver na cidade - aí incluídas, simultaneamente, a autoconstrução da casa e do próprio espaço urbano - e que seria "produtiva de noções de valor atreladas ao espaço da favela", conforme analisado por Cavalcanti (2009:74). Vinculada à "imaginação de um progresso ao longo do tempo", esse valor inerente à ideia de "luta" parece caracterizar, de um modo geral, o processo de autoconstrução da moradia como forma de acesso à casa própria, mesmo em loteamentos periféricos, onde se associa às dificuldades vinculadas à ausência do "urbano" (cf. entremeio II): na já mencionada "economia moral da casa própria", tal valor demarca uma distinção (que tenho por hipótese ser já geracional), em termos do esforço envolvido, em relação àqueles que acabam por conseguir uma casa própria já pronta, seja através de políticas habitacionais (como é o caso de Joana, cuja trajetória é analisada no capítulo 2), seja por meio das novas formas de financiamento possibilitadas pelo Programa Minha Casa Minha Vida (como é o caso de Jimmy e de Jefferson e Beatriz, cujas trajetórias são analisadas também no cap. 2), seja ainda por outro meio qualquer (como na trajetória de Marielen, analisada no cap. 3).

113 Sobre os "fatores objetivos e subjetivos" implicados na concepção de casa própria como etapa de ascensão social, ver Bolaffi (1982). Entretanto, como as trajetórias analisadas neste capítulo permitem apreender, bem como alguns estudos antropológicos ancorados na noção de casa nas chamadas sociedades complexas (cf. Woortman, 1982; Sarti, 1996; Marcelin, 1999; Lindón, 2005, 2006; Guedes e Lima, 2006; Cavalcanti, 2007, 2009; Guedes, 2008; Lima, 2008; Duarte e Gomes, 2008; Machado, 2010; McCallum e Bustamante, 2012; Pedrosian e Latierro, 2013, para citar alguns), há uma miríade de dimensões simbólicas implicadas na consecução de uma casa própria, à qual se associam concepções sociais e morais de família, parentesco, redes de relações, e mesmo de indivíduo, que não se restringem nem à sua concepção como "bastião da sobrevivência familiar" diante das dificuldades financeiras, incertezas em termos de trabalho ou incompletude dos sistemas de proteção social, nem como forma de realização (e/ou demonstração) de ascensão social.

114 Cf. Guedes e Lima (2006:133): “O acesso a uma casa - que representa sua inclusão em uma família - pode representar a diferença entre a possibilidade de se manter nos segmentos mais estabilizados da classe trabalhadora ou de se transformar em um morador de rua, naquele 'trabalhador que não deu certo'(...)". Silva (2006), em estudo sobre redes de migração no bairro Cidade Aracy, aponta um sistema de classificação interno aos migrantes, definidora do caráter "bem sucedido" ou "mal sucedido" de uma "trajetória migrante", operado através da categoria "ter", que poderia ir desde "ter comida", passando por "ter uma casa" até "ter mais que uma casa": "estar bem significava 'ter comida' e 'ter uma casa'", por oposição a um passado de extrema dificuldade e pobreza; "ter mais que uma casa" caracterizaria uma "trajetória migrante" que, a partir da consecução de uma casa, teria passado a orientar-se por projetos mais individualizantes, desvinculando-se de 
Entretanto, dentre os diferentes critérios morais, simbólicos, sociais e econômicos acionados em tais operações de classificação interna em que a posse (ou não) da casa se inscreve, Jimmy já havia feito uma escolha antes mesmo da oportunidade inesperada de mudança para essa casa aparecer: ao contrário de alguns conhecidos cuja decisão de adquirir uma casa por conta própria esteve diretamente associada à intenção de fugir do Aracy (como no caso de uma trajetória analisada no capítulo 2), Jimmy sempre frisou que, se fosse possível ${ }^{115}$, sua opção seria por permanecer no bairro. De fato, após mais de dez anos morando ali, a despeito da aguda consciência crítica sobre aspectos como a insuficiência dos serviços públicos e o estigma associado ao bairro, suas razões para permanecer são muitas: sua atuação como rapper e a vinculação de sua produção àquele território; a concepção de que ali a acessibilidade (síntese nativa que expressa a proximidade da casa em relação a equipamentos, serviços e comércio) já estava garantida ${ }^{116}$; a representação do Aracy como um lugar tranquilo; as variadas redes de relações ali estabelecidas ao longo dos anos e, sobretudo, a manutenção das dinâmicas familiares ampliadas vinculadas àquela concepção alargada de casa, para a qual a permanência próxima ao restante da família, no bairro, seria crucial.

Eu não saio do Aracy, não. Apesar de ter toda essa... todo lugar tem uma precariedade, todo lugar tem... Pra mim é melhor aqui, aqui eu já tô bem mais habituado, já sei os problemas que tem, já aprendi a contornar isso, né? Tem que ser que nem água, não adianta ficar batendo no obstáculo, tem que contornar e vai embora! E aqui eu consigo fazer isso, aqui no Aracy eu consigo. Agora, se fosse em outro bairro, eu não sei se eu conseguiria... Em se tratando de convivência, né, você tem que chegar, se habituar, se adaptar, ai é complicado. Eu só abracei esse financiamento por causa disso, é no bairro! Aí até fui contestado por muitos, mas daqui eu não saio, porque isso aqui eu conheço como a palma da minha mão. Pelo fato também de conhecer todo mundo! (...) Então, por essa questão das pessoas, a questão de que eu conheço o bairro, sabe? Sei o que tem, o que não tem, o que é bom, o que é ruim... então, pra gente que conhece, é muito tranquilo, não tem por que sair, sabe? Tem tudo aqui. Pra que eu ia querer comprar uma casa em um lugar sem transporte, sem comércio, igual

redes mais amplas e densas tecidas entre grupos de migrantes e distanciando-se ainda mais, nesse sentido, de um possível passado de pobreza.

115 Antes da "oportunidade inesperada" de financiar uma "casa pronta" através do PMCMV, a única perspectiva vislumbrada por Jimmy (assim como por Núbia e toda sua família) era aquela vinculada aos sorteios da PROHAB, na qual não haveria possibilidade de escolha de localização: "onde vier a bênção da casa própria a gente vai, porque, PROHAB, não tem como escolher. E, mesmo se tivesse, ia ser ou Zavaglia, ou Santa Angelina, ou São Carlos VIII", referindo-se aos territórios de produção habitacional pela empresa. Ou, ainda: "Eu num trocaria o Cidade Aracy, só se, suponhamos que eu fosse sorteado na PROHAB, e os caras: 'ah, vãos direcionar você pra bairro tal, pra uma casa sua'. Aí, beleza, seria uma outra história. Mas se eu pudesse escolher, seria aqui [no Cidade Aracy]."

116 "Aqui eu sei que eu tenho uma acessibilidade confortável pra minha família, aqui tem tudo, eles não precisam andar de um bairro pro outro pra fazer qualquer coisa, ir na escola, fazer uma compra..." [Jimmy]. Voltarei a este tema no Entremeio II. 
muitos fizeram só pra sair do Aracy? Eu não troco esse bairro, onde eu vou, aqui, eu tenho amigos. [Jimmy]

Também Núbia expressaria o desejo de permanência no bairro, evocando a experiência anterior de fixação no antigo orfanato e apontando praticamente para os mesmos aspectos elencados por Jimmy como motivos a corroborar sua decisão de não tentar reaver o apartamento em seu nome no São Carlos VIII, associado à concepção de que uma casa própria somente lhe faria sentido "se fosse pra morar; pra vender ou alugar eu não quero, não acho certo. Brigar por uma casa que depois eu vou passar pra frente? Sei que muitos vão falar que tô errada por pensar assim depois de tudo que já passei, mas o que eu quero é um cantinho pra eu morar, sair dessa vida cigana, assentar o pé num lugar." [Núbia]

"Assentar o pé num lugar". Aqui se explicita não apenas outra forte razão para não quererem mudar do bairro, mas também mais um elemento a complexificar, tendo em conta a perspectiva êmica, o "sonho da casa própria", apontando para uma dimensão que se vincula menos à ideia de "propriedade privada", aproximando-se mais daquela de "segurança da posse"117: é o histórico da vida de aluguel, a experiência das ocupações, o contexto de tantos deslocamentos, arranjos e rearranjos familiares, habitacionais e urbanos que permite apreender tal "sonho" a partir de sua associação a um ideal de fixação num território, numa casa, "de onde ninguém vai mais me tirar". Como explicita Jimmy, a maior motivação em conseguir sua própria casa é justamente "por causa de tudo que nós passamos com minha mãe, sabe?"

A perspectiva de fixação associada à "segurança da posse", ao ter um endereço vincula-se também àquela concepção de vizinhança elaborada durante os anos vividos no orfanato como síntese da relação entre casa e território: uma casa própria representaria ainda, em tese, o fim do constante "ter que refazer a vizinhança", destacado por ambos como uma das grandes dificuldades da vida de aluguel.

Não é só por ter algo meu... Mas também parar com esse negócio de ter essa ideia de um dia eu tô aqui, no amanhã vai saber, saca? Eu queria um lugar meu. Não só pra chamar de meu, mas pra ter um lugar, assim, que eu sei onde é meu endereço, é na rua tal, bairro tal, CEP tal, acabou, sabe? Daqui ninguém me tira, entendeu? É uma coisa, assim, pra fixar mesmo, pra ter paz, uma tranquilidade

117 "Por seguridad de la tenencia se entiende un conjunto de relaciones con respecto a la vivienda y a la tierra, establecido en el derecho codificado o consuetudinario, o mediante acuerdos no oficiales o híbridos, que permite vivir en el propio hogar en condiciones de seguridad, paz y dignidad. La seguridad de la tenencia es parte integrante del derecho a una vivienda adecuada y un componente necesario para el ejercicio de muchos otros derechos civiles, culturales, económicos, políticos y sociales. Todas las personas deberían gozar de un grado de seguridad de la tenencia que garantice una protección jurídica contra el desalojo forzoso, el hostigamiento y otras amenazas." Cf. relatório sobre segurança da posse ONU, disponível em http://direitoamoradia.org/wp-content/uploads/2014/03/AHRC-25-54_spfinal.pdf (consulta em junho de 2014). 
a mais aí, porque morar de aluguel é aquilo, né, é incerteza... Mesmo que você pague tudo direitinho, no outro dia o dono pode querer a casa, aí você vai ter que ficar mudando toda mão, sabe? Eu tava cansado dessa vida já. [Jimmy]

Desde que eu desci pra cá, pro Aracy, eu não tive mais aquele senso de vizinhança que a gente tinha no orfanato. Onde eu mais tive isso aqui embaixo, que foi o lugar que eu mais gostei de morar, foi naquela casa ali, que você conheceu [que depois virou de Jimmy], ali eu tava já com uma boa relação de vizinhança. Aí, muda de novo... Então eu tô cansada, eu queria parar num lugar, fixar mesmo numa casa, numa rua, onde eu pudesse me acertar com os vizinhos e não sair mais dali. [Núbia]

Embora tudo indicasse que Jimmy concretizaria o financiamento da casa onde já estava morando há alguns meses, até o término da pesquisa de campo isso ainda não havia acontecido. A dificuldade em dar conta da burocracia exigida pela CEF articulava-se às dificuldades financeiras do casal e às constantes mudanças nesse panorama. Num primeiro momento, logo que se mudaram para a casa, os entraves eram o nome sujo de Jimmy, cuja resolução envolvia um gasto de cerca de $R \$ 800,00$, a intermitência de seus recebimentos e a ausência de renda de Júlia, então desempregada. Enquanto Jimmy dava conta desses entraves, buscando levantar recursos para pagar as dívidas e encontrando uma estratégia para comprovar uma renda fictícia do casal - através da consecução, com um amigo, de uma declaração de autônoma para Júlia118 - a situação se modificou: com a renda de Jimmy comprometida com as dívidas antigas, o casal fez uso de um cartão de crédito de Júlia, gerando novas dívidas, que também acabaram por sujar o nome dela. Por outro lado, ela conseguiu um emprego temporário através de uma empresa de terceirização e passaria a trabalhar, com registro em carteira, na Faber Castell. As expectativas do casal, nesse momento, eram as melhores, pois acreditavam na chance de Júlia ser efetivada na indústria. Sem condições de pagar todas as dívidas de uma vez para "limpar os nomes" de ambos, aproveitaram a condição relativamente estável de Júlia para fazer um empréstimo. Dívidas sendo quitadas às custas de nova dívida, o problema agora era outro: com a renda de Júlia somada à de Jimmy eles ultrapassariam o limite para o recebimento do subsídio máximo concedido pelo PMCMV.

Primeiro a gente tem que acabar de limpar os nossos nomes, porque, na verdade o nome da Júlia também tá no prego agora, né, por conta de um passado recente que a gente tava os dois quebrados, a gente acabou utilizando o cartão de crédito dela e estourou. Mas agora ela arrumou um trampo também, então já vamos começar a acertar essa situação, e eu tenho que acabar de limpar o meu também, inclusive tem que ser essa semana. Aí, o caso da renda, agora que ela tá trabalhando registrado, dificilmente a gente vai poder deixar a renda dela de fora, vai ter que ser a primeira, vai ter que inverter, porque antes a gente pegava

118 As estratégias das "famílias de baixa renda" (alçadas à "nova classe média") para dar conta de ultrapassar a primeira etapa da consecução de um financiamento são muitas, como o caso de Jimmy permite entrever. No Capítulo 2, veremos outros dois casos nesse sentido. 
a minha renda como a renda primária, e a dela, como secundária, porque ela ia entrar como autônoma, a gente ia fazer um esquema, já tinha arrumado um comprovante. Mas agora ela trabalha registrado e eu somei, então, a gente vai ter que fazer um jogo, sabe, eu ainda não sei como vai ser feito isso assim, não entendi, mas a gente vai ter que fazer um jogo pra ver se nossa renda encaixa... /Thaís: Porque tem um limite de renda? / Não é nem que tem um limite de renda, mas é assim, se nossa renda for muito alta, a gente nem pega o subsídio total do governo, que é uma coisa que a gente quer, porque, meu, o governo rouba tanto da gente, que não é possível que não vai poder subsidiar né? Pro valor da casa não ficar algo fora da realidade, entendeu? Então, primeiro é limpar o nome, essa semana a gente tá correndo atrás... tô vendo de fazer um empréstimo aí. $E$ tem que resolver esse problema da renda. / Thaís: Antes vocês tavam tendo que aumentar, agora vocês vão ter que diminuir, é isso? / Isso, exatamente, porque, com a renda dela, ficou maior do que a gente esperava, do que a gente precisava, na verdade. Mas eu acredito que vai dar tudo certo, acredito que a gente vai conseguir entrar num financiamento legal aí, e... não é que eu tô interessado de entrar na malandragem e ter que pagar uma mixaria pela casa, não é isso, eu só não quero que isso vire um problema num futuro próximo aí, porque também tem o negócio da pensão dos meus filhos, que eu tenho que pagar, né? / Thaís: $E$ você tá com os outros aluguéis atrasados ainda? / Isso, tem que acertar, então isso é uma coisa assim, que pelo menos por um ano, vai virar uma rotina isso, mas que seja aquela rotina que depois um ano eu falo: 'meu, aliviei lá, né? Aqui já dá pra chegar com um pouco mais', entende? Vai ter que ser algo assim, porque senão... Eu sei do peso que isso vai ser no começo, ano que vem vai ser um ano que todo mundo vai estar comemorando a copa e eu vou tá com a cabeça desse tamanho... Mas eu tô confiante. / Thaís: E quando vocês fizeram a simulação aqui, a parcela sua dava de quanto? / $R \$ 538,00$, procê ver, pouca coisa a mais do que eu pagava de aluguel naquela casa, daquele jeito! [Jimmy]

Enquanto eles procuravam uma alternativa para a questão da renda, veio uma nova mudança, agora com a não renovação do contrato de Júlia. Com ela novamente desempregada, restava a Jimmy dar conta dos gastos familiares, das parcelas do empréstimo e ainda se manter com o "nome limpo". O proprietário da casa, por mais próximo de Jimmy que fosse, já começava a ficar preocupado com a real possibilidade do casal efetivar o financiamento. Temendo ter de deixar a casa, Jimmy chegou a propor pagar um aluguel até que a situação se resolvesse, mas o proprietário não concordou. Juntos, descobriram que as notas que Jimmy vinha emitindo como Micro Empreendedor Individual (MEI), decorrentes de suas oficinas de produção musical, poderiam ser usadas como comprovante de renda, não sendo necessário maiores esquemas para envolver uma renda inexistente de Júlia (no máximo, a emissão de algumas notas a mais por Jimmy, que poderia ser facilmente resolvida emitindo notas em seu nome para trabalhos de outros amigos). Na última vez que conversamos, passados já sete meses da mudança para a casa, parecia que, finalmente, o financiamento iria se encaminhar. Com sua esposa ainda desempregada e ele com empregos intermitentes, Jimmy começava a temer pelo futuro pagamento das prestações do financiamento, mas ainda assim se mantinha bastante confiante:

Meu, essa sensação de assumir uma dívida desse tamanho é foda, outro dia mesmo eu fiquei pensando: 'pô, tem amigos meus que já têm casa própria financiada, eu quero perguntar se eles tiveram essa mesma sensação'. É muito, 
sabe, fico pensando 'putz cara, quando a gente vacilar, daqui um tempo já passaram-se 10 anos', tá ligado? E a gente vai ter pago a metade o bagulho. É a vida inteira, mas o que me conforta é aquilo que já te falei, sair do aluguel... Ok, morando de aluguel, dá pra ir empurrando daqui, dali, negociando com o proprietário... Num financiamento, nunca que eu vou poder ficar oito, dez meses sem pagar... se eu fizer isso, perco a casa! Então, não sei como vai ser, mas a gente vai se virar, porque a gente quer muito essa casa, ela já é como nossa, não tem como a gente sair daqui a essa altura. Mas o que me conforta, primeiro: a comodidade, a gente vai tá aí com a nossa casinha, vai tá sempre aí, é o nosso endereço, até falei pra Júlia: 'meu, isso é o nosso endereço', não é aquele negócio de hoje a gente mora aqui, amanhã a gente tá morando em outra rua, em outro bairro, saca? A gente tem o nosso endereço, né? Meu, e ter um lugar assim, gostoso como é essa casa, pra receber meus filhos, meu sobrinhos, minha familia, inclusive a família dela, sabe? Que agora que a gente tá nessa casa vai poder vim aqui passar as férias com a gente... É algo assim, tremendamente, é o que conforta a gente, mas a gente tem sim essa preocupação, a gente fica pensando nisso, mas não é uma coisa que faz a gente falar 'não, é melhor não' e voltar pra trás. / Thaís: Não chega a meter um medo... / Não, não, não, eu nunca tive tão confiante na minha vida. [Jimmy]

Se Jimmy seguia confiante, já não se podia dizer o mesmo de Núbia. Ela continuava com processos correndo na Justiça Federal e na CEF, mas sem nenhum retorno, e com pouco empenho por parte dela em buscar informações sobre o andamento dos mesmos. Desencorajada completamente pela Defensoria Pública em investir contra a PROHAB, ela, ainda assim, fizera contatos com um advogado particular, visando entrar com uma ação, mas até nosso último contato nada havia sido encaminhado. Mais recentemente, descobriu diversos casos de conhecidos em igual (ou pior) situação, para os quais a PROHAB estaria, inclusive, negando o acesso aos arquivos de cadastro. Mais do que nunca, ela enfatizaria sua descrença em relação às políticas públicas e a renovada sensação de impotência decorrente da experiência acumulada de quem, por três vezes, acreditou que conquistaria uma moradia, todas elas resultando em frustração:

Eu já tô desanimando de novo, viu, Thaís. Porque eles lá, a PROHAB, sempre vão dar um jeito de enrolar a gente, vem com uma história aqui, um documento ali, some com uma informação acolá e, no fim, essa história não vai virar é nada. Já tô perdendo as esperanças, não tenho mais a mesma disposição pra briga que eu tinha antigamente. Eu até achei que dessa vez fosse conseguir minha casa, mas tô vendo que não vai virar e já tô cansada de ilusão. Não quero acreditar e depois chorar mais uma vez. [Núbia]

Assim, a casa própria seguia sendo, para ambos, ainda que sob diferentes circunstâncias, uma espécie de miragem: no caso de Jimmy, mais propensa a materializar-se, sobretudo porque vinculada às lógicas de mercado; no caso de Núbia, prestes a se desmanchar frente àquela realidade, sua velha conhecida, do estado como promotor de violências múltiplas no campo do urbano. 


\section{[entremeio I ]}

\section{Política habitacional e mercado imobiliário informal: imbricamentos}

De modo geral, na pesquisa de campo e, sobretudo, nos diversos contextos, deslocamentos e pontos de condensação das trajetórias aqui analisadas, o acesso à moradia evidenciou-se, quase sempre, como questão do mundo privado, que não passa pela dimensão dos direitos, dependendo da sorte, de uma bênção ou, mais concretamente, de redes de relações e arranjos cotidianos e, ao fim e ao cabo, do mercado (preponderando o informal e, apenas mais recentemente, também o formal tendo-se tornado uma opção para alguns). As políticas habitacionais aparecem sempre de forma residual, como algo inacessível ou, quando acessada, como obra do acaso: "ah, fiquei sabendo do sorteio por acaso, me inscrevi e já fui sorteada"; " $a$ vizinha ali debaixo nem sabia direito o que tava indo fazer lá, foi, se inscreveu assim, no acaso, e conseguiu uma casa".

Por outro lado, todos conhecem, ao menos de ouvir falar, a PROHAB (já mencionado órgão operador das políticas habitacionais no município) e, invariavelmente, têm histórias de injustiças que teriam sido promovidas pela mesma para contar. O próprio caso de Núbia é exemplar nesse sentido e articula-se a uma impressionante recorrência de representações negativas sobre tal órgão e as políticas habitacionais no município ${ }^{1}$, o que me levou a considerá-las como aspecto fundamental do "problema da habitação" 2 no campo ampliado de estudo, a cidade de São Carlos. Embora não seja objetivo da pesquisa aprofundar tal questão, pareceu-me importante deter-me um pouco sobre ela.

A PROHAB constituiu-se legalmente em 1985, em um contexto político nacional de municipalização compulsória das políticas habitacionais e urbanas (após a dissolução do $\mathrm{BNH})$, num contexto estadual de espraiamento de inúmeras empresas mistas

1 Observadas desde minha pesquisa de mestrado (Rosa, 2008), bem como em trabalhos de campo para realização do PLHIS (PMSC, 2010), e intensificadas durante a pesquisa de campo do doutorado.

2 Villaça (1986). 
como operadoras de tais políticas (no rastro do modelo de atuação das $\mathrm{COHABs})^{3} \mathrm{e}$ num contexto municipal de grande disputa em torno de seu projeto de lei e objetivos, no qual a erradicação da primeira favela da cidade - a já mencionada Favela do Gonzaga - foi, então, transformada em mote político para a aprovação de sua criação como uma empresa mista destinada à "solução de problemas de habitação e urbanização" e "realização de atividades de caráter social"4. Assim a lei aprovada descrevia os objetivos de tal empresa":

Execução da política habitacional do município, estudando e propondo planos para Habitação, na erradicação de favelas prioritariamente, aproveitando áreas ociosas ou mal destinadas, que com o devido estudo urbanístico atendam ao proposto neste item.

O município passava a contar com um órgão especialmente direcionado à execução de sua política habitacional, algo realmente inédito em sua história urbana ${ }^{6}$, e não seria equivocado afirmar que a constituição da PROHAB - e mais: os moldes adotados pela empresa - somente foi possível em função do "problema urbano" materializado na Favela do Gonzaga7, atestando o papel significativo que esta assumiu no direcionamento das políticas públicas urbanas e habitacionais do município.

De fato, em sua primeira década de atuação, a PROHAB voltou seu foco intensamente para as tentativas de resolução de tal "problema", desde a perspectiva inicial de erradicação da Favela, através da realização de um "mutirão de desfavelamento", entre 1986 e 1988 (que acabou removendo apenas 89 das cerca de 280 famílias cadastradas), até a execução de uma "urbanização em tempo recorde", concluída nos primórdios dos anos 1990, que traria visibilidade e consolidaria a atuação do órgão no município, uma vez que este teria, supostamente, cumprido com aquele que seria o objetivo primeiro de sua criação. Tal intervenção, a despeito de todos os problemas dela decorrentes (os quais não caberia aqui retomar) ${ }^{8}$, consolidou-se na memória urbana de São Carlos como um dos maiores feitos da PROHAB na cidade.

Após essa primeira sequência de intervenções frente ao "problema da favela", a documentação encontrada sobre o período entre 1990 e 2000, ainda que escassa, evidencia dois momentos distintos de sua atuação no município. Entre os anos de

3 Para uma recuperação desse contexto político ampliado, ver Rosa (2012).

4 Cf. Processo da Câmara Municipal de São Carlos no 674/85. Para uma reflexão mais aprofundada sobre os contextos de constituição da Prohab e sua atuação desde então ver Rosa $(2008,2012)$ e PMSC (2010). As informações apresentadas a seguir sobre tal atuação baseiam-se em tais trabalhos.

5 Lei Municipal no 9.348/85.

6 Rosa (2012); Lima (2007).

7 Cf. Atas da Câmara Municipal de São Carlos, 03 de setembro de 1984 e 10 de junho de 1985.

8 Para um estudo aprofundado sobre a trajetória do Gonzaga de favela a bairro de periferia e as disputas aí engendradas, ver Rosa (2008). 
1990 e 1996 não há registro de projetos levados a cabo pela empresa9; revela-se apenas, na documentação pesquisada, que nos anos de 1994 e 1995 houve, por um lado, repasses de recursos destinados a "cobertura dos déficits de manutenção" da empresa ${ }^{10}$, evidenciando possíveis problemas financeiros e administrativos e, por outro, tentativas de ampliação de seu escopo, numa manobra aparentemente destinada a redirecionar a atuação da empresa para atividades mais "lucrativas". Com efeito, em 1995, a despeito de todas as polêmicas iniciais em torno dos objetivos da constituição de uma empresa mista na cidade, o então prefeito municipal propôs uma lei alterando as finalidades da PROHAB, ampliando significativamente o escopo de possibilidades de atuação da empresa, que, além da realização de atividades de "caráter social", passou a poder desempenhar também atividades de "exploração e execução de serviços públicos e de expansão industrial"11.

Entre 1996 e 1998, são executados dois grandes "loteamentos sociais": o Santa Angelina (914 lotes) e o São Carlos VIII (1089 lotes). Únicas iniciativas da PROHAB no sentido de promover, produzir e comercializar "lotes urbanizados", elas parecem reproduzir o modelo de atuação adotado pelas $\mathrm{COHABs}$ no último período de atuação do $\mathrm{BNH}^{12}$, inclusive em termos da magnitude dos loteamentos, bem como de sua localização nas periferias extremas da cidade, desprovidos de infraestrutura, equipamentos e serviços urbanos.

Dos anos 2000 em diante, a atuação do órgão esteve focada quase que exclusivamente na produção de novas unidades habitacionais e em algumas ações de regularização fundiária, através de projetos elaborados ao sabor dos financiamentos disponibilizados pelo governo federal ${ }^{13}$, não chegando a 1.000 o número de unidades produzidas até $2010^{14}$. Outras iniciativas ganharam força, tais como uma usina de

9 Até esse momento, ainda atuavam na provisão habitacional no município as COHABs Ribeirão Preto, Bauru e Bandeirante, sendo que, nesse período, a primeira teria sido responsável pela produção de 1950 unidades habitacionais distribuídas em três conjuntos na cidade. Na figuração popular, entretanto, toda provisão habitacional no município (bem como suas injustiças) são creditadas à PROHAB.

10 Cf. Lei Municipal 10.946/94.

11 Cf. Lei Municipal no. 11.013/95.

12 Cf. Royer (2009). A partir de então, durante décadas, os "Iotes urbanizados" se institucionalizaram como "solução" política para o problema da habitação popular no país, disseminando-se em outras políticas públicas de ordem nacional e estadual, em uma perspectiva que retira da pauta do Estado a questão do direito universal à moradia (Pulhez, 2007:5,81). Vale lembrar que, nessa mesma época, o vice-prefeito Airton Garcia doava meios-lotes em seu loteamento irregular Antenor Garcia, na região do Cidade Aracy.

13 Através de programas como: Imóvel na Planta - Individual; Imóvel na Planta - operações coletivas; Promoradia; Programa de Arrendamento Residencial (que anteciparia, em alguns aspectos, alguns moldes de atuação que se consolidariam com o Programa Minha Casa Minha Vida, cf. Bonates, 2007).

14 No mesmo período (entre 2001 e 2003) seriam construídas pelo CDHU 978 unidades em dois conjuntos habitacionais. Desde então, o órgão estadual não promoveu mais nenhum 
produção de artefatos de cimento e a execução de algumas obras públicas com esses materiais produzidos, como praças e pavimentação de vias. Para esse período, vale ainda destacar que, passados quase vinte anos da criação da PROHAB sob o mote do "desfavelamento", e quinze anos da referida "urbanização em tempo recorde", em 2004, o Jardim Gonzaga voltou a ser alvo de atuação da empresa (em parceria com diversas secretarias municipais), em um Projeto de Urbanização Integrado, que, financiado pelo Programa Habitar Brasil Bid, se configuraria publicamente como a maior intervenção urbana "de interesse social" da história do município, ainda que com ínfima atuação em termos habitacionais ${ }^{15}$. Na mesma época, como visto no Capítulo 1, intervenções remocionistas se fariam na cidade, sendo os moradores alocados em conjuntos habitacionais nos dois já mencionados "loteamentos sociais" promovidos pela empresa, pautados, sobretudo, na realização de mutirões ou autoconstruções assistidas.

É desse período, ainda, a combinação entre duas principais ferramentas de operacionalização da política habitacional no município, que se tornariam o cerne tanto do modus operandi e dos discursos públicos da instituição, quanto das representações negativas sobre a mesma: a chamada "lei do sorteio", aprovada em $1999^{16}$, e o "cadastro da demanda", que, sem registro sobre a data de início de sua implementação, sofreu uma renovação em seu sistema em 2007, para o qual foi necessário um processo de recadastramento geral dos inscritos, tendo em vista a impossibilidade de importação dos dados presentes no sistema anterior. A primeira seria uma espécie de atestado público da incapacidade de atender universalmente ao segundo (que, em 2009, contabilizava quase 8.400 inscritos ${ }^{17}$ ), ao "explicitar a impossibilidade da administração pública responder efetivamente à questão

empreendimento na cidade (PMSC, 2010). De modo geral, em campo, também essa produção (e suas irregularidades) é associada à PROHAB.

15 PMSC (2010); Baron e Anelli (2009); TEIA (2002); PMSC (2002).

16 Lei Municipal no 12.117/99, "pela qual o município fica obrigado a realizar a distribuição de benefícios habitacionais por ele promovidos, sejam eles recursos materiais ou unidades de lotes urbanizados ou de moradias, exclusivamente através de sorteio público". Sem registros documentais sobre a existência de procedimentos e critérios de atendimento adotados pela PROHAB até então, a constituição dessa lei teria o "intuito de proteger o cidadão de políticas clientelistas", especificando critérios que procurassem garantir alguma transparência ao processo, de forma a restringir "o uso do poder discricionário de agentes políticos". (PMSC, 2010:82, 83).

17 Tal cadastro, "reconhecido como a principal fonte de dados, embora ainda desorganizada e imprecisa, sobre a realidade habitacional da população pobre da cidade" (Pulhez, 2012:106), apresentaria, segundo o PLHIS (PMSC, 2010) problemas flagrantes ligados à sua operacionalização, que comprometeriam a qualidade dos dados armazenados, permitindo, por exemplo, que se gerassem cadastros em duplicidade, impossíveis de serem identificados, o que explicaria tão vultoso número de inscritos. Após esmiuçar o cadastro da PROHAB, cruzando seus dados com outros obtidos através da Fundação João Pinheiro e do Cadastro Único para Programas Sociais (Cadúnico), o PLHIS chegou a um número referente à "demanda de atendimento por provisão" de 3.360 unidades até 2020 (PMSC, 2010:102). 
habitacional em São Carlos, pois o princípio do sorteio é o da premiação de certas pessoas em detrimento de outras (os não contemplados) nos casos em que os bens ofertados não são suficientes para atender a todas as pessoas."18

Em 2009, a PROHAB seria responsável pela rápida adesão do município ao Sistema Nacional de Habitação de Interesse Social (SNHIS), dando início à elaboração do Plano Local de Habitação de Interesse Social (PLHIS) ${ }^{19}$. No mesmo ano, seria lançado o Programa Minha Casa Minha Vida, ao qual o município também aderiria imediatamente, de modo que o processo de desenvolvimento do PLHIS e o início de uma produção habitacional financiada pelo MCMV foram praticamente concomitantes, esta última ocorrendo de forma absolutamente paralela - para não dizer contrária - às diretrizes elaboradas pelo primeiro, concluído em 2010 e nunca implementado ${ }^{20}$. Desde então, a provisão de "habitação de interesse social" no município tem-se feito exclusivamente através do PMCMV: como veremos com um pouco mais de detalhe no Capítulo 2, até o fim de 2014, duas construtoras terão sido responsáveis pela produção de 2.792 moradias na cidade, para a qual a atuação da PROHAB (e da gestão municipal de um modo geral) terá se restringido ao cadastro e à seleção das famílias demandatárias por meio do sorteio: a despeito de haver pessoas cadastradas junto ao órgão desde pelo menos 2007 (quando foi realizado o tal recadastramento), a cada conjunto produzido, um novo cadastramento é convocado, de modo que a demanda é sempre renovada (e amplificada) ${ }^{21}$.

18 PMSC (2010:83). Curioso notar que, embora as representações populares negativas estejam também relacionadas à prática do sorteio, em nenhum momento se articulam a esta crítica mais ampla que remete ao direito universal à habitação.

19 Os PLHIS inserem-se no quadro mais amplo da Política Nacional de Habitação, implementada a partir de 2004, no governo Lula. No âmbito dessa política, renova-se o Sistema Financeiro da Habitação (SFH) e institui-se o Sistema Nacional de Habitação de Interesse Social (SNHIS), ao qual se articula o Fundo Nacional de Habitação de Interesse Social (FNHIS), que reuniria recursos federais, estaduais e municipais na perspectiva de incrementar a parcela de subsídios destinados ao atendimento habitacional das camadas de menor renda da população. Dentre os critérios estabelecidos para acesso aos recursos do FNHIS estava a elaboração do PLHIS, que passou a ser francamente estimulada pelo Ministério das Cidades a partir de 2007, em ações de normatização dos conteúdos a serem abarcados pelos Planos e, posteriormente, de capacitação de consultorias e quadros técnicos municipais e estaduais para a elaboração dos mesmos. Tão logo aderiu ao SNHIS em 2009, a prefeitura municipal de São Carlos, através da PROHAB, contratou, no mesmo ano, uma equipe de consultoria (da qual fui coordenadora) para a elaboração do PLHIS, desenvolvido entre agosto de 2009 e setembro de 2010. Cf. PMSC (2010).

20 Para uma reflexão sobre o desenvolvimento dos Planos Locais de Habitação de Interesse Social PLHIS e a concomitante implementação de uma produção habitacional de peso, via Programa Minha Casa, Minha Vida, que tem no caso de São Carlos seu referencial empírico, ver Pulhez (2012).

21 A despeito do recadastramento realizado em 2007 e de pelo menos outras três chamadas públicas para novas inscrições desde a implementação do PMCMV no município, a cada sorteio, um novo cadastramento é realizado, sobrepondo-se aos anteriores (de modo que uma pessoa anteriormente inscrita que não compareça a esse novo cadastramento não participará do sorteio subsequente), conforme divulgado recentemente na imprensa local, por ocasião do sorteio do segundo conjunto habitacional para a faixa de renda até $\mathrm{R} \$ 1.600,00$, que está prestes a ser concluído no município: “O 
Embora as representações negativas da PROHAB e os relatos de injustiças cometidas pelo órgão remontem à primeira intervenção junto à Favela do Gonzaga (na qual menos de um terço da população ali moradora foi atendida, deixando descontentes os que permaneceram, os que foram removidos e a sociedade local, que ansiava pela eliminação do "problema"), passando pelas desocupações da última década (em que moradores foram removidos compulsoriamente para conjuntos habitacionais, além dos desgastes decorrentes de mutirões que se estenderam por três gestões municipais), ou ainda remetendo às incongruências no funcionamento do cadastro desde seus primórdios, reforçadas pelo processo de recadastramento ocorrido em 2007 (dando margem a que pessoas que se julgam cadastradas há pelo menos duas décadas não consigam entender como outras, recentemente inscritas, tenham sido contempladas com uma moradia), é neste contexto mais recente que tais representações se amplificam e ganham mote renovado: a relação entre a política habitacional empreendida na cidade (associada diretamente à PROHAB), as falhas e injustiças na seleção da demanda empreendida pela instituição e um mercado informal de aluguel, troca e venda de moradias estabelecido nos conjuntos por ela promovidos.

De fato, paradoxalmente, a PROHAB nunca esteve tão na ordem do dia entre as camadas populares na cidade: no contexto atual de produção massiva de "habitação de interesse social" na cidade (quase 2.800 moradias em quatro anos, algo nunca antes realizado), ainda que o órgão não seja responsável por nenhum aspecto concreto da operacionalização e execução de tal produção, aos olhos das camadas populares esta é associada diretamente à PROHAB, não apenas por ser o órgão teoricamente responsável pela "execução da política habitacional no município", mas, sobretudo, por ser a face estatal a mediar sua destinação ao "público-alvo" demandatário. $E$, com mais moradias sendo sorteadas, mais pessoas sendo inscritas e beneficiadas (e também não-sorteadas ou mesmo excluídas, como no caso de

diretor-presidente da Progresso e Habitação de São Carlos (Prohab), Mauro Moraes, reuniu a imprensa na manhã desta segunda-feira, 14, no Paço Municipal, para anunciar as diretrizes de inscrição e sorteio das moradias populares do Programa 'Minha Casa, Minha Vida', do governo federal. Independente de inscrições anteriores, as famílias devem refazer um novo cadastro [sic] a partir desta terça-feira, 15, até sexta-feira (18) e do dia 21 a 25 de julho, no Ginásio de Esportes Milton Olaio Filho, das 8 h30 às 16h30." Essa mesma reportagem informou que o atual déficit habitacional na cidade seria de 4.500 unidades e que a PROHAB estimava receber 8.000 inscrições para o sorteio. (Cf. http://www.jornalpp.com.br/cidades/item/65212-prohab-da-inicio-as-inscricoes-de-1-792-moradias, consulta em julho/2014). Em reportagem subsequente, registrava-se uma fila de espera quilométrica em frente ao ginásio onde se daria o cadastramento desde a noite anterior ao primeiro dia de de inscrições, ao fim do qual, teriam sido contabilizados já 5.000 inscritos. (Cf. http://www.saocarlosagora.com.br/cidade/noticia/2014/07/15/55899/prohab-inicia-as-inscricoespara-casas-populares, consulta em julho/2014) 
Núbia), mais se amplificaram tanto as expectativas em relação à consecução de uma casa, quanto as representações negativas sobre o órgão, estas últimas proporcionais à movimentação imobiliária estabelecida imediatamente após a entrega de chaves do primeiro conjunto voltado à "habitação de interesse social" concluído no âmbito do PMCMV, o já mencionado Jardim Zavaglia ${ }^{22}$, acionada como prova inconteste das injustiças cometidas pelo órgão.

Tal situação evidenciou-se na pesquisa a partir das reiteradas críticas à PROHAB e suas práticas políticas, recorrentes em todos os relatos (e em inúmeras conversas e observações em campo), revelando um processo socioespacial que parece ser bastante corrente, mas pouco estudado: o fato de que as políticas habitacionais movimentam e amplificam significativamente o "mercado imobiliário informal" (e, nesse caso, também ilegal) vigente entre as camadas populares ${ }^{23}$.

22 O estabelecimento de um "mercado imobiliário informal" ativo em conjuntos habitacionais na cidade não é algo que se observe apenas no atual contexto da produção massiva pelo PMCMV, como destacado já para o caso do conjunto construído por mutirão no São Carlos VIII, em que algumas famílias negociavam suas casas antes mesmo de concluído o mutirão (cf. tb. Carneiro, 2008), e cuja dinâmica continua intensa, como pudemos ver no caso do apartamento em nome de Núbia, já no terceiro proprietário, e alugada informalmente. Entretanto, tal dimensão quantitativa do Programa amplifica também as dimensões de tal mercado, além de contar com uma porcentagem relativamente pequena de moradores removidos compulsoriamente para tal conjunto (ao contrário do mencionado mutirão e de outros conjuntos anteriormente produzidos, para os quais muitos moradores não desejavam se mudar), o que implica algum grau de voluntariedade em termos de inscrição e recebimento da moradia no mesmo. Tal contexto dá outros contornos ao estabelecimento desse mercado informal. Além disso, não se tratou de investigar em profundidade essa questão, da qual me aproximei através das trajetórias, não sendo possível aferir sua extensão em relação aos vários conjuntos habitacionais da cidade, pesquisa que valeria ser realizada, dada a escassez de estudos sobre o assunto, como destacado na nota seguinte.

23 Como visto no Capítulo 1 (notas 13 e 93), as investigações sobre o chamado "mercado imobiliário informal" centram-se quase que exclusivamente nas favelas ou "assentamentos informais"; não encontrei pesquisas sobre as dinâmicas de tal mercado em conjuntos habitacionais promovidos através de políticas públicas. Exceção é o estudo pioneiro promovido por Lícia Valladares na década de 1970, que, embora tivesse como foco o programa de remoção de favelas no Rio de Janeiro, deparou-se com uma alta rotatividade de residentes nos conjuntos habitacionais para onde se destinavam os favelados removidos: "As entradas e saídas por vias ilegais e oficiosas passaram a dar uma tônica de vaivém ao conjunto. Passou-se a praticar o empréstimo de habitações a parentes ou amigos, limitando-se o interessado a pagar o valor da prestação do mutuário oficial, sem o conhecimento da COHAB. Alugava-se também o imóvel, sendo o aluguel igualmente praticado às escondidas, já que a COHAB proibia a locação das habitações antes da assinatura da escritura definitiva. Estas duas modalidades de entrada para o conjunto habitacional acabaram se tornando práticas correntes" (Valladares, 1978:86). A autora identifica o processo de valorização das moradias nos conjuntos, que se configurariam em mercados específicos: "Essa valorização foi responsável pelo fato de passarem as habitações populares a representar mais um bem de capital do que propriamente um bem de consumo. Se a finalidade das habitações da COHAB, segundo foram concebidas, era servir como moradia, na prática, a tendência verificada foi outra: o que serviria para morar passou a servir para vender. Cada conjunto habitacional constitui um mercado específico, cujos preços de venda e revenda oscilam, não só em função das características particulares de cada conjunto, mas também das benfeitorias introduzidas ou não em cada unidade habitacional por seu morador."(p.89) Contudo, no caso analisado pela autora, as circunstâncias eram distintas, dentre as quais destaco não apenas o fato de se tratar de conjuntos destinados majoritariamente à remoção compulsória de moradores de 
Eu conheço muita gente que se inscreveu e que conseguiu casa da PROHAB. Muitas! Tem gente também que não tem holerite e falsifica: uma amiga minha, ela faz faxina, também ganhou lá no São Carlos VIII. Muitas pessoas, conheço muitas! Conheço gente que tem casa própria e conseguiu. Daí tá alugado lá. Tem gente que tem casa no Santa Felícia, que eu conheço, sei quem é. Muitas pessoas! Tem casa no Santa Felícia e conseguiu casas da PROHAB e hoje vive assim, tipo de aluguel, mora na sua casa e alugou pro irmão, pra não sei quem. / Thaís: $E$ como será que essas pessoas conseguiram? / Ah, não sei. É no sorteio. Lá é tudo no sorteio. Se inscreve, é sorteado, ganhou. Por exemplo, eu moro numa casa, só que eu não tenho casa no meu nome. Eu posso me inscrever lá. / Thaís: As pessoas fazem isso? / Isso! Tipo assim, lá no bairro, é muito difícil a pessoa ter a escritura da casa. Todo mundo tem o contrato do terreno. Escritura da casa ninguém tem. Porque é muito caríssimo. São tudo casas meio que assim, meio terreno. É, tipo assim, fica dois, três mil reais pra pagar pro engenheiro fazer a planta... Então é muito difícil alguém ter uma escritura. O meu vizinho mesmo, a casa é dele, mas ele não tem a escritura. Ele não tem e ele não tá preocupado, porque ele tem o contrato do terreno. Igual meu outro vizinho, também. Ele foi agora lá no cartório fazer a escritura, porque faz muitos anos que ele mora lá e não tem a escritura. / Thaís: Então, às vezes, a pessoa ganha a casa, não tem escritura e aí ela consegue pegar a casa na PROHAB porque não aparece nada no nome dela? / Isso, ou o marido, ou a esposa. Então todo mundo tem duas casas sim. A maioria tem uma casa própria e uma casinha da PROHAB. [Marielen]

Quando o assunto era a PROHAB, invariavelmente os relatos apontavam tanto para um conhecimento generalizado dos mecanismos acionados entre os populares para conseguir casas através do órgão, quanto para as dinâmicas que, após a distribuição das casas, conformariam esse mercado informal bastante ativo nos conjuntos habitacionais promovidos pelo órgão, bem como para as eficientes redes de informações a respeito desse mercado, que fazem circular os meandros dessas trocas políticas e comerciais: todos têm conhecimento de pessoas que possuem casas próprias e são contempladas nos sorteios, acabando por vender ou alugar a habitação conseguida, e também são constantemente notificados sobre potenciais

favelas, cujas condições vantajosas em termos de custos das moradias (bastante inferiores a qualquer aluguel no restante da cidade) acabavam por atrair o interesse das camadas baixas e médias, que também buscavam equacionar seu problema de moradia (p.87), como também, o fato de que a COHAB disponibilizava o instrumento da "cessão de direitos" como forma de oficializar tais movimentos de compra e venda nos conjuntos (embora nem todos fizessem uso de tal instrumento, além de o órgão ter, por algum tempo, suspendido essa prática, de modo que muitos "novos proprietários chega[va]m a morar ilegalmente") (p.93). É curioso que tais dinâmicas não sejam alvo de estudos mais recentes; encontrei apenas um estudo sobre um conjunto habitacional em Fortaleza, no qual se faz referência pontual a um "mercado informal de compra e venda de casas ofertadas pela política pública" (Dias, 2013). No entanto, encontrei algumas reportagens, entre 2011 e 2014, abordando a "venda ilegal" de moradias em conjuntos habitacionais produzidos no âmbito do CDHU, PAC e PMCMV em cidades como Santo André, Fortaleza, Teresina, Manaus (cf. www.adh.pi.gov.br/interna.php?id=315; $\quad$ www1.folha.uol.com.br/cotidiano/2013/08/1331774venda-ilegal-de-imoveis-e-atrasos-em-obras-marcam-conjunto-habitacional-no-piaui.shtml; www.dgabc.com.br/Noticia/343241/imoveis-da-cdhu-sao-vendidos-de-forma-ilegal; g1.globo.com/am/amazonas/noticia/2014/03/beneficiarios-do-minha-casa-minha-vida-oferecemimoveis-na-internet.html; www.youtube.com/watch?v=89oDDnXAZCY). 
negócios em tais conjuntos. O relato de Joana, feito cerca de quatro meses após as primeiras famílias se mudarem para o Jardim Zavaglia, evidenciava, já naquele momento, o quão dinâmico é esse mercado informal associado às políticas habitacionais, bem como a circulação de informações sobre o mesmo ${ }^{24}$ :

Teve gente que pegou a casa e vendeu com um contrato de gaveta... nem mudou e já vendeu. Então. E tem gente que já alugou. / Thaís: Já teve gente que alugou? / Teve! Conheço vários! / Thaís: E quanto tá o aluguel aqui? Cê sabe? / Então, uma dessas é minha prima! [risos] Ela tá morando de aluguel aqui, e o rapaz falou que era pra ela pagar... porque assim, cada casa aqui, por causa do contrato que foi feito, cada um paga um valor, de acordo com o salário. No caso, eu acho que ela tá pagando só o valor da casa para ele. Cento e cinquenta reais, que, na verdade, eu acho que ela tá pagando exatamente a parcela da casa. I Thaís: Mas a casa tá no nome dele, e ela paga o aluguel pra ele. É isso? / Isso, a casa não vai ser dela. Ela tá pagando pra pessoa. Entraram num acordo que ela paga o valor da prestação, como um aluguel... [Joana]

Tem gente que ganhou casa da PROHAB e que tem duas, três casas! Eu mesmo conheço um senhor que tem uma casa aqui perto do posto de saúde do Aracy, tem mais duas casas no Santa Felícia e recebeu a casa da Prohab. Ali no Zavaglia. Agora, como que esse povo faz pra receber essas casas? Tem um empurrãozinho! Me desculpe se eu tiver errada, mas eu acho que deve ter um empurrãozinho de alguém de lá de dentro. Porque não é possivel! Eu acho que não é justo. (...) Por isso que eu falo que tem um tropeço aí, que é difícil pra gente, assim... Eu mesmo, às vezes eu paro, fico pensando e não chego a uma conclusão. Mas tem um tropeço! Igual, tem pessoas ali que tinham casa no Santa Felícia, e a casa tava alugada! Entendeu? Então eu falo que nem todos têm a necessidade de receber a casa, por quê? Porque tem gente que recebeu casa ali e, ao invés de mudar pr'ali, alugou a casa. Como a pessoa consegue, eu não entendo. [Núbia]

Há uma espécie de círculo vicioso que alimenta esse processo: ao atestar a incapacidade do estado em garantir universalmente o "direito à moradia", a prática instituída do sorteio das habitações pretende estabelecer algum parâmetro de imparcialidade no "atendimento à demanda", que não cessaria de crescer. Além disso, o estabelecimento de critérios para a seleção ${ }^{25}$ conferiria ainda maior confiabilidade à "execução das políticas", agora ainda acentuada com o procedimento de aprovação dos cadastros pela CEF. Nesse contexto (e fechando o círculo), alguns dos muitos não atendidos acabam acessando a moradia no conjunto

24 Pouco tempo depois, um jornal local noticiaria que "Boatos sobre venda de casas no Jardim Zavaglia começam a circular na cidade", em cuja reportagem se lê que algumas denúncias sobre vendas de casas no bairro teriam sido feitas a um conhecido programa de rádio da cidade, bem como a própria PROHAB. (Cf. www.saocarlosdiaenoite.com.br/Imno/cidade/item/19346-boatos-sobrevenda-de-casas-no-jardim-zavaglia-come\%C3\%A7am-a-circular-na-cidade, última consulta em maio/2014).

25 Os critérios estabelecidos para o sorteio de habitações pela já mencionada lei eram: “a) Ter renda familiar comprovada de no mínimo de 01 (um) salário mínimo e no máximo 10 (dez) salários mínimos; b) Comprovar residência no Município de São Carlos de no mínimo 03 (três) anos consecutivos ou alternados; c) Não ser proprietário de imóvel no Estado; d) Ter família constituída, legal, concubinato ou arrimo de família." Esta lei foi adaptada aos critérios estabelecidos pelo PMCMV, cf. Cap. 1, nota 106. 
por outras vias, seja ocupando casas cujos proprietários não tomaram posse, seja alugando por um valor abaixo do já estabelecido mercado informal nos demais bairros da região, ou mesmo comprando informalmente a moradia. Como forma de isentar-se das críticas e revoltas (e mesmo dessas práticas imobiliárias informais e ilegais movimentadas pela própria política) que tal círculo vicioso origina, os "critérios" de seleção são a justificativa técnica sempre mobilizada pelos gestores municipais:

\begin{abstract}
"Depois do sorteio, as famílias beneficiadas deveriam retornar para apresentar os seus documentos e comprovar que eles [sic] moravam em São Carlos há mais de três anos, que tinham família constituída, que não tinha [sic] nenhum imóvel e que a renda da família era de até $\mathbf{R} \$ 1.395$ " diz João Muller, presidente da Prohab. "Muitas famílias foram desclassificadas porque não conseguiram provar que se enquadravam nesses critérios, e foram desclassificadas pela Caixa Econômica Federal" completa. Para o prefeito Oswaldo Barba, a exclusão das famílias que não se encaixavam nos critérios da Caixa foi uma demonstração da seriedade do programa Minha Casa Minha Vida. "Quando estive no primeiro sorteio, as pessoas me cercavam e diziam que tinha gente que estava sendo sorteada que não atendia a alguns critérios, e eu sempre disse que a responsabilidade pela seleção é da Caixa, e ela é muito criteriosa. Então, aquelas famílias que foram sorteadas e não preenchiam os requisitos foram excluídas ${ }^{26}$.
\end{abstract}

Entretanto, ao contrário do que queria fazer crer o então prefeito, a realização de novos sorteios de casas já sorteadas anteriormente, associada à existência de casas que ainda permaneciam vazias após algum tempo da inauguração do conjunto, às notícias de invasões e, principalmente, ao fato de que pessoas estavam vendendo ou alugando as casas sem nem sequer mudar-se para as mesmas apenas acentuaram as representações negativas sobre a PROHAB, fazendo circular figurações de injustiça, maracutaia, troca de favores, perpetuação de desigualdades ("pessoas que não precisam e recebem, enquanto a gente, que não tem onde morar, é excluída" - Núbia), todas apontando para a falta de seriedade e confiabilidade do órgão em fazer a seleção e acompanhamento dos sorteados, já que, aos olhos de meus interlocutores, os critérios seriam aplicados seletivamente, somente aos "mais pobres", sendo que outros "menos necessitados" conseguiriam burlá-los, recebendo as casas.

É aquele negócio, é uma maracutaia muito grande isso daí, né, Thaís? Igual, quando a gente vai fazer inscrição, eles fazem praticamente um levantamento da vida da gente. Que é para saber se a gente não tem um terreno, se a gente não tem uma casa no nome da gente, alguma coisa desse tipo. Aí, quando você vai ver, é essa palhaçada. Tem pessoas que estão lá que não precisam. ... nome sujo na praça eu não tenho; meu sobrinho deve até as cuecas e recebeu a casa... ele está morando lá [no Jardim Zavaglia]. E, assim como ele, tem muita gente, viu? O genro da minha vizinha aqui... Conheço um monte de gente que conseguiu

26 Trecho extraído de reportagem em jornal local sobre segundo sorteio de unidades no primeiro conjunto de HIS produzido no âmbito do PMCMV, após cerca de 300 das 1000 famílias sorteadas terem sido excluídas do Programa, em função da não aprovação de seus cadastros pela CEF. (CF. www.afolha.com.br/noticias.php?noticia=1227, consulta em fevereiro/2014). 
casa lá, mesmo tendo um monte de problema, nome sujo, ou então quem já tem outra casa. Um monte de gente!. [Núbia]

Eu vejo assim, sabe, eu acho muita enrolação. Porque a gente vai lá, eles apresentam um tipo de coisa pra gente; quando as pessoas pegam as casas a gente vê que... Eu acho que é, assim, uma média de oitenta por cento do que eles falam pra gente não é cumprido. / Thaís: Em relação a o quê você fala? / Em relação à casa, em relação à renda, várias coisas, sabe? Igual, em relação à renda mesmo, quando eu fui fazer inscrição pro Zavaglia, eles falaram que a renda não podia passar, parece, de dois salários mínimos, um pouco mais, não lembro certinho não, sabe? Mas eu conheço pessoas que receberam a casa lá, que ganham mais de três! / Thaís: Que você acha que não deveriam estar lá? / Ah, eu acho assim, até poderiam estar, Thaís, mas em outro programa. Cê entendeu? Porque eu vejo assim, são pessoas que têm uma condição mais... que não têm tanta necessidade. Porque quem ganha um salário, um salário e meio, sabe, é mais difícil. É mais complicado. [Núbia]

Beatriz: Parece que quem já recebia o Bolsa Família, nem precisou ir atrás. A irmã dele recebe Bolsa Família, nunca foi atrás de casa, porque ela já tem, e ela conseguiu uma casa no Zavaglia. Mas ela não pegou. / Thaís: Ela não quis? / Beatriz: Não, ela não precisa. / Jefferson: Não, é que ela tinha a casa no nome dela. / Beatriz: Tinha a casa no nome dela, daí, na hora que fosse fazer as papelada, ela não ia poder pegar... Cê vê, até nisso tem uma burocracia que... Acho que, sei lá, acho que tinha que ter pego a assistente social pra investigar, entendeu? Ir na casa da pessoa, ver se ela realmente precisa./ Jefferson: $E_{\text {, diz }}$ que tem, né? Mas.../ Beatriz: Mas não funciona. Todo mundo reclama. Se tem uma coisa que é unanimidade é isso: PROHAB. Porque, pra você ter uma ideia, no Zavaglia, tem um gerente de banco que tem duas casas no Zavaglia. Uma no nome dele e uma no nome da esposa. As duas melhores casas do Zavaglia. Tá com muro, pintadinha, bonitinha. / Thaís: Como cê sabe? / Beatriz: Porque a filha dele trabalhou comigo. Uma no nome dele e uma no da esposa. Meu, quem viu isso? Com mil famílias... mas eu acho que tinha que ser uma coisa mais investigada. Sabe? Porque eu acho que tem que ser realmente pra quem precisa. [Jefferson e Beatriz]

O fato é que a prática concreta da distribuição de casas pela PROHAB, confrontada aos trânsitos, experiências e redes de relações e informações de meus interlocutores, evidenciaria não apenas a insuficiência das políticas habitacionais, mas, também, as supostas irregularidades a que estariam atreladas: o beneficiamento de pessoas que, mesmo possuindo outras "casas próprias", foram contempladas; de pessoas que já receberam mais de uma casa nestes próprios processos ou de pessoas que não são necessitadas; o favorecimento de pessoas próximas aos gestores (ou dispostas a negociar com eles), para citar algumas das reiteradas denúncias colhidas em campo sobre a PROHAB e suas políticas. É o caso de uma conhecida de Marielen que, valendo-se de contatos na instituição, não apenas teria ganho uma casa, mas também conseguido que esta, que havia sido invadida, fosse desocupada, após o que ela a teria alugado:

Uma vizinha da minha cunhada conseguiu, meio por baixo dos panos, uma casa no Zavaglia e não foi morar. O esposo dela diz que não vai pra lá nem morto, então o que que aconteceu? / Thaís: Por que que ele não quis ir pra lá? / Ele não quer ir pra lá, não gostou do bairro, não quer sair de onde já conhece. Daí, 
aconteceu o seguinte, invadiram a casa. A moça foi na PROHAB, ela tem uns contatos lá, e reclamou a casa. Eles foram lá e desocuparam. E agora ela vai alugar pro meu cunhado e a esposa. Lá no Zavaglia. Só que a PROHAB pensa que é ela, a dona, que vai morar... / Thaís: Mas é seu cunhado que vai morar lá? / Vai morar na casa que era invadida, conseguiu desinvadir, só que o marido dessa moça que ganhou a casa diz que pra lá não vai nem morto. Aí meu cunhado vai alugar, morar de aluguel. E ele é cadeiero, não falo nada se ele não vai montar uma boca lá. E a PROHAB nem sonha que tirou uma casa de alguém que precisava pra isso. [Marielen]

Sem pretender uma aferição da veracidade de tais informações, críticas e denúncias, sua generalidade é algo que chama a atenção e, somada às observações de campo, que atestam a presença inconteste de casas alugadas, vendidas ou trocadas (além de algumas invadidas) nos conjuntos produzidos pela empresa e, sobretudo, nesse mais recentemente produzido no âmbito do PMCMV (o Jardim Zavaglia), além da constante oferta de negócios nesse sentido, constituem algumas das pistas que permitem futuras incursões por essa perspectiva aqui esboçada.

Por ora, vale ainda destacar que também circulam muitas informações sobre os mecanismos acionados por conhecidos para conseguirem cadastrar-se, para terem seus cadastros aprovados quando sorteados, para garantir maiores chances de serem contemplados: estes vão da falsificação de documentos como holerites, declarações de renda, comprovantes de residência (havendo uma espécie de 'mercado' instituído nesse sentido), passando pela inscrição de membros da família que estejam com o nome limpo ou que não possuam outra propriedade em seu nome (estando já disseminado o conhecimento de que a ausência de escritura de uma outra propriedade, nesse caso, pode ser uma vantagem), até a inscrição de vários membros de um mesmo núcleo familiar (havendo inclusive notícias de casais que teriam se separado para que ambos pudessem se inscrever para os sorteios, ou para que, uma vez sorteados, um deles pudesse tomar posse da casa quando o outro tivesse propriedade em seu nome), para citar apenas alguns exemplos.

A despeito do quão acionados são tais mecanismos, ou de qual seja sua eficácia, é inegável que a ausência de títulos de propriedade da grande maioria dos moradores das periferias (seja pelas "informalidades" e/ou "ilegalidades" que permeiam tal posse ou, nos casos em que a posse é regular, pelos custos envolvidos em legalizá-la, procedendo à regularização do imóvel e ao registro da escritura) por si só inviabiliza qualquer perspectiva de "ordenar" ou conferir legitimidade ao processo de distribuição de moradias pela PROHAB. Desse modo, mesmo uma família que já possua uma casa própria poderia efetivamente ser contemplada nos sorteios, já que não seria possível comprovar legalmente sua posse de outro imóvel. Ou, ainda, um casal cuja união não se oficializou legalmente (o que é bastante comum) também poderia facilmente recorrer à estratégia de inscrever-se separadamente nos cadastros: além de aumentar as chances no sorteio, no caso de ambos serem 
contemplados, estaria assim conquistada mais uma fonte de renda para a família, a partir da mercantilização ("informal”, "ilegal”) de uma das habitações conseguidas, por meio do aluguel ou mesmo da venda com repasse do financiamento.

Acionados já na intenção de fazer negócio, ou ainda como garantia de futuro frente a dinâmicas familiares e financeiras cambiantes, tais mecanismos estariam na origem desse mercado informal que parece ter-se estabelecido, desde os primeiros dias, nos conjuntos habitacionais produzidos no âmbito do $\mathrm{PMCMV}^{27}$. E, paradoxalmente, por esses mesmos motivos, essas tão criticadas práticas são aventadas entre seus próprios críticos:

Eu nunca me inscrevi. Mas na próxima inscrição eu vou me inscrever, nem que eu não more lá, que eu já tenho minha casinha, mas, pelo menos, é uma coisinha que eu vou pagar e é meu. E, quem sabe, um filho meu não pode morar lá, no futuro? Então, na próxima inscrição eu vou me inscrever. [Marielen]

Antes da gente financiar essa casa aqui, a gente se inscreveu na PROHAB, mas nunca foi chamado. Acho que tinha que ir lá, no sorteio, e a gente nunca foi. $E$ agora eu fui chamada, que vou participar do sorteio pras casinhas que vai sair no Aracy. Já me ligaram pra eu ir lá coisar [atualizar] meu cadastro, eu fui. Aí fiz tudo, daí ligaram que a gente não é casado, nada, eu não tenho nada no meu nome, o carro é tudo no nome dele, aí puxaram lá, e falou que, no meu caso, que tenho filho e tô lá como solteira, que tenho mais chance... / Thaís: Mas e aí, o que você vai fazer, você vai tentar? / Ah, vou... Se nós ganhasse essa casa, tipo... Só que não é pra gente, eu vou dar pra tia dele que paga aluguel até hoje, já é de idade e paga aluguel. Então, se eu ganhar, eu aceito... porque o cadastro que tá lá não é verdade, porque hoje em dia eu já trabalho... Se chegar a sair e der certo, porque talvez, com o salário, essas coisas, talvez não dê certo, mas se for da vontade de Deus que dê certo... Que nem assim, se sair, eu não alugaria nem nada, deixaria a tia dele morando. Até quando ela quisesse. Porque é assim, você não pode alugar, mas, por exemplo, a gente ganha, a primeira pessoa que vai morar lá vai ser a tia dele, quem vai saber que foi ela ou não que ganhou? Ninguém, não tem assistente social que fica indo nas casas, vendo quem tá morando... O que acontece mais é denúncia, de gente morar três meses, sair e mudar outra família. Então, não teria problema. E daí, mais pra frente, quando ela não morasse mais lá, daí podia ser mais um sustento pra gente. [Beatriz]

E, em outro sentido, tal mercado informal nos conjuntos é também considerado por alguns interlocutores como uma possibilidade de, quem sabe, finalmente conseguir uma casa própria, a despeito das políticas da (e politicagens atribuídas à) PROHAB, mesmo entre os que tecem duras críticas a tais práticas por baixo dos panos. Por um lado, a presença de moradias desocupadas incita a invasões, em que a incerteza de

27 Vale dizer que, uma vez que tal reflexão partiu de questões trazidas pelo próprio campo da pesquisa, detenho-me aqui a essa faceta do mercado informal insuflado pelas políticas habitacionais que emerge já nos primeiros tempos de vida de um conjunto; há, entretanto, toda uma movimentação imobiliária posterior, decorrente das dinâmicas de fixação das famílias nos novos territórios (tal como será apresentado no Capítulo 2), vinculadas a relações de vizinhança, proximidade ao tráfico de drogas, estabelecimento de redes de relações, dificuldades na manutenção do custo de vida na nova moradia etc, que também é significativa e mereceria outros estudos. 
permanência e o temor pela situação mais explícita de ilegalidade foram apontados como motivos de objeção por meus interlocutores mais próximos (todos com histórias de pessoas que, revoltadas, teriam apelado para tal alternativa); por outro, ao longo de toda a pesquisa, pude acompanhar ofertas recebidas por eles (ou pessoas próximas) para compra/venda de casas no Jardim Zavaglia: desde propostas logo após o sorteio e a distribuição de chaves da primeira leva de casas no conjunto (como foi o caso de Núbia, que recebeu oferta de um conhecido do bairro Cidade Aracy para comprar a casa que ele havia conseguido no conjunto por $\mathrm{R} \$ 2.000,00$, à vista, além de assumir as prestações junto à $\mathrm{PROHAB}$, que, sendo proporcionais à renda, no caso dele eram de $\mathrm{R} \$ 130,00$; ela afirmou com segurança que, se tivesse o dinheiro, teria comprado essa casa, mesmo sabendo que, em algum momento, enfrentaria problemas com a PROHAB), até negócios propostos após uma primeira acomodação em termos de moradores, vizinhança e estrutura do conjunto (como foi o caso de Joana, que recebeu oferta de $\mathrm{R} \$ 25.000,00$ por sua casa, ou de um conhecido de Núbia, que vendeu a sua por $\mathrm{R} \$ 17.000,00$ ), ou ainda aqueles casos em que o proprietário, passado um tempo explorando o "mercado informal de aluguel" no local e valendo-se da gradativa estruturação do bairro, eleva o valor da "mercadoria", aproximando-a dos padrões de bairros mais consolidados da região, como o Cidade Aracy (como foi o caso do vizinho de Joana, que ofereceu a casa a uma conhecida dela pelo valor de $\mathrm{R} \$ \mathbf{6 0 . 0 0 0 , 0 0}$, passados dois anos de implantação do conjunto).

Núbia: Conheço gente que tem casa no Santa Felícia e está morando ali. Conheço gente que recebeu a casa e está vendendo. / Cleiton: Tem casa ali que nego tá vendendo por dois mil real. Vendendo por dois mil casa que nem deles não é. / Núbia: Eu vou falar uma coisa para você, eu não tinha dois mil reais na mão, porque se eu tivesse dois mil reais na mão, eu tinha comprado a casa que o rapaz ofereceu. Lógico que depois eu ia ter que brigar com a PROHAB... (risos) Mas aí eu já estava lá... Mas é porque eu não tinha esse dinheiro na mão... e ele queria o dinheiro, assim, não era nem para hoje, era para ontem... Falei: 'não tem como levantar esse dinheiro tão rápido, né?' Aí ele vendeu pra outra pessoa. [Núbia e Cleiton]

Tem muita gente também que vendeu as casas aqui. A vizinha aqui, ela vendeu a casa aqui na frente, e tem outras casas à venda também. Inclusive eu tenho uma conhecida que mora numa casa alugada aqui vizinha, e o cara falou pra ela que, se ela quisesse, ele vendia pra ela./ Thaís: Ele falou o preço? / Falou. Sessenta mil. / Thaís: Sessenta mil mais as prestações, ou as prestações já tão quitadas? / Então, como a prestação é super baixa, porque, mesmo quem paga cento e trinta, cento e cinquenta reais, nunca você vai achar um aluguel numa casa dessa daqui por esse valor, entendeu? É, aí, no caso, esse dinheiro seria a parte dele, ela pagaria sessenta mil pra ele e ela continuaria pagando a prestação. Porque cento e trinta reais não é tanto, né? / Thaís: Mas ele queria sessentão assim na mão? / É, à vista. Mas ela não tá pensando em comprar não, porque ela acha um preço alto, entendeu, pelo lugar. [Joana]

Tem um moço aqui, amigo do Jaelson, que a mãe dele recebeu uma das casas lá do São Carlos VIII, aí ele recebeu a casa aqui no Zavaglia e ele vendeu! Ele nem mudou na casa! Ele passou a casa pra frente. Ele vendeu. Por dezessete mil, a casa nova. / Thaís: E aí é a pessoa que vai continuar pagando a prestação dele? 
/É, mas o duro, que quando eles fazem esse tipo de coisa, a Prohab nem sabe. $O$ duro é que quem ficou na casa é que vai ter dor de cabeça mais tarde, pra ter a escritura dessa casa, né? Porque a pessoa vai ficar pagando uma coisa que, amanhã ou depois, ela não tem certeza se vai ser dela. [Núbia]

Em todas essas ocasiões, as condições de irregularidade ou ilegalidade frente à PROHAB e à CEF são acionadas como aspectos que confeririam um grau de incerteza a esses negócios, mas nunca a ponto de torná-los inviáveis, não apenas porque, quase sempre, conhecem outras pessoas que já fizeram esse tipo de transação há mais tempo e ainda não tiveram problema, mas sobretudo porque correm notícias de que, de uma forma ou de outra, passado um tempo de sua efetivação, se houver interesse em regularizar a situação, isso seria possível, desde que com investimentos próprios, como atesta a fala de uma moradora que, tendo comprado a casa logo após a conclusão das obras do conjunto, após dois anos pagando as prestações em nome da pessoa que fora sorteada pela $\mathrm{PROHAB}$, decidiu ir à empresa verificar sua situação ${ }^{28}$ :

Fui lá na PROHAB ver como ficava minha situação, já que fui a única moradora dessa casa desde que inaugurou aqui e sou eu que tô pagando as parcelas, que a pessoa que foi sorteada vendeu pra mim logo em seguida da entrega das chaves. Ela já pegou a casa na intenção de fazer negócio. Daí, eles disseram lá que o que interessa é que as prestações tão sendo pagas, porque, depois que eu quitar a casa, com o contrato de gaveta e as prestações quitadas, eu posso entrar na justiça pra casa vir pro meu nome. Tem que ter como provar, e tem que entrar na justiça, já até avisei outros conhecidos que tão na mesma situação que eu, porque tem muitos que não têm nem contrato de gaveta. Então, se eu quiser fazer isso um dia, vou ter que gastar um dinheiro com advogado, mas eles garantiram que assim a casa viria pro meu nome. Daí fiquei mais tranquila, porque mesmo que eu nunca faça isso, sei que dá pra fazer, tem jeito. E se um dia eu passar essa casa pra alguém, também é uma garantia que tenho pra poder fazer o negócio, mesmo sem ter as papeladas da Caixa e da PROHAB. [Maria]

Assim, embora a PROHAB recorra aos "critérios" estabelecidos pela lei do sorteio em associação àqueles definidos pelo PMCMV para aprovação dos cadastros pela CEF como forma de conferir alguma legitimidade técnica ao procedimento de distribuição de moradias por ela efetivado, ao tomar ciência da existência desse mercado informal e passar esse tipo de informação àqueles que adquiriram, por esse meio, casas subsidiadas pelo Programa em nome de outras pessoas, o órgão estaria contrariando as regras estabelecidas pelo próprio Programa, as quais os beneficiários deveriam cumprir "para não perder o imóvel" ${ }^{29}$, contribuindo ainda mais para a perpetuação

28 Outros depoimentos bastante semelhantes foram recolhidos não apenas no Jardim Zavaglia, mas também em visita ao conjunto produzido por mutirão no São Carlos VIII, dando indícios de uma postura que teria sido adotada pela PROHAB para lidar com tais transações promovidas no mercado imobiliário informal estabelecido nos conjuntos habitacionais na cidade, que em muito dialoga com a postura adotada frente aos casos semelhantes ao de Núbia, em que o próprio órgão repassou o financiamento contratado por uma família junto à CEF a outra, sem regularizar a situação.

29 Cf. seção do site da CEF sobre o Programa Minha Casa Minha Vida intitulada "O que você deve fazer para não perder o imóvel", cujas regras seriam: "Mudar para o imóvel financiado até 30 dias após a assinatura do contrato; Pagar as prestações mensais e cumprir o que está no contrato de 
de tal mercado informal e atestando mesmo uma espécie de conivência para com ele.

Sem pretender aprofundar-me muito nesse tema que, apesar de instigante, não é o foco principal desta pesquisa, interessa aqui fazer dois apontamentos, que se articulam com aspectos específicos abordados nos Capítulos 1 e 2 e podem contribuir com as reflexões mais gerais da tese. O primeiro refere-se à concepção mesma de déficit habitacional, a partir da qual "a habitação é apresentada publicamente como uma deficiência numérica que deve e pode ser mensurada e igualmente revertida" pela provisão massiva de "unidades habitacionais genéricas" 30 . A despeito de um já consolidado acúmulo teórico e metodológico no sentido de dissociar as concepções de "demanda" e "déficit" habitacional (sendo este último considerado um componente da primeira, entendida, de forma mais ampla, em termos de "necessidades habitacionais") ${ }^{31}$, as políticas habitacionais no país, de forma ainda mais acentuada a partir da implementação do Programa Minha Casa Minha Vida, seguem pautando-se quase que exclusivamente pelo discurso de superação do déficit.

Entretanto, como, em algum sentido, as observações empíricas apresentadas nesta tese permitem entrever, tal concepção numérica de uma demanda a ser suprida torna-se algo perpetuamente inatingível, por razões que fogem a qualquer forma de controle. A principal delas é que tende a ser sempre crescente, considerando-se, de um lado, o impulso normativo das políticas públicas ao nucleamento como condição

parcelamento; Pagar IPTU, energia elétrica, água, condomínio, limpeza urbana e outras taxas; Morar no imóvel e não vender, alugar, ceder ou emprestar o imóvel a outras pessoas; Não usar o imóvel para fins comerciais ou outros fins que não residencial; Pagar as prestações mensais até o vencimento. Caso deixe de pagar mais de 3 prestações você pode perder o seu imóvel; Cumprir todas as determinações do seu contato de financiamento." (http://www.caixa.gov.br/novo_habitacao/minha-casa-minhavida/urbana-prefeitura-mov-sociais.asp, última consulta em junho/2014)

30 Nascimento e Braga (2009:100,107), em um dos poucos artigos encontrados que procuram tecer uma reflexão suficientemente crítica sobre a construção histórica da noção de déficit habitacional.

31 Cf. Fundação João Pinheiro (1995); Ribeiro et al (2003); Azevedo e Araújo (2007). A metodologia para o cálculo do déficit habitacional desenvolvida pela Fundação João Pinheiro em 1995 e desde então aprimorada tornou-se referência nacional ao ampliar o entendimento de "demanda habitacional", tradicionalmente entendida tão somente como "falta de moradia", propondo que se trabalhe com o conceito mais amplo de "necessidades habitacionais". Desse modo, o cálculo das necessidades habitacionais, tal como proposto pela Fundação, é composto pelo déficit habitacional quantitativo, por reposição ou incremento do estoque e pela inadequação de domicílios, ou déficit qualitativo. Como componentes de déficit quantitativo são considerados: as habitações precárias; a coabitação familiar forçada; ônus excessivo com aluguel; os domicílios alugados com adensamento excessivo. Como componentes de inadequação habitacional são considerados: carência de infraestrutura; adensamento excessivo de moradores; problemas de natureza fundiária; cobertura inadequada; ausência de unidade sanitária domiciliar exclusiva; alto grau de depreciação. (Cf. Brasil, 2009). 
familiar ideal, ou, de outro, a plasticidade das dinâmicas familiares nas camadas populares, que constantemente configuram novos arranjos e demandam, consequentemente, novas moradias. Outra razão, não menos significativa, é que tal demanda é continuamente produzida e renovada, já que a própria produção em massa e sua divulgação tendem a estimular a ainda mais nucleamentos familiares demandando uma moradia própria, bem como conduz a que indivíduos ou famílias que poderiam ter acesso a moradia por outros vieses que não a casa própria acabem sendo transformados também em demanda. Por fim, as dinâmicas subjetivas que perpassam tal demanda por moradia dificultam sua captação por indicadores numéricos: um exemplo é o caso de uma família que, acreditando estar sua casa própria tomada por demônios, abandonou-a passando a morar de favor junto a outra família na vizinhança - configurando um domicílio a mais no componente "coabitação forçada" ou "adensamento excessivo" do déficit; outro exemplo é o da mãe cujo companheiro expulsou o filho bandido de casa, de modo que também ela abandonou a casa própria que ajudara a autoconstruir e passou a viver de aluguel com o filho - podendo ser contabilizada como mais uma família a sofrer "ônus excessivo com aluguel", outro componente de déficit; para citar apenas dois dos muitos exemplos observados em campo.

Assim, é no contexto desse reiterado direcionamento das políticas habitacionais a "suprir o déficit" (que, em se considerando esses meandros, é incomensurável e impossível de ser suprido) e dotar seus processos de "isenção", que são gerados mecanismos não apenas de produção, mas também de "gestão dos ilegalismos" ${ }^{32}$, os quais acabam por atingir justamente aqueles que estão efetivamente - e historicamente - despojados de moradia, como é o caso de Núbia. E aqui chegamos ao segundo apontamento.

A questão do acesso à habitação, portanto, é um dos vieses a partir dos quais se pode alargar a dimensão dos processos socioespaciais investigados através das trajetórias: a reflexão sobre o lugar do estado e das políticas habitacionais em tais processos

32 Foucault (1987). Sobre a ideia de "gestão dos ilegalismos" e suas implicações, o comentário de Hirata (2010:7), a partir de Foucault, é esclarecedor e merece citação literal: “A palavra 'ilegalismo' foi cunhada por Michel Foucault no livro Vigiar e Punir. Ao contrário da ideia de 'crime', que pressupõe um conjunto classificatório de práticas a partir da lógica da transgressão da lei, o conceito de ilegalismo coloca em evidência uma estratégia global que organizaria uma gestão diferencial dessas práticas. Inversamente, a ideia de que a lei organiza um campo de interdições e transgressões, essa gestão diferencial dos ilegalismos produziria, sob a forma da lei, uma administração seletiva de tolerâncias e repressões. Os ilegalismos não seriam acidentais nem imperfeições mais ou menos inevitáveis, mas um elemento absolutamente positivo do funcionamento social, cujo papel é previsto na estratégia geral da sociedade. Essas relações estratégicas parecem apontar para o sentido do político que se encontra inserido na gestão diferencial dos ilegalismos, sendo a pergunta fundamental: O que faz que, em uma taxonomia de infrações possíveis, algumas sejam toleradas e outras repreendidas, se não as relações de força que são constitutivas da sociedade?" 
evidencia o quanto a "ordem urbana" se produz nas mediações entre o formal e o informal, o legal e o ilegal. Os imbricamentos entre as políticas habitacionais e um dinâmico mercado imobiliário informal aqui esboçados revelam que, para além das irregularidades e ilegalidades associadas quase que exclusivamente ao "urbanismo não oficial"33, aos "assentamentos irregulares", há que se considerar também os assentamentos produzidos pelo estado, onde a "irregularidade", a "informalidade", a "ilegalidade" passam a vigorar, como decorrência da própria política (ou de sua insuficiência).

De modo mais amplo, o que se pretendeu com este primeiro intervalo entre os capítulos centrados mais especificamente nas trajetórias urbanas investigadas foi atentar para as múltiplas dimensões de informalidades e ilegalidades imbricadas nas trajetórias e territórios em foco, para além da já esgarçada dicotomização cidade legal-ilegal ou do foco exclusivo na dimensão de criminalização associada ao tráfico de drogas, ampliando um escopo possível de análise e explicitando as imbricações do estado como parte fundamental das relações entre legalidade e ilegalidade que atravessam diversas dimensões das trajetórias e experiências urbanas investigadas, estando implicado em muitos dos processos e dinâmicas socioespaciais que a partir delas se fazem ver.

Em diálogo com Veena Das ${ }^{34}$, seria possível afirmar, diante do aqui exposto, que "não é que há primeiro uma lei e então uma transgressão - primeiro um indivíduo que é inteiramente definido pelas normas e então um que transgride": a relação intrínseca entre a "legislação fixadora de normas" e sua transgressão é algo que a articulação entre a implementação local das políticas habitacionais e as estratégias de acesso à moradia dos moradores das periferias permite claramente observar.

33 Refinetti (2006).

34 Das (2011:32;39); Das e Poole (2008). 


\section{NOVAS POBREZAS, NOVAS PERIFERIAS?}

Ah, eu acho que tá tudo em construção, tanto o bairro, quanto a casa, os sonhos... tudo em processo de andamento. | Jefferson

\section{- Dinâmicas familiares e deslocamentos habitacionais até a conquista da "casa própria"}

Joana (quarenta anos em 2013) veio ainda muito criança para São Carlos, quando, em 1976, seus pais, que viviam migrando entre fazendas desde o Paraná até Minas Gerais em busca de trabalhos na roça, decidiram firmar o pé na cidade. Ela, a irmã mais velha e os dois irmãos mais novos são nascidos cada um em uma dessas várias cidadezinhas por onde passaram. Como tantos outros migrantes que aportavam em São Carlos nessa época, seus pais vinham em busca de serviço em fábrica, fugindo das dificuldades que quem trabalhava no campo passou a enfrentar com o avanço da mecanização da agricultura. Perfazendo uma típica trajetória de migração do campo para a cidade com vistas a melhorar de vida ${ }^{1}$, os pais conseguiram - por indicação de outros parentes que já viviam na cidade - empregos em indústrias locais e, como forma de complementar a renda bem como de garanti-la em períodos de desemprego, o pai trabalhava como pedreiro, e a mãe, como empregada doméstica. Também ela e sua irmã mais velha começaram desde cedo (por volta dos doze anos) a auxiliar na renda da família, trabalhando como empregadas domésticas.

A família passou a viver de aluguel junto a parentes e conhecidos que haviam chegado alguns anos antes, em bairros como Jardim Beatriz e Redenção, cujos loteamentos haviam sido criados entre o fim dos anos 1960 e o início dos anos 1970 no que era, então, a fronteira sudeste da malha urbana de São Carlos, repetindo o ponto de

1 Durham (1973). Os pais de Joana configuram o caso clássico dos migrantes que "se integraram" pelo trabalho (Feltran, 2011). 
chegada de tantas outras trajetórias de migrantes que venho acompanhando desde a pesquisa de mestrado ${ }^{2}$. Após quase cinco anos na cidade, no início dos anos 1980, o pai conseguiria um acerto em um processo de demissão de uma das fábricas em que trabalhara, com o qual compraria um terreno na Vila Madre Cabrini, loteamento recém-criado, também na fronteira sul da cidade.

Entre a compra do terreno e o fim da experiência terrível de viver de aluguel foram muitos anos, já que não tinham condições de começar a construir: "se comprasse o material, não tinha o que comer, se comprasse o que comer não tinha... sabe? Aquela coisa". Quando sobrava algum recurso, o pai ia armazenando material de construção dentro das exíguas casas que alugavam. Até que, por volta de 1986, apareceu uma oportunidade de trocar aquele terreno por outro ${ }^{3}$, no extremo oposto da cidade, e ainda ficar com algum dinheiro em mãos para comprar material e iniciar a construção da casa. O negócio seria feito por intermédio de um parente que já vivia no Santa Felícia, bairro que definia, até então, o limite leste da malha urbana - a proximidade de alguns parentes compensaria a completa ausência de infraestrutura urbana nesse novo trecho loteado do bairro que se expandia. No mesmo ano o pai iniciaria as obras e, com a ajuda do cunhado, também pedreiro, em dois anos a família se mudaria para sua casa própria, acessada através do recurso à autoconstrução 4 .

O ano era 1988, Joana tinha então quinze anos e não se mudou com a família, pois estava no meio do ano letivo e, no novo bairro, o deslocamento até a escola, do outro lado da cidade, à noite (já que durante o dia ela trabalhava como empregada doméstica), era inviável, dada a ausência de asfalto, iluminação e pontos de parada de ônibus nas imediações da nova casa. Além disso, na mesma semana em que a

2 Rosa (2008). Bairros como Vila Prado, Boa Vista, Vila Sônia, Jardim Beatriz, Redenção, Jardim Cruzeiro do Sul e Jardim Pacaembu - todos situados na chamada Zona Sul de São Carlos - são locais de moradia inicial ou posterior recorrentes nos depoimentos de migrantes chegados na cidade entre as décadas de 1970 e 1980, coletados em ambas as pesquisas, denotando trajetórias comuns de deslocamentos por bairros populares, em grande parte loteamentos voltados aos trabalhadores urbanos pobres de São Carlos. Ver mapas nos Anexos.

3 O mercado popular informal de lotes e casas muitas vezes assume esse formato de troca entre imóveis, na qual a transação não envolve a necessidade de nenhuma das partes despender recursos financeiros. Um dos mecanismos mais recorrentes nesse sentido é a chamada "troca de chaves", em que se realiza a troca de casas no mesmo bairro ou em áreas diferentes da cidade, atendendo a interesses de ambas as partes em mudar de casa, sem que isso implique um mecanismo formal ou informal de comercialização.

4 Inseridos no marco dos debates acadêmicos sobre a "questão urbana" (Castells, 1983) no Brasil, nos quais as periferias urbanas ocupariam lugar central, nas décadas de 1970 e 80 inúmeros estudos se debruçariam sobre o trinônimo loteamento periférico - casa própria - autoconstrução (Bonduki, 1998) que se configurava como uma das principais formas de produção do espaço urbano e de acesso a uma moradia na cidade por parcelas das camadas populares cuja "integração pelo trabalho" fora lograda (como por exemplo: Oliveira, 1972; Kowarick e Brant, 1975; Valladares, 1980, 1983; Sampaio e Lemos, 1978; Bonduki e Rolnik, 1979; Maricato, 1979). Em trabalhos anteriores, promovi uma revisão sobre tal literatura (Rosa, 2008, 2009). 
família se mudou, uma jovem foi morta em um terreno baldio próximo à nova casa. Com isso, ela permaneceu morando na casa de uma tia até finalizar o ano, e somente com a transferência para outra escola - ainda distante do novo local de moradia, mas com acesso um pouco mais facilitado via transporte público, e onde outros jovens da vizinhança também iriam estudar - ela voltou a morar com os pais e os irmãos.

O impacto não podia ser pior: além de não ter asfalto, nem transporte e iluminação públicos, também não tinha rede de água, e a vizinhança era escassa. "Um bairro que estava começando, sem recurso nenhum". Ainda assim, em pouco tempo o local já estaria "praticamente completo de casa, porque era um bairro de pobre, né, o pessoal comprou lá, na verdade, porque era mais facilitado e foi construindo rápido para poder sair do aluguel" - suas memórias deixam entrever uma dinâmica de venda informal dos lotes entre conhecidos e parentes que teria agilizado a ocupação do loteamento. Apesar das dificuldades enfrentadas - foram mais de dez anos até o local ser asfaltado - Joana deixa transparecer um certo orgulho em ter acompanhado toda a transformação do bairro : a referência de, como ela diz, ter visto "um bairro surgir do nada" pautaria toda sua experiência urbana posterior.

Nessa nova casa, nesse novo bairro, Joana assumiria os cuidados da casa e dos irmãos mais novos, já que a irmã mais velha logo se casaria, indo morar com a família do marido. Com isso, ela deixa de trabalhar, mas não de estudar: consegue uma vaga no Centro Específico de Formação e Aperfeiçoamento do Magistério (CEFAM), "não porque meu sonho era ser professora, mas porque eu podia ganhar para estudar e continuar ajudando em casa". Nos trajetos entre a escola e a casa, foi conhecendo outros jovens da vizinhança e, entre eles, aquele que se tornaria seu marido. Em 1992, no último ano do CEFAM, ela engravidou de sua primeira filha, Cláudia, e não pôde concluir o curso, perdendo a bolsa de estudos. Nesse mesmo ano, também ela se mudaria para a casa da família do então namorado ${ }^{6}$, iniciando aí a trajetória residencial de seu próprio núcleo familiar.

5 É interessante notar que, embora Joana afirme que seu bairro era o Santa Felícia, este bairro já existia quando o trecho em que seus pais construíram a casa foi loteado, tendo inclusive alguma estrutura de comércio e serviços que atendia aos moradores do novo loteamento. Ainda assim, em alguns momentos menciona a noção de bairro para remeter à região específica do loteamento; em outros, para remeter ao Santa Felícia como um todo, quase como se aquele fosse um bairro dentro do bairro. Essas distinções e fronteiras - a um só tempo físicas e simbólicas e, sobretudo, plásticas são fundamentais nas trajetórias investigadas.

6 Para ela, esse momento de ir morar na casa do marido representa o 'casar': foi assim com a irmã mais velha, foi assim com ela, foi assim com sua filha mais velha. Chama a atenção o quanto essa dinâmica de engravidar/casar e ir morar na casa da sogra é recorrente, assim como o fato de a mesma não funcionar como o esperado e as famílias (ou apenas a mulher e as crianças) retornarem para a casa da mãe. Tais movimentos relacionam-se com a já mencionada dinâmica dos "quintais", que parece também se organizar em torno de uma ética própria: a primeira opção nunca é a mulher permanecer na casa de seus pais, seja pelo orgulho do marido em fazer-se (mesmo que nas 
Foram cinco meses morando no pequeno cômodo no fundo da casa dos sogros, que o namorado pedreiro havia construído durante a gravidez. Banheiro e cozinha eram compartilhados com os donos da casa, que não respeitavam a privacidade do casal:

Meu sogro abria a porta do cômodo - era um cômodo só, a porta tava fechada, eu deitada na cama - ele abria a porta e entrava, não batia, na verdade ele achava que era uma extensão da casa dele... Nossa comida tava no fogão, ele chegava, ia abrindo as panelas, entendeu? Então eu não gostei, a gente brigou $e$, como a casa era dele, então quem tinha que sair era a gente... aí eu fui pra casa da minha mãe. [Joana]

Com um bebê a tiracolo, ela volta com Fábio, agora seu marido, para a casa da mãe, tornando a ocupar o quarto das meninas ${ }^{7}$, que ela e a irmã haviam deixado vago após casarem e que havia sido ocupado por um dos irmãos. Mas o arranjo seria temporário, já que sua mãe ofereceria a eles um pedaço do quintal ${ }^{8}$ para construírem "dois cômodos - quarto e cozinha - e um banheiro" - o material e a mão de obra seriam por conta deles. Durante um ano e meio, o marido faria duplo expediente como pedreiro, e, em 1994, eles passariam a viver nesses cômodos ("mudamos só com parede e telhado, o resto, piso, reboco... veio tudo depois") que, embora construídos por eles, eram entendidos por todos os envolvidos como sendo parte da casa dos pais dela, da qual se separavam apenas por um corredor de um metro de largura.

Fábio não se sentia nem um pouco confortável nessa relação de dependência dos sogros e, mal haviam mudado, começou a procurar outras alternativas. Através de uma tia de Joana, ele toma conhecimento do loteamento Cidade Aracy II (que era, nesse início dos anos 1990, uma expansão ainda muito pouco ocupada do Cidade Aracy I, aberto em torno de 1983), no extremo sul da cidade, e, por meio de conhecidos dela (que moravam há pouco tempo na divisa entre o Cidade Aracy I e II), consegue adquirir um meio-lote bem baratinho ${ }^{9}$. Inicia, então, com muito custo, a

dependências dos pais) o "provedor", seja pelas relações hierárquicas estabelecidas internamente às famílias. Veja-se, nesse sentido, Duarte e Gomes (2008) e Guedes (1998).

7 "Era assim, a casa da minha mãe, com o passar do tempo, ficou com três quartos: um pra eles né, pro casal, um pras meninas e um pros meninos. Quando eu casei a Sônia já era casada, então, quando eu casei, o meu quarto ficou vago. Como eu tinha dois irmãos, ficou um quarto pra cada um. Aí, quando aconteceu isso de eu ter que voltar pra casa da minha mãe, meu irmão cedeu o quarto que ele dormia, que era meu quando solteira, aí eu voltei para aquele quarto lá, já com a família." (Joana)

8 Sobre a categoria "quintal", ver nota 45 do Capítulo 1.

9 Como já introduzido no Capítulo 1, no presente Capítulo se reafirmará a centralidade da região conhecida como Grande Aracy, ou simplesmente região do Cidade Aracy, nas trajetórias aqui investigadas. Composta pelos loteamentos Cidade Aracy I, Cidade Aracy II, Presidente Collor e Antenor Garcia (abertos todos irregularmente pelo já mencionado proprietário de terras e político da cidade, Airton Garcia), e mais recentemente também pelo conjunto habitacional Jardim Zavaglia (produzido no âmbito do PMCMV), a região começou a ser ocupada em meados dos anos 1980, a partir da abertura e venda de lotes do Cidade Aracy I. Os bairros Cidade Aracy II, Presidente Collor e Antenor Garcia seriam ocupados a partir dos anos 1990, mediante estratégia do loteador de doação de meioslotes, que deveriam ser ocupados imediatamente de alguma forma (sob pena de ter o lote doado a 
construção dos alicerces de uma casa para a família. Entretanto, Joana, ao visitar a tia no bairro e conhecer o local onde o marido iniciava as obras de sua futura casa, ficou horrorizada:

Como eu vinha na casa dessa minha tia, eu via que não tinha recurso nenhum e como era difícil pra eles, que num tinha carro, tinha que ficar dependendo de ônibus, e tudo era longe, não tinha nada perto aqui, entendeu? Apesar que agora não, agora tem mais, é mais fácil, mas, na época, um ônibus passava uma hora, duas horas, então era mais difícil... na época não tinha nada, não tinha mercado, não tinha o comércio que tem hoje, não tinha, sabe? era bem... num tinha asfalto onde eles moravam, entendeu, era assim um lugar bem precário mesmo! Então eu não quis construir aqui ${ }^{10}$. [...] Ele já tava abrindo o alicerce, tudo certinho, $e$ eu vim trazer almoço pra ele. Só que, como era um terreno super aberto, não tinha casa, não tinha nada, e o ponto de ônibus era longe - longe mesmo, tinha que andar uns dois quilômetros ou mais, sabe, do ponto até o meu terreno! - $e$ nesse intervalo que eu desci do ônibus pra ir no terreno, eu... porque aqui a Cidade Aracy era uma fazenda enorme que foi loteada, e do ponto que eu desci até o terreno vinha aquele vento cheio daqueles carrapatinhos, nossa! Quando eu vi aquilo, que eu cheguei no terreno, eu falei: 'Deus me livre, eu não vou vim pra cá'! E outra, a quadra que ele comprou, que era enorme, só a gente que ia construir, não tinha mais nada, tudo mato, tudo terra, eu falei 'imagina, de noite, se acontece alguma coisa, como que a gente vai sair daqui?' Fiquei horrorizada, eu falei, 'eu não vou deixar minha casa lá', que eu tinha construído com muito esforço também, né! [Joana]

Para Joana, naquele momento, ter uma casa independente dos pais não compensava o esforço de ir morar em um lugar tão longe, tão precário. Sobretudo porque ainda eram recentes as memórias da experiência de recomeçar a vida em um bairro sem recurso nenhum e, ainda mais, do árduo processo de autoconstrução da moradia, pelo qual ela já tinha passado duas vezes.

outrem), com a condição de zelarem pela outra metade do lote até que ela fosse vendida. Nesse contexto, muitas pessoas construíam pequenos barracos, ou iniciavam alicerces e, em seguida, vendiam ou trocavam os meios-lotes ganhos (foi nesse contexto que o marido de Joana conseguiu adquirir um). A região (em especial o bairro Cidade Aracy 1, já mais adensado) somente começaria a receber, gradativamente, infraestrutura urbana a partir de meados dos anos 1990 (quando, como visto, o próprio proprietário dos loteamentos e sua mãe foram vice-prefeitos da cidade), sendo que, até os anos 2000, os demais bairros da região permaneciam sem asfalto e com redes de água, iluminação e coleta de esgoto apenas parcialmente implantadas. Cf. Laisner (1999); Gaspar (2000); TEIA (2005); PMSC (2005); Maurício (2008); Silva (2006); Ávila (2006).

10 É interessante notar como ela, ao se referir ao Cidade Aracy do passado, o faz como se fosse o local onde ela mora atualmente - aqui -, atestando o quanto, apesar das distinções e delimitações que são reafirmadas localmente entre os diversos bairros que configuram o território genericamente conhecido como região do Cidade Aracy, há também a introjeção de que a região toda é a mesma coisa, um aqui que talvez tenha a ver com um sentido de identidade que se constrói forçosamente entre os que estão dentro de tal região em resposta ao estigma generalizado frente a ela que vem de fora. Além disso, na fala que denigre o Aracy do passado e dá o cerne da justificativa para ela ter amputado o "sonho da casa própria" que vinha sendo levado a cabo pelo marido, ela faz questão de frisar a diferença daquele tempo com relação aos dias atuais - quando a região estaria bem melhor -, reforçando a percepção desse mesmo sentimento identitário de que, hoje, é lá que ela mora, naquele todo denominado "aqui". 
Como o bairro tava começando, e eu já tinha passado por muita coisa no Santa Felícia, quando começou lá também, com dificuldade, porque não tinha água perto, num tinha asfalto, não tinha nada, então eu não quis vim pra cá por isso, porque não tinha recurso nenhum. (...) Então falei: 'não, eu não vou sair de lá da Santa Felícia', que eu já tinha passado o maior perrengue, pra começar tudo de novo, né? Não precisava, porque a gente não pagava aluguel, porque a gente construiu a casa no terreno da minha mãe, falei: 'não, do mesmo jeito que a gente conseguiu esse daqui, a gente vende e guarda o dinheiro' - achei que era uma fortuna (risos) - 'a gente guarda dinheiro, junta mais um pouquinho $e$ compra em outro lugar, nem que for lá na Santa Felícia também', que tinha bairro ali que também estava começando, mas já tava melhorzinho. Aí ele parou de fazer o serviço, ele tinha vindo já uns dois finais de semana abrir alicerce e aí eu joguei um balde de água, né, eu falei: 'ah, pra cá eu não vou vim'. Ele ficou supertriste, porque ele queria construir a casa dele, ter a casa dele. [Joana]

Desiludido o sonho do marido de construir uma casa efetivamente própria - o terreno com o alicerce iniciado seria vendido pouco tempo depois ${ }^{11}$-, seguem tocando a vida na casa cedida pelos pais, o que, para Joana, facilitava em termos de poder trabalhar e completar a renda familiar. Com a filha já maiorzinha e a mãe com disponibilidade para cuidar dela, por conta de problemas de saúde que dificultavam sua manutenção em empregos, Joana volta a trabalhar como doméstica, trabalho que seguiria desempenhando, mesmo após engravidar novamente em 1997 (de seu filho Ryan), até por volta dos anos 2000 , quando foi demitida ${ }^{12}$ do serviço e sua mãe já não tinha mais condições de ajudar com as crianças. "Abandonei, parei de trabalhar, comprei uma máquina de costura e comecei a fazer consertos, comecei fazer roupa pra mim e pros de casa... aí começou o boca a boca, sabe, e eu comecei, faz pra um, faz pra outro, quando eu vi já tava nessa profissão, até hoje". Assim ela conta como virou costureira, profissão que, quando a conheci, lhe dava identidade e à sua casa no Santa Felícia, sendo sua oficina de costura o centro de sua rede de relações no bairro.

Essa passagem é importante porque, mais do que uma transformação em sua vida, trata-se de uma transformação da casa (cedida, como ela sempre faz questão de frisar) em ambiente de trabalho: inicialmente, ela instala a máquina no quarto do casal; conforme as demandas vão aumentando, ela necessita de mais máquinas e

11 Destaca-se, aqui, a perspectiva atual dela sobre essa venda do terreno, que reflete uma consciência das mudanças no mercado imobiliário na periferia da cidade dos anos 1990 para cá: "Aía gente vendeu o terreno dali, pra comprar material. Só que não ajudou em nada né, porque era tão barato, inclusive o meu tio tirava sarro, porque ele falava assim que ele trocou um terreno aqui no Antenor Garcia por uma bicicleta que ele tinha, pra você ver o quanto valia! / Thaís: Nos anos noventa isso? / É, isso nos anos noventa... porque não valia nada. E foi a época... hoje é um absurdo, né, nem casa pra alugar você não acha, um terreno pra comprar aí é um absurdo também! Então, hoje eu penso, se a gente tivesse segurado o terreno, mesmo que não valesse nada, hoje tinha um dinheiro em caixa."

12 Apesar de ela constantemente se referir aos trabalhos anteriores à sua transformação em costureira como se fossem formais, ela nunca teve registro em carteira. 
passa a usar também a garagem recém-construída da casa dos pais, materializando ainda mais a simbiose entre os cômodos onde ela vivia com marido e filhos e a própria casa dos pais. Com isso, o pai decide expandir a garagem com mais uma área coberta e um banheiro, onde ela se instala definitivamente com todas as suas máquinas, montando sua oficina. $\mathrm{O}$ atendimento à clientela era feito com entrada pela garagem dos pais, o que os levou a fazer uma abertura para a rua, colocando "uma porta daquelas de comércio, para que futuramente se eu quisesse abrir ou eles quisessem alugar, né, já tava preparado". Mais uma vez, a mãe sugeriu que o marido de Joana fizesse o acabamento todo da oficina e do banheiro, numa via de mão dupla que melhorava o ambiente de trabalho de Joana, mas também servia de investimento em sua própria casa, espécie de troca pelos espaços cedidos à filha e sua família. Nesse meio tempo, fizeram também uma ampliação na casa, que ganharia mais um quarto e uma sala.

Porém, se o aumento dessa simbiose doméstica podia trazer benefícios profissionais para Joana e tanto os mantinha distantes da vida de aluguel (ainda que com custos esporádicos de melhorias nos cômodos por eles utilizados) como próximos à sua família (Joana sempre foi muito apegada à mãe), essa relação não era vista por seu marido com a mesma positividade, já que, além de periodicamente ter de realizar turnos duplos como pedreiro, investindo os já parcos recursos em uma casa que não era propriamente deles, ele ainda se sentia privado de sua liberdade, seja no que tange a chegar e sair de casa quando bem quisesse, seja na possibilidade de receber familiares e amigos em casa, ou, sobretudo, em ter que dar satisfação para os pais dela sobre qualquer alteração que pretendessem fazer nos cômodos e na oficina, situações que sempre lhes faziam lembrar que não eram os donos da casa.

Assim, depois de quase doze anos nessa situação, em 2005 ele decide mudar-se com a família para Novo Horizonte - SP, cidade natal de seus pais, que já há algum tempo haviam vendido a casa em São Carlos e voltado para lá. Joana aceita, mesmo contrariada, por acreditar que ele ficaria melhor próximo aos pais - ele já havia se sacrificado ao morar com a família dela; agora era a vez dela. A única condição era que não morariam na casa dos pais dele e, com isso, passaram a viver de aluguel. Foram pouco mais de três anos morando na cidade, período que ela associa às maiores dificuldades enfrentadas, sobretudo financeiras (devido à ausência de trabalho para ambos e ao fato de pagarem aluguel), mas também pessoais, principalmente pela situação de isolamento que ela experimentava, morando em um bairro muito afastado da cidade, sem conhecer ninguém, tendo se afastado da religião Testemunhas de Jeová, que frequentava com os pais e, como se não bastasse, com o marido passando quase todo o tempo fora de casa, "nem sempre a trabalho".

Em 2008, ela engravida novamente. Nessa época, tentando reverter a situação difícil que enfrentavam, ela chegou a ver possibilidades de financiamento para a 
construção de uma casa em Novo Horizonte, mas as condições eram incompatíveis com a situação de renda da família naquele momento.

Eu fui na Caixa Econômica, que falaram que tinha... tinha aberto uma porta lá pra quem não tinha registro conseguir a casa própria, aí eu fui atrás e tinha mesmo essa possibilidade, só que mesmo eu não tendo registro, eu tinha que ter algum dinheiro em caixa. No caso, lá a gente ia financiar o terreno e o material, porque aí era feito por mutirão, como ele tinha um monte de parente lá, se a gente conseguisse o material pra erguer a casa... O pessoal ia ajudar, não ia ter o gasto da mão de obra. Ai eu fui na Caixa lá pra ver, só que um terreno de dez mil reais, eu precisaria ter cinco só pra fazer a papelada, não sei se aqui era a mesma coisa... Aí eu desanimei, falei: 'a gente num tem nada, se a gente já tá indo atrás de fazer um financiamento porque a gente não tem', como é que ia ter esse dinheiro, né? [Joana]

Frustrada essa tentativa de conseguir uma casa própria, ela decide voltar para São Carlos logo após o nascimento da terceira filha, Bruna, motivada pela mãe: durante o período em que estiveram fora, ela havia realizado melhorias na casa para alugá-la e antes de renovar o contrato de gaveta ${ }^{13}$ com os inquilinos, consultou se a filha não pretendia voltar. Ainda que sua fala revele um certo rancor pelo fato de a mãe ter melhorado a casa justamente quando eles não moravam mais lá, há também a gratidão por ela ter aberto mão da renda extra para ceder a casa mais uma vez para Joana e as crianças, já que o marido não voltaria com elas.

Lá foi super difícil, porque o aluguel, você tendo ou não, você tem que arrumar o dinheiro, né? E aí eu vim embora, porque você imagina: você largar sua casa aqui, que você não paga nada, pra pagar um aluguel lá, é um absurdo, né? Aí resolvi que ia voltar pra cá, a inquilina da minha mãe tinha saído... eu já não aguentava mais ficar lá, só que ele num queria vir, porque ele não gostava de morar na casa da minha mãe... A gente combinou que eu ia vir, que ele ia ficar trabalhando lá até terminar o serviço que ele tinha, e depois que ele viesse pra cá, a gente ia pra Limeira, que é uma cidade onde ele tem parente, porque ele não queria ficar aqui em São Carlos. Nosso acordo foi esse, eu vim pra cá, voltei pra mesma casa, porque eu não ia ter condição de pagar aluguel, né? Só que aí eu vim e ele se acomodou, porque eu tava sem pagar aluguel e ele tava lá na casa da mãe dele... [Joana]

Fábio permaneceria em Novo Horizonte ainda por cerca de um ano, vindo apenas visitar a família esporadicamente ("ele não queria voltar a depender da minha família"); Joana, com uma filha pequena, recorreu ao Bolsa-Família nesse período ("eu tava sem marido e sem emprego nessa época, nem precisei mentir"14), e pouco

13 Cf. mecanismos do "mercado informal de aluguel" nas periferias descritos no Capítulo 1.

14 Chama atenção a menção recorrente, entre os interlocutores, à estratégia de mentir para driblar a burocracia estatal e ter acesso a benefícios sociais - aí incluídas as políticas habitacionais. Veja-se, por exemplo, o que diz Beatriz, cuja trajetória será descrita adiante: "Eu nunca fui atrás de BolsaFamília, porque nunca achei justo, assim, eu não gosto da mentira, sabe? Se eu tiver que ir lá falar que eu tô vivendo uma coisa que eu não tô, eu não acho legal. Porque a irmã dele, um monte de gente que a gente conhece... Ah! (risos) Se humilham, choram, vão pra fila quatro hora da manhã, mentem, falam que tão passando fome... E quando chega a assistente social na casa, tira as TV, tira um tanto dos móveis, pra ver que é pobrezinho, depois vai embora e põe de novo. Tem isso, infelizmente. Eu não 
a pouco retomou suas atividades como costureira, agora passando a atender comercialmente, "com a porta aberta pra rua". Quando a situação começou a melhorar, fez um ultimato ao marido: se ele não voltasse, seria o fim do casamento. Ele voltou, mas não aceitaria fazer mais nenhum tipo de investimento em construção naquela casa que não era deles:

Eu queria tirar o taco e colocar piso, eu queria aumentar um cômodo na frente, que tinha espaço, mas ele não queria, porque ele falava 'ah, eu vou ficar fazendo aqui pra quê?' Porque ali, tudo que a gente ia fazer, não era pra gente, né? Então ele falava: 'eu quero ter minha casa, eu quero guardar pra comprar minha casa', entendeu? Mas a gente não conseguia, porque era difícil, né? Porque eu, também, eu sempre falava pra ele: s'e for pra comprar terreno pra construir, a gente nunca vai conseguir ter uma casa terminada... e outra, você vai ficar um, dois, três anos construindo, é muito tempo! Então eu quero uma casa, que se eu tiver que gastar, eu quero já entrar dentro da casa pra morar'. Minha sogra falava assim: 'ah, ela quer ser rica, porque todo mundo compra terreno e constrói; ela já quer uma casa pronta'15! Mas eu via a dificuldade que era, eu vi a dificuldade do meu pai que foi pra construir, demorado... [Joana]

Pode-se dizer que $\mathbf{2 0 0 9}$ foi um ano de impasse sobre a situação de moradia da família: por um lado, a relação do marido com os cômodos cedidos era péssima; por outro, ela descartava completamente a alternativa da autoconstrução, não apenas pelas condições financeiras da família, que não eram boas, mas principalmente pelo fato de que não queria ter que passar por todo o longo processo (e as dificuldades dele decorrentes) novamente. Viver de aluguel também estava fora de cogitação, tanto pela renda familiar, quanto pela comodidade de ter a casa cedida pelos pais. A salvação veio pelo rádio:

Eu fiquei sabendo pelo rádio que ia ter o sorteio da casa. Foi assim uns dois meses antes do sorteio... o sorteio foi dia primeiro de maio, né? Então, acho que no final de março eu escutei no rádio, aí falei pro meu marido: "Ah, eu vô lá fazer a inscrição, né?". A gente nunca teve casa! $!^{16}$ Aí peguei, fui lá, marcaram um dia

consigo fazer isso, nem quando eu tava precisando muito". Também é de se notar, nos relatos, que quem um dia dependeu da bolsa e hoje não depende mais, parece se sentir na obrigação de justificar o fato de ter recebido, como se fosse uma vergonha, ou, ainda, como se precisasse comprovar que não usou de mentiras para conseguir o benefício. Entretanto, mesmo depois de ter voltado a trabalhar e do retorno do marido, Joana continuou recebendo o auxílio, apenas tendo deixado de receber na segunda renovação, quando já haviam sido sorteados para receber uma casa pelo PMCMV e não teria como ela não incluir a documentação do marido: "quando a gente mudou pra cá, que eu tive que ir lá pra renovar, aí eu tive que incluir o documento dele, aí cortaram, entendeu?".

15 Note-se, aqui, a diferença entre a visão de Joana e a de sua sogra sobre os modos de consecução da casa própria, que talvez possa ser lida numa espécie de quebra geracional na qual, em função das reconfigurações socioeconômicas decorrentes de décadas de neoliberalismo no país, em associação com a generalização da provisão habitacional através do PMCMV, a autoconstrução parece deixar de ser uma opção, e os valores a ela atrelados (como a já mencionada ideia de "luta") já não são produtores dos mesmos sentidos que orientaram os "projetos de integração" de toda uma geração de trabalhadores pobres.

16 Vale observar que, mesmo morando em uma casa relativamente autônoma no quintal dos pais, sem pagar aluguel, Joana nunca sentiu a casa como sua, o que era vivenciado simbolicamente menos pela positividade de manutenção dos vínculos com a família ampliada (como visto no caso de Núbia e 
pra mim voltar com a documentação, tudo. Aí eu levei. Depois, já me falaram, já me deram um papelzinho que era pro sorteio, né? Que já ia entrar no sorteio. Aí dia primeiro de maio eu fui. [Joana]

Era início de 2010, e estavam abertas as inscrições para o primeiro sorteio do Programa Minha Casa Minha Vida na cidade; seriam sorteados mil titulares, mais quatrocentos suplentes. Apesar de fazer questão de frisar que, por ela, permaneceria na casa cedida pelos pais pro resto da vida, foi pensando no marido (e na manutenção de seu casamento) que ela se inscreveu na PROHAB: "Porque, se a gente não arrumasse essa casa, talvez ele não taria aqui em São Carlos". É interessante notar que, mesmo sendo o marido quem tanto queria uma casa própria para a família, para "ter a vida independente", é Joana quem toma a iniciativa de se inscrever no sorteio, e será ela, até o final, a mobilizar todas as estratégias para dar conta do processo até a posse da casa.

Joana nunca havia se inscrito na PROHAB até então, por pensar que fosse necessário ter registro em carteira para poder ter direito à moradia ${ }^{17}$. 0 recurso à política pública foi quase um acaso ("fiquei sabendo de última hora do sorteio e resolvi me inscrever") e, na primeira vez, já foi sorteada - ela mesma tem conhecidos que há anos estão inscritos e até hoje não foram contemplados -, mas para suplente, o que a deixou totalmente descrente de que pegaria a casa, já que havia muitas pessoas na sua frente:

Eu fui sorteada depois de duzentos suplentes. Então, eu nunca imaginei... Entre mil casinhas e mais duzentas pessoas na minha frente! Impossível mais de duzentas pessoas perder, né, assim, por alguma documentação, algum problema, ou porque já tinha alguma casa... [Joana]

Logo ela saberia que, além de inúmeras famílias não se enquadrarem nos critérios e documentações exigidos pela Caixa Econômica Federal ${ }^{18}$, diversas outras também

Jimmy e veremos no caso de Jefferson, a seguir), do que pela negatividade da dependência e falta de autonomia do núcleo familiar, sobretudo do ponto de vista das redes de relações sociais de vizinhança e parentesco, onde eram vistos como uma família que não prosperou.

17 O relativo desconhecimento, entre os populares, sobre as políticas levadas a cabo pela PROHAB na cidade foi extremamente recorrente não apenas durante a pesquisa de campo, como visto no Capítulo 1, mas também nos levantamentos realizados quando de minha participação na elaboração do PLHIS - São Carlos (PMSC, 2010).

18 Aqui cabe uma observação sobre a inconsistência dos procedimentos de comunicação, cadastro e realização do sorteio implementados pela PROHAB (PMSC, 2010) e as dificuldades inerentes aos critérios de aprovação da "demanda" pelo PMCMV (via CEF), que acarretam em desistências ou exclusões do Programa e desembocam também na criação de estratégias para conseguir se encaixar nas exigências do mesmo: holerites e comprovantes de residência falsificados; novos empréstimos para limpar o nome, que, em seguida, ficará sujo novamente; apresentar-se ou não como casados, a depender da situação e por aí afora. Assim como Jimmy, tanto Joana quanto Beatriz enfrentarão essas dificuldades fazendo uso de algumas dessas estratégias, como veremos. 
desistiriam da casa sorteada ${ }^{19}$, em função da localização e dos preconceitos com a região do Cidade Aracy, como veremos adiante, o que faria com que a PROHAB não apenas acionasse os suplentes, como também realizasse um novo sorteio de casas no conjunto ${ }^{20}$. Ela entrou, portanto, nessa brecha das desistências e do desencaixe entre essa população e a documentação exigida pelo programa.

Mas também Joana correu o risco de ser eliminada, já que um dos critérios era não estar com o nome sujo, e ela tinha uma dívida com um banco há mais de cinco anos. Ela chegou a cogitar que o marido vendesse o carro adquirido logo após o retorno de Novo Horizonte, mas ele alegou que dependia do veículo para dar conta dos serviços em andamento. Mais uma vez ela contou com a ajuda da mãe, sem a qual ela - como tantos outros inscritos - também seria desclassificada:

Minha mãe falou assim: 'você vai lá, vê se você faz um acordo e eu te ajudo a resolver isso aí, senão você não vai pegar sua casa.' (...) aí eu fui lá, fiz um acordo, minha mãe me emprestou o dinheiro e eu consegui reunir a papelada. Até então eu não acreditava que eu ia pegar a casa, justamente por causa dessa imposição que tinha. Demorou pra eu acreditar que eu tinha ganhado mesmo! Aí eu fiquei muito feliz, né? Nem acreditei! Falei: 'puxa vida!' (risos) Eu fiquei feliz da vida, só que eu pensei assim: 'eu só vou acreditar quando eu tiver assinando o contrato da casa mesmo'. ${ }^{21}$ [Joana]

Além disso, ainda havia a questão do enquadramento na faixa de renda atendida pelo programa, não apenas porque ambos eram autônomos e ela acreditava que seria necessário alguma comprovação dos ganhos, mas também porque, somadas as rendas dela e do marido, eles ultrapassariam o limite máximo de renda que definia o 'público-alvo' atendido pelo conjunto. Informada de que poderia assinar uma declaração de renda de próprio punho, ela optou por declarar apenas a sua, ainda assim minimizando o valor recebido para garantir a menor prestação a ser paga ${ }^{22}: \mathrm{R} \$$ 50,00 por mês, o equivalente a dez por cento do salário mínimo na época.

19 Ela própria e todos os outros interlocutores da pesquisa conhecem pessoas que abriram mão da casa no local: "Muita gente que foi sorteada, foi lá, e quando viu onde era, desistiu da casa, não quis. Não quis porque o lugar era muito longe, ou porque morava há muito tempo no bairro perto de parente e não queria sair, entendeu? Mas muitos desistiram porque era do lado do Antenor, da Aracy."

20 Mais de $40 \%$ das famílias (entre titulares e suplentes) não tiveram seus cadastros aprovados pela CEF, sendo mais de 350 unidades sorteadas novamente. Cf. informações obtidas em campo e notícias veiculadas em jornais locais, como http://www.noticiasdacidade.org/?p=304637 e http://www.afolha.com.br/noticias.php?noticia=1227, consultas em fevereiro de 2014 .

21 Essa desconfiança também é recorrente entre outros interlocutores que acessaram a casa própria através do programa, ou de outras políticas públicas: a felicidade é intensa, mas já passaram por tantas dificuldades, que se tornaram céticos.

22 Tal estratégia, bastante frequente entre os beneficiados por programas habitacionais levados a cabo pela PROHAB, como pude observar em campo, dialoga com aquela anteriormente mencionada a respeito do acesso às políticas sociais, como o Bolsa-Família, e demonstram um deslize nos relatos de Joana, ao evidenciar que mentiu para não deixar de pegar a casa, contrariando todo seu esforço anterior em justificar que não havia propriamente mentido para acessar o Bolsa-Família. 
Aí eu peguei e fiz a inscrição, entendeu? Só que eu não tinha como comprovar renda, porque as casas aqui era pra pessoas que ganhavam até mil e trezentos reais por mês, não podia passar disso. Mas eu não tinha como comprovar renda, aí eu fui lá na PROHAB pra conversar, eles me deram um papel, lá mesmo, que era pra gente declarar o que a gente ganhava. Aí eu consegui fazer a inscrição, entendeu? (...) Então aqui a gente paga cinquenta reais! Porque pra cada salário que a pessoa ganhava, era um valor estipulado: um salário... o pagamento mais caro das casas que tem aqui é cento e trinta reais, que é dez por cento do salário que a pessoa ganha. Não podia ultrapassar isso, então, quem ganhava mil e trezentos ia pagar cento e trinta. Então, como a gente... na verdade eu declarei que ganhava seiscentos, só que a gente não tinha registro, e quem não tem registro, é declaração de boca, entendeu? Então eles não podiam basear pelo salário que a gente ganhava. Então quem não tinha registro, todo mundo que não tinha registro, que era autônomo, no caso, paga cinquenta reais. [Joana]

Superados os obstáculos que poderiam excluí-los do programa, a felicidade de Joana, quando constatou que realmente a casa seria sua, só é suplantada pela do marido, que, após a confirmação de que pegariam mesmo uma casa, passou a ir semanalmente visitar as obras do conjunto, várias vezes levando toda a família, mesmo sem saber ainda onde exatamente seria a casa deles, já que também isso seria decidido por sorteio. Apesar dos comentários negativos que receberam na vizinhança, no Santa Felícia, pelo fato de o novo bairro ser na região do Cidade Aracy, o desejo e, mais que isso, a necessidade que o casal sentia de formar um núcleo familiar independente os fizeram desconsiderar inclusive as próprias opiniões prévias sobre o local ${ }^{23}$.

Quando eu fiz a inscrição, eu já falei pro meu marido: 'Vamo lá vê onde que vai ser, né? Se é mesmo longe'. Porque todo mundo falava: 'Ai, do lado do Antenor Garcia? Ninguém vai querer, né?!'. Mas eu tinha aquele pensamento: aonde fosse, aqui dentro de São Carlos, eu queria! Não importasse aonde. Nem que fosse na Cidade Aracy, no Antenor Garcia, todo mundo tem preconceito, né? Mas é um bairro como outro qualquer. [Joana]

Necessidade essa ainda mais premente após a filha mais velha engravidar: seguindo os passos da mãe, da tia e de tantas outras mulheres das camadas populares, ela foi morar com a família do marido, a coabitação não durou muito tempo, e Joana acabou cedendo um cômodo de sua também cedida casa para a nova família, em um novo arranjo do "quintal" 24 .

Quando a minha filha casou, ela tava morando com a sogra dela e não tava dando certo. Aí eu falei pra ela: 'ó, eu fecho a porta da minha sala, te dou a minha sala, você faz de quarto, e a gente continua cozinhando tudo junto.' Né?

23 Esse confronto entre o estigma associado à região, que moldava a própria imagem que eles mesmos faziam dali, e a referência de agora ser um morador local compõem jogos de perspectivas sobre a cidade que são interessantes para entender as dinâmicas classificações e hierarquizações entre os bairros populares promovidas internamente às próprias camadas populares, cuja reflexão mais detida se fará no Entremeio III.

24 Tais arranjos denotam aquela já mencionada plasticidade da casa, que se molda a essas dinâmicas familiares cambiantes. 
Aí ela foi pra lá. Mas depois, naquele espaço que era o meu quintal, ela montou uma cozinha pra ela. Então eu fiquei com os dois quarto e a cozinha. [Joana]

A mudança para o novo local de moradia aconteceria somente mais de um ano depois da notícia da conquista da casa, mas ela foi o suficiente para alimentar os planos não apenas de Joana e Fábio - que além de "sonhar com uma casa só pra gente", começaram a economizar para adquirir móveis e acabamentos para a casa -, mas também de sua filha, que, embora não tivesse sido contemplada com uma casa no mesmo bairro (já que também tinha se inscrito quando da segunda rodada do sorteio), sentiu-se contemplada indiretamente, pois poderia assumir a casa cedida pelos avós.

Quando eu ganhei a casa, aí ela já começou fazer planos que ela ia ficar com a casa inteira. Aí ela já foi, já comprou os móveis, mesmo antes de eu mudar pra cá, como ela tinha que... ela foi muito precipitada, né? Aí ela foi lá e comprou os móveis da casa. Aí, o que que eu tive que fazer: eu tive que juntar as minhas coisas, porque o montador ia vim pra montar os móveis dela. Aí eu tive que juntar tudo as minhas coisa na cozinha dela... [risos] ...pra ela poder montar os móveis dela. Então, na verdade, a minha mudança já tava pronta pra vir pra cá. Era só pegar a chave pra vim mesmo. Só que eles falaram que ia entregar a casa dia trinta de agosto... E aí, eles ficaram adiando, adiando, porque não tinha terminado, não tinha terminado. Foram entregar era dia quatorze de outubro. Então, até outubro, ficou tudo amontoadinho dentro de uma cozinha lá. [Joana]

Após alguns meses vivendo com ainda menos espaço e liberdade, finalmente o grande dia: o sorteio da localização da casa e a entrega das chaves, em outubro de 2011. Nas visitas deles às obras e, depois ao conjunto concluído, ela sempre desejava uma casa mais pro meio, nos arredores das áreas institucionais, onde mais famílias já tinham escolhido suas casas no primeiro sorteio de localização, ao passo que o marido preferia uma casa que desse fundo para a mata que faz a divisa do Jardim Zavaglia com o Antenor Garcia, "para não ter vizinho de fundo". No fim, como foram uma das últimas famílias a ser sorteada para a escolha, acabou sobrando para eles justamente uma das casas que o marido queria.

No mesmo dia, Fábio já começou a dormir na casa, por medo de que esta fosse invadida, pois já circulavam notícias de que isso vinha ocorrendo. No dia seguinte, iniciou as obras dos pisos dos quartos e da sala (a casa foi entregue com piso apenas na cozinha e no banheiro), cujos materiais foram doados pelo pai de Joana. Nesse meio tempo, começaram, aos poucos, a trazer a mudança no próprio carro do marido, para evitar mais gastos ("a gente não tinha muita coisa"). Em pouco mais de uma semana, estavam devidamente instalados na casa ${ }^{25}$ com dois de seus filhos e com direito a mobília nova - "jogo de sofá, a cama-box e o guarda roupa, que a gente

25 Ela conta que, no dia do sorteio da localização das casas, muitas famílias já estavam com o caminhão de mudança pronto, só esperando a entrega da chave para ir para a casa, "de tanto desespero para sair do aluguel ou da casa de parentes". 
não tinha" - adquirida em doze parcelas para diluir as dívidas, pois ainda teriam gastos para fazer o muro em todo o limite do terreno, a calçada e o contrapiso em torno da casa, que estava tudo na terra. Mas, para Joana e, sobretudo, para Fábio, começava ali uma nova vida, na qual os gastos com a casa e mobiliário eram agora vistos como investimentos para o futuro da família, feitos com prazer, apesar das dificuldades: afinal, se, como ela mesma disse, "o sonho de todo mundo que casa é de ter sua casa", a deles finalmente fora conquistada, após quase vinte anos de vida em comum.

Nas palavras de Joana, a casa própria teria sido a carta de alforria do marido em relação à família dela e, de certa forma, a dela própria: "agora eu posso fazer o que eu quiser, do jeito que eu quiser, que a casa é minha", ela me diria, referindo-se não apenas à estrutura física da casa, mas também às dinâmicas de criação dos filhos e de seu relacionamento com o marido. " $E$ tudo isso pagando apenas $R \$ 50,00$ por mês", como ela tantas vezes fez questão de frisar, em uma espécie de resposta à sua sogra, que não acreditara que eles seriam capazes de acessar uma casa própria sem passar pelo processo de autoconstrução.

Beatriz e Jefferson ${ }^{26}$ completaram, respectivamente, vinte e sete e vinte e oito anos em 2013; são também, portanto, o núcleo familiar mais jovem que acompanhei (embora tenha tido outros interlocutores mais jovens, nenhum deles ainda havia constituído um núcleo familiar próprio). Sua trajetória conjunta inicia-se em 2004, quando ela tinha dezoito e ele dezenove anos. Até então, suas trajetórias, a um olhar apressado, poderiam parecer relativamente próximas; aos olhos deles, entretanto, apresentam-se como radicalmente distintas.

Beatriz e seu irmão são nascidos no Paraná, onde vive até hoje boa parte de seus parentes maternos e paternos, com os quais tem pouco contato. A mãe separou-se do pai quando ela tinha dois anos e, com um novo companheiro, passou a migrar entre Paraná e Minas Gerais em busca de trabalhos na roça (caso semelhante ao dos pais de Joana, mas com algumas décadas de diferença). Ela e o irmão viviam entre a casa do pai e da avó (em cidadezinhas distintas) - além de, por alguns períodos,

26 Dentre as quatro famílias sobre cujas trajetórias urbanas me debrucei mais detidamente ao longo da pesquisa, esta foi a única com a qual a interlocução aconteceu com o casal, já que, além deles, o núcleo familiar conta apenas com mais um filho, Fabiano, oito anos em 2013. Nesse sentido, foi bastante interessante, por permitir apreender, de um lado, as perspectivas que se constroem conjuntamente, em termos de um projeto familiar propriamente dito e do lugar da casa nele; de outro, as visões absolutamente distintas, de cada um, em termos da cidade, dos bairros, da atual situação em que se encontram, e que trazem contrapontos bastante interessantes para a reflexão aqui proposta. 
acompanharem as migrações da mãe e do padrasto - até por volta de 1995, quando a avó, cansada de cuidar das crianças, sugeriu que a mãe buscasse um lugar para viver onde tivessem mais oportunidades de trabalho, como a cidade de São Carlos, onde alguns parentes seus viviam há muitos anos. A mãe e o padrasto vieram primeiro passar uma temporada na casa de um tio, para conhecer a cidade, buscar moradia, tentar conseguir empregos. Quando ele foi admitido na indústria onde o tio trabalhava, matricularam as crianças na escola e voltaram para buscá-las.

Beatriz chegaria a São Carlos em 1996, aos dez anos de idade, para viver de aluguel em uma casa inacabada vizinha à do tio, no bairro Jockey Clube, onde também se localizava a empresa onde o padrasto iria trabalhar. Loteado já há algum tempo, este bairro limitava, então, a cidade em seu extremo norte, tendo permanecido por décadas como o único bairro do lado de lá da Rodovia Washington Luís. São Carlos era a primeira cidade de verdade que ela conhecia, já que antes havia morado apenas em pequenos núcleos rurais.

A mãe conseguiu um emprego de faxineira em um clube próximo ao bairro, e o irmão começou a trabalhar como aprendiz em um mercado local, enquanto Beatriz estudava e acompanhava a mãe no serviço. Como o aluguel era barato, por conta de a casa ser inacabada, e não tendo gastos com água e luz, já que a casa tinha ligação direta (o popular gato), a situação da família foi se estabilizando, e o padrasto começou a buscar possibilidades de saírem do aluguel.

A primeira tentativa foi, como a do marido de Joana, na região do Cidade Aracy: ele tinha notícias de que os terrenos ali tinham sido doados e tinha expectativa de conseguir alguma coisa. Mas naquela época (e ainda hoje), a região era tida como a pior de São Carlos, antro de bandido e vagabundo, equiparando-se somente ao Jardim Gonzaga, a 'eterna' favela da cidade. A recepção de sua mãe foi completamente negativa, seu padrasto desistiu da ideia e, para Beatriz, restou a percepção de que o Cidade Aracy era 'a' periferia da cidade, associada inclusive à ideia de favela, visão que será determinante nos rumos futuros de sua trajetória.

Quando a gente tava no Jóquei, surgiu os terrenos na Aracy II, e muitos seriam dados... Meu padrasto foi ver, só que, naquela época, era aquelas notícias mesmo do Aracy, sabe? Naquela época que morreu muita gente, muita briga, $e$ tudo aparecia no rádio, jornal... às vezes nem acontecia na Aracy, mas já falava que era lá, é, a notícia era que não podia ter ônibus pra lá, nem coleta de lixo, ninguém queria descer. Meu padrasto foi lá, e minha mãe falou: 'não, se for pra comprar terreno lá, ou até ganhar o terreno e gastar dinheiro com construção lá, vamos continuar a pagar aluguel'. Então eu já ouvia a conversa dentro de casa, minha mãe: 'Aracy não, Aracy não', e meu padrasto: 'mas é dado o terreno...' Então, assim, na minha cabeça, Aracy era periferia, ou melhor, favela, porque de onde eu vinha, terreno dado era favela, assim, era popular, né? Então dentro de casa eu já ouvia... [Beatriz] 
Depois dessa primeira iniciativa frustrada, somente três anos depois, em 2000, o padrasto chegaria em casa com a notícia de que tinha comprado um terreno, do outro lado da cidade, sem dar margem para a mãe decidir:

No Belvedere, um bairro que era um monte de terreno do Airton Garcia ${ }^{27}$, eu não sei, era uma fazenda, aí lotearam... só que era muito feio, muito feio mesmo! Quando a minha mãe viu, era um subidão, minha mãe viu aquilo, ela "não, não vou morar aqui". Mas ele já tinha comprado de um cara; comprou, aí começou a construir, a gente ia todo fim de semana pra lá. [Beatriz]

Ela, então com quatorze anos, e a mãe demorariam a se acostumar com a ideia de viver no meio do nada: "a gente só chorava! Minha mãe chorava, e eu chorava junto!" Embora o Jardim Social Belvedere, recém-loteado, fosse praticamente uma extensão do já mencionado Jardim Beatriz (onde a família de Joana primeiro viveu e era já um bairro relativamente consolidado), direcionava-se ao chamado buracão - uma grande encosta que divide a região sul da cidade em parte alta e parte baixa (sendo esta última equivalente à região do Cidade Aracy) - e era propriamente o limite da urbanização, sendo cercado de mato. Para piorar, o terreno adquirido pelo padrasto ficava bem na ponta do loteamento, praticamente na encosta, e ainda não havia morador algum na vizinhança.

Concluída a primeira etapa do processo de autoconstrução da casa (já que, como ela e todos os outros interlocutores sempre fazem questão de lembrar, " $a$ casa nunca acaba, tá até hoje construindo", apontando para uma dimensão processual da casa), a família mudou-se para o bairro, que agora já tinha mais outras duas casas construídas, mas Beatriz não veio com eles. Como no caso de Joana, ela estava em pleno ano letivo e trabalhava em uma loja de materiais de construção próxima à escola. Não sendo ainda, o novo bairro, atendido por transporte público, ela permaneceu no antigo, morando na casa de uma tia e deslocando-se para a nova casa apenas aos finais de semana ("e olhe lá! Eu odiava aquele lugar").

No ano seguinte, após ser transferida de escola e conseguir outro trabalho próximo ao novo bairro, ela se mudaria em definitivo para a casa nova e suas memórias desse período, ainda que destaquem positivamente a melhoria em termos de condições da moradia ${ }^{28}$, evocam um desgosto com a ausência de infraestrutura urbana, de

27 Beatriz refere-se ao já mencionado proprietário de terras e político Airton Garcia, personagem recorrente na história (não contada) das periferias ao sul da cidade de São Carlos. Dono de porções significativas de terras, ele as loteara durante as décadas de 1980 e 1990 (como toda a região do Cidade Aracy, mas não apenas), muitas vezes de forma irregular e seguindo o melhor roteiro da especulação imobiliária. É de se notar que os moradores desses bairros populares são conhecedores da atuação do político, que, até os anos 2000, gozava dos benefícios políticos de ser o 'pai dos pobres' local. Cf. Rosa (2008); Maurício (2008); TEIA (2005).

28 É interessante que ela faz questão de dizer "mas a casa era legal", após contar que a casa tinha três cômodos -quarto, cozinha e sala -, que ela dormia no quarto com a mãe e o padrasto, e o irmão, na sala, e que a casa não tinha acabamento, para frisar a diferença em relação tanto à casa anterior, 
vizinhança, de amizades. Contudo, além de a mudança para uma escola próxima ao bairro ampliar seu círculo de amigos na região, o passar dos anos veria a ampliação da vizinhança e a chegada de infraestrutura, serviços e comércio ao bairro, a ponto de, hoje, o local (e sua região) - considerado por ela um bairro de classe média baixa - ser sua grande referência em termos urbanos e de moradia.

Será na escola, em 2004, que ela conhecerá Jefferson que, como outros colegas de sua turma, era morador do Cidade Aracy, bairro que, de sua casa, ela avistava lá embaixo, depois do morro, e o qual passaria a frequentar, contrariando os avisos de sua mãe e superando seu próprio medo em relação ao local.

E por mais que eu já tivesse ido morar num lugar feio que foi melhorando, os bairros em volta do meu, tirando o Gonzaga, eram bons. Então, periferia, pra mim, era o Aracy. Desde a época que minha mãe não deixou meu padrasto comprar o terreno no Aracy, pra mim, o Aracy era isso. Então, nas primeiras vezes que eu fui no Aracy, tirava relógio, tirava brinco... morria de medo! Mas as meninas com quem eu ia conheciam todo mundo, então elas não tinham medo... $E$, depois dessa época, eu comecei a conhecer também e perdi o medo. (...) Mas é que, como todo mundo tratava o Aracy diferente, você vai no ritmo, né? $\mathrm{Na}$ escola, tipo "com aquela menina ali não invoca, que ela é do Aracy". E o que mais pegava pra mim era o morro... Desceu o morro, sabe? Aquela visão de morro, de favela, então descer a serrinha do Aracy, um morro... já pensava em coisa feia, coisa ruim. E as casas do Aracy era lona, tábua, então era o que eu via, eu via. Tanto que, naquela época, e até hoje, o povo lá chama as casa de barraco. Falava: 'ó, cola lá no meu barraco à noite, fazer um som', virou gíria mesmo. Mas quando minha mãe ouvia... era casa normal, mas ela ouvia e falava: 'mas você vai prum barraco? Nem pensar!' [Beatriz]

Se, para Beatriz, o Cidade Aracy era a periferia que metia medo, para Jefferson, era a base de sua identidade de rapper. Sua família - mãe, padrasto, duas irmãs e dois irmãos - chegou à Cidade Aracy I em 1994, também no rastro de parentes do padrasto que já viviam em São Carlos. Suas memórias anteriores remetem a duas vivências distintas de moradia em São Paulo, de onde vieram: a primeira, onde nasceu e viveu toda a primeira infância, era o clássico "quintal" 29 da casa da avó paterna, um terreno muito grande no qual se situavam, ao fundo, a casa da avó; na frente, a casa onde vivia com seu pai, sua mãe e duas irmãs e, ao lado, a casa do tio. Quando a mãe e o pai se separaram, e ela conheceu aquele que se tornaria seu padrasto, eles continuaram vivendo no mesmo bairro, em uma casa alugada próxima ao "quintal" da avó. Um tempo depois, o padrasto alugou o apartamento financiado de um parente em um conjunto habitacional promovido pela Cohab no distrito de Artur

em que viviam de aluguel, quanto às casas em que moraria depois de formar seu próprio núcleo familiar.

29 Dentre todas as trajetórias acompanhadas, é na de Jefferson que se manifesta a prática do "quintal", mencionada anteriormente, de forma mais típica, e toda sua experiência de casa, vizinhança, bairro e cidade terá como base tal referência, mesmo após a mudança para sua casa própria, como espécie de contraponto a referenciar positiva ou negativamente a atual experiência. 
Alvin ${ }^{30}$ : se, por um lado, ele perderia a vivência cotidiana com a família ampliada, avós, tios e primos ("era todo mundo junto, as casas eram uma coisa só"), por outro, se manteria essa experiência de "sempre ter bastante gente perto", que ele atribui ao fato de viver em um conjunto habitacional, "onde tinha muita gente e todos se conheciam". Ambos se tornaram referências fundamentais de experiência urbana e moradia para ele, como veremos.

Em 1994, após algumas vindas da família para São Carlos em casas de parentes de seu padrasto, este trocou um terreno que havia adquirido em Descalvado - SP (onde também tinha parentes) por uma casa inacabada no bairro Cidade Aracy 1, por acreditar que, em São Carlos, teria melhores chances de conseguir trabalho como pedreiro. Jefferson tinha nove anos quando então se mudaram definitivamente para a cidade e, até se casar com Beatriz, viveria nessa mesma casa e ajudaria seu padrasto a dar continuidade à construção, na qual foram realizados, inicialmente, apenas alguns reparos e, com o passar do tempo, inúmeras reformas e ampliações, incluindo uma "outra casa no fundo", para abrigar a família que crescia: a ele e suas duas irmãs por parte de pai e mãe somaram-se mais dois irmãos, filhos da mãe com o padrasto. Alguns anos depois da chegada ao bairro, o irmão da mãe veio de São Paulo e passou a também morar com eles. No início dos anos 2000, esse tio seria assassinado no bairro, deixando uma mulher grávida ${ }^{31}$; quando a menina nasceu, a mulher entregoua para a mãe de Jefferson criar. Enquanto isso, uma das irmãs casou, o marido não tinha família na cidade, e passaram a morar na casa dos fundos. Quando conheci a casa, no final de 2013, o irmão de Jefferson estava construindo mais um cômodo no quintal, onde iria morar com a namorada.

Suas lembranças da chegada à cidade, mais especificamente ao bairro (já que pouco saíam dali) são boas, apesar das ruas de terra, que tanto incomodavam sua mãe, ou do fato de estudar em uma escola improvisada no cemitério existente logo na entrada do bairro, a cerca de seis quilômetros a pé de sua casa, situada na penúltima rua do bairro.

Ah, pra nós, quando é pequeno, a gente não entende, né? Então, foi até boa. Porque... ruas de terra, você tá sempre brincando ali, entendeu? Correndo, jogando bola, entendeu? Então, foi tranquila. (...) quando eu comecei estudar, foi na época que, a gente, o pessoal do Aracy estudava lá no cemitério. / Thaís:

30 Ele faz questão de dizer que morava em "Cohab 1, Artur Alvin, Itaquera", demonstrando um certo orgulho por ter tido essa experiência, pois foi onde tomou contato com o rap. De certa forma, ter vindo de São Paulo e morado nesse local o conferia certo 'prestígio' entre os amigos que foi fazendo após a mudança para o Cidade Aracy, cujo contato com o rap apenas se iniciava.

31 Os anos 2000 são tidos por todos os interlocutores como o ápice da violência no bairro Cidade Aracy, sendo que duas das famílias cujas trajetórias são investigadas em profundidade na pesquisa tiveram um membro assassinado no bairro nessa época. Seus relatos são idênticos: ambos homens de vinte e poucos anos, que teriam sido assassinados em decorrência do relacionamento com mulheres que, simultaneamente, eram envolvidas também com bandidos locais. 
Naquele cemitério que tem ali na Serrinha? / Jefferson: É. No cemitério da Serrinha. / Thaís: Por quê? Tinha uma escola ali? / Beatriz: Já era o cemitério ali [risos]./ Jefferson: É, ali era a escola. O pessoal estudava lá. Ali onde é o velório agora. O pessoal estudava lá. Enquanto... já era cemitério. Eu peguei esse tempo aí. Que quando eu comecei estudar foi quando a gente fez a transferência de carteiras. Cada aluno catava uma carteira e subia aquela subida até o CAIC ${ }^{32}$. Levaram do cemitério pro CAIC. E aí eu já peguei esse período do CAIC funcionando. [Jefferson e Beatriz]

O bairro, cujo loteamento irregular fora iniciado em meados dos anos 1980, como visto, somente nessa época começava a receber infraestrutura e equipamentos públicos, como rede de esgoto, drenagem, asfalto e escola, para citar algumas das obras das quais ele se lembra de ter vivenciado - "quando a gente mudou, o bairro tava em obras". A rua de sua casa, entretanto, seria asfaltada somente em 2004 (ironicamente, o ano em que ele sairia pela primeira vez da casa da mãe), atestando o lento processo de urbanização do bairro. Também em termos de comércio e serviços, ele acompanhou, nos dez primeiros anos vividos ali, a lenta transformação, intensificada já na segunda metade dos anos 2000.

Mas, a despeito dessas condições do bairro quando chegaram - que, para ele, só começariam a ser encaradas com um olhar mais crítico ao ingressar no cenário hiphop local, já na adolescência, montando um grupo e compondo letras de rap - sua relação com o bairro, narrada (e por mim observada) desde o presente, é pautada prioritariamente por uma extrema afetividade, sobretudo pelas amizades estabelecidas primeiramente na vizinhança, mas que depois se estenderam por todo o bairro. São memórias da casa da família, onde viviam todos juntos, e "qualquer coisa virava um churrasco"; da esquina ${ }^{33}$, onde encontrava os amigos, onde criou seu primeiro grupo de rap e onde passou a ter contato e algum envolvimento com o tráfico de drogas; dos raps juninos organizados em casas de amigos, diversão alternativa e econômica de uma parcela dos jovens do bairro; dos shows de rap que passou a protagonizar ao lado de outros poucos grupos que se iniciavam na cidade, para citar algumas das referências mais recorrentes. É sobretudo uma relação que ele denomina como sendo de comunidade, na qual o valor máximo está no fato de

32 Os CAICs - Centro de Atenção Integral à Criança - passaram a ser implantados em todo o país nos anos 1990, no âmbito do PRONAICA - Programa Nacional de Atenção Integral à Criança e ao Adolescente. Essa obra representou um marco na paisagem e na produção do urbano na região, conforme relatos em campo e observações realizadas ao longo dos últimos quinze anos.

33 "Minha infância era jogar bola, era brincar o dia inteiro, e a noite ficar ali na esquina ali. E as drogas chegou até nós né? Tava ali vendendo e a gente tava ali antes, a gente denominava: 'aqui é nossa esquina', era nossa área né, aí quando isso aí chegou, meio que virou uma boca ali...". Em diálogo com Foote-Whyte (2005), Gomes e Duarte (2008:187) chamam a atenção para o "papel das 'esquinas' e 'calçadas' como locais de agregação e sociabilidade das periferias urbanas", aspecto extremamente valorizado por Jefferson em relação ao Cidade Aracy, mesmo após o maior espraiamento do tráfico de drogas no bairro e o domínio de determinadas esquinas para este fim. 
ter sua rede de relações, ser conhecido e ter um sentido de mundo comum construído ali desde a infância.

Eu gostava muito de morar lá. Como ali eu fui crescendo, acompanhando o crescimento de tudo, você cria meio que raiz, né? Então eu tenho esse sentimento, eu gosto dali, porque as pessoas moram lá, tipo, a comunidade, elas são muito ligadas na comunidade mesmo, entendeu? Então... Pelo menos nós, ali, que vivia ali, falava: 'pô, a gente faz nosso mundo aqui.' Entendeu? A gente constrói nosso mundo junto, ali. Tipo, a gente não pensava: 'ah, vou sair daqui e ir pra outro lugar.' A gente não tinha muito essa mente. Eu vim ter, eu vim mudar isso de uns tempos pra cá, entendeu? Eu gostava dali, pensava: 'aqui é meu lugar, vou ficar aqui, vou arrumar um emprego... alguma coisa pra fazer aqui', entendeu? Tipo, não pensava: 'Não, vou sair daqui, vou...'. Eu sempre me imagine i ficando ali, onde eu cresci, onde tenho parentes, amigos, entendeu? (...) Eu vivia aquele mundo. Eu queria construir meu mundo lá. Como as pessoas de lá fazem lá. [Jefferson]

Eram também essas festas e shows que Beatriz já frequentava no Cidade Aracy, quando vieram a se conhecer na escola em que ela estudava, para a qual ele tinha sido transferido após ser expulso de outra escola. Esse processo de transição de escolas é interessante na trajetória de Jefferson, porque aponta para um sentido identitário de território que vai sendo transformado com o tempo, aspecto fundamental nos rumos que sua trajetória tomará a partir de então: após concluir o então primeiro grau no bairro, não havia ali escolas onde os jovens locais pudessem concluir os estudos. Era necessário subir a serra e isso representava, para ele e seus amigos, entrar em bairros de boy ${ }^{34}$, (com exceção da favela, o Jardim Gonzaga): por isso, a maioria dos jovens do Cidade Aracy optava por estudar em uma escola próxima à favela, logo no início da serra ${ }^{35}$, onde podiam ir inclusive à pé ${ }^{36}$. Para ele, portanto,

34 Beatriz denomina essa perspectiva anterior de Jefferson, que ele afirma ainda ser corrente entre os moradores do Cidade Aracy, como mente fechada, "pessoas que só querem viver no mundinho deles". Essa questão será retomada adiante.

35 Essa escola, denominada Aracy Leite Pereira Lopes (em homenagem à mãe de um industrial da cidade cujas terras originaram o bairro Cidade Aracy, assim denominado pela mesma razão), é ponto de convergência de diversas trajetórias que venho acompanhando desde o mestrado, funcionando como espécie de conexão entre localidades como Cidade Aracy, Antenor Garcia, o antigo orfanato, o Gonzaga - nas palavras de Jefferson, "todos bairros que falavam a mesma língua, o estilo de vida era o mesmo". É dessa conexão, pela escola, que se estabeleciam vínculos de amizade entre jovens que, mesmo seguindo caminhos distintos - alguns se envolveram com o tráfico e o crime, outros não permaneceriam amigos, configurando redes de relações bem menos duais do que a distinção trabalhadores/bandidos dá conta (Feltran, 2011) e que são fundamentais em trajetórias como as de Jimmy, Jefferson e também Marielen (abordada no Capítulo 3). Por estarem mesmo na base de redes de interconhecimento que, com o passar do tempo, extrapolaram a região sul da cidade, conectando diversos bairros populares, parece-me tratar-se do que Vera Telles denominou "operadores urbanos", em debate no seminário "Território, crime e ordenamento social nas margens da cidade", realizado em maio de 2012 no CEBRAP (Centro Brasileiro de Análise e Planejamento).

36 A prática de subir a serra que conecta a região do Cidade Aracy com o restante da cidade a pé ou de bicicleta, em função tanto da insuficiência do transporte público, quanto dos custos que tais deslocamentos cotidianos representariam no orçamento familiar, é comum ainda hoje, sobretudo entre os mais jovens: "aqui o carro era bicicleta, subir o morro a pé, descer o morro a pé. Agora é que 
passar a estudar nessa escola de boy foi inicialmente sentido como um castigo mesmo, até começar a fazer amizades e mudar de opinião:

Até então, a visão que a gente tinha do povo de cima aqui embaixo era: 'não, só patricinha, mauricinho.' [risos] Porque eram da Vila Prado, Redenção $0^{37}$, você passava lá, e todo mundo bem vestidinho e tal... Aí falava: 'não, não vô.' Aí fui e gostei. [risos] (...) Eu fui começar a pensar diferente quando eu vim estudar pra cá. Que eu vim estudar aqui pra cima, então você conhece pessoas daqui, entendeu? [Jefferson]

Beatriz foi sua primeira amizade na escola e, segundo eles, teriam provavelmente permanecido apenas amigos, se ela não tivesse engravidado. Ambos trabalhavam de dia e estudavam à noite, encontrando-se eventualmente fora da escola nos finais de semana. A gravidez inesperada trouxe muitas novas demandas, entre elas, a de onde morar, já que ele trabalhava de servente de pedreiro e ganhava pouco, e ela trabalhava como secretária sem registro em carteira e sabia que seria demitida com o avanço da gravidez. Sem condições de alugar uma casa e com a gravidez sinalizada como de risco, acabam indo morar juntos na casa da mãe dele $e^{38}$, onde ficariam até o sétimo mês de gravidez.

Se, para Jefferson, a experiência de uma casa que vai 'englobando' os agregados dos familiares quando estes passam a formar novos núcleos era algo quase natural - na já mencionada lógica do "quintal" em que foi criado -, para Beatriz tratava-se de uma situação nova, estranha, vivida com sofrimento. O trecho abaixo, apesar de longo, é bastante ilustrativo das divergências de perspectivas sobre a relação e o lugar da casa frente às dinâmicas familiares ampliadas:

Jefferson: ...isso é bem da onde que eu vim mesmo, de onde meu pai morava, que lá era um terreno, minha vó morava no fundo, meu tio morava desse lado, aqui era a casa do meu pai... Lá em São Paulo, até minha irmã tá morando lá agora, e aí vai, passando de geração em geração.../ Beatriz: é uma prática de morar em cômodo, de morar de favor... Nós também chegamos a morar assim, porque não tinha outra escolha... / Jefferson: No fundo da minha mãe tem dois cômodos e banheiro no fundo, que ela aluga pra uma senhora, e tipo, o meu irmão já puxou

mais gente lá embaixo tem carro; antes, quase ninguém tinha, só meia dúzia de filhinho de papai" [Jefferson].

37 Vale dizer que esta era exatamente a região onde Beatriz morava e que, nas representações oficiais sobre a cidade (notícias de jornais, atas da câmara - Cf. Rosa, 2008), configurava-se como uma região periférica da cidade, mas as falas de Jefferson fazem ver que, para uma parcela dos moradores da periferia extrema em que se configurava o Cidade Aracy - era o lugar de moradia de boys, evidenciando os jogos de perspectivas sobre a cidade. Por outro lado, ele indica que já havia também boyzinhos no próprio Aracy, os filhinhos de papai, que não colavam com ele e seus amigos, usavam outro estilo de roupa, às vezes tinham carro, atestando distinções internas àquele território desde o princípio. Mais recentemente, Jefferson, em seus deslocamentos socioespaciais após o casamento com Beatriz, será ele próprio alvo dessa distinção, sendo tachado de boy.

38 É interessante notar como a casa é sempre da mãe (mesmo nos casos em que foi autoconstruída pelo pai ou padrasto), tanto na fala dos próprios filhos, quanto na fala dos 'agregados', em todos os casos investigados. 
um outro quarto pra fora, o que pode vir a acontecer ali? Ele casar, puxar mais um e no quarto dele já virar casa... / Thaís: E vocês não quiseram fazer isso? / Jefferson: Naquela época pra mim era meu sonho. Eu queria, porque já tinha dois cômodos lá, beleza lá, e como eu vim disso daí, tipo assim, naquela época falava que era cortiço, né? (risos) / Thaís: Vocês mesmos falavam que era cortiço? / Jefferson: Não, em São Paulo lá. A minha mãe falava: 'ah, vocês moravam no cortiço, lá', não sei o quê, porque minha tia em cima, minha vó na outra casa, aí um sobrado desse lado, a casa do meu pai aqui, né, então... / Thaís: Você achava isso legal? / Jefferson: Eu achava legal, porque naquela época eu era moleque, então, pô, que da hora: saía pra fora, via meu primo, minhas primas; já descia aqui era minha vó; já virava na minha tia, beleza. Aí, fomos morar em Itaquera, Arthur Alvin, beleza, lá perto do campo do Corinthians lá, e tipo, COHAB, meu, você saía pra fora era mais de 50 nego, então você brincava, conversava, beleza. Então, quando eu vim com a Bia pra cá, era esse mesmo pensamento: 'pô, vou ficar perto da minha mãe, o pessoal tá tudo ali', então não tinha esse pensamento: 'ah, vou sair'... eu não me via morando em outro lugar... / Thaís: Até a Beatriz encrencar... (risos) / Jefferson: Isso... ela barrou um pouco, né, falou 'não, nós não vamos ficar aqui', não sei o quê... (...) / Beatriz: Não, de onde eu vim isso não existe! Quem casa quer casa, não existe isso de casar e continuar morando com mãe, de onde eu vim isso não existe! Não tem ninguém na minha família que casa e continua, não tem, isso é uma coisa que não é normal pra mim. / Jefferson: Eu aprendi isso quando fui morar com a mãe dela. / Beatriz: Sim, nós tivemos os dois lados. Minha gravidez era de risco, e eu precisava de alguém que tomasse conta de mim, eu nem tava na conversa, eles decidiram entre eles lá que eu descesse, porque as irmãs dele não trabalhavam, porque a mãe dele trabalhava, né, mas eram poucos dias da semana, então eu desci [para morar no Aracy]. Morei com sogra, com cunhados, tudo, era horrivel. / Thaís: Por quê? / Beatriz: Porque eu vim de uma família, que... sei lá, tipo... não que tenha mais educação... / Jefferson: Na casa dela, a tradição de casar é isso: casar e sair... / Beatriz: É, casar e sair... Os mais novos respeitam os mais velhos, todos respeitam a alimentação... Na casa dele era muita gente, então você tava fazendo janta, tinha quatro tomando café da tarde, isso era inadmissivel pra mim! Assim, hoje eu mudei bastante, mas na época era inadmissivel, fazendo janta, e a pessoa lá pegando a carne moída pra pôr no pão, sendo que a carne moída era pra mistura, sabe? Eu não aceitava isso. Era muita gente de domingo, até hoje, né? Aquele monte de gente, aquela falação, gritaria, eu falava: 'meu Deus, o que é isso! Onde eu fui parar?' [Jefferson e Beatriz]

O que para Jefferson sempre foi um valor, quase uma tradição - a vida num núcleo familiar ampliado, um espaço que garante a segurança dos vários membros da família, geração após geração -, para ela se associava a uma ideia de escassez, de precariedade, de dependência, sintetizada nas expressões - de claro menosprezo morar em cômodo e morar de favor, situações a que ela considera que teve de submeter-se pela falta de escolha decorrente de estar grávida e não terem condições financeiras para constituírem um núcleo familiar independente, o que seria a tradição de onde ela vinha: casar e sair de casa. Esse conflito de valores e perspectivas frente ao lugar da casa na construção de um projeto familiar permeará toda a trajetória habitacional do casal.

Quando Beatriz vai chegando ao fim da gravidez e realmente perde o emprego, a sogra dá uma espécie de ultimato a eles, pois aquele arranjo era temporário - ela não 
queria uma família com bebê permanentemente dentro de sua casa, já bastante adensada ${ }^{39}$. A opção seria eles irem morar nos cômodos do fundo, contribuindo com alguns gastos, ou procurar outro lugar para ficar.

Beatriz: eu fui, mas por causa da gravidez de risco, já sabendo que seria temporário... A mãe dele já falava, né: 'não dá pra ficar uma criança aqui, não tem condição'. Então lá com meus sete meses de gravidez eu falei: 'fio, e agora?' Ele ganhava pouco, eu não tava trabalhando. (...) Por ele, ia pros fundo, porque a mãe dele tem dois cômodos no fundo, e eu falei que não queria, falei: 'não, a gente mudando ali, você nunca vai sair dali, ali você vai aumentar mais um cômodo, quando não caber...'/ Jefferson: Porque ali serviu, tipo, minha irmã casou e foi morar lá, ficou maior tempo lá, então já era mais pessoas... eu sempre fui acostumado cheio de pessoas, então minha irmã lá, meu cunhado lá e os parentes deles lá, também, então era maior... tipo, pra fazer churrasco era dois palito. / Beatriz: Aí, eu falei assim com a minha sogra: 'não aceita que a gente venha morar no fundo, porque senão a gente nunca vai sair daqui, daqui a pouco o Jefferson, na hora que ver que tá apertado porque a criança cresceu, constrói mais um cômodo, daqui a pouco eu engravido de novo e assim vai'. Porque espaço tem, é dois cômodo construído, e espaço é que não faltava, então o que ele ia fazer? Ele ia aumentar a casa, e a gente nunca ia sair dali... e eu vim de uma família que quem casa quer casa, e não existe isso. [Jefferson e Beatriz]

Se, para Jefferson, seguindo os passos de tantos outros casais de sua família e das famílias com as quais convivia no bairro, esse seria o caminho natural - e, mais do que isso, até sonhado, como visto no trecho anterior -, Beatriz via essa opção como fim de linha, numa espécie de associação entre o tipo e o lugar de moradia - um cômodo na casa da sogra - e um destino individual, familiar e social - seguir engravidando e deixar de trabalhar, nunca mais sair do Cidade Aracy, não ter perspectiva de crescer. Mesmo sem condições de escolher, esta definitivamente não era uma opção para ela.

Entretanto, como ela estava desempregada, e ele, apesar de ter conseguido seu primeiro emprego registrado como servente de pedreiro em uma construtora (curiosamente a mesma construtora a construir a casa e o bairro onde vivem hoje), tinha um salário bastante reduzido, ainda não havia a menor possibilidade de conseguirem alugar uma casa e sustentar uma família naquele momento. Com o filho às vésperas de nascer, a opção foi pedir socorro à mãe dela, que, apesar do desgosto com a filha grávida (e, ainda pior, de um rapaz da Cidade Aracy!), decidiu ajudar,

39 Embora a mãe de Jefferson os tenha abrigado em sua casa temporariamente, os irmãos dele não receberam bem o arranjo, sobretudo uma das irmãs que ainda vivia na casa, que teve de ceder o quarto que ocupava sozinha e passar a dividir o outro quarto com os dois irmãos. Beatriz narra, inclusive, episódios em que os cunhados a maltratavam, grávida, criando situações para que ela caísse, zombando da barriga dela, sujando o quarto deles logo após ela fazer a faxina, uma espécie de 'bullying' doméstico, o que Jefferson confirma, rindo, defendendo-os: "eram tudo moleque, e você era mesmo a intrusa na casa! (risos)". Tais memórias atestam que a dinâmica do "quintal", embora naturalizada para Jefferson, era prenhe de conflitos. 
acreditando que assim a filha não voltaria mais a morar naquele bairro. Deste modo, em 2005, pouco antes de o filho nascer, eles se mudariam para lá.

Beatriz: Aí falei: 'na casa da minha mãe já tem um cômodo no fundo' - não tinha muro na casa da minha mãe um tempo, aí construíram lá, ficou bem esquematizado, 'é só construir uma cozinha'... E esse aqui: 'ah não!', por ele não ia! Eu falei: 'eu tô indo, sua mãe não quer a gente aqui' - não é que não queria, ela não tinha condição mesmo, coitada. (...) E a casa da minha mãe é bem grande. Ela construiu mais um cômodo no fundo, emendou com outro que já tinha, aí fomos morar lá. Na Redenção. Fomos morar com ela, ficamos lá pouco tempo. Não deu dois anos. O Jefferson mesmo, quando morava lá, não era muito feliz (risos)... Ele odiava morar lá (risos). Talvez assim, por ser com a sogra, mas era separado... Mas é que tudo dele era na Aracy, os amigos na Aracy, os contatos do Rap na Aracy, tudo na Aracy. / Jefferson: Ah, eu mesmo não me adaptei lá em cima. Eu ficava louco, porque ela morava no Belvedere lá, no Redenção. Aquelas ruas que você quase cai no buraco ali do Aracy. Então, no começo, eu saía, de noite, assim, saía pra fora, olhava pra um lado era um buracão, olhava pro outro, uma subida enorme, aí eu olhava o Aracy e: 'nossa, o que será que os cara tá fazendo lá agora...' (risos). E era longe! / Beatriz: Aí, era época de carnaval, maior batuque no Aracy, pegando fogo (risos). / Jefferson: É, eu ficava louco. Fiquei mal pra caramba. / Beatriz: É que Aracy é um bairro movimentado demais, cê senta na rua e um monte de gente já vem conversar com você. Então, pra ele, foi terrível. / Jefferson: Terrível! E eu sempre morei em lugar agitado. Igual, morei em Itaquera, na Cohab I, então você saía pra fora e você via os vizinhos, né? Na Aracy também, conhecia todo mundo, Aracy inteira, então, aí cê vai pra um lugar onde não conhece ninguém, não tem ninguém na rua... / Beatriz: O Jefferson sumia, cadê o homem? Olhava pra cima da laje, tava ele lá, olhando pro Aracy, tipo, na maior saudade! / Jefferson: Eu surtava. / Beatriz: De domingo ele acordava 7h30, 8h00, a gente num tinha carro, tinha que pegar ônibus, e ele: 'vamo pra Aracy'. Às vezes eu com um monte de roupa pra lavar, e ele: 'vam'bora'. Aí eu catava o Fabiano e: 'vamo'! Ah, se eu não fosse! Nossa! Ele tinha mania de Aracy, que só por Deus. Até hoje, né? Domingo, não importa onde nós vamos. A primeira parada é no Aracy. (Risos). [Jefferson e Beatriz]

Seria a vez de Jefferson sofrer com a adaptação à casa e às dinâmicas de uma família que não era sua e, ainda por cima, passar a morar em um dos bairros que ele e seus amigos consideravam de boy. Porém, mais do que tudo isso, o sentimento de sofrimento que ele associa a esse período relaciona-se com o fato de deixar de morar no Cidade Aracy, de estar distante de sua família, seus amigos, das práticas cotidianas associadas àquele lugar - sobretudo a dimensão do movimento do bairro, tão caro a ele. Se, em alguns contextos, a ideia de movimento pode ter sentido negativo, sendo associada ao mundo do crime ${ }^{40}$, também é recorrente entre meus interlocutores esta

40 Feltran (2011, 2009:19), em pesquisa que se propôs a etnografar as fronteiras políticas que se conformam entre as periferias da cidade e o mundo público, num contexto de transformações radicais ocorridos nas últimas décadas, destacou como principal novidade "a presença marcante do mundo do crime nas dinâmicas sociais cotidianas, em múltiplos sentidos". O autor assim sintetizou os significados da expressão mundo do crime, usual nas periferias urbanas paulistas: "Trata-se de expressão que designa o conjunto de códigos sociais, sociabilidades, relações objetivas e discursivas que se estabelecem, prioritariamente no âmbito local, em torno dos negócios ilícitos do narcotráfico, dos roubos, assaltos e furtos." Entretanto, o próprio autor alerta para o fato de que "o exame dessas 
outra acepção, positiva, associada à ideia de bairro movimentado, que remete a uma concepção de vizinhança - "você saía pra fora e você via os vizinhos", "todo mundo na rua" - e àquele sentido combinado de pertencimento e segurança sintetizado nas já mencionadas expressões ser conhecido e ter conhecimento ("ali eu conhecia todo mundo", "conheço cada pedaço daquele lugar", "todo mundo me conhece").

Some-se a isso o fato de que, na casa e no bairro dela, ele era alvo do preconceito comumente destinado aos moradores do Cidade Aracy, o que contribuía ainda mais para que ele se sentisse mal morando ali:

Jefferson: Quando eu fui pra casa da sua mãe, era só: 'nossa, a Bia casou com um cara da Aracy!'/ Beatriz: Sim, ele passou por isso. / Jefferson: Mano. 'Casou com um mano da Aracy!' / Beatriz: Ninguém fala mano! / Jefferson: Assim, ó, eu descia a ladeira lá, todo mundo abria caminho pra mim (risos). (...) Eu me sentia meio recriminado. O lugar, bem mais desenvolvido, as casas mais desenvolvidas, né? Entendeu? E eu lá... (risos) Pô, estranhei. / Beatriz: Sim. Você passou por isso. Só que assim, eu acho muito mais fácil você tá no ruim e se acostumar com o melhor, do que tá no melhor e ter que se acostumar com o ruim. / Jefferson: Não! Às vezes o seu melhor não é o meu melhor (risos). [Jefferson e Beatriz]

É interessante notar que o sentir-se recriminado tem a ver não somente com esse preconceito direcionado a ele por conta de seu lugar de origem na cidade, mas também com uma sensação de não pertencer àquele lugar, que, se está relacionado com aquela dimensão de ausência de movimento - "não conhecer ninguém", "não ter ninguém na rua", "não ter nada para fazer" - também é por ele associado diretamente às condições socioespaciais do bairro de Beatriz, mais desenvolvido, em suas palavras, melhor, nas de Beatriz, as quais fariam com que ele se sentisse deslocado. As distintas perspectivas do casal sobre o que seria mais ou menos desenvolvido, melhor ou pior em termos socioespaciais têm por referência comum o Cidade Aracy e apontam para sistemas de classificação e hierarquização socioespaciais vigentes nas camadas populares ${ }^{41}$.

Com tudo isso, ainda assim permaneceram por dois anos na casa da mãe de Beatriz, sobretudo porque, durante esse período, como podia contar com a ajuda dela para

fronteiras do 'mundo do crime', traçadas no tecido social, não pode ser feito sem que estejam também em pauta as relações que esse "mundo" trava com as dinâmicas sociais consideradas legítimas" (Feltran, 2008c:94). Vieira (2011: 281, 296), a partir de etnografia realizada em instituições de cumprimento de medidas socioeducativas no estado de Santa Catarina, identifica a mesma expressão em uso nativo, argumentando também por sua apreensão como algo que "não é estanque em relação à sociedade abrangente" e remetendo, em franco diálogo com Feltran, "a uma noção de fronteira porosa: há sim especificidades, mas há trânsitos de valores, de moralidades, de objetos, de sujeitos" entre tal mundo e as dinâmicas sociais consideradas legítimas, como a escola, a família, a religião, o trabalho, a justiça, o Estado. Sobre o progressivo tensionamento que tal "mundo do crime" passa a estabelecer frente a "outros sujeitos e instâncias legítimas das periferias da cidade", veja-se, além do próprio Feltran (2010:592), também Telles (2009); Biondi (2010); Hirata (2010), dentre outros. As concepções êmicas de mundo do crime e de movimento serão desdobradas no Capítulo 3.

41 Os quais serão retomados, em maior profundidade, no Entremeio III. 
cuidar do filho, ela pôde voltar a trabalhar. Jefferson também conseguiu, logo após o nascimento do filho, seu primeiro emprego em fábrica, por indicação de um amigo do hip-hop, e passou a ganhar um pouco melhor. Jovens, eles aproveitavam a boa vontade da mãe dela, que cuidava do neto para trabalharem e para ele finalizar os estudos, e começaram a sair direto pra balada. Passavam todos os finais de semana no Aracy, com a família dele e os amigos, deixando para ela as tarefas de limpar a casa e lavar as roupas. Além disso, como não tinham que pagar aluguel e só contribuíam com uma ajuda de custo para as contas de luz e água, Jefferson gastava todo o salário em roupas, CDs de hip hop, shows. A gota d'água, para a sogra, foi quando ele apareceu com um celular novo e fazendo planos de comprar um carro ("ela via tudo nosso, ouvia nossas conversas, porque era tudo junto, né?" - Beatriz): já que eles estavam esbanjando, estava na hora de arrumarem uma casa para a família e criar juízo - assim ela os expulsa de casa.

Nesse mesmo período, Beatriz fica desempregada novamente, e a solução foi passar mais uma temporada na casa da mãe dele, enquanto "caçavam casa para alugar no Aracy": a expressão é fiel à situação disputada do aluguel informal no bairro, relatada por diversos interlocutores, na qual é bastante improvável conseguir alugar uma casa sem contar com indicações de conhecidos, conforme apresentado no Capítulo 1.

Aí fomos embora, não tinha onde ficar, fomos pra casa da mãe dele. Aí, de imediato que a gente chegou na casa da mãe dele, ela sabia nossa situação, eu sem emprego, a irmã dele falou assim: 'ó, tem uma amiga minha que tá indo embora, ela vai alugar a casa, vocês querem?' A gente falou que queria sem nem ver, sem saber como era a casa. Fomos lá na mesma hora, de noite, fomos na porta e falamos: 'então tá bom, vocês vão sair, a gente já entra'. [Beatriz]

Assim, a primeira casa alugada no Aracy, em 2007, foi conseguida seguindo o script de funcionamento desse "mercado informal de aluguel" no bairro e, com isso, em função da pressa, acabaram alugando uma casa descrita por eles como super ruim. Essa experiência - a primeira casa onde eles moraram como um núcleo familiar independente - é tida por ambos como a pior, em termos de localização (em relação a acesso a serviços, comércio, ônibus e também à casa da família de Jefferson, mas sobretudo por ser no Cidade Aracy $\mathrm{II}^{42}$, no limite do bairro com uma mata), de tamanho (a casa se constituía de dois cômodos e um banheiro) e por ser inacabada e mal executada (chovendo dentro, sendo muito quente, não possuindo piso, reboco e portas entre os cômodos), para destacar algumas das críticas feitas por eles a essa primeira casa.

42 "Uma casa super ruim, muito longe. Assim, no fim do bairro mesmo, longe de ponto de ônibus... No Aracy II. Bem longe!". O fato de ser na Aracy II conecta as opiniões, quase sempre divergentes, de Jefferson e Beatriz sobre o Cidade Aracy: há uma clara distinção, tanto para ele que é cria do bairro, quanto para ela que é de fora, de que o Cidade Aracy II é pior do que o I, anunciando distinções bastante importantes para a compreensão do local. 
Mas, além disso, ela está também associada ao período em que enfrentaram as maiores dificuldades, pelo fato de terem que manter uma casa sozinhos, arcando com todas as despesas; de Beatriz estar desempregada e morando num local onde não podia contar com nenhum apoio, pois não tinham relações na vizinhança e a casa era longe da casa da mãe dele; de não terem móveis e eletrodomésticos básicos (" $a$ gente já entrou sem nada, sem armário, sem geladeira, sem nada"), nem condições de adquiri-los - para elencar algumas das narradas com mais ênfase. Se, até então, o começo da vida da nova família tinha sido difícil pelas agruras da coabitação, agora ela se tornara terrível. O próprio valor do aluguel ( $R \$ 130,00$ na época), era também um problema decorrente de terem alugado às pressas, não tanto pelo valor em si, mas por estar acima do que sabiam valer uma casa como aquela no bairro; em contrapartida, não tinham que arcar com as contas de água e luz, porque a casa tinha ligação direta.

E, acima de tudo, essa casa materializava o sofrimento vivenciado por Beatriz pelo fato de terem regressado ao Aracy, de estarem iniciando a vida como núcleo familiar independente ali, o que só piorava com o fato de estarem morando num pedaço do bairro onde mesmo Jefferson não tinha muitas relações, e ela acabava sendo tratada como alguém de fora, uma estranha:

Beatriz: Olha, foi por muito amor que eu fui pro Aracy, porque, meu, eu chorava! Eu gostava do Aracy como passeio, descia, via meus amigos, ia nas festinhas e casa! Segura, eu tava segura! Agora, quando eu fui mesmo morar no Aracy, Senhor Jesus! Eu me sentia mal, não conversava com os vizinhos.../ Thaís: Você tinha medo? / Beatriz: Ai, eu não gostava! Tipo, assim... Não é que eu tinha medo... Eu não tinha medo porque eu sempre fui bocuda. Mas eu não gostava das pessoas. Porque assim, no meu bairro, Redenção, cê anda à noite na rua, se tem uma pessoa na rua, ela vai te cumprimentar: 'Oi! Tudo bem?'. No Aracy não, se tem uma pessoa na calçada, cê olha: 'Que foi?' / Jefferson: Ah, não é assim [risos]. / Beatriz: É assim, sim! / Thaís: Mas por que você acha que isso acontecia? / Beatriz: Porque eles não me conheciam! Se eu tava com ele, que é conhecido, normal. Mas se eu andava sozinha por ali, Senhor! [Jefferson e Beatriz]

Essa passagem é interessante pra mostrar como o que é um valor do bairro Cidade Aracy para ele - "ser conhecido", "ter conhecimento" - para ela, é vivido justamente como o oposto - ela é desconhecida, uma estranha, veio de cima pra casar com alguém dali, não se identificava (e não queria ser identificada) com aquelas pessoas. E se isso é relatado por ela como uma das principais causas de seu sofrimento por estar morando no bairro, é sobretudo porque está articulado com o fato de que ela relutou até o fim em admitir para si mesma e para suas redes de relações anteriores - familiares, amigos, colegas de escola e trabalho - que agora estava definitivamente morando no Cidade Aracy.

Embora eles estivessem decididos a sair da casa assim que a vida melhorasse um pouco - já que mesmo Jefferson se sentia "excluído do bairro" morando ali, pela distância não apenas da rede de conhecidos, mas também de pontos de ônibus, de 
serviços, das ruas de comércio, do centro do Aracy -, após apenas alguns meses, eles sofreriam, pela primeira vez, as vicissitudes do mercado informal de aluguel: a proprietária, que tinha saído da cidade para tentar a sorte em outro lugar, retorna e pede a casa de volta para ela própria morar. Numa situação típica dos contratos de boca que vigoram nesse mercado ${ }^{43}$, eles não tiveram direito algum, nem sequer um tempo para caçar outra casa melhor, passando a sofrer o assédio cotidiano da proprietária e de seu marido, o que gerava conflitos, nos quais a violência era iminente.

Porque essa moça foi embora, mas não deu certo pra onde ela foi, ela voltou e quis a casa. Aí a gente entrou em desespero porque ela não queria dar um tempo pra gente sair, ela tava todo dia na porta de casa, que queria a casa, todo dia. 0 marido dela é encrenqueiro, então eu evitava do Jefferson e esse cara conversar, eu ia na frente conversar com a mulher, que o cara realmente não era boa coisa. Mas eu bati muita boca com ela. [Beatriz]

Uma nova casa seria conseguida, mais uma vez, através de suas redes de relações e relativamente rápido, o que eles consideraram uma sorte tendo em vista a dificuldade já narrada de conseguir alugar um imóvel no bairro. Um amigo de Jefferson estava saindo de uma casa, ficou sabendo que eles estavam na caça e perguntou se queriam ficar com ela. Mais uma vez no desespero, eles aceitam sem nem conhecer a casa: o amigo os indicou para a proprietária e, em poucos dias, fizeram o contrato de gaveta e a mudança.

Entre 2008 e 2011, eles morariam nessa casa, considerada bastante melhor que a anterior, apesar de, como aquela, ter apenas dois cômodos e um banheiro ${ }^{44} \mathrm{e}$ localizar-se no Cidade Aracy II. Mas a casa tinha laje e piso, e eles negociaram com a proprietária a colocação de azulejo e piso no banheiro, descontando do aluguel: essa diferença em termos de acabamentos é algo bastante relevante na qualificação que fazem da casa. Além disso, "mesmo sendo na Il também", a casa situava-se no início

43 A situação é recorrente nesse mercado informal de aluguel que predomina no bairro, ancorado em contratos de boca. Há ainda a modalidade do contrato de gaveta, mas este não oferece muito mais garantias, como visto anteriormente. Entretanto, a flexibilidade que esse mercado oferece, se pode ser favorável aos proprietários, como neste caso, também pode favorecer os inquilinos, como visto no capítulo anterior, e como veremos em relação à segunda casa alugada por Beatriz e Jefferson. Esse é um dos motivos - ao lado da ausência de burocracias e do valor mais baixo - relatado pelos interlocutores e observado em campo para o predomínio dessa forma de aluguel nas periferias, mesmo após a entrada das imobiliárias no mercado local.

44 Jefferson faz questão de ressaltar uma característica curiosa da casa: o fato de que era uma casa única, grande, onde vivia uma família, e, quando o casal se separou uma reforma dividiu a casa na metade: uma metade ficou para o marido, que permaneceu vivendo ali, e a outra metade ficou para a mulher, que saiu do bairro e passou a alugar a casa. "Só que a casa, ela era assim, uma casa grande, enorme, só que aí, o casal que morava lá se divorciou, e aí como tinha criança, o que fizeram: dividiram a casa no meio, fizeram um muro no quintal de fora a fora, dividiram os portão, e dois cômodo e um banheiro ficou uma casa, e dois cômodos e um banheiro ficou a casa dele, então era dividido, mas... Era normal, uma divisão normal, mas o engraçado é que era a mesma casa". 
do bairro, o que fazia toda a diferença, principalmente pela maior proximidade das casas da mãe e da irmã de Jefferson, facilitando os deslocamentos cotidianos, bem como possibilitando uma rede de apoio com os cuidados do filho para que Beatriz pudesse trabalhar. $O$ aluguel era um pouco mais caro (começaram pagando $R \$$ 150,00 e, no último ano, estavam pagando $\mathrm{R} \$ 230,00$ ), e eles passaram a ter gastos com água e luz - "ali era tudo normal" -, mas as condições e a localização da casa compensavam.

Por outro lado, as boas memórias associadas à casa se devem ao fato de que, durante o período em que viveram ali, a situação de vida da família também foi melhorando. Beatriz conseguiria um novo emprego - na noite, como dublê de faxineira e garçonete, mas ganhando bem se comparado aos outros empregos que ela já tivera -, e Jefferson, após ser mandado embora de uma fábrica (segundo ele, por vontade própria, pois estava descontente com o serviço, queria acessar o seguro-desemprego e poder se dedicar ao novo grupo de rap que estava formando) e ser admitido em outra com salário pior, conseguirá, em 2009 - novamente por indicação de um amigo -, um emprego em uma distribuidora de alimentos, ganhando quase o triplo dos salários que vinha recebendo nas fábricas. Segundo Beatriz, "foi ali, naquela casa, onde a gente começou a conseguir as coisas que não tinha, que nunca tive: fogão, geladeira e até um carro ${ }^{45}$, um fusca velho do pai dele".

É nessa época que Beatriz, motivada pela melhora nas condições de vida, começa a pensar na possibilidade de conseguir uma casa própria, tão logo quitaram a compra do carro. A alternativa da autoconstrução foi descartada de imediato: "A gente pagava aluguel; ainda pagar terreno e construir, era impossível!" As primeiras

45 O fato de possuírem um carro já há alguns anos revelou-se um tema importante para eles, tendo aparecido espontaneamente diversas vezes em nossos encontros. Nas primeiras vezes, eu não entendia bem, porque me parecia que eles acionavam tal tema sempre com um ar de justificação, como se tivessem transgredido alguma regra pelo fato de terem tido um carro antes mesmo de terem uma casa própria. Aos poucos, fui compreendendo que, por um lado, isso representou uma ruptura com um modo de viver com o qual não concordavam - a dependência de um transporte público ineficiente ou de outras pessoas que possuíam transporte próprio, sobretudo pelo fato de terem criança pequena e terem vivenciado situações de emergência - ; por outro, eles realmente se sentiam em posição de justificar-se perante parentes e amigos pelo fato de investirem em um carro quando ainda viviam de aluguel e passavam dificuldades: não se tratava de esbanjamento, nem de ostentação, mas de algo visto como ainda mais necessário do que a casa, naquele momento, por associarem a dependência do transporte público a uma dimensão de sofrimento cotidiano. "De manhã, pegar ônibus com criança de colo, no Aracy é impossível. Porque os ônibus são lotados. Ninguém te respeita! Ninguém te dá um banco pra sentar. Nossa, eu sofria muito! (...) Tipo, quer levar no médico sete horas da manhã, antes de ir pro trabalho? Impossível! De ônibus, impossível. Passou mal à noite, não tem como ir pro hospital, porque você vai voltar como depois? Se a criança fica lá tomando soro até umas onze da noite, como já aconteceu comigo, não tem mais ônibus pra voltar. E aí, faz como? (...) Então, naquela época, o carro foi mais importante que a casa... Porque era muito sofrido!". Em um segundo momento, a troca do carro velho por um melhor, associada à aquisição da casa própria, será vista entre os pares como uma transformação radical de Jefferson, que eles sempre procuravam esclarecer para mim, nas entrevistas, acionando os mesmos argumentos com os quais costumam se explicar para eles. 
oportunidades concretas apareceram no Antenor Garcia : "essas casas que o pessoal vende barato, sabe?", diz Beatriz, referindo-se a uma prática comum na região, espécies de 'negócio de ocasião', em que, em função de dinâmicas familiares cambiantes (como separações, brigas entre irmãos, mudanças de cidade), as pessoas precisam vender a casa com alguma urgência e querem o dinheiro na mão. Por duas vezes, esses negócios informais não deram certo - uma, porque, quando conseguiram o dinheiro, a casa já tinha sido vendida; outra, porque, quando foram fechar a compra, a proprietária desistiu de vender, pois tinha se entendido com o marido. Algum tempo depois, fizeram simulações "desses financiamentos pela CAIXA" para aquisição de algumas casas próximas de onde moravam, mas as parcelas ficavam acima do que podiam gastar com moradia, e ainda era necessário ter recursos para dar uma entrada: "a gente falou: 'pô, não é pra nós', porque exigia ter uma renda boa, que a gente não tinha na época".

Beatriz: Aí, a gente viu que não ia dar. Nessa época, eu tava toda empolgada pra comprar a casa! (...) Mas era impossível, não tinha como, ele ganhava $R \$$ $1.000,00$ e a parcela ficava quase $R \$ 700,00$. Aí passou na nossa cabeça assim, vamos trocar o carro e continuamos morando de aluguel. O que a gente ganhava e o que a gente pagava de aluguel era tranquilo, porque pagava duzentos de aluguel, então era pouco, não morava bem mas pra gente tava tranquilo assim, aí.../Thaís: Não morava bem por quê? / Beatriz: Ah, a casa era assim, dois cômodos, o Fabiano dormia junto, não tinha privacidade, a gente queria ter... / Jefferson: Privacidade... A visita chegava tinha que ficar lá... / Beatriz: Tinha que sentar na cama. A visita sentava na cama! [Jefferson e Beatriz]

Com isso, desistem da casa própria e compram um carro melhor, financiado. Entretanto, as condições da moradia já eram insuficientes: eles queriam mais privacidade, mais espaço, mais conforto. Jefferson queria morar bem, mesmo que isso significasse gastar com aluguel todo o recurso que poderiam ir guardando para, futuramente, adquirir uma casa própria, o sonho de Beatriz.

Aí chegou uma época que o Jefferson queria porque queria alugar outra casa, porque a gente ia fazer um churrasco e a gente tinha que escolher quem ia, porque não cabia todo mundo, verdade! No dia que resolvia ir todo mundo, a gente passava sufoco! No dia que tava quente assim, mandava pro quintal, porque o quintal ainda era grande, mas se começasse a chover e tivesse que entrar dentro de casa, não cabia! Ai ele encanou que ia alugar uma outra casa, nem se fosse $R \$ 500,00$, porque ele queria morar bem, queria fazer churrasco... $E$ eu segurando: 'não Jefferson, se a gente pagar $R \$ 500,00$ de aluguel'... sem contar que toda mudança que você faz você tem gastos, porque às vezes faltam móveis, o móvel quebra na mudança... / Jefferson: Uma casa de quinhentos conto, na época, era uma casa boa, com azulejo, tudo./ Beatriz: Dois quartos./ Jefferson: Então, daria, mas eliminaria a possibilidade de comprar nossa própria casa, né?/ Beatriz: Na época ele queria né, mas eu barrei um pouco, falei: 'não, eu já fui na Caixa, vou tentar ir de novo'. Porque aí começou a ter as casinhas da Caixa, né? No Aracy ainda não tinha, mas no Cruzeiro, por ali, já tinha. Eu tava vendo, e tal, aí chegou o amigo dele falando daqui. [Jefferson e Beatriz] 
Ela consegue convencê-lo a esperar um pouco mais. O ano é 2010 e, como Joana, ela fica sabendo das inscrições na PROHAB para o sorteio de casinhas. Mesmo sem saber onde seriam, ela se inscreve: "Vai que saía, né? Mas na Prohab a gente foi por ir, assim. Nunca corremos tanto atrás, nem fomos no sorteio, nada." Em paralelo, busca informações sobre as casinhas da Caixa (unidades avulsas promovidas por pequenos construtores no âmbito do Programa Minha Casa Minha Vida) no bairro Cruzeiro do Sul (relativamente próximas à casa da mãe dela), mas Jefferson não admitia a hipótese de sair do Cidade Aracy. Já Beatriz, por outro lado, acreditava que essa seria a oportunidade de ela sair de lá, já que, ao longo de quase seis anos vivendo ali, jamais se acostumara com aspectos da vida no bairro.

Um deles, talvez o mais importante para ela, era a proximidade cotidiana com a violência e o mundo do crime, principalmente em função de ter um filho pequeno. Um de seus principais argumentos quanto aos motivos por que desejava deixar de morar no Cidade Aracy tem a ver com a tranquilidade na criação do filho, a possibilidade de deixá-lo brincar fora de casa sem contato com violência e com todo esse mundo ${ }^{46}$ : o Cidade Aracy seria um lugar impróprio para criar o filho.

Beatriz: Quando a gente conversava em comprar terreno, ou comprar uma casa ele: Aracy! E eu: Não! Ele não gosta que eu fale, mas eu sempre falei, eu não queria criar meu filho no Aracy. / Thaís: Por quê? / Beatriz: Não, é, assim. Muito bandido mesmo, mulheres que não presta, boteco, boteco, boteco. As crianças com onze anos já estão fumando. Eu acho que é um mau exemplo, sabe? Ele não concorda. / Jefferson: Só que eu sempre falei pra ela, pô, eu sou a prova viva, entendeu (risos)? De que nem todo mundo é assim. / Beatriz: É. Ele, no caso, ele veio com nove anos, a mãe dele soube criar todos. Os irmãos dele, até hoje, até ele mesmo, a mãe falou, abaixa a cabeça e sai andando. Concorda ou não concorda, a mãe tem razão. Os filhos dela, é que nem eu falo, eu queria que o meu filho fosse que nem um deles. Todos educados. Cresceram no Aracy, mas não parece (risos). Foi uma criação boa, mas eu não sei se eu vou conseguir dar essa criação. E o Fabiano, ele já nasceu ali, praticamente já nasceu no Aracy, criado ali, e a gente já teve umas situações difíceis no Aracy. Já tivemos com o Fabiano, de vizinho ensinando a roubar, brigas violentas por causa de brinquedo.... (...) Aí eu tinha que... eu ficava de portão trancado, e ele não brincava com vizinho nenhum. Não brincava, eu não deixava. Tipo, vou morar num bairro onde tenho que deixar meu filho trancado em casa? (...) Assim, por mim, eu moraria em qualquer lugar. Mas, depois que eu tive filho, eu acho que não. Se eu posso criar num lugar melhor, porque criar ele no Aracy? [Jefferson e Beatriz]

Nessa mesma seara, ela também nunca se acostumou com uma espécie de naturalização da violência que ela identifica como sendo característica entre os

46 Vale dizer que Beatriz teve ela própria um contato muito próximo com o tráfico de drogas antes de morar no Cidade Aracy, tendo chegado, inclusive, a atuar como aviãozinho (jovens que fazem o leva e traz das drogas ilícitas) até começar a se relacionar com Jefferson. 
moradores do bairro, sobre a qual ela ainda hoje tem muitas divergências com Jefferson:

Beatriz: Ele adora ali, porque ele conhece todo mundo... Sim, só que, tipo, e o lado de você acordar e saber que um amigo seu acabou de levar cinco tiros... Quantas vezes já não aconteceu isso? / Jefferson: É, pra nós isso... ficou normal. / Beatriz: Normal! Mas pra mim não é normal. / Jefferson: Porque as pessoas convivem, eu convivi com isso. / Beatriz: Mas, no caso, eu... pra mim não é normal. Tipo, você acordar de manhã e ver um corpo lá na frente da sua casa. Não é normal. Tipo, eu, beleza. Mas meu filho eu não queria que visse. (...) E, assim, eu passei por várias situações dessas no Aracy. Da gente ir comprar uma pizza... isso aconteceu há dois meses atrás, tava voltando pra casa, um morto lá! E era amigo dele ... Perdi a vontade de comer a pizza! / Jefferson: Eu não. Já acostumei. / Beatriz: Tá vendo? Não é normal isso. E ainda era amigo dele! [Jefferson e Beatriz]

As relações de vizinhança também eram um problema para ela: além de não se sentir bem aceita por não participar das relações que se teciam na rua - "o Jefferson gostava daquele agito, daquele movimento; eu não. Pra mim, era da porta de casa pra dentro, no máximo na casa da minha sogra, das amigas que eu já tinha ali. Nem meu filho eu queria que ficasse brincando na rua" -, a ela incomodava, sobretudo, a convivência próxima a dinâmicas familiares que ela julgava violentas, nas quais ela tendia a interferir, por vezes até chamando a polícia. Mas Jefferson a repreendia, por ter conhecimento de uma espécie de política a ser respeitada nas relações de vizinhança em um bairro como o Aracy ${ }^{47}$ :

Beatriz: Na casa que a gente morou antes de vim pra cá, eu queria lavar louça e não podia, porque o vizinho da frente tava espancando o filho. Aí eu me estressava, a vontade que eu tinha era de catar ele pelo pescoço. Aí eu falava pro Jefferson, e ele: 'fecha a janela e entra.' E eu: 'não! Não é assim!', sabe?! / Jefferson: Mas é assim que se resolve (risos)... vivendo ali. / Beatriz: Mas eu não aceitava isso! / (...) Jefferson: Ah, pô, ali tem gente de todo tipo assim, né? Aí, às vezes, não se dão, então o que eu posso fazer? É aquilo: se eu não puder ajudar, eu não atrapalho, né? Então, vamo supor, se o cara tá resolvendo uma richa ali, eu solteiro, se é um conhecido, alguma coisa, pô, vou pro arrebento, não tô nem vendo. Mas com família, hoje em dia, eu penso, né: 'vocês tão brigando, eu não conheço, não é comigo, passa reto, vamo embora', entendeu? Se eu não puder ajudar eu não atrapalho, deixo o pau comer pô, não é comigo. / Beatriz: Eu já sou o contrário, eu não consigo... / Jefferson: Era isso, era, 'pô, eu não vi nada'... Essa é a política de morar num bairro como o Aracy. / Beatriz: Tinha que ser assim, mas eu não concordava, me fazia mal... / Jefferson: A política da boa

47 É de se reter, aqui, mais um componente desta categoria êmica ter conhecimento, que se associa aos sentidos já apresentados no Capítulo 1 (ver especialmente nota 51): aquele associado a um conhecimento de certas dinâmicas socioespaciais que somente quem é de dentro, nascido e criado ou morador antigo de um determinado território poderia ter, com forte dimensão geracional e, muitas vezes, associado à inserção em redes sociais específicas (como no caso de Jimmy e Jefferson, aquelas ligadas ao circuito hip-hop), estando aí implicado, inclusive, o conhecimento relativo a viver próximo ao mundo do crime, mesmo sem ser um envolvido. Esse sentido do ter conhecimento também é fundamental para a construção da representação de um lugar tranquilo e da sensação de segurança associada a uma determinada localidade. Ver também Capítulo 3. 
vizinhança geralmente é o quê? Você ver uma briga ali, ligar pra polícia, eles vão lá e vão resolver, os caras são determinados a isso. Agora lá, se você chamar a polícia, você seria o delator, capaz de os dois parar de brigar e vir pegar você. / Beatriz: Porque se você ficasse olhando, e a polícia chegasse, era mais fácil de achar que você, que tava olhando, que ligou pra polícia. / Jefferson: Então, pô, fecha o portão, entra pra dentro, vocês tão seguros... / Beatriz: Quando a gente mudou na nossa segunda casa, a gente tinha uns vizinhos de frente que era quebra-pau direto, eu não me importava quando era com eles, aí começaram a judiar de uma criança: ele tava preso, o cara, aí ele saiu da cadeia e começou a judiar da criança, um pouco maior do que o Fabiano, eu não aceitava sabe? Nossa, eu queria ir lá e ele: 'fecha a janela e entra', eu chorava, eu não achava justo, sabe? Judiar do menino, e a minha vontade era de ir lá, catar ele de porrada, sabe? Chamar a polícia, ir na frente e falar: 'eu vi, olha como é que tá a criança', não sei o quê... Porque é assim, o cara bate na esposa, você chama a polícia, e a esposa fala que é mentira, que ela sabe que se ela falar que é verdade, depois vai apanhar mais ainda, né? Então assim, ele falava pra mim 'vai Bia, fecha a janela e entra pra dentro'. [Jefferson e Beatriz]

E, por fim, um dos aspectos mais importantes a alimentar a expectativa de Beatriz de deixar de morar no bairro seria a questão do preconceito dirigido a quem ali vive, o qual ela própria sempre alimentou (e, de certa forma, ainda alimenta) e que passou a sofrer desde que se tornou uma moradora local, sobretudo profissionalmente:

E tem a discriminação também, né, Thaís. Eu cheguei a ter serviço meu, que eu sei que eu fui mandada embora porque eu morava no Aracy. Tipo: 'Ai, mora no Aracy?' Eu tive um emprego meu que eles tinham que me trazer embora algumas vezes e o dia que descobriram que eu morava no Aracy, a pessoa que tinha que me trazer: 'Mas eu vou levar ela? Ela mora no Aracy!' Aí o outro: 'Ah, mora no Aracy?' Então, tipo... meu! Eu não queria isso pra mim, pro meu filho. [Beatriz]

Em meio a essa disputa pelos rumos do projeto familiar - no qual o local de moradia assumia papel determinante - Jefferson tomou conhecimento, através de um amigo, da possibilidade de financiar uma casa em um loteamento próximo ao Cidade Aracy. Em um primeiro momento, ele escondeu a informação de Beatriz, porque não queria, de forma alguma, deixar de morar no Cidade Aracy. Mas, pouco tempo depois, ele encontraria o amigo novamente, agora acompanhado de Beatriz, e este contaria ao casal que acabara de adquirir uma casa no tal loteamento, incentivando-os a fazer o mesmo. Seria o suficiente para Beatriz começar a buscar mais informações sobre o assunto, até descobrir que as condições do financiamento, ali, estavam muito mais acessiveis às condições deles do que aqueles que ela havia simulado anteriormente.

Então, saiu o "Minha Casa Minha Vida", saiu o subsídio de dezessete mil, todo mundo foi atrás. Quem tava noivo pra casar foi atrás, quem namorava muito tempo, quem já morava junto, tudo foi atrás. Chegava lá, teve vários: Azulville, Novo Horizonte, né? Tudo igualzinho, igualzinho aqui, só que já tá bem mais avançado, já tem praça, tem há muito mais tempo. Vai ficar assim aqui um dia, nós esperamos. Aí, então, teve pros lados do Santa Felícia, foram tendo vários. Então, muita gente aqui foi mudando pra esses lugares. Aí, o amigo dele pegou aqui [no Parque Novo Mundo] e falou: 'Ó Jefferson, tem um, vai ser ali'. Porque aqui não tinha nada! Quando a gente comprou aqui não tinha nada! A gente nem imaginava como que ia ser. Se ia ser mais perto da fábrica, se ia ser mais lá 
pra baixo, que até então, pra gente, isso aqui era tudo um terreno do Carrefour, né? A gente não sabia o que ia ser aqui. Aí: 'Não, vai ser depois da pista', que não sei o quê. A gente não tinha noção de onde era o começo do bairro, onde era o final... sem saber de nada. Aí a gente foi, mas no escuro! [Beatriz]

A opção deste loteamento apresentou-se como um meio termo entre os sonhos e projetos tanto de Beatriz como de Jefferson, por ser fora do Cidade Aracy, mas perto o suficiente para que Jefferson mantivesse suas relações cotidianas por lá. Contudo, acessar a tão sonhada casa própria não seria tão simples: foram necessários diversos arranjos até conseguir o financiamento naquele local.

O primeiro obstáculo parecia insuperável: quando foram até a imobiliária para se inscrever para o tal loteamento, já não havia mais casas disponíveis ali, e a corretora tentou convencê-los a financiar uma casa em outro loteamento semelhante que estaria sendo feito na "região do Santa Angelina" (loteamento popular produzido pela PROHAB), "do outro lado da cidade". No entanto, ambos acordaram que não queriam uma casa em qualquer loteamento, mas, sim, naquele, por ser próximo do Cidade Aracy e fazer a mediação entre o projeto de ascensão dela e as relações afetivas dele. Inconformados com a situação, seguiram insistindo com a corretora, até que ela questionou se eles teriam o dinheiro para dar a entrada imediatamente - se a resposta fosse positiva, ela passaria para eles uma casa já negociada com outro casal, que não estava conseguindo juntar o dinheiro da entrada ${ }^{48}$.

Jefferson: Até na época que eu fui lá, a mulher da Caixa... ela tentou me arrumar um loteamento que ia acontecer lá perto do Santa Angelina. É. Aí, na época lá, eu: 'Não, tem que ser lá, se não é lá eu não quero'. Eu só queria aqui [no Parque Novo Mundo], porque era perto da Aracy. Eu queria escolher... Porque, praticamente, você está comprando uma casa. / Beatriz: Quando nós fomos ver, já não tinha mais casa aqui nesse bairro, já tinha acabado. Aí ele deu uma desanimadinha. / Jefferson: Mas eu fiz inscrição mesmo assim, aí, depois de um tempo insistindo, a mulher lá da imobiliária deu um jeito.../ Beatriz: É que essa casa aqui foi de um casal que não tinha o dinheiro da entrada. Aí ela ligou: 'Cês têm o dinheiro?' Nós não tinha, né? [risos] Aí ela ligou: 'cês têm o dinheiro?', aí o Jefferson: 'Tenho!' Aí ela falou: 'É que tem um casal que tava comprando a casa lá, só que ainda não deram essa entrada, já falaram que vão trazer, vão trazer e não trazem. Como o problema de vocês é documentação, que é mais fácil resolver, traz o dinheiro, que o resto a gente espera. É de vocês então.' Acho que era dois mil e quinhentos a entrada, né? Aí o Jefferson falou: 'Bia, nossa, a gente não tem esse dinheiro!', eu falei: 'Não, mas peraí que a gente arruma'. Aí a gente conseguiu. [Jefferson e Beatriz]

Em menos de uma semana, tiveram que promover uma verdadeira 'saga' a fim de levantar recursos para dar entrada no financiamento e ainda juntar toda a

48 Chama atenção o fato de que, em nenhum de nossos encontros, o casal ter deixado transparecer qualquer preocupação por ter tirado a casa de outra família, como visto no caso de Núbia, relatado no capítulo anterior. E ainda justificaram a atitude da corretora: "Eles são vendedores, né, então eles têm que vender. Quem tem o dinheiro, leva!" 
documentação necessária. Eles tinham cerca de $\mathrm{R} \$ 1.000,00$ que vinham guardando desde que decidiram comprar uma casa, e o restante do dinheiro conseguiram através de um empréstimo feito pelo pai de Jefferson, aposentado, no banco. A casa estaria garantida com o pagamento da entrada, mas ainda havia o problema da documentação. O limite mínimo de renda para conseguir o financiamento naquele loteamento era de $\mathrm{R} \$ 1.350,00$, e a renda da família, então, era inferior a isso: o registro em carteira de Jefferson não chegava a $\mathrm{R} \$ 1.000,00$ (e não era possível contabilizar as comissões), e Beatriz havia ficado desempregada recentemente. Ela poderia conseguir uma declaração de renda com uma antiga patroa para 'complementar' a renda de Jefferson; entretanto, estava com o nome restrito (ou seja, inscrita nos sistemas de proteção ao crédito) e isso invalidaria todo o processo. Decidiram usar o dinheiro que tinham guardado para limpar o nome dela e, depois, teriam que conseguir o recurso de outra forma, e os planos eram de tentar realizar um empréstimo. Quando Beatriz estava na fila do banco para sacar o dinheiro, Jefferson ligou desesperado: "Sai daí que arrumei um jeito!". Ele havia conseguido, junto a uma organização onde já tinha desenvolvido projetos de hip-hop, uma declaração de renda que complementava o valor registrado em sua carteira de trabalho de modo a atingir o mínimo necessário para ter o financiamento aprovado. Após essa sequência de estratégias e arranjos, finalmente eles conseguiriam dar entrada no processo de financiamento da $\operatorname{casa}^{49}$, mas restou a sensação de que não é pra qualquer um essa possibilidade de acessar uma casa própria.

O governo, em si, ele quer tirar o aluguel, quer que não exista mais aluguel, mas é muito difícil. Porque pra conseguir essas casas aqui é muito difícil! É uma burocracia assim... Com nós, nossa! A gente passou uns três meses tentando assim, mas de todo dia ter que ir, aí acontecia alguma coisa. É muito difícil. Tem pessoas que desistem! Fala: 'Meu, não é pra mim.' Tem a renda, os documentos... A renda é muita! Gente, quem ganha mil trezentos e cinquenta na carteira? Quem? Daí, podia juntar renda. Mas não podia ter nome sujo... Quem não está com o nome sujo em alguma coisinha? Meu, quem, hoje em dia, não tem nada no nome? Muito, muito difícil! A gente tava perdendo a casa, assim. Foi quando ele falou: 'Nossa, vou pedir pra um camarada uma declaração de autônomo, já sei que tenho um não, agora vou tentar conseguir um sim' [risos]. Aí ele conseguiu... Porque faltava só isso. Só comprovar uma renda de mil trezentos e cinquenta. $O$ resto tinha dado tudo certo. Tudo, tudo, tudo. A gente tinha conseguido já o dinheiro, que também foi difícil [risos], mas o meu sogro é aposentado e consegue sacar até na boca do caixa. / Jefferson: Por isso que eu acho que é difícil, porque se você não comprova uma renda que diz que você é

49 Como visto também no caso de Joana, há um evidente descompasso entre a realidade financeira dessa população e os critérios de aprovação dos financiamentos no âmbito do PMCMV: além desses dois casos que pude acompanhar mais de perto, tive contato, em campo, com inúmeros outros sobretudo de famílias que tentavam adquirir a casa pelo formato 'varejista' do programa, no próprio bairro, e, em muitos casos, após cerca de um ano entre idas e vindas da documentação entre os agentes intermediários (imobiliárias, agências CAIXA AQUI) e a CEF, acabavam desistindo do negócio, restando ainda um longo processo para obter de volta o recurso da entrada, que pode chegar a até $\mathrm{R} \$$ $5.000,00$. 
capaz de pagar o valor da parcela, você não pega [risos]. / Beatriz: É muito difícil! [Jefferson e Beatriz]

Com o negócio fechado, começaram a sonhar, acompanhando, durante quase dois anos, o processo de construção do loteamento e da casa. A construtora realizava algumas reuniões com os moradores, para informar sobre o andamento das obras, e fazia algumas dinâmicas para que os vizinhos se conhecessem e entrassem em acordo quanto à construção dos muros, já que as casas seriam entregues sem fechamento, mas eles não puderam participar de nenhuma, pois eram aos sábados, dia em que ambos trabalhavam. Assim, praticamente até o final da obra, eles não sabiam exatamente qual seria a casa deles.

Aí, quando loteou, assim, colocou uns pauzinhos na entrada, aí a gente veio ver né. A gente achava que era aqui. Aí, no dia da primeira vistoria... a gente vinha direto ver a casa, né? Nossa, toda semana, nosso passeio de domingo de manhã era vim ver a casa. 'Ah, vai ficar assim, oh, vai ficar assim'. Aí, no dia da vistoria, o rapaz caçando lá nossa casa, o Jefferson: 'eu acho que é aqui ó! Eu sempre vinha ver essa mas se é minha eu não sei'. Aí era essa mesma. [Beatriz]

Durante esse período de construção da casa, os gastos da família aumentaram, pois tiveram acrescidos aos gastos pré-existentes com aluguel, contas da casa e o financiamento do carro, uma taxa de construção do loteamento. Nessa época, Beatriz conseguiu um novo emprego, passando a trabalhar como vendedora em uma empresa de telefonia, com registro em carteira, o que melhorava a condição financeira da família.

A entrega das casas foi feita em duas etapas, e a deles estava na segunda, de modo que somente em março de 2012 puderam fazer a mudança. O contrato de gaveta com a proprietária da casa alugada no Cidade Aracy ainda estava em vigor, mas, nesse mercado informal, isso pode ser facilmente resolvido - ainda que, em muitos casos, possa resultar em conflitos, violentos ou não. Não foi o caso, sobretudo porque, assim como havia acontecido com eles, quando foram sair da casa, já indicaram uns conhecidos para a proprietária: "Nós saímos, e eles mudaram no mesmo dia também. lgual à gente".

A mudança, embora esperada, trouxe muitos gastos não programados, principalmente para mobiliar a casa nova: num primeiro momento, optaram por investir em mobiliários para a área comum da casa, já que "pela primeira vez eu tenho uma sala e vou poder receber pessoas em casa". Além disso, as contas de água e luz aumentaram significativamente, pois, no Cidade Aracy, a única casa em que tiveram esse gasto tinha descontos de caráter "social", o que no novo bairro não seria mais possível.

Hoje em dia, assim, vai levar mais um tempo pra gente se organizar com as contas. Porque a mudança pra cá foi muitos gastos. A gente gastou demais, assim. Gastou o que tinha e o que não tinha. / Thaís: Pra fazer a mudança? Pra 
quê? / Móveis, assim. A dificuldade maior foi móveis. Porque os que eu tinha, não tinha como trazer. Meu guarda-roupa já tinha feito quatro mudanças. Assim, na hora que eu arrancasse tudo a roupa, podia fechar as portas e falar 'tchau', porque ele ia cair sozinho. Sofá, eu tinha um sofá que tava.... não tinha como trazer. Eu não tinha nada! O meu armário, não tinha como trazer. Veio o fogão, a geladeira, ó... veio o fogão, a geladeira, a televisão, essas coisas, mas o rest, o a gente teve que comprar tudo. Ainda assim, eu optei. Eu tô sem máquina, ainda, sem tanquinho. Lavo roupa na mão e, quando junta muito, eu vou na minha sogra. As calças do Jefferson, que é pesada, eu levo na minha sogra, lavo lá e estendo aqui. E, sem minha cama, a gente tá dormindo num colchão no chão. Porque eu falei: 'Não, isso aí a gente aguenta'. Tipo, ou era a cama ou o sofá. Falei: 'Pelo amor de Deus, sofá.' Já não tem mesa... Vai comer onde? Vai receber as pessoas, né?! Aí eu tive que fazer escolhas. Aí, hoje, que tá eu trabalhando e ele também, eu falei: 'Mais três meses, graças a Deus, a gente... já pode começar a comprar o resto que falta, fazer o muro...' [Beatriz]

Beatriz montou uma espécie de plano de investimentos na casa: primeiro as mobílias das áreas comuns; depois, o quarto dela; em seguida, o quarto do filho. Ao final de cada parcelamento, iniciariam outro, garantidos pelo fato de ambos estarem empregados. Além disso, assim como no caso de Joana, mal entraram na casa e já começaram os planos de reformas e ampliações, como veremos adiante: construir os muros em volta de toda a casa, fazer contrapisos externos, fechar a lavanderia. A renda familiar estaria toda comprometida por anos a fio para dar conta de todos esses sonhos, mas a nova casa - e os investimentos destinados a melhorá-la representam a superação de uma fase de dificuldades, um patamar melhor de vida: "é a primeira vez que a gente tem esse conforto" (Beatriz).

Porém, ambos sempre fizeram questão de ressaltar que pagam, pela casa própria, menos do que estariam pagando de aluguel por uma casa nas mesmas condições no antigo bairro, discurso elaborado também como uma espécie de justificativa para os parentes e amigos moradores do Cidade Aracy, que questionaram a opção deles pela mudança para o Parque Novo Mundo - seja pelo fato de terem saído do bairro, seja por considerarem as casas muito pequenas, ou ainda por acharem que as condições da casa e do bairro não valiam o investimento feito, uma vez que, com muito menos recursos, poderiam ter continuado no "quintal" da casa de mãe de Jefferson.

Beatriz: A maioria dos nossos amigos é tudo assim, não pensa nisso. Constrói um cômodo em cima da casa que a mãe mora e acha que tá... Fomos uns dos poucos que pensou assim. Até, na época, quando a gente comprou aqui, a gente também saiu falando pros outros, que nem falaram pra gente, e a gente viu que é possível: a gente, com dois e meio deu entrada, hoje em dia tá fazendo em $R \$ 300,00$ por mês. / Jefferson: Mais barato do que um aluguel que a gente tava pensando em pagar, na época. / Beatriz: Tem pessoas que paga mais que a gente paga aqui, lá. Tipo, paga trezentos e cinquenta, quatrocentos reais de aluguel. Aluguel! Nós tamos pagando trezentos e quatorze na nossa casa. / Jefferson: Mas é que é difícil conseguir, pela burocracia, e também pela entrada que tem que dar. I Beatriz: Mas sabe o que a gente escuta, assim, eu escuto muito, ele também deve ter escutado já: 'ai, aquelas casinhas pequenas'. Até quando a gente comprou aqui, a gente ouviu, até de parente, sabe? 'Mas você já viu as casas?', 'eu nunca vi', 'nossa, é horrivel as casas, depois de um ano que você tá lá trinca tudo, a casa 
é minúscula, não tem cozinha, é um ovo'. Gente, eu não sinto uma noção, porque pra quem morava em dois cômodos! Nós nunca tivemos uma sala! Esse é o primeiro sofá da nossa vida. [Jefferson e Beatriz]

De fato, após a mudança para a casa, eram recorrentes, em nossos encontros e nas conversas deles com parentes e amigos, diálogos sobre o contraponto entre a opção corrente entre estes de ficar no bairro, de viver de cômodo nos quintais e a nova possibilidade, acessada por eles, de ter uma casa própria pelo mesmo valor de um aluguel. Evidencia-se, aí, o quanto ter financiado essa casa (e fora do Cidade Aracy, num bairro novo) se associa a modos de minimizar certas marcas, certas condições (neste caso, espaciais) por eles mesmos associadas à ideia de pobreza, acabando por colocá-los, também, em um novo lugar entre iguais - os quais não perdem a oportunidade de demarcar essa distinção ao dizer que Jefferson e Beatriz estariam "virando boys", numa crítica explícita ao projeto familiar de ascensão social, no qual a casa é o nódulo central.

É que nem, assim, eu não tenho nada contra o Aracy, mas eu não quis criar raízes... É, porque comprar uma casa é algo muito sério, é meio que pra sempre, não que seja pra sempre, mas que você compra... pra sempre. Então, eu falei, 'meu, comprar uma casa no Aracy, ai é pra sempre', principalmente com ele, que ama o Aracy, você acha que ele ia largar uma casa no Aracy pra morar pra outro lugar? Nunca! Então, meu problema não é conviver no Aracy, porque, nossa, minhas amigas são do Aracy, a minha vida também é no Aracy, hoje em dia, só que eu não queria criar raiz, eu não queria morar lá, nunca quis... criar raiz, eu não queria ter que dar meu endereço e ser no Aracy, sabe? Meio que resumindo, quando eu morava no Aracy, nossa era horrível, até o emprego que eu tive, quando descobriram que eu era do Aracy, acho que até fui mandada embora por causa disso. Que chegava tarde de viagem, a pessoa tinha que trazer no Aracy, era sempre tenso. [Beatriz]

Por mais que a opção pelo Parque Novo Mundo tenha sido feita em função da proximidade com o Cidade Aracy, conforme sempre fizeram questão de frisar - "nós só moramos aqui porque é um bairro perto do Aracy (risos)" -, na tentativa de Jefferson de preservar sua conexão com seu antigo projeto de vida (agora alvo de críticas por parte também dele), cujas práticas cotidianas e redes de relações baseavam-se naquele bairro, e ainda assim atender ao desejo de Beatriz de sair de lá, a mudança acaba por enfatizar a perspectiva dela, assumindo ares de 'conversão': distanciando-se de um lugar e uma população estigmatizados, e de "tudo de ruim" a eles associado ${ }^{50}$, como visto, é como se tivessem escapado de um 'destino', conquistando instantaneamente um novo status social a partir da nova casa e do novo local de moradia. 


\section{- Parque Novo Mundo e Jardim Zavaglia: novos territórios tão próximos e tão distantes}

Meus primeiros contatos com ambos os locais para onde se mudaram os interlocutores da pesquisa cujas trajetórias iluminam o presente capítulo - Jardim Zavaglia e Parque Novo Mundo, nessa ordem - se deram pouco antes que estes se tornassem espaços abarcados, de alguma forma, pela pesquisa de campo, antes mesmo que estivessem ocupados e, curiosamente, ambos foram vislumbres de passagem.

O primeiro, avistei-o literalmente da forma que Certeau (1994) denominaria a visão "do alto" de urbanistas, visão panorâmica em que o espaço se mimetiza em plano: um 'mar' de casas enfileiradas, com uma área vazia ao centro, rodeado de mato por todos os lados, desconectado fisicamente da malha urbana da cidade e, sobretudo, desconectado dos bairros limítrofes a ele, Antenor Garcia e Cidade Aracy. Eu descia, então, a serrinha para o Cidade Aracy, e a sensação imediata, quando tive tal visão, foi de perplexidade: o município estava finalizando o processo de elaboração do já mencionado Plano Local de Habitação de Interesse Social de São Carlos (PLHIS), cujas recomendações se ancoravam na perspectiva de uma "cidade compacta" - à qual se associa a diretriz de "contenção da expansão urbana periférica"51 -, propondo diretrizes e programas que visassem garantir que a produção de habitação de interesse social no município se fizesse integrada à malha urbana consolidada com infraestrutura e serviços e que fosse qualificada do ponto de vista arquitetônico, urbanístico e ambiental ${ }^{52}$. E ali estavam mil unidades habitacionais prestes a serem distribuídas a cerca de cinco mil pessoas, implantadas em uma região da cidade imprópria para tamanho adensamento ${ }^{53}$, e na qual já viviam mais de vinte mil pessoas em condições de infraestrutura urbana, equipamentos e serviços

51 PMSC (2005).

52 PMSC (2010).

53 Cf. Gaspar (2000); Jardim (2004); TEIA (2005); Carrara (2010). Incorporando tais análises, o Plano Diretor do município (PMSC, 2005) classificou a região onde hoje se encontra o empreendimento como sendo parte da "Zona 3 de Recuperação e Ocupação Controlada", por apresentar encostas com alta declividade; solo suscetível a erosões com córregos assoreados; infraestrutura precária; parcelamentos irregulares localizados nas proximidades de encostas de alta declividade e em áreas isoladas com precariedade de interligação viária com a malha urbana consolidada; concentração de população de baixa renda. Entretanto, como destaca Pulhez (2012), "de acordo com a SMHDU, o processo de aprovação do loteamento remonta ao ano de 2001 e é, portanto, anterior à lei do plano, datada de 2005. Sua incorporação ao MCMV deu-se no calor dos incentivos federais propostos, o que veio a calhar tanto para a construtora quanto para o poder público local, fortalecendo uma parceria desejada e estimulada pelo programa." 
diagnosticadas e constantemente reafirmadas (por moradores, políticos e mídias locais) como insuficientes e precárias ${ }^{54}$.

O segundo, avistei-o da janela de um carro quando cruzava uma autopista em direção também ao Cidade Aracy. Parei para olhar, ainda que a distância, pois tivera a notícia de que uma das famílias que eu havia contatado para participar da pesquisa se mudaria para lá. O empreendimento estava em fase final de obras, e estas foram minhas apressadas anotações em caderno de campo, indicando visitas futuras para melhor apreendê-lo:

Essa primeira e rápida visão do empreendimento me impressionou muito, pois me pareceu um conjunto habitacional, como os tantos promovidos por COHABs e afins Brasil afora: muitas casas juntas, infraestrutura urbana inacabada, sem conexão com a cidade (a não ser pela estrada), sem nenhum equipamento público por perto, num local que me pareceu um misto de área industrial e área rural. Em muitos aspectos, nessa primeira visão, me pareceu bastante semelhante à situação do Jardim Gramado [Jardim Zavaglia], só que o Parque Novo Mundo, pelo que consta, não foi produzido para a faixa de 0-3 salários mínimos. Fiquei curiosa para saber mais. [Diário de campo, 4/10/2011]

De fato, em minha primeira impressão o Parque Novo mundo se configurara como um misto de conjunto popular e condomínio inacabado, no que, de resto, não estava totalmente equivocada, como veremos ao longo desta seção e das próximas. No entanto, talvez por ter visitado outros empreendimentos produzidos por construtoras no âmbito do Programa Minha Casa Minha Vida para o mesmo "público" ao qual se direcionava o Parque Novo Mundo (então, famílias na faixa de renda de 3 a 6 salários mínimos) na região leste da cidade ${ }^{55}$ - que se estruturam sob a "forma-condomínio": murados, com portaria e com uma espécie de 'maquiagem' externa dos empreendimentos (jardinagem, pintura, pórticos) que camufla alguns destes mesmos aspectos por mim observados nessa visão de relance dos dois bairros

54 NPD/UFSCar (1994), Laisner (1999), PMSC (2005), Ávila (2006), Silva (2006). Com relação ao número de moradores da região, as informações são desencontradas: embora pesquisas remetendo a dados do Censo 2010 afirmem que quinze setores censitários englobam a região, totalizando 19.079 habitantes (Maciel, 2012; Angelin, 2012), a informação conflita com dados divulgados pela Secretaria Municipal de Habitação e Desenvolvimento Urbano, que teria anunciado, em 2010 (cf. www.saocarlos.gov.br), a emissão de vinte mil carnês de IPTU para os imóveis regularizados na região - que certamente não são a totalidade dos imóveis locais -, bem como informado a uma pesquisadora o número de quarenta mil moradores para a região (Maciel, 2010). Este número coincide com o divulgado por organizações atuantes no bairro, como o jornal digital local disponível em http://aracynews.blogspot.com.br (consulta em maio/2014).

55 Condomínios padronizados promovidos por grandes empresas construtoras que, embora também configurem hoje o limite da malha urbana a noroeste (expandida inclusive para abarcar os empreendimentos), situam-se numa região onde há uma mistura de condomínios fechados de alto e médio padrão. Veja-se o que diz o proprietário da Construtora Rodobens sobre o "sucesso" das "casas populares com pequenos luxos" promovidas por sua empresa para a "nova classe C": "Entendemos o básico: ninguém quer morar em condomínio com cara de cortiço". (veja.abril.com.br/040608/p_162.shtml, consulta em maio/2014). 
mencionados - eu não esperasse uma situação e uma forma urbanas tão próximas à que tinha visto panoramicamente no Jardim Zavaglia e, anteriormente, em tantos outros conjuntos habitacionais promovidos historicamente pelo estado em tantas cidades Brasil afora. Por outro lado, pareceu-me, também, um indicativo de que, embora destinado supostamente para uma faixa de renda superior àquela do Jardim Zavaglia, o fato de localizar-se na zona sul da cidade, com relativa proximidade à região do Cidade Aracy, poderia significar que ao menos uma parcela de seu "público" fosse, em alguma medida, coincidente com aquele "atendido" no Jardim Zavaglia hipótese que as próprias trajetórias apresentadas neste capítulo vieram, em alguma medida, corroborar.

O Programa Minha Casa Minha Vida, implementado no país a partir de 2009, teve, desde o início, um duplo viés, configurando-se simultaneamente como uma das principais reações do governo federal frente à crise econômica internacional e como uma política social de grande escala: com o objetivo inicial de produzir um milhão de moradias em dois anos, o programa delinearia uma série de medidas garantidoras do desenvolvimento dos setores imobiliário e da construção civil, prenunciando, a um só tempo, a geração de empregos e a redução do déficit habitacional ${ }^{56}$.

Pautado quase que exclusivamente na criação de mecanismos de incentivo à produção e à aquisição de novas unidades habitacionais por famílias com renda de até dez salários mínimos - estendendo o mercado habitacional às camadas populares - se, por um lado, o Programa pôde ser considerado como "a locomotiva da produção habitacional do País, em inédito esforço de enfrentar a questão da moradia" ${ }^{57}$, por outro, foi, desde o início, alvo de inúmeras críticas $^{58}$, em especial por tratar-se de uma política habitacional regida por uma lógica empresarial, absolutamente desconectada de políticas urbanas, sendo a iniciativa privada sua principal protagonista ${ }^{59}$, já que a quase totalidade do subsídio público é destinada à oferta e produção direta por construtoras privadas.

O PMCMV estrutura-se operacionalmente ${ }^{60}$ em modalidades distintas de atendimento por "faixa de renda" (ou "público-alvo"), a saber: a "Faixa 1",

56 Posteriormente, tal meta foi ampliada para a produção de 3,4 milhões de unidades habitacionais em apenas cinco anos (2009-2014), e os recursos disponibilizados, então R\$ 34 milhões, alcançariam expressivos R\$ 120 bilhões. Cf. Shimbo (2014); Cardoso e Aragão (2011).

57 Ferreira (2012).

58 Arantes e Fix (2009); Bonduki (2009); Maricato (2009); Rolnik e Nakano (2009).

59 Desde a própria formulação do Programa, como alerta Shimbo (2010).

60 As informações seguintes sobre a operacionalização do Programa, foram baseadas em Shimbo (2014); Cardoso e Aragão (2011, 2013); Ferreira (2012). 
inicialmente de 0 a 3 salários mínimos (ou, mais recentemente, até $R \$ 1.600,00$ ) e a "Faixa 2", de 3 a 10 salários mínimos, (e atualmente entre $R \$ 1.600,00$ e $R \$ 5.000,00$ ), eventualmente subdivida em 3 a 6 e 6 a 10 salários mínimos (atualmente $R \$ 1.600,00$ a 3.100,00 e $\mathrm{R} \$ 3.100$ a 5.000,00), de acordo com os "públicos-alvo" visados pelas construtoras. Correspondendo aos programas de habitação de interesse social implementados no país na primeira gestão do governo Lula (2003-2006), a produção habitacional destinada para a "Faixa 1" conta com subsídio público integral (através do uso de investimentos a fundo perdido oriundos do Orçamento Geral da União), sendo as prestações mensais limitadas a $10 \%$ da renda por um período máximo de dez anos. Interessa destacar aqui que, para esta faixa, a produção é realizada "por oferta", o que significa que, sob o manto da 'parceria' com os governos municipais, são as construtoras que definem terrenos e projetos, aprovam-nos junto aos órgãos competentes e têm a garantia da venda integral de sua produção habitacional à CAIXA, sem gastos de incorporação imobiliária e comercialização, e sem os riscos que seriam inerentes a esta faixa de renda, tais como inadimplência dos compradores ou vacância das unidades. O papel dos municípios limita-se ao cadastramento da "demanda" (a partir do qual a CEF definirá o acesso às unidades), além da criação de condições que facilitem a produção, seja por meio de doação de terrenos, ou, mais comumente, de isenção tributária e desburocratização nos processos de aprovação e flexibilização das normas urbanísticas permitindo maiores índices de utilização do solo.

Já na "faixa 2", correspondente à "habitação de mercado" ou "segmento econômico", apenas uma pequena parte compõe-se de recursos não onerosos (na forma de subsídios parciais, a título de complementação de renda, chegando ao máximo de $\mathrm{R} \$ 23.000,00$ para famílias com renda de até $\mathrm{R} \$ 3100,00$ ), sendo o restante recursos onerosos provenientes do FGTS, cujos financiamentos podem chegar ao máximo de trinta anos, com comprometimento de renda de $20 \%$. Destacam-se, para esta faixa, o aumento do volume de crédito e a redução dos juros. O modelo de produção e comercialização para tal faixa se dá da seguinte forma: os projetos dos empreendimentos são apresentados pelas construtoras/incorporadoras à pré-avaliação da CEF, para que sejam autorizados o lançamento e a comercialização, que conta com uma taxa mínima exigida para que a construtora possa obter o "Contrato de Financiamento à Produção". A comercialização é feita pelas próprias construtoras, por parcerias destas com imobiliárias ou através dos "feirões" da Caixa, sendo que os próprios interessados podem também pleitear uma carta de crédito vinculada ao Programa para financiamento direto da moradia.

São Carlos, como tantas outras cidades no país, aderiu ao Programa tão logo ele foi lançado, dando início a uma política de incentivos que favorecesse a atuação dos agentes privados na produção habitacional local. Já em 2010, conforme 
levantamentos realizados no âmbito da elaboração do PLHIS, o município contava com oito empreendimentos habitacionais vinculados ao PMCMV aprovados ou em processo de aprovação, sendo apenas um deles destinado à "Faixa 1", mas totalizando significativas 1.000 unidades ${ }^{61}$. Atualmente, mesmo sem dados precisos sobre os novos empreendimentos promovidos no âmbito do Programa no município desde então62, sabe-se que a produção vinculada a ele chega a contabilizar um incremento de mais de $10 \%$ em relação aos domićlios existentes, sendo que a parcela dessa produção voltada ao "segmento econômico" ("Faixa 2") excede a demanda habitacional contabilizada no município para esta faixa de renda ${ }^{63}$. Para a "Faixa 1", mais dois empreendimentos encontram-se em andamento, na mesma macrorregião onde já se localiza o primeiro, totalizando 1.792 unidades.

Nesse contexto, os novos territórios para onde se mudaram as duas famílias cujas trajetórias fundamentam o presente capítulo - Jardim Zavaglia e Parque Novo Mundo - são exemplares da produção habitacional destinada, respectivamente, à "Faixa 1" e à "Faixa 2" no município já nessa primeira 'leva' de empreendimentos vinculados ao Programa no município, destacando-se o fato de terem sido produzidos pela mesma construtora - RPS, sediada em São Carlos - a qual, desde o início, tem direcionado seu foco para construção de empreendimentos destinados para as faixas de 0 a 3 e 3 a 6 salários mínimos em diversas cidades do interior do estado ${ }^{64}$.

O Jardim Zavaglia, localizado em área anteriormente de uso rural, no limite sudoeste da malha urbana e sem contiguidade a ela, foi o primeiro empreendimento produzido para a faixa de 0 a 3 salários mínimos no município. O loteamento que, como destacado anteriormente, foi implantado em área classificada como "zona de recuperação e ocupação controlada" pelo Plano Diretor do município (PMSC, 2005), encontrava-se aprovado desde 2001, antes da própria aprovação do Plano e, portanto, muito antes do lançamento do PMCMV; foi, portanto, "no calor dos incentivos federais propostos"65, que se fez sua incorporação ao PMCMV, resultando

61 PMSC (2010).

62 Dados publicados em matérias de jornais locais dão conta de mais de 7.000 unidades construídas no âmbito do PMCMV para ambas as faixas de renda em São Carlos. (Cf, por exemplo: www.revelandosaocarlos.com.br/sao-carlos-ganha-150-milhoes-em-habitacao-de-interesse-social, consulta em março de 2014).

63 Conforme apontam Shimbo e Lopes (2014) a partir de dados de Brasil (2013) e Krause et al (2013). 64 A construtora conta com inúmeros empreendimentos já concluídos ou em andamento, no âmbito do PMCMV, em cidades como São Carlos, Limeira, Rio Claro, Piracicaba, Ribeirão Preto. Mesmo sendo uma construtora local, sua atuação corrobora com a situação evidenciada por Alcântara e Melazzo (2012): “as dificuldades em adquirir frações do solo urbano num preço viável para o posterior financiamento pela Caixa, têm feito com que grandes incorporadoras ampliem cada vez mais seu alcance geográfico de atuação, elencando como áreas "privilegiadas" para investimentos as cidades médias". Veja-se também o trabalho de Shimbo e Lopes (2014).

65 Como destaca Pulhez (2012). 
na "parceria" entre o governo municipal e a empresa construtora que viabilizou a consecução não apenas deste empreendimento e do Parque Novo Mundo, como também de outros três em uma segunda 'leva' de produção habitacional vinculada ao PMCMV no município ${ }^{66}$.

Tal "parceria" foi levada a cabo nos moldes mais exemplares do programa: à construtora coube a aquisição do terreno, elaboração e aprovação do projeto, investimento na execução da produção habitacional e da infraestrutura básica ${ }^{67} \mathrm{e}$ viabilização do negócio junto à CEF; ao governo municipal coube o cadastro e a seleção das famílias demandatárias, além de uma contrapartida, em forma de recursos próprios e captados junto ao Ministério das Cidades, totalizada em cerca de $\mathrm{R} \$$ 2,6 milhões que garantiram a pavimentação da estrada vicinal que configura a principal conexão do novo bairro com a malha urbana pré-existente, bem como as demais vias de acesso ao novo bairro ${ }^{68}$, sendo parte delas executadas quase um ano após a entrega das últimas casas aos moradores.

O cadastro da demanda, a cargo da PROHAB, foi composto pelo cadastro preexistente da empresa ${ }^{69}$, acrescido de novas inscrições realizadas após o anúncio da aprovação do empreendimento. A seleção das famílias foi realizada por meio de sorteio público, obrigatório e regulamentado por lei municipal ${ }^{70}$, que também define os critérios para participação no mesmo: residir em São Carlos há pelo menos três

66 Jardim Tijuca, 125 unidades, já concluído e Jardim Araucária, 687 unidades, em andamento ambos para a "Faixa 2" - e Residencial Eduardo Abdelnur, 986 unidades, em andamento, destinado para a "Faixa 1". Anteriormente, a construtora já vinha executando diversas obras promovidas pela PROHAB, sobretudo no âmbito do Programa Arrendamento Residencial (PAR), tendo o Programa Minha Casa Minha Vida apenas contribuído para 'afinar' tal 'parceria'.

67 Os empreendimentos são aprovados e entregues contando com infraestrutura das redes de água, esgoto, iluminação, além de asfalto, guias e sarjetas. Shimbo e Lopes (2014) destacam como uma característica comum aos empreendimentos produzidos no âmbito do PMCMV, em algumas cidades do interior do estado de São Paulo, o fato de toda a infraestrutura urbana interna aos empreendimentos ser produzida pelas empresas construtoras responsáveis.

68 Cf. site www.valor.com.br/impresso/especial/minha-casa-entrega-projeto-incompleto, última consulta em fevereiro de 2014.

69 Sobre tal cadastro, ver Entremeio I (em especial nota 17). O cadastramento ocorre diretamente na sede da PROHAB e atende a um público cuja faixa de renda varia entre 0 e 10 salários mínimos. Em fevereiro de 2010, o cadastro era composto por 8.393 fichas cadastrais, das quais cerca de 6.400 referentes à faixa de 0 a 3 salários mínimos. Entretanto, o PLHIS, após o cruzamento de dados deste cadastro, do Cadúnico e aqueles referentes ao déficit no município produzidos pela Fundação João Pinheiro, apontou para uma demanda por provisão habitacional que girava em torno de 3.360 unidades em 2010 (PMSC, 2010). Em 2012, a PROHAB realizou um processo, com ampla divulgação, para "atualização" do cadastro, com vistas aos novos empreendimentos do PMCMV, cujos números atualizados não foram divulgados.

70 Vigora em São Carlos desde 1999 a “Lei de Sorteio Público” (Lei n¹2.117), criada por iniciativa da Câmara Municipal, pela qual o governo municipal "fica obrigado a realizar a distribuição de benefícios habitacionais por ele promovidos, sejam eles recursos materiais ou unidades de lotes urbanizados ou de moradias, exclusivamente através de sorteio público" (PMSC, 2010:63). 
anos, ter família constituída, ter renda familiar menor do que $\mathrm{R} \$ 1.395,00$, não possuir imóvel ou financiamento pelo governo federal. Foram sorteadas 1.455 famílias, sendo 1.000 titulares, e as demais, suplentes. Após o sorteio, os contemplados foram instados a providenciar a documentação, enviada para aprovação pela CEF. Como visto anteriormente, em função da não aprovação de cerca de $40 \%$ dos cadastros, foi necessária a realização de um segundo sorteio de cerca de 350 unidades, para o qual novas inscrições foram abertas. Dentre as mil unidades do empreendimento, $9 \%$ foram reservadas para moradores de "áreas de risco" da cidade, 5\% para deficientes físicos e $3 \%$ para idosos ${ }^{71}$.

Com 1.000 unidades habitacionais ${ }^{72}$ de pouco mais de $42 \mathrm{~m}^{2}$, edificadas em lotes de $200 \mathrm{~m}^{2}$, o Jardim Zavaglia configurava-se, quando de sua conclusão em 2011, como "um dos maiores empreendimentos do Minha Casa, Minha Vida para a faixa de renda de 0 a 3 salários mínimos" ${ }^{73}$, congregando recursos da ordem de $\mathrm{R} \$ 42$ milhões (ou seja, um repasse público de $\mathrm{R} \$ 42.000,00 /$ unidade habitacional). Pelo grande porte do empreendimento, mas também pelo tamanho das unidades $\left(10 \mathrm{~m}^{2}\right.$ maiores que o mínimo aceito pela CEF para casas térreas ${ }^{74}$ ) e dos lotes, além da alardeada "qualidade" com que as obras teriam sido executadas, o empreendimento foi considerado pelos gestores municipais como uma "referência" local em termos de produção habitacional de interesse social e, segundo os mesmos, também para o Programa como um todo, como atestam diversos depoimentos do então diretorpresidente da PROHAB e do próprio prefeito aos meios de comunicação locais: "É um empreendimento de grande qualidade que visa atender a população que não tem condições de comprar uma casa"75; "Nosso projeto é referência para todo o país"; "O prefeito aproveitou a oportunidade para convidar a população a comparecer ao evento e conhecer o empreendimento, que é considerado modelo entre os projetos executados pelo "Minha Casa, Minha Vida"76.

O empreendimento conta, ainda, com alguns lotes destinados a empresas comerciais, vendidos de forma independente pela construtora RPS através de uma imobiliária que vem atuando em parceria com ela. Foi prevista e anunciada - mas

71 Cf. site www.saocarlos.sp.gov.br (consulta em fevereiro de 2014).

72 Sobre as estratégias adotadas pelas empresas construtoras para burlar o limite, estabelecido pela CEF, de 500 unidades habitacionais por empreendimento, ver Cardoso e Aragão (2011).

73 Vale destacar que apenas a oferta habitacional promovida por esse empreendimento equivale a quase toda a produção pública ocorrida entre 2005 e 2010 na cidade de São Carlos, em termos de número de unidades habitacionais (PMSC, 2010).

74 A normativa definia em $32 \mathrm{~m}^{2}$ a área mínima para casas térreas (Cf. Cardoso e Aragão, 2011).

75 Cf. site www.saocarlosagora.com.br/cidade/noticia/2011/11/11/23962/prefeitura-e-prohab-sereunem-com-futuros-moradores-do-residencial-zavaglia (consulta em fevereiro de 2014).

76 Cf. site http://www.saocarlos.sp.gov.br/index.php/noticias/2011/159955-prefeitura-e-prohabrealizam-2o-sorteio-de-casas-do-jardim-zavaglia.html consultado em fevereiro de 2014. 
ainda não executada - a implantação de duas praças, uma Unidade de Saúde da Família, um Centro Municipal de Educação Infantil (CEMEI), um Centro da Juventude ${ }^{77}$ e uma escola de ensino fundamental, cujo terreno foi doado ao governo estadual.

O Parque Novo Mundo foi o primeiro empreendimento 'oficialmente' anunciado como produção vinculada ao PMCMV no município, já em setembro de 2009. Localizado também na região sul da cidade, no limite sudeste da malha urbana, o loteamento encontra-se inserido na mesma "zona de recuperação e ocupação controlada" definida pelo Plano Diretor (PMSC, 2005), nas imediações do CEAT (Centro Empresarial de Alta Tecnologia) e cercada por três das quatro Áreas de Especial Interesse Industrial (AEII) definidas pelo plano.

Produzido pela mesma construtora RPS, esta foi responsável, como já destacado, pela definição e aquisição do terreno, pelo desenvolvimento dos projetos de loteamento e unidades habitacionais, pela aprovação deles junto à prefeitura e à CEF e pela articulação com uma imobiliária local para a comercialização das unidades. Conforme divulgações oficiais da prefeitura à época, o empreendimento teria recebido investimentos da ordem de $\mathrm{R} \$ 29$ milhões do PMCMV. O governo municipal esteve envolvido indiretamente, facilitando, literalmente, a execução do negócio:

77 Destaca-se, nesse sentido, que, antes mesmo da conclusão e entrega das habitações, o governo municipal já havia firmado uma "parceria" com uma organização não-governamental denominada Associação Sal da Terra, regulamentada legalmente, à qual concedeu o uso, por vinte anos, de uma das áreas institucionais do loteamento, com cerca de $4.000 \mathrm{~m}^{2}$, para a implantação de equipamentos e desenvolvimento de atividades de cunho "social" e "esportivo", substituindo a implantação, pelo governo municipal, do Centro da Juventude. Vale notar que tal Associação conta, entre seus dirigentes, com proprietários da imobiliária parceira da construtora RPS. Não se trata, aqui, de aprofundar tal questão, não apenas por fugir ao escopo da pesquisa, mas também porque tal organização não foi sequer mencionada pelos interlocutores da família envolvida diretamente na pesquisa, nem pelos demais moradores com os quais tive contato através deles. De todo modo, reproduzo a notícia veiculada quando da aprovação do projeto de lei que autoriza a concessão, por conter elementos interessantes sobre a produção - e gestão - desses novos territórios pelo PMCMV: "A Câmara Municipal de São Carlos aprovou, na tarde desta terça-feira (10), o projeto de lei 109, que dispõe sobre a concessão administrativa de uso de bem público municipal, localizado no Residencial 'Deputado José Zavaglia'. Com o sinal verde do Legislativo Associação Sal da Terra, deve implantar aparelhos públicos em área pública do novo bairro para atender cerca de 4.000 pessoas que devem habitar em breve o bairro José Zavaglia. O investimento será de $\mathrm{R} \$ 475$ mil numa área de 4.000 metros quadrados, onde serão implantadas quadras esportivas, um campo de futebol e um prédio com salas de aula. No artigo primeiro, o projeto prevê a concessão administrativa de uso de bem público municipal, localizado na parte "A" da área de uso institucional do Residencial 'Deputado José Zavaglia', à Associação Sal da Terra pelo prazo de 20 (vinte) anos, prorrogáveis por igual período, para construção de centro esportivo social para desenvolvimento de atividades. Ainda segundo o projeto, a associação Sal da Terra deverá desenvolver ações de cunho social, como reforço escolar, curso profissionalizantes, alfabetização, recreação e esportes, entre outras, de forma a contribuir para formação integral de crianças e adolescentes. A concessão será outorgada com dispensa de licitação, por se tratar de destinatário certo, havendo interesse público." Cf. site: www.saocarlosagora.com.br/cidade/noticia/2011/05/10/17594/jardim-zavaglia-camara-aprovaconcessao-de-area-para-sal-da-terra (consultado em fevereiro de 2014). 
"agilizando" a aprovação do projeto, "cedendo" o cadastro da Prohab para as empresas construtora e imobiliária envolvidas, "concedendo incentivos tributários", como isenções de ISS (Imposto Sobre Serviços) da construção, de IPTU (Imposto Predial e Territorial Urbano) durante o período de obras e de ITBI (Imposto sobre Transferência de Bens e Imóveis) na transmissão do imóvel ${ }^{78}$.

Destinado àquela "Faixa 2" do PMCMV, mais especificamente famílias com renda entre 3 e 6 salários mínimos ( $R \$ 1.395,00$ a 2.790,00 na época), o Parque Novo Mundo conta com 491 unidades habitacionais de pouco mais de $45 \mathrm{~m}^{2}$, implantadas em lotes de $150 \mathrm{~m}^{2}$. Além da produção habitacional vinculada ao Programa, o projeto da construtora para a área também conta com 43 lotes comerciais de $350 \mathrm{~m}^{2}$ e 105 lotes industriais de $1.000 \mathrm{~m}^{2}$ cada um, comercializados por conta própria, através de parceria com a mesma imobiliária responsável pela comercialização das habitações. Quando da apresentação do projeto aos futuros moradores, indicou-se a implantação de uma área de lazer, uma escola e um posto de saúde, ainda não executados.

Os contatos posteriores com ambos os novos territórios, ainda nos primeiros tempos da pesquisa de campo - já mais ao rés do chão, mas ainda 'estrangeiros' -, só vieram acentuar a primeira impressão panorâmica de que, apesar da distinção de faixa de renda que os diferenciava perante o Programa, em vários aspectos as condições socioespaciais de ambos seriam muito próximas: isolamento e desconexão em relação à malha urbana preexistente, ausência de equipamentos públicos e serviços, atendimento insuficiente por transporte público, habitações mínimas e entregues com parte de acabamentos por fazer (dos quais a ausência de limites físicos entre as casas e de pavimentação no entorno delas, gerando espaços de terra batida entre as moradias e em frente a elas, amplificava a sensação de que se encontravam inacabadas) foram aspectos que minha visão de urbanista tendia a comparar, inevitavelmente, pelo fato de ambos terem sido produzidos no âmbito do mesmo Programa, numa mesma macrorregião da cidade, mesmo ainda sem saber, então, que haviam sido promovidos pela mesma construtora - informação que só corroborou essas primeiras leituras.

Entretanto, a pesquisa se encarregaria de aprofundar tais perspectivas, ao apreender esses novos bairros pelas trajetórias, narrativas e práticas de meus interlocutores: esses novos espaços e as territorialidades que ali se produziam, para além da semelhança visual que os aproximava (ainda) de imediato, se mostrariam muito mais

78 Cf. http://www.saocarlos.sp.gov.br/index.php/noticias-2011/161180-prefeito-visita-491-casasdo-novo-mundo.html (consulta em fevereiro de 2014). 
complexos a partir dessa mirada mais detida e, sobretudo, pela oportunidade de apreendê-los, simultaneamente, em contraste e em comparação. Ainda que o objetivo não tenha sido etnografar os bairros em si, na já clássica tradição de estudo de "áreas pobres e degradadas", "bairros de pobres" ou "bairros de periferia"79, o lugar que esses novos espaços produzidos na cidade ocuparam na trajetória de meus interlocutores tornou inevitável refletir um pouco sobre eles ou, melhor dizendo, tentar apreender, a partir das narrativas e dos jogos de perspectivas que se criam nos cruzamentos das percepções de meus interlocutores (e delas, com as minhas), alguns elementos relativos a pontos de conexão e distinção entre esses novos territórios, de modo a iluminá-los.

Ao passo que ia adentrando no universo cotidiano de meus interlocutores através das entrevistas e de observações - e ainda que suas casas tenham sido o principal espaço que frequentei e onde permaneci ao longo da pesquisa -, o simples fato de deslocar-me até tais bairros e transitar por eles foi me permitindo observar alguns de seus processos de transformação e apropriação ao longo desses dois anos de pesquisa. Melhorias gradativas nas conexões com o entorno e a malha urbana facilitaram os acessos aos bairros e destes para o restante da cidade (evidenciando também uma espécie de 'preparação urbana' para anunciados novos investimentos habitacionais nos arredores de ambos os bairros); a homogeneização inicial da paisagem foi, aos poucos, transformando-se com a construção dos muros e portões e alterações nas casas, conferindo aos bairros cada vez menos a aparência de "conjuntos" e mais a de "bairros populares", nos quais a presença contínua de materiais de construção nas calçadas passaram a fazer parte da paisagem local; a somatória entre a observação de casas vazias que pouco a pouco foram sendo ocupadas (e, em seguida, transformadas), do aparecimento de pequenos comércios aqui e ali e de um progressivo aumento do movimento de pessoas nas ruas e calçadas, tudo foi eliminando as primeiras imagens quase 'fantasmagóricas' que eu tinha formado sobre os bairros, cuja ausência, inicialmente observada, de dinâmicas socioespaciais para além do espaço doméstico quase me fez acreditar que se trataria de "bairros dormitórios".

Já nesta perspectiva, começavam a anunciar-se não apenas muitos matizes naquilo que eu havia notado panoramicamente como semelhanças, mas também uma vasta paleta de distinções entre os bairros (e também internamente a eles), como atestam alguns exemplos elencados a seguir. A construção dos muros e portões e a ampliação das casas foi a diferenciação mais evidente, seja porque ocorreu de forma muito mais rápida, disseminada e, de certa forma, homogênea no Parque Novo Mundo do que no Jardim Zavaglia, seja porque, neste, tal processo visibilizou maiores distinções e 
precariedades, contrastando casas com muros e portões 'reluzentes' com outras cujos fechamentos foram sendo feitos com materiais de descarte (como restos de madeira e placas metálicas), ou ainda casas com garagens e novos cômodos construídos contrastando com aquelas onde ainda imperavam o piso de terra batida ou os muros e ampliações inacabadas, paralisadas por longos períodos (conferindo uma sensação de 'ruína' às casas ainda novas). A presença de uma escola improvisada no barracão do canteiro de obras do Jardim Zavaglia, depois demolida; a posterior construção de um grande "equipamento social" por uma organização-não governamental nesse mesmo bairro; a construção (mais recente) de um posto de saúde, bem como uma sequência de faixas anunciando "atividades sociais" da prefeitura no conjunto, durante o período em que o frequentei, também foram indicativos de distinções nos modos de tratamento dos bairros pelo governo municipal, já que no Parque Novo Mundo não houve sinais de atuação neste sentido. Também chamou a atenção a construção de pelo menos quatro estabelecimentos comerciais formais no Jardim Zavaglia, enquanto as áreas destinadas ao comércio no Parque Novo Mundo seguem como um grande vazio. A progressiva vitalidade dos bairros também mostrou distinções, uma vez que se deu de forma muito mais evidente no Jardim Zavaglia, seja pela cada vez maior quantidade de pessoas observada nas ruas do bairro em fins de tarde e finais de semana, seja pelo rápido desenvolvimento do comércio informal no bairro, situações que lentamente passaram a acontecer também no Parque Novo Mundo, mas em escala muito menor. E, por fim, uma característica que me pareceu bastante distintiva entre o que pude observar em ambos os bairros: o cada vez mais intenso "movimento nas esquinas" do bairro Jardim Zavaglia, indicativos, para quem está habituado ao universo das periferias, da presença ativa do tráfico de drogas no local.

E, se os próprios bairros, bem como a minha perspectiva sobre eles, foram se transformando ao longo desse período, pude acompanhar também essa transformação na perspectiva de meus interlocutores, captando desde suas primeiríssimas impressões, quando recém-mudados para o local, ainda quase abstratas e pautadas muito mais em expectativas do que em uma vivência real dos locais, até as perspectivas já mais concretas, um tanto consolidadas após cerca de dois anos vivendo nos bairros.

A perspectiva inicial, em ambos os casos, esteve muito voltada para a casa em si, pela sensação inédita, misto de segurança e liberdade de "ter onde morar sem depender dos outros", que ambas as famílias frisaram muitas vezes. A experiência - também inédita - de terem se mudado para uma casa prontinha era o aspecto sempre exaltado nos primeiros tempos da pesquisa, que coincidiram com os primeiros tempos após a mudança das famílias. Depois de algum tempo morando na casa, a 
ausência de alguns acabamentos internos, no caso de Joana, e de muros e pisos externos em ambos os $\operatorname{casos}^{80}$, passam a ser acionados como elementos que atestam a incompletude das casas entregues, quer evocando as dificuldades para dar conta dessas melhorias, quer, e sobretudo, comparando-as às casas de outros empreendimentos considerados semelhantes (no caso de Beatriz e Jefferson) ou às notícias evocadas por Joana de que "no Zavaglia $\|^{81}$ vai ter tudo o que faltou aqui: laje, pisos, muro... Eu não acho isso justo." Nada disso, porém, diminui a ênfase na positividade da casa prontinha, o que tem relação direta com as experiências anteriores de autoconstrução da moradia, ou de viver de aluguel em casas inacabadas, as quais seriam sua contraface ${ }^{82}$. Isso não significa que esta casa não passará, também ela, pelo processo de autoconstrução; ao contrário, a ideia de reforma ou ampliação das casas é algo pulsante - como veremos a seguir -, mas é justamente o fato de terem um núcleo-base construído, para onde puderam se mudar (deixando o aluguel ou a coabitação) e a partir do qual podem articular ampliações e melhorias, que configura essa noção da casa prontinha, extremamente valorizada.

A essa concepção se associa outra, também recorrente em ambos os casos, do espaço organizado das novas casas, entendido, em contraposição aos espaços das casas autoconstruídas por seus familiares ou aos cômodos cedidos ou alugados onde moraram (também autoconstruídos), como uma compartimentação dos espaços internos que permite separar os mais privados (quartos, banheiro) daqueles mais coletivos (sala, cozinha), possibilitando que possam receber pessoas em casa sem que estas tenham que sentar na cama, ou que os membros da família possam dormir em quartos separados, sem mais ficarem amontoados ou usando a sala de quarto. Entretanto, se esse era um ponto fundamental nas primeiras entrevistas, nas últimas, em especial no caso de Joana (cuja família não apenas se ampliou, com a chegada inesperada de um bebê, mas também a casa passou a abrigar a filha mais velha e a

80 As casas do Jardim Zavaglia foram entregues sem revestimentos de piso na maior parte dos cômodos e sem laje, o que teria sido apresentado como elementos distintivos, pela construtora, na construção das casas do Parque Novo Mundo, que apresentavam tais acabamentos. Em ambos os casos, as casas foram entregues sem muros e sem contrapiso nas áreas lindeiras à casa.

81 Joana se refere à construção de mais 986 casas pela mesma construtora, praticamente contíguas ao Jardim Zavaglia, que, embora seja denominada oficialmente "Residencial Eduardo Abdelnur", já é conhecida popularmente como "Zavaglia II". Jefferson também chegou a mencionar um futuro "Parque Novo Mundo II". Essa forma de nomear traz à tona o quão introjetado parece estar, para esta população, o caráter de 'reprodutibilidade' desse tipo de empreendimento, a ponto de, independente de os novos bairros terem efetivamente o mesmo nome dos bairros anteriores, a que serão contíguos, já são encarados praticamente como uma 'extensão' destes, ou seja, mais do mesmo.

82 Também Jimmy expressaria essa dimensão a respeito da futura casa própria: “aqui é tudo acabadinho, tudo bonitinho, não tem comparação com nenhum lugar onde eu morei antes. É outro nível, não tem como, antes era só casa inacabada, mal feita, mal organizada, de fundo, porta que não fecha, encanamento que não funciona... aqui é tudo certinho, tudo prontinho". 
neta, que inicialmente haviam permanecido na casa anterior da família, totalizando sete moradores), mas também no de Beatriz e Jefferson, a insatisfação quanto ao fato de a casa ser pequena passou a ser mais recorrente, embora sempre atravessada por uma espécie de condescendência em relação ao fato de terem conquistado a tal casa prontinha, que seria um privilégio que não lhes daria direito de reclamar:

Satisfeita, satisfeita a gente nunca tá, porque, igual, aqui só tem dois quartos e eu tenho o Ryan, né, que é solteiro, e tem as meninas. Então, aqui eu acho que falta um quarto, pra caber toda a família. Pra gente ficar mais aconchegado, eu acho que precisaria de mais um quarto e uma cozinha maior, que essa é quase um corredor, né? (risos) Tanto é que a gente fez aqui na frente, você viu? Já fez o alicerce, aqui do lado né, já tá feito a estrutura embaixo, então é só erguer as paredes. Na verdade, a parede dali que tá sendo erguida dá estrutura pra depois cobrir e fazer a cozinha do lado. (...) porque... é uma casa pequena, né? Sala, quarto, banheiro, tudo bem, tá num tamanho que pra mim até tá bom, é pequeno, mas... se eu fosse construir, nem isso eu ia conseguir. Mas uma cozinha maior e mais um quarto é necessário, né? Então é nisso que a gente tá investindo. Mas... do jeito que tá, dá pra morar. [Joana]

No entanto, com todas as questões que possam ter, em ambos os casos se sobrepõe sempre a percepção de que mudança de casa representou uma melhoria efetiva nas condições de vida cotidiana, expressa em afirmações de que agora eles moram bem, de que "pela primeira vez a gente tem conforto de verdade". Nessas afirmações estão associadas a garantia de ter uma casa (estando livres das dificuldades e vicissitudes da vida de aluguel, da coabitação ou da dependência de cômodos cedidos), o fato de essa casa ser prontinha, ter o espaço organizado, onde se acomodam mobiliários e eletrodomésticos que antes não tinham condições de adquirir, nem espaço para colocar, além de estar implícita, também, a própria possibilidade de poder ampliar a casa (tida como fundamental), que ambas as famílias destacam que não teriam, se tivessem permanecido nos cômodos nos "quintais" familiares, por falta de espaço.

De fato, apesar da valorização da casa prontinha, ambas as famílias deram início a alterações e projetos de ampliações nas casas imediatamente após a mudança, numa prática em que à necessidade associa-se uma relação com o espaço que passa pelo seu ajuste às práticas cotidianas da família, e não pelo estabelecimento de uma funcionalidade a priori ${ }^{83}$ : a casa prontinha instantaneamente se tornou uma casa em processo, inacabada, sempre com algo por fazer, e isso, paradoxalmente, é um valor intrínseco a ela. Instalados na casa prontinha, ajustando-a aos poucos, conforme os

83 Cf. destacam Nascimento e Tostes $(2011: 3,4)$ em artigo crítico sobre o Programa Minha Casa Minha Vida: "nos espaços não planejados por arquitetos é muito comum a presença de arranjos espaciais mais complexos, sem a correspondência unívoca espaço-atividade e principalmente atividade-setor, em arranjos mais condizentes com as práticas cotidianas de seus habitantes: a cozinha é muitas vezes um espaço de sociabilidade, e não de mero "serviço" a cargo de trabalhadores domésticos como nas casas de classe média, assim como é usual dormir em espaços que não sejam exclusivamente quartos, uma vez que a especialização de usos em cada espaço nem sempre está presente". 
recursos permitem (na conhecida dinâmica da autoconstrução), o "sonho da casa própria" converte-se no 'sonho da casa pronta':

Como a gente, a maioria aqui tá mexendo na casa desde que mudou, ou antes de mudar mesmo. Tem outros que já mexeram, que já tá pronta a casa, já tão com uma casa maior... as casas prontas mesmo você fica babando, porque ficaram lindas! Quando a gente vê, a gente até vai conversar com a pessoa: 'ah, deixa eu ver', vai dentro pra ver, porque daí você já tem uma ideia, né? (Beatriz)

Embora em ambos os bairros haja uma normatividade referente às possibilidades de ampliações nas casas (e ao próprio uso do espaço exclusivamente para moradia) expressa pela construtora em reuniões com os moradores e em documentos entregues aos mesmos (contratos e espécies de 'manuais do proprietário') ${ }^{84}$, as dinâmicas observadas em profundidade nas casas de Joana e de Jefferson e Beatriz e, de forma geral, na grande maioria das casas nos dois bairros - indicam que, apesar dessa normatividade, as práticas cotidianas, as necessidades que a vida nas novas casas impõe aos seus exíguos espaços prontinhos, a situação econômica e, principalmente, a forma como as famílias usam os espaços vêm incidindo em uma significativa transformação das casas. ${ }^{85}$

No contrato tá escrito que não podia vender, não podia alugar, não podia fazer comércio, nem colocar pessoa estranha pra morar sem cobrar. Tudo que todo mundo tá fazendo! Tem vários comércios aqui na vila, já tem sorveteria numa casa, tem cabeleireira, tem igreja... Tem gente que transformou a casa em igreja, entendeu, ou construíram na frente um cômodo e tá usando como igreja... Então, tudo que não podia, tem! Se fosse mexer na casa, tinha que seguir as instruções. E tá todo mundo mexendo na casa, construindo como bem quer, como dá... a gente mesmo! Se fosse realmente fiscalizado, nada disso taria tendo. (Joana)

A essa dimensão primordial da casa própria - e prontinha - associava-se ainda, inicialmente, a satisfação de terem se mudado para um bairro novo, mas também ele pronto: a existência, já no ato da mudança, de infraestrutura urbana básica (água, iluminação, esgoto, asfalto) é vivida quase como uma prerrogativa (sobretudo por

84 Tal normatização no Jardim Zavaglia chegou a um patamar "inédito no âmbito do Minha Casa, Minha Vida", através da pré-definição de oito modelos padronizados de alteração do projeto arquitetônico original, disponibilizados no site da prefeitura (http://www.saocarlos.sp.gov.br/index.php/plantas-pre-aprovadas-res-dep-jose-zavaglia.html, consulta em fev/2014). Conforme depoimento do então diretor-presidente da Prohab à revista Valor Econômico, quando da conclusão do empreendimento: “Queremos evitar os puxadinhos, que o bairro cresça de forma desordenada e fique feio. Vamos dar oito alternativas de plantas. Se a pessoa quiser fazer um quarto e um banheiro, ou um novo quarto e mexer no quintal, o desenho estará pronto, não vai precisar gastar com engenheiro". (cf. http://www.valor.com.br/impresso/especial/minha-casaentrega-projeto-incompleto, consulta em fev/2014). Veja-se, também, o que diz Jefferson sobre tais normativas no Parque Novo Mundo: "Pelo que eu sei a casa tem um seguro aqui, ela tem um seguro. Vamos supor, a partir do momento que eu quebrar uma parede, já perdi todo o seguro. (...) Tem um livrinho que orienta tudo, onde você pode mexer, onde pode ou não pode quebrar. Só que quase ninguém segue".

85 Ver, a esse respeito, o estudo de Hernández (2006). 
Joana), sobrepondo-se também, nesse primeiro momento, a outros aspectos inconclusos dos bairros, que eles mesmos viriam a destacar com o passar do tempo, por representar um patamar inicial diferenciado em relação às experiências anteriores de mudança para bairros ainda sem urbanização, vividas por todos eles em maior ou menor grau (como apresentado na seção anterior).

Nesse sentido, essa percepção evidencia, ainda, o fato de que ambos os bairros são bastante distintos, em termos visuais, de todos os outros locais onde eles já viveram, que se caracterizavam pela feiúra associada ao barro das ruas e ao mato que circundava as poucas casas existentes inicialmente, e onde predominava a autoconstrução de moradias e demais edificações (com exceção da experiência de Jefferson em um conjunto habitacional em São Paulo): se a homogeneização inicial da paisagem dos novos bairros, que chegou a confundir até eles próprios, nos primeiros dias ali (tanto Beatriz e Jefferson quanto Joana me relataram que, logo após a mudança, por uma ou duas vezes quase entraram em casas que não eram as deles), era algo significativo nessas primeiras impressões, aos poucos foi se transformando com a construção dos muros e portões, alterações nas casas ou mínimas apropriações que pudessem conferir alguma identidade, como atesta Beatriz: "depois que eu coloquei essa cortina, aí ficou mais nossa. Mais pra frente, vai ser o muro e o portão". É realmente notável a profusão de portões diferenciados a reconfigurar essa paisagem: se, por um lado, tais intervenções respondem a esse sentido de conferir alguma identidade às casas, por outro, relacionam-se aos materiais e condições mais 'à mão' para executar uma melhoria considerada prioritária: o fechamento das casas. Com o passar do tempo, esses fechamentos vêm se transformando em elementos de distinção interna, como indica a fala de Joana em um de nossos últimos encontros:

Então, porque tem muita gente, igual os aposentados, ou o pessoal que veio de área de risco, que ganharam casas aqui, tem muita casa sem muro, sem portão, porque num tem condição de fazer o muro, entendeu, porque a mão de obra é cara, né, num consegue financiar o material... Aí fica sem muro, ou vai fechando com esses tapume, papelão... [Joana]

Ainda em torno dessa dimensão de bairros prontos e distintos dos bairros onde moraram anteriormente, é interessante destacar que esses novos bairros têm limites e acessos muito bem definidos, em função de suas próprias inserções e localizações urbanas - ambos se encontram em extremos ao sul da malha urbana, delimitados por áreas verdes, áreas rurais, estradas - sobretudo no caso do Parque Novo Mundo, em que a isso se somam um desenho urbano quase condominial ${ }^{86}$, a ausência de

86 Sobre o fato de o Parque Novo Mundo ter uma delimitação aparentemente condominial, sem, no entanto, configurar-se efetivamente como um condomínio, os próprios Jefferson e Beatriz mencionaram sua expectativa, quando da aquisição da casa, de que o local fosse se configurar como tal, em função de outros empreendimentos produzidos no âmbito do Programa na cidade, para a 
outros bairros vizinhos e a necessidade de se cruzarem estradas para acessar qualquer outra parte da cidade. Se a sensação de isolamento já fora sentida por meus interlocutores em outros locais de moradia (conforme seção anterior), essa delimitação precisa dos bairros, com pontos de entrada e saída bastante definidos, é mais um aspecto que os diferencia muito dos bairros anteriores onde já moraram, que são espécie de "ficção", com limites e fronteiras ilegíveis para um observador externo, mas que conferem sentidos de identidade aos que compartilham desse reconhecimento comum ${ }^{87}$.

A questão do isolamento se acirra quando o assunto são os deslocamentos entre o bairro e o restante da cidade: em ambos os casos é reiterado o fato de que os bairros são longe (embora o significado dessa qualificação varie - o parâmetro, em geral, são os bairros de origem de cada um deles, ou, mais eventualmente, a região central da cidade) e que há uma grande dificuldade em relação ao transporte público, ainda que seja o tópico em que mais se evidencia a já mencionada reticência em apontar problemas nos novos bairros, nas novas casas, como se não tivessem esse direito, ou, ainda, não quisessem macular o prazer da conquista da casa própria. Assim, mesmo que o assunto do transporte público e das limitações que a lonjura dos bairros impõem tenha surgido espontaneamente por parte dos interlocutores em diversas conversas e entrevistas, sempre em tom crítico, este acaba sendo amenizado pelo fato de ambas as famílias terem um carro (e, mais recentemente, uma moto) e porque os deslocamentos têm se tornado gradativamente mais reduzidos.

Ambas as famílias relatam o parco atendimento por transporte público; entretanto, evidenciam-se aí distinções relativas ao 'perfil' dos bairros (que parece seguir a mesma lógica de "públicos-alvo" por "faixa de renda" do PMCMV): no Jardim Zavaglia operam duas linhas de ônibus, além de haver a possibilidade de os moradores deslocarem-se até o bairro vizinho (Antenor Garcia) para fazer uso, em caso de necessidade, de outras três linhas que ali operam - as quais, somadas, possibilitam o deslocamento para a quase totalidade do perímetro urbano, em trajetos que duram entre uma hora e uma hora e meia (tempo considerado excessivo pelos moradores, tendo em vista a escala da cidade); já no Parque Novo Mundo há apenas uma linha em atividade, com amplitude de deslocamento na cidade bastante mais reduzida ${ }^{88}$. Tal situação faz Jefferson e Beatriz afirmarem, diversas vezes, categóricos: "não tem

chamada "Faixa 2", reproduzirem, em sua maioria, essa "forma-condomínio". Entretanto, embora o bairro tenha apenas uma entrada e seja bem delimitado em seu isolamento (como já mencionado), não se configurou em nada como um condomínio, frustrando as expectativas sobretudo de Beatriz. Para uma reflexão sobre a reprodução dessa "forma-condomínio" em "versões populares", denominada pela autora de "la clonación del paisaje de la exclusión", ver Chumillas (2007).

87 Cf. Portal (2006:69).

88 Informações confirmadas no site da empresa concessionária de transporte público na cidade: www.athenaspaulista.com.br (consultado em 26/02/2014). 
como morar aqui sem carro", evidenciando a vinculação estreita entre a produção desses novos territórios e o pressuposto do transporte individual. Este seria, inclusive, motivo de novo deslocamento habitacional de algumas famílias que adquiriram uma casa no bairro, as quais "abriram mão da casa própria" e estariam vivendo de aluguel em bairros mais bem localizados da cidade, às custas do aluguel de suas casas no bairro para famílias que não dependam do transporte público ${ }^{89}$.

E se a dificuldade de deslocamento a partir do bairro é vivida - cada vez mais, com o passar do tempo - como um problema, ele se torna ainda mais agravado em função da ausência de comércio, serviços e equipamentos públicos ${ }^{90}$ em ambos os bairros. Desde nossos primeiros encontros, esse aspecto fora ressaltado por ambas as famílias; porém, nesse primeiro momento, havia o entendimento de que estavam destinados espaços para tanto, sendo questão de tempo sua implantação.

Então, logo no início das obras [do Parque Novo Mundo], eles apresentaram uma maquete no dia da reunião, que foi no prédio da prefeitura, onde essas áreas eram denominadas por cores: o que era comércio, o que era da prefeitura... Falaram que seria construído área de lazer, escola e posto de saúde. A construtora reservou os terrenos, e a prefeitura ia fazer. Mas depois, em nossas mãos só chegou coisas relacionadas às casas, só, então a gente não sabe nem o quê e nem quando será construído. [Jefferson]

Com o passar do tempo, esse aspecto também passou a diferenciar ambos os locais: no Jardim Zavaglia, passados os primeiros meses, já foram aparecendo, aqui e ali, comércios informais no próprio espaço das casas (contrariando as determinações do Programa de "não usar o imóvel para fins comerciais ou outros fins que não residência" ${ }^{\prime 1}$ ) e ao menos três instalações comerciais foram implantadas nos locais destinados oficialmente para comércio no bairro (um supermercado, um sacolão e um açougue) já no primeiro ano; por sua vez, no Parque Novo Mundo, apenas muito recentemente foram instalados um sacolão, uma lanchonete e uma lan house nas próprias casas, permanecendo um grande vazio onde estaria prevista "oficialmente" a implantação de áreas comerciais e equipamentos públicos.

89 Tive a oportunidade de conhecer duas famílias que haviam acabado de se mudar para o bairro, em casas alugadas via mercado informal, cujos proprietários haviam deixado o bairro por este exato motivo. Vale destacar que, em ambos os casos, os novos inquilinos possuíam carros.

90 Em termos de equipamentos públicos, como mencionado anteriormente, nos primeiros tempos chegou a funcionar, no Jardim Zavaglia, uma escola improvisada no barracão do canteiro de obras do bairro, mas que, em pouco menos de um ano, já estava desativada, sendo as crianças transferidas para uma escola no bairro Antenor Garcia. Em 2014, estavam em andamento as obras de um posto de saúde no mesmo bairro. No Parque Novo Mundo, até 2014 não havia sinal de implementação de qualquer tipo de equipamento público.

91 Cf. seção informativa na página da CEF sobre o Programa, intitulada "O que você deve fazer para não perder o imóvel", disponível em: www.caixa.gov.br/novo_habitacao/minha-casa-minhavida/urbana-prefeitura-mov-sociais.asp (última consulta em maio/2014). 
Aqui no bairro, já foi decretado que não poderia ter comércio entre as casas. Porque já tinha área certa pra comércio. Então têm uns terrenos lá embaixo que é justamente pra isso. Aí o pessoal dali da Rede 10 comprou o terreno e montou o mercado, tá entendendo? Como qualquer outro bairro... Tem que comprar o terreno pra fazer ali, na área que é reservada. / Thaís: Por enquanto o que tem de comércio é só o mercado? / Então, na verdade o pessoal abriu algumas coisas por aí, sim. Nas casas. Aqui em cima, tem um barzinho; tem outro na rua de cima, acho que é na rua de cima mesmo, se eu não tô enganada. Tipo um barzinho, entendeu? Que vende bebida, cigarro, salgadinho, essas coisas assim. Aqui embaixo, na rua de baixo aqui, quase perto da escolinha que fizeram ali, tem uma mulher que vende bolo, salgado, refrigerante, entendeu? Mas também... aqui tem o Antenor, o que divide o Zavaglia do Antenor Garcia é só uma estradinha de terra, que a gente atravessando a estradinha de terra, já tem mercado, tem sacolão, tem farmácia... tudo ali pertinho. [Joana]

Além disso, outro aspecto destacado nos relatos de Joana acerca do Jardim Zavaglia, que atesta uma diferença relevante em relação ao Parque Novo Mundo, é o fato de que haver ao menos um bairro contíguo a ele (o Antenor Garcia) e, como no caso do transporte público, também em termos de comércio e serviços - sobretudo acesso a equipamentos públicos de educação e saúde - essa proximidade acaba por atender algumas demandas dos moradores do novo bairro. ${ }^{92}$ Já o Parque Novo Mundo não tem conexão alguma com outros bairros, sendo necessário deslocamentos a distâncias razoáveis para se ter acesso a esses serviços.

Se, entretanto, a proximidade com o Antenor Garcia passou a ser vista com bons olhos por Joana após algum tempo vivendo no Jardim Zavaglia, antes e no ato da mudança, a situação gerara preocupações e temores relativos à caracterização pública do bairro (e da região do Cidade Aracy) como polo de criminalidade e tráfico de drogas na cidade. Casas próximas à sua haviam sido roubadas ainda em obras, e

92 É de se retomar que, a despeito da sabida insuficiência dos equipamentos e serviços públicos no bairro Antenor Garcia (PMSC, 2005; Ávila, 2006; Angelin, 2012) - que, inclusive, foi alvo de manifestação recente por parte dos moradores, reivindicando "melhorias como: asfalto, saneamento básico e um posto de saúde, além de mais ônibus" (cf. www.saocarlosagora.com.br/cidade/noticia/2014/03/26/52546/moradores-protestam-pormelhorias-no-bairro-antenor-garcia/) -, sua sobreutilização pelos moradores do novo bairro já fora prevista pela $\mathrm{PROHAB}$, responsável municipal pela implementação do conjunto produzido pela construtora RPS, sendo acionada inclusive como justificativa perante as exigências do Programa em termos de infraestrutura urbana nos empreendimentos produzidos para a "Faixa 1", como atesta este depoimento do então diretor-presidente da Prohab, em reportagem de 2011 do Jornal Valor Econômico: "A exigência do Minha Casa, Minha Vida é que os equipamentos públicos estejam num raio de dois quilômetros do empreendimento. Estamos correndo contra o tempo para deixar tudo pronto aqui, mas enquanto não é possível temos duas creches, posto de saúde e escolas no Antenor Garcia, bairro que fica a 600 metros". (Cf. www.valor.com.br/impresso/especial/minha-casa-entregaprojeto-incompleto, consulta em fev/2014). A mesma informação foi divulgada em site do Ministério do Planejamento, quando da divulgação da inauguração do conjunto: “A comunidade será atendida, ainda, em um raio de dois quilômetros por Posto de Saúde da Família, Unidade Básica de Saúde, Escola Municipal de Ensino Infantil, três Escolas Estaduais, bem como por centro comunitário, pista de skate e piscina para atender aos moradores." www.planejamento.gov.br/conteudo.asp?p=noticia\&ler=7615, consulta em fev/2014). 
as suspeitas recaíram, inicialmente, aos "usuários de drogas do bairro vizinho"; posteriormente, incidiriam em usuários de drogas do próprio bairro. Depois de pouco mais de um ano morando ali, a presença de um ponto de venda de drogas em frente à sua casa já seria tratada com alguma naturalidade, sobretudo a partir de referências anteriores de moradia, tanto no bairro Santa Felícia quanto no Jardim Beatriz, nos quais ela teria convivido com situações bastante próximas.

Aí, quando eu falava que ia vim pra cá, eles [familiares e vizinhos do Santa Felícia] falava assim: 'ah mas você vai pro Zavaglia'? Não, eles não falava Zavaglia, falava: 'você vai lá pro Cidade Aracy? Lá, um lugar violento, onde tem droga'... Gente, mas todo lugar tem, no Santa Felícia também tem, que eu sei que tem, então se a gente for ficar com medo de ir pra algum lugar você não vai viver, não vai pra lugar nenhum. [Joana]

Em que pese essa gradativa adaptação, sua narrativa permaneceu enfatizando o fato de que não foi uma escolha viver ali, mas quase uma condição para a família ter acesso a uma casa própria:

Eu tive sorte de conseguir logo na primeira vez que me inscrevi! Mas eu acho que não é que seja sorte minha, é que eu não escolhi lugar. Porque teve gente que ganhou aqui e não quis! Eu conheço gente que ganhou aqui e desistiu, conheço gente lá da Santa Felícia mesmo. Não quis, desistiu, na hora que foi sorteado e viu onde era, desistiu, não quis. Alguns alegou que é porque era muito longe, mas se for ver, a maioria não quis porque era perto da Aracy. [Joana]

De fato, Joana não escolheu morar no Jardim Zavaglia, e seus relatos deixam entrever que, mais do que enfrentar os preconceitos de familiares e conhecidos, ou submeterse a morar em um bairro longe, ela teve de superar seus próprios preconceitos após a conquista da casa no bairro. Essa situação é bastante diferente, talvez até oposta, da de Jefferson e Beatriz, que decidiram comprar uma casa em um loteamento específico, sem nem sequer cogitar a possibilidade de adquiri-la em loteamentos semelhantes em outras regiões da cidade. Para eles, tratou-se de uma escolha consciente, que teve por objetivo atender, simultaneamente, a demandas bem distintas de cada uma das partes do casal, como visto: a dela, de sair da Cidade Aracy a qualquer custo e a dele, de manter-se próximo e vinculado ao local a que tinha tanto apreço. É de se recordar que tal escolha passou, inclusive, por "não ir atrás do sorteio" de casas pela Prohab, para o qual chegaram a se inscrever, por não saberem para onde seriam mandados.

Porque, se você é sorteado numa casa da Prohab, você pode ser mandado pra qualquer bairro. Por exemplo, você chegou conhecer o Zavaglia, né? Dá umas andadinhas lá, você vai ver, é totalmente diferente daqui! (risos). É um bairro de pessoas de baixa renda, que, se você for à noite andar, as pessoas já... perguntam, sabe? Saiu tiroteio, sabe? (...) Porque, tipo assim, o que acontece, no caso, o Zavaglia, separaram acho que uma ou duas ruas lá pra pessoas que moravam em área de risco ou lugares que precisavam ser desapropriados, $e$ mandaram pra lá, entendeu? (...) sabe aquela parte ali de cima, aquelas duas ruas de assim? São casas dadas. Ali são doadas. [Beatriz] 
Aqui chegamos a um ponto crucial em termos das aproximações e distanciamentos entre os dois territórios, seus modos de produção e apropriação, mas também entre as trajetórias aqui investigadas e os projetos familiares que delas decorrem. Se em tantos aspectos esses novos bairros parecem bastante similares, há outras tantas diferenças não insignificantes que já foram apontadas, dentre as quais este seria o aspecto mais específico em que a distância entre eles parece agudecer: a presença do tráfico de drogas e da violência no Jardim Zavaglia. Essa distinção, essencial aos olhos de Jefferson e Beatriz, é vista por eles como decorrente da localização e dos modos de produção e ocupação dos territórios e das moradias, bem como dos públicos-alvo a que se destinaram - se mais próximo ou mais distante da região do Cidade Aracy, se comercializadas via mercado formal ou sorteadas pela PROHAB, se compradas por pessoas com melhores condições ou se ganhas por pessoas de baixa renda.

Tem muita diferença aqui e lá! Muita diferença! Zavaglia, Zavaglia... que nem essa favelinha que a gente tá falando, eles tiraram essa favelinha da Aracy ${ }^{93}$, fizeram uma escola, e depois o pessoal dessa favelinha ganharam uma casa no Zavaglia. Tipo, eu não acho que a pessoa, só porque ganhou uma casa, vai mudar o ramo de vida. Se tava vendendo droga aqui, vai vender droga lá. Se fazia ponto aqui, vai ser ponto lá. Infelizmente as pessoas não crescem com as oportunidades ali. A mente é tão pequena, que, pô, 'ganhei uma casa, vou montar um mercado...', não! A pessoa continua com a mesma mente. E lá, se você receber Bolsa-Família... qualquer, todas as pessoas de baixa renda ganharam casa lá. Aqui não, aqui a renda mínima, foi até aí que a gente teve que correr atrás, era pra mil trezentos e cinquenta. Quer dizer, não é preconceito meu, mas uma pessoa que ganha mil trezentos e cinquenta, tem um emprego fixo... Sei lá, na minha opinião, pode ser preconceito [risos], mas é melhor. Não é uma pessoa que tá... É uma pessoa que trabalha. Que nem, você vem aqui de dia, isso aqui tá vazio. Tá todo mundo trabalhando. [Beatriz]

A dimensão de que, no Parque Novo Mundo, as casas teriam sido compradas por famílias cuja renda mensal mínima equivale à renda mensal máxima das famílias que pegaram casas no Jardim Zavaglia se coloca como eixo central dessa distinção entre os bairros e, mais, entre o que Beatriz acredita ser uma nova posição socioespacial de sua família (classe média baixa) e aquela das famílias de baixa renda que habitariam o Jardim Zavaglia. Ao promover essa distinção entre ambos os bairros e entre os tipos de pessoas que neles habitam, parece haver muito mais uma intenção de reafirmar essa posição que ela acredita ter adquirido com a compra da casa do que, propriamente, um conhecimento de causa sobre as reais condições do Jardim Zavaglia, bairro que ela e Jefferson instituíram em contraface do seu próprio bairro: por um lado, em sua fala, ela relembra que a renda de sua própria família não atingia,

93 Ela refere-se a um pequeno trecho do Cidade Aracy I, conhecido entre os moradores do bairro como favelinha pelas condições mais precárias das moradias e do espaço urbano e por sua identificação como lugar de grande concentração de vendedores e usuários de drogas ilícitas. 
quando da compra, a renda mínima necessária para enquadrar-se na faixa a que se destinava o Parque Novo Mundo; por outro, ela se refere aos moradores do Jardim Zavaglia como se todos fizessem corpo mole para o trabalho, encontrando, no tráfico de drogas, uma forma fácil de ganhar a vida, estendendo, assim, ao bairro o preconceito generalizado que incide sobre o Cidade Aracy e que ela mesma admite não ser condizente com a realidade, tendo em vista o período em que lá viveu. De todo modo, o fato é que, para Jefferson e Beatriz, o Parque Novo Mundo seria um bairro de trabalhadores, enquanto no Jardim Zavaglia predominariam os mais pobres, e, dentre eles, os envolvidos com o tráfico de drogas.

É interessante notar que, se para Jefferson e Beatriz o Jardim Zavaglia representa o oposto do bairro onde vivem, para Joana, o Parque Novo Mundo não é uma referência, nem sequer contraponto, indicando um movimento de mão única. Por outro lado, considerando informações obtidas em campo no bairro Cidade Aracy, junto a pessoas do círculo de Jefferson e Beatriz, verifica-se, por vezes, a percepção genérica de uma indistinção entre ambos os bairros ("é tudo a mesma coisa" me diria, por exemplo, Jimmy, por diversas vezes, até que seu irmão foi morar lá e sua opinião mudou) e até mesmo certo tom de deboche pelo fato de Beatriz e Jefferson terem comprado a casa, enquanto, no Jardim Zavaglia, as pessoas teriam ganho: ainda que tal percepção também não se ancore em um conhecimento efetivo de ambos os bairros, o que interessa aqui apreender é que esse tipo de concepção circula no meio que eles seguem frequentando e ilumina os sentidos dessa recorrente diferenciação evidenciada em suas narrativas, espécie de justificação quanto à escolha realizada em torno da moradia.

Isso se torna ainda mais notório quando os relatos do casal deixam entrever essa consciência de que a condição socioeconômica deles não é assim tão melhor do que a de algumas famílias moradoras do Jardim Zavaglia, que eles mesmos conhecem, e que as próprias condições gerais do bairro onde vivem também apresentam muitas semelhanças com as daquele, sobretudo em termos de ser afastado e destinado a uma população que não teria outra forma de acessar a casa própria, aspectos que Beatriz associa à ideia de periferia.

Eu moro na periferia, eu também moro na periferia. / Thaís: Você considera que aqui é uma periferia? / Sim. É um lugar afastado, que foi feito pra pessoas terem oportunidade de ter a casa. Aqui não é um condomínio fechado, eu sei, aqui foi uma forma fácil de pessoas que não tinham condição de comprar casas, comprar, mas, que nem, aqui ficou bonito, ficou legal, moram pessoas legais e tudo. Então isso é o que diferencia do Zavaglia, por exemplo... [Beatriz]

Thaís: Você gostaria de morar no Zavaglia? / Jefferson: Não, nem um pouco. / Thaís: Não por quê? / Jefferson: Ah, porque é um bairro que eu acho que é muito isolado, muito distante de tudo. Aqui também é, mas no Zavaglia é mais ainda. I Thaís: Distante de tudo, que você fala, é em relação a quê? / Jefferson: Ao próprio Aracy, ao centro. É que no Aracy tem um centro dentro, então... Fica longe disso 
também, entendeu? Pô, ali no Zavaglia, meu, não dá pra explicar, porque lá é como se fosse aqui, né? Por ser isolado também. / Beatriz: Mas lá foi meio que uma reunião, né, tirou de cada periferia tirou um pouquinho, então chegou lá... lá tem muita coisa feia também... [Jefferson e Beatriz]

Ou seja, apesar dessas semelhanças - que Beatriz sintetiza na ideia de que ambos os bairros são periferia, e Jefferson, no fato de que ambos são isolados -, na opinião do casal, as diferenças - que estão muito associadas à ideia de que, apesar de não ser um condomínio fechado, o bairro e as casas do Parque Novo Mundo foram produzidos para serem comercializados, o que funcionaria como uma espécie de 'filtro' social - são substanciais e fazem com que o Jardim Zavaglia seja elencado como um dos lugares onde eles não gostariam de morar se pudessem escolher. Uma das diferenças fundamentais seria, portanto, o "público-alvo" a que se destinaram cada um dos bairros: no Jardim Zavaglia teriam se concentrado os mais pobres, enquanto o Parque Novo Mundo se destinaria àquela "nova classe média". Como consequência disso, estariam as diferenças em termos da qualidade da moradia (acabamentos, tamanho dos espaços internos); entretanto, essa diferença é minimizada pelo fato de o terreno, no Jardim Zavaglia, ser maior, possibilitando maiores perspectivas de ampliação da casa. Mas, se isso deixa transparecer alguma qualidade - ao menos espacial - em que o Jardim Zavaglia superaria o Parque Novo Mundo, Beatriz logo retoma o argumento que seria o ponto máximo da diferenciação entre os dois novos territórios: o da junção de pessoas - e problemas - de várias periferias da cidade.

Beatriz: E ali é classe baixa, baixa mesmo, ali é $10 \%$ do salário, o salário era $R S$ 510,00 na época, quando foi loteado. Nossa amiga paga $R \$ 51,00$ a parcela, e $O$ terreno é imenso, dá pra você construir uma casa no fundo, uma na frente. A casa não é legal: ali não é laje, num tem cozinha, é um corredorzinho, assim. / Thaís: A casa é menor do que aqui? / Beatriz: Não, acho que é praticamente o mesmo tamanho. / Jefferson: área construída, eu acho que é a mesma metragem, acho que cada projeto é um arquiteto, (risos) aí entorta tudo. / Beatriz: Mas dá pra mexer legal mesmo, tem corredor dos dois lados, o fundo é imenso. / Thaís: $O$ terreno é maior que aqui? / Jefferson: bem maior, aqui é 7 por 26, eu acho, lá é 10 de largura. / Beatriz: Ali tem corredor dos dois lados, é melhor... Mas a casa não é legal. E ali juntou, sabe, juntou gente de tudo quanto é lado, assim: 'ai, lá no Santa Argelina tem umas casas desmoronando, taca lá no Zavaglia'... [Jefferson e Beatriz]

Nesse ponto, é possível entrever uma distinção que decorre do entendimento de que o Parque Novo Mundo teria sido produzido por uma empresa, e o Jardim Zavaglia, pela prefeitura ${ }^{94}$ : os bairros produzidos por meio de políticas habitacionais, ou, nas palavras deles, que são $P R O H A B$, teriam essa característica de "juntar pessoas de

94 É interessante notar que, ao longo de toda a pesquisa de campo junto a Jefferson e Beatriz, o Parque Novo Mundo sempre foi totalmente associado por eles à construtora RPS, com quase nenhuma menção à prefeitura, a não ser quando se tratava da ausência de equipamentos e transporte público. "Aqui foi parcerias, assim, a construtora RPS, a imobiliária Cardinalli e a CAIXA. E cada um fica com uma parte" [Jefferson]. 
baixa renda de vários bairros", aí incluídas suas respectivas "áreas de risco" (como a favelinha do Cidade Aracy, a que ela se refere), resultando na criação de um bairro violento, a já mencionada panela de pressão.

Jefferson: Acho que o que aconteceu no Zavaglia, que eu vejo, é assim: eles pegaram pessoas de baixa renda do Gonzaga, da Aracy, do São Carlos VIII, de diversos pontos e colocaram essas pessoas junto, entendeu? Então, pô, é um estopim. O São Carlos VIII acho que foi bem parecido. Que são Prohab, né? Que o pessoal ganhou... / Beatriz: Ah, porque ali foi assim: um pessoal que morava em lugar de alto risco aqui na favelinha do Aracy ganhou casa lá, pessoal que morava em local de risco ali onde fizeram aqueles predinhos ali no Gonzaga, que deu errado, jogou lá também... / Jefferson: O São Carlos 8 também foi meio assim também né, tirou as pessoas de algumas áreas de risco e juntou tudo num lugar. É aquilo, cê junta todo mundo ali, cê resolve o problema dum lado, mas, do outro, você agrava. É, porque vários rivais que tinha no Antenor com o Gonzaga, com outros bairros, acabaram morando no mesmo bairro! Aqui no Zavaglia. / Beatriz: Sim. É, cê queria o quê? Duas pessoas que de longe não se entendiam, foram morar tudo junto! Daí, esse aqui, que tinha uma boca aqui no Aracy, o de lá tinha lá, mudou tudo pro Zavaglia e virou concorrente. Disso aí, já vem a briga, lá já teve tiroteio, desde quando surgiu o bairro, teve vários... / Jefferson: Tipo, eles passam a solucionar o problema de um bairro, e joga todos num só. Aí é um estopim, né? Eles criam um bairro violento, dessa forma. (...) Então, é um lugar assim, que eu não tenho vontade de morar, talvez eu moraria lá de boa se eu tivesse conseguido lá primeiro. Eu moraria lá de boa, tranquilo, como já tá adaptado a isso né, não cuidar da vida dos outros, né? Mas aqui eu vejo que, pô, eu posso deixar o Fabiano brincando na rua tranquilo, lá eu já não poderia deixar. / Thaís: Por causa desse lance da violência assim? / Jefferson: Isso. Tráfico nas esquinas e tal. / Beatriz: Mas assim, tudo vai da necessidade, se a gente tivesse ganhado uma casa lá, que nem quando teve no São Carlos 8 , eu acho que a gente teria ido, porque a gente almejava muito ter uma casa. / Jefferson: A gente queria ter uma casa independente do lugar, mas se fosse pra escolher... [Jefferson e Beatriz]

E aqui chegamos a um termo: se, como as trajetórias apresentadas neste capítulo (e no anterior) permitem entrever, o Programa Minha Casa Minha Vida parece estar se configurando como forma de acesso quase exclusiva à casa própria para as camadas populares no país (indicando que autoconstrução, nos moldes clássicos, vem deixando de ser uma opção, dentre várias razões, pelo cada vez mais alto custo dos terrenos, mesmo nas periferias - efeito do próprio Programa), suas diferentes modalidades apresentam desdobramentos que implicam, mutuamente, produção do espaço e de relações sociais, na qual destaca-se a dimensão, ou não, de uma escolha associada à mudança para esses novos territórios.

Como visto nos casos de Beatriz e Jefferson e de Joana, embora ambos tenham acessado a casa própria via PMCMV, há uma série de distinções e mediações associadas às práticas e figurações envolvidas em comprar ou ganhar uma casa, não apenas relativas a questões como a localização dos novos bairros e a manutenção ou ruptura de conexões com antigas redes estabelecidas nos bairros de origem (como veremos na seção seguinte), mas, sobretudo, no que se refere a perspectivas de 
mobilidade social e possibilidades de manipulação de estigmas direcionados a populações e territórios: se, para Jefferson e Beatriz, a nova casa representa uma possibilidade de ascensão social, simetricamente, para Joana, ela representa, de imediato, um rebaixamento, configurando o que seria uma diferença essencial entre os dois novos territórios e suas dinâmicas socioespaciais e apontando para uma relação intrínseca entre a produção desses novos territórios e uma reconfiguração nos sistemas classificatórios e nas hierarquizações socioespaciais preexistentes entre as camadas populares na cidade, assunto a ser retomado no Entremeio III.

\section{- A fixação nos novos bairros: alguns fragmentos de um longo processo}

Acerca das aproximações e distinções que se estabelecem tanto entre os dois novos territórios quanto entre as trajetórias analisadas neste capítulo, que têm neles seus atuais pontos de condensação habitacional, há um aspecto que possibilita complexificar a reflexão sobre as "novas pobrezas" e as "novas periferias" a elas correspondentes: o processo de fixação das famílias nesses novos territórios.

Se, como apontado na seção anterior, ao longo da pesquisa foi possível apreender as transformações nas percepções e expectativas dos interlocutores quanto aos novos bairros e às novas casas, também o foi em relação a esse processo de fixação, o qual se mostrou bastante revelador das dinâmicas urbanas e sociais implicadas nos processos de produção e apropriação desses novos territórios, bem como suas conexões com as dinâmicas urbanas e sociais preexistentes na cidade.

Nos dois casos aprofundados que compõem este capítulo, bem como em inúmeros outros observados em campo, percebe-se que, quase sempre, é um árduo processo até fixar-se de vez no novo local, mantendo-se, por um longo período, as conexões com os territórios de moradia anteriores e com as redes sociais a eles vinculadas. Isso se amplifica, se pensamos que essas "novas periferias" não possuem equipamentos e serviços. Nesse meio tempo, rearranjos familiares muitas vezes acabam por interromper esse processo de fixação, fazendo emergir novos trânsitos e deslocamentos simultaneamente físicos, sociais e simbólicos.

Nesta seção do capítulo, apresento alguns fragmentos do processo de fixação de ambas as famílias, que pude acompanhar ao longo da pesquisa de campo, compostos a partir da conjunção entre narrativas, observação e acompanhamento de alguns deslocamentos cotidianos de meus interlocutores. Através desses fragmentos, pretende-se iluminar esse processo, que tem como cerne as relações dessas famílias com seus "bairros de origem" - aqui entendidos como os bairros onde viviam e possuíam redes de relações minimamente estabelecidas antes da mudança para os novos bairros (a de Joana com o bairro Santa Felícia e a de Beatriz e Jefferson com o 
bairro Cidade Aracy) - e as "casas-matriz"95 aí situadas (a casa dos pais de Joana e a dos pais de Jefferson), bem como os esforços no sentido de constituição de vínculos cotidianos e de tessituras de relações nos novos bairros, buscando elaborar novos pontos de referência sociais e espaciais a partir de sua experiência urbana prévia, a qual "proporciona elementos para orientar-se dentro de um mundo de relações interpessoais em um entorno físico recém-criado." 96

\section{. primeiros tempos}

Após todos os trâmites desde o sorteio até a entrega das chaves da casa, mesmo ansiosa e espremida na antiga moradia, como visto anteriormente, Joana não se mudou imediatamente para a nova casa no Jardim Zavaglia. Um dos motivos foi a necessidade de algumas reformas antes da mudança - a colocação de piso no interior da casa e a construção dos muros, esta última ligada ao segundo motivo, que fez com que apenas seu marido passasse a acampar na casa vazia: o receio sentido em relação ao bairro, tanto pelo estigma associado à região do Cidade Aracy, como pelas notícias de que os poucos vizinhos já instalados haviam sofrido alguns furtos e de que casas desocupadas estariam sendo invadidas. A questão do piso seria resolvida rapidamente, mas o muro teria que esperar um pouco, por razões financeiras. Com a parca garantia de que o marido havia passado uma semana lá, sozinho, sem contratempos, Joana decide mudar-se assim mesmo, e os primeiros tempos são de insegurança, não apenas pela ausência de muros, mas também pela ausência de conhecidos na vizinhança.

A casa de Beatriz e Jefferson estava no último lote de casas entregues do loteamento Parque Novo Mundo, mas, ainda assim, haviam poucos moradores na vizinhança. Apesar disso e da ausência dos muros, mudaram-se imediatamente, e sentiam-se completamente seguros, a ponto de Beatriz passar a ficar sozinha em casa com o filho nas noites em que Jefferson fazia apresentações de rap, algo impensável quando viviam no Cidade Aracy. De fato, tal segurança, do ponto de vista de Beatriz, decorria sobretudo do contraponto em relação ao antigo bairro, pela crença de que no Parque Novo Mundo, por ser um bairro novo, cujas casas haviam sido vendidas para pessoas legais, estaria livre da proximidade com o tráfico de drogas e a violência com que convivera no Cidade Aracy, como visto.

95 As ideias de "bairro de origem" e "casa-matriz" remetem às abordagens de Duarte e Gomes (2008) sobre "casa e família nas classes populares".

96 Kuri e Díaz (2006:10). 
A insegurança de Joana nos primeiros tempos se amplificava pelo fato de a casa permanecer vazia o dia todo, já que o marido trabalhava em obras em diversos locais da cidade, ela mantinha suas atividades na oficina de costura no Santa Felícia, e os dois filhos que se mudaram com eles para o Jardim Zavaglia seguiam matriculados em escolas no antigo bairro. Durante quase um ano, a rotina da família, de segunda a sábado, envolvia deslocamentos para o outro lado da cidade, uma vez que sua vida cotidiana ainda estava toda vinculada ao bairro de origem, em função do trabalho, de acesso a serviços e comércio e das redes de relações e apoio. Joana descreve o período como tendo sido meio difícil, apesar de inicialmente ter imaginado que seria tranquilo, tendo, inclusive, sido uma decisão planejada a de manter a rotina da família vinculada ao antigo bairro, em decorrência da manutenção de sua oficina de costura ali.

Eu já tinha feito planos, desde que a gente já ganhou a casa aqui, já tava em mente que todo dia de manhã eu ia lá, porque aqui não ia ter lugar pra eu colocar minhas máquinas, né? E como aqui também não ia poder abrir comércio ${ }^{97}$, falei: 'Então, vô manter minha lojinha lá mesmo, né?'. Então, eu já fiz planos pra ir todo dia de manhã, até fiz a inscrição da Beatriz da escola pra lá mesmo, meu filho também não mudou de escola.

Inicialmente, o marido levava toda a família de carro para o Santa Felícia de manhã, os filhos iam para a escola, e ela, para a oficina. Ela levava almoço para que comessem por lá e, à tarde, a filha mais nova ficava com a avó, e o filho trabalhava como aprendiz em uma oficina de bicicletas no próprio bairro. No fim do dia, o marido ia buscá-los e voltavam para a nova casa. Nesse período, durante os dois primeiros meses, o pai de Joana fazia o deslocamento inverso, para garantir que a moradia da filha não ficasse vazia e suscetível a furtos ou invasões.

Algum tempo depois, com o carro quebrado e a aquisição de uma moto para o serviço do marido, ela e os filhos passaram a ir de ônibus para o Santa Felícia, em um trajeto de cerca de uma hora. Quando o filho passou a trabalhar de dia e estudar à noite, o marido de Joana ainda o levava de moto às $19 \mathrm{~h} 00$ e buscava novamente às $23 \mathrm{~h} 00$.

97 Vale notar o quanto essa dimensão de legalidade/ilegalidade é acionada conforme critérios de ordem subjetiva: enquanto a norma de não poder executar reformas e ampliações nas casas que não estivessem de acordo com os modelos fornecidos pela construtora é ignorada solenemente, aquela referente à proibição de instalação de estabelecimentos comerciais nas moradias é acatada, tanto porque, antes da morte da mãe, ela não tinha interesse em abandonar sua oficina de costura no antigo bairro, quanto porque a abertura de um comércio envolveria uma maior exposição da transgressão relativa às reformas internas à casa, por pressupor uma relação direta com a rua. Sobre os trânsitos "nas fronteiras incertas entre o ilegal, o informal e o ilícito" que configuram as experiências urbanas contemporâneas das camadas populares, ao lançarem mão "de forma descontínua e intermitente das oportunidades legais e ilegais que coexistem e se superpõem", são referência os trabalhos de Vera Telles e Daniel Hirata, dentre outros (Telles e Hirata, 2010:40; Telles, 2009; 2010; Hirata, 2010). 
Aos sábados, a família voltava para casa com a neta de Joana, que passava os finais de semana ali, pois sua filha mais velha, após deixar o emprego na oficina de costura e conseguir outro com carteira assinada, passou a não ter mais folgas aos finais de semana. Nesses primeiros tempos, Joana acomodava a filha mais nova e a neta no quarto do casal, e o filho ficava no outro quarto. Durante o pouco tempo que permaneciam no novo bairro, a família ficava confinada em casa, porque o quintal, ainda todo aberto, conectava-se com a rua à frente, com a mata ao fundo e com as outras duas casas vizinhas, o que deixava Joana apreensiva pelas crianças.

A sensação de segurança em relação à nova casa e ao novo bairro garantiu a Beatriz e Jefferson tranquilidade para manterem a mesma rotina de quando moravam no Cidade Aracy, deixando a casa o dia todo vazia, de segunda a sábado. A diferença, agora, era que, para manter essa rotina, uma nova logística do uso do carro teve de ser estabelecida, já que somente assim (ou a pé) seria possível à família deslocar-se até o antigo bairro: se, antes, o carro era para uso a trabalho de Jefferson, sendo os deslocamentos da família no bairro feitos a pé e os de Beatriz para o trabalho, de ônibus, com a mudança, toda a família passou a se deslocar de carro, muito cedo pela manhã, até o antigo bairro, para deixar o filho sob os cuidados da mãe de Jefferson. O casal seguia para o centro da cidade, onde Beatriz trabalhava, para só depois Jefferson iniciar seu turno de trabalho, às 7h00. O filho Fabiano almoçava com os avós e era levado por um deles para a escola no próprio bairro. No fim do dia, Jefferson e Beatriz voltavam para pegá-lo ali, muitas vezes ficando para jantar e voltando para casa somente para tomar banho e dormir.

Além dessa manutenção dos vínculos cotidianos com o Cidade Aracy, relacionada à educação e à rede de apoio para o cuidado do filho ali baseadas, o fato de, no Parque Novo Mundo, não ter nada, fez com que todas as atividades do dia-a-dia relativas a consumo doméstico, acesso a serviços públicos e lazer seguissem sendo realizadas no Cidade Aracy, distante cerca de $4 \mathrm{~km}$ do novo bairro, o que somente foi possível pelo fato de possuírem um carro. Aos finais de semana, a família também se deslocava para o antigo bairro, para encontrar amigos e familiares, dinâmica que passou a servir de parâmetro para uma distinção corrente entre os bairros novo e antigo promovida pelo casal, mas sob óticas distintas: enquanto Beatriz exaltava o silêncio e a ausência de movimento no Parque Novo Mundo, afirmando que se sentia morando no meio do mato, Jefferson ansiava pelo agito do Cidade Aracy, pela presença de conhecidos nas ruas, embora fizesse questão de dizer que já estaria se acostumando a esta nova experiência urbana. 
Gradativamente, os domingos foram passando a ser o dia em que ambas as famílias permaneciam nas novas casas, motivadas pelas perspectivas de reformas. Nos dois casos, o fechamento da casa era o foco principal: Jefferson e Beatriz começaram a comprar e armazenar materiais de construção no próprio quarto, enquanto ele, a cada domingo, avançava lentamente na construção dos muros laterais; Joana e Fábio compravam apenas o material necessário para o uso a cada domingo, executando primeiro o contrapiso em volta de toda a casa e, em seguida, os muros laterais e de fundo. A casa de Joana ficaria um tempo ainda aberta na frente, pela dificuldade em adquirir um portão, mas logo seu marido improvisaria um; a de Beatriz e Jefferson permanecia ainda sem portão quando da finalização da pesquisa de campo, em função da ausência de recursos para tanto.

\section{. rupturas e acomodações}

A relação cotidiana de Joana com o bairro de origem será reconfigurada após a inesperada morte da mãe ${ }^{98}$, tendo um efeito de 'turning point' no processo de fixação da família no novo bairro.

Eu gostava muito de morar na Santa Felícia, entendeu, mas quando a gente tava todo mundo lá... Na verdade, eu comecei desgostar da Santa Felícia quando minha mãe ficou doente... aí eu já... sabe assim, quando você.... parece que o lugar já não era mais o mesmo, entendeu? Porque a gente passou tantos momentos felizes lá e, de repente, acontece uma dessa... Eu desgostei... tanto da casa quanto do bairro, entendeu? E aí, depois que minha mãe morreu, aí sim eu desgostei do lugar, entendeu, porque agora eu vou pra lá e tudo no bairro, na casa, me lembra ela. Eu chego lá, eu fico... as lembranças me fazem mal. Aí parece que perdeu um pouco a graça sabe o lugar, então... acabou meio que vindo a calhar eu ter mudado pra cá. [Joana]

Ela decide fechar a oficina de costura e, por um tempo, fica sem trabalhar. Pouco depois, por conta das demandas financeiras da nova casa (dívidas relativas à compra de mobiliário e às reformas), ela faz uma tentativa de voltar a costurar em casa, trazendo da oficina duas de suas máquinas de costura. Entretanto, o espaço exíguo e a insistência do pai pela presença dela junto a ele a fez desistir da empreitada, que, mesmo curta, teve como resultado o início de relações com algumas mulheres da

98 O acontecimento de um evento crítico como a morte de uma pessoa próxima, sobretudo quando essa morte é provocada (como no caso de brigas violentas entre pares ou embates com a polícia), mas também em casos de morte por doença (como no caso da mãe de Joana), tem efeitos significativos sobre a relação de meus interlocutores com determinados espaços da cidade, variando da negação e desconexão (como aconteceu com Joana) ao aprofundamento do enraizamento, como veremos no caso de Marielen, apresentado no Capítulo 3. Interessa destacar aqui as dimensões de afetividade, memória e significado que compõem espaço urbano e o quanto tais eventos permitem evidenciar o entranhamento entre a produção de territorialidades e subjetividades. Veja-se, nesse sentido, a coletânea organizada por Kuri e Díaz (2006). 
vizinhança que, ao saberem que ela era costureira, passaram a demandar seus serviços.

Eu fui conhecendo as pessoas aqui também por causa do meu trabalho, eles ficaram sabendo, através da vizinha aqui... quando eu resolvi que eu ia costurar aqui, não ia costurar lá, e aí a vizinha viu que eu costurava e trouxe uma roupa pra mim arrumar, através dessa vizinha a outra lá de cima ficou sabendo, ela pegou e trouxe roupa, aí a outra vizinha de baixo da casa dela ficou sabendo que ela trouxe aqui e também trouxe, e através disso eu fui conhecendo alguns vizinhos. [Joana]

A segurança de Beatriz e Jefferson em relação ao bairro seria abalada em menos de um ano de vivência ali, quando passaram a ocorrer algumas sequências de roubos em casas da vizinhança. O fato de haver ainda muitas casas desocupadas e de as demais casas permanecerem o dia todo vazias, de não ter movimento nas ruas, fez com que a perspectiva do casal, antes dominada pela visão de Beatriz sobre o Cidade Aracy, se invertesse a ponto de afirmarem que eles tinham mais segurança no antigo bairro, onde a maioria dos vizinhos se conheciam e cuidavam uns das casas dos outros, e era mais difícil um estranho perambular pelas ruas ou entrar nas casas. Além disso, o fato de, lá, Jefferson ser conhecido e ter conhecimento, no que se inclui o fato de que tinha amigos envolvidos no mundo do crime local, garantia-lhes ainda mais segurança.

Lá em casa era assim: se alguém entrasse em casa e roubasse a televisão, a gente sabia onde buscar, o Jefferson ia lá nos caras falar assim: 'ô, na minha casa, pô!', por isso, por ser de lá, ser conhecido, conhecer quem faz... ele conhece todo mundo, eu nem tanto. Mas assim, uma outra pessoa que não tem esse conhecimento, já não ia ter essa segurança... [Beatriz]

Já no Parque Novo Mundo, a ainda parca rede de relações no bairro tornava "difícil saber quem é e quem não é daqui". Além de começar a pagar um vigilante informal que passou a atuar no bairro, Jefferson chama alguns parentes para acelerar o processo de construção dos muros, mas um episódio inesperado interrompe os planos de fechamento da casa: Beatriz é demitida de seu emprego. A finalização do muro dos fundos é conseguida - e comemorada - graças a trocas de Jefferson com seu cunhado, que aceitou ser pago com um aparelho de som e um de DVD. Os muros laterais seriam paralisados, e os vizinhos acabariam por concluir seus muros antes que ele tivesse condições de finalizar os seus. De todo modo, com isso, o fechamento de quase toda a casa estava garantido, permanecendo apenas a parte da frente ainda por fazer.

Com a demissão, são suspensos todos os investimentos na casa, já que os gastos com os financiamentos não apenas da casa, mas também do carro e do mobiliário adquirido não eram poucos, e Jefferson teria de arcar com tudo sozinho. Os recursos 
do acerto e do seguro-desemprego, que inicialmente seriam a garantia de manutenção de tais investimentos até que Beatriz arrumasse outro trabalho, acabaram sendo gastos em um imprevisto envolvendo a saúde do filho. Desempregada, suas manhãs passaram a ser de permanência no Parque Novo Mundo, período em que estabelece algumas poucas relações no local, com uma ou outra vizinha cujos filhos passaram a brincar com Fabiano, e toma conhecimento de alguns pequenos comércios que começam a surgir por ali, nas próprias casas dos moradores. Por outro lado, Beatriz passa a frequentar ainda mais o Cidade Aracy, visto que, ao assumir os cuidados do filho nesse período, passaria a levá-lo e buscálo na escola todos os dias e, na ausência de transporte público que possibilitasse a ela deslocar-se facilmente entre os bairros, chegava a passar a tarde toda no antigo bairro até o horário de saída do filho da escola.

Então, como aqui [no Parque Novo Mundo] não tem nada e meu filho estuda na Aracy, eu vou na Aracy pelo menos duas vezes por dia, levar e buscar na escola, quando não fico o dia todo lá e depois ainda volto lá de noite. Então, acabo fazendo compra lá, tudo é lá. No dia-a-dia, eu resolvo tudo no Aracy... Tudo, tudo mesmo. [Beatriz]

O período desempregada, que Beatriz imaginava que seria curto, estende-se por quase um ano, e o que inicialmente seria apenas um adiamento nos planos de reformas e ampliações na casa, passou a ser uma incerteza quanto à manutenção daquela estrutura que haviam criado: parcelas da casa, do carro, do mobiliário e dos eletrodomésticos adquiridos. Mas, para eles, a pior situação decorrente do desemprego foi a continuidade da insegurança em função de não conseguirem finalizar o fechamento da casa:

A situação mais preocupante é isso, esses roubos, a questão da segurança, né? $E$, assim, de imediato, eu num consigo mexer na frente aqui agora. Tem umas contas que eu tenho que pagar primeiro, então, tipo... Eu preciso pôr um portão, eu preciso fechar o vão disso daí urgente, antes que acontece alguma coisa. Mas agora não vai dar. [Jefferson]

Quando Joana decidiu voltar ao serviço em sua oficina no antigo bairro, já não tinha mais tanta disposição em atravessar a cidade todos os dias para ir trabalhar: passou a ir mais tarde e voltar mais cedo, deixou de ir aos sábados. A maior permanência no Jardim Zavaglia, a abertura dos primeiros comércios formais e informais no bairro e a pavimentação na via de conexão com o bairro vizinho, Antenor Garcia, fizeram com que ela redirecionasse algumas das atividades que realizava no Santa Felícia para 
esses bairros, sobretudo ligadas ao consumo doméstico cotidiano, e começasse a construir relações de vizinhança no bairro ${ }^{99}$.

Eu sou um tipo de pessoa que não sou muito de frequentar a casa de ninguém, as pessoas vêm mais a mim do que eu vou a elas. Mesmo eu com meus parentes, sempre tem um aqui, entendeu, mas eu não sou de ficar indo na casa deles. E lá no Santa Felícia era a mesma coisa: eu conheço todos os meus vizinhos, mas porque a gente se conheceu através de uma outra vizinha, também por causa do meu trabalho né, que fazia com que as pessoas viessem até mim, e a gente ficava... Um vizinho vem com outra pessoa que conhece, no fim você conhece aquela pessoa, entendeu, por isso. Mas eu nunca fui de ficar entrando na casa de vizinho. Tem vizinho lá que... eu morei tanto tempo lá e, se me perguntar como que é a casa dele, eu não sei, porque eu nunca entrei, entendeu, mas tem contato, conversa, se precisar de alguma coisa, ajuda... (...) Se bem que aqui, a minha vizinha aqui do lado, as duas vizinhas são muito... elas vêm... sabe, assim, acho que eu tenho mais contato com essas vizinhas aqui, de menos de dois anos que eu tô morando aqui, do que com a vizinha de frente que eu morava lá no Santa Felícia, entendeu? Que eu nunca fui na casa da vizinha lá, eu conheço as filhas, os netos, todo mundo, mas não frequentava a casa dela, e essa, sim. Eu não sou tanto de ir na casa dela, mas ela vem na minha, entendeu? A gente fez uma amizade. [Joana]

Embora Joana faça questão de afirmar que não procura ter muitas relações com vizinhos, por ter sido criada em quintal, e não na rua ${ }^{100}$, a vizinhança vai ganhando um papel importante no novo bairro, em termos de garantia de tranquilidade, decorrente sobretudo da constituição de redes de apoio, mas também de sua inserção nas dinâmicas locais relativas à já mencionada "política de viver em um bairro como esse e101. $^{\prime 10}$.

99 Além disso, a mudança de duas primas para o Jardim Zavaglia auxiliaria no processo de estabelecer contato com novos conhecidos: uma delas fora sorteada na mesma época em que Joana, mas não tinha se mudado até então, porque o marido não queria morar no bairro; a outra alugara uma casa ali, por ser próximo ao sítio da sogra - onde vinha vivendo com o marido -, na tentativa de, como Joana, constituir um núcleo familiar independente.

100 Veja-se o relato de Joana, que parece situar-se entre uma vinculação a um ethos associado à sua experiência junto à "casa-matriz" (cujo caráter aglutinador e centralizador das relações familiares, enquanto sua mãe era viva, ela sempre fez questão de destacar), onde prevaleciam as redes de relações consanguíneas mais do que as de vizinhança, e uma espécie de tentativa por manter-se (ao menos discursivamente) distanciada de dinâmicas socioespaciais com as quais não quer se identificar (sobretudo perante suas antigas redes): "é porque se eu fosse, assim, uma pessoa que ficasse, ah, vai na casa do vizinho da frente, vai no do lado, entendeu, para pra conversar, fica lá na frente, igual eu vejo bastante gente, os vizinhos se reúnem assim nas calçadas pra conversar, entendeu? Eu não, esse hábito eu não tenho, então pra mim não fez muita diferença. / Thaís: E por que você não tem esse hábito? / Não é que eu não goste, mas é porque eu fui criada assim, entendeu, minha mãe sempre foi aquela pessoa que criou os filhos assim, na base do quintal dela, entendeu, a gente não ia na casa dos vizinhos pra brincar, nem ficava na rua, então eu fui criada assim."

101 Aproximando-se dos relatos de Jefferson sobre as relações de vizinhança no Cidade Aracy, Joana também irá descrever o convívio próximo com dinâmicas familiares violentas, como a do casal de vizinhos que, constantemente brigando, culminou no esfaqueamento do marido em frente à sua casa, ou a de outro casal, cujo marido agride constantemente a esposa e, vez por outra, esta o põe para fora de casa, ficando o mesmo dias a perambular pelo bairro, sob comentários dos vizinhos, até que ela o receba de volta. Ciente daquela política (referida anteriormente por Jefferson) frente a essas 
Duas situações aqui merecem destaque: a primeira, referente ao fato de que a casa de um dos vizinhos de frente seria um "ponto de venda de drogas", mantido pelo filho, do qual a vizinhança toma conhecimento pelo movimento na casa e pela presença de grupinhos de usuários nas redondezas. Apreensiva em um primeiro momento, Joana, em pouco tempo, encararia com naturalidade ${ }^{102}$ a relação de troca que se estabeleceu entre eles e que garantiu a ela a segurança que passou a ter no bairro, mesmo antes de concluído o fechamento da casa.

Esse meu vizinho aqui da frente, eu conheço, mas não tenho, assim, uma amizade com ele... O filho dele vende droga... toda hora chega uma pessoa na frente, chega uma pessoa aqui e grita por ele, porque ele vende cocaína, a casa dele vive cheia, entendeu? Se quisesse denunciar, a gente sabe onde... mas não. Então, você vê, é aqui na frente. (...) mas ele protege nossa casa! Quando ainda não tinha o muro, vieram aqui pra tentar roubar, e aí levaram, levaram a torneira do tanque, o sapato do meu marido, e ele sabia quem era. Nunca mais mexeram aqui! Mas por quê? Porque sempre que precisam da gente, a gente está disposta a ajudar né? Já vieram aqui buscar até dipirona, se a gente tem, a gente ajuda, né. É relação de vizinho, vizinho mesmo, entendeu? [Joana]

A outra, refere-se à visita de um grupo de parentes do marido de Joana. Sua casa, insuficiente até para a própria família, foi rearranjada para abrigar uma parte dos visitantes, mas não seria possível acomodar a todos. Uma de suas vizinhas ofereceu,

relações de vizinhança, ela simplesmente ignora tais dinâmicas e acontecimentos: "é coisa deles, eu não me meto. Não me afeta".

102 É de se destacar que a proximidade tanto com essas dinâmicas familiares violentas, quanto com a venda de drogas ilícitas na vizinhança é naturalizada por Joana, sempre evocando experiências anteriores, vinculadas aos tempos que viveu com seus pais no bairro Jardim Beatriz e a dinâmicas vivenciadas também na vizinhança no Santa Felícia. Os dois trechos aqui selecionados são interessantes nessa compreensão: "Inclusive na Redenção, lá no Jardim Beatriz, na casa que a gente morava, em frente tinha uma família, eles... uma família bem típica de periferia mesmo, tinha um que ele tava preso, todo mundo tinha medo dele, porque ele era violento... Então, já naquela época a gente já foi criada, inclusive, eu era muito amiga desse rapaz lá, que era o mais perigoso, ele era superamigo da gente, ele guardava a gente! É, porque o meu pai e minha mãe nunca fez distinção de ninguém, eles precisavam das coisas, procuravam lá com meu pai, procuravam com a minha mãe, a gente sempre ajudou, entendeu? Então, em troca disso, a gente tinha a segurança de que nada ia acontecer com a gente, porque eles mesmo... entendeu? Já naquela época, eu aprendi que você tá mais segura se você for amiga do que inimiga. Então, eu nunca tive medo por isso, eu já cresci nesse ambiente." // "Também, tinha um sobradinho que era quase em frente à casa lá do Santa Felícia, que a menina se envolveu com um cara, saiu do serviço, era menina de boa índole, trabalhava até então e foi se envolver com um cara que era traficante. É... o cara foi preso, e ela, de fora da cadeia, ficava vendendo droga pro cara, entendeu? Em frente à nossa casa. E a família dela é uma família superótima, sabe assim, honesta, tudo, e a menina se envolveu com esse cara ...... Mas era ali, do lado da minha casa, então eu já tô acostumada." Essa perspectiva de não ter medo, de ter crescido nesse ambiente e de estar acostumada poderia parecer contraditória com a insegurança inicial dela perante o Jardim Zavaglia; contudo, tal insegurança, como visto, teria menos a ver com a presença propriamente de bandidos do que com o fato de ela não ser conhecida e não ter conhecimento. O modo de Joana lidar com tais situações, estabelecendo conscientemente relações de reciprocidade que acabam tendo como contrapartida uma espécie de proteção, remete àquela dimensão apontada anteriormente acerca do "render homenagem" aos bandidos (cf. Fonseca, 2004): uma vez inserindo-se em tais "circuitos de reciprocidade negativa" ou compulsória, reestabeleceria as bases para a construção daquela "segurança ontológica". Ver nota 67 do Capítulo 1. 
então, um quarto de sua casa para que os parentes dele pudessem passar o fim de semana, estreitando, assim, relações e ultrapassando as barreiras que ela aprendera a ter em relação à vizinhança, enquanto vivia nas dependências dos pais.

Apesar de Beatriz ter estabelecido relações com uma ou duas vizinhas, os demais vínculos dela e de Jefferson no Parque Novo Mundo eram todos oriundos do Cidade Aracy: as famílias de uma prima e de dois amigos dele, de uma amiga dela e de dois conhecidos da nova igreja que passaram a frequentar, todos ex-moradores do bairro e que também mantiveram os vínculos por lá - "a gente se encontra mais na Aracy do que aqui". Com a vizinhança imediata, com exceção dessas "mães de amiguinhos do Fabiano", as relações se mantiveram restritas a cumprimentos à distância, numa dinâmica bastante distinta daquela a que sempre estiveram acostumados no Cidade Aracy (e mesmo nos locais anteriores de moradia de ambos). Então, Beatriz passou a desentender-se com a irmã de uma vizinha de frente, em discussões que se estenderam por algumas semanas e culminaram, inclusive, em agressões físicas, fato que dificultaria ainda mais a consolidação das relações de vizinhança no novo bairro. A riqueza na reconstituição da situação justifica a longa transcrição:

Beatriz: A vizinha da esquina, eu briguei com a irmã dela./ Thaís: Brigou? Mas por quê, o que aconteceu? / Jefferson: Ela para aqui na frente, pra chamar a irmã dela, e fica buzinando, mas você sabe que é implicância. / Beatriz: Ela, tipo, apertava e ficava... de domingo, sete horas da manhã, a gente dormindo $e$ acordava assustado, às vezes à noite... Aí foi indo, aí teve um domingo que o Jefferson tava dormindo, aí ela começou com essa buzina, ele acordou assustado, nervoso, já queria ir lá... Eu falei: 'calma, calma, você é homem, ela é mulher', já viu, né? Aí, até escondi um gancho que tenho, porque ele queria quebrar o carro dela, eu falei: 'calma, você vai preso!' / Jefferson: Eu queria a buzina só, que é o coração do carro... / Beatriz: E eu sou muito calma, só que eu tenho calma até um nível, se eu passo disso eu me transformo. Foi o que aconteceu com ela. Uma vez eu falei pra ela: 'calma, fia!', porque era pura implicância, ela chegava ali e o portão da irmã dela tava aberto, ela que descesse do carro e entrasse pra chamar a irmã dela, não tem por que ficar buzinando, sabe? Aí eu falei: 'fia, você já me acordou, pode parar, já conseguiu me acordar'. Aí, começou assim, acho que teve umas duas discussões assim, de eu aqui e ela lá. (...) Aí teve um sábado, menina, eu tranquila aqui, de manhã ela veio e me acordou com a buzina, eu falei: 'não vou, não vou brigar', só saí lá fora de cara feia e entrei. Falei: 'Eu já acordei, vou limpar a minha casa', porque de sábado eu faço faxina. Fiz faxina, acabei, falei: "vou cochilar um pouquinho que aquela lazarenta me acordou'. Sabe quando você consegue cair no sono? Daí, bem nessa hora ela buzinou de novo: quando eu vi, eu tava lá fora já, xingando já! / Thaís: E o resto dos vizinhos? / Beatriz: Tinha uma vizinha que eu converso, esse dia ela tava ali debaixo da árvore, tava com o marido e o filho, só vendo tudo. Eu falando e a outra apertando a buzina. Foi coisa de cinco minutos buzinando, aí o vizinho até levantou pra ajudar ela, pra perguntar se tinha travado a buzina... e tinha travado o caramba, ela já tinha saído do sério, falei: 'pra que isso, você é louca!'. E ela: 'isso é meu jeito de chamar a minha irmã, e eu vou continuar'. Eu falei: 'você não vai! Se você for inteligente minha filha, você nunca mais aperta essa 
buzina, porque senão você vai perder o dedo pra nunca mais buzinar, ou você não vai ter mais carro pra buzinar'. Ela falou: 'você é louca? Você não me conhece, você não sabe de onde eu vim, você não sabe onde eu moro!' Ela falou isso, acredita? Deve ser na Aracy, você sabe que é verdade Jefferson, o povo da Aracy é folgado (risos). Aí eu falei: 'filha, eu não tô falando de ninguém, tô falando de mim, você também não sabe de onde eu venho ${ }^{103}$, e eu não chamo ninguém, não chamo marido, não chamo ninguém' e foi discussão! Aí, no que eu virei as costas pra vir pra casa, falei: 'não vou brigar', o Fabiano aqui meio querendo chorar, sabe? Aí eu entrei, ela não buzinou de novo? Ah, quando eu vi eu tava dando uma voadora lá no carro dela, comecei a xingar já, catei ela pra querer matar ela, os vizinhos quietos ali... / Thaís: Tudo olhando... / Beatriz: É, ninguém fez nada, aí virei e vim entrar, na hora que eu olhei, ela não veio atrás? Eu falei 'agora ela vai ver'... porque se eu mato ela na rua é uma coisa, mas se eu mato na minha casa é legitima defesa, ela entrou aqui pra me matar, eu matei ela. Já pensando, né, 'eu não posso ser presa', aí ela vindo, cheguei aqui, e ela ali na área de baixo, discutindo e entrando, falei 'se ela entrar, eu mato ela'. A mulher tirou eu do sério! / Thaís: Mas e aí? / Beatriz: E aí foi maior briga menina, dei uns cascudos nela e falei que se ela fosse inteligente ela nunca mais buzinava. Porque ia acontecer o pior. Aí, a vizinha que tava ali na árvore já veio, começou a tossir pra mostrar que tava ali, sabe? O marido dela veio também, ficou ali na rua. Daí, com isso, ela meio que virou as costas e saiu, sabe? Aí, chegou lá no portão da irmã dela e começou a xingar, eu fui pra cima de novo, a minha vontade era quebrar o carro, mas não consegui não, aí a irmã dela saiu, e até o marido da irmã dela saiu, colocou ela pra dentro e tudo, aí ela ficou meses sem soltar nenhuma buzina... Ela continuava vindo, mas você não escutava nem o carro dela! E porque ela não parou antes de acontecer isso? (...) Os vizinhos que viram tudo, depois até veio, perguntou: 'você tá bem, você tá calma?' Falei 'tô', aí conversei bastante com eles, com a outra vizinha, falei 'gente, desculpa né, seu filho tava ai e tal, mas essa mulher me tirou do sério'. [Jefferson e Beatriz]

Paradoxalmente, Beatriz seria ela própria a protagonista de um tipo de relação violenta na vizinhança do atual bairro, aspecto que ela tanto criticava em relação à vizinhança no Cidade Aracy, e um dos vários motivos pelos quais ela quis deixar de viver naquele bairro. Do ponto de vista da vizinha cuja irmã fora agredida por ela, como os outros vizinhos fizeram questão de informar ao casal, o novo bairro se tornara um lugar ruim para viver e estariam dispostos a vender a casa e mudar-se para outro bairro "em que a vizinhança fosse melhor". Por outro lado, o episódio também pôs por terra o critério, tantas vezes exaltado por Beatriz, de que, no Parque Novo Mundo, a vizinhança seria melhor, um dos grandes diferenciais destacados por ela em relação ao Cidade Aracy, justamente pela presença de pessoas legais, com mais condições: embora a contenda tenha sido com a irmã de uma vizinha, ela denotou o quanto essa perspectiva era relativa, especialmente porque, após o episódio, mesmo as relações recém-estabelecidas na vizinhança retraíram.

103 Chama a atenção o fato de ambas terem acionado a 'origem habitacional' para intimidar uma à outra, manipulando o próprio estigma a que estão ou foram sujeitas em função do local de moradia. 


\section{- versões de fixação}

Após quase dois anos de arranjos no trabalho e nas dinâmicas familiares de Joana, um processo de desprendimento em relação ao bairro de origem entrou propriamente em curso. Com uma gravidez inesperada e o nascimento de sua quarta filha em 2013, ela deixou definitivamente de trabalhar na oficina de costura, embora suas máquinas ainda permanecessem todas lá. O pai casou-se novamente e, com sua nova esposa vivendo na casa que era da mãe, ela não voltou mais ao bairro. A filha mais nova foi transferida para uma escola no bairro Antenor Garcia, redirecionando ainda mais os deslocamentos cotidianos da família para este bairro, que já vinha oferecendo suporte a algumas necessidades de comércio e serviços, como já visto. Nesse período, a filha mais velha separou-se do marido e ficou um tempo desempregada, o que fez com que deixasse a casa cedida no Santa Felícia e viesse morar na casa da mãe com sua filha, também esta sendo transferida para uma creche no Antenor Garcia.

Tudo isso gerou novos arranjos no espaço da casa, exíguo para acomodar toda a família: o bebê ocupou o espaço daquela que era a filha caçula no quarto do casal; as três meninas - duas filhas e a neta de Joana - passaram a dividir duas camas no segundo quarto, e o filho se viu obrigado a dormir num colchão no chão desse quarto ou no sofá da sala, numa situação que já era velha conhecida dos tempos vividos nos cômodos cedidos no Santa Felícia. Esse filho, que preferira não deixar a escola no Santa Felícia, permaneceu algum tempo mais na dinâmica de deslocamentos entre este bairro e o Jardim Zavaglia, mas o cansaço por sair bem cedo e chegar depois da meia-noite todos os dias, e ainda não ter mais um espaço próprio na casa dos pais, justificou a opção por morar durante a semana na casa do avô, passando apenas os finais de semana com a família, numa dinâmica semelhante à que Joana já vivenciara na juventude ${ }^{104}$. Em movimento contrário, a filha mais velha passava os finais de semana, feriados e folgas do trabalho com a filha na casa cedida do Santa Felícia, pela mesma razão de a casa dos pais não comportar toda a família, como ela e o menino fizeram questão de me dizer mais de uma vez ("a gente fica sem espaço, não cabe todo mundo nos quartos, nem na sala").

Assim, embora Joana e o marido tenham praticamente eliminado os antigos vínculos com o bairro Santa Felícia - "agora já não me faz falta ir lá" -, os filhos e a neta permanecem ainda numa circulação intensa entre os dois bairros e as respectivas casas, situação decorrente da desestabilização definitiva dos antigos arranjos

104 Essa dinâmica familiar em que, em função de vínculos pré-estabelecidos em um determinado território (escola, emprego, amigos etc), os filhos não acompanham os deslocamentos habitacionais dos pais é algo recorrente em minha pesquisa de campo, como os casos de Beatriz, Joana e seu filho permitem evidenciar. 
familiares que a maior fixação da família no novo bairro tem acarretado e que faz com que ela não se sinta plenamente confortável nesse processo, sobretudo pela preocupação com o filho adolescente.

Ele ficar lá é um incômodo pra mim e um incômodo pro meu pai também, porque ele nem mora lá e nem mora aqui, fica dividido... E tem certas coisas que ele tem que fazer aqui, onde a gente mora, onde tem a mãe, como, por exemplo, quando ele precisa ir no médico, meu pai não vai com ele, quem precisa ir sou eu, né? Então ele tá na metade do caminho, nem lá, nem aqui, tem coisa que ele só faz aqui e tem coisa que ele só faz lá, então está complicado... Por minha vontade, ele não ficaria lá, porque filho tem que ficar perto de pai e mãe, porque se precisa ou se acontece alguma coisa, é pai e mãe que vai correr, né? [Joana]

No entanto, Ryan não demonstra a menor intenção de voltar a morar com a família, não tanto pela casa - que ele considera melhor que a casa cedida onde viviam anteriormente - mas, sobretudo, "pelo bairro". Há, de um lado, uma relação de afeto e pertencimento em relação ao antigo bairro, por ter passado ali seus dezesseis anos de vida, por ser onde estão todas as suas relações de amizade, sua namorada, seu trabalho, suas atividades cotidianas, as quais ele nem cogita abandonar e tentar refazer no novo bairro.

É, eu fico mais lá no Santa Felícia, porque, sei lá, num gosto muito daqui. Sei lá, porque a minha vida inteira foi lá, tudo que eu faço é lá, entendeu? Todos os meus amigos é de lá, aí, tudo que eu vou fazer é lá então... eu gosto de ficar lá. $E$ aqui, ah, não sei, não gosto do lugar, eu não consigo acostumar ficar aqui. (...) Acho que é também porque falaram, quando eu vim, antes de eu vim, falaram que ia ter bastante... bastante traficante, essas coisas do tipo. / Thaís: Falaram pra você lá no Santa Felícia? / Falaram pra mim, é. Daí eu já vim já com esse conceito, que ia ter pessoas ruins aqui, e aí, já vim assim, já vim pensando nisso. / Thaís: Mas, quando você chegou aqui, você achou isso também? / Não exatamente; tem, porque tem em todo lugar, mas não é exatamente do jeito que falaram pra mim, eu vi diferente do que falaram. Tem, lógico que tem, porque qualquer lugar que você for tem isso, só que tem bastante gente conhecida também, que era de lá e de outros lugares, que eu conhecia de outros lugares, que veio pra cá. Gente que eu conheci lá do bairro mesmo, que eu conheci em outro lugar, que eu conhecia em trabalho que eu fui ou em curso, alguma coisa do tipo, aí veio pra cá, tem bastante pessoa que eu conheço aqui. Mas, mesmo assim, eu não consigo ficar aqui, por gostar mesmo, gostar de lá. (...) Então eu acho que é um preconceito, né? Porque são pessoas que mudaram pra cá, pessoas que moravam em bairros que num podia, ou que ganhou, né, a casa, ganhou entre aspas, mas tem, aqui tem pessoas, vamos supor, mais pobres do que lá... mas não exatamente bandido, essas coisa tipo, porque lá também tem. Então, questão de segurança, eu me sinto seguro, de certa forma, nos dois lugares, como lá, como aqui, e eu acho que é a mesma coisa, num mudou muito. /Thaís: Então isso, pra você, não interferiu na decisão de ficar lá? / Foi mais por eu gostar de lá mesmo, e pelo preconceito, porque segurança total num tem, porque sabe que tem pessoas desse tipo, mas lá também é assim. Só que eu me sinto seguro por não achar que é além do que tem lá, entendeu, então fica normal pra mim, fica tranquilo. Mas as pessoas têm preconceito, eu senti isso quando a gente mudou pra cá, e isso eu não gosto, não quero. [Ryan] 
Como se vê, a talvez mais contundente razão para que ele tenha desistido dos deslocamentos cotidianos entre ambos os bairros e decidido não se 'converter' em um morador do Jardim Zavaglia seja a questão do preconceito destinado ao bairro e a seus moradores já desde sua concepção, fato que faz com que Joana, em princípio, entenda a opção do filho, pois ela mesma vem progressivamente sofrendo tal preconceito desde a mudança para o bairro:

Porque aqui a gente tem esse preconceito, 'ah, mora no Zavaglia, vizinho do Cidade Aracy?' É onde todo mundo acha que é bandido, entendeu? Tem esse preconceito. Eu já sofri isso quando morava no Santa Felícia, antes de virar o que é hoje. Mas aqui é pior. (...) Então, com isso, eu não consegui transferir meu filho, ele não quis de jeito nenhum, porque ele não gosta daqui, né? Ele veio com a gente, mas já desde o início ele mal ficava aqui... Ele não gosta daqui, não só pelo lugar, pelos amigos dele estarem tudo no Santa Felícia, porque ele foi nascido e criado lá, então ele gosta de lá por isso, não queria sair de lá. (...) Mas porque ele sofria desse preconceito também, porque quando ele falava lá no bairro que tava morando no Zavaglia todo mundo: 'Nossa! Lá no Zavaglia!', entendeu? Porque todo mundo tem preconceito, né, fala: 'Nossa! Foi morar lá nesse fim de mundo!' [Joana]

Apesar de o filho afirmar que não quer se mudar para o bairro de jeito nenhum, ela alimenta planos de ampliações na casa, que considera que seriam a solução para os vários problemas decorrentes deste cada vez maior 'desprendimento' da família em relação ao Santa Felícia: a construção - já iniciada quando da finalização da pesquisa de campo, mas paralisada por falta de recursos financeiros para aquisição de material de construção - de uma edícula de dois andares nos fundos da casa, que comportasse, além da área de lazer sonhada pelo marido, também sua oficina de costura e um quarto para cada um dos filhos mais velhos. Seguindo a lógica do "quintal" em que ela foi criada, a intenção é construir cômodos que ampliem o espaço da casa e auxiliem no cotidiano atual da família, mas que, futuramente, possam funcionar como uma casa para abrigar outro núcleo familiar de algum dos filhos - e, em caso de necessidade, ser alugada para gerar uma renda extra.

A gente faz planos, né (risos), mas a construção vai devagar, vai andando como Deus quer, né? Mas a intenção é de fazer dois quartos em cima e um banheiro, $e$ em baixo vai fazer uma sala e uma cozinha, porque vai ser um cômodo pra guardar umas coisas, que se, futuramente, uma família quiser morar, então vai ter todas as dependências, né? / Thaís: Uma familia dos seus filhos? /É, mas tudo é possivel, porque, estando pronto, se os filhos não quiser e futuramente a gente precisar, a gente aluga. Mas a primeiro momento é pra eles mesmo. Então, a parte de cima, vai ser dois quartos e um banheiro, e na parte de baixo, vai ser tipo uma área de lazer: o meu marido vai fazer uma churrasqueira, vai colocar pia, fogão, tudo, tudo fechado, com porta, com tranca, tudo, então, se futuramente precisar de alguém morar, entendeu, vai tá pronto pra isso. [Joana]

Com essa ampliação em curso nos fundos da casa, ela também começou a fazer planos de mudar de ramo na própria área da costura, mirando nos serviços terceirizados por empresas e que não dependeriam da clientela estabelecida no antigo bairro, facilitando seu retorno ao trabalho no Jardim Zavaglia. Além disso, o 
marido já definiu as próximas reformas, após a conclusão dessa em andamento e da próxima, que prevê a ampliação da cozinha: a construção de uma garagem coberta e um comércio na frente da casa, porque, caso os novos planos profissionais de Joana não se concretizem, ele não quer que ela trabalhe fora de casa. Assim, embora tenham recebido uma casa prontinha, esta não deixa de conservar a dinâmica processual característica da autoconstrução, que se amplifica conforme esse movimento de fixação no novo local de moradia vai se consolidando.

Como é muita coisa que a gente quer fazer, né, então ele fala assim: 'vou fazer tal coisa', que nem você viu, ele tá fazendo aquilo tudo no fundo pra construir em cima, então, por exemplo, vai fazer uma viga, ele vê o material que precisa pra essa viga, vai lá, compra e faz. Vai erguer uma parede? Tá, quantos tijolos precisa, quantos metros, vai lá, compra e faz aquilo, entendeu? Não tem aquele dinheiro pra ir lá, comprar um tanto de material grande, pra fazer de uma vez. Vai fazendo aos poucos. [Joana]

Os investimentos na casa e os planos a ela atrelados atestam o que também é evidente nas falas de Jona e do marido: esta casa é, para eles, o lugar definitivo, ponto de fixação realmente. Não há planos de sair dali, nem ela é vista como uma possibilidade de investimento: logo que se mudaram, o marido de Joana chegou inclusive a receber uma proposta de compra da casa - "ofereceram $R \$ 25.000,00 \mathrm{na}$ minha casa, acredita? A pessoa queria comprar minha casa e assumir as prestações. Mas eu não vendo de jeito nenhum, eu falei: 'acha, minha casa não é pra vender' (risos), tanto sacrifício pra conseguir!" - e, embora ele tenha ficado em dúvida quanto a aceitar, ela recusou com veemência, tendo em mente a experiência da "casamatriz" que ela teve com os pais e que julgava que nunca poderia oferecer aos filhos, mas que agora se tornava realidade.

Essa casa é agora nosso lugar, é aqui que vamos ficar. É o que vai dar a segurança da nossa família, né? Igual, os filhos, eles podem sair, eles podem casar, no caso da Claudia, que está lá nos cômodos, ou do Ricardo, que está querendo morar sozinho... eles sabem agora que, se eles precisarem, eles vão ter pra onde ir, entendeu? Numa hora de aperto, todo mundo sabe pra onde vai. [Joana]

Além disso, se, quando vivia no Santa Felícia, sua experiência já era circunscrita ao bairro, pelo fato de trabalhar em casa e não circular tanto pela vizinhança, com a mudança para o Jardim Zavaglia - embora por um tempo ela tenha transitado entre ambos os bairros -, a partir do momento em que as várias situações na sua vida se encaminharam para uma efetiva fixação no novo bairro, seus relatos passaram a dar conta de uma circunscrição territorial ainda maior: sendo a mobilidade para outros pontos da cidade mais dificultada no novo bairro do que era no antigo, os eventuais deslocamentos são sempre para o Antenor Garcia, acompanhados do marido e com objetivos bastante específicos, e praticamente nem pelo bairro ela circula, a não ser esporadicamente em sua própria rua.

Eu não saio nunca daqui! Porque agora eu moro num bairro longe. (...) Você perde muito tempo com transporte, pra tudo que se vai fazer, por exemplo, se eu 
vou da Santa Felícia pra cá eu gasto pelo menos uma hora de ônibus, se eu vou pro centro, não é muito melhor, não. É diferente de quando eu morava lá, que em vinte minutos de ônibus eu tava em qualquer lugar, entendeu, aqui não! Então, na verdade, eu aqui não vou a lugar nenhum! Nem aqui no bairro eu saio muito... (...) Minhas únicas saídas é levar e buscar a menina na escola, no ônibus da prefeitura. [Joana]

Nesse contexto, decorrente sobretudo da ausência, ainda, de familiaridade com o novo território e de redes de relações mais efetivas, a casa assume importância crucial, e o caráter processual que ela adquire - as reformas, os planos de futuras ampliações, os investimentos em mobiliário - parece preencher a lacuna deixada por uma sociabilidade exercida no âmbito do antigo bairro, ancorada em sua identidade de costureira ${ }^{105}$ e bastante mediada pela presença dos pais. Importante dizer que ela própria tem se agoniado com essa condição, a ponto de frisar, várias vezes, que "não fui criada pra ver a vida passar dentro de casa", dividindo-se entre os planos de montar uma oficina de costura na nova casa e os de buscar um emprego como costureira em uma empresa, este último mais recente e acionado como forma de se contrapor à expectativa do marido de que ela permaneça em casa, cuidando das crianças. Ao que tudo indica, ainda mais mudanças nas dinâmicas cotidianas da família estão por vir.

Após cerca de um ano desempregada, Beatriz conseguiu um emprego fixo como telefonista em uma agência bancária relativamente próxima à casa de sua mãe. Com isso, os arranjos familiares, antes completamente vinculados ao Cidade Aracy, vêm sendo gradativamente deslocados para cima ${ }^{106}$ : embora o filho continue estudando no antigo bairro, Beatriz - que agora fica com o carro, já que Jefferson comprou uma moto - busca-o na saída da escola e o leva para almoçar e passar a tarde na casa da mãe dela; quando sai do serviço, às $15 \mathrm{~h} 00$, passa para apanhá-lo e seguem para o Parque Novo Mundo. Quando Jefferson chega do trabalho, no fim da tarde, é o momento em que vão para o Cidade Aracy, seja para jantar com a família dele, seja para tomar um sorvete, ou ir à academia. $O$ ingresso na religião batista, cujas células acontecem naquele bairro, tornou-se mais um elo deles com o local.

Beatriz: Tirar o Jefferson totalmente do Aracy não é fácil (risos). Mas eu não teria outra opção, morando aqui... lá é o lugar mais perto daqui pra tudo, nossos

105 De fato, após a morte da mãe e a ruptura mais radical de vínculos com o antigo bairro, Joana, costumava reafirmar seu desgosto atual com o local e, por vezes, deixava entrever - e até verbalizava - uma saudade do bairro, ligada não às memórias da mãe, mas à movimentação de sua oficina de costura, aos contatos com a vizinhança, que ela estabelecia desde ali, sempre em contraponto com essa situação atual de não sair nunca de casa e não encontrar quase ninguém.

106 Referência àquela já mencionada distinção (simultaneamente geográfica e simbólica) entre o Cidade Aracy ("lá embaixo") e o restante da Zona Sul ("lá em cima"). O ápice do projeto de mobilidade socioespacial do casal (impulsionado por Beatriz) é morar em cima. 
apoios estão todos mais pra lá mesmo. / Jefferson: Tudo que a gente quer fazer só eu e ela, tipo, a gente depende de alguém pra olhar o Fabiano, tá ali, tem umas quatro ou cinco opções. / Beatriz: Tipo assim, vai pra academia, fica na vó, na tia, na cunhada... / Thaís: E no Aracy, tudo o que vocês precisarem tem lá? / Beatriz: Tudo, tudo, tudo. Pagar uma conta é na Aracy, que é muito mais fácil vir no Aracy do que ir pro centro. / Jefferson: Lá tem mercado bom. / Beatriz: Tem banco, tem tudo. Nosso centro é o Aracy. É muito mais perto, é cômodo pra mim. [Jefferson e Beatriz]

Ainda que seja pequena a permanência no Parque Novo Mundo, visto que todos os vínculos de trabalho e demais atividades cotidianas estão estabelecidos fora do bairro, são indiscutíveis os esforços de Beatriz em minimizar a relação da família com o Cidade Aracy, como atesta a decisão que vem sendo negociada com o marido de transferir o filho para uma escola mais próxima ao seu local de trabalho e à casa da mãe, em mais um deslocamento das dinâmicas cotidianas para cima. Tal tentativa de reconfiguração não deixa de ser uma continuidade daquelas disputas entre as perspectivas do casal: por um lado, Jefferson deseja manter o máximo de vínculos possíveis com o antigo bairro, a ponto de ter-se aproveitado do fato de Beatriz estar novamente empregada para pedir demissão e realizar um antigo sonho de montar, junto com o irmão, um negócio similar àquele em que estava trabalhando, com base no Cidade Aracy; por outro, Beatriz quer cada vez menos vínculos cotidianos com o bairro, ancorando-se sempre em argumentos sobre o tipo de sociabilidade com a qual o filho estaria convivendo no Cidade Aracy, ora invocando o fato de que a mãe de Jefferson não estaria mais disposta a cuidar do neto, e ela acabava tendo que deixá-lo aos cuidados de uma amiga que não teria a mesma atenção com as amizades do menino no bairro e deixava-o passar muito tempo na rua, ora destacando as brigas violentas que estariam acontecendo frequentemente em frente à escola do filho, pelas quais a escola estaria se isentando de responsabilidade, por serem coisa do bairro.

Para Beatriz, portanto, esse processo de reconfiguração das relações com o antigo bairro, menos do que um movimento no sentido de fixação no Parque Novo Mundo, parece representar um estágio a mais no projeto de mobilidade socioespacial iniciado com a compra da casa fora do Cidade Aracy. Ao afirmar que "tirar o Jefferson totalmente da Aracy não é fácil", ela dá indícios de sua estratégia progressiva para fazer da mudança de casa aquela espécie de 'conversão': sair do Cidade Aracy para um local próximo foi a forma inicial que ela encontrou para garantir que a relação do núcleo familiar com o bairro deixasse de ser de permanência para se tornar de ida e volta, estando sua casa fora dali e, portanto, livre não apenas do convívio cotidiano com o tráfico de drogas e a violência, mas sobretudo dos estigmas associados ao bairro; no atual momento, a desvinculação de algumas demandas cotidianas que ainda os mantinham dependentes do antigo bairro tem o sentido não de eliminar todos os vínculos com o local (até porque ela sabe que isso seria o fim de seu casamento), mas de reduzi-los a uma relação em que, cada vez mais, ir para lá seja 
uma opção e não uma necessidade (embora ela tenha consciência da inevitável manutenção de uma relação cotidiana - e de relativa dependência, em função de o Parque Novo Mundo ainda não ter nada - com o Cidade Aracy).

Beatriz: Eu não queria criar raiz, saber que eu ia ficar só ali, porque quem mora no Aracy, vive de Aracy, gente: o mercado no Aracy; pagar as contas, no Aracy; comprar roupa, nas lojinhas do Aracy. / Thaís: Mas hoje você, mesmo morando aqui, não faz uma boa parte disso no Aracy também? / Beatriz: Não mais... / Jefferson: Ah, bastante! / Beatriz: Sim, ainda, às vezes ... Mas eu não sinto mais que eu dependo daquilo ali; eu vou porque eu quero, às vezes porque é mais perto, mas, assim, eu não dependo daquilo. Se eu tivesse continuado lá, talvez eu arrumaria até um serviço ali mesmo no Aracy, aí ia ficar o quê? Morar no Aracy, trabalhar no Aracy, então... Isso que eu não queria, mas é assim, a gente tá aqui, vamos tomar sorvete no Aracy, porque eu até gosto do sorvete de lá (risos). / Jefferson: Não, tem tudo lá, pô! / Thaís: E você, Jefferson, como você vê isso, de vocês fazerem tudo lá e a casa estar aqui? / Jefferson: Pô, é legal, porque, pra mim, não mudou muito meus planos, né, tipo, eu fico lá e venho aqui dormir, né, então tá do jeito que eu gosto. / Beatriz: Que nem, tipo no dia de hoje, que não tem igreja, não tem nada, a gente janta e vai pro Aracy, a gente vai tomar um sorvete no centro ali. / Jefferson: É que... eu gosto de movimento, então, tipo lá ainda tem um som e tal, aqui não acontece nada! / Beatriz: Mas aí, um dia ele quer escrever, ele vai escrever as músicas dele, eu vou pôr o Fabiano pra brincar ou assistir TV; mas aí, tem outro dia, que nem hoje, que tá calor, hoje tá gostoso pra ir pra rua, a gente vai pro Aracy. Então, tipo, deu a nossa vontade de ir embora, a gente tá aqui. A gente tem carro, quer ir no Aracy, pega o carro, vai, mas volta. [Jefferson e Beatriz]

Há, portanto, a gradativa construção de uma nova realidade que permite a Beatriz afirmar que o mundo de sua família é distinto do mundinho dos moradores da Cidade Aracy, maneira como ela se refere - e com a qual Jefferson demonstra concordar - a uma espécie de confinamento no próprio bairro ${ }^{107}$ que ela identificaria como característica dos que ali permanecem e do qual ela desejou escapar ao comprar a casa fora do bairro.

Beatriz: As pessoas ali são muito presas no bairro. Eles ficam só no Aracy! É só Aracy. Eles vão comer lanche, no Aracy. Eles vão no circo quando tem tenda, na Aracy. Tudo é Aracy pra eles. Tudo! Tudo. Pra irmã dele também, ela compra roupa no Aracy, ela vai na farmácia do Aracy, ela vai no mercado, do Aracy. Tudo é Aracy! Então, ela vai no centro uma vez por mês, porque tem que pagar as contas e receber o pagamento do marido que é no Banco no centro. (...) Então, muita gente ali é assim, vivem naquele mundinho, naquele ciclo. / Jefferson: É, eu acho que é que nem aqui. Vamos supor, hã... ônibus de hora em hora, se a gente não tem um carro e tem algumas coisas aqui que a gente não depende de ir pra lá, a gente acaba sendo forçado a viver esse mundo, no Parque Novo Mundo. Entendeu? Se você não tem um carro pra você sair, então... / Beatriz: Não, mas o mundinho deles é tão bom ali que eles acham que não precisam de carro. A gente conhece vários que acham que não precisa de carro, porque tudo tá perto dele: sacolão, mercado, padaria... é aquilo e acabou. / Jefferson: é... os parentes estão tudo ali, os amigos também... (...) Então, é a visão que as pessoas têm. De se limitar, entendeu? Fala: "Não, sou periferia." Mas se deixar o cara vai

107 Tema a ser retomado no Entremeio II. 
ser periferia pro resto da vida. Ele não vai procurar sair dali, ele não vai procurar uma casa melhor, entendeu. Têm pessoas que me vê aqui e fala: 'Ó, o Jefferson virou boy, véio.' Pô! [risos]. Então, são pessoas que se limitam àquele mundinho, entendeu? / Beatriz: (...) É que no Aracy, eles vivem tanto no mundinho deles que atravessou a pista, já é boy, subiu o morro, já é boy. Não importa o que for. [Jefferson e Beatriz]

Nesse sentido, a construção desse mundo distinto está diretamente ligado ao status que eles acreditam ter alcançado com a mudança para o novo bairro e, sobretudo, para esta que eles consideram uma casa legal. Assim, os investimentos na casa, retomados após a consecução do novo emprego por Beatriz, parecem ter duplo caráter: de um lado, atingir o patamar de morar bem, pelo qual eles anseiam desde os tempos vivendo de aluguel no Cidade Aracy (ampliar os espaços que julgam muito diminutos, como sala, cozinha e área de serviço; garantir um espaço para Jefferson se dedicar ao rap - "não aguento mais disco no quarto" - e, eventualmente, um quarto para mais um filho, já que, nesse novo patamar, eles consideram inconcebível que os quartos sejam compartilhados) - e de poder mostrar aos outros que agora eles moram bem (sendo a construção de uma área de lazer definida como a ampliação prioritária após a conclusão do fechamento da casa, justamente para "poder receber pessoas em casa"); de outro - e tão importante quanto o primeiro - promover a valorização do imóvel, alcançando o patamar de casa pronta mesmo e, assim, facilitar um futuro negócio, cujas dinâmicas são assunto entre vizinhos e passaram a ser tema também de nossas conversas.

Beatriz: Pra mim, aqui é só um começo, até essa casa ficar pronta mesmo. Então, assim, eu acho que a gente não vai ficar aqui pra sempre. Eu tenho pretensão de vender, alugar essa casa, ou comprar outras pra vender ou alugar, eu acho que podem dar um retorno financeiro. Eu tenho planos! Mas só de ter saído da Aracy, já ficou bom. / Jefferson: E meus planos são abrir uma passagem direto daqui pra Aracy. / Beatriz: Tá bom, se for pra passeio, pode!! (risos) O sonho dele, mais do que a casa ficar pronta, é ter uma entrada, aqui debaixo, direto pro Aracy, pra ficar ainda mais perto! Mas, falando sério, aqui vai ser um bom negócio. E o pessoal tá procurando, a gente fica domingo em casa, passa pessoal na rua perguntando se sabe de alguém que tá vendendo, a pessoa coloca placa de vende-se ou aluga-se, deu uma semana já tem caminhão de mudança. / Jefferson: Uma amiga minha que comprou agora aqui tá pagando $R \$ 700,00 \mathrm{na}$ parcela já. Acho que ela comprou por $R \$ 120.000,00$ / Beatriz: financiou por cento e vinte! A gente financiou essa casa por quarenta e três. Ela vai pagar trezentas parcelas de $R \$ 700,00$ ao invés de $R \$ 350,00$ que a gente começou pagando. $E$ as pessoas tão comprando, e tão pagando setecentos e pouco, rindo ainda: 'nossa olha.' / Jefferson: Agora imagina a hora que tiver uma escola, uma creche... uma passagem pro Aracy! (risos) [Jefferson e Beatriz]

Embora ambos estejam de acordo em encarar essa casa como uma etapa, como perspectiva inclusive de negócio que lhes proporcionaria melhores condições de vida, a etapa seguinte parece não estar plenamente acordada, como descobriu Beatriz ao flagrar Jefferson negociando uma "troca de chaves" entre a casa no Parque Novo Mundo e uma outra construída por um conhecido no Cidade Aracy. 
Beatriz: Esses dias eu peguei ele querendo trocar nossa casa numa casa lá no Aracy. Fazer troca de chaves, acredita? / Jefferson: não, foi brincadeira, eu falei... Ela leva a sério: 'ah, mas você já não ia nem me comunicar', não sei o quê... / Beatriz: você acha que isso é conversa? O irmão do cunhado dele construiu uma casa bacaninha, ali na rua da irmã dele mesmo, onde a gente passou, e tá quase pronta assim, a parte de dentro tá pronta, falta só parte de fora, Aí ele chamou pro rolo! Só que o cara é maior rolista, e se ele falar 'eu topo'? / Jefferson: Não, eu não troco aqui por lá... eu até queria, mas não troco... Porque aqui dá pra crescer bastante, mais do que lá, aqui vai crescer mais preparado, mais organizado do que lá. Lá, bem dizer, já cresceu, só a casa dele, que ele tá construindo, o resto lá já cresceu tudo, já tem meio que um limite... Aqui não, aqui a gente não sabe o limite ainda; lá você já visualiza isso. [Jefferson e Beatriz]

Mas, se a relação afetiva com o Cidade Aracy quase falou mais alto nessa tentativa frustrada de fazer valer a ideia de que a "casa pode ser um negócio", tantas vezes elaborada por Jefferson em nossos encontros, prevaleceu uma dimensão mais racional, verbalizada em torno da ideia, constantemente reiterada por Beatriz, de que "a casa é capital", que o fez crer que a troca talvez não fosse um bom negócio, em razão de uma grande perspectiva de valorização da casa no Parque Novo Mundo, que não se daria da mesma forma no antigo bairro:

Beatriz: Ainda bem que ele caiu em si a tempo! (risos) Porque a gente tem que pensar na valorização também, né? Uma casa no Aracy, você constrói, você mexe, mexe, não vai valorizar. E aqui, em dois anos dobrou, tá cento e cinquenta mil. Se a gente for vender essa casa hoje, desse jeito, cento e cinquenta mil! / Jefferson: Tipo, a casa dele, já pronta, vai valer uns cento e vinte mil. A nossa já vale isso sem ter escola, creche, mercado, açougue, essas coisas... Então eu vejo isso, aqui eu vejo que pode crescer mais. (...) Mas é que eu também penso assim: enquanto aqui tá sem nada... é loucura, mas pô, pra vender, tá de cento e vinte a cento e cinquenta mil já, pra eu quitar meus trinta e nove mil... Pô, se eu fosse um cara mais atirado... / Beatriz: la ter voltado pra Aracy! E eu sou louca? / Jefferson: Ou então, que nem eu falei pra ela, a gente já tem a casa, se quiser alugar aqui, tá seiscentos conto, e alugar em outro lugar, o dinheiro de uma paga outra, entendeu? Eu até tava falando outro dia, 'pô, Bia, aqui é muito parado, a gente devia ir pra lá, pra outro lugar e depois voltar quando tiver mais movimentado', né? [Jefferson e Beatriz]

Embora ele afirme que tudo não passou de uma brincadeira, a situação evidencia seu descontentamento com os desdobramentos do processo de fixação no bairro, não apenas pelo fato de não ter nada, mas, sobretudo, pela ausência de movimento, de conhecidos, de relações cotidianas no local: são recorrentes seus comentários sobre o quanto a vida no bairro se diferencia de sua experiência anterior de família ampliada, "quintal" e bairros movimentados, desde os tempos em que vivia em São Paulo, e sobre o quanto ele sente falta disso tudo. Embora muitas vezes faça questão de dizer que está tentando se acostumar ao silêncio e à ausência de redes de relações no novo bairro, essa perspectiva, que vez ou outra aparece - não apenas nos encontros da pesquisa, mas também em conversas com amigos e com a família -, de trocar a casa por outra, seja no Cidade Aracy, seja em outro bairro na Zona Sul, atesta 
que seu descontentamento com tais condições do novo bairro vem gradativamente se sobrepondo, inclusive, à sua sempre reiterada expectativa na melhoria do bairro.

A isso somam-se as notícias sobre a iminência da chegada do tráfico de drogas no bairro, das quais Jefferson tomou conhecimento no final de 2013, prestes a completar dois anos da mudança da família para lá: além de não ter aspectos que ele considera positivos em um bairro ${ }^{108}$, o local poderia passar a ter também aqueles considerados, por Beatriz, tão negativos no Cidade Aracy.

Jefferson: Tipo assim, já chegou em mim que compraram esse bairro. / THAís: Como assim, o que significa comprar esse bairro? / Jefferson: É tipo assim, ele tem o direito de montar a biqueira dele aqui. / Thaís: Mas comprou de quem, ele paga pra alguém? / Jefferson: Não sei diretamente se é pro PCC, mas eu sei que aqui o direito de ter biqueira é dele, de uma pessoa que mora ali no Aracy. É até uma pessoa que eu conheço, então se de repente instalar aqui eu já vou chegar nas ideia. Falar: 'pô, você quer fazer você faz, mas você faz pra lá meu', então... / Thaís: E como você ficou sabendo disso? / Jefferson: Amigos... Amigos que contou. Falei: 'Ah, tô morando no Parque Novo Mundo', ele: 'ow, da hora tal', aí entrou nesse assunto, porque é tudo amigo de infância e tal, aí falou: 'Ah, o fulano comprou uma biqueira lá no seu bairro lá'. Aí eu já falo: 'desde que não seja perto de casa...' / Thaís: Mas ele tem uma casa aqui? / Jefferson: Não, ele tem o direito de montar aqui. Acho que ele paga pro próprio crime mesmo, não sei se é pro PCC, que rege isso hoje, mas eu sei que agora ninguém mais pode montar aqui sem o consentimento dele, porque, sei lá, ele cuida dessa região, não sei. Então, pode acontecer, dele alugar uma casa aqui.../ Beatriz: Isso é uma coisa que a gente não tinha pensado, sabe que pode acontecer, porque em todo lugar tem, mas não tinha pensado que seria tão rápido...

Embora acredite que, com o conhecimento que tem dos envolvidos no bairro Cidade Aracy e sendo de lá o tal 'proprietário' do direito de montar uma biqueira no Parque Novo Mundo, ele conseguiria ao menos evitar que a boca se instalasse próximo à sua casa, tal notícia põe em cheque diversas expectativas do casal frente ao local, sobretudo aquelas que teriam motivado propriamente a intenção de morar fora do Cidade Aracy. Mesmo acreditando que talvez isso não se concretize, pelo perfil dos moradores e do próprio bairro, aquela perspectiva da casa como capital é novamente acionada pelo casal, agora em termos de uma etapa seguinte no projeto de mobilidade socioespacial que incorpore os desejos de ambos.

Jefferson: Se aqui continuar valorizando, eu pensaria em trocar na Vila Prado. Ali é bem mais desenvolvido e é mais valorizado, então é difícil... mas quem sabe a gente consegue, num futuro não tão distante... / Beatriz: Eu também! Perto do meu serviço, da minha mãe... / Jefferson: Ali você tem meio que acesso a tudo e muito rápido. Pela localização... Ali, bem dizer, é uma continuação do Centro... / Beatriz: Tem escola. / Jefferson: Às vezes tem os mesmos problemas dos outros bairros, mas você não vê, não sei se é mais escondido... esse problema que tem no Aracy, das drogas e tal, perto das casas, ali eles meio que juntam naquelas

108 Chama a atenção o fato de que aquele sentido de bairro, para Jefferson, permanece ainda muito associado ao Cidade Aracy I: enquanto ao referir-se a este, ele sempre o faça como meu bairro, não registrei nenhuma menção dele nesse sentido em relação ao Parque Novo Mundo. 
praças ali. Não fica mais na frente da casa dos outros. Escolas boas tem ali, entendeu? É tudo perto, ali.../Thaís: E se vocês morassem na Vila Prado, como é que seria a relação com o Aracy? / Beatriz: Igualzinho, todo dia à tarde tem que ir lá (risos). / Jefferson: Com o carro... não tinha problema. E, de ônibus, é mais fácil de lá do que daqui. Por isso eu não penso em morar no outro lado da cidade; eu penso em morar da linha de trem pra cá... Zona Sul. Porque até ali é um lugar que eu conheço também, né, seria fácil pra eu ir pra lá, e tanto pra eles virem. Por isso... ${ }^{109}$

Reiterando que o limite de deslocamento aceitável para ele circunscreve-se à Zona Sul, Jefferson e Beatriz acordam que o lugar ideal, que concatenaria tranquilidade e movimento, facilidade de deslocamento para o Cidade Aracy e para o restante da cidade e acessibilidade a comércio, serviços e equipamentos públicos, além de ser próximo ao novo trabalho de Beatriz e à casa da mãe dela seria a Vila Prado, um dos primeiros locais de moradia operária para além da linha férrea, datado do final do século XIX e hoje completamente consolidado - justamente um dos bairros de boy que Jefferson e outros amigos moradores do Cidade Aracy diziam desprezar na juventude. Mesmo que limitado voluntariamente à Zona Sul da cidade, o projeto familiar de ascensão socioespacial encontra-se à toda e com cada vez menos perspectiva de ancoragem definitiva no Parque Novo Mundo.

\section{- Processos movediços: entre fixação e novos deslocamentos}

Como os fragmentos aqui reconstruídos permitem perceber, os processos de fixação nas novas casas e nos novos bairros são tensionados, o tempo todo, pelas constantes mudanças e instabilidades em todos os outros aspectos da vida, especialmente nas dinâmicas familiares e seus arranjos cotidianos envolvendo situações de emprego e desemprego, trânsitos religiosos, circulação dos filhos entre casas e bairros, projetos individuais e familiares, para citar alguns, sendo muitas delas também decorrentes da mudança de bairro e de casa. As mulheres, sobretudo em sua condição de mãe,

109 É interessante perceber, aqui, que apesar das perspectivas divergentes sobre vários aspectos de suas experiências urbanas e, principalmente, sobre o bairro Cidade Aracy e suas dinâmicas socioespaciais, há uma perspectiva comum que se evidencia em seus relatos e práticas cotidianas: de que a cidade, para eles, se limita à Zona Sul. De fato, a Zona Sul é um elo de conexão entre as experiências urbanas, em grande medida distintas, de ambos, e isso me faz pensar na reflexão, promovida por Leite e Machado da Silva (2013), acerca da limitação territorial das experiências dos jovens moradores de favelas e periferias. Mas, por outro lado, ambos veem cidade ali: não é só porque, na Zona Sul, estão dentro dos limites do que lhes é conhecido, mas porque ali se concentra a maioria das coisas que eles gostam de fazer, que são o universo deles, e que essa região da cidade supre, contempla. Nesse sentido, esse trecho evidencia muito claramente quais são os valores de urbanidade que importam na escolha de um lugar para morar e que na parte de cima da Zona Sul estariam contemplados: proximidade ou facilidade de acesso ao trabalho; acessibilidade a comércio, serviços e equipamentos públicos de melhor qualidade; facilidade de deslocamento tanto para o Cidade Aracy quanto para o Centro; proximidade das redes de relações; manutenção dos vínculos estabelecidos territorialmente (no caso de Jefferson, no Cidade Aracy). 
têm papel determinante não apenas nos processos de conquista da casa e de mudança, mas também nos rumos do processo de fixação nos novos territórios, que envolvem novas relações entre casa, trabalho, cuidados com os filhos e os deslocamentos na cidade.

Nesse sentido, muitos fatores influem nesse processo de fixação e, embora as duas famílias investigadas permaneçam - ainda - nos novos territórios, em situações distintas de fixação e perspectivas de futuro frente às casas e aos bairros, em campo travei conhecimento com inúmeros outros casos - cuja recorrência me chamou atenção - que apontam para a forte dimensão de subjetividades, quase sempre ligadas a dinâmicas familiares cambiantes, a reger a tênue linha entre a permanência nos novos territórios e novos deslocamentos habitacionais.

É o caso, por exemplo, de uma prima de Joana, que também conseguiu uma casa no sorteio para o Jardim Zavaglia. Ela demorou mais de seis meses, após a entrega das chaves, para se mudar, porque morava com o marido na casa da mãe dele e ele estava indeciso entre permanecer na casa da mãe ou mudar-se para o novo bairro com ela. Então ela decidiu mudar-se sozinha, acreditando que, assim, ele viria. Um ano depois, a casa já estava alugada, pois o marido decidira não vir, ela voltou a morar com ele e a sogra, mas quis manter a garantia de uma casa em seu nome, "porque ninguém sabe o dia de amanhã, né? Essa casa é minha segurança no futuro."

Então, eu me inscrevi, porque tava morando na casa da minha sogra, né? Era só ele e a mãe dele, porque tem a casa e a edícula, a mãe dele mora na casa, e ele morava na edícula, eu fui lá morar com ele. Só que ele é o único filho que não tem recurso, que não tem casa, que mora ali junto com ela, e ela já é de idade, então, os outros irmãos abriu mão da casa... Quando ela morrer, a casa vai ficar pra ele, então jamais que ele ia querer morar numa casinha assim, entendeu? Ele disse que jamais vai morar do lado da Cidade Aracy, porque ele mora ali perto da Estação, no centro... Mas eu me inscrevi, ganhei, e não vou vender essa casa, não, porque a gente não é casado no papel, só moramos juntos, então eu tenho medo de futuramente ficar... Apesar que meu direito é igual se eu fosse casada, né, mas eu penso que, futuramente, posso ficar sem nada, posso separar dele nada é eterno, né (risos) - e ficar sem lugar pra ir, porque pra casa da minha mãe, eu não quero voltar... Então, mesmo sem morar aqui agora, pelo menos já tenho um lugar garantido pra morar, em caso de necessidade. Agora tá alugada pra uma conhecida. [prima de Joana, conversa informal registrada em caderno de campo, dia 08/09/2012]

É, também, o caso de um senhor que vinha utilizando a casa no Jardim Zavaglia quase como uma segunda residência: amasiado com uma mulher que já possuía uma casa no Jardim Cruzeiro do Sul, ele se cadastrou como idoso na Prohab e foi contemplado no sorteio, porque uma porcentagem das moradias deveria ser destinada a essa parcela da "população de baixa renda". Entretanto, ao conhecer o bairro, a companheira não quis se mudar para lá. O senhor não quer se desfazer da casa e segue indo toda semana ao bairro, passando tardes inteiras "mexendo numa coisinha aqui, outra ali" na casa, mas sem propriamente morar nela, que continua vazia. Ele 
ainda tem planos de convencê-la a vender ou alugar a outra casa que está em nome dela e mudar-se com ele para sua casa, "porque não sou homem de depender de mulher", mas, em nenhum momento, demonstrou intenção de mudar-se para a casa sem ela. Entretanto, após dois anos nessa situação e tendo havido tentativas de invasão da casa, ele começa a pensar na possibilidade de cedê-la para algum conhecido morar, de modo que sua posse seja preservada, e ele possa continuar a frequentar a casa para fazer suas coisinhas.

Recorrente também é o caso de um casal com um filho pequeno que, após menos de um ano vivendo juntos na casa ganha no Jardim Zavaglia, resolveram se separar e, para que o marido não tivesse que dar pensão ao filho, fizeram um acordo de que a casa ficaria para ela. Quando, após alguns meses, ela encontrou um novo companheiro, mudou-se para a casa da mãe deste e alugou a sua pelo dobro do valor das prestações. As últimas notícias davam conta de que ela pretendia voltar a viver na casa, já que "não está dando certo morar com a sogra".

Há ainda casos de famílias que, após todo o processo de aquisição da moradia (que, como visto, envolve uma série de enfrentamentos burocráticos quase sempre difíceis para essa população) e de mudança para o novo bairro (com todos os custos financeiros aí envolvidos), ao longo do processo de fixação encontram obstáculos que motivam um novo deslocamento habitacional, inserindo a nova moradia no circuito do mercado informal de aluguel ou venda ${ }^{110}$. Tais obstáculos podem dizer respeito às dificuldades de deslocamento cotidiano entre os novos bairros e o restante da cidade (como visto também no caso do Parque Novo Mundo), ou ainda decorrentes do próprio processo de fixação, como é o caso de duas famílias, uma moradora do Jardim Zavaglia, e outra, do Parque Novo Mundo, oriundas de bairros do outro lado da cidade, como o Santa Felícia ou o São Carlos 8.

Em ambos, as famílias, que enfrentaram situações semelhantes àquelas vividas por Joana nesse processo de fixação, ao contrário do que vem acontecendo com ela, não conseguiram reestruturar as dinâmicas cotidianas nos novos bairros sem continuar dependendo das antigas redes de apoio baseadas nos bairros de origem, o que acabou gerando uma amplitude de deslocamentos cotidianos entre os bairros, bem como gastos e desgastes nas relações decorrentes de tais circunstâncias, que levaram

110 Há, evidentemente, também a possibilidade de inserção no mercado formal, sobretudo quando se trata de venda, como evidenciam vários anúncios encontrados em sites de imobiliárias locais, bem como placas de imobiliárias em frente às moradias, sobretudo no Parque Novo Mundo. De fato, nesse bairro, chama a atenção o recente aumento na quantidade de anúncios nesse sentido, evidenciando não apenas essa dificuldade de fixação no bairro e a rotatividade dos moradores, como também a maior dificuldade em "passar a casa para frente", diferentemente do observado no Jardim Zavaglia, onde predomina um dinâmico mercado informal não só de aluguel, mas também de compra e venda, tal como discutido no Entremeio I. 
tais famílias a desistir das novas moradias - que, por sua vez, acabaram também sendo inseridas no mercado informal de aluguel ou venda - e retornar aos "bairros de origem" antes que os antigos arranjos familiares e de vizinhança se desestabilizassem por completo, acarretando consequências financeiras, sociais e familiares que não foi possível aprofundar no presente trabalho.

Tais casos permitem compreender melhor, por contraponto, os processos de fixação nos novos territórios enfrentados por Beatriz, Joana e suas famílias e reforçam a questão, evidenciada empiricamente, do quanto tais processos estão atrelados a arranjos familiares e de vizinhança, e como eles podem, a depender dessas dinâmicas cambiantes, acabar também resultando em novos deslocamentos habitacionais. As questões referentes a esses processos de fixação aqui descritos parecem iluminar, ainda, modos de constituição de dinâmicas socioespaciais que interconectam os bairros populares, tecendo redes de relações e interconhecimento que os atravessam. Além disso, apontam para a dimensão fundamental dos processos de produção e apropriação do urbano que se fazem atrelados a esses processos de fixação nesses novos territórios, como é o caso do lugar que a região do Cidade Aracy passa a ocupar nessas novas tramas socioespaciais e que dá a tônica das reflexões desenvolvidas a seguir. 


\section{[ entremeio II ]}

\section{O urbano em ato: territorialização da pobreza e produção de uma 'centralidade periférica'}

Os processos de fixação descritos no Capítulo 2 denotam esforços dos moradores desses novos territórios - que, ainda que produzam efeitos coletivos, pautam-se em estratégias predominantemente individuais - em "transformar um espaço que em princípio é estranho em um lugar apropriável; ou ainda territorializar momentos significativos da própria existência" como "formas de se situar na realidade cambiante da cidade, onde as transformações obrigam a modificar e criar novos pontos de referência pessoais e sociais" ${ }^{1}$. É de se notar que tais processos se articulam a dinâmicas de produção de urbanidade, de "fundação da cidade a partir das margens urbanas" ${ }^{2}$, e ancoram-se numa espécie "saber de experiência"3 disseminado entre as camadas populares: o de que, bem ou mal, com mais ou menos "luta", o urbano sempre se faz.

Se, como visto, a ausência de redes sociais e relações de vizinhança cabe aos próprios moradores transformar cotidianamente, a ausência de equipamentos, serviços, comércios é vivida, simultaneamente, como sofrimento e expectativa de um futuro melhor: apesar das dificuldades iniciais, prevalece a crença de que, mais cedo ou mais tarde, aquele lugar também se tornará uma parte estruturada da cidade, a priori, através de sua própria atuação, ao dar conta, informalmente, de certas demandas

1 Kuri e Diaz (2006:10), tradução livre a partir dos originais: "transformar un espacio en principio extraño en un lugar apropiable; o bien territorializar momentos significativos de la propria existencia"; "formas de ubicarse en la cambiante realidade de la ciudad donde su transformación obliga a modificar y crear nuevos puntos de referencia personales y sociales".

2 Agier (2011:39).

3 Bondía (2002:27): “Durante séculos, o saber humano havia sido entendido como um páthei máthos, como uma aprendizagem no e pelo padecer, no e por aquilo que nos acontece. Este é o saber da experiência: o que se adquire no modo como alguém vai respondendo ao que vai lhe acontecendo ao longo da vida e no modo como vamos dando sentido ao acontecer do que nos acontece. No saber da experiência não se trata da verdade do que são as coisas, mas do sentido ou do sem-sentido do que nos acontece."

4 Cf. já mencionada abordagem proposta por Cavalcanti (2007; 2009). 
locais (sobretudo em termos de espaços de comércio, sociabilidade, culto mercadinhos, lanchonetes, bares, campos de futebol, igrejas), e, posteriormente, de outros agentes, como estado, empresas, ongs. O que interessa reter aqui, nesse sentido, é o fato de que, nas trajetórias apresentadas na tese (e em diversas outras acompanhadas em campo), há sempre uma experiência anterior de acompanhar o urbano se fazendo processualmente a embasar a confiança numa inescapável conformação de urbanidade nesses novos territórios, como evidencia o relato de Joana:

\begin{abstract}
Ah, a [região do] Santa Felícia é mais bem estruturada que aqui [Jardim Zavaglia], né. Com certeza, com certeza, ó, tinha um posto de saúde ali pertinho, tem posto de gasolina, ali na avenida tem padaria, o que você pensar, ali na Santa Felícia você acha, entendeu? Você num precisa sair pra lugar nenhum, num precisa ir longe pra conseguir o que você quer. Ao contrário daqui, que é um pouquinho dificultoso, entendeu? Mas quando eu mudei pra Santa Felícia lá também não tinha nada, não tinha nada! Na verdade quando eu mudei pra lá, igual eu te falei, nem água tinha lá, nem água, nem luz, nem asfalto, precisou puxar a água longe, mais de dois quilômetro... Então a gente viu o bairro começar e estruturar, eu acho que aqui também tem essa mesma possibilidade. Acho que daqui uns quatro, cinco anos, acho que não vai ter muita diferença de lá, não. / Thaís: você acha que aqui também isso vai acontecer? / É, porque eu tô vendo acontecer, porque agora tá... Quando eu mudei aqui também não tinha nada... num tinha mercado, num tinha açougue, num tinha sacolão, num tinha lanchonete... e agora já tem tudo isso! O posto de saúde, daqui uns meses tá inaugurando o posto de saúde. Já é uma grande coisa, você não precisa ir tão longe. Já é mais uma melhoria. Assim que inaugurar o posto de saúde, já tem a proposta de começar a escola... Então, é com o passar do tempo que as coisas vão melhorando. A tendência é crescer, estruturar. Diz até que vão construir mais quinhentas casas no Zavaglia $1 !^{5}$ (...) Então, eu acho que do mesmo jeito que a Santa Felícia prosperou, entendeu, de quando eu mudei lá que num tinha nada, eu acho também que o bairro aqui a tendência é crescer, como tá crescendo. [Joana]
\end{abstract}

Tal "saber de experiência” parece conformar uma espécie de 'imaginação urbana' na qual o presente, mediado por experiências passadas, se orienta a um horizonte de progresso, de melhoria: a casa, o bairro, a cidade, sempre em processo, em inacabamento, são vislumbrados através de uma "imaginação do futuro" ${ }^{6}$, de uma

5 Aqui, Joana refere-se novamente ao novo empreendimento produzido pela mesma construtora, quase contíguo ao Jardim Zavaglia, que passou a ser conhecido popularmente como "Zavaglia II". A produção de novos bairros junto àqueles onde vivem aparece sempre nas narrativas como algo bom, positivo, quase uma garantia de que o urbano vai chegar definitivamente, como se percebe também nesta fala de Jefferson: "A tendência é melhorar, crescer mais, valorizar. Que nem, essa parte aqui debaixo é empresarial. Aonde você não vê casa aqui, vai ser tudo empresa também. Então vai ficar rodeado mesmo de empresa, entendeu? E eu já ouvi até falar... do Parque Novo Mundo 2! Eles pretendem abrir outro bairro ali. Então, vai crescer, vai melhorar."

6 Inspiro-me em reflexões de Cavalcanti (2007; 2009) estabelecidas a partir da realidade das chamadas "favelas consolidadas" no Rio de Janeiro. Guardadas as devidas distinções em termos dos contextos urbanos investigados, a abordagem da autora ajuda a pensar essa confiança numa urbanidade por vir: "Nesses testemunhos podemos discernir uma narrativa subjacente que, na maioria das vezes, elabora a percepção de - progressivas, porém inegáveis - melhorias materiais do lugar. É 
urbanidade por vir. Joana recupera sua experiência anterior de ver o Santa Felícia tornar-se um bairro estruturado quase como uma garantia de que o mesmo irá acontecer com o Jardim Zavaglia. É algo que observei com recorrência na pesquisa de campo nesses novos territórios: em vista de experiências anteriores de bairro e moradia, a experiência presente (por mais difícil que seja) é sempre positivada por essa convicção na produção processual do urbano, por essa "imaginação do futuro". Evidencia-se inclusive, como visto, uma espécie de condescendência com as condições atuais desses novos bairros produzidos no âmbito do PMCMV, como se ainda fosse muito cedo para tecer críticas ou exigir direitos, tendo em vista o fato de terem se mudado para bairros prontos; ou seja, uma parte da referência de urbanidade que, nas experiências anteriores, esteve atrelada a esse longo processo de estruturação dos antigos bairros onde viveram, estava já dada quando da mudança para os novos territórios - água, luz, asfalto, transporte (ainda que insuficiente ou precário). É nesse sentido que se deve compreender a afirmação de Jefferson sobre o Parque Novo Mundo, onde, como visto, não há mais nada além de moradias: "o bairro é bom pra caramba e tende a melhorar. Chegar os comércio, escola, essas coisas. Então, sei lá. Acho que vai ficar bem da hora".

Nesse mesmo sentido, os relatos de Jefferson evidenciam ainda outro aspecto também bastante recorrente em campo, qual seja, o fato de que, em parte, é justamente a experiência de acompanhar essa produção do urbano em ato que configuraria o sentimento de pertencimento em relação aos antigos bairros, como deixa claro este trecho sobre sua relação com o Cidade Aracy: "ali eu fui crescendo e acompanhando o crescimento de tudo, e você cria meio que raiz, né?". O testemunho da transformação de um espaço onde "não havia nada" em um "bairro estruturado" é narrado quase sempre como um misto de memória do sofrimento e de orgulho: um sentido de luta, de conquista, de que 'eu estava lá', 'eu fiz parte desse processo'7.

certo que essa imaginação de um progresso ao longo do tempo coexiste com expressões de desespero e desalento no que concerne ao futuro imediato, marcado por um contexto de grande desemprego e subemprego, de poucas perspectivas e de um acesso precário à educação, à saúde etc. Como os moradores do "asfalto", a preocupação com a segurança dos filhos figura como elemento central da vida cotidiana (...) Todo esse contexto engendra narrativas de declínio social ou moral, e de um futuro pior do que o presente. (...) Nesse contexto, a imaginação da melhoria gradativa é necessariamente reflexiva. Ela requer uma abstração das vicissitudes e das "lutas" da vida cotidiana (ontem e hoje) para que os processos de longo prazo - todos esses componentes da "melhoria" (outro termo nativo) concatenem uma narrativa mais coesa de progresso, cujas evidências são visíveis (...)" (Cavalcanti, 2009:74).

7 E aqui remeto novamente ao trabalho de Cavalcanti (2007; 2009:74), ao enfatizar "o modo como a ideia de 'luta' é produtiva de noções de valor atreladas ao espaço da favela", ao que eu acrescento também dos bairros populares nas periferias, guardadas suas distinções. Uma tal concepção de luta "produz os moradores como sujeitos de sua própria história, e é constitutiva de uma ética que valoriza o trabalho duro e a perseverança: nada vem facilmente." 
No caso específico do Cidade Aracy, a referência corrente de que "hoje em dia é um bairro bem estruturado, tudo acontece ali" (Jefferson), para além de uma positivação do bairro promovida histórica e constantemente por seus moradores (e, mais recentemente, também pelos moradores do Jardim Zavaglia, como visto no caso de Joana) visando a contrapor-se ao estigma associado ao local, evidencia também um certo reposicionamento desse bairro no contexto urbano mais amplo da cidade de São Carlos, ou, ao menos, em relação à Zona Sul. A estruturação, o desenvolvimento do Cidade Aracy seria mesmo a comprovação máxima, entre moradores antigos e novos do bairro e da região, de que assim como o urbano se fez ali, "onde não havia nada", também nos novos bairros se fará.

E, se as experiências passadas e a "imaginação do futuro" moldam uma visão que positiva o presente, no caso do Cidade Aracy tal positivação é sobretudo relacional ao passado do próprio bairro, ao seu contexto de formação e consolidação ao longo de trinta anos: de um "bairro feito para tacar as pessoas de qualquer jeito em qualquer lugar" e sua transformação em "um bairro mesmo, um bairro onde todo mundo quer ter sua casa" [Jimmy].

Depois de tudo que a gente já passou, eu, minha mãe, minhas tias, a gente acabou entendendo que a forma dos caras [os políticos] de resolver o problema [da moradia] é tacando as pessoas de qualquer jeito em qualquer lugar e, querendo ou não, boa parte da Cidade Aracy foi criada assim. / Thaís: E você acha que foi criado assim, mas e hoje? / Não, hoje não. Hoje é um bairro mesmo, um bairro onde todo mundo quer ter sua casa. Que nem, muita gente daqui tá querendo financiar casa aqui mesmo. Tá, porque é o bairro que gosta de viver, sabe? E o bairro que já tá acostumado, que conhece todo mundo, bairro que chama muita atenção de muita gente. É um bairro onde hoje tem tudo. [Jimmy]

A gente já morou em bairros que, naquela época, eram a periferia da cidade, como o Jardim Botafogo, eram os últimos bairros da cidade, e onde tinham os mesmos problemas sociais, de serviço público, que ainda tem hoje aqui, porque não dá pra negar que melhorou, mas ainda tem problemas. Mas, assim como lá mudou, melhorou, aqui também já se desenvolveu muito, e continua melhorando. [Núbia]

Tornou-se, de fato, cada vez mais corriqueiro escutar entre os moradores da região que "hoje, a Aracy tá bem desenvolvida! Em vista do que era antes...". Tal assertiva contém, de um lado, justamente a perspectiva de que o urbano se fez, ali, passados todos esses anos, apesar de todas as dificuldades, testemunhado - e, sobretudo, também construído - por eles: e, em sendo "um bairro de gente pobre" que tanto se estruturou na última década, o Cidade Aracy é a prova cabal de que o urbano sempre chega, e isso, além de ser um valor para os moradores do próprio bairro, também o é para os que estão se fixando nesses novos territórios produzidos na região, como é o caso de Joana. De outro, a dimensão de alcance de um certo estágio de desenvolvimento que, no âmbito da "região pra baixo da serrinha" (o "grande Cidade 
Aracy") e na relação entre os bairros pré-existentes e os novos territórios a se configurar, começa a ganhar destaque, para o bem e para o mal.

Ah, ao longo desses anos, aumentou, tem vários supermercados, hoje a gente já tem farmácia, tem banco, tem casa lotérica. Quando eu mudei pra cá, não tinha nada disso. Dependia muito mais do centro. Hoje em dia, a gente não tem necessidade, por exemplo, se precisar de ir pagar uma conta de água, de ir lá em cima, sabe? Se depende de um remédio, ir lá em cima... tem tudo aqui. Então, hoje em dia, quase dez anos depois, tá bem melhor. Mudou muito. / Thais: E que mais mudou, fora essa parte do comércio? / Serviço público continua a mesma droga (risos). Ah, eu acho que melhorou, assim, a situação de moradia: hoje a gente vê aí muita casa nova, casas recém-construídas, então acho que melhorou, além da parte de comércio, a questão da moradia. Sabe, eu acho que melhorou bastante, o bairro aumentou bastante. Encheu mais. Antes tinha mais terrenos vazios, agora já não. [Jimmy]

Uma vez que novos bairros destinados à moradia das camadas populares passam a ser produzidos na região, mais ou menos acoplados a esse território periférico preexistente e completamente desprovidos de equipamentos, serviços e comércios, como é o caso dos bairros Jardim Zavaglia e Parque Novo Mundo, tratados no capítulo anterior, o bairro Cidade Aracy, até então a periferia extrema da cidade e polo de todos os estigmais locais, passa a ocupar, paradoxalmente, um lugar central: enquanto o urbano não se faz nesses novos territórios, como creem seus moradores, parece se acentuar ainda mais a consolidação do Cidade Aracy como uma espécie de 'centralidade periférica's.

Ah, porque se eu atravessar aquela avenidinha, ali na Cidade Aracy, no Antenor tem tudo. O que eu precisar, eu sei que ali tem. No Antenor dá pra ir a pé, mas se vai, por exemplo, no meio do Aracy, lá onde é o centro, a rua do comércio, tem que ir de ônibus, porque fica um pouco mais longe. [Joana]

Daqui é muito mais fácil vir no Aracy do que ir pro centro da cidade. Então a gente faz tudo aqui. O nosso centro é o Aracy. [Beatriz]

Hoje em dia, o Aracy é nosso centro, pra muita gente que mora na região é, porque tem tudo ali, tudo acontece ali. Você quer ir no correio, ali tem; você quer pagar uma conta, você vai ali na rua principal; você quer ir fazer reclamação no $S A A E$, lá tem (risos). [Jefferson]

O centro mesmo é na I né? Vem gente da II, do Antenor, do Collor e agora também do Zavaglia e Novo Mundo fazer tudo ali. / Thaís: Você sempre diferencia bem o Aracy l e o Aracy II, né? / Sim, na verdade sim, porque não tem como não dizer isso, não tem como, lá o comércio é mais forte, o principal ponto é isso. E por causa disso o bairro é mais estruturado, porque foi mais povoado. Lá é o centro comercial mais forte que tem aqui embaixo, todo mundo concentra

8 Inicialmente, essa categoria foi decorrente da própria pesquisa de campo, sendo adotada mais como categoria empírica, descritiva, do que propriamente analítica ou como modelo explicativo. Entretanto, conforme a necessidade de refletir um pouco mais sobre tal reconfiguração socioespacial (e também econômica) ali identificada, algumas referências conceituais ofereceram instrumental à análise aqui esboçada, e serão apontadas a seguir. 
suas coisas lá, lá tem caixa eletrônico, farmácia do Rosário tá lá, pra você ter uma ideia, tem padaria, mercado, açougue. [Jimmy]

Se as trajetórias trabalhadas no Capítulo 2 permitiram lançar luz sobre a relação desses novos territórios periféricos com o que seria uma "periferia consolidada" ${ }^{9}-\mathrm{e}$ nesse sentido a centralidade que vem sendo adquirida pelo bairro Cidade Aracy é emblemática, uma vez que até bem pouco tempo atrás ele ainda era a fronteira de urbanidade da cidade -, esse contexto se complexifica ainda mais quando se considera que mais dois conjuntos habitacionais vinculados ao PMCMV estão sendo produzidos na região.

Por mais desenvolvido e estruturado que o Cidade Aracy possa estar - e, vale reforçar, essa medida êmica é sempre comparativa com as origens do bairro -, é notório que tal estrutura, como visto, nunca chegou sequer a ser suficiente para as milhares de pessoas que ali vivem atualmente, sobretudo em termos de serviços públicos, com destaque para a questão do transporte. Ainda assim, é com base nessa estrutura urbana e socioespacial pré-existente que um vetor importante de implementação local do PMCMV vem se dando, de forma a amplificar significativamente a ocupação urbana da região (desconsiderando todas as diretrizes em contrário promovidas por diversos estudos e pelo próprio Plano Diretor, como visto no Capítulo 2) e a reafirmála de forma acintosa como o lugar de moradia por excelência das camadas populares na cidade: até o momento já são, portanto, três grandes conjuntos promovidos no âmbito do Programa para a "Faixa 1" - ou o "público de baixa renda" - na região10, totalizando mais 2.792 "habitações de interesse social" e algo em torno de 15.000 pessoas entre 2010 e 2014 (além das 491 unidades do Parque Novo Mundo, construído para a "Faixa 2" - ou a "nova classe média" - fora do perímetro oficial do "Grande Cidade Aracy", bem como sua anunciada ampliação, ainda não iniciada).

9 Emergindo no debate acadêmico no final dos anos 1990, a partir da constatação empírica de que existiriam "estágios diferentes de periferia" (Bonduki, 2001:96), o termo "periferia consolidada" (Lago, 1998; Ribeiro, 2001; Torres, 2005; Cardoso et al, 2007) passou a ter uso corrente na literatura especializada, tendo sido, entretanto, raramente aprofundado (Saraiva, 2008; também Cavalcanti, 2007, observou situação semelhante em relação à noção de "favela consolidada"). Nesse sentido, como aponta Saraiva $(2008: 72,73)$ em estudo sobre as periferias consolidadas em São Paulo, o termo seria "utilizado pela necessidade de nomear - tanto em estudos sobre a estrutura sócio-espacial da metrópole quanto na prática do planejamento urbano - áreas originalmente precárias e irregulares, que, no momento da observação, apresentam razoável oferta de infra-estrutura e acesso aos serviços. Estas áreas apresentariam, no momento da observação, pequena taxa de crescimento face a periferias recentes, permanecendo como uma região ocupada por população pobre, ainda que esta possa ter apresentado alguma mobilidade social ascendente. (...) Na maioria das vezes, o termo é utilizado como uma categoria mediadora entre dois outros conceitos (por exemplo, centro ou núcleo e periferia)."

10 Retomando: Jardim Zavaglia, com 1.000 unidades, já construído; Residencial Planalto Verde, com 806 unidades e Residencial Eduardo Abdelnur, com 986 unidades, ambos em construção. 
E, tipo, a cidade vai engolindo, e vai ficando bairros mais afastados, tipo o Aracy, que ainda tem mais coisas a se fazer, entendeu? Às vezes nem tá tudo certo nesses bairros, e já tá fazendo outro bairro ali, e assim vai, pô. [Jefferson]

A isso soma-se uma série de outras produções habitacionais de caráter 'varejista' vinculadas ao PMCMV nos bairros Cidade Aracy I e $\mathrm{II}^{11}$, dando conta de ainda mais transformações promovidas pelo Programa nas dinâmicas da região, não apenas no entorno dos bairros pré-existentes, ou em termos da configuração dessa nova "centralidade periférica", mas também em termos da própria produção recente da paisagem urbana local, da conformação de um novo mercado habitacional formalizado e, ainda, de reconfigurações nas classificações e hierarquizações socioespaciais locais, como veremos no Entremeio III. Esses investimentos pulverizados na construção de moradias para financiamento em terrenos nos próprios bairros pré-existentes (com destaque para o Cidade Aracy II) são percebidos por meus interlocutores como um dos grandes motores de melhorias mais recentes, sobretudo em termos materiais, acentuando as representações de desenvolvimento do bairro: casas prontinhas, com acabamentos, muros e portões, contrastando com o padrão anterior de casas autoconstruídas lentamente, muitas delas sem acabamento nenhum.

Conheço muita gente que tá fazendo o mesmo esquema que eu, de pegar uma casinha pra financiar por esse Minha Casa Minha Vida aqui no bairro. Aqui do lado mora um conhecido meu, o irmão dele parece que pegou uma ali em cima, tudo nesse esquema. O meu líder da igreja... bastante gente, tem bastante gente fazendo isso aqui, assim como tem bastante casinha aí que não fechou negócio, que tá fazendo, tem muita, muita casa. [Jimmy]

Ah, tipo assim, de um ano e oito meses, dois anos, vamos arredondar pra dois anos, de dois anos pra cá, o que cresceu de casa aqui não tá escrito. / Thaís: Você percebeu em quantidade de casas mesmo... / Isso, quantidade de casas mesmo, quase todas as ruas aqui têm pelo menos umas quatro casinhas desse tipo./ Thaís: E só no Aracy Il você sentiu isso? porque era aqui onde tinha mais terreno?/ É, mais aqui, né, lá na I também teve bastante, mas bem mais aqui. No Antenor, menos, mas a tendência é ter lá também. / Thaís: E como você identifica que essas casinhas são do Minha Casa Minha Vida? O que faz você perceber a diferença? / Primeiro, o modelo, né? E depois, quase sempre tem a plaquinha lá 'Minha Casa Minha Vida'./ Thaís: Mas e o modelo, o que o modelo tem de diferente das casas do bairro? / Ah, que é assim, os caras sempre fazem a mesma coisa que o meu colega fez aqui né, compram o terreno inteiro, desmembra, divide no meio o terreno e faz uma casa-vagão em cada meio terreno. Então, pode ter certeza que é sempre Minha Casa Minha Vida isso aí, a grande maioria,

11 Através da já mencionada modalidade "Carta de Crédito Individual", que vem sendo explorada por pequenos e médios construtores como negócio: eles adquirem os terrenos, executam a obra e contatam (ou são contatados) por imobiliárias e/ou "Correspondentes CAIXA Aqui" (que, em alguns casos, funcionam também como imobiliárias), agenciando a venda financiada do imóvel. Essa modalidade, como já mencionado, ainda não tem sido objeto de estudos acadêmicos (o único encontrado foi o de Ramos e Cardoso, 2011), embora chame a atenção, ao menos no caso de São Carlos, sua significativa atuação em áreas urbanas já relativamente consolidadas, como é o caso do Cidade Aracy. 
99\% seguramente é. Então, tem um tipo de um projeto, é uma casa que você vê que foi pensada. E tem outro detalhe também, os acabamentos! Ali na rua de cima de casa, ali tem mais umas quatro casas desse modelo já, sabe, e você vê que é tudo acabadinho, portãozinho fechado, coisa mais linda. [Jimmy]

Nos últimos dez anos, mais ou menos, Aracy desenvolveu muito, estruturou. Mas mais a l, né, formou o centro, mesmo. Mas agora, de uns dois anos pra cá, a II também tá mudando bastante, tá se estruturando, de quando a gente morou ali, vixe! Quase não tinha casas, não tinha nenhum comércio, todos que tinham era na I. Agora, olha hoje, aqui onde a gente tá passando, já é uma rua mais de comércio, é o sinal da mudança do bairro. E também essas casinhas novas [mostra uma casa produzida no formato varejista do PMCMV], tá mudando bem a cara do bairro. Os imóveis tão mais caros, terrenos, casas, aluguéis... tudo valorizando também. [Jefferson]

Com mais investimentos na região, o desenvolvimento, antes concentrado no Cidade Aracy I, estaria se estendendo também aos bairros Cidade Aracy II e Antenor Garcia, de modo que esses três bairros, justamente os que se situam em contiguidade com os três novos conjuntos de "habitação de interesse social" vinculados ao PMCMV, parecem estar (ainda que com distinções entre si, decorrentes justamente de suas condições anteriores de produção e apropriação) em franco processo de transformação, num paradoxo em que se articulam a territorialização da pobreza nessa região da cidade e essa transformação do Cidade Aracy em uma 'centralidade periférica'.

O trecho a seguir expressa o claro processo de reconfiguração em curso nesse território, movimentado principalmente pela implementação da atual política habitacional, cujos efeitos territoriais ${ }^{12}$ demandam, ao menos discursivamente, um impulso estatal à tal consolidação dessa 'centralidade periférica', incluindo naquela "imaginação do futuro" o atendimento às necessidades básicas das milhares de famílias ali instaladas:

[O prefeito] Paulo Altomani finalizou a visita reforçando o compromisso com os moradores do grande Cidade Aracy. "Meu compromisso é deixar o Cidade Aracy tão bonito quanto os bairros mais centrais da cidade". Para isso, o prefeito citou algumas ações da prefeitura que estão projetadas para a região, como a construção de cerca de duas mil casas populares, a reforma da piscina e dos vestiários do Centro da Juventude, o projeto de construção de uma UPA [Unidade de Pronto Atendimento] avançada no bairro, com exames laboratoriais e 25 leitos para pré-estabilização, a construção de adutora do CDHU [conjunto habitacional] até o CEAT [distrito industrial], para que a água da região do [bairro] Vila Alpes ajude no abastecimento da região e de um reservatório, já licitado, com capacidade para 2.652 mil litros, além da duplicação da Avenida Morumbi, entre outros. "Estamos preparando o Cidade Aracy e região para o futuro. Num futuro breve todos que moram aqui não encontrarão mais 
dificuldades na Saúde, na Educação, no Saneamento Básico, enfim, todos terão orgulho desta região. São Carlos está no Caminho Certo", concluiu o prefeito. ${ }^{13}$

Embora tal discurso se alinhe com o movimento, aqui analisado, de consolidação do Cidade Aracy e de sua conformação em 'centralidade periférica', de forma a minimizar o impacto da nova frente de expansão urbana empreendida ali através do PMCMV, tal trecho é revelador do quanto, não obstante a melhoria de suas condições urbanísticas, estas estariam ainda muito longe das condições presentes nos "bairros mais centrais da cidade": mesmo desenvolvido, ali continua sendo o lugar dos pobres, o oposto (inclusive estético) ao centro, o 'outro' da cidade.

Fato é que o Cidade Aracy já vinha se mostrando, ao longo de minha pesquisa de campo, como uma espécie de 'centralidade simbólica' ao apresentar-se conectado, de alguma forma, a todas as trajetórias investigadas em profundidade e a diversas outras com as quais tomei contato em campo, nas quais o bairro (ou a região) aparece como articulador de "tranças de relações" existentes na cidade entre "geografias mais ou menos distantes", polarizando redes de interconhecimento que conectam diversos bairros populares da cidade ${ }^{14}$ e dando indícios importantes do quão estabelecido já estava, também entre as camadas populares, como o principal lugar de moradia dos pobres na cidade: "Aracy é um bairro de classe pobre mesmo" (Joana); "aqui sempre foi um bairro de pobre, de gente mais humilde, mas também tem classe média baixa" (Jimmy); "ali sempre foi o lugar onde os mais pobres, que nem eu era, sabiam que iam encontrar lugar pra morar" (Marielen).

Parecia haver, assim, uma dupla condição de centralidade: simbólica (como lugar de referência - e mesmo experiência - das camadas populares locais: a grande maioria já viveu ou tem algum conhecido vivendo ali) e físico-geográfica (em relação não apenas a toda uma territorialização da pobreza historicamente concentrada na Zona Sul, cujas fronteiras foram gradativamente se deslocando, sendo o Cidade Aracy, até o início de 2010, sua última margem, mas também a essa reafirmação e reconfiguração de tal territorialização promovida recentemente pelo PMCMV). Da convergência entre as duas decorreria ainda uma terceira, como território a concentrar genericamente todos os estigmas associados à pobreza, sendo representado socialmente como 'a periferia' da cidade: destaca-se, nesse sentido, um contraponto entre visibilidade (tanto pela escala da região conhecida como Grande Cidade Aracy - que é apreendida pelas camadas médias e altas da cidade como uma coisa só - quanto por ter sido, durante décadas, considerada "o maior

13 Cf. reportagem sobre a construção de uma Unidade de Saúde da Família no bairro Antenor Garcia, na qual o atual prefeito declara que tal unidade atenderá "pelo menos 12 mil pessoas do Antenor Garcia e bairros vizinhos": http://diariosaocarlos.com.br/site/index.php/cidade/10150-usf-comeca-aser-construida-no-antenor-garcia.html, consulta em junho/2014.

14 Cunha (2002:102). 
bolsão de pobreza"15 da cidade, ou ainda pelo processo de criminalização por que passou ao longo dos trinta anos desde a abertura do primeiro loteamento irregular até o espraiamento recente do tráfico de drogas) e invisibilidade (por ser um território absolutamente desconhecido - mesmo do ponto de vista dos estudos acadêmicos e das políticas públicas - em termos de sua heterogeneidade socioespacial, das problemáticas e das potencialidades ali concentradas).

A essas dimensões de polarizações simbólicas, físico-geográficas, sociais se articularia esta mais recente, cujas facetas políticas e econômicas se evidenciam sobremaneira: à medida que um novo vetor - a política habitacional em curso no país - passa a promover uma expansão urbana cuja estruturação se vincula e é dependente desse território periférico pré-existente e, supostamente, "consolidado" (e mesmo se pauta por sua existência e consolidação), potencializa-se a conformação dessa centralidade progressivamente conferida ao Cidade Aracy em múltiplos sentidos, talvez não stricto sensu, mas na perspectiva empírica de uma 'nova centralidade periférica'16 - um território que reúne hoje alguns atributos polarizadores dessa significativa parcela

15 NPD/UFSCar (1994); Laisner (1999); PMSC (2005).

16 A abordagem aqui esboçada se alinha, de alguma forma, à perspectiva de que a dinâmica das cidades se desenvolve sob modulações bem mais complexas do que a clássica dicotomia centro/periferia, a partir da qual se configura a concepção de múltiplas (e móveis) "centralidades" urbanas (Frugoli, 1999), ou ainda de "centralidades" tradicionais que, em decorrência dos usos e de sua apropriação pelas camadas populares, se tornam "periféricas" em relação a outras centralidades produzidas pelas e para as camadas de maior renda, como destacam Nakano, Campos e Rolnik (2005:127) para o caso do "centro histórico" de São Paulo: “Do ponto de vista funcional, impõe-se uma condição paradoxal às áreas abrangidas pela subprefeitura Sé e parte da Mooca: ser simultaneamente uma centralidade, relativamente às já referidas zonas norte e leste metropolitanas, e uma periferia, relativamente às centralidades e aos bairros de alto padrão do quadrante sudoeste." Entretanto, a expressão 'centralidade periférica' aqui é adotada em outro sentido. No caso em tela uma periferia extrema que adquire centralidade frente a uma determinada região da cidade em um contexto de reconfigurações socioespaciais e político-econômicas - não se trata, evidentemente, de uma "nova centralidade" produzida em decorrência da saturação do que seria o centro principal (ou histórico) da cidade frente às necessidades de reprodução e acumulação do capital. Essa concepção empírica aponta para "novas centralidades" (também chamadas de "subcentros" por alguns autores) que nada têm a ver com aquelas identificadas como tal a partir da migração da sede de grandes empresas ou bancos, hotéis e shoppings centers. Mas que, como destaca Rizek $(2014: 7,8)$ remetendo a achados da presente pesquisa, apesar das dificuldades de nomeação (que revelam a própria dificuldade em identificar o que se quer nomear), são "centralidades indiscutíveis", não apenas da perspectiva da lógica do consumo, mas também das redes e formas de sociabilidade e de lazer: "Centros populares de comércio, comércio de rua, os botecos, centros de cultura e, por vezes alguns equipamentos públicos como os CEUs conformam essas outras 'centralidades' ou subcentros, cujo caráter não se assemelha aos centros financeiros. Essas dimensões da morfologia urbana e de suas formas de apropriação permitem mapear as cidades para além de algumas categorias que parecem nublar mais do que evidenciar as formas de leitura do espaço urbano e de suas formas de apropriação e expropriação." De todo modo, é possível apreender também de definições mais clássicas, tais como a proposta por Sposito (2004:120), os elementos que, por mais que incompletos ou frágeis, foram progressivamente conferindo, especialmente ao Cidade Aracy I, perante seus moradores e os dos demais bairros da região, essa dimensão de centralidade agora acentuada: "O centro constitui-se por meio de um processo de concentração de atividades de comercialização de bens e serviços, de gestão pública e privada, de lazer e de valores materiais e simbólicos em uma área da cidade." 
das camadas populares da cidade que ali vive, por meio de comércio, serviços, consumo, lazer e trabalho (ainda que com todas as restrições e insuficiências já anteriormente mencionadas nos relatos de meus interlocutores), mas, sobretudo, lugar inegável de encontro e relações sociais.

Não se trata, aqui, de apontar este como um fenômeno consolidado ou definitivo, mas de detectar essa movimentação recente, em termos de produção e apropriação do espaço urbano que o cruzamento das diversas trajetórias e o acúmulo da pesquisa de campo permitiram apreender, ao evidenciar a configuração deste território como potencial centralidade sob diferentes enfoques. Se, por um lado, a implantação desses conjuntos habitacionais no âmbito do PMCMV amplifica a territorialização da pobreza nessa região da cidade, por outro instaura novas dinâmicas socioespaciais internas em que a reconfiguração pela qual parece passar o Cidade Aracy pode ser lida sob vários matizes. O paradoxo anteriormente mencionado é apenas aparente: a conformação dessa 'centralidade periférica', nesse contexto, não apenas fornece as bases para esse processo que acentua a territorialização da pobreza na região (agora promovida oficialmente sob os auspícios do PMCMV), como também evidencia a consolidação da diferença social inerente à consolidação desse território periférico.

Nesse sentido, caberia indagar pelos efeitos desse processo, em pleno ato, de transformação de toda uma região, a partir dessa conjunção entre acirramento da territorialização da pobreza e emergência dessa 'nova centralidade periférica'. Mesmo que este não tenha sido aspecto específico sobre o qual a tese se debruçou, foi inevitável apreender o quanto tais efeitos não são unívocos como a literatura sobre periferias pode fazer parecer, apontando quase sempre apenas para os processos de substituição dos antigos moradores, de contínua expulsão dos mais pobres que decorreriam dos processos de consolidação desses espaços ${ }^{17}$.

Está, pois, em curso uma série de reconfigurações nas dinâmicas socioespaciais locais, dentre as quais as trajetórias possibilitaram entrever pelo menos três movimentos coexistentes, atestando a complexidade dessa produção do urbano captada em ato. Nesse contexto, embora não sejam a única resultante desse processo, são evidentes os deslocamentos internos e externos promovidos pelo aumento do custo de vida que o reposicionamento do bairro Cidade Aracy na região vem promovendo, sobretudo aqueles vinculados ao mercado imobiliário local. $A$ presença de investimentos vinculados ao PMCMV não apenas no seu entorno, mas dentro dos próprios limites do bairro, seria o motor mais recente dessa valorização

17 Bonduki e Rolnik (1979); Mautner (1999); Barbon (2004). 
associada ao desenvolvimento dos bairros Cidade Aracy I e II, da qual a chegada das imobiliárias e o progressivo aumento nos preços de terrenos, casas e aluguéis ${ }^{18}$ seriam o principal impacto sentido pelos moradores:

Júlia: Aqui no Aracy, antes, os terrenos eram mais baratos, que tinha rua que às vezes não tava nem asfaltada, ou tipo, por causa de ser anos atrás né? No caso, assim, periferia, o povo acha que pode ser que seja mais barato, mas alguns lugares, sabe, a partir do momento que começa a crescer muito, aquele lugar já começa a não ser tão mais barato, já começa a subir o preço de tudo, né? No Aracy, antigamente, era mais barato os terrenos, casas, algumas coisas, mas hoje não é mais, não. / Jimmy: Sim, hoje tem uma supervalorização aqui. Até pouco tempo atrás nenhuma imobiliária, ninguém queria investir em casas de aluguéis ou vendas de casas aqui. Aracy I, II e Antenor Garcia. Isso já fazia décadas que tinha o bairro. Então, por isso que os aluguéis aqui eram baratos, porque era direto com o proprietário, e por ter essa visão negativa do bairro, esse preconceito, ninguém alugava casa aqui muito caro, os proprietários se adaptaram à essa realidade. Depois, mais pro fim dos anos 2000, que começaram a aparecer casas de aluguel por imobiliárias... mas, mesmo hoje, ainda é pouco, comparado com os de boca. Aí que vai chegar essa parte do Minha Casa Minha Vida, porque daí começou as pequenas imobiliárias, que não é tão fodona como aquelas mais conhecidas, mais antigas. Aí as outras já vieram atrás, e isso fez o aluguel e o preço dos terrenos das casas subir, subiu numa margem de ter época das pessoas dizerem: 'imagina que eu vou pagar tanto num terreno no Cidade Aracy', porque continuava a mesma linha de complexo sobre o bairro, como se aqui não pudesse valorizar. Aí apareceu o Minha Casa Minha Vida, e os terrenos começaram a ser todos comprados. Essa rua aqui, pra você ter uma ideia, não tinha tudo isso de casa, não tinha essas daqui, essas duas ó, essas duas da frente e essas duas aqui embaixo, elas foram construídas faz pouco tempo, não tinha aquelas lá bem no comecinho quando eu vim aqui, quando essa casa não tinha nem cobertura ainda. Lá atrás, não tinha; aqui em cima, não tinha! A rua era cheia de terreno vazio, sabe? Aí teve um boom a mais, porque aí

18 Vale apontar algumas referências dessa reconfiguração no mercado imobiliário local: o aluguel de uma pequena edícula de quatro cômodos, que em 2012 custava $\mathrm{R} \$ 350,00$, um ano depois já valeria $\mathrm{R} \$ 500,00$, valor superior à prestação estimada do financiamento a ser contraído por Jimmy. O pai de Jefferson vendeu um meio-terreno há cerca de quatro anos por $\mathrm{R} \$$ 8.000,00; em 2008 era possível encontrar terrenos a $\mathrm{R} \$ 5.000,00$, os quais, atualmente, estão valendo em torno de $\mathrm{R} \$ 25.000,00 \mathrm{ou}$ $\mathrm{R} \$ 30.000,00$. Já se tornou corrente no bairro a referência a esse novo mercado imobiliário que atinge também as casas prontas, referidas como "casas com padrão Caixa", que vêm sendo postas à venda a preços exorbitantes se comparados com os valores praticados há cerca de dois anos (tive notícias de casas vendidas a $R \$ 100.000,00$ no bairro e fui apresentada a duas casas à venda, respectivamente a $\mathrm{R} \$ 120.00,00$ e $\mathrm{R} \$ 170.000,00)$. Assustada com os valores, alguns moradores me esclareceram: "É que, aqui, as casas são construídas tudo de qualquer jeito. Essas não. Se você esticar a conversa, é capaz do proprietário mesmo já falar: 'minha casa tem padrão CAIXA, e o fiscal aceita'”, apontando para essa nova dinâmica em curso no bairro. Destacam-se, nesse sentido, muitas placas de "vende-se", inclusive no bairro Antenor Garcia. Outro dado de campo é o fato de que, até bem recentemente, haveria uma certa homogeneidade nos valores dos aluguéis informais, de acordo com certos padrões de moradia; já no fim da pesquisa, a discrepância entre valores passou a chamar a atenção, além de uma cada vez maior diferenciação entre os aluguéis praticados no Cidade Aracy II em relação aos praticados no Antenor Garcia e no Jardim Zavaglia. Alguns moradores chegaram inclusive a dizer que o aumento dos aluguéis no bairro teria o sentido mesmo de diferenciar-se desses dois bairros, para onde iriam as pessoas com menos condições. 
entra construtor, imobiliária, com corretor, não sei o que tem, aí explodiu de vez mesmo, aí o valor subiu mais um pouco, né? [Jimmy e Júlia]

Desse modo, tal valorização simultaneamente amplifica as diferenciações socioespaciais internas pré-existentes e configura novas linhas de clivagem dos mais pobres, de modo que, por exemplo, um antigo morador que possua mais de uma casa possa tirar proveito financeiro da situação, enquanto outro, que mora em um barraco situado em um terreno que se valoriza, opte por vendê-lo e mudar-se para as bordas dessa "periferia consolidada", como o bairro Antenor Garcia, ou o novo Jardim Zavaglia, ou mesmo voltar para sua terra natal; ou, ainda, que famílias que vivem de aluguel passem a se deslocar internamente para casas menores ou em piores condições, ou mesmo para casas nestes bairros mais à margem da região, em função da alta dos valores nos bairros Cidade Aracy I e II.

Tais deslocamentos conectam-se, ainda, com a discussão proposta no Entremeio I, uma vez que, a despeito dessa construção inédita de moradias destinadas às camadas populares na cidade através do PMCMV, aquelas dinâmicas imbricadas entre política habitacional e (re)produção de um mercado informal realimentam um ciclo que não se encerra jamais, continuamente produzindo novas demandas, sem que seja possível atender àquelas pré-existentes: haja vista a recente ocupação, por cerca de duzentas famílias, de uma área pública justamente no bairro Antenor Garcia (após pelo menos uma década sem notícias de ocupações na cidade), cujo encaminhamento, anunciado pela PROHAB após a conflituosa reintegração de posse do local, foi a viabilização de aluguel social até que as famílias sejam alocadas em um dos dois novos conjuntos do PMCMV em obras ${ }^{19}$.

Em sentido inverso, observa-se ainda que tal estruturação do bairro, bem como as novas oportunidades de acesso à moradia ali consolidadas através do PMCMV, permite também nova perspectiva de fixação das pessoas no próprio Cidade Aracy como foi o caso de Jimmy, por exemplo -, destacando-se o fato de que, em muitos casos, as parcelas a serem pagas no financiamento da moradia são equivalentes (ou até menores) que os valores de aluguel de uma casa similar no bairro. Assim como Jimmy, a atual conjuntura parece favorecer também outros moradores antigos do bairro que vivem de aluguel, moram de favor ou naquela mencionada lógica dos "quintais" e desejam permanecer no local, justamente em função de, após tanta

19 Cf. notícias em site da prefeitura, jornais locais e página da ocupação no Facebook: www.saocarlos.sp.gov.br/index.php/noticias-2014/166587-prefeitura-libera-aluguel-social-parafamilias-do-bairro-antenor-garcia.html; www.revelandosaocarlos.com.br/noticias/reintegracao-dearea-sem-apoio-da-prefeitura-revolta-sem-teto-antenor-garcia;

www.facebook.com/pages/Ocupacao-Luis-e-Rosa-Sundermann (consultas em julho de 2014). 
"luta", poder usufruir dos benefícios do desenvolvimento do bairro, de morar nessa 'centralidade periférica':

Aqui eu sei que eu tenho uma acessibilidade confortável pra minha família, aqui tem tudo, eles não precisam andar de um bairro pro outro pra fazer qualquer coisa, ir na escola, fazer uma compra... Agora, no Zavaglia e no Novo Mundo, é um absurdo! Que nem no caso do Parque Novo Mundo mesmo, que num tem comércio no bairro, eles têm que atravessar a pista e vir aqui, ou em outro bairro mais distante... Quem tem carro... mas, e quem não tem? Então eu achei isso muito foda, muito foda. Afasta o povo de tudo e dane-se, saca? Só que, porque nesses bairros de periferia a pessoa tem que sair da casa dela e andar 3 ou $4 \mathrm{~km}$ até um mercado? É mais um motivo pra eu gostar tanto do Aracy. Porque aqui, você sai da minha casa, nessa esquina já tem um mercado. Desceu aqui tem outro mercado, ali tem outro sacolão, tem uma padaria, tem opções a milhão. Já o Zavaglia, não, cê tem que sair, o mercado é aqui (mostra um mapa imaginário), cê tem que sair, por exemplo, cê mora aqui em cima. O bairro é enorme, tem casa até lá em cima, cê tem que andar tudo isso aqui pra chegar no mercado. Eu acho incrivel! E no Parque Novo Mundo nem isso tem. Eles têm que atravessar a pista pra vir aqui no Aracy. É um absurdo. Por isso que eu prefiro aqui, já tem uma acessibilidade mais fácil pra minha família, pra tudo que a gente quiser fazer. [Jimmy].

Observa-se, em contraponto àquele movimento de expulsão, justamente um movimento de fixação de uma parcela dos moradores no próprio bairro, assim como uma reafirmação daqueles moradores mais antigos - que se consideram os grandes responsáveis pelo desenvolvimento do bairro - em termos de sua permanência no local, justamente em função de sua consolidação: "agora que tá ficando bom, eu vou sair daqui? Eu não. Meu vizinho mudou daqui pro Novo Mundo, ele é doido, aquele lugar não tem nada!" (Jorge, morador do Cidade Aracy I). O usufruto das melhorias conquistadas no bairro em termos de comércio, serviços e mesmo oportunidades de trabalho, o desejo de ali permanecer são alvos de representações distintas por parte de seus moradores: enquanto uma parcela opta deliberadamente por essa permanência, enaltecendo as condições alcançadas pelo bairro e positivando o presente (e o futuro) ali, diversos moradores (como visto para o caso de Jefferson e Beatriz) apreendem tal fixação no bairro como falta de visão, já que este seria justamente o momento (dadas as inéditas condições de financiamento habitacional para as camadas populares no país) de aproveitar a oportunidade para fugir dali, para romper com o isolamento que viver no Cidade Aracy representaria.

Jefferson: Tem bastante gente ali que vive e trabalha ali mesmo, tipo meu irmão: meu irmão, ele tá trabalhando num mercado lá, então... ganha pouco, tudo, mas, tipo, ele vive ali, entendeu? E tem muita gente ali, que trabalha ali, as pessoas são autônomas ali. Pessoas que vivem do produto interno bruto [risos]. O PIB [risos]. / Beatriz: Vai pro centro uma vez por mês, e olhe lá. / Jefferson: É. Vai pagar conta quando tem que ir mesmo, entendeu? É. Quer dizer, tudo tem ali, é um bairro bem estruturado. Então... Existe pessoas que não sai de lá. / Beatriz: Sua irmã é uma. / Jefferson: É. Tem pessoas que não sai de lá, praticamente, pra nada. / Thaís: Mas não sai porque não quer, ou não sai porque não dá? / Jefferson: Porque se acostumou com o cotidiano.... / Beatriz: Porque não precisa. Acha que o mundinho deles é tão bom ali, que não precisa. / Jefferson: Entendeu? 
Quer comprar uma roupa nova, tem a principal lá que tem uma loja, que ela comprando lá, vai... né? Daí vira aquele ciclo, comprou lá, gastou lá, o cara ali ganhou dinheiro, pagou o funcionário, que também é do Aracy, que... movimenta ali mesmo. (...) Então as pessoas ficam muito presas na comunidade ali. / Thaís: E o que vocês acham disso? / Beatriz: É terrível. As crianças só conhecem o Aracy; sair do Aracy, pra eles, é viagem... / Jefferson: Ah, impede de você conhecer outras coisas, né? Então... é bom... ah, é bom e é ruim (risos). Tem os dois lados. [Jefferson e Beatriz]

Faz-se muito presente, entre moradores que optaram por deixar o bairro ou planejam fazê-lo, bem como entre moradores de outros bairros cujos familiares vivem no Cidade Aracy, essa visão de isolamento das pessoas no bairro, de que ali todos estariam restritos por demais ao mundinho da comunidade, em representações que atribuem a essa permanência no bairro dimensões simultaneamente de escolha e acomodação desses antigos moradores. Veja-se o que diz Marielen sobre sua madrasta e as irmãs, que vivem no Cidade Aracy:

Elas só vivem lá; se deixar, não saem de lá pra nada, tão muito acomodadas ali. Assim, elas até saem um pouco dali pra passear, mas pra fazer compra, fazer as coisas do dia a dia é tudo ali. Comer uma pizza, tomar um sorvete... Elas não trocam lá por outro lugar nenhum, pergunta do bairro pra elas que você vai ver, só vão elogiar. Elas não trocam o mundinho delas lá por nada. [Marielen]

Se, por um lado, a permanência desses moradores no bairro e a pouca circulação para além dele podem ser lidas na chave do apreço à comunidade, do costume, da valorização do desenvolvimento local, é inevitável apreender, como o outro lado da moeda dessa centralidade que vem sendo adquirida pelo Cidade Aracy, um cada vez maior confinamento territorial da experiência urbana ${ }^{20}$ de ao menos uma parcela

20 Embora possa se observar, nesse processo, a localidade como "instrumento de contenção socioespacial de uma categoria estigmatizada" (Wacquant, 2007:1), a própria observação dos vários movimentos simultâneos em curso (associada a uma relativa heterogeneidade socioeconômica e à não estanqueidade de suas fronteiras físicas e simbólicas) refuta a associação entre essa perspectiva de territorialização da pobreza, de confinamento territorial da experiência urbana de uma parcela dessas camadas populares àquela concepção de "gueto" (Wacquant, 2007), ou mesmo de "bolsão de pobreza" (NPD/UFSCar, 1994). Rizek (2012:1-4), recobrando distinções presentes nas reflexões de Walter Benjamin sobre "limites e limiares", aponta para a transformação contemporânea do limiar de "zona de transição" a "zona de detenção", em reflexão que parece iluminar alguns aspectos desse contraponto entre centralidade e confinamento observado no processo de consolidação do Cidade Aracy. Zonas menos definidas que as fronteiras, os limiares remeteriam a fluxos e contrafluxos, lugares e tempos indeterminados e de extensão indefinida, um "entre", uma "zona de transição". Entretanto, da positividade de um futuro em aberto, viveríamos, contemporaneamente, o achatamento dos limiares, transformados em "zonas de detenção": as prisões cotidianas da mercantilização, da gestão, da homogeneização e, sobretudo, da crença continuada em um "projeto de melhoria contínua de vida" sob o qual se escamoteiam incertezas e inseguranças cada vez mais agudizadas. "As grandes questões - as questões sobre as passagens - ficam ali presas ao se transformarem em problemas administrativos, em problemas de gestão em que não há mais escolha, mas acomodação, gestão sobre vivos e mortos, sobre corpos que vagueiam em limiares indefinidos e inchados, quase figurações do humano. Esses limiares correspondem a uma região sem nome, à norma secreta, o nomos, da biopolítica. São espaços dilatados, zonas cinzentas, lugares de indeterminação, objetos de indiferença generalizada." 
deles, como o caso de Núbia permite iluminar: trata-se de um cotidiano cada vez mais limitado ao bairro, com raros deslocamentos para outras partes da cidade que não sejam a trabalho, o que se atribui não apenas ao fato de que "o bairro hoje tem tudo $e$ "as pessoas não querem sair dali por nada", mas, sobretudo, às dificuldades de mobilidade vivenciadas por uma significativa parcela dos moradores, cuja relação com o restante da cidade está mediada pela dependência do transporte público - e sua precariedade, sua insuficiência e os custos daí decorrentes ${ }^{21}$ - diferenciando ainda mais a pobreza entre os que têm ou não acesso ao carro.

Eu mais me viro por aqui mesmo, aqui tem tudo que eu preciso. Pra mim ir pro centro... a não ser, assim, que eu vá pra comprar alguma coisa bem específica. Ou, às vezes, quando saio do trabalho, paro pra fazer alguma coisa, mas é difícil. Meu dia a dia é bem por aqui mesmo, só saio pra trabalhar. Eu quase não saio de casa. Às vezes, quando eu saio daqui de dentro eu vô na vizinha ali da frente e fico conversando, fico aqui na frente, ou faço minhas coisas por aqui mesmo. (...) No orfanato era, assim, mais fácil deslocar, não dependia tanto de condução. Porque eu gosto bem de andar a pé, sabe? Por exemplo, se eu tivesse que ir no centro, se eu tivesse que comprar alguma coisa, eu podia ir a pé, fazia uma caminhada de quinze, vinte minutos e estava no centro, resolvia o que queria resolver, entendeu? Agora aqui já torna-se um pouco mais difícil, porque tudo o que a gente vai fazer depende do ônibus, não tem opção. Principalmente as coisas que depende de fazer lá pra cima, tem que ir de ônibus. (...) E além da dificuldade, da lotação, dos horários, acaba saindo caro, principalmente pra quem tá desempregado, procurando emprego, fica difícil bancar uma condução todo dia. Então já foi mais difícil. Mas agora, que o bairro melhorou, estruturou, já tem como fazer tudo aqui mesmo. [Núbia]

E, a esse outro paradoxo (também apenas aparente) - o fato de que a estruturação do Cidade Aracy, sua transformação em 'centralidade periférica', acentuaria ainda mais o confinamento das pessoas ao bairro - contrapõe-se o terceiro movimento observado, referente aos moradores que estão deixando o bairro por opção própria, buscando simultaneamente fugir do estigma que segue associado à região como um todo, a despeito de seu desenvolvimento, e buscar alguma mobilidade socioespacial ascendente, como visto no Capítulo 2 para o caso de Jefferson e Beatriz.

21 Essa questão do transporte público esteve presente desde meus primeiros dias em campo, na qual meus interlocutores fizeram questão de enfatizar a desconexão do Cidade Aracy e do Antenor Garcia do restante da cidade. Tive contato, através de Jimmy e Núbia, com famílias tidas por eles como mais carentes, que se organizam para ir apenas uma vez por mês ao centro da cidade, por não terem condições de gastar $\mathrm{R} \$ 5,50$ para ir cotidianamente para a cidade. O próprio Jimmy, muitas vezes, se desloca a pé, e seus irmãos priorizam o deslocamento por bicicleta, apesar da longa distância e das íngremes subidas que caracterizam as duas únicas conexões da região com o restante da cidade. A dimensão da mobilidade tem sido explorada por muitos estudos como um dos aspectos cruciais nos processos recentes de reconfiguração da pobreza e seus espaços na cidade, seja enfatizando a associação entre pobreza e ausência de mobilidade (Prevot-Chapira, 2001), seja enfocando a questão das possibilidades ou impossibilidades de circular efetivamente pela cidade, não apenas do ponto de vista físico ou do acesso a meios de transporte coletivos ou individuais, mas sobretudo simbólico, em termos de constrangimentos sociais (Leite e Machado da Silva, 2013). 
Tem bastante gente do Aracy que o sonho era comprar casa em outro lugar que não fosse ali, meio que sair daquela realidade. Porque as pessoas pensavam 'não, pra mim fugir disso aqui, é comprar casa em outro lugar', eu acho que comprando a casa... Fugir da realidade humilde, né, tipo ônibus lotado, fila no postinho... e do mundo do crime, né? E que agora tão conseguindo. [Jefferson]

Essa ideia, que acabou sendo a que vigorou no projeto dessa família, de que a mudança de casa, de bairro, configuraria uma espécie de fuga, de 'conversão', de imediata mudança de status social, já foi apresentada anteriormente, não sendo necessário retomá-la aqui. Importa, contudo, destacá-la como motor desse terceiro movimento identificado como efeito das transformações em curso naquele território ${ }^{22}$, sendo o caso de Jefferson e Beatriz apenas um entre muitos semelhantes observados em campo. Importa, ainda, apreender que, não apenas para o restante da cidade, mas também para uma parcela dos próprios moradores da região, o desenvolvimento do Cidade Aracy, seu processo de transformação numa "periferia consolidada" e a relativa diferenciação social ali instaurada, seu potencial como 'centralidade periférica' e os progressivos investimentos públicos e privados na região não são suficientes para que deixe de ser percebida como lugar de moradia dos pobres, periferia ${ }^{23}$ e, sobretudo, para que deixe de pairar sobre o território os estigmas decorrentes dessa representação social; ao contrário, a implantação dos três conjuntos habitacionais via PMCMV na região, ao reafirmar a territorialização da pobreza ali historicamente promovida, reforça ainda mais as figurações sociais estigmatizantes que pesam sobre a região, como retomarei no Entremeio III.

E, aqui, aquela "imaginação do futuro" e a complexidade dos processos efetivamente em curso se encontram, não sem conflitos. Essa breve apreensão da reconfiguração pela qual passa o bairro Cidade Aracy - de "fronteira urbana" a "periferia consolidada", em direção a tornar-se uma 'nova centralidade periférica' - importa no sentido de atestar o quão complexo e dinâmico é tal fenômeno, dando indícios, a um só tempo, de sua especificidade local e de sua conexão com processos em curso em

22 Certamente há outros, ainda, como a constante chegada de novos moradores ao bairro, agora ainda mais acentuada em razão dessas novas oportunidades de financiamento de moradia pelo Programa, e à região, em função da enorme quantidade de moradias produzidas nos conjuntos e do intenso "mercado imobiliário informal" que, a exemplo do que já ocorre no Jardim Zavaglia, possivelmente se reproduzirá nos demais conjuntos, apenas para citar alguns exemplos.

23 Saraiva (2008:137), ao estudar o caso de Itaquera - SP, chegará a conclusão semelhante a respeito dessa que seria uma "periferia consolidada": "Assim, e considerando os efeitos recíprocos do espaço social e do espaço físico, percebemos porque a periferia, embora com razoáveis condições urbanísticas e mercado de bens e serviços, não deixa de ser percebida como periferia, ou seja, de maneira condicionada à posição social ocupada por seus moradores nas hierarquias sociais que organizam a vida urbana." 
todo o país, no rastro da impressionante reconfiguração urbana em escala nacional que vem sendo promovida pelo $\mathrm{PMCMV}^{24}$.

Não se trata de aprofundar, além do já exposto, a discussão especificamente sobre os efeitos territoriais do PMCMV ou o quanto acentuam ou não os já históricos processos de periferização das cidades, mas de destacar como as trajetórias urbanas investigadas e seus pontos atuais de condensação possibilitam uma reflexão ampliada sobre essas dinâmicas de produção de urbanidade ${ }^{25}$ em curso atualmente no país, sobre a tênue fronteira entre precariedade e estabilidade, sobre o lugar do tempo na construção do urbano ${ }^{26}$ e das representações sobre ele. Ou, nas palavras de Rizek (2014:7,8):

Assim, recriando no "fim do mundo" a cidade naquilo que ela tem de mais indispensável à satisfação das necessidades cotidianas e de suas urgências, talvez possamos encontrar pontos e lugares em que se recria um mundo comum, para além dos transportes, das compras e das igrejas evangélicas. Centros ou centralidades onde se vislumbra o lugar do encontro e das relações, essa esfera também poderia ser pensada para além da materialidade que permite identificar o que afinal se conforma como possibilidade de um mundo comum.

24 Para análises sobre tais efeitos do Programa em escala nacional, ver Cardoso (2013). Para análises mais específicas sobre tais transformações no interior do estado de São Paulo, ver Araujo (2013) e Cunha (2014).

25 Agier (2011).

26 Rui (2012:236). 


\section{PARA ALÉM DA MORADIA E DA POBREZA: vulnerabilidades territorializadas}

Em vista do que eu já passei, eu hoje sou bem de vida. | Marielen

\section{- Deslocamentos habitacionais: moradia e gênero, segundo ato}

Com 38 anos completos em 2013, Marielen costumava contabilizar, a cada aniversário, também o tempo de moradia em São Carlos: nesse ano, fazia já 27 anos que ela viera, ainda criança, do interior de Pernambuco com o pai, a avó e três meiosirmãos (duas meninas e um menino) atrás da madrasta, que migrara primeiro, com outros parentes, para tentar conseguir casa e trabalho. Esta havia conseguido um emprego em uma fábrica, mas, quando o pai e os demais chegaram na cidade, descobriram que não tinham propriamente uma casa para morar.

Quando chegou aqui, foi um susto. Porque lá, pelo menos, a gente tinha casa, tudo. Meu pai não queria vir: ele tinha uns boizinhos, tipo uma terrinha lá. Quando nós chegamos aqui, a madrasta não quis falar pro meu pai que não tinha arranjado casa. E a gente teve que morar numa casa abandonada, que não tinha portas, nem nada. / Thaís: Ela já tava morando lá? / Ela tava morando com a colega dela... e ela arrumou essa casa abandonada pra gente ficar. Porque se ela falasse pro meu pai que não tinha arrumado casa, ele não viria. E ela não podia colocar quatro criança, um marido e uma sogra junto com a colega dela, que também veio do Pernambuco. A colega dela já tinha várias criança. Então... eles brigaram, meu pai queria voltar na mesma hora. Vai morar numa casa abandonada na Cidade Aracy? Uma casa abandonada na Cidade Aracy, no meio do mato! / Thaís: E não tinha móvel, não tinha nada? / Nada. Não tinha nem banheiro... a casa era só terra. Não tinha piso nem nada, era só parede, telhado e terra. [Marielen]

Sem condições financeiras para voltar para Pernambuco, o pai, resignado, construiu um fogão a lenha e um banheiro improvisado no local, onde morariam por alguns meses. Uma colega de trabalho da madrasta, tomando conhecimento da situação da família, cedeu a eles um pedaço do quintal de sua casa no Jardim Morumbi para a família construir um barraco (em troca de um auxílio com os custos de água e luz), onde pudessem ficar até que conseguissem se estabilizar na nova cidade. 
Embora a condição de moradia não fosse muito melhor, ao menos tinham água e luz, e a localização facilitava os deslocamentos do pai em busca de emprego. Não tardaria para que também ele conseguisse um serviço em fábrica, o que lhe permitiria alugar uma edícula para a família no bairro Vila Prado. Pouco tempo depois, um parente da madrasta ofereceria a eles uma casa com um aluguel mais barato, nos fundos da sua, no bairro Cruzeiro do Sul: "eram tudo umas casinha pequenininha, tudo dois cômodos, todo mundo junto, sempre no fundo de outras casas com muitas crianças"1.

A vida de aluguel duraria cerca de três anos: em 1989, o pai comprou de um colega de fábrica um meio-terreno no próprio Cidade Aracy ("no Aracy I. Não existia Aracy II, Antenor Garcia, nada. Eles só conseguiram comprar porque, naquela época, era bem baratinho"), construiu um barraco de tábua no fundo do terreno para a família morar e iniciou a gradativa autoconstrução de uma casa de tijolo na frente. Às memórias de um "bairro sem nada, no meio do mato, com poucas casas", onde "nem ônibus circulava, porque era só areia lá embaixo" e das dificuldades materiais enfrentadas $^{2}$ (a vida no barraco, a ausência de infraestrutura urbana básica, os grandes deslocamentos a pé para buscar água ou ir e voltar da escola), somam-se as lembranças desse período inicial no Cidade Aracy, que Marielen considera boas: o pai e a madrasta empregados, investindo na construção da casa; ela e os irmãos começando a estudar; ela conseguindo seu primeiro trabalho na cidade, como empregada doméstica de sua professora: "aí a vida começou a melhorar um pouco".

Enquanto construíam a casa, também o bairro Cidade Aracy se construía, como visto nos capítulos anteriores. Nos anos 1990, na esteira do adensamento da ocupação do loteamento promovido pelo proprietário através da já mencionada doação de meioslotes, a mesma estratégia seria adotada para a ocupação de seus entornos, de forma ainda mais radical: os moradores do Cidade Aracy seriam 'convocados' por Airton Garcia $^{3}$ para auxiliar no desbravamento dessas terras, em troca também de meioslotes nos loteamentos que aí se configurariam. A já mencionada experiência comum do "fazer a cidade" é aqui literal: às vicissitudes da ausência de urbanidade vividas pelos moradores em seu próprio bairro se somaria o trabalho braçal na abertura de

1 Cabe ressaltar, mais uma vez, que os deslocamentos habitacionais que pautam as trajetórias, em grande medida (e sobretudo a partir dos anos 1990) se dão sempre pelos mesmos bairros, sempre na Zona Sul da cidade. Note-se que Marielen se refere a esses deslocamentos como "migrações": "Da cidade Aracy nós migramos pro Morumbi"; "Só que nisso, já migramos pra um bairro que chama Vila Prado"; "Aí, depois, fomos morar no fundinho da casa de uma moça, migramos pro Cruzeiro do Sul". Chama a atenção, ainda, o quanto esses deslocamentos realizados nessa fase, com o pai, a madrasta e os irmãos, se aproximam daqueles que compõem a trajetória de Núbia - os tipos de casas, sua localização, as redes de relações como forma de acesso à moradia.

2 "A gente era muito pobre", Marielen me diria diversas vezes sobre as condições de vida da família nessa época, numa clara dissociação de sua condição atual. "Tendo em vista tudo o que eu passei, até fome, quando chegamos aqui, eu hoje sou muito rica".

3 Já referido político e proprietário de terras locais (ver nota 27 - Cap 2). 
novos bairros, nos quais novos moradores enfrentariam as mesmas condições. Mas, além da visão positiva de que, com isso, a região seria mais ocupada e tenderia a se desenvolver mais rápido, havia o forte apelo da consecução de terrenos, que poderiam abrigar mais familiares ou, ainda, configurar um investimento futuro.

pai de Marielen seria um dos muitos que veriam benefício nessa 'troca' com o proprietário das terras, acrescendo ao turno duplo entre o trabalho na indústria e a autoconstrução da casa própria um terceiro, desmatando o grande terreno vizinho ao bairro. Por sua dedicação e pelo envolvimento de toda a família na empreitada, o pai conseguiria dois meios-lotes no que viria a ser denominado Jardim Social Presidente Collor.

Thaís: Você falou que cês já moravam no Aracy, e aí seu pai foi carpir lá, pra abrir o outro bairro... Me conta um pouquinho desse processo, como foi.../ Então, aí, - Airton Garcia ia derrubar as mata lá da Cidade Aracy, e quem fosse lá ajudar derrubar as mata ia ganhar um terreno. Pra fazer o Collor de Melo. E daí foi todo mundo. Uma turma desceu tudo, com facão... / Thaís: Você lembra que ano mais ou menos? / Começo dos anos 90. / Thaís: Depois que cês já tinham a casa? / Isso. Assim, a gente tava no barraco ainda, mas a casa já tava construindo na frente. Aí, meu pai conseguiu dois terrenos. Tudo lá no Collor de Melo. Porque quem fosse derrubar as mata lá, iria ganhar um terreno. Era muito fácil. Daí meu pai construiu a casinha pra vó e construiu outra dele, também no Collor de Melo. / Thaís: Ele construiu outra casa no Collor de Melo? / Construiu, no mesmo esquema, de fim de semana, a gente que ia com ele ajudar. Então, ele construiu a casinha e alugou. Construiu as três casinha, quase ao mesmo tempo. [Marielen]

Como as condições estabelecidas pelo loteador para que a doação dos lotes se efetivasse eram as mesmas já implementadas pouco antes no Cidade Aracy, logo após a abertura do novo loteamento, o pai de Marielen deslocou os investimentos (tanto materiais, quanto a própria mão de obra familiar) em sua própria casa, ainda em obras, para construir rapidamente uma casinha em cada terreno ${ }^{4}$, de forma a garantir sua posse: uma para a mãe dele, e outra para alugar 5 .

Nesse contexto, seriam quase três anos morando no barraco até a família se mudar para a casa construída pelo pai, ainda inacabada, em função do exaurimento do

4 Ao falar dessas casinhas, pela primeira vez Marielen utilizaria a expressão "tipo um barraco", que depois ela usaria para descrever outras casas por onde passou. Ao me interessar pela distinção aí operada, ela me esclareceu: "A casa de vovó tinha só os tijolo e a Brasilit, só isso. Não era uma casa". Em outra ocasião, falando sobre outra casa, ela detalharia ainda mais a distinção: "Era tipo um barraco, de tijolo, mas um cômodo só, coberto com Brasilit e não tinha saneamento básico". Nesse contexto, ela esclareceria que também a casa construída pelo pai para a família teria esse padrão e que somente teria se transformado numa casa mesmo em um árduo processo levado à cabo pela madrasta, ao longo de muitos anos, após a morte do pai. Interessa notar, nesse sentido, que há todo um léxico (migração entre bairros, casas tipo barraco, favela versus bairro planejado...) que, por assunção ou negação, conforma e é conformado pela experiência urbana dos deslocamentos em busca de moradia.

5 Chama a atenção, aqui, a presença do mercado informal de aluguel já nesse momento, quando o bairro mal iniciara seu desenvolvimento, apontando para uma demanda por moradia entre as camadas mais pobres já bastante periferizada. 
fôlego - físico e financeiro - para tanto: "era só parede e teto, papai fez o contrapiso depois, com a gente já morando dentro". A ausência de infraestrutura urbana básica persistiria ainda alguns anos após a mudança, e os relatos de Marielen e sua madrasta evocam condições bastante semelhantes às encontradas nos relatos dos primeiros moradores da então Favela do Gonzaga na cidade: luz de velas, armazenamento de água em baldes, diferenciação entre vizinhos no acesso aos mínimos recursos (poços, geradores entre os que montavam os primeiros comércios informais), para citar alguns $^{6}$. O barraco, então, passaria a fazer as vezes de banheiro da casa, já que o bairro ainda permanecia também sem as redes de água e esgoto.

Meu pai construiu tudo. Sem saber ler nem escrever. Meu pai era marceneiro. Lá na Faber. E de final de semana, meu pai construía a casa, e de tardezinha também. Fazia o alicerce, e nisso todas as criança ajudando. Um pegava o tijolo, outro pegava massa. / Thaís: Demorou quanto tempo, mais ou menos, pra casa ficar pronta? Você lembra? / Meu pai mudou... mudamo na Cidade Aracy no ano de oitenta e nove, pro barraco. Oitenta e nove, noventa, noven... três anos pra casa ficar pronta. Porque nós era muito pobre. Não tinha condições de comprar tijolo. Então, demorou tudo isso. Três ano pra casa ficar pronta. / Thaís: Daí vocês desmontaram o barraco de madeira? / Não. O barraco ficou lá por muitos anos. A gente usava... como se fosse banheiro. Porque, naquele tempo, a Cidade Aracy não tinha encanamento, não tinha tubulação pra encanamento. Então ninguém tinha banheiro. Nossa casa tinha o banheiro, mas não tinha os encanamento. Então o barraco de tábua, o nosso barraco, ficou sendo o banheiro, até quando... chegou o encanamento na Cidade Aracy. E luz elétrica também que não existia, a gente usava candeeiro. / Thaís: Então, mesmo depois que construiu a casa de tijolo, ainda não tinha nem luz, nem água? / Nem luz, nem água, nem asfalto, nem saneamento básico nenhum. A gente tinha uma mina. Existe até hoje na Cidade Aracy, no bosque da Cidade Aracy, existe uma mina, que todo mundo ia buscar água, lavar roupa e louça lá, era bem longe. E tinha um homem que era mais ou menos bem de vida, o Seu João, ele tinha uma cisterna que é... uma cisterna, não, um poço... ele tinha um poço. Então, quando... só que era pra família dele, né? Não era pra todos da Cidade Aracy ${ }^{7}$. Então, faltava uma água, assim, um balde, dois balde, ele dava pra gente. [Marielen]

Embora a mudança para a "casa própria" tenha sido a realização máxima para o pai de Marielen (que enviou fotos do imóvel para os parentes em Pernambuco para "provar que tinha vencido na vida em São Paulo, porque os irmão dele não acreditava, né? Como que ele tava bem. 'ó, tô bem, tô trabalhando, tenho a minha casinha'”8),

6 Cf. Rosa (2008). Nessa época (fim dos anos 1980 e início dos anos 1990), o Cidade Aracy seria muito associado à ideia de favela, sobretudo na mídia local. Com o passar do tempo e a consolidação do bairro, como visto, tornar-se-á imperativo entre os moradores locais, sobretudo os mais antigos, diferenciá-lo de uma favela, acionando justamente suas condições iniciais de produção: ao contrário do Gonzaga, o Aracy não teria sido fruto de ocupação de terras, tendo sido um bairro planejado, onde muitas pessoas compraram seus terrenos, como fez questão de esclarecer Jefferson (cap. 2).

7 Nesse caso, como em tantos outros de favelas e loteamentos irregulares, a ausência de mínima infraestrutura básica transforma o acesso privado a ela (água e luz, sobretudo) em elemento primeiro de distinção entre os mais pobres. Cf. Rosa (2008).

8 Sobre a dimensão que "ter uma casa" implica nas "trajetórias migrantes" assentadas no bairro Cidade Aracy, ver Silva (2006). 
logo em seguida, a depressão $0^{9}$ que o assolava desde a migração para São Carlos tornou-se mais grave. As lembranças de Marielen e suas irmãs dão conta de que ele, que já desde a chegada a cidade passara a beber muito, após a mudança, tornou-se cada vez mais agressivo com as filhas. A madrasta, além de também a agredir fisicamente, a obrigava a fazer todo o serviço da casa após o retorno da escola. Não foram poucas as vezes que a ouvi dizer, ao se referir a esse período de sua vida, que "se eu pudesse escolher entre voltar pra minha infância e adolescência ou morrer, eu preferia morrer".

Aos quinze anos, ao chegar, certo dia, à escola toda roxa por ter apanhado mais uma vez da madrasta, uma colega a convidaria para ir morar em sua casa, no bairro Santa Felícia, e Marielen, num impulso, fugiu de casa. Depois de seis anos "pra baixo e pra cima, em busca de onde morar" com a família, justamente quando se assentavam em uma casa própria, a intensificação desta como lócus de violência ${ }^{10}$ motivaria a fuga. Embora a posterior consciência de ruptura com essa base material e, sobretudo, com os poucos vínculos familiares que the restavam resultasse em um grande arrependimento por parte de Marielen, tal caminho não teria volta, sendo o início de uma sequência de vicissitudes decorrentes de não ter casa, que duraria quase nove anos.

Então eu fiquei fascinada pra ir morar na casa dessa amiga. Achando que ia ser bom. E fugi de casa e fui morar na casa dessa minha amiga. Fui morar com a minha amiga aqui no Santa Felícia. Foi aí que eu conheci o Santa Felícia. Até então, eu nunca tinha saído da Cidade Aracy, Cruzeiro do Sul e Vila Prado. Tudo aqueles bairros por ali ao redor. Fugi da minha casa, achando que ia ser bom. Só que ela não contou pra mim que na casinha dela não tinha nem comida... porque lá em casa eu apanhava, mas eu tinha comida. E quando cheguei lá, foi uma história terrivel, que eu não sei nem se eu conto. Na casa da minha amiga. O pai dela, quando eu ia dormir de noite, ele... ele era pedófilo, queria me pegar de qualquer maneira. Aí, quando eu cheguei lá, que eu vi a situação da casa da minha amiga, do pai dela comigo... Eu me arrependi de ter fugido de casa. Eu me arrependi. Eu chorava, chorava... E não tinha mais pra onde eu voltar. Porque meu pai era muito ignorante, do Pernambuco, ele era muito ignorante, ele falou que pra casa eu não voltava mais. Meu pai não queria que eu voltava, porque eu tinha fugido, e ele falava que eu tinha perdido a honra. Aquele tempo era assim [risos], se você perdesse a honra, você não voltava mais pra casa. [Marielen]

A chegada ao Santa Felícia não foi fácil: embora uma parte do bairro fosse já mais desenvolvida (com infraestrutura urbana básica e mínimo acesso a serviços públicos),

9 Marielen designará como depressão diversas situações de sofrimento "simultaneamente físicos e morais" enfrentados pelo pai, pelo irmão ou por ela mesma, numa espécie de atualização - em tempos de popularização do acesso aos "saberes psi" promovido pela política dos CAPS - Centro de Atenção Psicossocial - da noção do "nervoso", que Duarte (1988), em trabalho seminal, identificaria como um código cultural hegemônico entre as classes populares para designar tais estados de sofrimento.

10 Uma tensão entre a apreensão da casa como ideal de abrigo e segurança ou como lócus de violência se fará presente em toda a trajetória de Marielen. 
sua amiga morava no que então era o limite do bairro, uma rua de terra, distante de pontos de ônibus, em uma casa descrita por ela como um tipo de um barraco ${ }^{11}$, revivendo algumas das dificuldades enfrentadas alguns anos antes, quando da chegada à cidade, ao que se somava o fato de ela não ter nenhum tipo de relações sociais estabelecidas na região (já que todos os seus familiares e conhecidos viviam no Cidade Aracy ou, no máximo, nos outros bairros da Zona Sul onde ela havia morado inicialmente com os pais).

O ano era 1992, e Marielen tinha então 15 anos. Ela continuava estudando na mesma escola e trabalhando para a antiga professora, mas voltava todos os dias para dormir na casa da amiga. Quando esta saía para namorar, Marielen dormia para fora, na porta da casa, por medo dos assédios do pai dela. Ela permaneceu quase um ano nessa condição, até que, ao conseguir transferência para uma escola no bairro Santa Felícia, conheceu aquele que seria o pai de seus dois primeiros filhos. Nesse mesmo ano, ela engravidaria e, antes que o namorado, Wando, descobrisse a gravidez, ela passou a frequentar assiduamente a casa da família dele, sempre na hora do jantar, para garantir ao menos uma refeição no dia, já que, assim que se descobriu grávida, ela abandonou o trabalho na casa da professora (onde antes garantia o almoço), por vergonha. A convite da irmã do namorado, de quem se tornara grande amiga e para quem contara dos assédios sofridos na casa da colega, ela passou a "praticamente morar com a família dele".

Ela seria a oitava moradora da casa própria, mas simples mantida pela mãe do namorado, cozinheira. Esta dormia em um quarto com a filha mais nova, ainda criança, os filhos homens dormiam num cômodo no quintal, e as mulheres, no segundo quarto da casa, onde Marielen passou a dormir. Quando a gravidez se tornou visível e foi comunicada à família do namorado, este não gostou da notícia e tentou, literalmente, devolvê-la ao pai:

Então, aí, eu comecei a ficar lá e, de repente, apareci grávida. Aí o Wando, ele não gostou que eu apareci grávida. Ele ficou muito nervoso, ficou bravo, ele queria me mandar embora pra casa de qualquer maneira. Porque ele não queria filhos. Ele não queria. Ele gostava de passear... ele ficou uma fera! Aí eu falei pra ele que eu não tinha pra onde ir. Ainda mais grávida. Aí ele foi falar com meu pai lá na Cidade Aracy. Meu pai era vivo ainda. Foi falar com meu pai e meu pai falou: 'imagine, voltar grávida!'. Que eu ia ter que ficar por lá mesmo. O Wando queria me devolver grávida ainda! Aí meu pai falou que de jeito maneira, lá eu não aparecia, só se fosse morta. (...) Aí eu fui ficando, com aquela briga, uma brigaiada! [Marielen]

11 Essa casa seria identificada por ela como tendo sido a pior casa em que viveu, numa articulação entre aspectos físicos (tipo barraco) e subjetivos: foi a mudança para essa casa que gerou a ruptura dela com a família e a "casa-matriz"; ali, pela primeira vez na vida, ela passou realmente fome, além de ter sofrido um assédio sexual continuado, sofrimentos e humilhações que ela teve de suportar para garantir um teto. 
Rejeitada a um só tempo pelo namorado e pelo pai, a mãe e as irmãs de Wando a acolheram, indo mesmo contra a pressão dele para que ela fizesse um aborto. Logo após o nascimento do primeiro filho, em 1993, a sogra casou-se novamente e foi morar na casa do novo companheiro, no Cidade Aracy, levando a filha mais nova. Pouco tempo depois, os dois irmãos mais velhos e uma das irmãs do namorado também se casaram e deixaram a casa, permanecendo apenas ela, o namorado e a cunhada-amiga. O namorado passava dias fora de casa, compensando a ausência com o dinheiro de seu trabalho para o básico necessário para ela e o bebê.

Marielen estava sem trabalhar desde que deixara o emprego na casa da professora, e também parara de estudar, dependendo totalmente dos recursos do agora marido. Além disso, o suicídio do pai ${ }^{12}$, concomitante ao nascimento de seu filho, trouxeraIhe uma grande depressão: "Então eu fiquei sem apoio nenhum. Eu já não tinha; depois piorou. Minha madrasta falou que, agora que meu pai faleceu, agora que eu não voltava mesmo pra casa."

Vivendo sob o mesmo teto, em um dos raros momentos de reconciliação do casal, Marielen engravidou novamente. O ano era 1995, e, a partir daí, Wando praticamente a abandonou, mantendo uma mínima contribuição financeira e retornando a casa apenas esporadicamente. Durante cerca de três anos, foi a cunhada quem a ajudou, inclusive cuidando das crianças para que ela pudesse concluir os estudos até a 8a série. Quando a cunhada se casou e deixou a casa, Wando expulsou Marielen e as crianças dali, levando-os para a casa da madrasta dela, onde ficaram por poucos meses, já que a madrasta também não os queria por lá. Então, por intermediação da sogra e da cunhada, o marido a recebeu de volta na casa, onde viveram sob o mesmo teto, entre idas e vindas dele, até o ano 2000, quando ele a deixou definitivamente para ir morar com outra mulher.

Os filhos estavam então com 6 e 4 anos, já frequentavam escolas, e ela tinha voltado há pouco a trabalhar como diarista. "Sem ter para onde ir", ela permanece na casa da família do agora ex-marido até 2001, quando a sogra decide vender a casa.

12 O pai de Marielen, que logo após a mudança para a casa própria, parara de trabalhar por conta da depressão, chegando mesmo a passar alguns meses internado no Hospital Psiquiátrico de Santa Rita do Passa Quatro, aos 39 anos provocou a própria morte, colocando fogo no barraco que servira de moradia da família e fechando-se dentro dele. Embora não acreditasse nos boatos que davam conta de que o pai teria se matado devido a uma traição da madrasta, a mágoa de Marielen em relação a esta se amplificou ainda mais após esse episódio, porque o pai teria deixado um bilhete para que ela acolhesse Marielen, e ela o ignorou: "Como eu não tenho mãe, só tinha ele, ele deixou um bilhete pra ela, que ela me mostrou, tem guardado até hoje. Disse assim pra minha madrasta, pelo apelido dela que chama Tula: 'Tula, por favor, não abandona minha filha, nem o bebê', que era eu. Mas a madrasta não ouviu mesmo assim (risos)." O fato é que, após a morte do pai, a madrasta vendeu as duas casinhas que ele possuía no bairro vizinho (trazendo a mãe dele para morar com ela), justamente quando Marielen passava tanta dificuldade em torno da moradia. E por duas vezes ainda se negaria a abrigála com as crianças naquela que se tornara sua casa. 
Eu ainda pedi pra ela se eu podia ficar lá com as crianças, porque eu não tinha pra onde ir. Nem mãe, nem pai, nada. Eu não tinha pra onde ir com as crianças e ela falou que não, que eu tinha que dar um jeito. Que eu tinha tantos dias pra sair de lá, porque já tinha gente que queria comprar a casinha. A casinha não valia muito, o que valia era o terreno. Um lugar privilegiado lá no Santa Felícia, perto do Posto de Saúde, quase na frente. Eu fiquei lá até ela me pôr pra fora, tipo assim, me obrigar mesmo. Aí eu tive que sair... [Marielen]

Inicia-se um período muito difícil na vida de Marielen, mãe solteira, com dois filhos e sem ter onde morar. Inicialmente, ela recorre à sua madrasta, que aceita acolher apenas Marielen, mas não seus filhos, que passam a viver na casa da ex-sogra, no vizinho bairro Cidade Aracy II. Em menos de um mês, ela deixaria a casa da madrasta, pois o convívio era um inferno: esta a agredia moralmente e fisicamente, e ela ainda tinha que dar conta de uma das irmãs, que também morava ali, então "viciada em crack, envolvida no mundo do crime e na prostituição também". Como se não bastasse, nesse mesmo período, seu irmão seria assassinado no Cidade Aracy ${ }^{13}$, transformando definitivamente sua relação com o restante da família e, sobretudo, com aquele bairro.

Contando apenas com uma ainda mínima rede de relações estabelecida no bairro Santa Felícia, ela volta para lá e passa alguns meses morando "de favor" em casas de colegas, "uma semana na casa de uma, uma semana na casa de outra". Os meninos continuavam na casa da avó paterna, do outro lado da cidade, e Marielen só os via aos finais de semana: "eu ficava me desdobrando, tava deprimida que meu irmão tinha morrido, indo todo dia lá embaixo ver as crianças, indo trabalhar e voltando pra dormir no Santa Felícia... Foi quando minha patroa entrou em jogo."

A intenção de Marielen era encontrar um cômodo qualquer para alugar no próprio bairro Santa Felícia, para poder trazer seus filhos para morar com ela, mas os custos do aluguel no bairro estavam acima do que ela podia arcar. Ela estava a ponto de alugar, relutante, uma casa no Cidade Aracy II, próxima à casa de sua ex-cunhada, onde os aluguéis eram mais condizentes com sua situação financeira, quando sua

13 O irmão, que aos 14 anos assistira à terrível morte do pai (foi ele quem percebeu o incêndio e chamou os vizinhos para arrombar o barraco), passou a beber muito desde então. Marielen faz questão de frisar que ele era um trabalhador (soldador), que nunca se envolvera com o mundo das drogas (diferenciando-o de uma de suas irmãs, então "usuária de crack e envolvida na prostituição"), mas "bebia e se envolvia com mulheradas. Mulheradas erradas. Dizem que ele tava saindo com uma moça que namorava ele e mais um, que era um traficante muito grande da Cidade Aracy, que hoje já morreu também. Ele tinha 20 anos, e tava bebendo mesmo, de ir pro bar todo dia. E nisso aconteceu a tragédia - foi brigar com esse grandão por causa de mulher... Então, aí, aconteceu mais essa tragédia, foi duas tragédias na nossa família. A gente não sabe qual foi pior, se a do meu pai ou a do meu irmão. Por isso eu não gosto nem muito de ir lá no Aracy. Me lembro dessas tragédias." Vale destacar que, a partir das narrativas de Marielen sobre o período em que tal tragédia aconteceu, é possível apreender algumas dinâmicas presentes no bairro Cidade Aracy, no início dos anos 2000, que só fizeram piorar os estigmas do bairro na cidade, como a presença crescente do tráfico de drogas, a penetração do crack entre os moradores, sua associação como lócus de prostituição (sobretudo infantil), a recorrência de mortes violentas entre os próprios moradores. 
patroa lhe comunicou que iria comprar um terreno e construir uma casa para ela. Entre perplexa, feliz e constrangida, Marielen a teria alertado sobre os valores mais baixos dos terrenos no Cidade Aracy. Entretanto, a patroa, sabendo da história de Marielen, mas, principalmente, impregnada do estigma que desde sempre se impôs àquele bairro, decidiu comprar o terreno em um loteamento recém-aberto nos limites do bairro Santa Felícia, denominado Romeu Tortorelli ${ }^{14}$ :

Ela sabia que eu gostaria mais no Santa Felícia que na Cidade Aracy, porque meu irmão tinha morrido e eu não queria mais voltar pra lá. E ela também falava que ela ia comprar um terreno num lugar onde ela pudesse ir me buscar, quando ela precisasse. Falava: 'não naquele fim de mundo' (risos). Ela não tinha coragem de descer lá15. E se não fosse ela, provavelmente eu iria ficar morando lá mesmo, porque, como eu não tinha onde morar, minha ex-cunhada tava procurando casas, barracos de aluguel pra mim lá, por quê? Porque aqui no Santa Felícia era difícil, não dava nas condições do meu pagamento, então lá era muito mais barato, tipo 100, 120 naquela época, então eu ia acabar indo pra lá mesmo ${ }^{16}$. Então, foi a minha patroa que me salvou. [Marielen]

Comprado o terreno e acertada a construção da casa com um pedreiro do bairro, conhecido de Marielen, após menos de três meses de obra, ela, que não aguentava mais "morar de favor na casa dos outros" e distante dos filhos, decidiu mudar-se para lá, mesmo com a casa inacabada: "era chão duro, laje e vidro." Após tantas idas e vindas entre casas de conhecidos, uma das vicissitudes desse 'não ter lugar' foi ter perdido os seus poucos móveis, que foram sendo 'apropriados' pelas famílias das casas por onde passava: ela conseguiu "salvar na briga" um colchão e o fogão, e a patroa comprou uma mesa e uma geladeira novas para a casa.

14 Essa decisão da patroa agrega ainda mais valor, para Marielen, à cessão da casa, não apenas pelo fato de que ela realmente preferia permanecer no Santa Felícia e pelas melhores condições do bairro à época (e ainda hoje), mas também em termos do investimento representado, pois, segundo ela, um terreno no Cidade Aracy, naquela época, estava em torno de $\mathrm{R} \$ 2.500,00$, enquanto o terreno adquirido pela patroa teria custado $\mathrm{R} \$ 6.500,00$. Essa decisão repercutiria ainda hoje, na valorização atual do imóvel, já que a casa de Marielen, nesta localização, valeria bem mais que uma casa semelhante no bairro Cidade Aracy. "Na cidade Aracy, eu não escolheria, porque eu tenho muitas lembranças de meu irmão que foi assassinado lá. Lá, só se fosse meio assim: 'Ah, tem só aqui, então vou morar aqui.' Mas, como a minha patroa deu a opção, eu nem insisti muito, porque eu iria sofrer muito na Aracy. Se ela tivesse comprado um terreninho lá, eu taria lá até hoje, mas ela não quis. Ela achou que seria ruim pra mim, eu andava chorando muito, mal trabalhava. E também seria ruim pra ela, pela distância..."

15 Marielen já havia tido contato com tal percepção sobre o bairro há quase dez anos antes, quando trabalhava para sua professora. Enquanto Marielen estudava na escola em que a professora lecionava, no bairro Cruzeiro do Sul (quase no topo da serrinha que fazia a conexão entre o Cidade Aracy e o restante da cidade), voltava com ela direto para a escola; após a transferência dos alunos do Cidade Aracy para uma escola improvisada em um velório no bairro e, posteriormente, para o CAIC, como visto, Marielen tinha que descer a pé da antiga escola até o bairro, já que a professora não tinha coragem de levá-la "lá embaixo", no Cidade Aracy. Também Beatriz (Cap. 2) mencionou ter enfrentado situação semelhante, já nos anos 2010.

16 Vale reter, deste relato, a presença de um mercado informal de aluguéis a operar como vetor de deslocamentos habitacionais na cidade. 
A casa tava só chão duro, laje e vidro, e eu entrei pra dentro da casa com os meus dois filhos. Minha patroa falava: 'Não! Aguenta mais um pouquinho que daqui a pouco a casa tá pronta.' Ela falava: 'Espera pôr o piso', eu falava: 'Não dá. Não tem como eu ficar na casa dos outros, eu não me sinto bem.' Então, tipo assim, quando eu entrei, tava um cheirão de cimento forte... A casa tava só a laje, chovendo por dentro. Mas eu falei pra ela: 'Eu vou entrar mesmo assim, porque eu tenho que buscar os meninos.'/ Thaís: Não tinha acabamento ainda? / Não tinha nada de acabamento. Não tinha o reboco... Não tinha portas no banheiro, nem nada. Era só a casca mesmo. Não tinha piso, nem telhado, nem nada. Absolutamente nada. Só uma casca assim. Os tijolo e o chão duro... e também eu não tinha muito móveis, tinha só um fogão, um colchão e só. [Marielen]

Após a mudança, ela finalmente voltou a morar com os filhos ${ }^{17} \mathrm{e}$, para arcar com as contas da nova casa, intensificou ainda mais seus trabalhos como diarista, dentre os quais se mantiveram os prestados para esta patroa, duas vezes por semana, como antes. Porém, se estabeleceria uma relação sutil de obrigação ${ }^{18}$ entre elas, uma espécie de dívida perene, que se perpetuaria, mesmo após a mudança da patroa para outra cidade, em 2007. Além de construir uma casa para ela morar e comprar-lhe alguns móveis, a patroa também a auxiliaria a conseguir a pensão alimentícia com o ex-marido, entre outros benefícios que Marielen atribui a ela, como o cadastramento para consecução do Bolsa-Família, que ela receberia entre 2003 e $2008^{19}$. Como

17 Chama a atenção aqui a similaridade com a trajetória de Núbia: ambas evidenciam, em gerações distintas, a perversa relação entre ter ou não ter moradia e poder ou não assumir o cuidado dos filhos.

18 Também como no caso de Núbia (ver nota 18, Cap. 1), a relação de Marielen com esta patroa encarna diversas dimensões da ambiguidade que seria constitutiva das relações entre patroas e empregadas domésticas, que já há algum tempo tem sido objeto de diversos estudos (cf., p.e.: Brites, 2007, 2001; Vidal, 2009; Georges, 2011; Dantas, 2013). Se, por diversas vezes, Marielen se referiu a esta patroa como mais que uma mãe, com quem ela teria uma relação sobretudo afetiva ("o que ela fez por mim foi um ato de amor; tem mãe que não faz isso por um filho"), em outras ocasiões, prevalece a descrição de uma relação ora discriminatória ("Ela é uma pessoa muito difícil, ninguém queria trabalhar pra ela. Ela é uma pessoa assim: se ela for cozinhar um brócolis, era só pra ela e o marido. Ela não dava pra faxineira comer. Ela acha que é diferente: 'esse aí é nosso, não mexe.' (risos) Ela aprontou muitas comigo. Um dia das crianças, ela deu uma caixa de bombom pros meus filhos e era do 1,99: os dois foi parar no hospital. Então, tinha vezes que eu ficava revoltada com ela. 'Poxa vida, tantos anos de trabalho aqui, não mereço ganhar uma caixinha da Nestlé, da Garoto, precisa ser lá do 1,99?' Então, às vezes, eu ficava super revoltada. Ela fazia esse tipo de diferença com as faxineira"); ora de obrigação, de dívida, que foi a que prevaleceu após todo esse tempo vivendo na casa cedida por ela ("eu sentia na obrigação de ir"; "assim [com o trabalho extra não remunerado] é o único jeito que tenho de pagar o que ela me fez").

19 Como no caso de Joana (cap. 2), Marielen recebeu o Bolsa Família durante quase todo o intervalo de tempo em que esteve sem um companheiro (desde o abandono do primeiro marido até a oficialização da união com o segundo). Para ela, ter recebido o auxílio financeiro foi fundamental, assim como para outras conhecidas suas que ainda o recebem: "hoje ninguém mais passa tanta dificuldade igual eu passei na infância e adolescência, não tem mais aquela pobreza [ênfase], porque tem esse Bolsa-Família". Recentemente, ela tentaria voltar a receber o benefício, mesmo não precisando tanto, porque "o Bolsa-Família eu tenho uns benefícios, com o cartão Bolsa-Família, eu poderia, por exemplo, eu pago oitenta reais de luz, eu ia pagar metade, eu ia ter uns benefícios, eu ia voltar a ter os benefícios que eu tinha, por exemplo, eu pago sessenta de água, é, tem 7\%, mas $7 \%$ faz diferença pra mim. Porque na verdade, quem sustenta a minha casa com água e luz sou eu, então eu iria, se eu conseguisse me cadastrar, nem que fosse com o mínimo, o auxílio gás, não é? do BolsaFamília, eu ia ter uns benefícios de, tipo assim, essas coisas." Ela, entretanto, acabou não conseguindo, 
contraparte, ela passou a demandar os serviços de Marielen para além dos dois dias pelos quais lhe pagava, sem que isso representasse acréscimo em sua remuneração. Muitas vezes acontecia de Marielen perder um dia de faxina em outra residência para atender esta patroa, tendo que compensar o recurso perdido com trabalhos extras aos finais de semana. Para ela, entretanto, essa troca valia a pena, pois a casa cedida pela patroa teria sido sua salvação naquele que tinha sido, até então, o momento mais difícil da sua vida.

Fiquei, no total, oito anos com essa patroa, sem carteira assinada, sempre nesse esquema de duas vezes por semana. Mas, tipo assim, depois que eu passei a morar nessa casa que ela fez pra mim, eu me senti como que eu devesse obrigação pra ela. Ela me chamava de domingo, sábado, não tinha mais dia. Depois que eu passei a morar na casa, não tinha mais assim, só segunda e quinta. Me chamava, podia ser a hora que fosse, que eu tava lá. E ela me pagava só os dois dias por semana. / Thaís: Mas aí, se você fosse extra ela não te pagava? / Não. Ficou meio que por favor assim. / Thaís: E você faz isso até hoje pra ela? Por favor? Essas vezes que você vai pra Ribeirão, por exemplo, ela te paga ou não? / Não. Sempre quando eu vou pra Ribeirão, eu vou mesmo por favor pra ela. Hoje em dia, eu tenho condições de conseguir outro lugar pra morar, e ela diz que não. Mas eu me sinto bem quando eu vou lá. Por mim, eu faria tudo de graça pra ela. Se ela morasse aqui, eu tiraria dois dias da semana especialmente pra ela, sem cobrar nem um centavo. / Thaís: Mas ela chegou a te exigir isso? / Nunca me exigiu!. A única coisa é que ela abusava um pouco nesses extras... Tipo assim, como ela é meio de idade, 'Ai, eu derramei um café aqui, você pode vir?' Eu saía correndo, pegava o ônibus e ia lá. / Thaís: Em qualquer momento que ela te chamasse? / Em qualquer momento. E eu ia normalmente. Foi uma troca que valia a pena. Vale até hoje. Se ela falar que eu tenho que ir toda semana pra Ribeirão, eu dou um jeito e vou lá. Eu já até me ofereci pra ela. Falou que não. (...) E quando eu vou pra lá, não fico trabalhando que nem louca. Eu dou uma força, eu limpo... / Thaís: Mas você vai porque quer ou ela que te chama? / Eu vou porque eu quero. Tipo assim, quando ela me chama, eu vou também, mas assim, às vezes eu sinto de ir. Eu penso: 'Ah, acho que ela tá precisando de mim, faz dois meses que eu não vou lá...'. Sinto na obrigação. [Marielen]

Assim, enquanto Marielen passou a estar 'disponível' para a patroa sempre que ela precisasse, sem que isso representasse uma remuneração adicional, a patroa, ano a ano, foi, aos pouquinhos, financiando a construção do restante da casa.

É a casa que eu moro até hoje. Que agora já tá mais acabada. Aos poucos, minha patroa, todo final de ano, fazia uma coisa. Um ano ela colocava um piso, outro ano ela colocava o telhado, aí no outro ano ela fazia a garagem. E foi assim que terminou a casa. (...) quando chegava no final do ano, ao invés dela me dar

pois, dadas suas condições atuais, ela teria que mentir a renda para obtê-lo, valendo-se de estratégia bastante recorrente em campo (ver também nota 14 - cap. 2): "Eu não consegui porque, hoje, como eu sou uma Testemunha de Jeová, eu teria que mentir, se fosse antigamente... Eu teria que mentir a renda, eu teria que falar que o meu marido ganha 1 salário mínimo, o que não é verdade. E que eu ganho um salário mínimo, o que não é verdade, eu não ganho um salário mínimo. A maioria das pessoas fazem isso, mentem a renda. Eu conheço alguém que tem loja e tem Bolsa-Família, ela tem três crianças na escola, mas ela tem uma loja que só o aluguel da loja é um salário mínimo, então não tem como ela ganhar um salário mínimo. Aí, eu fui mentir, fui lá, tentei, na hora de mentir a renda, eu desisti e não voltei mais." 
décimo terceiro, presentes, essas coisas, ela colocava um telhado, que ficava muito mais caro, e eu que tinha que correr atrás dos pedreiros, marceneiros, porque ela não conhecia nada. Ela realmente confiava, me dava cheque, me dava dinheiro e eu ia lá e pagava o homem, era assim. Foi ela que acabou a casa pra mim. [Marielen]

Em 2007, quando se mudou da cidade, a patroa parou de mexer na casa, e Marielen deu-a por terminada. Esse momento, que poderia ter sido de tensão para ela, em termos da garantia de sua permanência ali, foi relativamente dissipado com a promessa da patroa de que a casa estaria em testamento para ela. Ainda assim, foi somente depois de se casar novamente, em 2009, que a relação de Marielen com a casa ganharia mais contornos de apropriação, já que, só então, seriam feitas as primeiras intervenções na casa sem investimento da patroa: o marido, pintor, passou a investir na casa por conta própria, coisa que ela nunca tinha feito, justamente por não querer empregar seus parcos recursos em uma casa da qual não tinha a posse.

Nunca investi nada na casa até o dia que casei. Daí meu marido começou a investir na casa, fazer umas melhorias, pouca coisa, porque a casa não era nossa. Mas ela disse pra mim que a casa tá em testamento. Só que as pessoas do bairro não acreditava nisso e ficava, tipo, na minha cabeça: 'Ah, quando ela morrer você vai perder a casa'. Mas eu nunca pensei nisso, eu não tenho esse medo. Se hoje, nesse momento, ela aparecer na minha casa pedindo a casa, eu devolvo de livre e espontânea vontade e ainda falo: 'muito obrigado por deixar eu morar aqui'20. Mas eu não mexia, por causa disso. Aí ele começou a investir. [Marielen]

Quando iniciei a pesquisa de campo, Marielen já morava na casa há dez anos e, embora fosse enfática ao afirmar que tinha certeza de que a patroa nunca pediria a casa de volta ${ }^{21}$, ela ainda não sentia a casa como propriamente sua, mantendo as contas no nome da antiga patroa e informando a esta sobre qualquer problema ou alteração que ela precisasse ou quisesse fazer na casa.

Qualquer coisa que eu faço na casa eu ligo pra ela e falo. Ela fica brava, que não preciso ligar, mas eu sinto de avisar, porque a casa ainda é dela, né? Eu sei que a casa é dela, mas eu não sinto assim: 'ah, ela vai me pôr pra fora a qualquer momento'. E nisso já faz dez anos que eu tô morando na casa. [Marielen]

20 Embora sempre afirmasse que dormia tranquila por ter certeza de que a patroa nunca lhe pediria a casa, também era recorrente ouvi-la dizer, para mim ou para outros conhecidos da vizinhança, que, caso isso acontecesse, ela "entregaria a casa tranquilamente", pois sentia uma grande gratidão por a patroa tê-la favorecido tanto justamente no momento em que ela mais precisou, e que, agora, ela teria "condições de ir morar em outro lugar", situação bastante diferente da daquela época em que a então patroa a salvou.

21 Para reafirmar essa certeza, ela fez questão de contar que, certa vez, ela teria ido se inscrever para um sorteio na PROHAB, e a patroa, ao descobrir, teria ficado extremamente nervosa e ofendida por Marielen não confiar que a casa realmente seria dela: "Ela ficou chateada, falou: 'pra quê você vai se inscrever, se você já tem uma casa? Essas casinhas, você não tem privacidade nenhuma, é tudo colada uma na outra, a casa que te dei é muito melhor.' Ela ficou chateada, ficou sem falar comigo... que ela realmente ia me dar a casa. Aí eu confiei e não fui mais atrás. (...) eu fiquei acomodada mesmo com a casinha onde eu moro. Fiquei acomodada e não fui nunca mais atrás." 
Em verdade, mesmo com o continuado empenho do marido em promover melhorias, ela ainda relutava em fazer alterações no imóvel, não apenas por essa dimensão da incerteza da posse, mas também por uma dimensão afetiva e, sobretudo, moral, que permearia sua relação com a casa, mesmo (e talvez inclusive) após sua patroa declarar que passaria a casa para ela ainda em vida.

E esses dias também, meu marido inventou que queria trocar todo o piso da casa, mas eu não deixei, meu coração... Eu nem dormi de noite. Meu marido, tipo que queria fazer assim: queria pegar, fechar o corredor, fazer uma cozinha no corredor e a cozinha, onde que é a cozinha hoje em dia, ele iria fazer uma sala. Só que, pra isso, ele teria que demolir todo o piso. Aí, a hora que eu olhei pro piso, eu não tive coragem... A hora que ele falou que ia trocar o piso, eu olhei bem assim pro piso, porque eu lembro dela escolhendo o piso e falando assim: 'ó, eu vou colocar piso em tudo, aqui nas paredes também. Não vou por só no chão não, viu Má? Depois vai espirrar óleo aí e cê vai ter que ficar esfregando'. Então, a hora que ele falou que ia trocar o piso, aí eu peguei assim, e meu coração não deixou. Eu falei: 'Ah não, deixa assim mesmo!' E, também, eu sabia que ela ia ficar chateada se eu fizesse isso. [Marielen]

Mas, com o avançar da pesquisa, pude perceber um outro elemento de fundo a operar nessa relutância perante o desejo do marido de intervir na casa: a intenção de resguardá-la como um espaço de autonomia conquistado a duras penas, que representava o reverso de todas as humilhações enfrentadas com o primeiro marido, justamente por depender dele para ter um teto. A consecução da casa garantiu a ela uma independência que não teria volta, nem mesmo com o segundo casamento (o único oficializado): desta vez fora o marido a mudar-se para a casa dela, onde ela é 'quem dava as cartas'. É, pois, neste contexto que se pode apreender, também, além de sua recusa às propostas de melhorias na casa constantemente feitas pelo marido, também à proposta de transferência de posse da mesma para o seu nome, feita pela patroa em 2011.

Inicialmente eufórica, então, com a notícia, ao contar para o marido, este começaria imediatamente a "fazer planos com a casa" (num primeiro momento, de ampliá-la; posteriormente, de vendê-la), que não agradaram a Marielen: essa casa tinha sido, até agora, sua única segurança, e fora a partir dela que uma série de transformações em sua vida se desencadearam, como veremos adiante. Espelhando-se em tantos casos - como o de sua própria irmã, cuja casa, construída a duras penas com o recursos do Fundo de Garantia por Tempo de Serviço dela, transformara-se em objeto de disputa com o marido, que a deixara por outra; ou o da vizinha, que tivera sua casa negociada pelo marido sem que ela soubesse, e voltara a ter que viver de aluguel, porque o mesmo "desinteirou o dinheiro gastando com bobagens, e eles não conseguiram mais comprar outra casa" -, Marielen propôs à antiga patroa que esperasse seu filho Jairo completar dezoito anos e transferisse a propriedade para o nome dele, como forma de preservá-la de possíveis instabilidades no relacionamento 
com o marido e de garantir a continuidade da posse da casa também para os filhos, ao contrário do que acontecera com ela, quando da morte do pai.

O marido, sem saber disso e acreditando que, mais cedo ou mais tarde, teriam a posse, tentaria, por diversas vezes, convencê-la a fazer negócio com a casa. Na época, o engenheiro com quem ele trabalhava estava começando a construir casas para financiamento pelo Programa Minha Casa Minha Vida e, interessado no terreno onde a casa estava localizada, ofereceu $\mathrm{R} \$ 110.00,00$ por ela. Com esse recurso, o marido pretendia comprar dois terrenos em um loteamento "bem longe, onde tem uns terrenos superbaratos", com o objetivo de construir uma casa para morar e outra para alugar. Naquele momento, Marielen não quis nem pensar no assunto: da perspectiva de sua relação afetiva e moral com a casa, não era certo transformá-la em uma mercadoria, lucrar com ela.

O moço foi lá avaliar, o engenheiro que o meu marido trabalha. Meu marido que pediu: 'Quanto vale essa casa?' Porque ele queria vender. Ele ficou um tempão fazendo a minha cabeça pra eu vender essa casa e comprar um terreno num bairro mais inferior, que daria pra fazer duas casinhas mais ou menos. Aí eu falei pra ele que nunca! Jamais! / Thaís: Porque? / Então, porque ele quer meio que lucrar e eu não acho certo. / Thaís: Aí uma ficaria pra vocês, e a outra? / Uma ficava pra gente, e a outra alugava e comprava um carro melhor. E, vira e mexe, ele faz isso na minha cabeça, e o meu coração não deixa. Ele já arrumou um bom negócio num bairro que chama Novo Horizonte, era um terreno que dava pra fazer duas ou três casas. Um terreno lá do outro lado da cidade, bem longe. Tem uns terrenos superbaratos ali. Então o engenheiro que ele trabalha compraria o imóvel e daria o dinheiro. Só que eu não tenho escritura da casa e nem tenho vontade de ter. Já avisei minha patroa, ela vai esperar pra passar pro Jairo. / Thaís: Porque senão seu marido vai querer fazer isso? / É. Ele vai querer tipo fazer um negócio que vai lucrar mais. Mas eu gosto tanto da casa! Sou que nem o gato. (...) E, como eu nunca tive casa, só eu sei o que eu sofri morando de favor, eu não vou arriscar perder essa casa. (...) Não tenho coragem, tenho medo de depois não dar, entendeu? Por exemplo, tenho experiência de conhecidos, pessoas aqui no bairro... que vendeu a casa e depois ficou com uma mão na frente e outra atrás, foi morar de favor, ou voltou a viver de aluguel. E eu tenho medo de que aconteça a mesma coisa, depois de tudo que já passei. [Marielen]

A dimensão de salvação conferida por ela a essa casa seria a base de sua forte vinculação a ela, e a centralidade que tomou em sua trajetória articula-se com a experiência anterior do "não ter pra onde ir": a casa cedida pela patroa permitiu a ela voltar a morar com os filhos, trabalhar para sustentá-los, "sem a preocupação de não ter onde morar"; a casa, sobretudo, livrou-a do morar de favor, da subjugação a outrem, tido por ela como uma de suas piores experiências na vida:

Foi só depois que eu fugi de casa e fui morar de favor com aquela minha amiga que eu fui ter noção do que era ter um teto, até então eu não tinha. Porque morar de favor é horrível. Por que é horrivel? Porque até uma geladeira que você vai abrir você tem que pedir pra pessoa 'ó, tô abrindo aqui a geladeira', você vai tomar banho, você toma com medo, com medo, assim, preocupada que a pessoa vai xingar. Eu morava de favor, eu sempre trabalhei, né, de doméstica, aí eu chegava já cansada e o que eu ia fazer? Pra agradar a pessoa eu limpava tudo a 
casa, eu não sabia o que fazia pra pagar, então eu sempre tinha que estar agradando aquela pessoa, porque eu tava morando de favor. Até eu vir pra cá, pra essa casa minha. Aqui, foi a primeira vez que eu me senti em casa, e quando eu sei que tem alguém procurando casa pra alugar, alguém que não tem casa, me dói na alma, se eu pudesse eu daria uma casa igual eu ganhei uma. / Thaís: Porque fez muita diferença na sua vida. / Pra mim representa, tipo assim, uma liberdade, por exemplo, hoje, se eu precisar parar de trabalhar hoje, como já me aconteceu, eu não vou ter que me preocupar com aluguel, com casa, essas coisas, e antigamente não, eu vivia preocupada, quando eu morava de favor né, ia pra casa de um não dava certo, fui pra casa de uma amiga minha pra morar, chegou o pai dela, tentou abusar de mim enquanto eu tava dormindo, e não tinha pra onde eu ir, né? Eu não tinha pra onde ir, nenhum lugar. E hoje eu tenho. (...) Eu sei que eu tenho um lugar pra morar até eu morrer, eu sei que daqui eu não vou mais sair procurando casa, é um lugar fixo que eu tenho. Eu tenho um pé fixo, eu não estou com o pé lá fora, eu tenho um pé fixo aqui, eu tenho certeza absoluta. [Marielen]

De fato, a consecução da casa poria fim a nove anos de uma experiência de não ter lugar, estar à mercê dos outros: apreender esse contexto ilumina o valor que Marielen atribui ao pé fixo que a casa representou, que repercutirá no valor que as redes de relações que ela construirá a partir dessa fixação terão para ela, como veremos. Entretanto, se a fixação na casa representou uma salvação no contexto de sua trajetória, isso não significaria, em definitivo, a eliminação de outras dimensões de vulnerabilidade ${ }^{22}$ que a atravessariam desde então, trazendo à tona uma miríade de outros trânsitos e deslocamentos socioespaciais para além do acesso à moradia.

\section{- Uma experiência urbana entre fixação espacial e trânsitos sociais}

O estabelecimento de seu pé fixo numa casa praticamente própria no bairro Santa Felícia ${ }^{23}$, possibilitado somente em função da intervenção de sua patroa, seria decisivo nos rumos da trajetória de Marielen. De fato, se desde que deixara a casa paterna e o bairro Cidade Aracy, ela enfrentara uma série de vicissitudes vinculadas a "não ter para onde ir" que a fizeram se arrepender da fuga, relativizando o sofrimento e a violência enfrentados na "casa-matriz" e até resguardando memórias

22 Remeto, aqui, à já mencionada concepção ampliada de "vulnerabilidades socioeconômicas e civis", tal como proposta por Kowarick (2009).

23 O bairro Santa Felícia, tendo sido o primeiro e maior loteamento destinado às camadas populares, na chamada Zona Norte de São Carlos, e permanecendo por décadas como o ponto final da malha urbana nesse eixo de expansão da cidade, acabou por se configurar como uma espécie de região ampliada que, como no já mencionado caso da região conhecida como Grande Cidade Aracy (ainda que em menor escala, dada a maior conexão do Santa Felícia com diversos outros bairros da cidade, ao contrário da delimitação geográfica que circunscreve a região do Cidade Aracy), é apreendida genericamente como bairro pelos moradores dos diversos bairros populares limítrofes àquele oficialmente denominado Santa Felícia (como Arnon de Mello, Romeu Tortorelli, Santa Angelina, São Carlos I, II, III, IV e VI, Parque Iguatemi). Entretanto, quando se trata de vizinhança ou de especificidades socioespaciais das dinâmicas cotidianas dos interlocutores, a noção de bairro é aplicada para delimitar o próprio bairro, no caso de Marielen, o Romeu Tortorelli. Ver mapas nos Anexos. 
afetivas do período vivido naquele bairro, a morte do irmão suplantaria qualquer desejo de voltar a viver no local (a despeito de ali viverem ainda sua madrasta e duas irmãs que, de todo modo, nunca lhe ofereceram grande apoio), a menos que essa fosse sua única alternativa, da qual, justamente, sua patroa a salvara. Desde então, Santa Felícia e Cidade Aracy configurarão os dois polos de referência de sua experiência urbana, acionados por diversas vezes em suas narrativas.

Embora Marielen afirme que a possibilidade de permanecer no Santa Felícia a tenha favorecido, sobretudo porque ali se concentrava a maior parte de seus vínculos sociais, estabelecidos na região ao longo dos cerca de sete anos em que ali viveu desde a fuga para a casa da amiga, sua instalação na casa inacabada no novo loteamento envolveria todo um novo processo de construção de relações e práticas cotidianas até que ela pudesse chamar o bairro de seu. Mesmo mantendo algumas amizades na vizinhança da casa da ex-sogra, onde vivera a maior parte do tempo passado no Santa Felícia até então, não se configurara propriamente uma rede de apoio com a qual pudesse contar, por exemplo, no cuidado com os filhos ainda pequenos para que ela pudesse trabalhar para sustentá-los.

E ela precisava trabalhar muito, já que não recebia mais nenhum tipo de auxílio financeiro do ex-marido. Além de continuar trabalhando como diarista para a patroa que the cedera a casa, ela ainda trabalhava em mais duas outras casas durante a semana, mas os ganhos eram insuficientes. Por indicação de uma antiga vizinha, ela consegue um trabalho aos finais de semana - inicialmente como faxineira; depois também como balconista - em uma "lanchonete duvidosa" do bairro, conhecida como "Bar das Putas", por ser ponto de prostituição local. Durante a semana, os filhos "ficavam sozinhos em casa, pelo bairro. Eu tava com depressão por causa da morte do meu irmão, trabalhava muito pra não faltar nada pra eles, mas não conseguia dar amor". Aos finais de semana, para que ela pudesse trabalhar no bar, os filhos eram levados para a casa da avó paterna no Cidade Aracy, "do outro lado da cidade".

Nesse período, Marielen, mãe solteira e trabalhando nesse local, era excluída pela vizinhança do novo bairro - entenda-se, aí, pelas mulheres, com quem ela tinha constantes desentendimentos por conta de conversar com os maridos destas ou, ainda, porque seus filhos ficavam largados pelo bairro e arrumavam briga com outras crianças da rua. Some-se a isso o fato de que sua casa havia sido construída pela patroa, o que a desmerecia aos olhos daqueles que, com muita luta, haviam autoconstruído suas casas ali.

Eu brigava com as moça da rua. Ninguém falava comigo na rua. Porque eu andava, tipo assim, de shortinho, minissaia, era o meu estilo na época. Minissainha, miniblusinha. Então, como eu morei num bairro, separada, sozinha, com dois menino, sem marido... Desse jeito, lá fora lavando o quintal... E ainda trabalhava lá no bar... Ninguém falava comigo. Nenhuma vizinha! Hoje são todas 
minhas amigas. Mas nenhuma vizinha minha falava comigo, elas não me aceitavam. Tipo assim, queimava uma lâmpada lá em cima, a caixa d'água, de vez em quando, ela dava um problema, eu ia lá chamar o vizinho, a vizinha não deixava ele vim, ou senão vinha junto. Elas pensavam que eu queria roubar o marido delas. Era assim. (...) E, ainda mais, porque eu tava revoltada, comecei a sair com gente de tudo quanto é tipo, conheci o outro lado, conheci todos eles, tudo que é traficante... fui fazendo amizade. Mas nunca me envolvi, porque eu tinha os meus meninos... e o dinheiro da minha faxina era contado. Então não dava certo pra mim. Eu não usava as drogas, também nunca vendi, nunca passei droga - aqui no bairro fala 'passar'. Mas eu conheço todos os bandidos e as bandidas, desde essa época, convivia no bar, estudei junto. [Marielen]

Suas principais companhias eram, então, as colegas de trabalho do bar e outros conhecidos que ela fazia ali: embora afirme nunca ter se envolvido propriamente em programas $^{24}$ ou uso e venda de drogas, Marielen passou a ter contato com todos aqueles considerados 'maus elementos' no bairro - prostitutas, bandidos, traficantes - o que a tornava ainda mais rejeitada pela vizinhança. Desse período ela frisa, também, a depressão e a revolta sentida pelo abandono do marido e pela perda do irmão, que ela não conseguia superar, buscando vingança. Em alguns finais de semana, após o expediente no bar ela era levada por sua madrasta e suas irmãs para bailes de forró, na tentativa de que ela saísse da depressão; ela, entretanto, aproveitava essas oportunidades para ir em busca tanto da mulher e do assassino de seu irmão, quanto daquela que roubara seu marido, tendo, por diversas vezes, ido parar nas delegacias da cidade por agredir essas mulheres, bem como a desconhecidos que ela julgava estarem envolvidos na morte do irmão.

Eu tava sofrendo muito com a depressão, e sozinha com as duas crianças... Então, se eu encontrava a mulher que me roubou... eu achava que ela que me roubou o Wando, né? Se eu encontrava, eu batia mesmo! Ficava nervosa de ver eles juntos, e eu sofrendo com os meninos. Aí, ia no camburão da polícia, tinha que prestar conta no juiz... Ah, era muito rolo a minha vida! E sempre dava polícia, ai geralmente eu tinha que pagar hora pro governo, lavar os banheiros da rodoviária... (risos) [Marielen]

Em uma das ocasiões, armada com um revólver encontrado na casa de sua patroa, ela esteve perto de cometer um crime, na tentativa de vingar o irmão:

A última vez foi o seguinte, meu irmão faleceu na Cidade Aracy e veio uma conhecida e falou pra mim que a moça que tinha causado a morte dele tava numa lanchonete lá embaixo. Aí eu peguei um revólver [risos]... Falaram pra mim: 'O Marielen, sabe aquela moça... Cê viu que sacanagem? Ela fez o seu irmão falecer e tá lá todo sábado na lanchonete bebendo e dançando', falei: 'É?!' Peguei o revólver e falei pra uma amiga minha: 'Cê fica aqui com meus filhos...', levei os documentos, '...eu vou matar essa mulher!' E fui lá! Peguei o ônibus armada... Fui com um cara, um traficante, chamado Dentinho. Vou falar porque

24 Segundo Marielen, uma única vez ela teria "saído com um moço, porque gostava dele, ele era bonito" e, depois do programa, ele a teria levado em lojas para comprar roupas para seus filhos e dado uma quantia em dinheiro. "Nessa vez, eu vi que eu podia ganhar dinheiro assim, então eu dou graças a Deus que eu encontrei o João [marido], porque, senão, nem sei o que seria de mim". 
ele já morreu. Lá do Gonzaga. Ele foi comigo. Tipo assim: 'Mata mesmo!' [risos]. /Thaís: De onde você conhecia ele? / Era meu colega [risos]. Do Santa Felícia mesmo. Ele tava sempre no barzinho onde eu trabalhava, no Bar das Puta. Você conhecia tudo quanto era gente lá.../ Thaís: Mas e o que aconteceu? / Só que antes eu contei pra essa minha amiga: "Ó, olha meus menino, com certeza eu vou ficar presa, porque eu vou fugir pra onde? Vou matar." Nisso, quando eu desci do ônibus... Meu amigo desceu antes, né? Sabia que eu ia matar mesmo, ele desceu lá no Gonzaga, e falou: 'Ó, cê passa aqui depois, viu? Cê foge de lá e corre aqui, que eu te escondo aqui.' Aí, quando eu cheguei no ponto de ônibus, tinha umas dez pessoas me cercando. Porque minha amiga ligou pra minha exsogra, a mãe do Wando, e falou o que tava acontecendo. E ela avisou o resto. Quando eu cheguei lá, minha madrasta já me grudou pelo pescoço, e eu gritando: 'Vô matá ela! Vô matá ela!' O revórve tava dentro da minha bolsinha. Tava aqui ó, o revórve. Engatilhado. Com seis balas. Eu sei atirar. / Thaís: Como cê sabia atirar? / Aprendi com o Wando lá na matinha do bairro. Ah, ele caçava, ele ia pras fazendas, e eu ia junto, ele ia com a espingarda. Aí aconteceu tudo essas tragédias na minha vida, só que o Jeová sempre tinha um plano pra mim e não deixou acontecer nada de mal. / Thaís: Mas aí elas te impediram e você não... / Não. Eles me desarmaram. Na hora que eu desci, eu nem vi, quando eu dei por mim minha madrasta me grudou por trás, o Wando já catou o revórve, nunca mais eu vi aquele revórve na frente. Então, eu já arrumei muito rolo, revoltada porque mataram meu irmão. [Marielen]

A narrativa se articula de modo a contrapor esse período de cerca de um ano após a mudança para a nova casa - em que ela teria flertado com a prostituição, tido problemas com a polícia e quase cometido um crime - ao período seguinte, em que, quase simultaneamente, ela conhece a religião Testemunhas de Jeová e seu atual marido ${ }^{25}$. Ela atribui a esses dois fatos, ocorridos em 2002, sua vida não ter se encaminhado para o que hoje ela considera o lado errado: a prostituição, o tráfico, o mundo do crime.

Após a morte do irmão, sua depressão e revolta chamaram a atenção de uma conhecida do bairro Santa Felícia, que um dia a abordou para falar sobre o novo mundo, onde ela reencontraria o irmão. Ela agrediu a mulher, que nunca mais a procurou, mas passou a enviar cartas a sua casa durante quase um ano, reconfortando-a com a ideia de ressurreição dos mortos. A estratégia surtiu efeito, e Marielen passou a esperar ansiosamente por essas cartas, até que, em uma delas, a mulher se ofereceu para ir à sua casa "dar estudos sobre a Bíblia". Seriam cerca de seis anos de estudos e participação nas reuniões do Salão do Reino até ela ser batizada e poder "sair pregando no campo", atividade que se tornaria, progressivamente, uma parte importante de suas dinâmicas cotidianas ${ }^{26}$.

25 Cf. Duarte e Gomes (2008:154) sobre conversões religiosas: "O passado transgressor assume um significado importante no processo de restauração de suas vidas, tendo a religião e a família como principais elementos dessa ordenação de vida".

26 As Testemunhas de Jeová são um grupo religioso cuja prática se encaminha ao proselitismo, através de ações práticas de caráter missionário, como as saídas a campo, o testemunho informal, a pregação de porta em porta, as revisitas e os estudos bíblicos. Tais atividades organizam-se localmente 
O atual marido, João, ela o conheceu no próprio Bar das Putas. Morador do bairro Santa Felícia, ao observar que ela não fazia programas, ele passou a segui-la após o fim do expediente, oferecer carona, convidá-la para sair. Até que um dia, em que ela havia levado consigo o filho mais novo para o serviço no bar, ela resolveu aceitar uma carona. Logo ele estaria levando toda a família para passeios de carro aos domingos e começariam a namorar. Mas a condição dele para o relacionamento seria ela não mais trabalhar naquele bar; a dela, para deixar o trabalho, seria que ele a ajudasse com os gastos da casa:

Ele começou a levar tudo lá em casa. Verdura, fruta. Só pra mim não ir no bar. (...) Depois que eu conheci ele, nunca mais eu andei de a pé. E antes eu andava! Qualquer dinheirinho que eu ganhava, tipo assim, eu fazia uma faxina e ganhava o dinheiro do ônibus, eu guardava o do ônibus e não gastava, porque ele ia me buscar. (...) Nunca mais andei de a pé, então eu me sentia assim... Se acabasse o gás, 'ah, o gás vai acabar tal dia', eu ficava sossegada, sabia que ele ia comprar. 'Ah, a minha força, eu tenho que pagar tal dia', eu sabia que ele ia pagar. Aí ele começou a levar meus filhos pra tudo que é lugar, ficava doente eu ligava pra ele 'ai, meu filho tá passando mal'. (...) Então foi assim que eu tô com ele até hoje. Eu casei mais por comodidade, mesmo. [Marielen]

Além de ajudar na casa, ele passou a frequentá-la cotidianamente, por vezes dormindo ali, mas sem se mudar definitivamente, sobretudo porque o filho mais velho de Marielen não o aceitava. No início de 2009, quando ela já estava grávida de sua terceira filha, eles oficializariam a união em um casamento civil, requisito da religião Testemunhas de Jeová para que ela pudesse ser batizada e "sair no campo pregando para as pessoas".

Se a narrativa aponta para uma espécie de 'conversão' em sua vida, ela própria destaca que tal transformação teria sido muito gradativa - "eu fui mudando aos pouquinhos" - e foi ao longo desse processo que Marielen passou a estabelecer novas relações no bairro, tanto na vizinhança, em que passou a ser vista com outros olhos, mas principalmente com os irmãos da igreja, com os quais construiu redes de apoio essenciais para o cuidado com os filhos mais novos ${ }^{27}$.

Até então, eu não tinha apoio nenhum. Se eu precisasse de alguma ajuda com as crianças, pra olhar ou levar pra escola, só se eu pagasse eu conseguia. Então, depois que eu conheci Jeová, minha vida mudou totalmente, totalmente

a partir dos chamados Salões do Reino, que se distribuem delimitando territórios na cidade. A centralidade de sua concepção ancora-se na possibilidade iminente da volta do Reino de Jeová, que configura a ideia de um novo mundo por vir. Para um estudo aprofundado sobre o tema, ver Bornholdt (2004).

27 Almeida (2011), em estudo sobre relação entre religiões e desigualdade social na região metropolitana de São Paulo, embora enfocando religiões pentecostais, apresenta um argumento que auxilia no entendimento das construções e reconstruções de redes de relações por Marielen, desde sua conversão em Testemunha de Jeová: o de que a ajuda entre 'irmãos de fé' produziria um efeito de proteção e integração social, a partir da sobreposição entre redes religiosa, de parentesco, de relações de trabalho e solidariedade. 
diferente. Porque aí, se eu precisasse de uma ajuda, os menino ficasse doente, alguma criança, eu teria onde deixar. Então, eu não tinha nenhum apoio, tipo assim, nada, não tinha amigos que ajudava. E hoje eu tenho, se eu precisar, qualquer apoio. Hoje eu tenho, por causa da minha religião. [Marielen]

E se suas principais redes de relações passaram a girar em torno da religião (em especial quando passou a frequentar o Salão do Reino todas as quintas-feiras e aos domingos, levando os filhos mais novos), o mesmo aconteceu em sua relação com o bairro e o seu bairro ${ }^{28}$, apreendido agora a partir do campo (inicialmente apenas acompanhando outros irmãos, e, posteriormente ao batizado, ela própria passando a fazer pregações na rua): "a gente anda o bairro todo, fazendo o campo. Não tem uma rua, uma casa que a gente não passe. É o nosso território". ${ }^{29}$

Marielen é consciente da transformação operada em sua identidade frente à vizinhança e ao bairro e do esforço aí investido, mesmo que isso não fosse um propósito em si. A própria escala da cidade e as redes de interconhecimento que conectam pessoas e localidades nessa escala se encarregariam de fazê-la lembrar disso, em diversas situações, das quais a narrada abaixo é quase anedótica. Nela se articula, de um lado, o fato de que, a partir dessas novas redes, Marielen consegue seus primeiros empregos com carteira assinada, podendo, ainda, contar com apoio no cuidado com a filha pequena e, de outro, as implicações de antigas dinâmicas socioespaciais vivenciadas no bairro, cujas consequências o extrapolam:

Então, daí fica as consequências do passado. Do passado feio que você teve, não que você escolheu, mas que passou um passado na sua vida. Eu tava trabalhando na TAM, de ajudante de cozinha, aí veio a fila dos homens que veio almoçar e falou assim pra mim: 'Você não trabalhava no Bar da dona Lurdes?' Falei: 'Não, não sou eu não, você tá enganado'. 'É você sim! Lembra? Não sei o que...', [risos]. Eu falei: 'Não, não sou eu.' Aí pronto! Já fiquei desesperada, perdi o dia, acabou com meu dia. Outro dia também, eu tava andando na rua pregando as boas novas, veio um moço e falou: 'Oi! Sou eu! Você não trabalhava no bar da dona Lurdes? Lembra que a gente foi lá no Broa, não sei aonde?' Falei: 'Não! não sou eu não!' 'É você sim!' Falei: 'Não, não sou!' Mas, olha, você vê? As consequências fica pra sempre. Aí eu via ele lá na TAM todo dia. E ele falava: 'Ah, é você sim! Conheço seu sorriso, ah!' [risos]. O da TAM [risos]. E ele falava assim: "Tá trabalhando aqui agora?", 'Tô, tô trabalhando.' 'Cê casou com aquele moço do Monza, né? Eu vejo você'. Mesmo eu falando pro moço que não, 'Ah, tá querendo

28 Destaco aqui essa importante distinção, que tantas vezes Marielen sutilmente me apresentou em suas narrativas, e custei a apreender: quando ela mencionava o bairro, de maneira geral, estava se referindo a esse entendimento ampliado do Santa Felícia como um todo, englobando inclusive o Romeu Tortorelli, ao qual, quando ela quer mencionar especificamente, refere-se como meu bairro.

29 Essa concepção de um território designado para a pregação por cada grupo vinculado aos Salões do Reino espalhados pela cidade me seria explicada por Jairo: "Geralmente a gente tem um território já, cada congregação de Testemunha de Jeová de São Carlos tem um pedaço designado. Então o nosso, como a gente é do Santa Felícia, o nosso é da Avenida Bruno Ruggiero pra baixo, então toda essa área aqui a gente faz tudo." Conforme destaca também Bornholdt (2004:118): “Com um território específico para cobrir, as Testemunhas de Jeová se organizam conforme os territórios que estejam sob sua responsabilidade, saindo para visitar todas as casas de famílias que ali residam." 
me enganar? É você! É você sim!' Não tem como, o passado fica. Quando eu vejo uma pessoa dessa, eu finjo que não vejo, mas não tem jeito, né? [Marielen]

Mal Marielen tentava se livrar das consequências do passado e logo teria que enfrentar as do presente. Enquanto sua vida parecia melhorar, ficando "cada vez mais sossegada" ("primeiro eu ganhei a minha casinha. Depois que eu conheci Jeová, eu parei de ir nos bailes, não fui mais trabalhar no bar. Encontrei esse moço, e eu me senti meio protegida, assim. Não precisava mais ficar atrás de nada"), com a garantia de um lugar para morar, a inserção em uma religião, a construção de redes de relações na vizinhança e na igreja, a consecução de empregos melhores e menos desgastantes, a relação estável com um companheiro, seu filho mais velho "começou a dar problema". Os relatos familiares dão conta de um adolescente bastante revoltado pelo abandono do pai e que não aceitava ver a vida da mãe melhorando ao lado de outro homem: a relação do filho Jeison, em casa, começou a ficar cada vez mais violenta, com agressões físicas ao irmão e ameaças à mãe, além de destruições da própria casa e mobiliários. Ele queria ir morar com o pai, mas ela relutava em concordar, pois este nunca tinha se interessado pelos filhos.

Entretanto, sob a justificativa de preservar a casa e a integridade do filho mais novo, em 2007 ela mandaria Jeison para morar com Wando, então no bairro Antenor Garcia:

Ele quis ir morar com o pai dele, tipo assim: 'Ou você me manda eu morar com o meu pai ou eu me mato.' Era assim que ele colocava pra mim. Uma vez, ele colocou uma corda na garagem e falou que ia se matar. Aí eu peguei e levei ele. Coloquei num carro e levei ele lá na casa do Wando. Não deu seis meses, e ele tava no crack. Aí eu fui buscar de volta... / Thaís: Nossa, e como foi isso? / Cheguei lá e deixei ele com o pai dele. Aí ele ficou lá, e o pai dele era traficante lá. Eu não sabia que ele era traficante, já tinha ouvido falar que ele era viciado. Mas tava traficando lá no Antenor. Aí, depois, agora que tudo passou, o Jeison falou assim que ele chegou lá, e as droga ficava dentro do armário, à vista. Não ficava escondida. Contou pro Jairo e o Jairo me contou. Então ele foi experimentando um pouquinho aqui, um pouquinho ali, aí ele conheceu o mundo do crime, das droga. Começou a vender também, vender droga lá junto com o pai, se envolveu, o Wando teve que pagar o outro traficante, porque o Jeison foi vender e usou tudo. Sabe quando pega pra vender e usa tudo? Aí, às vezes, quando ele fica nervoso, ele fala que eu que levei ele pro mundo do crime, porque eu levei ele pra casa do pai dele. Só que se eu não levasse ele, como que eu iria trabalhar se ele espancava o Jairo, quando eu não tava em casa? Espancava mesmo, de ficar desmaiado! [Marielen]

A relação de Marielen com Wando, até então, era praticamente nula, já que ele pouco acompanhara o crescimento dos filhos (mesmo a pensão fora conseguida judicialmente com a ajuda da patroa, como visto); dava-se sob mediação da avó dos meninos - com quem ela mantivera muito contato durante a infância destes, por ser, então, uma de suas poucas bases de apoio - e da ex-cunhada - que até hoje é uma de suas melhores amigas. A mudança de Jeison para a casa do pai resulta num grande sofrimento para Marielen, sobretudo porque desemboca numa disputa judicial pela 
guarda do filho, em que este declara, perante o juiz, desejar viver com o pai, que, com isso, passa a pagar apenas a pensão do filho mais novo para Marielen, mesmo após o retorno de Jeison para a casa dela, que se dará também de forma traumática.

Após pouco mais de seis meses da mudança do filho - e falando com este apenas eventualmente, por telefone -, ela descobre, através de um encontro fortuito com uma vizinha do ex-marido, que o filho estaria perdido nas drogas. Isso se confirma numa incursão ao bairro, quando ela toma conhecimento de que Jeison tinha sido expulso da escola por agredir a professora e o encontra "acabado, só pele e osso". Ela decide trazê-lo de volta para casa, fato que ele só aceita sob uma série de condições, exigências que ela e o filho mais novo deveriam acatar, como poder ficar com o quarto só para ele (o mais novo passaria a dormir na sala) ou não sofrer nenhum tipo de controle sobre seus horários de saída e chegada em casa. Com este filho morando novamente com ela, começaria aí mais uma transformação na vida e na casa - de Marielen, a partir da progressiva inserção de Jeison no mundo do crime.

\section{- Dinâmicas socioespaciais fronteiriças: mediações de uma mãe de bandido}

Quando eu trouxe ele pra casa, aí eu conheci o outro lado do crime dele, que eu não sabia. Ele já tinha roubado várias vezes, traficado... Quando a polícia pegou ele com quinze anos, a polícia falou que ele já era experiente. Então, foi aí que aconteceu tudo. Pegou ele roubando muitas vezes. Até chegar na Fundação Casa, passou pelo NAl um monte de vez. / Thaís: Isso depois que ele voltou a morar com você? / Isso. Quando a polícia pegou ele a primeira vez aqui [no Santa Felícia], falou que ele já era muito conhecido deles lá do Antenor. Aí, eu falei: 'Não! Acha!', e ele falou: 'É sim. Seu filho é experiente em arrombar casas'. E eu falando que não. Porque eu achei que era o primeiro roubo, que alguém tinha induzido ele a fazer isso, que era o outro o ladrãozinho. Entendeu? Falou que não. Que ele era experiente. Que era ele mesmo que fazia aquilo, não era outro, não. Aí, eu achando que não, sempre colocando, tampando a peneira com o sol, aí que aconteceu que depois desse, veio outro, veio outro, veio outro, até que ele foi parar na Fundação Casa. Foi pra Ribeirão Preto... / Thaís: Então, mas como foi esse processo de ele parar na Fundação Casa? O que ele fez? / Aí ele não fez mais furto, porque se uma pessoa entrar na sua casa e roubar, levar seu DVD e não tiver ninguém em casa, é furto. Eu não sabia, tipo assim, eu conhecia as meninas que usa droga, se prostitui, mas eu não conhecia o lado do crime, o PCC, nem nada disso. Eu conhecia outras coisas. As meninas usava droga, saía pra se prostituir, nada de mundo do crime, de roubar, nada disso. Conhecia os traficante, sabia quem era traficante. Mas não me envolvia, né? Aí depois que meu filho voltou pra casa que eu fui me envolver. Antes não sabia qual artigo era. Agora sei quase todos. [risos] Até então, eu não distinguia. Entrar na sua casa, não tiver ninguém em casa e levar um objeto, é furto. Quando ele foi pra Fundação Casa, o policial me explicou, eu falei: 'Ah, vô ter que ir buscar ele de novo?' Ele falou: 'Não, agora ele vai ficar preso', 'Mas por quê?', 'Porque ele fez um assalto à mão armada. Agora não é mais furto, é 157.' Aí que eu fui entendendo tudo, fiquei... Entendeu? Aí ele foi levado pra Fundação Casa e ficou quase um ano. [Marielen] 
O momento da constatação de que o filho estaria envolvido com o crime é uma memória muito vívida para Marielen. Entre sofrida e resignada, foi evocada espontaneamente por ela diversas vezes em nossos encontros, como que para garantir que ficasse registrada sua perplexidade com tal descoberta, bem como sua total desconexão do rumo tomado pelo filho: embora tenha tido amizades duvidosas, ela nunca se envolvera com o mundo do crime. Além disso, ela procurava frisar tal desconexão também em relação à sua casa e a seu bairro, destacando que o envolvimento teria se dado na casa do pai, no bairro Antenor Garcia.

Entre a volta do filho para a casa dela e a dolorosa constatação de que este se tornara um ladrãozinho seriam menos de seis meses. A partir da primeira apreensão oficial ${ }^{30}$ de Jeison pela polícia, aos 15 anos, Marielen conviveria, durante cerca de um ano, com dinâmicas institucionais até então desconhecidas para ela, já que o filho seria apreendido cometendo roubos ou portando drogas por diversas vezes, acarretando uma série de passagens pelo NAI - Núcleo de Atendimento Integrado ${ }^{31}$, uma delas, inclusive, envolvendo o irmão mais novo, inocente.

Nesse tempo, depois que ele voltou pra casa, ele ficou aprontando, ele roubava, traficava... / Thaís: $E$ como foi esse período? Porque você falou que ele ficou na liberdade assistida, né? / Isso, mas não pagou. Ele ficava assim, roubando, traficando e colocando a nossa vida em risco, tipo assim, é, o Jairo ia com ele pro ponto de ônibus, o Jairo não sabia que ele tava com droga no bolso, a polícia parava, levava os dois pra cadeia lá, pro NAl, os dois, porque eles tavam juntos... /Thaís: E aí você tinha que ir atrás? / Eu ia atrás buscar, e eu trabalhava... toda semana era uma coisa... Ligavam: 'dona Marielen, a senhora tem que vir aqui buscar seu filho que tá no NAl', aí eu ia lá e buscava no NAl... [Marielen]

(...) a gente tava no ponto de ônibus, aí ele tava junto comigo por coincidência, que a gente nem ia pro mesmo lugar. Aí, nisso passou dois guardas municipais,

30 Cabe reter, aqui, o fato de que Jeison "já era muito conhecido da polícia", quando foi apreendido oficialmente pela primeira vez. Mallart (2011:77), em estudo etnográfico sobre a Fundação Casa e suas dinâmicas a partir das trajetórias de jovens internos, evidencia a circularidade de relações estabelecidas entre policiais e adolescentes 'infratores', ao narrar o caso de um garoto que, levado dezesseis vezes a uma determinada delegacia de Indaiatuba - SP, tornara-se conhecido dos policiais responsáveis pelo patrulhamento de rotina da região (ou vice-versa). Nesse contexto, como já notara Feltran (2011), a polícia passa a compor a experiência dos envolvidos no mundo do crime, nesse caso, o filho e, consequentemente, também a mãe.

31 O NAI - Núcleo de Atendimento Integrado - foi criado em São Carlos em 2001, visando a cumprir "o artigo 88 do Estatuto da Criança e do Adolescente (ECA), que prevê a integração operacional de órgãos do Judiciário, Ministério Público, Defensoria, Segurança Pública e Assistência Social em um mesmo local, para efeito de agilização do atendimento inicial ao adolescente que cometeu algum tipo de ato infracional". A articulação entre a Prefeitura Municipal, o Juizado da Infância e Juventude e o Salesianos São Carlos na execução de medidas socioeducativas em meio aberto, como Prestação de Serviço à Comunidade (PSC), Liberdade Assistida (LA) e Semiliberdade, teve repercussão nacional, tornando-se referência para implantação em diversos outros municípios. Segundo dados da Prefeitura Municipal, a implantação do NAI teria reduzido em $90 \%$ o número de adolescentes encaminhados para o cumprimento das medidas em privação de liberdade através de internação na Fundação Casa. (cf. http://www.saocarlos.sp.gov.br/index.php/prefeitura/utilidade-publica/nucleo-de-atendimento-

integrado-nai.html, consulta em abril de 2014) 
e parou a gente no ponto de ônibus, aí eles revistaram a gente, e comigo não tinha nada, que eu nunca fui disso, mas aí, ele e o outro menino que tava do lado, tinha drogas no bolso, daí chamou a polícia e já levou os três. Fui o laranja da história, tive que assinar junto. [Jairo]

Além de descumprir algumas das medidas socioeducativas determinadas, Jeison seguia "roubando e metido com drogas". Chegou até mesmo a fazer um roubo na própria rua da casa de Marielen, descoberto porque ele deu um carrinho de controle remoto de presente para o irmão mais novo, que, sem saber que era roubado, foi brincar com ele na rua, e a vizinha cuja casa havia sido roubada viu. Esse episódio, que precipitaria na vizinhança a constatação de que o filho mais velho de Marielen estava realmente virando ladrão, demandou dela mediações - ancoradas em sua trajetória de "batalhadora, que criou os dois filhos sozinha" e em todo o processo de 'conversão' que resultara na construção de suas relações de vizinhança. Tais mediações se deram em dois sentidos: um, de isolar a atitude do filho mais velho do restante de sua família (sobretudo do filho mais novo, que fora pego com o brinquedo roubado) e de sua casa; outro, de dar garantias à vizinhança de que isso não se repetiria, evitando o envolvimento da polícia.

Marielen estava a ponto de enviá-lo novamente para morar com o pai, temendo por suas relações na vizinhança e pelo futuro do filho mais novo, quando, em meados de 2009 , Jeison foi apreendido pela polícia cometendo um assalto a mão armada. Ao ser mais uma vez chamada para comparecer ao NAl, ela acreditou que era apenas outro furto, mas agora era mais grave: ele seria enviado à Fundação Casa, em Ribeirão Preto, devendo permanecer internado por nove meses.

Marielen, que tivera seu bebê - uma menina, Roberta - havia pouco tempo, ficou entre tempo abatida e aliviada: "pelo menos ali eu sabia onde ele estava". Após um mês deslocando-se para lá, com um bebê a tiracolo, todos os finais de semana (o NAI fornecia um auxílio de custo para a passagem), ela conseguiu que Jeison fosse transferido para São Carlos. Logo após a internação do filho, o marido mudou-se definitivamente para a casa dela, visto que, mesmo depois de oficialmente casados, ele permanecera morando com os pais, para evitar os desentendimentos com Jeison. Entretanto, mesmo acompanhando mais de perto as agruras de Marielen em torno deste filho, ele não se envolvia, recusando-se a levá-la de carro ou mesmo a ficar com a filha nos dias de visita. Assim, com Jeison internado mais perto, a rotina continuou se repetindo, agora custeada por ela própria: todo sábado ela ia visitá-lo de ônibus ou em lotações organizadas por outras mães na mesma situação, sempre levando o bebê. Foi nessa época que a conheci, quando ela ainda começava a se familiarizar com as dinâmicas mais próximas ao mundo do crime e, sobretudo, a se aproximar de 
outras mães do bairro na mesma situação que ela ${ }^{32}$, mas sempre acreditando (ou querendo acreditar) que o filho deixaria essa vida ao sair dali.

No entanto, cumprida a pena, Jeison retorna para casa e, após um curto período definido pela família como tranquilo, sem brigas em casa, sem sair muito e aparentemente distante das drogas, ele logo voltaria a se desentender com todos em casa - sobretudo com o marido de Marielen - e cometeria um novo roubo que desembocaria não apenas em mais um envolvimento do irmão, novamente inocente, mas na primeira invasão policial à casa de Marielen.

Eu tenho duas passagens por causa dele, porque, uma vez, ele fez um furto numa casa e, como a gente só tem um guarda-roupa e é metade dele, metade minha, então ele escondeu as coisas que ele roubou dentro do guarda-roupa dele. Aí, nisso, a polícia entrou aqui, eu tava em casa, aí já levou nós dois juntos. E eu tive que assinar junto por causa dele, ainda pra ele não caguetar o outro que era amigo, que roubou com ele, que amigo você não tem nessas horas. Aí, pra não caguetar o outro amigo... / Thaís: Ficou com você mesmo? / Fui o laranja da história de novo. (...) meu irmão assinou furto, o que eu assinei foi receptador, só que é como um cúmplice assim. A gente teve que cumprir L.A. [Liberdade Assistida]. [Jairo]

Depois desse episódio, Marielen o enviaria para morar com o pai novamente. Dessa vez, entretanto, ao contrário da anterior, em que ele pedira para ir, a própria Marielen o expulsaria de casa. Pela primeira vez, aparece em sua narrativa um indício de que tirar o filho de casa, além de proteger o filho mais novo, seria também uma tentativa de preservar a casa das marcas que a presença de Jeison, agora conhecido pela polícia, poderia vir a associar a ela.

Eu mandava ele morar com o pai pra casa ficar tranquila, pra ficar livre dos problemas, da polícia, dele espancar o Jairo, pra eu poder trabalhar sossegada. Ele colocava nossa vida em risco. Mandava como um castigo também. Eu falei pra ele: 'Vou trabalhar e, quando eu voltar, não quero mais você aqui. Se eu encontrar eu chamo a polícia, que eles mesmo falaram que era pra chamar se você ficasse violento. Pra não chamar, tô te mandando embora. Porque a polícia já te conhece, e não quero eles aqui'. [Marielen]

Entre 2011 e 2012, o filho moraria quase um ano com o pai, que, vivendo de aluguel, tinha migrado recentemente para um apartamento no Conjunto Habitacional

32 Feltran (2011) nos apresenta no capítulo 3 a trajetória de Maria e sua família, que, tendo no trabalho a ancoragem de seus valores morais, verá sua vida "virada de cabeça para baixo" com a descoberta de que seus três filhos, de 13, 14 e 16 anos, estariam envolvidos no mundo do crime na região de Sapopemba - SP. Sua breve descrição do que sucederia à dinâmica da família após tal descoberta auxilia no entendimento de algumas das questões abordadas neste capítulo: "Para além do impacto pessoal, é preciso redesenhar todas as rotinas da casa. Inserir nelas o orçamento e o cronograma das visitas, o circuito das negociações com entidades de atendimento, audiências e julgamentos. É preciso conviver com outros atores do crime local, das redes de relação dos meninos, além das delegacias de polícia, advogados do serviço público e instituições totais. É preciso explicar para toda a família ampliada, e para os amigos, o que estava acontecendo. Necessariamente, é preciso então remodelar toda a rede de sociabilidade familiar" (p.125). 
Waldomiro Lobbe Sobrinho, popularmente conhecido como CDHU. Wando, que de traficante se tornara "mais um viciado em cocaína", definhava a olhos vistos e mal tinha comida em casa. Jeison acabou assumindo os cuidados com o pai e com a casa. As notícias - obtidas através de colegas diaristas moradoras do conjunto habitacional - da falta de recursos no local preocuparam Marielen, que, "quando a raiva passou", começou a enviar comida, roupas e móveis para o filho. Com poucos conhecidos no local, e entendendo o sinal verde da mãe, Jeison voltou a se deslocar com mais frequência para o Santa Felícia, sobretudo após arrumar uma namorada no bairro e, em seguida, um trabalho na região.

Inicialmente, começa a almoçar ou jantar na casa da mãe; logo passa a dormir uma noite ou outra por lá. Entre idas e vindas para a casa do pai, por conta das brigas com a mãe, o padrasto e o irmão, aos poucos, Jeison foi voltando para casa e, quando Marielen se deu conta, ele já estava instalado novamente ali, contrariando a vontade do marido que, com isso, deixa de arcar com os custos da casa, bancando apenas a própria filha ${ }^{33}$. Entretanto, como Jeison estava trabalhando e namorando uma menina de família boa do bairro ${ }^{34}$, ela ainda acreditava que ele não se envolveria mais com "as drogas e o mundo do crime" e decide enfrentar a decisão do marido, arrumando ainda mais serviços como diarista para sustentar a casa e os filhos mais velhos.

Rapidamente essa ilusão seria desfeita, a partir de uma situação que teria como desdobramento a primeira mediação de Marielen mais próxima ao mundo do crime: "porque antigamente eu conhecia a bandidagem, as drogas, usuários, gente que roubava por ali, mas não tinha PCC, debate, nada disso... Foi com esse filho que eu conheci o mundo do crime mesmo. Hoje eu conheço gente de alta periculosidade,

33 Situações como essa foram recorrentes em campo: mães de meninos envolvidos com o mundo do crime, cujos maridos não são os pais e/ou se recusam a aceitá-los de volta a casa após internações ou prisões, ou deixam de arcar com os custos da casa quando eles estão morando ali, para citar alguns exemplos. No caso específico de Marielen, pude acompanhar diversos períodos em que João tanto a pressionava para não receber Jeison de volta, quanto ameaçava deixar a casa, se ele voltasse para lá. Entretanto, isso nunca se concretizou: de fato, a restrição financeira foi a maior 'punição' sofrida por Marielen por ter aceitado o filho de volta.

34 Recorrente também entre outros interlocutores nos quatro bairros por onde a pesquisa transitou com mais frequência, a polarização entre famílias boas e famílias de envolvidos passa a importar mais a Marielen à medida que se via cada vez mais próxima do mundo do crime. A família da namorada de Jeison era considerada boa, pois tanto o pai quanto a mãe eram empregados em fábricas e nenhum dos filhos seria envolvido no mundo do crime: "ah, é uma família que todo mundo trabalha, estuda, não tem ninguém envolvido no mundo do crime". O namoro dessa menina com Jeison, entretanto, dá indícios de que há matizes entre os dois polos. Tal distinção evoca a oposição "trabalhadores versus bandidos", cuja plasticidade foi explorada de forma bastante interessante por Feltran $(2008,2011)$. Em Zaluar (1985:133), há uma reflexão pioneira sobre a ambiguidade de "relações entre bandidos e trabalhadores no que elas iluminam a formação da identidade de trabalhador". 
gente que mata, é o mundo do crime mesmo." 35 Uma madrugada, Jeison gritou pela mãe no portão de casa, e quando ela, assustada, saiu na calçada, o filho estava no meio da rua, todo machucado, acompanhado por uns garotos de bicicleta e outros em um carro e rodeado pela vizinhança, que, acordada pelos gritos, saíra para ver o que acontecia: Jeison estava correndo o risco de ir para um debate por ter tomado atitudes consideradas erradas no mundo do crime ${ }^{36}$. Ele estava em dívida com um traficante e, para não enfrentá-lo, deu dinheiro para que um conhecido fosse buscar a droga para ele. Esse conhecido, entretanto, acabou usando a droga e, ao descobrir, Jeison foi tomar satisfações e tiveram uma briga violenta, que por pouco não teve como desfecho a morte do tal rapaz. Este, que teria ligações com os grandões do bairro ${ }^{37}$, denunciou Jeison por tê-lo agredido, passando por cima de normas e posições internas ao mundo do crime: ele não teria o direito de tomar satisfação, muito menos de agredir o rapaz sem antes ter procurado um primo ou um irmão ${ }^{38}$ para mediar a situação, ainda mais porque ele estava devendo dinheiro na boca. Acuado, Jeison consegue ir até sua casa, já na intenção de pedir socorro a Marielen que, de fato, consegue reverter temporariamente a situação, ao apelar justamente para sua posição de mãe $e^{39}$ : "pô, conheço vocês desde pequeno, conheço a mãe de

35 Esta fala de Marielen aponta não apenas para a transformação da 'bandidagem' nas periferias da cidade nas últimas décadas, com o espraiamento da presença do PCC, mas para a decorrente "expansão do marco discursivo do crime" e a "sociabilidade renovada, marcada pela violência" que a acompanha (Feltran, 2008:3). Veja-se, também, Misse (1999); Hirata (2010).

36 O mundo do crime se ordena sob um complexo e plástico conjunto de regras de conduta, que se expressam na noção de "proceder". Como referência a um modo correto (ou esperado) de ação (Rui, 2010), o proceder seria um "atributo do sujeito" (Marques, 2009:14), havendo diversos níveis de punições para aqueles cujo "proceder" é considerado falho. Esses casos encaminham-se para o debate: julgamentos coletivos, legitimados por uma espécie de tribunal composto por membros respeitados do PCC; forma de mediação de conflitos (no âmbito do mundo do crime, mas também entre moradores das periferias de modo geral), na qual se põe à prova justamente o "proceder" das partes. Conforme destaca Gabriel Feltran, em entrevista a Manso (2009), "esses debates produzem um ordenamento interno ao 'mundo do crime', que vale tanto dentro quanto para fora das prisões. Evidente que a hegemonia do PCC nesse mundo facilitou sua implementação. Com esses debates, aquele menino que antes devia matar um colega por uma dívida de $\mathrm{R} \$ 5$, para ser respeitado entre seus pares, agora não pode mais matar". Sobre a temática dos tribunais do crime, sugiro ainda a leitura de Feltran (2009a; 2010).

37 Grandões do bairro, chefões do tráfico, traficantão: assim Marielen se refere aos integrantes do mundo do crime que comandam o seu bairro e/ou que, em sua visão, teriam mais poder de mediação para com o restante dos bandidos locais. Essa maneira de referir-se a eles dá a medida do seu envolvimento involuntário: ela os conhece, sabe quem eles são, sabe que pode/deve recorrer a eles para regulação de determinados conflitos envolvendo seu filho, mas refere-se a eles de forma externalizada, distante, de alguma maneira reverenciando posições hierárquicas que ela apreende a partir dessa posição fronteiriça de "mãe de um filho no mundo do crime".

38 Como visto, os irmãos são os membros batizados do PCC, cuja admissão "só pode ser feita mediante convite e indicação de dois irmãos" (Biondi, 2010:99 - grifos no original). Já os primos são aqueles que, apesar de não serem batizados, seguem as orientações transmitidas pelos membros do PCC, auxiliando na sua disseminação e funcionamento.

39 Interessa aqui chamar a atenção para o lugar da mãe entre meninos e jovens moradores de periferias do estado de São Paulo, sobretudo, aqueles inscritos no mundo do crime: designada 
vocês, deixa que eu resolvo, vou resolver esse negócio ai". Os meninos acataram o pedido da mãe, mas fizeram questão de frisar várias vezes: "mas não vai ter jeito, vai ter que ir pra debate, vai ter que ir pra debate, a gente não vai poder fazer nada". No outro dia, Marielen foi interceder pelo filho junto a um chefão do tráfico local, negociando a dívida de Jeison e apresentando a versão dele para o desentendimento com o rapaz, tudo na tentativa de livrá-lo do debate. Enquanto isso, a contragosto, Jairo, a pedido da mãe, acionou redes de interconhecimento de pessoas envolvidas no tráfico para confirmar se a história do irmão era verdadeira. Com a dívida negociada ${ }^{40}$ e a história comprovada por outros envolvidos, Jeison se viu livre do debate.

Entretanto, se, ainda assim, Marielen seguia acreditando que ele só estava envolvido com drogas, tendo deixado a vida de ladrão, logo outro episódio, que quase resultou na morte do filho, a fez cair na real: Jeison, sem saber, realizou um roubo na casa do irmão de um ladrão, atitude vetada no mundo do crime.

Um dia ele foi roubar uma casa, ele mais dois ladrãozinho, e eles não sabiam que a casa era de um irmão de um outro ladrão. E isso é sentença de morte pro PCC. Ladrão não pode roubar parente de ladrão. Então, eles não sabia; mas também, o cara morava num condomínio que tem aqui no bairro! O condomínio fica de frente pro beco dos traficantes, olha o contraste! Ele ia morrer em uma semana, foi aonde eu fui interceder. Eu fui interceder por ele e, aí, eu cheguei lá no cara, e o cara... / Thaís: Quem era esse cara? / Era um outro traficante do bairro, mas quem comandava mesmo era um que tava na cadeia, que eu não conheço. É um mais grandão. Então, o cara que eu fui interceder ligou pra esse daí e falou assim: 'Ó, dá um desconto pro menino, o menino tá entrando no mundo agora, não sabe de nada.' Eu vi ele falando assim: 'Ele fez uma coisa errada, mas ele tava inocente

recorrentemente como guerreira, espécie de "figura santificada" (Feltran, 2011:74; Mallart, 2011; Lyra, 2010). Também Jimmy (cap. 1) e Jefferson (cap. 2) se referiram, por diversas vezes, às suas mães como guerreiras. Se, como apresentarei a seguir, a aproximação de Jeison ao PCC terá efeitos em sua relação com a mãe, que passará a ser alvo do máximo respeito e admiração, Marielen, por sua vez, gradativamente incorporará o papel (cada vez menos circunstancial) de "mãe de bandido", fazendose valer dele, como nessa primeira situação: destaca-se, aqui, a mediação pela confiança (Lyra, 2010) acionada pela mãe, invocando relações de interconhecimento anteriores mesmo ao envolvimento dos garotos no mundo do crime e equiparando-se às suas próprias mães, em busca de fazer-se respeitar.

40 A partir desse episódio, Marielen foi se tornando cada vez mais experiente nas novas gestões sobre a morte e sobre as dívidas financeiras presentes nas periferias sob a égide do PCC e seu "tribunal do crime": "As pessoas, principalmente os envolvidos, recorrem a eles, ao tribunal, porque a justiça não dá conta. Todo mundo sabe disso. [Comento sobre o fato de a justiça do crime ser entre a vida e a morte, e ela diz:] É, é isso mesmo. Mas eles não matam assim, de uma hora pra outra. Eles avisam. Por exemplo, se é dívida de droga: eles dão um tempo pra pessoa pagar, parcelam até em doze vezes! (risos) Se a pessoa não pagar num tempox, vai pro seguro. Só depois vai pra morte. Foi o que aconteceu com meu filho dessa vez, que ele quase foi pro seguro, mas eu paguei a dívida dele, e várias outras depois, que ele vivia em dívida com traficantes, e em algumas delas, foi pro seguro mesmo! 0 que é o seguro, nesse caso? É quando o traficante dá tantos dias pra ele pagar, tipo assim, ele vai lá num irmão do PCC e fala assim: 'ó, eu não tô podendo pagar agora, você pode segurar até eu conseguir um emprego?' Entendeu? Como ele não é do PCC, é o outro que intercede por ele. Aí, o cara dá um prazo pra ele, e esse prazo é o tempo que ele tá no seguro. Agora, se ele não pagar no prazo... Num gosto nem de pensar." 
nessa aí, vamo dar uma clemência pra ele.' Então ele teve essa clemência, porque ele era de menor, tava iniciando... / Thaís: $E$ esse que você foi falar você conhecia? / É, é um conhecido. A polícia também conhece bem (risos), é um traficante que nunca foi preso e paga uma propina pra polícia. Cinco mil por semana. / Thaís: Verdade? Ele é lá do seu bairro? / Não. Ele não é do meu bairro, é lá da Vila Isabel. Só que é tipo assim, todo mês ele tá num bairro diferente, às vezes ele tá até em Ibaté, ele não tem uma moradia fixa. Mas como a esposa dele, uma menina linda, maravilhosa, é minha vizinha, então eu tenho contato com ela. E, através dela, eu tenho contato com ele. [Marielen]

Se, até a passagem do filho pela Fundação Casa suas novas mediações foram sobretudo de caráter institucional - policiais, psicólogos, assistentes sociais -, depois disso, progressivamente, Marielen foi se vendo envolvida, cada vez mais, nas redes de relações que se tecem no entorno do mundo do crime, à medida que as atitudes do filho, então um "Iadrãozinho de bairro", como ela costumava dizer, demandavam dela novas esferas de mediação, principalmente locais. Essa situação, em que o filho estaria com uma "sentença de morte no tribunal do crime", seria considerada por ela como o marco inicial de seu envolvimento, de justificativa inquestionável: salvar a vida do filho, objetivo que passou a ser um dos eixos centrais de sua trajetória desde então.

Eu fui obrigada a me envolver. Eu comentei com minha vizinha: 'o Jeison fez isso $e$ isso e tem uns cara querendo pegar ele.' A menina falou assim: 'Eu vou falar com o meu marido tal hora, tal dia' - tem hora, lugar e dia pra você falar com eles. Até senha eu peguei uma vez, acredita? É bem organizado! (risos) É assim que eu me envolvi, que eu me envolvo. Meu filho tava sendo procurado pelos bandidos, dia e noite escondido, querendo matar ele mesmo, então eu fui salvar o meu filho. [Marielen]

Mesmo assim, enquanto Jeison se mantinha ainda matriculado na escola e trabalhando, sem maiores problemas com a polícia mesmo após completar dezoito anos, Marielen seguia crendo que o filho ainda podia se encaminhar, e isso fazia com que ela procurasse uma série de serviços extras (além das três casas em que trabalhava como empregada doméstica e diarista) para poder ajudá-lo financeiramente, acreditando que essa era uma forma de mantê-lo distante do crime. Mas, como ela própria constataria, "era sempre uma ilusão".

Eu pensava que, se ele não precisasse de dinheiro pra nada, ele não ia mais roubar. Então eu me matava de trabalhar pra dar tênis bom, roupa, comprei um computador, tava até ajudando ele a tirar carta... Aíme vem esse N., de saidinha. / Thaís: O que é saidinha? / É quando quem tá preso vem pra alguma ocasião, que nem agora, que foi dia das mães. Só que esse N. saiu e não voltou. E desde que esse moleque apareceu, o Jeison tá pra cima e pra baixo com ele. Já falou que vai parar de trabalhar, parou de ir na escola. Só fica perambulando pelo Santa Felícia, e eu já tô ficando preocupada, porque o policial X., que é um policial lá do bairro que eu conheço, já me falou pra eu avisar o Jeison pra não ficar andando com esse cara, porque ele tá jurado de morte pela polícia e, na primeira oportunidade, eles vão acabar com ele, e se o Jeison tiver com ele, vai junto. Eu falei pra ele, mas ele nem ligou. Tentei até ver um negócio que me falaram, fui lá na delegacia no Santa Paula pra ver se eu conseguia colocar uma barreira da 
justiça que o N. não pudesse se aproximar do Jeison, mas o delegado disse que o Jeison que tem que solicitar, não pode ser eu. E quando eu falei com ele, sabe o que ele disse? 'De jeito nenhum, nós somos parceiros, e eu nunca vou fazer isso com um parceiro'. Eles são parceiros no crime, você acredita? Daí fui eu lá falar com um grandão do bairro, pra saber sobre essa parceria, e ele me disse que, se eles tinham mesmo feito a parceria, se eles eram parceiros no crime, a única coisa que terminaria essa parceria seria a morte de um deles. [Marielen]

A consciência do quão próximo seu filho estava do mundo do crime veio quando este, suspeito de participação em um assalto, tornou-se foragido da polícia, em meados de 2012, aos 19 anos. Marielen havia acabado de conseguir mais uma nova casa para fazer faxina e, no primeiro dia de trabalho, o filho mais novo e o marido apareceram no local: "vam'bora rápido, que a polícia invadiu lá em casa, o Jeison tá foragido, a gente precisa ir atrás disso agora". Seria o início de uma 'saga' que não se encerraria no desfecho desse episódio. Durante mais de um mês, a vida de Marielen giraria em torno de mobilizar todas as suas redes de relações para tentar fazer algo pelo filho, visando a garantir-lhe o direito de permanecer vivo, o direito, ao menos, de poder ser preso: seu maior temor era saber que, se ele fosse encontrado pela polícia enquanto estivesse foragido, seria morto, como tantos outros filhos de mães do bairro com as quais ela passara a se relacionar mais intensamente desde os tempos em que Jeison estivera na Fundação Casa.

Este garantira a ela que não estava envolvido, mostrando inclusive as fotos do assalto, captadas pela câmera de segurança da residência e publicadas no site de um jornal local, os quais, aos olhos dela, comprovavam não ser ele o segundo assaltante: entretanto, um dos assaltantes identificados na filmagem era justamente N., o tal parceiro no crime de Jeison, para quem ele teria emprestado um chip de celular encontrado no local do crime; o outro, coincidentemente, era seu homônimo, daí a investida violenta da polícia atrás dele. Marielen, cada vez mais escolada, inicia uma série de correrias para salvar o filho: vai à DIG - Delegacia de Investigação Geral conversar com o delegado e descobre que seu filho estava sendo acusado de diversos outros assaltos a mão armada na cidade; contata outras mães de bandidos para conseguir um advogado; articula a rede de apoios familiares para abrigar o filho foragido e, sobretudo, circula pelo bairro todo em busca de informações sobre o crime junto a outros ladrões e aos irmãos. Através deles ela descobre que este outro Jeison, um "irmão do PCC de fora do bairro", assim como N., havia saído de saidinha da prisão e não teria voltado, estando também foragido. E Marielen, inocentemente, tenta arregimentar meninos no bairro que se dispusessem a esclarecer o malentendido à polícia. Embora obviamente sem sucesso nessa investida, ao menos os grandões do bairro passaram a auxiliá-la não apenas com informações sobre tal Jeison, mas também sobre o caminho das pedras para conseguir livrar seu filho de 
pagar por um crime que ele efetivamente não havia cometido ${ }^{41}$ : a orientação foi que ela contratasse uma advogada indicada por eles e, enquanto esta reunia provas de que ele era inocente, o filho deveria se manter foragido.

Para tanto, Jeison (e consequentemente também Marielen) transitaria por diversos bairros da cidade: escondido inicialmente em um mocó e, depois, em casas de outros ladrões no próprio bairro, esteve, a seguir, no $\mathrm{CDHU}$, na casa do pai; no Antenor Garcia, na casa da avó paterna; no Cidade Aracy, na casa da tia paterna; passou pela cidade vizinha, Ibaté, na casa de uma tia materna, até conseguir asilo na casa de um parente, em uma vila de empregados de uma usina de cana na região.

De posse de informações inclusive sobre o local de moradia do rapaz que teria cometido o crime, bem como as obtidas acompanhando, junto a outros envolvidos no mundo do crime local, os vários assaltos que este Jeison homônimo seguia cometendo pela cidade, Marielen e a advogada apresentam à polícia tais informações, bem como a documentação que comprovaria a inocência de seu filho e convencem Jeison a se entregar: se, até então, ela temia que a polícia encontrasse seu filho antes que pudesse comprovar sua inocência, agora seu maior medo era que o outro Jeison ou outros bandidos do bairro onde ele morava suspeitassem que ela ou alguém de seu bairro o teriam denunciado, "senão a gente morre tudo". ${ }^{42}$

Aí, foi onde eu fui lá e falei tudo pro delegado quem era... Chegou lá, o meu filho desmentiu. Desmentiu, pra não ser acusado de cagueta. Foi chamado perante o delegado no dia que foi se entregar e falou assim: 'Você conhece o Jeison assim, assim? Meu filho falou: 'Não, nunca vi na frente.' O delegado falou: 'Mas como sua mãe conhece?' Meu filho ficou bravo comigo. Falei: 'Falo sim, pra defender meu filho, eu falo sim'. Mas ele negou! Porque senão ele não ia poder nem andar

41 Segundo Marielen e outras pessoas de seu círculo com as quais pude conversar durante o episódio, um dos motivos pelo qual os bandidões decidiram ajudá-lo, mesmo sem ele ser um integrante do PCC, foi o fato de o considerarem muito inocente, por nunca ter tirado cadeia, tendo apenas tirado FEBEM. (Aqui, uma observação: entre meus interlocutores, dos quais apenas o filho mais velho de Marielen era envolvido diretamente no mundo do crime, as unidades de internação da Fundação Casa eram sempre denominadas FEBEM, sob a expressão tirar FEBEM; nunca ouvi menção a essas instituições como cadeias, embora Marielen se referisse ao período da internação de Jeison como o período em que ele esteve preso. Para um estudo sobre as conexões entre as unidades da Fundação Casa e o sistema prisional do estado de São Paulo, recomendo a leitura de Mallart, 2011). De fato, uma situação ocorrida enquanto ele estava foragido parece atestar tal 'inocência': escondido na casa de uma tia no bairro Cidade Aracy, ele tirou uma foto com o sobrinho pequeno na rua, em frente à casa, e postou-a no Facebook; a polícia, que na invasão à casa de Marielen havia rastreado o computador usado por ele, obtendo senhas de seus perfis e e-mails, foi direto em direção ao local. O tio, que também é bandido e teria "contatos no mundo do crime e da polícia", ficou sabendo e correu para tirá-lo de lá, levando-o para outro lugar a tempo.

42 Os relatos de Marielen, de Jairo e as conversas que pude acompanhar entre eles e Jeison dão conta de uma territorialização simultaneamente definida e fluida do mundo do crime na cidade, na qual podem se articular, se sobrepor e até mesmo se embater certas delimitações por regiões, bairros, ruas, pedaços, mesmo que todas vinculadas à presença do PCC. Embora extremamente instigante, esta não foi uma temática aprofundada na pesquisa, atendo-me apenas aos efeitos dessa territorialização e do conhecimento dela na trajetória de Marielen, tratados a seguir. 
no bairro. Seria morto pelos irmão, por ter caguetado. (...) Daí, mesmo com as provas que não era ele, a filmagem, tudo, como ele desmentiu sobre o outro Jeison, se não fosse a dona de um dos estabelecimentos que esse cara tinha roubado, um posto de gasolina, descrever ele e confirmar que não era o meu Jeison, ele tava preso até hoje. Então as vítimas dos postos de gasolina, casas, pizzarias que ele tinha roubado foram tudo lá na delegacia, no terceiro DP e nenhuma reconheceu meu filho. Aí ele foi solto e, um tempo depois, pegaram o outro. Só daí eu voltei a dormir tranquila. [Marielen]

Acompanhar os trânsitos e mediações de Marielen neste episódio evidenciou aspectos sobre a escala da cidade: ela a atravessou de ponta a ponta, até a cidade vizinha, na montagem das redes de apoio e informação sobre o crime e de suporte à fuga de seu filho. Simultaneamente conversava com advogados, delegados e policiais, articulava suas redes de relações locais e extralocais, buscava apoio e informações junto ao mundo do crime e ainda mediava tudo isso com suas relações profissionais e vinculadas à religião. Tais mediações, que, desde então, se fariam cada vez mais frequentes na vida de Marielen (polícia, PCC, família, empregos, religião, vizinhança...), dão indícios do quanto essas esferas não são estanques, embora o trânsito por cada uma delas (e, sobretudo, entre elas) demande o conhecimento de certos códigos específicos, que ela foi tendo de aprender. Vale destacar que foi acompanhando esse episódio que passei a refletir sobre o aparente paradoxo entre a evidente melhoria nas condições de vida de Marielen ao longo dos anos, e especialmente na última década - o fato de ela ter uma casa, "não passar mais necessidade", ser relativamente bem de vida como ela e seu filho Jairo tantas vezes mencionaram, em comparação ao passado dela - , e a persistência (amplificada) de uma condição de vulnerabilidade social, da qual decorre uma instabilidade e uma insegurança que permeiam suas dinâmicas socioespaciais cotidianas.

A partir desse episódio, embora o fato de o filho ter sido inocentado tenha configurado uma vitória pessoal para ela, tanto perante os policiais que a desacreditaram ao longo de toda sua correria, quanto - e sobretudo - perante a vizinhança e os irmãos da igreja - "Foi acusado e comprovado que não é ele. Então, tipo assim, ele usa droga, mas ele nunca mais teve nenhuma passagem pela polícia. As pessoas vão ter que engolir isso." -, o envolvimento dele com o mundo do crime passou a ser cada vez mais naturalizado em sua narrativa e em seu cotidiano. Tendo saído ileso da situação e, sobretudo, sem caguetar, Jeison passou a ser considerado no bairro, aproximando-se efetivamente dos irmãos do $P C C$, embora não tivesse condições financeiras para tornar-se ele próprio um irmão $0^{43}$ : "O Jeison não é safado, então ele é considerado, ele tem crédito com os caras, porque ele cai mas não

43 Mallart (2011:178 - grifos no original) chama a atenção "para o fato de que os irmãos que encontram-se dentro e fora das cadeias do PCC contribuem com uma quantia mensal em dinheiro, que, entre outras coisas, possibilita a concessão de alguns benefícios aos presos que cumprem as suas penas em unidades prisionais do Partido". 
cagueta. Deus me livre e guarde dele matar alguém, que daí, pronto, aí ele vai ficar mais considerado entre os ladrão."

Tal aproximação, paradoxalmente, foi vista por Marielen como tendo algum benefício, já que, passando a seguir a conduta do PCC, Jeison deixou de ser violento em casa, com a família. Se até esse momento a casa era a base de onde o filho era repelido ou para onde era atraído - conforme as situações impelissem Marielen a preservar a casa e o restante da família -, sempre em idas e vindas entre a casa dela e a casa do pai, isso muda com a aproximação dele ao PCC: a presença de Jeison em casa passou a representar segurança para ela, para a família e para a casa, aspecto que Marielen por várias vezes enfatizou, embora sempre fazendo questão de destacar que considerar positiva essa segurança não significava que se orgulhasse dela.

\begin{abstract}
Tipo, depois dessa época que meu filho era violento, que eu mandei embora'some e não volta mais aqui, só quando melhorar' -, que a polícia ficou atrás dele, e aí o que aconteceu? Ele entrou no mundo do crime, envolveu no PCC, e no PCC tem regras, a família em primeiro lugar. Depois disso, não é que eu gostei, mas é que ele mudou com a família, naquele tempo ele era violento com a família, $e$ agora hoje em dia aqui na minha casa ele não é mais violento, ele chega aqui e fala pro Jairo: 'Me empresta a bicicleta.' O Jairo fala: 'não'. Ele fala: 'ah, seu folgado' e pronto. Antigamente, ele vinha aqui, agredia e tomava a bicicleta. Até então, mesmo depois que ele voltou pra cá, ele ficava indo e vindo da casa do pai, por causa das brigas aqui. Daí, depois que ele entrou pro mundo do crime mesmo, conheceu a fundo o PCC, daí melhorou com a família, que é uma regra que tem... / Thaís: Mas ele é do PCC? / Ele não é do PCC, ele só tem contato, porque, como ele não tem condições de pagar a mensalidade, ele não é. Mas ele é bem envolvido. (...) É por isso que agora a minha casa, a hora que você chegar o portão tá aberto. Minha casa passou a ter essa ajuda, assim, fica 24 horas com o portão aberto, não preciso me preocupar. Todo mundo fica abismado. Eu saio e deixo a chave lá, só tenho essa, perdi a outra. É um requisito, eles não vão roubar aqui. Ninguém vai entrar aqui. Outra casa qualquer, os portões tão fechados, porque os ladrão entra e leva a televisão. [Marielen]
\end{abstract}

Se, até então, sua narrativa apresentava de forma externalizada o mundo do crime e, sobretudo, as mães de bandido, progressivamente ela passa a apresentar-se como parte - ainda que involuntária - dessa realidade, ou, melhor dizendo, dessa condição, cuja naturalização, embora efetivamente presente em todos os bairros por onde circulei durante a pesquisa e nas narrativas de quase todos os interlocutores que dela participaram direta ou indiretamente, pude observar sendo gradativamente construída em seu cotidiano e em seus relatos, como forma de reconstruir-se e a suas dinâmicas socioespaciais perante a constatação - agora não mais passível de negação 
- de que o filho era mesmo um bandido. E ela, portanto, tornara-se mais uma "mãe de bandido" 44 .

O que eu vou falar pra você é meio chocante pra alguém que nunca ouviu, mas é uma realidade, é uma coisa tão normal que ninguém nem liga, porque no bairro todo mundo tem alguém envolvido no mundo do crime, nas drogas, então é uma coisa tão natural, tão comum, que você anda normalmente e ninguém nem te aponta, nem faz isso, entendeu? / Thaís: Entendi, tipo assim, foi só mais um? / Isso mesmo. Foi só mais um. Ninguém fica com medo, nem nada. Vou no mercado e a moça fala: 'E aí, o Jeison tá bem?' 'Tá'. 'A polícia tava atrás dele né?', porque é uma coisa comum, que não acontece só comigo. Acontece comigo, com a minha vizinha, com a vizinha do lado, com a vizinha da frente, pra você ter uma ideia. Minha vizinha do lado, o filho ficou preso, acusado de estuprar; a do outro lado, do lado direito, do seu Juca, o menino é preso, desde os quatorze anos é ladrão; na frente, a Marcela, o filho dela cresceu junto com o meu e virou traficante, saiu da cadeia a semana passada e já tá envolvido de novo; então, é uma coisa tão comum, que ninguém fica... Tipo assim, as pessoas fica com dó quando acontece, porque, que nem eu, parei de dar atenção pra quem tá ao meu redor, nem marido, nem outros filho, eu fico só em função daquele menino, daquele que tá com problema./ Thaís: $E$ as outras mães que você convive também? Cê percebe que é a mesma coisa? / Também, igualzinho. Esses dias a minha vizinha tava com problema, o marido dela falou: 'Poxa vida, ol ha essa casa como que tá.' Ela falou: 'Eu não faço mais nada, não faço comida, enquanto meu filho não sair da cadeia.' Quer dizer, não é só eu. É uma coisa tão comum, todo mundo vive ali. É sorte uma família que não tiver ninguém envolvido no mundo do crime no bairro. [Marielen]

E, se o esforço por minimizar o impacto da assunção dessa condição em sua vida e em sua casa fora frequente em seus relatos nos primeiros tempos da pesquisa, isso se alteraria com o cada vez maior envolvimento do filho nesse mundo e sua decorrente - e também crescente - autoidentificação com as mães do bairro (expressão muitas vezes usada como alternativa mais generalizante àquela mães de bandido, que passou a ser empregada por ela mais ao final da pesquisa), sobretudo ao passar a experimentar certos entraves que tal condição colocaria em termos das relações tecidas no bairro - dos quais o mais expressivo para ela foi o fato de antigas colegas deixarem de indicá-la para trabalhos, que sempre fora um dos grandes valores atribuídos por ela à rede de relações construída ali - e, especialmente, no âmbito da religião Testemunhas de Jeová.

Embora seu batismo na religião e o início de suas incursões a campo para pregações tenham sido praticamente concomitantes à internação de Jeison na Fundação Casa,

44 É interessante notar que a denominação mãe de bandido, tantas vezes mencionada por Marielen a partir de então, incorpora uma designação exterior ao crime - bandido - categoria construída, historicamente, por oposição a trabalhador, ao invés de adotar a designação interna a esse mundo ladrão - forma pela qual seu próprio filho e seus amigos se autodenominam, inclusive com orgulho de uma espécie de 'categoria', e que designaria de maneira genérica os envolvidos diretos no mundo do crime. Em glossário ao final do trabalho de Biondi (2009: 191), ladrão seria "quem se reconhece ou é reconhecido como fazendo parte do 'Crime', independente de sua especialidade criminosa". 
foi após a liberação e retorno definitivo do filho para sua casa (após a segunda temporada na casa do pai) que Marielen passou a protagonizar mediações entre seu envolvimento com o mundo do crime e as atividades vinculadas à religião. Até então, sua maior dificuldade fora conseguir driblar o próprio sofrimento por ter o filho preso e transmitir boas novas a mães que, muitas vezes, estavam na mesma situação que ela, ou ainda pior.

(...) como que eu iria falar uma palavra, dar as boas novas pras pessoas do mundo, se eu não tava com a cabeça boa de ir lá transmitir, né? Então, por exemplo, eu podia bater numa casa e ter uma mãe com problema igual o meu, tá com filho preso... Já me aconteceu de eu sair de casa, ir pregar, bater numa porta, e a moradora, eu ir ler um parágrafo da bíblia pra ela, levando as boas mensagens pra ela, quando ela falou do problema dela, eu não consegui terminar de falar, eu comecei a chorar, falei que tava passando mal, por quê? Eu tava com um problema igualzinho, eu não poderia estar ali. Então, eu tenho que esquecer, né, tentar esquecer as coisas que acontecem na minha casa, me concentro na bíblia e esqueço... A moradora tava com um filho preso, e o meu também, eu tinha acabado de voltar da Fundação Casa, num sábado, e fui pro campo pregar no domingo... quando eu cheguei na casa da moradora, a moradora 'ah, tô tão arrasada, fui visitar meu filho na cadeia, no cadeião, $e$ aquilo é um lugar carregado, eu tô abatida, que bom que você me trouxe boas notícias'. E aí, eu peguei e desabei, não consegui mais terminar... [Marielen]

Entre 2009 e 2012, a religião e o campo tornaram-se parte cada vez mais estrutural de seu cotidiano, realizando pregações de casa em casa e nas ruas do bairro Santa Felícia aos sábados, domingos e sempre que tinha algum tempo livre durante a semana. Pouco antes do episódio que resultaria no período em que Jeison ficou foragido, também Jairo seria batizado como Testemunha de Jeová e passaria a fazer o campo no bairro, tornando-se um jovem bastante atuante no Salão do Reino que frequentam. Esse fato, somado à perspectiva do filho do meio concluir os estudos e ter um projeto de futuro profissional (ele quer ser mecânico), tornou-se o grande esteio de Marielen não apenas perante a família e a vizinhança, mas principalmente perante a comunidade de irmãos: ele era a prova viva de que a culpa não era dela, de que sua família e sua casa não eram parte do mundo do crime.

De todo modo, esse período em que Jeison foi acusado e esteve procurado pela polícia foi o primeiro de muitos em que tal mediação se faria mais difícil: a cada rolo do filho, a cada período de correrias dela para tentar salvá-lo, quanto mais crescente se tornava o envolvimento dele - e dela - no mundo do crime, mais distante ela ficava das obrigações para com a igreja e do relacionamento com os irmãos.

Me afastei. Eu me afastei da igreja. Não ia nas reuniões. Eu ficava achando que, chegando lá, as pessoas ia cair matando em cima de mim... Então eu preferi me afastar... eu tive uma designação nesse período, eu devolvi, fui na casa do ancião e devolvi, falei que não tava com cabeça pra fazer aquela, é tipo uma prova, né? Não tava com cabeça pra fazer e fiquei, assim, uns quinze dias sem ir. De medo também, porque elas iam vim me perguntar, por curiosidade, como qualquer ser humano, ninguém é perfeito, e ia vim pra cima de mim me perguntar as coisas. 
E eu ia responder mal. Ou eu ia responder mal, ou eles iam me magoar, igual aquela mulher falou, lembra? Que eu fui visitar meu filho e ela falou: 'Mas com o seu dinheiro você foi? Eu não iria jamais'. Teve outro, também, que me falou uma vez, que aconteça o que acontecer, era pra mim tá dentro do salão, tinha que deixar meus problemas de lado. Só que, como o filho é meu, sou eu que sei, sou eu que sofro. Não tinha como eu tá dentro do salão, com o meu filho foragido lá pro meio do mato, me ligando toda hora: 'Ô mãe, a polícia tá rondando aqui!' Então, eu preferi abaixar um pouco, pra mim poder voltar sossegada. / Thaís: Depois dessa história? [em que o filho esteve foragido] / Isso, tipo assim, quando eu voltei a ir, tipo que eu meio fugia. Eu era a última a chegar e a primeira a sair pra não conversar com ninguém. Eu chegava quando todos já estavam sentados. Sentava, ouvia a reunião, e aí, antes de acabar, cinco minutos antes, eu saía. Porque eu não queria conversa. Eu não queria falar sobre esse assunto. Só que, como era um assunto muito frequente, como eles não são perfeitos, eles iam falar alguma coisa e eu não queria falar. As pessoas vinham falar mal dos bandido perto de mim, e eu já sabia que era indireta, que tava falando pra mim. Então pra não brigar eu me afastei. Parei até de ir no campo. [Marielen]

Assim, enquanto no Salão do Reino que Marielen frequenta apenas ela e mais uma outra mãe enfrentam esse problema ${ }^{45}$, no pequeno território que delimita o que ela considera propriamente o seu bairro, "cada esquina tem uma mãe com um filho preso", o que reforçaria o processo de valorização dessa rede de relações das mães do bairro, que ela distingue como sendo suas amizades do mundo (e mundo, aqui, expressa efetivamente o caráter mundano dessas amizades, em contraponto àquelas estabelecidas com os irmãos do reino $)^{46}$. De fato, tratar-se-ia de mais uma transformação nas relações de vizinhança tecidas ao longo dos mais de dez anos, desde que ela se mudou para a casa cedida pela antiga patroa: se, inicialmente, Marielen fora renegada pela vizinhança do seu bairro, e após casar e virar Testemunha de Jeová, ela passou a ser aceita, mas construiu relações mais

45 Nesse sentido, é interessante observar que a localização desse Salão do Reino, embora situado no Santa Felícia, encontra-se numa interface entre dois territórios bastante distintos socialmente (Planalto Paraíso e Santa Felícia). Marielen, por diversas vezes, destacou a presença de pessoas gente fina em sua congregação, em comparação ao fato de que, em sua rua, por exemplo, apenas ela pertencia à congregação, sendo poucos os irmãos da igreja moradores do seu bairro propriamente dito. Interessa, ainda, destacar percepção de Jairo sobre o fato de serem praticamente a única família com tal problema na congregação de que fazem parte: "Lá dentro da igreja não tem ninguém na nossa situação [com um membro da família envolvido no mundo do crime], talvez tenha mais um só, mas fora tem bastante, né? É só ver aqui no bairro. / Thaís: E por que você acha que dentro da igreja tem pouco? / Ah, porque a maioria de hoje, assim, que a gente tá numa parte mais avançada, assim, que antes era a pessoa mais de antigamente que... uma pessoa que antes, quando começou [a frequentar a igreja], vamos supor, tinha uns 20 anos, hoje ela já tem 40, tem filhos, então os filhos deles já nascem dentro da igreja, então eles já não têm esse contato [com o mundo do crime]. Que nem, eu já não nasci dentro da religião, eu vim de fora pra dentro, então eu já conheço mais do mundo, por assim dizer. Então acho que é por isso. Mas tem casos, sim, que podem ter [um filho envolvido no mundo do crime], mas aqui, na nossa congregação, praticamente não tem".

46 Como também notou Feltran (2011), é curioso como há um léxico do mundo do crime que se aproxima daquele adotado por algumas religiões, sobretudo as neopentecostais - mas aqui também identificado entre os Testemunhas de Jeová (irmãos, mundo). Por vezes, nos encontros com Marielen, era necessário um esforço extra de compreensão, justamente por ela encontrar-se nessa mediação entre mundos. 
aprofundadas sobretudo com pessoas da mesma religião, será com a assunção do ingresso do filho no mundo do crime que ela reconstruirá sua rede de relações com muitas daquelas mulheres da vizinhança que a excluíram quando de sua chegada ao bairro e que foram, como Marielen, transformando-se, elas próprias, nessas mães do bairro, à medida que os filhos de uma ou de outra foram entrando nesse mundo.

O contraponto (frequente nas narrativas e no cotidiano de Marielen) entre os dois coletivos - os irmãos da igreja e as mães do bairro - expressa sua própria condição de "figura de fronteira" ${ }^{47}$, variando seu pendor a cada um deles conforme as situações viessem a exigir ${ }^{48}$. Com o cada vez mais crescente envolvimento do filho no mundo do crime, as mães do bairro se tornariam sua principal referência:

Mas também, que ajuda eles [os irmãos da igreja] poderiam me dar, né? Se eu pedisse pra me levarem na delegacia, ou coisa assim, eles até levariam, mas eu prefiro pedir pra outras pessoas, minhas amigas do mundo. Então não tem outro tipo de ajuda pra uma coisa que é frequente, tá toda hora acontecendo na minha vida. Só quem tá na mesma situação mesmo pra entender e apoiar. Porque quem sofre mesmo é a mãe, quem corre atrás é a mãe. [Marielen]

\section{- Saberes e lógicas territoriais}

De fato, as correrias envolvendo cuidados com o filho mais velho tornam-se parte significativa das dinâmicas cotidianas de Marielen em seu próprio bairro, Romeu Tortorelli, mas também no Santa Felícia como um todo. Se, por um lado, o envolvimento do filho com o mundo do crime foi transformando suas redes de relações na vizinhança e na igreja, simultaneamente, foi impulsionando-a a construir um novo repertório de mediações no entorno desse mundo, nas quais vai ficando cada vez mais experiente.

Eu não me envolvo com eles, mas eu faço as correrias pra ajudar meu filho. Porque meu filho já correu perigo de risco de vida, e, então, eu fui obrigada a me envolver, não é porque eu gosto, não. Eu fui obrigada a me envolver, pra salvar o meu filho. (...) Mas eu sou uma mãe consciente. Eu não fico falando que meu

47 Foote-Whyte (2005).

48 Vale lembrar, por exemplo, o período em que Jeison esteve morando com o pai, após o cumprimento da internação na Fundação Casa, quando tal contraponto se expressava nos termos irmãos da igreja e vizinhança, com claro pendor para o primeiro, entre os quais ela afirmava estar tecendo redes de apoio nunca conquistadas junto à vizinhança, sobretudo no cuidado com a filha mais nova. Outro aspecto interessante a ressaltar, nesse sentido, diz respeito à mediação inversa, a partir de sua proximidade ao mundo do crime em direção à religião: "Acontece direto: eu tô no campo, pregando as boas novas, aí eu tô na rua, no meu bairro mesmo, aí ali, debaixo de uma árvore, tem um monte de menino usando droga, embrulhando, e nesse meio tá lá quem? Meu filho, que que eu faço? Eu não passo reto; eu dou tchau, 'oi', eles falam 'ó lá a mãe do Jeison'. Porque, tipo assim, eu sou considerada, eu sou considerada, assim, entendeu? Na verdade, tem muitas mulheres igual eu, né? Eu não sou a única; tem muitas mães que tem religião e os filhos no mundo do crime, o que elas fazem? Elas ora pros filhos dela. Às vezes, quem tá pregando comigo acha meio estranho, fica com medo; mas eu já tô tão acostumada, que até esqueço que tô com alguém que não conhece esse mundo". 
filho é coitadinho. Se eu fico sabendo de um rolo, eu vou atrás, vou falar com quem precisar, com bandido, com quem for, pra saber o que tá acontecendo. $E$ se a polícia pega ele, eu vou atrás, mesmo se ele for culpado. Não existe uma mãe que não vai. Eu não conheço. [Marielen]

Ao longo dos dois anos em que pude acompanhar as trajetórias dela e de sua família, foram inúmeras as correrias em que ela se envolveu, circulando entre delegacias, mocós, bocas, bares, no próprio bairro ou fora dele, com a mesma desenvoltura com que pregava as boas novas no campo ao menos três vezes por semana. Nem sempre as situações estavam diretamente ligadas ao mundo do crime, mas o fato de o filho ser envolvido possibilitava a ela fazer uso das relações estabelecidas e dos códigos aprendidos a partir desse envolvimento, como nos casos em que Jeison se metia em brigas violentas no bairro por conta da namorada: com medo que o filho tivesse o mesmo destino de seu irmão, até nessas situações ela passou a se envolver, como narrado no trecho abaixo.

Tem casos que não tem como o PCC interceder, como nas brigas do meu filho por causa da namorada. E rolo com mulher é morte na certa. Nem a droga nem nada não mata que nem isso daí. Eu rondei o bairro inteiro atrás do cara. Achei. Fui eu e o $X$, ele é traficante, um cara bem considerado no bairro, entre os bandidos. Que agora eu só vou acompanhada, porque uma vez eu fui sozinha e quase me dei mal. Aí, cheguei no bar, fui falar com o cara que tava ameaçando meu filho e a versão dele era que meu filho que tinha encanado, que ninguém tinha mexido com a periguete dele! Então, nesse caso, não posso apelar pro crime, porque meu filho tá errado. Agora, se eles tivessem falado alguma coisa pra ela, mexido com ela, eu podia ir lá falar com os irmãos, pra proteger ele. Tive que resolver sozinha: falei que meu filho tem distúrbio bipolar e tudo, no fim, o cara até me convidou pra tomar uma cerveja (risos). [Marielen]

A vida do filho foi muitas vezes preservada pelas mediações de Marielen ${ }^{49}$, tanto junto à polícia, quanto aos bandidos, ou, em casos como esse, de "rolos por causa de mulher". Nas narrativas sobre essas situações, é como se ela buscasse sempre recuperar uma dimensão de humanidade do filho, ao interceder pela vida dele. Inserida em novas redes - ou com uma nova inserção em antigas, como visto - estas são mobilizadas não apenas como redes de apoio, mas, em grande medida, como redes de informações ${ }^{50}$ : uma vizinha casada com um traficante grandão da cidade; a

49 Conforme destacado anteriormente, esta mãe, que no início oscila entre acolher o filho desgarrado ou relegá-lo ao pai, acaba por incorporar o papel da mãe que protege, que faz de tudo para salvar o filho bandido, convertendo-se no personagem venerado (a já mencionada concepção da mãe como figura quase sacralizada, cf. nota 39). Em contraponto, o marido não se envolve, e ela também evita envolvê-lo, por medo de que lhe aconteça algo: "O João não se envolve. No máximo, eu deixo a Roberta com ele e vou atrás. Não quero que depois ele também apareça morto por ter se envolvido".

50 Fonseca (2004) já alertara para a importância da fofoca como forma de comunicação nas camadas populares. Entretanto, ainda que a intensa circulação de informação entre os pares seja essencial na vida cotidiana local - e especialmente destacada por Marielen, em função de sua condição de mãe de bandido, para quem toda informação sobre o que se passa em seu território é considerada útil -, também o universo dos noticiários policiais online ou no rádio foi encontrado como uma das fontes 
amiga sobrinha de uma bandida considerada da região; a cunhada que namora um policial; a cabelereira que tem "os dois lados na família, cinco tio é da polícia e quatro do mundo do crime"; a colega que tem o filho preso há muito tempo e já é mais experiente.

Então, agora [que o filho é do mundo do crime], elas contam tudo pra mim. Uma fala pra outra, vai atualizando. Aífala assim: 'Cê ficou sabendo que o fulano virou irmão?', vou lá comprar uma calcinha: 'Cê ficou sabendo que...?' 'Não.' 'Virou, nossa, eu odeio aquele cara, sabe o que ele fez?' Cê entendeu? É assim. Vende uma lingerie, vende um Avon, cê vai na casa, é assim que a gente sabe. Então, uma tá sempre contando pra outra. Uma fala: 'Ó Ma, fica esperta que o Jeison tá envolvido com não sei o quê, porque fulano me falou'; a outra fala: 'olha, eu vou te contar uma coisa, viu Ma, meu tio me falou que seu filho tá devendo pra ele. Ele tá devendo pro meu tio, hein?! Meu tio tá bravo!' É assim que fico sabendo de tudo, mesmo quando ele não me conta. [Marielen]

O acesso privilegiado a certas informações facilita essas correrias empreendidas pela mãe, e, na prática quase cotidiana desses trânsitos e mediações, Marielen vai construindo uma espécie de rol de 'saberes's1 necessários para exercê-las. Nesse sentido, sua vinculação a um determinado território (o bairro Santa Felícia e, mais especificamente, o seu bairro Romeu Tortorelli) se apresenta como um valor fundamental, que, mais uma vez, remete àquelas categorias êmicas ser conhecido e ter conhecimento. Comentando sobre a possibilidade de o filho mais novo ir morar, uma temporada, na casa da irmã, "em um lugar onde ninguém conhece ele, ele não conhece ninguém" e que, por conta disso, "poderia acontecer qualquer coisa a ele", ela reafirma tal valor associado tanto ao bairro de modo geral, quanto a seu bairro: "aqui eu já conheço todo mundo, todo mundo me conhece, meus filhos podem estudar em qualquer escola sem medo, a gente pode andar tranquilo no bairro". Reforça-se, dessa perspectiva, aquela dimensão que associa tais categorias à ideia de segurança e proteção em um determinado território ${ }^{52}$, e que, se é um valor fundamental destacado por aqueles sem envolvimento direto com o mundo do crime (como Jimmy e Jefferson, nos capítulos anteriores), mostra-se ainda mais fundamental no caso de Marielen, como mãe de bandido. Ela sintetiza na expressão

de informação mais recorrentes entre meus interlocutores (mesmo aqueles sem envolvimento nenhum com o mundo do crime), que os acompanham avidamente.

51 Essa formulação sobre certos 'saberes' que se construiriam a partir de determinadas experiências urbanas inspira-se na concepção de "competências circulatórias" desenvolvida por Tarrius (2002) para caracterizar os saberes necessários aos "novos nômades da economia subterrânea". Ver também Telles (2009; 2013:367): "Os indivíduos (e suas famílias) transitam nas fronteiras do legal e do ilegal, sabem lidar com os códigos e recursos de ambos os lados, mobilizando os critérios, sempre situados e sempre contextualizados, pelos quais se negociam os parâmetros de aceitabilidade moral de práticas, comportamentos e escolhas da vida."

52 Que pode ser o bairro, o seu bairro, a vizinhança, ou, ainda, outras delimitações socioespaciais e simbólicas que remetem à ideia de "localidade" (Leeds, 1978; Alvito, 1996) ou de "pedaço" (Magnani, 1984, 2002). Cf. abordado anteriormente no Capítulo 1 (mais especificamente nota 51) e Capítulo 2 (nota 47). 
"aqui todo mundo me conhece, sabe minha índole" a importância de tais conhecimentos e reconhecimentos tanto na relação com seus pares, de modo geral, quanto na relação específica com o mundo do crime: sua índole, de um lado, remete à sua identidade de trabalhadora, de "mãe que sempre batalhou pelos filhos", de Testemunha de Jeová; por outro, remete à dimensão de confiabilidade perante os bandidos, associada à previsibilidade de suas ações como mãe guerreira, que é humilde e respeita os envolvidos e os códigos e moralidades inerentes a esse mundo ${ }^{53}$.

Logo que a conheci, Marielen destacava certos 'saberes' como sendo comuns aos moradores do seu bairro de um modo geral, apresentados por ela quase como um efeito colateral do fato de viverem em um "bairro movimentado", que ela traduzia na expressão, frequentemente utilizada, "todo mundo sabe": quais famílias têm envolvidos, quais casas são de bandidos ou onde se localizam algumas bocas estariam entre tais 'saberes' comuns sobre certas dinâmicas e territorialidades locais do mundo do crime.

Todo mundo sabe. Porque sempre onde tem uma boca, você vai ver três, quatro, saindo e descendo, saindo e entrando o dia inteiro. Agora tem a Boca do X. Tipo assim, eles nunca ficam dentro da casa trancado, fica um lá dentro da casa, e o outro lá fora, como se fosse uma sentinela. Entendeu? Assim, olhando, vendo o movimento... E aí, pelo movimento, todo mundo sabe, por exemplo, que os nóia vai ali. Todo mundo sabe. / Thaís: Sabe pelo movimento? / O movimento. Do lado da casa da Clotilde tem uma boca que vende só craque. Ali o movimento é direto, dia e noite, noite e dia. Então, todos no bairro sabem, todo mundo sabe. Ah, a gente sabe! Tipo assim, o movimento, a casa. Na rua da casa da Paulete tem um, como que ela sabe que ali é uma boca? Porque ali é um entra e sai de gente dia e noite, todo dia, toda hora. Três horas da manhã, chamando, batendo palma, entendeu? É assim que as pessoas sabe. Porque numa casa não tem tanto movimento de tanta gente diferente, de bicicleta, descalço, rasgado. É assim que cê vê o movimento. Porque chega gente de todo tipo. Então, se eu sou vizinha de um traficante, como que eu não vou saber? Faz de conta, se ali não para de sair gente, dia e noite, noite e dia, toda hora. É assim que a gente sabe. [Marielen]

Faço aqui um parêntese para retomar as concepções de bairro movimentado, de movimento, que foram bastante recorrentes em campo, designando, simultaneamente, dinâmicas socioespaciais distintas, como já introduzido nos capítulos anteriores. De um lado, a ideia de movimento refere-se às dinâmicas do tráfico de drogas, não apenas aquelas vinculadas ao entorno imediato das bocas, como Marielen descreve no trecho anterior, mas a uma presença significativa do tráfico, do mundo do crime num determinado território, do qual a faceta mais visível

53 Lyra (2010:157) aponta, a partir da perspectiva dos "garotos armados do morro", a distinção que se opera entre "moradores antigos", sobretudo os "nascidos e criados" ("crias") em um determinado território, e os "novos moradores", ancorada na ideia de uma "mediação pela confiança": "Trata-se da valorização e mesmo da necessidade de relações sociais estáveis que possam exprimir algum grau de previsibilidade baseado em uma expectativa de confiança". 
seria a constante presença de meninos envolvidos na rua, nas esquinas, a circular pelo bairro dia e noite. ${ }^{54}$ Entre meus interlocutores, tal movimento foi, em geral, valorado negativamente, sobretudo pelo fato de que, onde este é mais intenso (como no caso do bairro de Marielen), a presença policial também seria.

Como aqui é um bairro movimentado, como eu te falei, movimentado do mundo do crime, muitas bocas de droga, então a polícia passa todos os dias, não tem um único dia que a polícia não passa de dia, e à noite a força tática tá rondando, por causa do movimento, das muitas bocas. [Marielen]

De outro lado, há o movimento referente ao cotidiano corriqueiro do bairro, que Marielen (como também Jimmy, Jefferson e diversos outros interlocutores) tanto valoriza e que a faz gostar muito de seu bairro: são as pessoas nas ruas, a conversa entre vizinhos, a troca de informações entre colegas, os encontros rotineiros. A essa ideia de movimento ainda se associa a possibilidade de circular pelo bairro para suprir demandas cotidianas - ida a um sacolão, uma farmácia, uma costureira - e também, nesses deslocamentos cotidianos, estabelecer essas trocas sociais que animam a vida local.

O bairro não é um lugar tipo assim o Planalto, que tá todo mundo lá trancado. Quando chega agora à tarde, você pode pegar por experiência própria, quando dá 6 horas, tá todo mundo sentado na porta. Vai tá todo mundo ali, minha vizinha ali no banco; ali em cima, perto da arvrinha vai tá cheio... eu vou sentar ali, daqui a pouco, eu não fico aqui, eu fico sentadinha ali. Então, não tem como, você se envolve, os vizinhos. Ah, a gente fica tudo ali sentado... conversando, né? Fofocando: 'ah, você não viu?' (risos). Aí, quando você não vem, você não vai lá, as vizinhas lá de cima vêm te chamar, 'o Má, a gente tá aqui na rodinha, você não vai vir?' 'Ai, tô fazendo serviço, não sei o quê', você entendeu? O que é a rodinha? É a conversa do dia-a-dia, 'hoje minha patroa fez isso...', entendeu? Então, não é um lugar tipo Santa Marta ${ }^{55}$, que todo mundo fica dentro da sua casa. Eu e minhas colega, a gente sempre comenta: 'bairro de rico é chato, né, muito parado, não tem ninguém na rua. Só tem casa bonita, mas não tem gente na rua, não tem comércio, credo, que chatice, ninguém sai de casa!' Porque no meu bairro, logo às sete da manhã, quando a gente tá saindo pro serviço, o pessoal já tá na rua, no sacolão, todo mundo já se encontra. Nos bairros, deu

54 Em ambas as concepções de movimento, mas sobretudo naquela vinculada à presença do tráfico, a escala de cada bairro popular parece fazer diferença em termos de sua concentração: tanto o Romeu Tortorelli, quanto outros bairros recorrentemente mencionados como "movimentados do mundo do crime" por meus interlocutores (Jardim Gonzaga, Antenor Garcia ou Santa Angelina, para citar alguns) foram sempre associados à sua escala mais diminuta (o que, se facilita a concentração do movimento, também facilita as investidas territorializadas da polícia), aí incluídos conjuntos habitacionais. Por outro lado, bairros mais amplos, como Cidade Aracy, facilitariam uma desconcentração, havendo pedaços mais ou menos movimentados, gerando inclusive diferenciações internas significativas entre os moradores de cada um de tais pedaços (ainda que, genericamente, toda a região da Grande Cidade Aracy seja associada a esse movimento). Tais concepções parecem ser fundamentais na conformação de sistemas de classificação socioespaciais entre as camadas populares, tema abordado no Entremeio III.

55 Ela se refere a bairros de classe média alta, situados relativamente próximos ao Santa Felícia. 
cinco horas, todos os bairros ${ }^{56}$, todo mundo fica lá, seis horas... Ainda mais com esse horário agora, fica todo mundo ali, fica cheio! De sábado, então, você vai dar sorte, porque fica todo mundo ali sentado. [Marielen]

A ideia de que existiriam, entre os moradores de bairros populares onde o tráfico de drogas tem maior capilaridade, 'saberes' comuns sobre certas dinâmicas e territorialidades locais do mundo do crime vincula-se, portanto, a essa dupla acepção de movimento: de um lado, remete àquela noção de "expansão do mundo do crime" e seu imbricamento a outras esferas legítimas do mundo social ${ }^{57}$; de outro, decorre do mecanismo da fofoca ${ }^{58}$, como principal meio de troca de informações em tais bairros, por onde tais 'saberes' comuns se fazem e circulam.

Assim, se o fato de viverem em um bairro movimentado faria com que, inevitavelmente, os moradores partilhassem de certos 'saberes comuns', as narrativas de Marielen evidenciam que, com o passar do tempo e o maior envolvimento de seu filho com o mundo do crime, a partir do qual ela própria passou a se considerar uma envolvida (embora sempre destacando que de forma indireta) ${ }^{59}$, seus 'saberes' foram se diferenciando daqueles de parte das pessoas com quem costumava conviver ${ }^{60}$, sobretudo os irmãos da igreja, mas também diversas colegas de serviço do bairro ou pessoas da vizinhança: "Não é todo mundo que sabe. Só sabe

56 É interessante notar que, para ela, como para a maioria de meus interlocutores, bairros são somente os bairros populares, onde esse movimento do cotidiano estaria presente; ou seja, por esse viés, um bairro só se configuraria a partir de tal movimento, o que excluiria dessa categoria os locais de moradia das classes médias e altas, que, por serem lugares parados (ou seja, sem uma dinâmica cotidiana de interação entre os moradores e destes com o próprio espaço local) não conformariam a dimensão simbólica que configura um bairro nessa perspectiva.

57 Feltran (2011).

58 Fonseca (2004).

59 Marielen faz sempre questão de frisar que haveria envolvidas e envolvidas: ela frequentemente contava histórias de outras mães de bandido que aceitam o dinheiro trazido pelo filho, que sabem que o filho guarda drogas em casa, "tem muita faxineira que nem eu que acaba até traficando também", para se diferenciar e destacar que seu envolvimento é sempre indireto, visando a preservar a vida do filho. Talvez por isso sua obsessão em se manter sempre com vários empregos, mesmo sem tanta necessidade financeira: além da expectativa de que, com os recursos da mãe, o filho ao menos diminuísse a intensidade de crimes, há também o esforço hercúleo em manter sua identidade de trabalhadora e Testemunha de Jeová preservada minimamente.

60 Com Galdeano (2013), é possível perceber que relação e contato com tráfico, crime e violência são diferenciados conforme engajamentos sociais e relações privadas e produzem, nesse sentido, efeitos diferenciados nas trajetórias e dinâmicas socioespaciais que os configuram, como visto a partir das analisadas em profundidade nesta tese. Lyra (2010) também chama a atenção para o fato de que os moradores podem adotar distintas posturas perante a presença da facção nas favelas no Rio de Janeiro (embora em todas elas haja a expectativa do correto proceder de não delatar, que se configuraria na já mencionada "lei do silêncio", a que o autor associa o "silêncio da lei"): "o morador pode solicitar a ajuda da boca ou pode manter relações apenas formais com seus membros, pode até mesmo ignorar sua presença na comunidade, mas não pode nunca vir a se tornar o último e mais intolerável arquétipo local, traidor do pacto e da própria comunidade: o x-9 [nas periferias paulistas o equivalente a cagueta]". 
quem tem filho ou alguém envolvido. Igual, eu tenho um filho envolvido; pra salvar meu filho, eu não sabia o que fazer, tive que aprender". ${ }^{61}$

Igual a Joana, roubaram a casa da Joana. Foi um nóia. A Joana não foi lá no traficante falar, ela não se informou, ela não foi procurar, nada disso. Então ficou por isso mesmo. Agora, tipo assim, se ela fosse procurar um grandão, levasse o caso ao tribunal do crime, aí nunca... eles iam sofrer uma punição e nunca mais roubaria lá. É que nem do lado dela também, no vizinho, o vizinho falou que roubaram o postinho de luz da casa dele várias vezes, ele coloca os fios, e eles roubam. Só que ele nunca tem o acesso a ir diretamente ao tribunal do crime, ao traficantão, pra pedir ajuda, porque ele não quer se envolver, ninguém se envolve. Assim, rouba e fica por isso mesmo. / Thaís: Entendi. Mas essas pessoas saberiam a quem recorrer? / Então, eu sei, porque tive que me envolver por causa do meu filho, agora, não sei se eles sabem, acho que não. Teria como saber, mas eles não querem, porque não são envolvidos e não querem se envolver. Geralmente, as pessoas que são roubadas, tipo assim, a Joana, o Jeison falou pra mim que os meninos tavam errado lá, porque roubou do lado de uma boca lá, né? Ela teria que ir falar com o irmão, podia até levar o caso ao tribunal do crime, que são mais de dez. É uma roda. / Thaís: Mas como que funciona isso, cê sabe? /Sei. É um tribunal. Igual aos juízes. / Thaís: Mas e aí, onde ela teria que ir? / Ela teria que ir diretamente a um traficante grande do bairro, que chama irmão. Então, tipo assim, lá no bairro, eu sei que tem dois que comandam ali. Ali do lado da Joana, era o X., só que o traficante jamais vai bater lá e falar assim: 'Ah, cê foi roubada?' Não, a pessoa que tem que ir procurar. Porque não é um tribunal da justiça, é um tribunal do crime. / Thaís: Entendi, eles teriam que ir lá falar com o irmão... / Isso, daí talvez iam montar o tribunal, com outros irmãos. Aí um julga, um dá ideia, o outro dá outra, é assim. Mas acontece que quem não tá envolvido de algum jeito, não sabe a quem recorrer, o que tem que fazer. Muitas vezes, também, não têm coragem de ir até um traficante. E não querem se envolver. Eu tô envolvida por causa do meu filho, por isso que eu sei. [Marielen]

O conhecimento das diversas posições no mundo do crime, de quem é ou não é irmão do PCC, de quais são os envolvidos mais ou menos considerados, de quais comandam o bairro, da existência de um tribunal do crime ou, ainda mais, da perspectiva de recorrer a ele, de quais são as bocas que pagam propina aos policiais e quem são esses policiais, são alguns destes 'saberes' diferenciados sobre o que ela denomina "o outro lado da vida do bairro": ainda que se possa questionar seu grau de veracidade, ou mesmo sua amplitude em comparação aos 'saberes' dos envolvidos diretos no mundo do crime (como seu próprio filho), é inegável que ter acesso a esse tipo de informação tornou-se essencial na experiência urbana de Marielen.

Nesse repertório de práticas e saberes que a auxiliam a lidar de perto com as dinâmicas e regras do mundo do crime, destaca-se a habilidade desenvolvida para

61 Vale destacar que nem todas as "mães que tem filho no mundo do crime" se envolvem como Marielen, nem adquirem tais 'saberes' aqui explorados analiticamente; inclusive nisso reside o interesse em sua trajetória. O trabalho de Feltran (2011), embora tenha enfocado trajetórias de adolescentes e jovens das periferias urbanas, oferece indiretamente um panorama das diferentes reações - e relações - das mães perante o envolvimento dos filhos no mundo do crime. 
dialogar com bandidos $^{62}$ e policiais, conforme a ocasião. Da relação com estes últimos, viu-se obrigada a aprender sobre o Código Penal e incorporou aos documentos pessoais as notas fiscais de todo objeto de valor adquirido, de modo a poder comprovar, a qualquer abordagem (na rua ou em casa), que não seriam roubados.

Hoje eu tô tão envolvida por causa do meu filho, que sei tudo os artigos dos crimes, antes eu não sabia, eu achei que roubava era tudo igual, mas não, tem 157, 155, 33. / Thaís: Você precisou aprender? / Eu aprendi indo na delegacia, chegava lá, o doutor falava: 'ó, seu filho tá enquadrado no 155, no 157', aí ele me explicava qual era a diferença de um pro outro. Fui aprendendo. [Marielen]

Isso foi outra coisa que eu aprendi, que eu não acho legal, mas, como eu tenho esse filho com esses problemas, sempre que eu compro alguma coisa, eu guardo a notinha, eu já te mostrei, né? Pra polícia não chegar lá e levar, porque, até eu ir lá no juiz, e o juiz liberar, dá muito trabalho pra mim. Já passei por isso, ir lá no fórum, no juiz. Então, como eu tenho esse filho assim, sempre quando eu tenho uma coisa, eu tenho a notinha. Se eu tenho computador, eu tenho a nota; se eu tenho um rádio, eu tenho a nota, tudo. Porque até meu pagamento me levaram uma vez, que eu não era registrada e não tinha como provar. [Marielen]

É algo realmente significativo o seu conhecimento dos sistemas de assistência e repressão, manifesto não apenas em termos de seus funcionamentos institucionais, mas principalmente num tipo de saber mais palpável (e aqui novamente a escala da cidade faz diferença), como conhecer pelo nome policiais, psicólogos, assistentes sociais, delegados envolvidos com as questões do crime e violência na cidade (bem

62 Foram diversos os relatos, como alguns já apresentados anteriormente, de suas mediações junto aos bandidos. Uma, em especial, chamou-me a atenção, por ter sido observada já mais ao final da pesquisa de campo, quando ela apresentava seus 'saberes' à irmã: esta a procurou para contar que o filho estava sendo ameaçado no Cidade Aracy II, por ter desdenhado de uma bicicleta roubada que um traficante lhe oferecera para comprar, dando-lhe uma resposta atravessada: "eu não, vou comprar bicicleta roubada, de ladrão? Sai fora". Marielen esclareceu a ela que o menino não teria tido um proceder correto: "tem que saber falar com esse pessoal, não dá pra falar desse jeito... tem que falar 'tô sem dinheiro agora, não quero, obrigada'... Tratar normal, na humildade, com respeito'. Ela, então, sugeriu que a irmã procurasse um irmão do PCC para interceder pelo menino. Quando a irmã se foi, ela comentou comigo: "Minha irmã não é que nem eu, que vou atrás de tudo, quero saber o que aconteceu, falo com o chefão e, se for preciso, levo até pra debate". Pouco tempo depois, ela telefonaria à irmã, para incitá-la a fazer isso: "vai deixar o menino morrer? O que tá morrendo de gente no Aracy, de molecada... temos que achar outro do PCC pra interceder por ele. Isso já aconteceu com o Jeison eu fiz isso. Eu posso te ajudar, eu conheço um monte de gente do PCC". Em seguida, ela aproveitaria para comentar que "lá no Aracy, a coisa não tá mais tão organizada como aqui, que não tem mais morte. Os que tão no comando lá não tão dando conta", o que tornaria ainda mais valiosos seus 'saberes': "por qualquer coisa já sai morte, tem que saber como lidar com eles, como andar por ali, com quem falar". Com relação ao enfraquecimento da atuação do PCC no Cidade Aracy II, Jefferson já mencionara tal situação e também Jimmy comentara, na mesma época, algo parecido em relação ao Antenor Garcia, indícios de que talvez se tratasse do "fenômeno recente nas periferias das cidades paulistas", analisado por Biondi (2011), "as quebradas largadas": "Com essa expressão, meus interlocutores se referem a uma sensação de desordem e abandono proporcionada pela ausência, inatividade ou falta de efetividade das ações do PCC em suas regiões. E esse fenômeno, ainda de acordo com os relatos colhidos em trabalho de campo, se daria em função, entre outras coisas, da presença do Estado nessas regiões." 
como os perfis profissionais e pessoais de cada um deles - um atende melhor as mães, outro acha que mãe de bandido também é bandida etc.), que faz toda a diferença nas mediações corpo a corpo em que ela foi se tornando experiente $n a$ marra.

Quando eu passo do lado da polícia eu passo até de cabeça erguida, porque eu tô com a minha bolsa limpa, não tenho droga, não tenho nada. E quando eu vou, você mesmo acabou de ter a experiência que eu acabei de entrar numa boca de droga, quando eu entrei lá, eu entrei com medo? Não, eu fui lá e chamei a pessoa, porque eu me sinto livre, porque eu não devo nada. / Thaís: Mas esse conhecimento que você tá me contando, de saber onde procurar, onde resolver, te ajuda em alguma coisa? / Me ajuda tipo assim, se meu filho tiver um problema com os bandidos, né? Aí eu vou falar lá com o tribunal do crime, porque a polícia não adianta nada. Aí, se ele for preso, eu vou falar com quem? Né? Com o delegado tal, eu já sei qual delegado é mais bonzinho, qual não é, aquele que dá mais clemência, tem um que nem prende, entendeu? Eu sei. [Marielen]

E, uma vez que esses trânsitos e mediações se tornaram parte de suas dinâmicas socioespaciais cotidianas, tais saberes deles decorrentes (e a eles indispensáveis) incluem toda uma apreensão de diversas territorialidades locais e extralocais configuradas pelo mundo do crime, cujo domínio acaba sendo fundamental em seu cotidiano. O conhecimento das dinâmicas de migração das bocas dentro do seu bairro, de quais são os pedaços do bairro na territorialização do mundo do crime e por quem são comandados, dos principais mocós (esconderijos) de drogas e dos próprios ladrões, dos estabelecimentos comerciais de fachada, das áreas de fuga, dos postos de observação do movimento, dos pontos de nóias passou a orientar parte de seus deslocamentos no bairro, desde aqueles relacionados às correrias em torno do filho mais velho até os vinculados à pregação religiosa desenvolvida no campo ${ }^{63}$.

63 De fato, quando ela e Jairo saem a campo para as pregações com pessoas que não são do bairro ou que não têm nenhuma proximidade com o mundo do crime, eles acabam funcionando como guias também por esse outro lado do bairro que as pessoas desconhecem e até temem. O relato de Jairo é interessante nesse sentido: "Às vezes, que nem, eu, minha mãe, que já temos o Jeison, a gente já conhece os lugares [do crime], mas tem... A gente sempre anda em dois no serviço de pregação, então, às vezes, o meu parceiro não conhece. Então, aí, às vezes, ele chega assim ó, às vezes tem um cara mais mal encarado assim que fala com você, então a pessoa que tá do seu lado, com você, ele não conhece, e ele bate pensando que vai vir uma pessoa normal, assim. No caso, aí, eu sempre aviso antes, eu falo assim: 'ó, fica meio esperto assim, porque ai não é uma casa normal...' / Thaís: Esse seu parceiro, ou uma pessoa que não tá envolvida, normalmente ela não vai saber? / Não. Não é todo mundo que sabe... É só quem tá no bairro assim, vamos dizer, que sabe assim. Uma pessoa que passa assim, de fora, não reconhece. / Thaís: Mas essas pessoas que vem pregar com você não são do bairro também? / Algumas sim, algumas não, é que eu e minha mãe, por já ter contato pelo meu irmão, então, as pessoas da igreja, a maioria não tem assim, tipo, o contato que eu tenho, que minha mãe tem. Então a gente vai meio que orientando as pessoas aqui no território: 'ah, aqui é uma boca', 'ali vamos passar mais rápido que é o ponto dos nóias', é mais ou menos assim. Porque a gente não pode deixar de... pular uma casa, ignorar um grupinho, a gente tem o dever de falar a todos, independente se é ou não do crime... Mas se você já vai preparado, sabendo, é mais tranquilo; então, aí que nosso conhecimento acaba ajudando." Marielen também faria referência a esse cruzamento entre tais 'saberes' e o trabalho no campo, nesses mesmos termos de 'preparar' os acompanhantes quando se 
Como eu tenho esse filho, eu conheço profundamente por causa do meu filho, senão eu só ia saber onde era a boquinha ali, igual todo mundo do bairro conhece. (...) Eu saía atrás do meu filho, quando ele ainda era de menor, eu rondava o bairro até altas madrugadas, assim fui conhecendo também o outro lado da vida do bairro. Encontrava um, falava 'você sabe onde é' e o cara 'é lá', e eu ia lá e buscava, por isso eu sou envolvida, por isso eu sei os locais onde as coisas acontecem...

Ao passo em que, através do trabalho no campo, Marielen reconhecia seu bairro e o bairro do Santa Felícia no âmbito do território designado à sua congregação dos Testemunhas de Jeová para pregação, como visto, simultaneamente ela conhecia $o$ outro lado do bairro, as dinâmicas territoriais envolvidas no mundo do crime, incorporando àquele rol de 'saberes' já mencionado novas delimitações simbólicas do espaço não apenas de seu bairro, mas também nas relações deste com o entorno. A experiência de duas décadas morando na região, somada aos aprendizados decorrentes dessas duas formas distintas de incursões por um mesmo território, tornam um tanto impressionante acompanhar alguns de seus deslocamentos locais, tamanha a desenvoltura com que transita por ali e, sobretudo, o conhecimento das fronteiras físicas e simbólicas locais. "Aqui nessa rua tem três bocas e quatro igrejas, acredita?" - ela fez questão de me mostrar, num dos dias em que acompanhei seus deslocamentos, como se, apesar da normalidade com que ela encara, isso devesse soar estranho para mim. E, de fato, se não fosse por tê-la como espécie de guia, eu não distinguiria, num primeiro olhar lançado às várias casas bastante semelhantes da rua, aquelas utilizadas para cultos religiosos ou para o comércio de drogas ilícitas, assim como, de maneira alguma, saberia dizer onde começam e terminam os diversos bairros que compõem a região do Santa Felícia e, muito menos, os lugares específicos destacados por ela, sobretudo na escala do seu bairro, que configuram fronteiras simbólicas demarcadas pela associação de certos espaços ao mundo do crime.

Todos bairros têm esses espaços, assim, que só os bandido, os menino conhece. Aqui no Tortorelli tem vários: por exemplo, a ruinha, é logo ali, mas é um lugar que quase ninguém conhece. Outro dia, fui eu e a Roberta [filha pequena] lá onze da noite atrás do Jeison e ele tava lá, eles tavam tudo lá. Aqui, onde a gente vai passar agora, é o beco, que já te falei. Agora você olha e não vê nada de diferente, parece uma simples rua sem saída, mas se você vier de noite, já vai ver a diferença. No Zavaglia, eu sei que tem um tal de um campinho também, que é mocozado, que é onde eles ficam, jogam futebol, ninguém conhece. [Marielen]

Há, ainda, um aprendizado sobre toda uma lógica territorial mais ampla, articulada a partir de redes de interconhecimento constituintes do mundo do crime, que simultaneamente conectam e contrapõem diversos bairros da cidade, evidenciadas a partir dos cada vez mais intensos deslocamentos do filho por alguns desses bairros: "Os traficantes tão sempre interligados, eles têm comunicação, por exemplo, não tem

aproximam a uma boca, ou mesmo a evitar certos espaços: "Algumas pessoas estranham eu saber dessas coisas, mas tenho parceiras de campo que já gostam de andar comigo por isso...". 
droga aqui no Santa Felícia, eles vão buscar lá no Gonzaga. Eles têm essas conexões na cidade inteira."

Tais interconexões já eram percebidas por Marielen a partir da experiência do marido de uma vizinha que "é da Vila Isabel, mas cada mês tá num bairro diferente", e haviam sido devidamente mobilizadas por ela no período em que o filho esteve foragido da polícia, quando tais redes foram articuladas - por meio de membros da família do ex-marido, igualmente envolvidos - em diversas regiões da cidade. Mas elas passariam a repercutir ainda mais em sua própria trajetória depois desse episódio, quando os deslocamentos do filho por alguns bairros se ampliariam - ao que tudo indica associados à sua maior aproximação ao $P C C-e$, consequentemente, também as correrias da mãe ganhariam ainda mais amplitude territorial (ainda que em menor intensidade, dada a insegurança dela em promover tais mediações em territórios onde ela não é conhecida e não tem conhecimento).

Aí ele já se enturmou mais [depois da maior aproximação ao PCC], tanto que hoje ele tem amizade em todos os cantos da cidade, no Jardim Gonzaga ele tem, porque, uma época, ele vivia socado lá, ele tem conhecidos lá, conhece todos no Antenor... Mas é aqui, no Tortorelli, que ele é considerado. (...) Agora, por exemplo, ele não sai mais do Zavaglia. Tá com uma boca famosa agora lá, tem várias, mas tem uma que tá mais assim... é lá que ele vai arrumar a arma. [Marielen]

Acompanhando os deslocamentos do filho de Marielen, bem como outros casos em campo, chama a atenção, ainda, que a capilaridade dessas redes vinculadas ao mundo do crime na cidade também decorre, em alguma medida, dos deslocamentos habitacionais que, temos visto, configuram uma experiência urbana comum entre os moradores das periferias aqui em foco: embora haja casos de deslocamentos (de uma casa a outra, de um bairro a outro) motivados por dinâmicas vinculadas propriamente ao mundo do crime ${ }^{64}$, instigam-me aqueles que não têm relação a priori com tais dinâmicas, mas, justamente em função da já mencionada "expansão do mundo do crime", acabam resultando tanto nessas interconexões entre territórios, como em disputas territoriais que podem tornar-se violentas, sobretudo nos casos vinculados a programas habitacionais ${ }^{65}$, em que envolvidos de diversos bairros se mudam compulsoriamente para um mesmo território, dando origem à já mencionada panela de pressão, como nos casos dos conjuntos conhecidos como CDHU, São Carlos VIII, predinhos do Gonzaga, Santa Angelina e, mais recentemente, o Jardim Zavaglia.

64 Para fugir da polícia; por interdições pelo PCC, vinculadas a um "proceder" considerado equivocado, que poderiam resultar na expulsão do bairro; para configurar uma nova boca em outro local - foram alguns exemplos encontrados indiretamente em campo, sobre os quais não me detive.

65 Interessa reter, aqui, a percepção de que essa lógica territorial mais ampla que se tece no mundo do crime também é atravessada pelas políticas habitacionais, aspecto instigante, mas que não me foi possível aprofundar dadas as limitações da tese, ficando aberto a futuras pesquisas. 
E agora ele tá no Zavaglia, também, porque inclusive tem uns menino aqui do Tortorelli que mudou pro Zavaglia porque as mães ganharam casas, os meninos migrou, mas são os meninos aqui do Tortorelli, que ele conhecia da mesma rua. A mãe ganhou casa, vivia de aluguel, mudou pra lá. São Carlos VIII, também, a Dona Maricotinha morava aqui do lado, não nessa, na segunda casa. A dona Maricotinha morava com o Lucas, com o Leandro, tudo os meninos ladrão, $e$ onde a Dona Maricotinha ganhou casa? São Carlos VIII, ela mora lá, onde que tá os colegas dele? No São Carlos VIII, no Zavaglia, tudo espalhado. [Marielen]

Nessa lógica territorial, que configura o mundo do crime e é por ele configurada, as redes de interconhecimento, conexões e deslocamentos entre os bairros parecem ser realizadas sempre a partir de um território base, ancoradas em um forte sentido de pertencimento, como quando Marielen faz questão de destacar que "é aqui, no Tortorelli, que meu filho é considerado", frase que ouvi diversas vezes também do próprio Jeison ${ }^{66}$. 0 valor desse pertencimento, acionado nas tantas ocasiões em que ela fez uso da mediação pela confiança, como visto, ganharia ainda mais força no primeiro episódio em que Jeison esteve foragido da polícia, e os bandidos de seu bairro a teriam auxiliado a salvar o filho. Em paralelo - e segundo essa mesma lógica - sua maior preocupação passou a ser que os bandidos do território do ladrão homônimo descobrissem e viessem em represália não apenas a ela e a seu filho, mas aos bandidos do bairro.

E tal preocupação funda-se justamente nessa articulação entre território e pertencimento, a qual, ela sabe, toma por vezes dimensões defensivas que podem chegar a ser extremas. Num território como o seu bairro, pequeno e, aos olhos dos moradores, claramente delimitado, o comando pelo PCC assume ares de uma gestão territorial propriamente dita, em que certas condutas são mais facilmente implementadas do que em outros territórios mais amplos, tanto em termos de dinâmicas internas ao próprio bairro (como no caso da definição dos vários pedaços e pontos de tráfico: "Agora disputa não tem mais. Aqui cada um tem seu lugar, cada um tem seu ponto") ${ }^{67}$ como aquelas que envolvem a delimitação do território frente a outros, como no caso narrado abaixo por Marielen:

66 Para uma reflexão interessante sobre o valor desse pertencimento, associado à noção de cria (indivíduos nascidos e criados em um determinado território, "sujeito que encarna individualmente as propriedades de toda comunidade", categoria que "diz respeito a todo morador, envolvido ou não com o crime, cujas raízes ao mesmo tempo remetam e se encontrem fincadas [...] onde vive"), sugiro a leitura de Lyra (2010:233,234). Foi recorrente ouvir Marielen (e o próprio Jeison) dizer, quanto a um dos aspectos que o faziam ser considerado, que ele era cria do bairro, invocando tal pertencimento: "É que ele é cria do bairro, todo mundo conhece. Cria não, né, que o bairro é novo e ele veio pra cá criança, mas tamo aqui desde o começo. Então é como se fosse cria mesmo".

67 Conforme apontado anteriormente (à nota 85 - Cap 1), alguns estudos destacam a relação entre a presença do PCC nas periferias paulistas e a redução da taxa de homicídios no estado, tal como Feltran (2009a), que apresenta como o já mencionado dispositivo do "debate", ao "bloquear a cadeia de vinganças privadas", incidiria na tendência de queda das taxas de homicídio na cidade de São Paulo. À nota 62 deste capítulo, comento alguns indícios de que a menor penetração, força ou presença deste 
Tipo assim, aqui no bairro não tem mais morte. Outros bairros ainda tem, mas aqui não. Por exemplo, ó, aconteceu o seguinte: aqui no bairro, ninguém pode sair matando assim, atirando. Aconteceu que uns meninos de outro bairro, vieram dar uns tiros nuns meninos ali na rua de cima, num menino. A polícia... Quem resolveu foi o PCC, o PCC foi lá na casa dos meninos, achou... o PCC assim, foi os caras né, e colocou o preto no branco, o preto no branco é a palavra deles: 'você não teve o direito de ir lá no Santa Felícia e atirar no Lerão', Lerão é o nome do menino, 'porque o que o Lerão fez não era caso de morte', pros caras, né. O Lerão se envolveu numa briga aí numa boate, Banana Brasil... Aí, vieram os meninos pegar ele aqui e deram tiro nele, atiraram nele. Então, os meninos lá do outro bairro ficaram devendo pro PCC aqui, fez o acordo, se os meninos de lá vierem aqui de novo pra matar o Lerão, aí não é mais com ele e nem com a família dele, e muito menos com a polícia, é o PCC que resolve. / Thaís: Entendi, mas esse pessoal tava... / Defendendo o bairro, o limite deles, falou assim: 'o que vem fazer aqui no bairro, no meu bairro [ênfase], entrar um monte de cara esquisito atirando?' / Thaís: No meu bairro, que é o Tortorelli, e não no Santa Felícia inteiro? / No bairro, não, no meu bairro [ênfase]. Esse pedaço aqui, o Tortorelli, tem quem comanda aí. Sempre tá pichado aí pelos muro: Tortorelli RT mundo do crime. Eles marcam bem o espaço. [Marielen]

Se do aprendizado dessas lógicas territoriais decorrem certas habilidades necessárias para transitar por esse mundo, também dele decorrem as maiores tensões desta mãe, seja quando a polícia resolve fazer investidas no seu próprio bairro, seja quando Jeison se encontra em bocas em outros territórios da cidade, seja, ainda, quando ela não consegue localizar, junto a suas redes de relações e informações, o paradeiro do filho, ocasiões em que pude encontrá-la verdadeiramente transtornada, deixando de lado todos os seus demais afazeres - inclusive os cuidados com a filha. Um período especialmente difícil que pude acompanhar durante a pesquisa de campo foi a chamada guerra ocorrida no final de 2012, quando uma sequência de homicídios de policiais e de moradores de periferias ocorreu em diversas cidades do estado de São Paulo68. Em São Carlos, a atuação da polícia evidenciou a territorialização de suas

coletivo em determinadas regiões conduziriam ao retorno tanto de disputas violentas por pontos de venda de drogas ou mesmo por territórios mais amplos, quanto ao retorno de um uso considerado mais arbitrário da violência, fora da normatividade instaurada pelo coletivo. Além disso, em territórios produzidos a partir de políticas habitacionais, como é o caso recente do Jardim Zavaglia, por exemplo, também se identifica o retorno a tais disputas violentas, em decorrência da junção de traficantes oriundos de diversos outros bairros da cidade onde seus pontos já estavam estabelecidos, que podem ter fim com a implementação do comando por um irmão mais respeitado, que é o que parece ter acontecido nesse caso, com a vinda de irmãos de Ribeirão Preto para o local. Embora não tenha me detido sobre o caso, dado o escopo da pesquisa, é tema que instiga e mereceria desdobramentos futuros.

68 Cf. conversa informal com Gabriel Feltran à época, teria havido, em 2012, um aumento significativo de policiais mortos pelo PCC e, sobretudo no segundo semestre, quando eclodiu publicamente tal guerra, evidenciou-se que eles estavam sendo mortos um a um, numa disputa quase artesanal. Com isso, a polícia também teria voltado a matar muito mais, em ofensivas direcionadas a territórios periféricos específicos nas cidades, e o próprio mundo do crime também teria aproveitado o momento pra fazer seus acertos, daí tantas mortes. Enquanto eu redigia este texto, reportagem bastante esclarecedora sobre tal guerra foi publicada pela Agência Pública, e pode ser consultada em http://apublica.org/2014/05/guerra-a-periferia/. Em São Carlos, uma onda de homicídios ocorreu no segundo semestre de 2012, após a morte de um policial na cidade, totalizando cerca de vinte 
investidas ${ }^{69}$ e das mortes, ocorridas em bairros como o Jardim Gonzaga, São Carlos VIII, Cidade Aracy, Antenor Garcia, Santa Felícia (aí incluído o bairro de Marielen), para citar alguns.

Nesse período, as dinâmicas socioespaciais do bairro como um todo se viram alteradas e, particularmente, as da família de Marielen, por possuir um membro envolvido no mundo do crime e, portanto, ainda mais sujeito a ser morto. Esta, que mantinha com o filho mais novo a rotina de ir ao Salão do Reino às quintas-feiras à noite, deixou de fazê-lo, ao constatar a transformação dessas dinâmicas: "normalmente, quando eu volto do Salão, por volta de nove da noite, o bairro estava sempre cheio de molecada pra rua, uma rodinha aqui, outra ali e agora o bairro fica um deserto à noite, ninguém sai de casa com medo de morrer"70. Numa dessas noites, em que até Jairo, o filho mais novo, deixou de ir à escola por medo das investidas policiais, Marielen ouviu tiros e saiu desesperada pelo bairro procurando Jeison. No caminho, encontrou-o branco de tanto pavor, pois

(...) uns homens, num carro todo preto, tinham acabado de matar um cara do Santa Felícia, um cara antigo no crime, e os dois meninos que tavam com ele ficaram feridos e tão internados na Santa Casa, sob proteção $o^{71}$. Esses meninos só

execuções publicizadas em dois meses, nos vários territórios periféricos da cidade (aí incluída uma chacina na qual sete pessoas foram executadas no conjunto habitacional conhecido como CDHU, além de mortes nos bairros Jardim Gonzaga, Antenor Garcia, Santa Felícia, São Carlos VIII, Cidade Aracy e na ocupação conhecida como 'favela da Fepasa'). Ainda que, se comparado com São Paulo, esse número seja irrisório, ele é bastante alto para os padrões de São Carlos e região, em especial considerando-se os anos anteriores (conforme dados da Secretaria de Segurança Pública do Estado, o número de vítimas de homicídio cresceu 121,4\% nos dez primeiros meses de 2012 em São Carlos, em comparação ao mesmo período do ano anterior, tendo sido o número de homicídios na cidade, nesse ano, o maior registrado nos últimos doze anos). Interessa notar que, se, em São Paulo, as ondas de homicídios ocorreram, em grande medida, em territórios onde policiais anteriormente haviam sido mortos pelo PCC (cf. demonstra a reportagem supracitada), no interior do estado, tal ofensiva se direcionava aos bairros periféricos das cidades como um todo. Por fim, conforme documentado em DOSSIÊ (2012) sobre os ecos de tal guerra na cidade de São Carlos: “Além dos casos de homicídios [...] registrados em sua maioria em bairros periféricos e empobrecidos, cumpre registrar e destacar a ocorrência de diversas ações abusivas e arbitrárias por parte de policiais militares contra os moradores destas comunidades no decorrer do cumprimento de suas funções: realização de agressões físicas e morais, utilização de bombas de efeito moral durante a madrugada, alçadas no interior da casa das pessoas, invasão de equipamentos públicos gerenciados pelo Executivo Municipal visando a agressão física e moral e a prisão de pessoas assistidas por programas sociais, entre outros casos testemunhados de abuso de poder".

69 Sobre a "actuação pro-activa das forças policiais" perante bairros específicos onde aqueles que carregam as "marcas individuais dos suspeitos" habitam ou transitam, coletivizando a suspeição para os próprios bairros que, assim, convertem-se em "um alvo generalizado", ver Cunha (2002:112-116).

70 Destaca-se a semelhança com depoimento de um morador de um bairro periférico em Taboão da Serra/SP à mencionada reportagem da Agência Pública sobre tal guerra (em http://apublica.org/2014/05/guerra-a-periferia/, consulta em maio de 2014): “Inventa de passar aqui depois das nove da noite para você ver... Não tem ninguém na rua. Onde tem uma turminha, eles metem bala".

71 Essa foi uma das quase vinte execuções realizadas nas periferias da cidade entre os meses de setembro e outubro de 2012, como visto; o fato de os dois meninos que acompanhavam o homem 
não morreram porque logo depois dos tiros o povo já tava tudo na rua, já tinham chamado a mídia ${ }^{72}$ e só por isso eles não voltaram pra acabar com os meninos. Eu só fico pensando na mãe deles, ela vai ter que dar um jeito de tirar eles da cidade, porque senão eles vão morrer. [Marielen]

Em outra ocasião, acompanhei um episódio em que se revelou a imbricação entre a territorialização da ação policial e a sociabilidade fundada na dor e no trauma que compõe a experiência compartilhada das mães do bairro: "Ontem de noitão, todas as mães do bairro foi bater no meu portão, que os filho tinham sido tudo preso. Teve dois assalto aqui no Acapulco e no Santa Marta, e a polícia vem direto aqui, fez o rapa lá no bairro. Elas foram lá saber se o Jeison tinha ido também". Esta não foi a primeira vez que acompanhei a agitação no bairro por conta desse tipo de operação realizada pela polícia em determinados territórios da cidade: "eles fazem uma batida no bairro e levam tudo quanto é ladrão, menino envolvido. Às vezes até inocente, como já quase aconteceu com o Jairo, já aconteceu com uns coleguinha dele".

Quando conheci Marielen, suas narrativas sobre o filho Jeison oscilavam entre considerá-lo apenas um "moleque envolvido com drogas por más influências" e um ladrãozinho de bairro. A partir de 2013, porém, isso mudaria radicalmente: ancorada justamente nessas lógicas territoriais apreendidas, ela passaria a se referir a Jeison que estaria cada vez mais terrível, traficando, assaltando e até mesmo guardando armas, drogas e produtos dos assaltos na casa dela - não mais como um ladrãozinho de bairro, por ele ter, agora, se tornado um bandido periculoso da cidade: "agora ele não rouba mais só na região do bairro, nos bairro vizinho ${ }^{73}$, coisa miúda. Agora é na cidade, é coisa grande mesmo". Ele estaria vinculado a "uns ladrões lá do Zavaglia,

que foi morto terem sobrevivido e de "não terem passagem pela polícia" gerou maior comoção na mídia local e amedrontou ainda mais os moradores da região. (Cf. notícia veiculada em 03/12/12 no site: $\quad$ saocarlosagora.com.br/.../homem-e-morto-a-tiros-e-outros-dois-sao-baleados-na-brunoruggiero/, consultado no mesmo dia).

72 Aqui se evidencia o "papel de polícia da polícia" atribuído à mídia, conforme apontado por Feltran (2011) e escancarado por Marielen: "As pessoas não têm mais como pedir socorro, porque vai ligar pra polícia como, se é a polícia que tá matando? Daí só tem a mídia."

73 Nos relatos de Marielen e no contato com seu filho Jeison, por diversas vezes, veio à tona a proximidade da região do Santa Felícia com diversos bairros de classe média alta e o fato de que os bandidos locais se valeriam de um conhecimento sobre o território e seus entornos para a realização de crimes. Foi recorrente ouvir sobre outras mães e mulheres envolvidas mesmo que, faxineiras ou domésticas, como ela, dariam a letra para os filhos e maridos bandidos, que só realizariam assaltos no entorno de onde elas trabalham. Ela faz questão de destacar que, no caso dela, ao contrário, ela sempre levava o filho para conhecer os locais onde ela trabalhava, para ele nem sequer chegar perto das ruas em seus assaltos. Certa vez, quando me ofereci para buscá-la em uma das casas onde ela trabalhava para que pudéssemos conversar um pouco em sua casa, pude presenciar uma cena em que ela avistou dois colegas de seu filho andando de bicicleta na rua desta casa em que ela trabalhava. Ela fez questão de acenar para os meninos "oi fulano, oi ciclano, tão fazendo o quê aqui? Ó, eu trabalho ali, viu? Não quero saber de problema!", ao que os meninos responderam "tranquilo, o Jeison já avisou a gente, tamo só dando um rolê". Por outro lado, ela disse temer que alguma das casas em que ela trabalha fosse assaltada por alguém de fora do seu território: "porque aí, além de eu não poder fazer nada, ainda ia ficar de refém e ia virar suspeita, por causa do meu filho". 
que vieram de Ribeirão Preto e alugaram casa lá, e chegaram juntando esses ladrão que nem o Jeison, de tudo quanto é parte da cidade". Saindo da escala territorial do bairro, na qual ela considerava ter alguma margem de atuação para resgatá-lo ou interceder por ele, na escala da cidade ele se torna apenas mais um, e os sobressaltos desta mãe tornam-se ainda maiores. Passou a ser recorrente ouvi-la dizer: "agora eu torço pro meu filho ser preso, porque, enquanto isso não acontecer, eu vivo o dia-adia esperando a hora que ele vai aparecer morto".

Então minha vida foi ficando assim, transtornada. Eu, que sou a mãe, eu vivo em transe 24 horas: se o telefone tocar, eu já penso que é uma má notícia; se for um número que eu não conheço, eu fico transtornada; se tocar depois das 22h00, eu já vou trêmula pro telefone, esperando má notícia, porque a mãe que ela tem o filho no mundo do crime, ela fica 24 horas, não esperando notícia boa, ela espera notícia boa e a ruim: a boa, que tá preso e a ruim, que morreu, porque ela sabe que o filho dela tá sujeito a isso. A vida da mãe que tem filho no mundo do crime é uma vida com medo, ela vive com medo, se ela ouve uma notícia que matou um ali ela já fica... E não é só eu, tem várias que fica transtornada. [Marielen]

\section{- A casa manjada e as reconfigurações na relação com o bairro}

Nesse contexto de trânsitos e mediações que se tornaram centrais na trajetória de Marielen, ter a casa, um pé fixo, foi por diversas vezes evocado por ela como um elemento de segurança em meio a toda a incerteza e o medo que permeiam a "vida da mãe que tem filho no mundo do crime": não tanto pela posse em si (já que a casa ainda era de propriedade da patroa), mas pelo fato de configurar uma mínima proteção material e simbólica não apenas para ela e seus filhos mais novos, mas, inclusive, para Jeison ("Aqui é nossa base, né? Mesmo o meu filho, com tudo que já aconteceu, qualquer problema que ele tem, ele corre pra cá. Ele sabe que a gente tem essa casa, aqui ele, a gente tá seguro").

À sua maneira, desde os primeiros indícios de que o filho "estava indo pro caminho errado", Marielen tentou preservar a casa e a família, seja o enviando para morar com o pai em determinados períodos em que esteve mais violento, seja acolhendoo e tentando ajudá-lo financeiramente nos períodos em que ela acreditou que ele iria se encaminhar, seja aceitando sua permanência na casa mesmo após a constatação de que ele estaria "envolvido no mundo do crime mesmo", mas com a condição de que ele não trouxesse para lá drogas ou produtos dos assaltos. Em cada uma dessas ocasiões, toda a dinâmica da casa se reorganizava. E, desde o retorno definitivo de Jeison, progressivamente ele foi ocupando cada vez mais espaço:

Ele dominou o quarto e o computador, tá roubando e vendendo as coisas na internet, acho que até droga! De noite, ele fica pra rua até tarde; de dia, ele não sai do computador, não deixa ninguém chegar perto. Eu mesmo tô dormindo na sala. O João tá ameaçando sair de casa se a minha mãe não puser o Jeison pra fora, mas ela não tem mais coragem, depois de tudo que já aconteceu. [Jairo] 
$\mathrm{E}$, quanto mais envolvido Jeison estava, mais coisas dos crimes começaram a aparecer na casa: joias, dinheiro nacional e estrangeiro, celulares, perfumes, bebidas, laptops, roupas. Marielen dava um prazo para ele tirar as coisas de lá e, em geral, ele cumpria. Mas sempre ficava com uma parte para si, já que ninguém mais da família aceitava os produtos de seus assaltos, ainda que ele sempre quisesse presenteá-los. Em mais um esforço para tentar preservar a casa, ela chegou a adotar a estratégia de jogar fora drogas e itens roubados, mas as ameaças do filho a fizeram parar:

Eu devia jogar fora, mas meu filho a gente tem um pouco de medo dele, assim, de jogar, tipo assim, de eu pegar um produto que ele roubou e jogar fora, assim. Eu tenho um pouco de medo, porque já me incentivaram de fazer isso e não deu certo. Não deu certo não, eu já joguei produtos e, uma vez, peguei uma porção de muitas drogas aqui na minha casa e joguei fora as drogas, fui jogando uma por uma na privada, até acabar tudo, quando meu filho ficou sabendo, ele ficou violento, quebrou a casa inteira e falou assim pra mim: 'agora vou fazer um roubo, pra pagar essas drogas que você jogou, porque não eram minhas'. E aí o que aconteceu? Eu fiquei com medo dele fazer o roubo e ser preso ou morto. Então, o que eu faço, ele chega com essas coisas roubadas eu falo pra ele 'tira aqui de casa', então quando ele rouba ele sempre dá um jeito de tirar... / Thaís: Ele te obedece? / Ele obedece assim, entre aspas, né? Ele sempre fica com alguma coisa do roubo pra ele, então fica dentro da minha casa um tênis, uma camiseta, um litro de whisky, uma joia, de homem assim, ele usa bastante, então sempre fica uma coisa de roubo na minha casa, inclusive tá ali, ó, um litro de whisky, do último roubo. [Marielen]

Nesse encontro em sua casa, em meados de 2013, em que ela me mostrou alguns produtos do último assalto realizado por Jeison ali presentes, lembro-me de tê-la questionado, na esteira das leituras de Cunha (2002), se não teria medo de que acontecesse alguma coisa a ela própria, à sua casa, à sua família, caso a polícia encontrasse aqueles produtos, ou as drogas. Eu temia que ela ou mesmo Jairo, prestes a completar dezoito anos, pudessem ser considerados cúmplices, ser até mesmo presos. De um lado, Marielen demonstrou tranquilidade quanto a isso, afirmando que "as polícia sabe qual mãe tá ou não tá no mundo do crime, e também já conhece tudo os moleque" 74 , o que garantiria a segurança tanto dela, quanto de Jairo. Por outro lado, demonstrou sentir-se pressionada, até amedrontada pelo filho mais velho, por isso aceitaria mantê-lo em casa, apesar dos riscos aí implicados:

74 Esse comentário de Marielen reitera uma mudança na abordagem de rotina dos policiais (evidenciada também nas narrativas de Jimmy e Jefferson), que teria se processado a partir da cada vez maior presença do PCC nos bairros periféricos da cidade: teriam se tornado cada vez mais raras as antigas operações de varreduras indiscriminadas nos bairros periféricos (a não ser em situações eventuais, de crise, como o período da guerra antes mencionado), visto que o envolvimento dos policiais com o mundo do crime seria tanto, que eles já saberiam exatamente aonde ir e quem seriam os envolvidos em cada território. Sobre a articulação entre polícia e mundo do crime no âmbito territorial, ver Hirata (2010). Entretanto, pouco tempo depois, como visto, com Jeison acusado e foragido, a opinião de Marielen mudaria completamente, já que agora ela e sua família também passariam a figurar rotineiramente como suspeitos aos olhos da polícia. 
Na verdade, a gente tem um pouco de medo dele. Ele diz que só sai de lá de casa preso ou morto. Outro dia, ele me mostrou uma pistola enorme, até a Roberta viu, e ele disse que era de mentira, só pra assustar. Mas outro dia eu peguei e era pesada, só homem pra aguentar aquele peso mesmo. A gente botou nas mãos de Jeová, eu peço pra Jeová tirar ele lá de casa, mas não peço quando, nem como. A gente não pode denunciar, que ele tá envolvido com os irmãos do PCC daqui e do Zavaglia e podemos sofrer represália, ele também pode até ser morto por isso. Por isso deixamos nas mãos de Deus e das polícia, né? Mas não precisa se preocupar, ele tira tudo lá de casa, ontem mesmo eu ouvi ele ligando pros irmão e dizendo que eu ia sair e era pra eles aproveitarem e tirarem tudo lá de casa, que ele não queria nada lá em casa. E os ouros ele vai hoje lá no centro vender, que o crime já tem os esquema pra vender, mas, se eles rodarem, o cara não pode se comprometer, ele vai dizer que não sabia que era roubado. [Marielen]

Crônica de uma fatalidade anunciada. Nesse mesmo dia, no início da noite, Marielen me ligaria afobada, pois a polícia descobrira que Jeison era um dos envolvidos em um assalto acontecido na noite anterior na casa de um figurão:

Thaís, você não acredita, a polícia invadiu lá em casa atrás do Jeison, tá cheio de polícia na minha rua, até a EPTV tá aqui, tô saindo de lá, ele tá fugido, foi só a gente conversar, bem que você falou, eles reviraram minha casa inteira, queriam saber se eu tinha ficado com as joias e tudo! Levaram tudo as minha bijuteria pra averiguação! Agora tô indo com a Roberta e o Jairo pra algum lugar - vai Roberta, anda, anda! / Pergunto, aflita: mas tá tudo bem, você precisa de ajuda? / Não, tá tudo bem, tô indo, ele tá fugido, tá bom então, tchau. [Marielen]

Passei o resto da noite agoniada, imaginando Marielen correndo pelo bairro com Roberta e Jairo, perguntando-me para onde ela teria ido, o que teria acontecido com sua casa. Dois dias depois, reencontramo-nos, e ela me contou sobre o assalto a mão armada realizado pelo filho, durante o qual ele foi registrado pelas câmeras de segurança e também descrito por uma das vítimas, bem como sobre a invasão policial à sua casa, na qual provas do crime foram encontradas. Contou-me ter sido revistada por uma policial feminina, tendo suas bijuterias sido levadas por suspeita de que ela tivesse ficado com produtos dos assaltos de Jeison. Dois armários foram quebrados, e até sua filha pequena sofreu a abordagem dos policiais (já que um dos motes para a identificação de Jeison como um dos assaltantes fora justamente uma tatuagem com o nome da irmã). Marielen relatou ainda suas correrias naquela noite, quando o marido ficou guardando a casa, e ela, após deixar Jairo e Roberta na casa de uma conhecida no bairro, foi de carro, com a irmã, até o Jardim Zavaglia, onde Jeison se escondera. Lá ela descobriria que seu atual parceiro do crime era o filho de uma faxineira com quem ela trabalhara há alguns anos e que migrara do Cidade Aracy para aquele bairro por conta do valor do aluguel, em mais uma evidência de como as redes de interconhecimento que atravessam os bairros populares se constroem por caminhos distintos: as mães se conheceram por conta do trabalho; os filhos por conta do envolvimento no mundo do crime.

Naquela noite mesmo, Marielen levou Jeison para a casa do mesmo parente morador de uma vila operária em uma usina de cana fora da cidade - que o acolhera 
naquela primeira temporada em que esteve foragido. Passado o risco do flagrante, ele estaria de volta ao Jardim Zavaglia, agora morando com um tio "caminhoneiro $e$ usuário de crack, que mal para em casa". Ela contou-me ainda que, dessa vez, ela tinha uma ajudante em suas correrias: "a mina dele 75 tá agora fazendo os corre pra recolher a grana que ele tinha pra receber dos assaltos que vinha fazendo. A gente quer convencer ele a usar essa grana pra pagar uma advogada do crime, ela vem em casa hoje à noite."

Os desdobramentos desse episódio puseram em evidência os efeitos da aproximação dessa família ao mundo do crime, não apenas nas trajetórias urbanas e redes sociais de seus integrantes (em especial de Marielen e do filho Jairo), mas também em suas relações com a vizinhança, o bairro e a casa. Se, desde que o filho mais velho tirou Febem, algumas dessas relações já foram se transformando, como visto, foi a partir do crescente envolvimento de Jeison no mundo do crime e, sobretudo, após a sequência de invasões policiais à casa de Marielen (das quais decorreria a comprovação do envolvimento dele não apenas nesse último assalto, mas em pelo menos outros três ocorridos no período na cidade), que essa transformação impregnaria definitivamente demarcações físicas e simbólicas nos espaços cotidianos da família, com destaque para a casa.

Então é o seguinte, o meu filho de estado de ladrãozinho, ladrão de carro, agora ele é assaltante mesmo, ele é assaltante, ele faz 157, ele faz assalto a mão armada, e como eu sei disso? Eu sei porque eu sou a mãe, o meu filho chega suado, ele não traz produtos grandes aqui pra casa, tipo coisas grandes, mas ele trazia joias, botava na gaveta dele, tipo assim, a gaveta dele ninguém mexe, só ele, mas eu como sou a mãe, eu abro lá e olho. Igualmente ontem, ele chegou aqui com uma mochila cheia de produtos roubados, e enquanto ele foi ali fora eu abri a mochila e eu vi que eram produtos roubados. E aí eu concordo? Eu aceito? Não. Eu falei pra ele 'ó, você some com isso aqui de casa', só que como aqui era casa dele, ele não trazia coisas grandes, mas ele trazia... E aí então ele entrou nesse status de ladrão grande mesmo, de 157, que é assalto a mão armada, então ele fez muitos roubos na cidade, vários. E ele fez um último roubo que foi reconhecido por câmeras e por vítima, é onde que a polícia pegou ele e veio direto aqui em casa, porque? Além dele ser reconhecido por vítima e por câmera, ele vendeu um dos produtos pra um menino que não é ladrão, mas é do bairro e compra os produtos roubados, a polícia rastreou o notebook da vítima, e foi lá pegou esse menino... esse menino não é do mundo do crime, mas ele compra o que os outros meninos roubam, entendeu como você se envolve? Sem querer, né,

75 A namorada de Jeison, que, como visto, era de uma família boa do bairro, aparece agora tão envolvida quanto Marielen, aspecto que esta não deixa passar despercebido, ao comentar em uma "rodinha na rua" que "os pais dela são empregados da Faber [Castell], mas agora a Faber inteira já tava sabendo, não tinha mais como ela esconder que o namorado era do mundo do crime." Ainda fez questão de dizer que ela não entendia como a menina, "de família boa, com estudo, empregada" fora se envolver com bandido. Comentou ainda que, uma época em que ela e Jeison estavam separados, ela teria se engraçado com um traficante do bairro, e que agora mais do que nunca "ela tava por dentro do mundo do crime". O papo terminaria com a expressão "coitada da família dela, tão trabalhadora!", com o que as vizinhas concordariam prontamente. 
'aí, vou comprar um celular que vale 1000 por 50'... Aí o menino, que não é do mundo do crime, foi lá e tomou uma surra da polícia e falou 'comprei de fulano de tal'... Aí eu cheguei, acabei de chegar do serviço, cheguei 4h20, sentei no sofá e a minha casa começou a ser invadida pela polícia. Aí o computador foi rastreado, hoje em dia meu telefone fixo tá grampeado. / Thaís: Aí eles entram... eles fazem o quê? / Eles chegam gritando, eles reviram tudo, colocam a geladeira de ponta cabeça, of fogão, minha bolsa, que eu tava com um pedaço de torta que a minha patroa tinha me dado... eles jogam tudo pro chão, procurando produtos roubados, procurando a prova do crime... inclusive eles encontraram aqui muitas provas do crime, que eram pequenos produtos de roubo... tinha a arma, que ele tinha me falado que era de brinquedo, mas eu sabia que não era... [Marielen]

Eu tava no computador, lá dentro do quarto, aí minha mãe gritou, me chamou na sala... daí do jeito que eu vim, eles já tava tudo entrando, aí eles mandaram eu deitar no chão, aí eles reviraram tudo lá pra dentro, só depois que viram que não era eu. É que eles acharam que eu era meu irmão, né, do jeito que eu apareci na porta, eles já tavam entrando no portão. Aí viram que não era eu, acho que por causa da tatuagem que eu não tinha, mas quase me levaram preso. E, vixi, reviraram tudo, a casa inteira. [Jairo]

Além do aspecto da violação da casa como espaço de proteção e de sua depredação interna - coisas quebradas, itens pessoais levados, o filho inocente ameaçado -, o segundo aspecto mais destacado nesse contexto por Marielen e Jairo referiu-se à reação da vizinhança diante da retomada das invasões policiais na casa e, sobretudo, da comprovação de que Jeison, dessa vez, era mesmo o culpado.

Então a polícia chega, nesse dia eles fecharam até a rua, porque acharam que iam pegar o Jeison. Aí fica um alvoroço aqui na frente, vem o bairro todo pra porta da minha casa, o bairro vem todo, por isso que a casa fica manjada: a polícia demora horas aqui fazendo ocorrência, porque achou os produtos, né? Aí ela não vem só uma vez, ela veio 4 horas e voltou as 7 da noite, porque ela quer pegar o bandido. Então ela fica vindo vários dias, até pegar... até inclusive agora eles desistiram um pouco, mas na hora que eles vierem, eles vêm na certeza. I Thaís: Mas e a vizinhança, que cê tava me falando... / Aí, a vizinhança já fica todo mundo em cima, quer saber o que aconteceu... Quer saber o que aconteceu e a gente é obrigado a contar, porque não tem como esconder. Aí, eu vou ali no mercado, e falo pra mulher 'nossa, a polícia invadiu lá em casa, o meu filho aprontou', eu não vou contar pra mulher do mercado os detalhes, 'meu filho roubou isso, roubou aquilo'. Mas falo logo: 'O meu filho aprontou e a polícia foi lá', 'nossa que dó de você, você trabalhou o dia inteiro e chegar em casa e a polícia...', entendeu? É assim. [Marielen]

Embora a casa já tivesse sofrido invasões policiais quando Jeison era ainda menor de idade, como visto, Marielen sempre fez questão de frisar não apenas para mim, mas em diversas conversas com vizinhas e amigas que pude presenciar, que, depois da internação do filho na Fundação Casa, ele "nunca mais teve passagem na polícia, só daquela vez, né, que foi acusado e comprovado que não era ele". Assim, se nas primeiras vezes, a vizinhança - por curiosidade - tenha enchido a rua a cada invasão policial para acompanhar o que acontecia em sua casa, depois daquela primeira invasão em que Jeison já era de maior - em que a casa estava limpa e o filho foi 
inocentado - durante quase um ano Marielen veria sua casa tranquila até essa nova sequência de invasões.

Já teve vez que eles invadiram a casa e o meu filho tinha coisas roubadas lá. Então, invadiram, acharam, ficou a vizinhança inteira lá do bairro, e não tem o que falar. Porque quando invadiu a casa da minha vizinha e eu também fui lá na frente e fiquei olhando. 'Ai coitada, não merece isso.' Então, não tem o que fazer. Mas então, da última vez que invadiu minha casa, eu não tava em casa. Eu cheguei, a casa só tava revirada, eu fui diretamente na DIG, ele me falou: 'Ó, a gente tá com ordem do juiz pra invadir sua casa e já invadimo. E vamos invadir quantas vezes precisar.' Aí, como eles não acharam droga, nem nada suspeito na minha casa, e depois ele foi inocentado, eles não voltaram mais. Aí a vizinhança deu um tempo também. [Marielen]

As invasões policiais são uma espécie de atestado público de que ali é uma casa de bandido. Embora naturalizadas, já que recorrentes no bairro, não deixam de ser um distintivo social: ali definitivamente não mora mais uma família boa do bairro, mas uma "família envolvida no mundo do crime". Se até esse momento, embora fosse de conhecimento geral da vizinhança a aproximação de Jeison ao mundo do crime, o fato de ele nunca ter tirado cadeia funcionava como espécie de 'atenuante social' em relação à casa da família, será a partir dessa sequência de invasões policiais que terá lugar tal processo de demarcação da casa como "casa de bandido".

Só que a polícia não invade qualquer casa, diretamente, todo dia. Só se o filho tiver no mundo do crime. Eles não chega, passa na rua e invade. Passa lá na rua, olha pra minha casa e entra lá. Não é assim. A não ser se tiver uma suspeita que é boca de droga, assim, ai eles vê que é, geralmente, vê que é molecadinha nova, aí eles pegam e invade mesmo. E se for molecadinha... Agora, quando é traficante grande mesmo, eles não invade. Eles sabem onde. Ninguém sabe quem é pior, se é a polícia ou os ladrão. (...) Que nem aqui, antes nunca tinha, a polícia passava reto, nem olhava. Só começou a ser invadida depois que o meu filho entrou pro mundo do crime. Agora, como a polícia já sabe que na casa mora um menino envolvido no mundo do crime, eles já passam olhando dentro, tipo assim, vigiando a casa mesmo. E invade. [Marielen]

Minha casa tá marcada, né? Não tanto pelas pessoas, mas pela justiça sim. Por exemplo, passa um carro de polícia aqui, eles descem a rua inteira, mas aqui na frente eles passam bem devagarzinho, olhando pra dentro da casa, e depois eles descem. Já foi invadida mais de sete vezes! Já é uma casa manjada. [Marielen]

A casa manjada ${ }^{76}$, expressão que se tornará recorrente nas narrativas de Marielen a partir de então, seria "uma casa conhecida pela polícia", que passa a fazer parte das

76 A expressão casa manjada parece sintetizar uma dimensão fundamental, referente à extensão do ato criminal ao corpo do sujeito que o realiza e de seus pares e, consequentemente, a seus espaços - o bairro e, em última instância, a casa. E aqui dialogo, entre outros, com Misse (2010); Feltran (2011); Wacquant (2007); Lyra (2010); Segura (2012), Cunha (2002), todos, sob enfoques variados, atentos aos deslizamentos dos estigmas, punições, violências do crime ao criminoso; deste a todos aqueles que têm, no corpo, as mesmas marcas distintivas (pobreza, cor da pele, modo de vestir...); por fim, de tipos de pessoas a tipos de espaços, de modo que bairros - e casas - passam a ser "suspeitos", tornando-se alvos territorializados, marcação que acompanha seus residentes a diversos espaços de 
rotas de policiamento no bairro: se, antes, a polícia passava reto, a casa manjada não apenas passa a ser alvo recorrente de invasões, mas também a sofrer assédios mais sutis, espécies de ameaças veladas (ou nem tanto) à casa e à família do envolvido ${ }^{77}$, como a intensificação da presença de viaturas que, ao passarem na rua, param em frente à casa e ali ficam durante um tempo, com os policiais olhando para dentro, por vezes descendo e encostando no portão, ou um carro blindado preto e com vidros escuros, que passou a fazer rondas noturnas na rua, chegando até mesmo a parar em frente à casa e direcionar o farol para dentro dela, para citar alguns exemplos, inclusive presenciados por mim.

É, como meu filho é envolvido no mundo do crime, acontece o seguinte: se a polícia passar aqui na rua, você vai ver daqui a pouco, ela vai passar, ela vai passar entrando aqui pra dentro, olhando aqui pra dentro. Tipo assim, se eu tô ali fora sentada, eles param, ficam encarando, perguntam do Jeison. Porque aqui já é uma casa manjada, porque pode ter... eles acham que pode ter droga, coisas roubadas. / Thaís: E a sua casa já foi invadida muitas vezes pela polícia? / Ah, umas sete, oito vezes com certeza. Então, eu tô meio traumatizada assim com a casa, por causa da polícia, mas não por causa de ladrão, vizinho, nada disso, eu não tenho nenhum problema, nem com o vizinho do lado esquerdo nem com o do direito. [Marielen]

O enfrentamento dessas novas dinâmicas, decorrentes de a casa ter se tornado manjada, transformarão todo o cotidiano de Marielen e também o de Jairo na casa e no bairro. Ações rotineiras como entrar e sair de casa e circular pela vizinhança se tornaram momentos de tensão; em especial, a presença constante desse carro blindado durante a noite a deixou amedrontada e motivou tentativas desesperadas de minimizar as marcas na casa e preservar o filho Jairo: de um lado, garantindo que Jeison não retornasse à casa e ao bairro tão cedo; de outro, acompanhando todos os movimentos de Jairo para que ele não fosse apreendido pela polícia na esteira dos atos do irmão.

Eu tenho medo, porque, mesmo que eu sou de uma descendência pobre, a gente nunca era envolvido na polícia, então eu tenho medo. Eu coloco coisa na cabeça, eu acho que eu vou tá entrando aqui dez horas da noite, posso ser... eu não, meu outro filho, eu tenho outro filho que não é envolvido, eu acho que... o que acontece? Meu filho chega $23 \mathrm{~h} 15$ da escola, e pode tá chovendo, pode tá frio, $e$ eu vou estar lá no portão esperando ele, de medo que ele seja confundido com o outro menino. Eu fico lá na frente esperando o Jairo, quando dá dez para as onze eu já fico ali. [Marielen]

interação social, como uma "desvantagem adicional àquelas que já experimentam" (Segura, 2012:124).

77 Diferentemente do que descreve Feltran (2011) sobre o caso de Maria, cuja casa, que antes abrigava uma "família trabalhadora", passa a figurar como "lugar de bandido" e ser alvo de investidas policiais abusivas, na relação de Marielen com a polícia não se evidenciam, para além da repressão que acompanha as invasões e das ameaças intimidatórias aqui descritas, extorsões financeiras ou agressões físicas aos familiares do bandido. 
Num primeiro momento, ela chegou a cogitar que a ameaça do carro blindado pudesse vir do próprio mundo do crime, pelo fato de Jeison ter "trazido os polícia pro bairro" num período em que este não estaria tão visado ${ }^{78}$. Contudo, após mediações com os grandões locais, ela descartou essa hipótese, ao constatar que ele seguia sendo muito considerado: "eles falaram que não foi o Jeison que trouxe os polícia pro bairro, que foi uma operação mesmo, e ainda ofereceram proteção pra gente, mas eu não quis, não quero ainda mais rolo pro meu lado". Assim, com informações obtidas junto ao crime, ela passou a considerar que o carro abrigaria policiais à paisana, e isso a amedrontou ainda mais:

Agora esses polícia à paisana tão todo dia passando devagarinho na rua, ontem pararam em frente de casa e tiraram umas fotos. Eu fiquei desesperada, nós tamo até pensando em fugir dali, deixar casa, tudo. Já pensou se eles resolvem invadir e atirar em nóis tudo, ou se eles confundem o Jairo com o Jeison e pegam ele voltando da escola? Ele volta todo dia à meia noite, foi bem a hora que esses hómi tavam lá tirando foto... [Marielen]

A insegurança dela em relação à casa, à rua, à proteção de sua família a impulsionou a "rodar as delegacias da cidade até encontrar o delegado que participou da batida lá em casa, que eu não conhecia e foi gente boa, ele entendeu que o Jeison também é vítima das drogas": a intenção era questionar sobre o carro que estaria rondando sua casa durante a noite e declarar que Jeison não morava mais ali, na esperança de demovê-los dessas investidas acintosas em relação à casa, o que parece ter surtido algum efeito, já que o tal carro nunca mais voltou. ${ }^{79}$

Então, depois de tudo, eu ainda fiquei mais preocupada por causa desse carro, porque eu tenho o outro filho que não é envolvido, e eu fui falar com o delegado que tá acompanhando o caso, fui lá falar assim: 'ó doutor', saí do serviço mais cedo, fui falar com o delegado que meu filho não mora mais aqui, e que tinha um carro rondando aqui, e que eu tava com medo, porque eu tinha outro menino que não era envolvido no mundo do crime... Aí depois que eu fui lá o carro parou de passar aqui, nunca mais passou. [Marielen]

É nesse contexto que tanto a casa quanto o seu bairro, antes tidos como espaços seguros por ela (seja pela espécie de proteção pelos e dos bandidos que a primeira teria, seja pelo já mencionado valor de ser conhecida e ter conhecimento, que the garantiria alguma imunidade naquele território delimitado), tornam-se espaços vulneráveis, fontes de insegurança e medo, paradoxalmente em relação à polícia. De fato, ainda que, genericamente entre os moradores de periferias (e, sobretudo, favelas), essa representação do bairro como espaço seguro seja constantemente

78 Aqui, mais uma vez, a tensão decorrente dos saberes aprendidos sobre as lógicas territoriais, discutidos na seção anterior deste capítulo.

79 Algum tempo depois, ao acompanhá-la em uma visita ao filho, ainda foragido no bairro Jardim Zavaglia, este relatou que o tal carro também o perseguira ali, e ele teria se escondido numa mata que contorna o bairro, até de madrugada, quando os meninos do bairro lhe informaram, pelo celular, que o tal carro tinha ido embora. 
interpelada por um sentimento de insegurança que, embora associado à presença do crime, é sempre visto como pior ou intensificado pela atuação da polícia ${ }^{80}$, a narrativa de Marielen evidencia o quanto isso se amplifica no caso de uma família de bandido, independente do envolvimento ou não dos demais membros.

Então, eu tenho medo da polícia, não tenho medo do mundo do crime, porque, até agora, nesse exato momento, o meu filho não deve nada pro mundo do crime, porque ele é envolvido né? Ele trafica, rouba, então ele não deve pros bandidos, ele deve pra polícia. Ele é considerado no mundo do crime. Você não viu que eu entrei agora numa boca? Fui lá pegar a minha sombrinha, que o Jeison deixou lá. Eu não tenho nada a temer com eles, mas com a polícia eu tenho.

Eu tenho medo pelo meu outro filho, que não é do mundo do crime, eu tenho medo de represália contra ele do lado da polícia. Do lado dos bandidos não, porque os bandidos, eles têm uma lei de não mexer com a família. Então eles têm uma lei, dentro do mundo do crime, tem uma lei de não mexer com a família, independentemente do que o meu filho faça, mesmo que ele vá para o tribunal do crime, a família não vai pagar, não pode mais, desde que o PCC entrou pra comandar, e é o PCC que manda e não tem isso, tem uma regra: o Jeison aprontou não sei lá o quê, eu não vou sofrer represália. Nem eu nem o Jairo. Mas da polícia, sim. [Marielen]

Desde então, fez-se cotidiana em sua vida a ideia de fugir da casa, de mudar-se dali, coisa que, ao longo de toda a pesquisa, ela havia frisado que nunca faria, a não ser se a patroa lhe pedisse a casa. O motivo era um só, como visto: não se tratava de problemas com os ladrões, nem de desentendimento com os vizinhos (outros dois motivos mais que legítimos, em sua opinião, para alguém abandonar a própria casa), mas o medo da polícia, que a deixara traumatizada com a casa.

A partir do momento em que a casa se tornou manjada, fonte de medo e de trauma, Marielen passou a dar ouvido às ideias do marido, que, desde 2011, vinha tentando convencê-la a fazer negócio com a casa, como já relatado. Marielen, que, então, não quis nem pensar no assunto, menos de dois anos depois passaria a cogitar vendê-la, mas não sem um embate entre a visão do marido - da casa como mercadoria - e sua relação afetiva - e moral - com a mesma. E justamente quando chegava o momento de a ex-patroa passar a casa para o nome do filho mais novo, como fora combinado há tanto tempo e que se concretizaria com a maioridade de Jairo, ocorrida em meio a esse turbilhão ocasionado pelo assalto e pela fuga de Jeison.

Eu gosto de morar aqui, porque eu mesma não tenho envolvimento, eu não tenho inimizade nem com o vizinho do lado esquerdo, nem do direito. Só gostaria de fugir, mesmo, por causa do meu filho que se envolveu, e eu queria um pouco de sossego, assim. Por exemplo, eu tenho medo, de noite, de ficar sozinha, da polícia invadir a casa, essas coisas. Então que é esse negócio de mudar da casa; só que aí eu também fico com aquele medo de perder a casa que a minha patroa fez com tanto amor. Isso aí foi um ato de amor que jamais alguém faz, então eu não

80 Cf. diversos estudos, sobretudo cariocas, dentre os quais me foram esclarecedores os de Lyra (2010); Machado da Silva e Leite (2007). 
queria magoar ela... Porque, primeiro, essa minha patroa, ela não é uma pessoa rica, que tem dinheiro pra ficar dando casa, ela fez um sacrifício, é um dinheiro que ela tava juntando, ela sempre me conta a mesma história: ela tinha esse dinheiro desde que ela era mocinha, de fundo de garantia, ficou velha e esse dinheirinho tava sempre guardado. Como ela disse que eu sou uma pessoa que mereço, que eu não acho, mas ela disse que eu mereço, ela foi lá e tirou o dinheiro dela da poupança e fez isso pra mim, um sacrifício pra mim. Então eu não acho justo eu lucrar com a casa. E vender a casa, sei lá, pra lucrar... pra mim, eu ficava aqui pra sempre. Então eu não acho certo por isso, e porque eu me apeguei, eu acho que ela me deu aqui, eu vou ficar aqui. / Thaís: Mas, e aí, como que tá isso agora? Você me falou outro dia que também já tava querendo sair daqui, da sua casa já estar marcada pela polícia, queria que você falasse um pouquinho disso. / Assim, eu penso... em sair mesmo, por causa dos problemas com a polícia, e a casa tá muito manjada, como fala aqui no bairro, minha casa tá manjada, a polícia passa aqui e já sabe né, 'no tal é casa de bandido', tá sempre invadindo, tudo. Só que, ao mesmo tempo, eu falo que vou fazer, e quando chega na hora, eu pulo pra trás, eu não vou em frente. Eu falo: 'tá bom, vou vender', mas quando chega na hora, eu não consigo, porque eu lembro da minha patroa colocando cada tijolinho, comprando cada saco de cimento, eu lembro das coisas mínimas assim, dela chegando aqui e falando 'olha Má, agora eu vou colocar um piso nessa casa pra você, tá muito difícil pra você limpar com o chão duro, vamo por um piso, arruma um pedreiro'. Era assim que ela fazia. / Thaís: E agora é a primeira vez que você tem vontade de sair daqui? Você nunca teve essa vontade antes? / Nunca, jamais. E agora eu tenho vontade de sair da casa, não do bairro, por causa que a casa tá manjada pela polícia, aí como eu tenho um outro filho, eu tenho medo de acontecer alguma coisa. / Thaís: E aí, o que vocês tavam planejando, vender? / Eu queria trocar por outra casa, no mesmo bairro. Trocar a casa, por que, como a gente tá marcado... só que ao mesmo tempo, eu pulo pra trás, porque o meu filho não tá preso ainda, então qualquer lugar que eu for, ele vai estar atrás de mim, a não ser que fosse preso... / Thaís: Não vai adiantar você sair daqui, é isso que você tá falando... / Não vai adiantar, e eu tenho medo, porque como eu nunca tive casa, como eu sempre morei de favor, eu tenho medo assim, de vender a casa, e depois não conseguir comprar outra e ter que começar tudo de novo, e só de pensar isso eu já fico em pânico. E eu só sairia daqui diretamente pra entrar dentro de outra casa. Pra ter que construir, essa história de comprar terreno e ter que construir depois, eu não confio. [Marielen]

"Para sair do foco da polícia", a família passou, então, a fazer planos de vender a casa, tão logo a ex-patroa passasse a propriedade para o nome de Jairo, tangenciando o atual "mercado habitacional popular" apresentado no capítulo anterior: enquanto o marido aventava a opção de, com o recurso da venda da casa, adquirir outra através do PMCMV, em um bairro inferior ${ }^{81}$, e ainda restar um lucro a ser, possivelmente,

81 É interessante destacar como os movimentos de produção de novos espaços urbanos e da reconfiguração de classificações e hierarquias socioespaciais promovidos pelo PMCMV atingem as periferias de um modo geral, perpassando, inclusive, a trajetória de Marielen, a única que, por viver já há um bom tempo em uma casa praticamente própria, até o momento não tinha apresentado relação alguma com o Programa. Nesse caso, o novo bairro seria inferior ao Santa Felícia, por encontrar-se ainda no lento processo de produção do urbano, assim como visto no caso do Parque Novo Mundo, apresentado no Capítulo 2. Por outro lado, tal bairro seria mais sossegado, já que, por ser novo e envolver a aquisição mercantil da moradia, teria menos envolvidos, menos bocas, menos movimento e, consequentemente, menos presença policial. Ver também Entremeio III. 
investido em um terreno, ou mesmo em um carro, Marielen oscilava entre aceitar essa proposta, pela oportunidade de adquirir uma casa nova e pronta em um bairro mais sossegado, e recusá-la, por ainda considerá-la moralmente inaceitável, uma ofensa à ex-patroa que tanto a ajudou.

Além da dimensão afetiva, moral e precatada que permeia sua relação com a casa, também a relação na vizinhança - mesmo prenhe de conflitos, como visto - é um dos grandes valores vinculados por ela à casa. Com tudo o que ela já viveu ali, um dos aspectos valorizados é que "é cada um no seu lugar": a percepção de "não ter problemas com vizinhos" é um elemento decisivo em sua dificuldade em deixá-la. ${ }^{82}$

Entretanto, como o desejo de fugir da casa era muito premente ${ }^{83}$, ela passou a cogitar, no máximo, realizar uma troca de chaves $^{84}$, permutando a casa por outra no mesmo valor, dentro dos limites do bairro Santa Felícia: de um lado, ela evidencia a precaução de quem já passou por vicissitudes demais por conta de não ter casa e não quer se arriscar, como tantos conhecidos do bairro, a vender sua casa e depois não conseguir adquirir outra, voltando a depender dos outros ou a viver de aluguel; de outro, traz à tona sua vinculação com o território do seu bairro e do bairro Santa Felícia ${ }^{85}$, enfatizando não apenas seu pleno domínio do mesmo - "não queria sair

82 Em campo, a apreensão das relações de vizinhança como elemento importante, que pode definir tanto a fixação em uma casa e um território quanto um novo deslocamento, foi recorrente não apenas em narrativas dos interlocutores, como Marielen, quanto no conhecimento de casos concretos nos bairros por onde a pesquisa transitou, como o daquela vizinha de Beatriz, mencionada no capítulo anterior, que acabou colocando sua casa à venda por conta dos desentendimentos desta com sua irmã, ou o caso relatado pela própria Marielen: "Por exemplo, você mora numa casa grande, mas você não se dá bem com os vizinhos, é aquela brigaiada, você vai morar n'outro lugar. Inclusive eu tenho uma amiga que morava aqui no Santa Felícia, e ela não se dava bem, assim, brigava, arrumava rolo no bairro. Aí ela vendeu e foi morar na Aracy. E esses dias ela me disse que, pra ela, lá é maravilhoso, ela se deu bem lá, é uma casa mais pequena, pior, mas ela vendeu aqui, porque ela não tinha convivência no bairro." Frases como "não tem um bairro pior pra morar, quando você não tem inimizade com o vizinho", escutadas em diversas variações, traduzem bem tal importância.

83 Nesse contexto, a despeito da efetivação ou não da fuga pretendida, chama a atenção o fato de que ter uma casa não representa efetivamente segurança ou estabilidade para esta camada da população, e como outros elementos - no caso, aqui, o envolvimento de um filho com o 'mundo do crime' - desestabilizam uma família relativamente 'enraizada' em um certo território.

84 A troca de chaves seria a troca, sem mediações formais, de uma casa por outra, podendo ou não envolver complementação em moeda. Encontrei, em campo, diversos casos semelhantes, de famílias que realizaram trocas de chaves visando a fugir da casa ou de um determinado território - seja por medo da polícia, como seria o caso de Marielen; seja para tentar sair dos limites do comando de um determinado irmão, caso de Aparecida, antiga moradora do Jardim Gonzaga que, após décadas de luta investida na transformação de seu barraco em uma casa, viu-se obrigada a deixá-la após o crescente envolvimento de seu filho com o mundo do crime, trocando sua casa por outra fora dos limites oficiais e simbólicos do bairro (ainda que muito próxima a ele), numa tentativa de, assim, sair também dos limites de ação do grupo ao qual o filho devia obrigações (Rosa, 2012a).

85 Aqui se insere, também, aquele já mencionado 'orgulho' por ter acompanhado o desenvolvimento do bairro, aquela concepção de "luta", enfim recompensada: ela agora mora em um lugar considerado bom na cidade e, pelo fato de finalmente estar estruturado, ela não quer sair dali: "O Santa Felícia não era tão grande igual é. Inclusive, esse bairro, onde eu moro hoje, outros bairros em volta, era só terra! 
daqui, porque conheço tudo aqui, nos detalhe. Aqui eu tô há mais de vinte anos, conheço cada buraquinho" -, mas, sobretudo, as redes de relações aí construídas. Na gramática êmica, também o já mencionado ser conhecido e ter conhecimento.

Suas redes de relações locais aparecem nesse momento, em suas narrativas, como seu principal 'bem', ainda mais valorizado que a casa (embora diretamente vinculado a ela): é da impressionante consciência do árduo processo de construção, reconstrução e consolidação de tais redes ${ }^{86}$ que decorre sua maior relutância - a de sair do bairro. São as já mencionadas redes de apoio, de informação e, muitas vezes, de simples interconhecimento (que também são consideradas fundamentais, principalmente em termos da representação do bairro como espaço seguro, como visto), aí incluídas tanto aquelas estabelecidas no âmbito da vizinhança, da religião, de colegas de trabalho, quanto as vinculadas, de alguma forma, ao mundo do crime local, a que tantas vezes recorreu para salvar o filho mais velho.

Porque aqui eu tenho comodidade, tenho amizades, se precisar de uma ajuda, eu vou ali, corro, eu sei onde ir, né? Eu vou ali na casa de um, de outro, eu sei quem vai me socorrer, faz vinte anos que eu moro aqui, então assim... Se eu precisar de uma ajuda, eu não vou ir lá na Aracy pedir, porque não tem ninguém lá que pode me ajudar, o bairro é bom, eu já morei lá, mas eu não sei aonde! Que casa eu vou lá pedir ajuda? Eu não sei, e aqui eu sei! Eu tenho uma criança, se eu precisar de uma ajuda aqui, eu vou ali do lado, ali na frente, se precisar de um emprego eu sei aonde que mora a pessoa experiente que me ajuda a arrumar um emprego. Lá não, não tenho. Aqui é onde eu encontro pessoas que me ajudam.

Eu gosto de morar aqui, por causa dos conhecidos que eu tenho aqui. Esse é o principal motivo, pra mim. Se eu for morar n'outro bairro e eu for precisar de uma ajuda, como eu te falei, vou ter que sair lá do outro bairro e vir pra cá, pedir ajuda, para as pessoas daqui. Se eu tô com algum problema, igual eu tenho esse problema com esse meu filho aqui, eu tenho uma filha pequena, vou pedir pra minha vizinha ficar; se eu for pra outro bairro, eu não vou conhecer ninguém, teria que fazer amizade no bairro e é difícil construir uma amizade de vinte anos. E aqui no bairro se meu filho cair ali em cima, na escola, as pessoas sabem que ele é meu filho, ele é conhecido no bairro, porque nasceu aqui. Qualquer coisa que acontece, a pessoa fala: 'você sabe onde mora a Marielen?', se você parar ali no mercadinho e perguntar onde mora a mãe do Jairo e do Jeison, as pessoas vão falar 'é ali ó'. Porque eu moro aqui há vinte anos. Eu já precisei de ajuda e é

Tinha algumas casas... mas não tinha asfalto. Só tinha asfalto na rua principal, o restante não. Eu vi construir tudo, colocar asfalto, tudo! O Santa Felícia, do ginásio pra cima era muito ocupado. E daí pra lá, já não era, pra cima também não tinha... têm muitos bairro novo hoje aqui na região do Santa Felícia, todos aqueles bairro não existia. Santa Angelina não existia. Só existia o miolo do Santa Felícia. Não tinha mais nada. Eu vi o bairro crescer inteirinho! Conheço cada pedacinho aqui. E agora que o bairro ficou bom, eu vou sair? Começar tudo de novo? Se eu puder, eu não saio daqui, já avisei meu marido. Posso até deixar a casa, se não tiver jeito, mas sair do bairro..."

86 Destaca-se o quanto a possibilidade de tal construção (e reconstrução) dessas redes de relações, consideradas tão fundamentais por Marielen, está absolutamente vinculada à possibilidade de fixação em um determinado território, proporcionada pela casa cedida pela patroa, fornecendo um contraponto bastante interessante à própria trajetória anterior de Marielen, bem como às demais trajetórias investigadas, sobretudo a de Núbia, pautada por intensos deslocamentos. 
aqui no Santa Felícia que eu encontrei. Eu sei direto onde eu vou. Conheço todas as mulheres, todo mundo. E todo mundo me conhece também. [Marielen]

Enquanto Marielen se debatia nesse conflito entre a proposta do marido de deixar casa e bairro, e sua alternativa de apenas fugir da casa, permanecendo nos limites ampliados do bairro, ou a tendência a continuar na casa, mesmo manjada, em função de sua relação moral e afetiva com a mesma e da ausência de problemas com a vizinhança, sua ex-patroa cumpriu o prometido e, um dia após Jairo completar 18 anos, veio a São Carlos para assinarem os papéis que transfeririam a posse do terreno para o nome do filho ${ }^{87}$. Coincidência ou não, será a partir deste fato que a questão da casa manjada e do desejo de mudança também passará a ser enfatizada por Jairo; ele, entretanto, não quer apenas fugir da casa, mas da vizinhança, do seu bairro, do bairro Santa Felícia como um todo.

Em suas narrativas, evidencia-se com força aquela perspectiva da mudança de casa e de bairro - quase como uma 'conversão', que, neste caso, carregaria a intenção de minimizar as marcas do envolvimento com o mundo do crime que estariam impregnadas na casa, mas também em seu corpo, sobretudo quando territorializado no bairro: fugir do preconceito, da fofoca, desse envolvimento que, ainda que compulsório, foi carimbado na casa, na família, e nele próprio.

A rua também, que nem, por ter muito problema com polícia, então, às vezes, as pessoas da rua pensam que a gente também faz parte dessas coisas, então você passa na rua as pessoas ficam olhando pra você assim. Pra família inteira, todo mundo. (...) Na rua também, os outros, os amigos dele aí, às vezes fala 'ó o Jeison passando', tem vez que confunde assim, já fui parado por polícia, assim, muitas vezes 'ó o Jeison, para aí'. (...) E, como eu sou Testemunha de Jeová, então, tipo, a gente se veste social, tal, e sai de casa em casa, e muitas vezes as pessoas falam assim 'mas você não é aquele, que anda com aquele outro lá? Porque você tá batendo na minha casa?'. Uma coisa que as pessoas não sabem, então elas confundem bastante, nesse bairro, então é por isso que eu não gosto desse bairro, isso interfere muito aqui assim, então... [Jairo]

Ao contrário de Marielen, Jairo dissocia completamente a casa do bairro: da casa ele gosta; do bairro, não. Em resposta ao desejo comum de fugir da casa manjada, seu destino seria "um lugar onde ninguém conhecesse a gente". Assim, o que se mostra como o principal valor para Marielen, mostra-se o oposto na passagem geracional: para ele, ser conhecido não é um valor, porque traz estigma ${ }^{88}$.

87 Ao final, a transferência da posse referiu-se apenas ao terreno, que era o que efetivamente estava em nome da antiga patroa; já o processo referente à casa, que incluiria toda a documentação legal junto à prefeitura para poder ter acesso à escritura (e os custos aí envolvidos) ficou por conta de Marielen, que ainda não o efetivou.

88 Localmente, portanto, Jairo carrega um duplo estigma: de um lado, o da associação imediata com o mundo do crime, por conta do envolvimento do irmão; de outro, o achincalhamento por parte de outros jovens locais (os amigos do irmão), justamente por não ser envolvido, o que denotaria uma covardia, e seria expressa no apelido borrinha: “é, o Jairo, ele sofre lá no bairro por não ser desse 
Eu queria sair do Santa Felícia como um todo. Porque, que nem, aqui é um bairro ligado, não tem uma separaçãozinha tipo, da rua de cima já é Tortorelli, da rua pra baixo já é Santa Felícia, não tem essa separação. Aqui todo mundo conhece todo mundo, então, se eu for lá pra cima, tem um milhão de gente que eu conheço lá. Então, quero ir pro outro lado da cidade mesmo, entre aspas. [Jairo]

Eu gosto de morar nessa casa, mas nesse bairro não. Ah, se for ver a maioria da minha vida eu cresci aqui, que eu cheguei aqui com 6 anos, mas o bairro, em geral, eu não gosto não. / Thaís: Por que você não gosta? / Não sei, acho que é um bairro já muito conhecido assim, tem muito tumulto também. / Thaís: Tumulto? / É, marginais. Essas coisas de droga etc. Me incomoda. / Thaís: Por isso você quer ir pra outro lugar? / Sim, outros bairros. Qualquer um, menos esse. /Thaís: Menos nesse... e você acha que em outros bairros não tem isso também? / Ah, ter, tem, mas aqui a gente já tem problema em casa, na família assim, então aqui já fica um lugar meio batido, com a justiça etc. No caso, eu queria ir pra um lugar onde ninguém conhecesse a gente. (...)/Thaís: E como você acha que seria chegar pra morar num lugar onde você não conhece ninguém? / Seria legal. Porque, além de eu não conhecer ninguém, eles não iam conhecer a gente, então não iam conhecer a origem nossa, o que a gente já passou. Os problemas que a gente tem, assim. / Thaís: $E$ isso seria uma coisa boa? Me fala um pouquinho disso. / Sim. Porque, por exemplo, aqui, se a polícia invadir aqui hoje, você vai na esquina ali, você vai entrar no mercado, 'o que aconteceu ali na sua casa, não sei o quê', mas se a polícia invadir aqui hoje e eu for morar noutro bairro amanhã, as pessoas não vão saber nada de mim, pô, é uma coisa assim, que você não tem nada a ver, mas por estar no local que você mora, os outros comparam você com aquilo. / Thaís: E, por exemplo, sua mãe tem uma relação com as vizinhas, se precisar de uma ajuda, de deixar uma criança e tal, e você acha que isso, pra você, não faria falta? / Pra mim, não. Porque em qualquer lugar que eu for, vai ter um Salão do Reino, então eu sempre vou fazer relações. [Jairo]

Contudo, ainda que João e Jairo compartilhem da intenção de deixar tanto a casa como o bairro, mesmo que com objetivos distintos, é Marielen quem dará a palavra final sobre o assunto: de nada adiantaria mudar de casa enquanto o filho ainda estivesse solto, pois ele carregaria as mesmas marcas para qualquer outra casa, em qualquer outro lugar ("o meu filho não tá preso ainda, então, qualquer lugar que eu for, ele vai estar atrás de mim"). De fato, passados alguns meses do fatídico assalto e de toda a situação subsequente, Jeison estava cada vez mais presente de volta à casa (ainda que não estivesse oficialmente morando lá), levando, nas palavras de Marielen, "uma vida praticamente normal": "ele vai no centro, vai em casa, tá de bicicleta pra lá e pra cá". Embora permanecesse morando no Jardim Zavaglia, voltou a circular pelo Santa Felícia e pelo Romeu Tortorelli e foi, aos poucos, retomando vínculos com a casa e a família, levando roupas para Marielen lavar, passando para ver a irmã mais nova, aproveitando para fazer uma ou outra refeição.

Nesse contexto, as perspectivas futuras de Marielen quanto à casa passam a girar em torno do fato de ter um filho bandido e ter que encontrar "um jeito dele sair da barra

mundo. Onde ele passa, ali, os meninos ficam gritando: 'ô Borrinha, olha o Borrinha ali'. Borrinha é um xingo, um nome pra cagão. Eles não se conformam quando um não quer entrar pro mundo do crime." 
da minha saia, e da minha casa, porque senão ele vai ficar morando comigo até morrer": certa de que ele, mais cedo ou mais tarde, seria preso, ela começa a mobilizar-se em busca de formas de acesso a uma casa própria, para garantir ao filho "um lugar pra ele morar, quando sair da cadeia", espelhada no caso de tantas outras mães do bairro que, após os filhos presos serem soltos, tiveram de escolher entre este ou o marido, que em geral não é pai do filho (como no caso dela) ${ }^{89}$. Ela fica sabendo de um leilão da COHAB em um bairro vizinho, e o próprio filho a informa sobre a nova leva de casas que será construída na continuidade do Jardim Zavaglia. Busca, então, informações sobre o funcionamento dos sorteios da PROHAB, pois, como grande parte das camadas populares da cidade, ela pouco sabia sobre o acesso às políticas habitacionais locais:

Eu achava que não podia ser autônomo, que eles davam prioridade pra quem tem carteira assinada. Agora que eu sei como é, na próxima inscrição, eu vou me inscrever, eu não tenho casa no meu nome, então eu posso pegar. Vai ficar pro meu filho, pra quando ele sair da cadeia, mas pelo menos é uma coisinha que eu vou pagar e é meu. [Marielen]

Então agora eu vou me inscrever. Eu sempre conheci bastante pessoas que tinham tentado, que ganharam terreno, casa... Só que... eu nem cheguei a tentar, né, porque eu morei com a minha sogra e eu era molecona, não pensava em ter casa e nada, quando eu fui pensar nisso a minha patroa já tinha me dado uma casa pra morar, e não deixou eu me inscrever. E agora eu voltei atrás, porque esse meu filho já tem vinte anos e ele precisa de um canto pra morar, então eu vou me inscrever. Caso se um dia eu ganhar, quem vai morar na casa é o meu filho. Não sou eu. Mesmo que ele vá preso, fique dez anos, um dia, quando ele sair... é isso que as mães do bairro fazem, a Delma tem uma casa, ganhou num predinho no CDHU, e o filho vai morar lá quando sair da cadeia. / Thaís: As mães se inscrevem pra conseguir casas pros filhos? /É, se inscrevem. O que aconteceu: esse meu filho tem uma namorada, pretende casar, vive aqui em casa, então eu não quero que ele more comigo. Como eu não tenho casa nenhuma no meu nome, eu acho que eu tenho direito de... Eu vou pagar, a casa vai ser minha, mas vou deixar ele morando, vou me inscrever, se um dia eu conseguir, quem vai pagar sou eu, vai ser minha, mas é só pra tirar ele daqui. [Marielen]

Enquanto Marielen estava às voltas com essa perspectiva, reunindo a documentação para se inscrever no próximo sorteio da PROHAB no âmbito do PMCMV, Jeison foi apreendido pela polícia em um novo assalto com um "bandidão considerado lá do bairro". Visivelmente aliviada - "prefiro ele preso do que morto" - após suas já usuais correrias para garantir os direitos do filho, ela me contaria, perplexa, sobre a sua inesperada soltura: após um dia detido na delegacia, enquanto Marielen estava de plantão aguardando o desfecho da situação, primeiro o parceiro dele saiu e disse a

89 E são muitos os exemplos elencados por Marielen nesse sentido, bem como outros observados em campo, mas penso especialmente no caso de uma de suas vizinhas que, vivendo com o marido e um filho numa casa própria (mas construída pelo marido, que não é pai de seus filhos), quando o outro filho, que se encontrava preso, é libertado, o marido não aceita recebê-lo em casa, e ela opta por ficar com o filho, alugando uma casa para viver com este e com o outro menino. 
ela: "fica tranquila, que o Jeison vai ser solto também". Entre a suspeita de que tal bandido teria feito um acordo com os policiais e a informação de que as vítimas não o teriam reconhecido ${ }^{90}$, Jeison estava oficialmente livre, não era mais um foragido. Voltaria a morar na casa dela e, mais uma vez, Marielen apostaria em seu encaminhamento: ela convence o marido a empregá-lo como ajudante de pintor em uma das obras em que estava trabalhando na cidade, e o filho Jairo a emprestar seu documento de identidade para que Jeison pudesse realizar o serviço, porque era em um condomínio fechado e, para poder ingressar no mesmo, todos os trabalhadores eram obrigados a deixar a identidade e tinham sua ficha policial consultada.

Menos de um mês depois, no mesmo dia em que Jairo descobrira que, sob sua identidade, o irmão tramava um assalto ao condomínio onde estava trabalhando com o padrasto, Jeison foi morto pela polícia durante um assalto a mão armada a uma casa em um bairro popular próximo ao seu ${ }^{91}$. Minha pesquisa de campo já se encerrara há alguns meses, e eu estava viajando quando tudo aconteceu, mas Marielen me telefonou completamente desolada, após o enterro. Tão logo cheguei à cidade, voltei a encontrá-la mais algumas vezes na tentativa de oferecer-lhe algum apoio: ela abandonara todos os trabalhos, deixara de frequentar o Salão do Reino e realizar o campo, parara de comer, mal conseguia cuidar de si mesma, que dirá de seus dois outros filhos. Ao longo de quase três meses, pude acompanhar seu sofrimento, bem como o lento processo de refazer-se e à própria vida ${ }^{92}$, em meio a uma perda tão brutal.

90 "O delegado falou que é comum isso daí: depois de um tempo dos crimes, as vítimas ficam com medo de identificar o suspeito e acabam não comparecendo ou não reconhecendo os bandidos", me diria Marielen, logo após deixar a delegacia, quando ela ainda tentou interceder para que o filho, ao menos, fosse encaminhado para uma clínica para drogados, temendo pelo futuro próximo dele: "o policial que pegou ele, quando foi soltar, avisou: 'fica esperto, que se eu te pegar de novo não vai ter segunda chance, eu mesmo vou resolver'. Ele falou, eu ouvi. Preferia que ele tivesse ido preso, porque agora vai ser mais sufoco na minha vida, preocupada com ele".

91 As condições em que a morte do filho ocorreu despertaram em Marielen inúmeras suspeitas, tanto em relação ao mundo do crime quanto à atuação da polícia. Por um lado, para ela, não se encaixava o fato de o filho, agora já um bandido experiente, ter ido assaltar um bairro vizinho ao seu que, além de ser bairro de pobre, também estaria sob o comando dos irmãos. Sobretudo porque o assalto teria sido proposto a ele e a outro menino do bairro por um bandido de fora daquela região (o qual teria, inclusive, fornecido as motos e as armas para tal). Por outro lado, o fato de o assalto ter sido realizado justamente numa rua sob comando de um bandido cuja consideração no mundo do crime não estava em alta, a fez pensar, inclusive, na possibilidade de ter sido uma emboscada armada pela polícia junto a tal bandido, como uma espécie de propina não monetária. Se tais suspeitas procedem, não importa aqui; também não me detive, por já não estar mais em pesquisa, nos desdobramentos da situação: interessa o fato de que os 'saberes' de Marielen a impelem a não aceitar simplesmente a situação, por saber que há outras dimensões que envolvem normas, lealdades, procederes, dinâmicas territoriais internamente ao mundo do crime e que ela, como mãe, poderia tentar fazer justiça ao menos nesse âmbito, mobilizando-se em uma última correria em nome do filho.

92 Cf. Das (1999, 2007, 2011). Parece-me importante distinguir, com a autora (2011:16), a dimensão de "vulnerabilidade" a que a trajetória aqui analisada remete daquela de "vitimização": "ser vulnerável não é o mesmo que ser vítima" - distinção que se evidencia claramente nas trajetórias apresentadas, 
Pesquisar não era meu objetivo naquele momento, mas, ao acompanhá-lo, pude compreender um pouco melhor a importância conferida por ela às redes de relações e à vinculação ao território: de um lado, houve, de sua parte, uma espécie de negação da casa, quase uma autopunição por não ter conseguido fazer dela o necessário abrigo para a família e, sobretudo, para o filho (durante o período subsequente à morte de Jeison, em que ainda mantive contato com Marielen, ela não conseguia ficar em casa, especialmente se estivesse sozinha ou com a filha pequena: ali ambas permaneciam em alerta, como se à espera de que ele - e, em alguns momentos, a polícia - fosse aparecer a qualquer momento); de outro, porém, manifestou-se um reforço dos vínculos com o espaço ampliado do bairro, especialmente através de uma nova reconfiguração nas redes de relações, que volta a enfatizar aquelas estabelecidas junto aos irmãos da igreja (nesse período, ela passa a circular intensamente pelo bairro, sozinha ou acompanhada da filha pequena, inicialmente transitando entre casas de vizinhas, conhecidas e irmãos da igreja; por vezes, saindo para "andar pelo bairro no meio da noite, coisa que sempre fiz atrás dele e devia ter feito naquela noite...". Passado o esmorecimento inicial, ela mergulharia de cabeça na religião, voltando a fazer o campo todos os dias pela manhã, e, às tardes, frequentando as casas dos irmãos: "eu preciso estar o tempo todo ouvindo que o novo mundo está chegando, senão eu não vou aguentar").

As ideias de deixar a casa e o bairro já não faziam o menor sentido, por mais que João seguisse insistindo nelas, talvez por acreditar que agora fosse o momento de "recomeçar a vida em outro lugar". Mas, para Marielen, mais do que nunca seu lugar era ali:

Agora eu não fico mais em casa, eu só quero ficar pelo bairro. Só volto pra casa quando todo mundo já está lá. Abandonei a casa, só fico pelo bairro. Andando por aqui meu coração se acalma, cada pedacinho aqui me lembra meu filho... eu vejo os outros meninos nas esquinas ou de bicicleta, é como se eu tivesse vendo ele por aqui... eu tenho as outras mães do bairro pra me consolar, tem os irmãos pra me falar as boas novas. Qualquer hora, do dia ou da noite, tem gente que acha até que eu tô louca, mas é andando pelo bairro, tudo aqui, às vezes até de madrugada, que eu tô sobrevivendo. [Marielen]

nos já mencionados processos de ressignificação cotidiana, em operações de conexão presentepassado, das violências perpetradas, sofridas e/ou testemunhadas (não apenas aquelas de caráter eventual, mas especialmente aquelas infiltradas nas relações correntes), que permitem que a vida prossiga seu curso, marcada pela violência, mas não necessariamente determinada por ela. 


\title{
[ entremeio III ]
}

\section{Expansão urbana, classificações socioespaciais e linhas de clivagens nos territórios populares}

\begin{abstract}
A hierarquização socioespacial a partir da qual se estrutura a produção das cidades constitui tema já consolidado nos estudos urbanos. Em se tratando de periferias, as fronteiras físicas e simbólicas que se estabelecem e se disputam em relação ao restante da cidade e, sobretudo, ao mundo público ${ }^{1}$, bem como os processos de estigmatização que sobre elas se abatem têm sido alvo de importantes investigações ao longo das últimas décadas ${ }^{2}$. Tais processos apontam, em grande medida, para figurações públicas que, ancoradas em perspectivas homogeneizadoras e estereotipadas sobre tais espaços e seus moradores, oscilam entre vitimização, culpabilização e, de forma mais recorrente, criminalização dos mesmos ${ }^{3}$. São, nesse sentido, representados socialmente como espaços de pobreza, violência,
\end{abstract}

1 Feltran (2008).

2 Em perspectiva internacional, são referências alguns trabalhos produzidos no âmbito da chamada "Escola de Chicago" (como Foote-Whyte, 2005, ou aqueles integrantes de compilação organizada por Grafmeyer e Joseph, 2004) e alguns desdobramentos contemporâneos (Joseph, 1998); ou ainda os trabalhos de Davis (2006) e Wacquant $(2001,2007)$. Há também uma vasta produção sobre o tema na América Latina, da qual recorri especialmente aos trabalhos produzidos por Segura (p. e. 2012a; 2012b), aos livros organizados por Carmán, Vieira e Segura (2013) e por Kuri e Diaz (2006). Em âmbito nacional, destaco as reflexões e revisões promovidas por Frugoli (2005; 2009); Marques e Torres (2005); Marques e Bichir (2001; 2001a); Torres et al (2003); Caldeira (2000) ou Telles e Cabanes (2006), para citar alguns. Em meu trabalho de mestrado, refleti também sobre tais questões (Rosa, 2008).

3 Rizek (2014); Melo (2014). Feltran (2008:194) elabora uma refinada reflexão sobre a associação entre o que denomina "expansão do mundo do crime" e a figuração pública das periferias, que se produz de fora para dentro (e que é, de certa forma, incorporada pelos próprios moradores desses territórios, como veremos): “Uma segunda dimensão da 'expansão do mundo do crime nas periferias' é vinculada a uma figuração que se produz de fora para dentro, e que partindo da dimensão pública da sociedade se impõe como visão geral sobre estes territórios e seus habitantes. Esta figuração se confunde com o que se chama usualmente de "criminalização" das periferias urbanas. Trata-se aqui de um processo vinculado diretamente às formas de distribuição da categorização social e da repartição da legitimidade pública a partir destas categorias. E nesta dimensão, cada vez há menos espaço para mediação entre extremos. Conforme os anos passam, fica mais nítida a impressão do senso comum: ou se é trabalhador, ou se é bandido." 
marginalidade, lócus dos mais diversos problemas sociais, os quais seriam compartilhados por todos os seus moradores.

A presente pesquisa, como visto, estruturou-se na contramão tanto dessas representações sociais externas e homogeneizantes sobre as periferias, quanto daqueles estudos que partem da premissa da "segregação" (muitas vezes em associação com a ideia de "exclusão") como categoria autoexplicativa ${ }^{4}$, questionando as perspectivas excessivamente dicotômicas e propondo uma abordagem relacional da produção e apropriação de tais espaços, a partir das dinâmicas socioespaciais captadas através de trajetórias urbanas. Entretanto, ao aproximar-se da experiência, das práticas e representações de moradores das periferias, uma dimensão paradoxal se fez cada vez mais presente, imprevista anteriormente à pesquisa de campo e ainda relativamente pouco estudada 5 : o fato de que, muito embora, em inúmeros aspectos, seja possível delinear uma inegável experiência urbana comum de tais moradores das periferias, por outro lado, estes se percebem, classificam e relacionam internamente como grupos sociais distintos ${ }^{6}$. Ou, em outras palavras, a percepção de que aquela já mencionada "trança de relações" entre os bairros populares, as redes de interconhecimento e informações que os atravessam, simultânea e paradoxalmente os conectam e os apartam, incorporando dimensões como os processos de estigmatização - quase sempre associadas àquelas representações externas.

À medida que a pesquisa de campo avançava, cada vez mais se evidenciava a relação, já introduzida nos Capítulos e Entremeios anteriores, entre a dinâmica processual de

4 Brun (1994). Não se trata, evidentemente, de negar os processos de segregação, mas problematizar as abordagens que os tomam como dados em si mesmos, ainda muito arraigada nos estudos urbanos; nesse sentido, a coletânea organizada por Brun e Rhein (1994) é esclarecedora, assim como aquela organizada por Carmán et al (2013), na qual questionam-se as ideias de unidade e coesão social pressupostas na concepção de segregação, propondo distintas maneiras de aproximar-se da questão e enfocando a complexidade e a historicidade de seus processos. Outras boas reflexões nesse sentido podem ser encontradas em: Preteicelle e Valladares (2000) e Valladares (2005) para o caso das favelas no Rio de Janeiro; Almeida et al (2009), que, a partir de três casos empíricos que configuram situações heterogêneas de pobreza no espaço urbano, contribuem para relativizar a associação imediata entre desigualdade, pobreza e segregação espacial; Marques e Torres (2005), que realizam uma revisão crítica da concepção de "segregação", propondo uma noção mais relacional para usos contemporâneos.

5 Entre os poucos trabalhos encontrados nesse sentido estão os produzidos por Segura (2011, 2012, 2013). Descobri tais trabalhos do autor já ao final da produção da tese, e as reflexões aí propostas foram de grande valia para esta abordagem preliminar sobre as classificações socioespaciais sob as quais meus interlocutores matizam, hierarquizam, experienciam e produzem sentidos sobre as periferias da cidade de São Carlos. No Brasil, alguns estudos vêm atentando para tais dinâmicas classificatórias no âmbito da produção da territorialidade das favelas, cuja diferenciação perante o mundo público seria uma das estratégias para minimizar a criminalização de tais espaços e os estigmas a eles associados, bem como para disputar recursos políticos, sociais, econômicos. Dentre eles, destaco os de Rocha (2008; 2009) e Piccolo (2006, 2009), para citar alguns.

6 Segura (2011:85). 
produção do urbano apreendida através das trajetórias e a produção e reconfiguração de classificações e hierarquizações socioespaciais pelos próprios moradores das periferias. A densa trama relacional que a tese apresentou até aqui se mostrou atravessada, todo o tempo, por categorias de classificação de pessoas e lugares que, vistas mais de perto, pareciam configurar-se mesmo como potentes sistemas classificatórios êmicos, produzidos mediante o acionamento e a conjugação de uma série de critérios morais, econômicos e simbólicos e que apontam para disputas internas acerca das representações dos territórios da cidade homogeneizados sob categorias como "periferias" ou "bairros populares".

Em um primeiro momento, chamaram a atenção as delimitações e diferenciações internas a cada um dos bairros onde vivem ou viveram meus interlocutores, as quais pressupõem saberes específicos sobre os territórios, que se baseiam numa experiência do espaço (ao mesmo tempo que a conformam) e configuram um primeiro nível, mais fino, de linhas de clivagem no âmbito das relações sociais e dos usos cotidianos desse espaço: "ali é o local conhecido como favelinha, o pior local do bairro" (Jefferson, sobre um "pedaço" no Cidade Aracy I); "não olha muito, mas aqui é o famoso beco do tráfico" (Marielen, sobre uma rua sem saída, a uma visada exterior idêntica a pelo menos outras duas do bairro); "aqui também tem uma favelinha, são as piores casas do bairro" (Marielen, sobre um "pedaço" de seu bairro onde vivem famílias mais pobres); "ali no final tem a rua dos baianinhos" (Jefferson, sobre uma rua do bairro Presidente Collor, contíguo ao Cidade Aracy I, onde vivem predominantemente migrantes oriundos da Bahia); "a pior época foi quando a gente morou nos fundos do bairro, ali é horrível, não tem nada, os vizinhos são péssimos" (Beatriz, referindo-se ao período em que viveram em uma casa no limite entre o bairro Cidade Aracy II e, de um lado, uma mata que delimitava o fim da malha urbana, e, de outro, o bairro Antenor Garcia); "pra mim, essa esquina é o bairro, o melhor lugar pra mim, mesmo tendo virado o que virou, conheço todos ali" (Jefferson, sobre a esquina onde passou parte da infância e da adolescência no Cidade Aracy I, que teria se tornado um ponto de venda de drogas). Lembro-me de Núbia ter-me dito, um dia, referindo-se ao Cidade Aracy II, que "a esquina do bosque é um dos piores lugares do bairro", ao que indaguei: "Vocês já moraram por ali, não?" e ela imediatamente fez questão de me corrigir: "Não, nunca morei ali; morei na rua de baixo e agora moro na rua de cima. Deus me livre de morar ali.", evidenciando delimitações e diferenciações internas que só fazem sentido entre os moradores locais, pois que indissociáveis das relações que ali se estabelecem ${ }^{7}$. Assim, uma rua (ou mesmo uma esquina) faz toda a diferença na representação desses "pedaços", na construção dessas territorialidades e linhas de clivagens mais locais (e também

7 E aqui remeto à concepção de "territórios de subjetivação" de Guattari (1985). 
são variáveis conforme a experiência urbana individual e coletiva naquele espaço, além da anterior a ele, como procurei demonstrar anteriormente).

Sem me deter muito nesse nível de produção de fronteiras socioespaciais internas aos bairros ${ }^{8}$, importa reter aqui que, a partir da recorrência dessas diferenciações mais locais, passei a atentar para o fato de que os próprios moradores das periferias não se veem, nem se relacionam sempre como iguais, como levam a crer não apenas o senso comum, que sustenta aquelas já mencionadas representações externas, como também alguns estudos clássicos sobre periferias, cujo enfoque na identificação de uma "experiência de classe" (ou de uma experiência da cidade como experiência de classe $)^{9}$, muitas vezes deslizaria para seu tratamento categorial, enfatizando uma homogeneidade socioeconômica e cultural, uma unidade e coesão social que configurariam territorialidades e sociabilidades tidas como "específicas" em relação ao restante da cidade (e da sociedade), mas "uniformes" e semelhantes entre $\mathrm{si}^{10}$. Passei a considerar - com Foote-Whyte (2005), Simmel (2006), Elias e Scotson (2000) - que os modos de viver (e seus tempos) produzem valorações e estão cotidianamente em contato com outros modos de viver e outras valorações, sempre:

8 No mestrado, eu já observara essa produção de distinções e fronteiras internas a um território (no caso, uma favela que se transformou oficialmente em bairro), mas estas se produziam, em grande medida, em mediações com intervenções estatais no espaço urbano (Rosa, 2008). Na presente pesquisa, entretanto, chamou a atenção a produção social e cotidiana dessas clivagens finas, e o quanto elas estão imbricadas na produção e apropriação dos espaços em questão. Para o caso do Cidade Aracy, também Silva (2006) identificou tais divisões e distinções socioespaciais: “As divisões por status entre os espaços do bairro, feitas pelos próprios moradores, associavam-se às redes sociais ali existentes" ou "Segundo a posição de cada um, as diferentes partes do bairro eram apresentadas a mim de modo diferente". Referências seminais nesse sentido são o estudo de Elias e Scotson (2000) sobre uma "pequena comunidade" norte-americana (cuja figuração "estabelecidos-outsiders" foi revisitada por Segura (2011) em artigo bastante inspirador) ou o de Bourdieu (2008) sobre os conjuntos habitacionais nas periferias francesas, no qual o autor e sua equipe os evidenciam como espaços que, homogêneos de uma mirada distanciada, mostram-se como um vasto repertório de diferenças ao serem encarados a partir de suas dinâmicas cotidianas.

9 Paoli et al (1984). Como destacam Rizek e Shimbo (2010:5): “No contraponto à tônica estrutural de uma leitura marxista dominante até então, é possível perceber a grande presença da noção de experiência a partir de E. P. Thompson e da poderosa revisão historiográfica britânica durante esse período. Assim, também parte significativa das etnografias fabris, de bairro, de formas de organização popular passava pelo crivo de uma concepção que punha em tela um fazer-se (real ou presumido) da classe trabalhadora brasileira em suas cenas cotidianas e em suas múltiplas formas de existência."

10 Refiro-me aos já clássicos estudos dos anos 1970 e 1980, dentre os quais destaco o trabalho de Caldeira (1984). Torres et al (2003:38) assim sintetizam tal caracterização da "periferia" presente nesses estudos: "espaços socialmente homogêneos, esquecidos pelas políticas estatais e localizados tipicamente nas extremidades da área metropolitana". A própria adoção de "segregação" como categoria, stricto sensu, pressupõe unidade e coesão social do grupo segregado, associando-se à ideia de "exclusão" para caracterizar "espaços com alto grau de homogeneidade social" ou "grande homogeneidade interna" (Bógus, 2009:119, 120). Alguns daqueles estudos, como o de Zaluar (1985), apontavam já para uma diferenciação interna às camadas populares, mas ancorada na dicotomização "trabalhadores versus bandidos". Machado da Silva (1967), em estudo pioneiro, também já questionava o estereótipo de que favelas seriam um todo homogêneo, identificando a presença de uma grande diferenciação social interna e analisando a presença de uma "burguesia favelada". 
o status é relacional, é situacional; as valorações e as categorias delas decorrentes são construídas na interação e em situação. Há, portanto, movimentos de aproximação e distinção conforme circunstâncias; são identificações ou oposições absolutamente relacionais, e é sob essa perspectiva que se configuram as classificações socioespaciais aqui em foco. Ou, ainda, com Marc Augé (1996), em sua reflexão sobre a vinculação entre as questões da alteridade e do espaço na tradição antropológica:

Sea como fuera, la simbolización del espacio se da en distintos niveles: se aplica a la casa, a conjuntos de casas, a reglas de residencia, a divisiones del poblado (en barrios, en zonas profanas y sagradas), al terruño, al territorio, a la frontera entre espacio culturalizado y naturaleza salvaje. Si construye una identidad relativa, lo hace siempre por oposición a una alteridad externa y en función de una alteridad interna. (Augé, 1996: 100)

Tendo isso em conta, as trajetórias investigadas foram permitindo entrever, a partir de seus cruzamentos e das narrativas que as recompunham, a construção de linhas de clivagem mais gerais, que, para além do estigma generalizado dirigido externamente aos pobres e a seus territórios, configuravam hierarquizações êmicas desses espaços: dentre a pluralidade de escalas em que é possível observar esses processos de simbolização e representação socioespacial, interessou-me particularmente apreender os meandros dessa classificação mais abrangente, dessa hierarquização mais ampla, na escala da cidade. De todo modo, esses vários níveis de classificação (na escala intrabairro, entre bairros distintos, ou mesmo entre regiões da cidade) operam simultaneamente e configuram-se como partes de um mesmo processo de diferenciação e aproximação entre pessoas e espaços, resultando na conformação de distintas territorialidades ${ }^{11}$. Se, por um lado, na escala interna aos bairros tais classificações delineiam uma topografia simbólica vinculada sobremaneira a uma proximidade social e a uma experiência espacial, na escala da cidade conformam uma dinâmica e relacional taxonomia territorial, que não se baseia somente (ou necessariamente) nessa experiência mais direta dos espaços ou nessa relação interpessoal mais próxima, estando mais relacionada à experiência urbana acumulada no tempo e articulando dimensões estruturantes e subjetivas em jogos de perspectivas orientados, sobretudo, pela existência daquelas redes de interconhecimento e informação que atravessam a cidade de ponta a ponta, pelo fato de que as pessoas transitam entre os vários bairros periféricos e conhecem gente em todos eles (decorrência justamente da articulação entre dinâmicas familiares e deslocamentos habitacionais já profundamente apresentada na tese).

11 Valendo-se muitas vezes, inclusive, de categorias bastante semelhantes, transpostas a escalas distintas, como as que enfocarei a seguir. 
É de se notar, nesse sentido, que essa classificação mais abrangente opera a partir (e é produtiva) de uma certa concepção da cidade - a um só tempo concreta e simbólica - que, com pequenas variáveis, apresenta contornos muito semelhantes nas várias narrativas dos principais interlocutores da pesquisa: aquela dos bairros, cuja acepção nativa, como visto nos capítulos anteriores, remete exclusivamente aos lugares de moradia das camadas populares na cidade, às assim chamadas periferias (muito embora, como veremos, a concepção êmica de periferia acompanhe tais classificações, sendo bastante relacional) ${ }^{12}$.

Assim, pareceu-me fundamental refletir, mesmo que brevemente, sobre tais hierarquizações socioespaciais na pobreza, sobre algumas dimensões da produção dessas linhas de clivagem internas às camadas populares, atentando a algumas das categorias que pautam tais classificações, perguntando por seus parâmetros e sentidos, bem como por suas reverberações simultâneas nas trajetórias urbanas investigadas e nos processos de produção e apropriação dos espaços a que se referem.

As categorias aqui apontadas são aquelas mais recorrentemente evidenciadas em campo, havendo, certamente, outras que os limites da pesquisa não permitiram aprofundar. Embora, como veremos, tais categorias não sejam estanques e, em grande medida, adquiram sentido somente em relação com as demais, considerei importante elencá-las separadamente, de modo a captar os critérios e as lógicas que as orientam e como operam na construção de figurações e práticas espaciais entre as camadas populares. Nesse sentido, a exposição a seguir tem função

12 Sobre tal concepção de bairros, ver, em especial, nota 56 do Capítulo 3. Em todas as narrativas, evidenciava-se um conjunto de bairros que compunham esse sistema classificatório: bairros por onde as pessoas já haviam transitado ou permanecido em seus deslocamentos habitacionais, onde vivem ou viveram familiares e amigos, onde gostariam de morar, onde só morariam "se não tivesse outro jeito" ou onde não morariam de jeito nenhum. De modo geral, tal sistema classificatório considera, de forma quase icônica, os bairros Cidade Aracy I e II, Antenor Garcia, Jardim Gonzaga, a parte alta da Zona Sul, Santa Felícia (apreendido como um todo), Santa Angelina, Arnon de Mello (no qual estão inclusos diversos conjuntos habitacionais produzidos na região do Santa Felícia pelas COHABs), São Carlos VIII e alguns bairros novos (a maioria produzida no âmbito do PMCMV ou, atualmente, lócus de produções vinculadas ao programa), como Jardim Zavaglia, Parque Novo Mundo, Jardim Novo Horizonte, Embaré (ver mapas nos Anexos). Enquanto o centro aparece, em geral, apenas como parâmetro geográfico, sobretudo para definir o perto e o longe, os locais de moradia de classe média e alta nem sequer figuram nessa taxonomia. Mesmo quando as narrativas remetem a uma hipotética liberdade de escolha, sintetizada na expressão "se eu pudesse escolher", esses bairros não figuram como uma opção, atitude em geral justificada com argumentos como os apontados por Marielen e descritos no capítulo 3: "bairro de rico é chato, né, muito parado, não tem ninguém na rua. Só tem casa bonita, mas não tem gente na rua, não tem comércio. Credo, que chatice, ninguém sai de casa!" 
simultaneamente descritiva e analítica, visto que, empiricamente, observa-se uma complexa sobreposição dessas categorias na conformação das classificações.

\section{. tipos de casa e modos de morar}

Dentre os critérios acionados nessa produção de categorias de territórios (e pessoas), a dimensão da moradia e, mais, dos modos de morar parece ser a que estabelece maior interface entre as escalas micro e macro desses sistemas de simbolização e classificação observados. Sem entrar na dimensão da propriedade da moradia (ou dos modos de aquisição da mesma) ${ }^{13}$, as características físicas das casas emergem como elemento crucial na valoração não apenas de um indivíduo, de uma família ou de um grupo social, mas também de um determinado território.

As já mencionadas definições de Núbia sobre casas tipo cortiço e tipo favela são emblemáticas nesse sentido e dão indícios de que algumas dessas categorias remetem, de certa forma, à incorporação interna de representações externas estigmatizantes, transferindo-as a um outro: muito da distinção, por exemplo, entre os bairros Cidade Aracy I e II, ou entre estes e o Antenor Garcia relaciona-se à dimensão de que, do primeiro em direção ao último, as casas seriam progressivamente menores e piores, sendo cada vez maior a concentração de casas tipo favela (categoria associada genericamente a casas construídas total ou parcialmente com materiais de descarte, com poucos recursos financeiros e materiais, sem acabamentos, com maior proximidade entre si, "onde moram várias pessoas juntas"). A própria figuração do mencionado Jardim Gonzaga como favela, por exemplo, que perpetuou também entre os populares, mesmo após duas intervenções urbanizadoras (e antes ainda da intensificação da presença do tráfico de drogas no local), tem, em muito, relação com as condições de grande parte das habitações e com a forma de adensamento da ocupação através da construção em lajes e quintais.

A prática de construção de cômodos nos quintais, vinculada à configuração de novos núcleos familiares, também é associada à ideia de favela e maior pobreza, sendo uma das caracterizações que rebaixariam, por exemplo, o Cidade Aracy nas classificações promovidas por aqueles que desejam diferenciar-se dessa condição (como é o caso de Beatriz, por exemplo, mas também de Marielen): a essa perspectiva de viver em "lajes" ou "quintais" estaria contraposto um outro "código ético de como habitar"14 que se configuraria em bairros novos, como o Parque Novo Mundo ou mais desenvolvidos, como Santa Felícia, por exemplo, e que seria correspondente a outro

13 Que também são potentes categorias classificatórias, como visto ao longo dos capítulos.

14 Kopper (2013). 
modelo e a outro projeto familiar, mais afeito à ideia de classe média baixa, conforme fazem questão de distinguir tanto Beatriz quanto Marielen.

\section{. o estágio de desenvolvimento dos bairros}

A essa distinção por critério de tipos de casas e modos de morar articula-se uma dimensão classificatória dos bairros e de suas regiões em mais ou menos evoluídos, desenvolvidos, estruturados, em uma espécie de gradação relativa a estágios de produção do urbano (cf. Entremeio II), que são, também, associados à caracterização ou não de uma localidade como favela ou periferia entre meus interlocutores. Ou seja, haveria toda uma relação entre aquela mencionada dinâmica processual de produção do urbano e a contínua construção e reconfiguração das hierarquizações socioespaciais, entre expansão urbana e conformação de novas linhas de clivagem entre os territórios populares: é o caso, por exemplo, do Jardim Botafogo mencionado por Jimmy e Núbia que lá viveram -, que já foi um limite da área urbana, uma das periferias da cidade onde, nos anos 1990, foram construídos diversos conjuntos habitacionais e que hoje é considerado um bairro de classe média baixa, assim como outros da mesma região (como o Redenção, onde vive a mãe de Beatriz e que confere a esta os parâmetros ideais de sua experiência urbana, como visto). Também o Santa Felícia é emblemático nesse sentido, tendo sido um dos primeiros bairros periféricos na zona norte da cidade, consolidando-se nos termos também de uma 'centralidade periférica', à qual se vinculam outros loteamentos populares e conjuntos habitacionais promovidos desde os anos 1980 por COHABs e pela PROHAB, ocupando hoje posição privilegiada nessa hierarquia nativa dos bairros populares. Sob tal categoria emerge a percepção, recorrente em campo, de que certos bairros, após atingirem um certo desenvolvimento, deixariam de ser periferia, que, no repertório nativo, estaria associada sobretudo àquela ausência do urbano:

Antigamente, aqui [Santa Felícia] era periferia, mas agora o bairro saiu do estado de periferia. / Thaís: Mas por quê? O que é esse estado de periferia? / Periferia é um lugar, assim, onde você não tem condições mínimas pra nada, você não tem estrutura, não só de água, luz, asfalto, essas coisas, mas uma lotérica, você não tem um banco - aqui no Santa Felícia não tem banco, mas tem o caixa 24 horas, ali no Carrefour -, é um bairro onde você não tem condições mínimas de nada, tipo lá no Aracy ${ }^{15}$, no Zavaglia, todo mundo tem que sair, subir pra cima, pra fazer as coisas... (...) Mas aqui não, aqui tem até prédio agora! Periferia é não ter serviço pra comunidade; assim, aqui tem bastante praça pras crianças, bastante escola... também tem o quê de bom? Vários sacolão, várias padarias, eu posso escolher. Aqui tem Posto de Saúde bom. E tem vereador que luta pelo bairro, não é mais excluído, como outros. Mas já foi periferia. Porque, até nos anos 90, tinha

15 Note-se que ela se refere ao Cidade Aracy de forma bastante distinta da figuração de centralidade que dele emerge na região (cf. Entremeio II), em grande medida devido à experiência anterior dela com o bairro, mas também associando a ele as condições ainda relativamente presentes em toda a região, sobretudo no que tange ao Antenor Garcia e Jardim Zavaglia. 
bairro aqui no Santa Felícia, como o meu mesmo, que não era asfaltado, e eu cheguei a ver, não era asfaltado, era terra pura, não tinha lotéricas, também não tinha supermercado, e o que aconteceu? O bairro foi crescendo, devido a essas fabriquinhas que veio pra cá. O bairro foi evoluindo, hoje ele é um bairro caríssimo, hoje um terreno aqui não é menos do que $R \$ 80.000,00$. Meio terreno, pra você ver, como tá a coisa aqui, a coisa tá boa aqui pra morar ${ }^{16}$. Todo mundo quer morar aqui. [Marielen]

Também exemplar nesse sentido, a centralidade que vem adquirindo o Cidade Aracy no contexto da produção de novos bairros pelo PMCMV em seu entorno e as figurações daí decorrentes parecem movimentar uma reconfiguração do posto que o bairro geralmente ocupava em tais hierarquizações êmicas (seja pela já mencionada dimensão dos tipos de moradia e dos modos de morar, ou por aquelas, tratadas a seguir, de sua forma de ocupação e da presença do tráfico de drogas): destacandose seu desenvolvimento, procede-se ao deslocamento de características antes associadas a todo aquele território para partes específicas dele, como o Antenor Garcia ou o Jardim Zavaglia. Assim, num movimento semelhante ao que teria acontecido com o Santa Felícia, também o Cidade Aracy deixaria de ser considerado, por alguns, como periferia (numa associação recorrente entre concepções de periferia e favela):

Periferia é viela, é um lugar, assim, onde polícia não passa, não entra; só entra, que nem, se for que nem na Rocinha, pra invadir mesmo e tirar, mas não deixa de ser uma periferia. Periferia é um lugar onde as pessoas têm mais necessidade, assim, se for ver, aqui, o bairro que a gente mora [Romeu Tortorelli, no Santa Felícia] não tem necessidade desse jeito, né, aqui a gente tem saneamento básico, água, luz. Tem comércio, é estruturado, né? Periferia é mais pra favela, eu acho... Aqui em São Carlos, eu não sei, não, de favela, mas que tem, tem, porque eu ouço falar muito. Uma vez, eu tinha uma moto velha, aí, eu ficava na mecânica, tinha um povinho ali meio de má índole, assim, então uma vez eu tava

16 Vale destacar, aqui, o quanto essa figuração de desenvolvimento dos bairros está diretamente associada a uma percepção do posicionamento dos mesmos nas dinâmicas imobiliárias locais: bairros mais estruturados seriam mais bem valorizados, tanto no mercado "formal" quanto no "informal". Nesse sentido, processos como a produção de uma 'centralidade periférica' (como em curso no caso do Cidade Aracy) ou a atuação das políticas habitacionais são determinantes na produção e reorganização dessas classificações, incidindo diretamente sobre tais mercados (como acontecido já na região do Santa Felícia e como vem acontecendo recentemente, ainda que com outros contornos, no Cidade Aracy I). É o caso dessa produção mais recente vinculada ao PMCMV, em que se observa a simultaneidade do "aumento do mercado formal da habitação para setores populares" (Shimbo, 2014:8) e a reprodução do mercado informal sobre bases talvez ainda mais clivadas (cujos valores acompanham também a associação - ou não - de estigmas a tais novos territórios), dificultando o acesso da população mais pobre até mesmo a esse mercado informal de aluguel. Vide o Cidade Aracy, que, até recentemente, era a região com os menores valores nesse mercado informal e que, pós PMCMV, viu tais valores aumentarem vertiginosamente, de tal modo que os menores valores se encontram atualmente nos bairros Antenor Garcia e Jardim Zavaglia. Assim, tais classificações informam também sobre a relação entre deslocamentos e perspectivas de mobilidade social ascendente, que tem uma ancoragem naquela percepção (apontada por Jefferson e Beatriz) da casa como capital, sendo partes de um cálculo sobre as posições dos territórios nessas hierarquizações populares os estigmas associados ou não a eles e as perspectivas futuras de produção do urbano (desenvolvimento do bairro) e de valorização da casa que os mesmos oferecem. 
lá, chegou um cara e falou assim 'é, você vai chegar a noite lá?', eu falei 'onde?', o outro falando com o outro, 'ali na favela ali', 'porque eu não sei onde é essa favela', daí falou 'é, você não viu o tamanho do fuzil que o outro fica andando na rua?' Então... eles tavam falando mais pro lado do Gonzaga ali. Que é favela. (...) Já o Aracy, por exemplo, não é periferia pra mim, lá também já tá desenvolvendo. Já o Antenor é, tem uns princípios. / Thaís: Por quê? / Ah, por meu pai já morar lá, eu já... eu tenho bastante tio lá também, então eu ando por ali, e é meio encanado, pode se dizer uma periferia, uma miniperiferia. Aqui no Santa Felícia, e Aracy mesmo, a gente tem rua asfaltada, com luz, tudo, você desce aqui você vê saída, sai daqui você tem outra rua. E lá no Antenor, tem várias ruas que é terra, e as casas são tipo barracos, assim, de madeira. Tem, e você chega no final da rua, não tem onde você sair, você tem que voltar, e se você chegar no final da rua, ali, sempre tem um povo que fica lá, então, se você for até lá... E não é só o bairro né, as vezes um bairro pode ser, que nem, uma chácara é terra e sem luz, mas as pessoas de lá são diferentes. O que faz o bairro é as pessoas, né, e não o bairro ${ }^{17}$. [Jairo]

O caso do Cidade Aracy é emblemático nesse sentido, justamente em função das questões analisadas no Entremeio II. Seu desenvolvimento, em se impondo como representação mais à tona nesse momento, faria frente àquela associação do bairro à forma de ocupação e às moradias tipo favela, ou mesmo àquela relativa à presença do tráfico de drogas e da violência no local: o Aracy é hoje melhor classificado, sob vários aspectos, do que os bairros do entorno ou, ainda, do que o Jardim Gonzaga (ainda denominado por muitos como "Favela do Gonzaga"), território ao lado do qual esteve, nas últimas décadas, em termos de posição nessas classificações e, sobretudo, de estigmatizações também nos meios populares.

Hoje em dia, é bem diferente o Aracy do Gonzaga, do Antenor. Aqui, o problema é, tipo, os caras não querem resolver os problemas que tem no bairro, mas, querendo ou não, a gente tá muito melhor que muita gente que mora lá pra baixo da barroca do Gonzaga, por exemplo; tem gente lá morando em situação de risco até hoje. Então, a gente não pode reclamar. Tem lugar lá que não tem iluminação pública, que nem no orfanato, não tinha iluminação pública... aqui, o serviço é ruim, mas pelo menos tem... [Jimmy]

Nessa classificação associam-se, ainda, outras duas dimensões: aquela da acessibilidade, tal como incorporada por meus interlocutores, que remete ao acesso diferencial a bens e serviços, infraestrutura urbana, políticas públicas - "lá no Aracy tem tudo, tenho acessibilidade a tudo, opções a milhão lá. Já nesses conjuntos $e$ bairros novos, Zavaglia, Novo Mundo, ou não tem nada, ou você tem que andar um monte pra chegar. É o principal motivo pra eu não querer sair daqui". [Jimmy] - e a da mobilidade, associada a concepções de perto e longe, que, de alguma maneira, têm a região central e a facilidade de acesso a variadas regiões da cidade como

17 Esta frase - "quem faz o bairro são as pessoas" - eu a ouvi recorrentemente em campo, apontando, por um lado, para a associação (entre meus interlocutores) entre determinados tipos de lugares e tipos de pessoas, que conformaria também as bases das classificações operadas; por outro, para uma representação que minimiza a dimensão física em favor da dimensão social dos espaços, das redes de relações aí tecidas, do ser conhecido/ter conhecimento. 
parâmetro - "aqui, no Santa Felícia, eu tenho comodidade, eu posso ir de a pé pro centro, eu gasto vinte minutos. Aqui é perto de tudo e tem transporte pra todo lugar, tem vários pontos, várias linhas. Já o Aracy é longe demais, é longe de tudo" [Marielen].

\section{. formas de produção do espaço urbano e de acesso à moradia}

Nessa categoria, que se relaciona diretamente aos processos de produção das periferias urbanas na cidade, evidenciaram-se, inicialmente, as figurações que vinculavam a "invasão de terras" - como nos casos da Favela do Gonzaga, da Favelinha da Fepasa e de uma ocupação antiga no bairro Santa Maria - ou a "doação de terrenos" - característica associada à região do Cidade Aracy de modo geral e, mais especificamente, ao Antenor Garcia - como principais condicionantes dos problemas associados a tais espaços, levando-os a ocupar as mais baixas posições, sob tal ponto de vista, dentre as classificações aqui mencionadas:

Como no Aracy foram terrenos doados, o Airton Garcia doava meio terreno e reservava a outra metade pra vender depois, começou a vir gente de tudo quanto é lado e de tudo quanto é jeito, porque imagina, terreno doado! Aí começou a fama da Cidade Aracy, porque tinha disputa de terreno, foi ficando violento... $E$ como era um bairro pobre, o pessoal vinha, não achava serviço, foi começando a ter prostituição, roubos... e aí ganhou a fama que tem. [Joana]

Jefferson: Tem gente que fala que o Aracy é favela, mas eu não acho, não é bem favela assim, porque Aracy é um bairro que foi planejado. / Beatriz: É, cada um chegou com as suas tendas e montou [risos]. / Jefferson: Não, assim, favela... acho que não é favela porque... o fato que separa é que o Aracy é planejado. Então, favela cê vê tudo invadido, o cara fala: 'Aqui, esse pedaço é meu.', lá não, o que diferencia é que é tudo certinho, algumas casas é de alvenaria, tudo, entendeu? Favela acho que não. / Beatriz: É favela bem organizada. (...) /Jefferson: Planejado tipo assim: você tira a favela da Rocinha, Heliópolis, você vê que lá é tudo beco, né? Tudo, o pessoal fala 'esse lugar aqui é meu e pronto'. Já, tipo, no caso do Aracy, eles fizeram a rua tudo certinho, então foi bairro planejado, os terrenos já eram divididos, entendeu? [Jefferson e Beatriz]

Entretanto, como, em São Carlos, tais condições atualmente se restringem a essas localidades mencionadas, bastante mais significativos dessa categoria são os conjuntos habitacionais: espécie de unanimidade entre os vários interlocutores da pesquisa, os territórios produzidos através de políticas públicas ocupam as posições mais baixas nas classificações socioespaciais êmicas. Rótulos como "ser conjunto", "ser Prohab" ou "os predinhos", "as casinhas"18 são automaticamente acionados

18 É interessante ressaltar como tais classificações estão inseridas em jogos de perspectivas cujos matizes e variáveis, apenas a visão "de dentro" da etnografia possibilita perceber. Em minha pesquisa de mestrado sobre a trajetória de transformação do Gonzaga de favela a bairro, uma das primeiras intervenções ali foi a execução de um mutirão habitacional que removeu 89 famílias da favela para um conjunto habitacional contíguo a ela, mas no bairro vizinho, que passou a ser conhecido como "as casinhas", numa segmentação socioespacial representada pela distinção Favela - "casinhas" que permaneceria até os dias de hoje. Após alguns anos, o espraiamento da favela se estenderia até 
quando se trata de tais espaços, associando-os a uma espécie de 'atestado de pobreza' (assim como o seria o recebimento do Bolsa-Família, como visto - ambos muitas vezes articulados para reforçar caracterizações simultâneas desses espaços e de seus moradores). Exemplos emblemáticos que figuram em todas as classificações identificadas em campo são os conjuntos denominados CDHU, São Carlos VIII, Santa Angelina, Arnon de Mello, Jardim Zavaglia e os "predinhos do Gonzaga", produzidos em diversos momentos, em diversas regiões da cidade, por diversos órgãos e programas públicos.

Dois aspectos, em especial, contribuem para essa representação negativa dos conjuntos habitacionais no âmbito dessa classificação mais ampla de que trato aqui ${ }^{19}$ : as noções de "vir gente de tudo quanto é lado" e de supostamente serem casas ganhas, que os aproximariam, por exemplo, daquelas representações associadas ao Cidade Aracy, como mencionado no início desta seção. Dessas duas dimensões decorreria aquela imagem, profundamente recorrente em campo, do conjunto habitacional como uma panela de pressão, por força da reunião, nesses locais, de pessoas de baixa renda oriundas de diversas regiões da cidade, condição que levaria inevitavelmente a tensões e conflitos (a que se associam a presença do tráfico de drogas, abordado adiante, e as disputas no âmbito do mundo do crime)..$^{20}$

É que aqui, as pessoas que mudaram pra cá, são pessoas que moravam em bairros que num podia, ou que ganhou, né, a casa, ganhou entre aspas, então aqui tem pessoas, vamos supor, mais pobres do que lá, são pessoas que ganharam essas casinhas, entre aspas... [Ryan]

Acho que, sei lá, o que aconteceu no Zavaglia, que eu vejo, é assim, eles pegaram pessoas de baixa renda do Gonzaga, da Aracy, do São Carlos VIII, de diversos pontos, de áreas de risco, e colocaram essas pessoas junto, entendeu? Então, pô, é um estopim. Não tem como dar certo, é uma panela de pressão! O São Carlos VIII é, acho que foi bem parecido, né? Que é Prohab também, né? Que o pessoal

alcançar a região das "casinhas", tornando-as, com o passar do tempo, praticamente indiferenciáveis. No entanto, a demarcação simbólica da diferença, sobretudo pelos moradores que permaneceram na Favela, tornou-se algo absolutamente incorporado e aparecia de maneira quase automática em seus depoimentos, apontando também para uma estigmatização e uma diferenciação interna, mas às avessas: ser casinha, desse ponto de vista, era ter subido na vida, ter se tornado esnobe, ter esquecido as origens na favela (Rosa, 2008).

19 Sabe-se que existem outros aspectos que podem conformar concepções negativas dos moradores de favelas e periferias frente aos conjuntos, como o tamanho das casas, ou o fato de serem apartamentos, a qualidade dos materiais, a pouca flexibilidade para ampliações e reformas, entre outros que não foram enfatizados por meus interlocutores especificamente, mas que vêm sendo objeto de estudos, cf., por exemplo, Dias (2013); Alcântara e Monteiro (2010).

20 É curioso notar como, na composição das classificações, essas dimensões são acionadas de maneira monolítica, chocando-se com aquelas representações, tratadas no Entremeio I, que apontam para uma distribuição das moradias, nesses conjuntos, que não é tão homogênea em termos de condições sociais (já que, por exemplo, "pessoas bem de vida conseguiram casas ali" ou "conheço gente que tem mais de uma casa e conseguiu ali"). Entretanto, o simples fato de se destinar a esse perfil social (o "público de baixa renda") e de destinar uma parcela das unidades para famílias "em situação de risco" são suficientes para compor essa classificação negativa dos conjuntos. 
ganhou... (...) Então é meio que isso, a visão que a gente tem do Zavaglia agora: 'Ah, pessoas de vários lugar, tudo no Zavaglia'. [Jefferson]

O caso do Jardim Zavaglia, sobretudo apreendido em relação ao Parque Novo Mundo, como visto no Capítulo 2, é bastante iluminador de como tal categoria é determinante na diferenciação entre essas territorialidades populares: se, de um lado, os conjuntos habitacionais promovidos por políticas públicas quase sempre se encontram no ponto mais baixo das classificações - mesmo no caso do Jardim Zavaglia, ainda bastante recente -, de outro, as novas configurações decorrentes da ação de construtoras no âmbito do Programa Minha Casa Minha Vida, sem vinculação de nenhum tipo com qualquer órgão público de habitação, tendem a conquistar um posto mais alto nas mesmas. Esses dois bairros são exemplares nesse sentido, porque, a despeito de terem sido produzidos pela mesma construtora, em entornos de uma mesma região periférica da cidade, com moradias bastante semelhantes, o simples fato de um deles estar vinculado estritamente ao mercado, de ser formalmente direcionado a famílias de renda mais elevada que aquelas abrangidas pelos conjuntos, e destas famílias terem comprado suas casas traz consigo uma série de distinções, somente perceptíveis mais de perto, como abordado no Capítulo 2. As trajetórias de Beatriz e Jefferson permitiram evidenciar fortemente esse contraponto, porque reivindicam de forma consciente a distinção ${ }^{21}$ : a opção pela compra da casa representa, justamente, uma tentativa de fugir de estigmas e práticas estritamente associadas tanto a um bairro de pobres, como o Cidade Aracy, quanto a um conjunto habitacional, como o Jardim Zavaglia ${ }^{22}$.

De todo modo, pela posição que outros empreendimentos produzidos pelo PMCMV para a chamada "Faixa 2" vêm ocupando nessa produção de classificações, a uma primeira vista me parece que, até o momento, essa distinção por eles reivindicada tem ecos mais amplos na reconfiguração dessas hierarquizações êmicas na escala da cidade. A essa percepção associa-se, ainda, a de que outros conjuntos produzidos em período imediatamente anterior ao lançamento do PMCMV, no âmbito do Programa de Arrendamento Residencial (PAR ${ }^{23}$, também não figuram nessas representações negativas associadas aos conjuntos habitacionais (mesmo tendo sido produzidos e

21 Bourdieu (2004, 2007).

22 Vale dizer, entretanto, que, no âmbito das representações externas, o Parque Novo Mundo figura como "habitação social" ou "conjunto habitacional", sendo também associado (ainda que em menor grau e com menos estigmas) à "região do Cidade Aracy".

23 Programa habitacional lançado em 1999 com objetivo de reativar a produção de conjuntos habitacionais no país, bem como reduzir o nível de inadimplência no âmbito das políticas habitacionais. Cf. Bonates (2007:21): “o programa se destaca por apresentar uma forma diferente de acesso à moradia, por meio de uma operação financeira chamada "arrendamento mercantil", ou leasing, em que o imóvel é de propriedade fiduciária da Caixa, e o arrendatário paga uma taxa de arrendamento mensal por um período de 15 anos, conforme entendimento geral, para poder tornarse proprietário desse imóvel". 
distribuídos sob tutela da PROHAB), podendo-se levantar como hipótese, para tanto, as características diferenciadas de sua produção - localização em bairros relativamente estruturados, inserção na malha urbana, menor dimensão dos conjuntos e destinação final para um público mais próximo à atual "Faixa 2" do MCMV, entre outros ${ }^{24}$. Nesse sentido, tal categoria e as representações dela decorrentes permitem entrever que, nesse dinâmico sistema classificatório, a produção dessas 'novas periferias' (agora efetivadas quase que exclusivamente no âmbito do PMCMV) para uma "nova classe média" reconfigura e hierarquiza ainda mais esses territórios e suas populações ${ }^{25}$.

\section{. a intensidade da presença do tráfico de drogas ou mundo do crime}

Temos, por fim, o lugar do tráfico de drogas e das violências associadas ao crime e à polícia na produção dessas representações hierárquicas: esta é, sem dúvida, a principal e mais recorrente categoria identificada em campo a orientar as classificações socioespaciais operadas por meus interlocutores, quase sempre associada a uma ou a todas as demais elencadas. É principalmente sob tal categoria que se evidencia a vinculação entre a dinâmica das classificações socioespaciais aqui tratadas e a produção de territorialidades: a afirmação de uma identidade sempre por oposição a um outro, as disputas cotidianas entre valorização e desvalorização socioespacial, as linhas de clivagem estabelecidas apesar (ou a partir) de uma experiência urbana comum.

Se, por um lado, em todas as trajetórias perscrutadas em profundidade pela pesquisa (e nas diversas outras também observadas indiretamente em campo), em alguma dimensão ou contexto, emergiu a temática do convívio cotidiano - mais ou menos próximo - com o "mundo do crime", por outro, a espacialização dessa presença nos territórios que configuram ou configuraram pontos de condensação das trajetórias era, em geral, minimizada sob expressões como "em todo lugar tem isso" ou "não é só aqui, todos os bairros têm".

24 Bonates $(2007,2008)$ estabelece uma interessante reflexão sobre a produção habitacional no âmbito do PAR, enfatizando aspectos que teriam delineado, de certa forma, uma possibilidade de acesso diferenciado à moradia e à cidade pela população de baixa renda, caracterizando-se, a princípio, pela construção de conjuntos de pequeno porte, inseridos na malha urbana, seguindo uma tendência de aproveitamento dos vazios urbanos em locais dotados de infraestrutura urbana e serviços e com qualidade construtiva bastante diferenciada em relação a outros programas habitacionais.

25 Kopper (2013, 2014:3), em pesquisa que propõe apreender etnograficamente a "nova classe média" brasileira a partir da configuração do mercado da casa própria, mais especificamente da produção vinculada ao PMCMV, atenta para os fluxos espaciais, urbanos e subjetivos que acompanham a elaboração e implementação do programa na cidade de Porto Alegre/RS, iluminando "os investimentos morais e econômicos em jogo na negociação, ressignificação e adaptação dos critérios de elegibilidade formulados por planejadores e urbanistas, em diálogo com as mudanças de classe que os deslocamentos populacionais pelo tecido urbano sugerem." 
A partir da generalização de tal presença no espaço urbano - apontada quase como uma onipresença -, uma série de critérios e gradações entrava em cena, de forma a relativizá-la ou acentuá-la, conforme a posição socioespacial do interlocutor, tais como: maior ou menor intensidade dessa presença em determinados bairros, por vezes associada à escala dos mesmos (e, consequentemente, à maior ou menor chance potencial de ser vizinho de uma boca); a existência ou não de disputas em um determinado território (e aqui novamente a escala importa, entrando em cena cálculos como a possibilidade de um filho assistir a uma morte violenta na vizinhança); ou, ainda, a presença ou ausência de um comando eficaz naquele território, capaz de dirimir as disputas, reduzir a violência e os homicídios e garantir a tranquilidade do local, entre outros.

É nesse aspecto, por exemplo, que, em associação com a categoria anterior, reforçase a classificação negativa dos conjuntos habitacionais (dentre os quais se destacam Santa Angelina, São Carlos VIII e Jardim Zavaglia), naqueles termos da panela de pressão, aqui associada a uma dimensão de conflito propriamente territorial: diferentemente de um bairro qualquer, um conjunto mesclaria compulsoriamente famílias oriundas de diversos bairros populares e de áreas de risco da cidade, quase sempre pondo em confronto traficantes em busca de reconfigurar seus pontos de venda e seu domínio.

Lá no São Carlos VIII está ruim mesmo. Diz que sai briga lá todo santo dia. A pessoa não pode ir na padaria e deixar a porta aberta. Esses tempos atrás, até encontrei uma senhora que mora lá, encontrei ela no Pronto Socorro, ela falou 'Núbia, lá não dá para a gente piscar porque os caras entram dentro da casa da gente, tira o que a gente tem, a gente não pode abrir a boca, não pode falar nada'... Você passa lá você vê, dez, doze, treze, quatorze fumando na porta... Está muito largado, sabe? [Núbia]

Beatriz: Zavaglia, mal iniciou o bairro e já teve tiroteio... / Jefferson: Então, é que o que aconteceu ali foi aquilo, virou uma panela de pressão: se as pessoas normais já num dá certo misturando, ainda mais... [refere-se ao tráfico de drogas] porque vários rivais que tinha no Antenor com o São Carlos VIII, com outros bairros, acabaram morando no mesmo bairro! Aqui no Zavaglia. / Beatriz: Sim! É, cê queria o quê? Duas pessoas que de longe não se entendiam foram morar tudo junto! / Jefferson: É, cê junta todo mundo ali, cê resolve o problema dum lado, mas do outro, você agrava. / Beatriz: Que nem, o cara tinha uma boca no Antenor e foi morar lá, ele continuou com a boca dele. Aí o cara do São Carlos VIII vê que tinha a dele lá, também montou a dele. Não vai dar certo. Não vai dar certo [risos]. Não dá certo! Cada um vai defender a sua. / Jefferson: Ainda é do lado do Antenor, que é um bairro assim, é... desde... o Antenor sempre foi visto como mais perigoso do que Aracy, sempre. Se um fala: 'Ah, sou do Antenor', aí os cara do Aracy já: 'Opa!' [risos]. Então foi isso que aconteceu ali e em outros bairros que são Prohab. [Jefferson e Beatriz]

Por outro lado, empreendimentos como o Parque Novo Mundo ou outros "bairros novos" eram, em geral, apresentados por meus interlocutores como espécies de lugar ideal para as famílias que desejassem fugir da proximidade com esse mundo e 
a insegurança a ele associada, seja pela suposta ausência de biqueiras (ressalvando que, no caso do Parque Novo Mundo, ao final da pesquisa de campo, Jefferson já tivera notícias acerca da aquisição do "direito sobre o bairro" por um traficante do Cidade Aracy); seja, no caso de outros empreendimentos mais recentes em que já se tem notícia da presença do tráfico de drogas, pelo fato destes não serem, ainda, "bairros movimentados do mundo do crime" (conforme apontado no capítulo 3), e, nesse sentido, "bairros muito batidos, onde a polícia tá toda hora passando". Em outras palavras, parece não se tratar da presença em si - já que "em todo lugar tem" - mas da maior ou menor interferência dessa presença nas dinâmicas cotidianas dos bairros, das famílias, da maior ou menor possibilidade de garantir aquela mencionada "segurança ontológica", apesar dessa presença.

Então, aí agora, depois que eu tive esses problemas com o mundo das drogas, eu gostaria de mudar pra um lugar calmo, onde não tem muita bandidagem, assim, sabe? / Thaís: E qual lugar seria esse? / Tem uns bairros novos na cidade, mas o que a gente pensou seria um bairro chamado Novo Horizonte, que você nunca ouve falar no rádio que roubou isso, que tem bandido, e é um bairro que você anda por ele e você não vê uma pessoa na rua. E eu tenho uns conhecidos lá, e quando você vai pra lá você anda no bairro, e você não vê gente na rua, é igual o seu bairro. É um bairro calmo, um bairro calmo com pessoas que não têm envolvimento, não tem boca. Por exemplo, aqui no meu bairro em cada esquina tem uma boca, lá não. / Thaís: Como você sabe que lá não tem? / Não, lá tem, mas não em cada esquina, porque todos os lugares têm. Todos os lugares têm, né? Só que não é igual aqui, por exemplo, aqui na minha rua não tem nenhuma boca, porque os meninos da rua tão tudo preso, o vizinho... ai meu Deus, tô falando muito alto. Então, o menino do vizinho tá preso, que mexe com drogas, ou o menino da outra vizinha, que é assassino, tá preso, então... O meu filho tá foragido da polícia, então, aqui na minha rua, não tem nenhuma boca de droga. / Thaís: Mas já teve? / Já teve, mas na rua de trás tem, aqui atrás da minha casa. / Thaís: E lá no Novo Horizonte, não? / Não, lá tem, mas não em cada esquina, em cada rua. Não tem esse movimento, da bandidagem, do mundo do crime assim, na rua. Aqui a polícia vem toda hora, se eu sentar ali na frente a polícia vai passar umas dez vezes, porque é um bairro movimentado. Lá, a polícia só vai se for chamada, tiver uma ocorrência... é um bairro considerado tranquilo. [Marielen]

De um modo geral, essas gradações são acionadas num comparativo entre os bairros na cidade ou numa determinada região, ou mesmo entre regiões da cidade, sempre tendo em vista a valorização de uma determinada localidade por efeito da desvalorização de outra. Por exemplo: em comparação à região do Cidade Aracy, a região do Santa Felícia é geralmente considerada mais tranquila; já o Cidade Aracy costuma figurar como menos violento do que conjuntos habitacionais como São Carlos VIII ou Santa Angelina. E mesmo internamente às regiões, os estigmas são polarizados sobre determinados bairros, classificados de forma quase unânime como "os piores lugares para morar", de modo que o Antenor Garcia seria considerado 
mais perigoso que o Cidade Aracy, ou o Santa Angelina mais pesado que os demais bairros do Santa Felícia ${ }^{26}$, para retomar alguns exemplos.

Então, eu não gostaria de morar, tipo assim, no Antenor Garcia, por causa da violência, lá em cada esquina tem um bar, aqui é droga, lá tem os dois. Então, como o meu filho dá problema, e ele também briga, tem envolvimento, eu tenho medo. Lá tem muita violência, só hoje na Cidade Aracy morreu duas mulheres esfaqueadas. Então, lá tem mais violência que aqui [no Santa Felícia], ah, muito mais... lá toda semana morre um. Então, na violência, pra mim, Aracy e Antenor é igual, eu tenho um pouco de medo assim. Então eu não iria. Nem pro Zavaglia, nem pro Antenor e nem pro Aracy. (...) Aqui, no Santa Felícia... meu bairro, o Tortorelli, é tranquilo, tranquilo. Mas no Santa Felícia, como um todo, tem lugares violentos. Arnon de Mello, por exemplo, perigosíssimo. Sempre foi e ainda é. Mas, agora, no Santa Felícia, o lugar mais perigoso é o Santa Angelina. Tá perigosíssimo, ninguém quer comprar mais terreno lá. Lá tem os traficantes mais pesados, os mais perigosos, uns grandão mesmo. Já o Tortorelli não, tem só uns moleques, em todas as esquinas, e tem crime passional, de bar, sabe? Esses dias mesmo, teve uma mulher que o marido matou ela a marretada. Mas é diferente do Arnon de Mello, lá é violento mesmo, lá tem todas as drogas e traficante antigo tá lá. O Tortorelli é bem sossegado, todo mundo conhece todo mundo. [Marielen]

Cidade Aracy é um lugar que eu, particularmente, não moraria. / Thaís: Não? Porque? / Ah, que se for ver pelo que eu vejo, lá é pior que aqui [Santa Felícia], se for ver. / Thaís: Por que você tem essa opinião? / Sei lá, porque eu passo, de vez em quando eu dou umas volta por lá, então lá é toda rua que você passa, tem sempre aquela rodinha de gente assim, de má índole, assim, vamos dizer. Você já conhece de longe assim, o que é e o que não é, lá eu já vejo que tem bem mais do que aqui, então. / Thaís: Isso seria um critério pra escolher onde morar, você acha? / Se fosse pra escolher, sim. Lá eu não moraria. Naquela parte ali, nenhuma, por isso. Zavaglia, o Antenor, Cidade Aracy, Cidade Aracy II, nenhum. Gonzaga também não. Tudo pelo mesmo motivo. / Thaís: Mas por que você acha que esses lugares têm mais... / Não é que tem mais, mas são lugares que você fala assim: 'o Cidade Aracy', e: 'Ah, onde morreu fulano lá, tal', então o lugar, ele já é bem batido, o bairro é batido assim, é um bairro com história, como já se dizia, assim, entre aspas. Aí, eu sou mais sossegado, então, eu preferia morar no Embaré, Novo Horizonte, uns bairros mais novos. / Thaís: E você conhece esses bairros? / Conheço. / Thaís: E por que você gostaria de morar neles? / Ah, é mais sossegado né. Não ter é impossível né, todo bairro tem, até onde você pensa, assim... o lugar que você menos espera que vai ter, você fica sabendo de alguma coisa. Então, tipo, é impossivel um bairro que não tem, mas esses são uns bairro

26 Vale dizer que, ao considerar tais categorias e classificações de forma relacional, certamente novos elementos e dimensões poderiam ser introduzidos com a incorporação, na pesquisa, de trajetórias de moradores desses bairros, que acabam por figurar recorrentemente nessa hierarquização popular como os piores lugares, ou os mais pesados, como Antenor Garcia, Santa Angelina e São Carlos VIII. Fica como um indicativo para pesquisas futuras. O que importa reter, nesse sentido, refere-se ao que Wacquant (2007:195) denominou “lógica de desqualificação lateral e distanciamento mútuo", a qual tenderia a desfazer ainda mais qualquer dimensão de coletividade, já enfraquecida, das "zonas urbanas pobres": "La aguda sensación de indignidade social que envuelve a los barrios de relegación solo puede ser atenuada transfiriendo el estigma a um 'otro', satanizado y sin rostro: los vecinos de abajo, la família de inmigrantes que vive en el edifício al lado, los jóvenes del outro lado de la calle, de quienes se dice que 'se drogan' o que son 'buscones' callejeros o aun los residentes de la outra cuadra, de quienes se sospecha que cobran de manera ilegal pagos por desempleo o beneficencia". 
assim, mais sossegado, que tem menos, você pode ficar mais tranquilo. / Thaís: E você percebe isso como? / É, pelo movimento, por você já conhecer o lugar, que nem, quando você tem uma família que faz essa parte, você vê uma pessoa na rua, e você sabe se ela é ou não. Então, por eu ser, eu gosto de andar bastante, então eu sei onde pode ter mais e onde não pode. E esses bairros são alguns onde a gente sabe que não tem... são mais sossegado. Quer dizer, não tem, não, mas tem menos, assim, é mais tranquilo. [Jairo]

Nesse sentido, embora, em geral, meus interlocutores afirmem que "não tem nenhum bairro pior pra morar, quando você não tem inimizade com os vizinhos", todos, em suas narrativas, irão elencar bairros nos quais não gostariam de morar (e, em alguns casos, que também não gostam de frequentar) em função de serem mais violentos, perigosos ou pesados (remetendo, em uma escala mais ampla, àquela distinção entre lugar tranquilo e lugar pesado explorada anteriormente nos capítulos) - essa é, sem dúvida, a principal categoria a orientar as classificações, sendo, também, a mais dinâmica e relacional. A caracterização como lugar tranquilo ou lugar pesado é ainda mais plástica nessa escala ampliada - e, consequentemente, as classificações e hierarquizações dela decorrentes, reforçando aquele já mencionado jogo de perspectivas sobre a cidade. São representações que dialogam com a situação dinâmica das periferias - uma hora está tranquilo, outra hora está um transtorno -, vinculando-se não apenas às dinâmicas concretas relativas ao mundo do crime, mas também às redes de relações tecidas nos territórios, aos saberes sobre os mesmos, ao referencial socioespacial presente, à experiência urbana acumulada: o Cidade Aracy, hoje, para Núbia e Jimmy, é o lugar mais tranquilo da cidade, embora até alguns anos atrás fosse "bem mais complicado"; já para Beatriz, Marielen ou Jairo, continua figurando genericamente como o ápice da concentração do crime, do tráfico e da violência; o círculo social de Joana considera o Jardim Zavaglia (por extensão do Cidade Aracy) como "o pior lugar da cidade para se viver"; ela, que já pensou assim, hoje tem uma outra perspectiva sobre o bairro e a região como um todo.

Em geral, o bairro onde cada um vive atualmente foi classificado como referencial de lugar tranquilo, justamente em função das relações de vizinhança, do ser conhecido e ter conhecimento, sendo tal classificação parte fundamental da construção daquela "segurança ontológica". Sobrepondo-se a todas as demais categorias aqui elencadas, o estigma associado à presença do tráfico de drogas e à violência é o elemento central a orientar a produção e reprodução de tais classificações socioespaciais: não se trata apenas de uma reprodução das desigualdades internamente às camadas sociais ${ }^{27}$, mas também, de alguma forma, uma manipulação dos mecanismos de incriminação - "modo contemporâneo de sujeitar territórios e populações pobres, apartando-as 
da comunidade moral que rege a distribuição de direitos" 28 - que sobre eles incidem de modo genérico, na tentativa de transferir (lateralmente) o estigma deles decorrentes a um 'outro'. De alguma forma, é como se ao se orientar por tais categorias e manejar tais mecanismos no intuito de reposicionar certos estigmas, fosse possível reconfigurar simbolicamente suas posições socioespaciais, em alguma medida 'desmarcando-se', ou à sua casa, ou ao seu território ${ }^{29}$.

Se eu pudesse eu queria continuar morando aqui mesmo. Se eu tiver oportunidade... Eu gosto daqui, por gosto mesmo. Eu gosto, sabe? Apesar de ser, assim, um pouco distante do centro da cidade, é bem tranquilo. É calmo, sabe? Quem mora aqui, em geral, gosta bastante, né? Ah, o bairro é tranquilo. Se fosse pra mim morar no Antenor eu teria um pouco de medo. / Thaís: Medo? / Do Antenor eu já tenho um pouquinho de medo, sim. / Thaís: Por quê? / Por causa da violência, né? Lá a violência é um pouco mais. / Thaís: E o que que tem de diferente lá e aqui? / Eu acho que por ser assim, um bairro um pouco mais distante, assim, a droga corre a solto. Não é que nem, por exemplo, aqui ou na Aracy I, que passa viatura toda hora, a polícia tá sempre perto, sabe, o povo é mais tran... mais resguardado, vamos pôr assim. Lá não! Lá corre a solto na calçada, no meio da rua. $O$ povo não tá nem aí. Porque quando acontece um fato, até a polícia chegar lá leva, pelo menos, quarenta minutos [risos]. Sabe? Sem contar que o povo lá é... não é tudo, mas são mais dados à violência, é muita briga na rua e é muita pancadaria... relacionado com droga, bebida, sabe? 0 duro que lá até as mulheres briga [risos]. Viu? Porque diz que isso é coisa só de homem, mentira, porque até as mulheres briga, sabe? Então... eu tenho um pouco de medo lá, sim. / Thaís: Você conhece gente que mora lá? / Conheço! muito de vez em quando, eu vô lá na casa da avó dos meninos. Que ela mora lá, sabe? Mas é muito difícil. Eu não vou não, tenho um pouco de cisma, eu tenho um pouco de medo, sabe? E sei lá... a violência lá é muita. O povo lá pra bater e matar não tem... Eu mesmo já presenciei uns três crimes. / Thaís: Verdade? Porque o pessoal fala que agora nessa coisa do PCC, que o PCC controla a violência... / Ah, não controla muito não viu? Eles até tinha até um certo controle, mas não controla muito não. Lá... é que é aquele negócio, o responsável pelo bairro não consegue controlar, porque na realidade, é assim, cada bairro tem um membro deles que controla aquele bairro, né? Mas a pessoa que puseram pra controlar o Antenor é bem devagar [risos]... Assim, a única coisa que, graças à Deus, não tem acontecido por lá, que acontecia com muita frequência, são os homicídios, né? Agora tá bem calmo. Porque antes, Deus me livre! Coisa de uns dois anos atrás era demais! Eles tinham semana que assassinava duas, três pessoas. Assim do nada. Por conta de droga... Então, isso mudou. Mudou sim. Mudou bastante, viu? Mas é de época também, tem época que aquilo vira um transtorno! Pra cá é mais difícil. É mais pra lá mesmo. Aqui é difícil a gente vê acontecer alguma coisa desse tipo. (...) Então não, no Antenor não moraria não [risos]. Não sei, mas eu tenho um medo daquele Antenor, danado. O Gonzaga é tranquilo, moraria, sim. E no São Carlos VIII, por causa daquela história que envolveu meu filho, pelo rapaz morar lá, eu não moraria não. [Núbia]

28 Feltran (no prelo), em franco diálogo com as abordagens propostas por Michel Misse, dentre as quais destaco a coletânea organizada sobre o tema (Misse, 2008).

29 Tal movimento simbólico pode resultar, como visto, em 'conversões' também materiais, como a mudança de casa e de bairro. 
Para além da constatação de que há sempre um território melhor ou pior que outros tantos, é curioso notar como a reprodução desse mecanismo de incriminação é potente a ponto de, mal um novo território se produz, a depender da somatória das categorias aqui mencionadas, a ele já se associa tal estigma, não apenas externamente, mas sobretudo internamente às camadas populares. E aqui remeto novamente ao caso do Jardim Zavaglia, um território novíssimo, recém-produzido sob padrões oficiais e tido como "exemplar" na cidade (do ponto de vista da produção pública ${ }^{30}$ ), o qual já nasce carregado de estigmas, não apenas por ser um conjunto ("ser Prohab"), no qual as casas teriam sido ganhas por pessoas mais pobres, onde se instauraria uma panela de pressão social, mas também por uma espécie de "efeito de lugar" ${ }^{31}$, em função da contiguidade com o bairro Antenor Garcia (e com a região do Cidade Aracy como um todo), de modo que se estende 'naturalmente' o estigma preexistente ao território novo.

Porque aqui a gente sente esse mesmo preconceito, 'ah, mora no Zavaglia, que é vizinho da Cidade Araci, do Antenor?' É onde todo mundo acha que é bandido, entendeu? Todo mundo mesmo, meus parentes, meus antigos vizinhos... todo mundo. [Joana]

Nesse sentido, destaca-se o papel das redes de informação que circulam entre os bairros (a partir de redes de interconhecimento que os atravessam) - aí incluídos a fofoca e o boato - mas também os noticiários locais no rádio e na internet (sobretudo policiais) como componentes importantes na produção desses sistemas de classificação socioespaciais e suas categorias, mais especificamente no que se refere a esta última - à qualificação de uma localidade como tranquila ou pesada -, bem como à possibilidade de um bairro conseguir ou não expurgar antigos estigmas:

Cara, o Parque Novo Mundo é um lugar muito louco, assim, você não ouve falar de lá, de tão sossegado que é aquilo. Você não ouve falar nada de lá. Eu só fico sabendo o que acontece lá, quando eu vou lá e meu irmão comenta 'o vizinho ali comprou um carro'... Lá é muito sossegado. Todo mundo falou que ia ser mais uma favela, mais num sei o quê... porque todo mundo faz a alusão de favela a crime, quando favela, na verdade, é um bairro sem estrutura, desestruturado. Mas aí, queimaram a língua, que lá é um lugar super tranquilo, tanto que meu irmão fala, meu irmão fala: 'olha, se eu não conseguir comprar uma casa no Aracy, cara, eu compro uma aqui, que aqui é muito tranquilo'. [Jimmy]

30 Cf. Capítulo 2, p.199.

31 Bourdieu (2008). Wacquant (2007:194 - grifo no original), abordando o que denomina "infâmia territorial", irá destacar que, quando espaços considerados marginais (e lócus de marginalidade) "son - o amenazan com volverse - componentes permanentes del paisage urbano, los discursos para descalificar se intensifican y se cierran alrededor de ellos, tanto 'desde abajo', en las interaciones ordinarias de la vida cotidiana, como 'desde arriba', en los campos periodístico, político y burocrático (y a veces científico). Una mancha de lugar se sobrepone así a los estigmas ya operantes, tradicionalmente associados com la pobreza o la pertenencia étnica o con el status del inmigrante postcolonial, a los cuales no se reduce aunque tengan una estrecha relación". 
Os principais bairros que tão na mídia aqui são Antenor Garcia, São Carlos VIII, Gonzaga, Santa Angelina. E, infelizmente, o que eles noticiam não é nada bom. Fica na cabeça das pessoas, elas acabam comprando isso como verdadeiro. Porque, mesmo as pessoas que um dia conheceram esses bairros, ficam ainda com aquela imagem que presenciou na antiga: o bairro pode até ter melhorado, como foi o caso do Aracy, mas fica ainda essa imagem negativa. [Jefferson]

Porém, as delimitações e classificações de que trato aqui vinculam-se sobremaneira a dimensões um tanto subjetivas, sendo, neste sentido, contextuais e situacionais: não apenas elas vão variar de acordo com a referência socioespacial atual e a experiência urbana acumulada, com ter ou não algum envolvimento direto ou indireto com o mundo do crime, como também aquelas dimensões de ser conhecido/ter conhecimento ou possuir algum elo de redes de relações em um território vão determinar a posição deste nessas movediças classificações. Além disso, estas vão se alterando também em conformidade com as dinâmicas familiares e os deslocamentos habitacionais ${ }^{32}$, dando a ver o jogo de perspectivas dessas classificações entre os populares: por um lado, o problema sempre está no outro, no bairro ao lado; por outro, a partir do momento em que eu vivo ali, ou um filho, um parente, um amigo, um conhecido, esse quadro classificatório pode se reconfigurar.

Para além de possibilitar apreender formas mais complexas do desenho das desigualdades (e sua reprodução) no espaço urbano, as questões aqui alinhavadas tiveram a intenção de refletir sobre os entrelaçamentos entre, de um lado, o estabelecimento de redes de relações e intercâmbios e, de outro, a produção de limites e fronteiras entre os territórios populares. Ou seja, pensar as relações de proximidade e diferenciação na segregação e na pobreza; analisar como as malhas de relações conectam os bairros e regiões periféricas ao mesmo tempo em que os apartam, fazendo ver as periferias a partir de suas dinâmicas internas (e simultâneas) tanto de continuidade e conexão, como de hierarquização e distinção.

Ao propôr uma reflexão sobre as linhas de clivagem socioespacial internas às camadas populares e a seus territórios, uma aproximação às articulações e tensões entre experiência comum e distinção socioespacial, homogeneidades e heterogeneidades territorializadas, buscou-se complexizar um pouco mais aquelas abordagens duais da cidade, as visões dicotômicas de centros e periferias como territorialidades permanentes e estáveis, as concepções de segregação que pressupõem uniformidade social e isolamento territorial. Atentar para essas múltiplas categorizações, classificações, hierarquizações socioespaciais se mostra

32 Nesse contexto, se, por um lado, os deslocamentos anteriores (em associação a estas outras dimensões subjetivas) orientam a produção de classificações num nível mais subjetivo, por outro, serão essas classificações a orientar outros possíveis deslocamentos futuros. 
terreno fértil para pensar as cidades e suas periferias em suas dimensões contextuais, processuais e, sobretudo, relacionais.

As categorias aqui destacadas evidenciam dinâmicas de produção e disputas de sentidos sobre a cidade estabelecidas a partir de um contínuo e cambiante processo de construção de identidades e alteridades socioespaciais também entre as camadas populares. O breve mapeamento aqui ensaiado revela, nesse sentido, o quanto aquela mencionada "produção de demanda" para os programas sociais e habitacionais, bem como a produção ideológica de novas formas de nomeação ("nova classe média") e novas territorialidades (PMCMV) se articulam a essa produção de sistemas classificatórios e hierarquias socioespaciais internas, acrescentando ainda mais camadas a eles.

Entre ancoragens espaciais e entramados sociais, há uma potente lógica da diferença e da diferenciação ${ }^{33}$ a operar no delineamento interno dessas 'cidades outras', através do estabelecimento de limites simbólicos e classificações socioespaciais que configuram também a experiência urbana (a um só tempo comum e diversa) dos moradores das periferias, sendo sua consideração fundamental para uma reflexão sobre as dimensões e os potenciais dessa urbanidade tecida nas margens da cidade ${ }^{34}$. 


\section{CONSIDERAÇÕES FINAIS .}

Circulación, muro, gueto, periferia, frontera: el vocabulário es en nuestros días espacial, pero las palabras de este vocabulario tienen todas que ver con la relación entre el sí mismo y el otro. | Marc Augé

Experiência. Exploração. Tantas vezes remeti a tais noções para pensar e descrever o modo como a pesquisa e, por consequência, a própria tese se delinearam. Se não ouso dizer que se tratou de uma etnografia stricto sensu, a ideia de uma exploração etnográfica define bem as opções, não apenas metodológicas, mas, sobretudo, epistemológicas adotadas, como espero ter se evidenciado ao longo da tese. E tal dimensão etnográfica, justamente por fazer emergir do campo empírico uma multiplicidade de questões, facetas, indagações, torna ainda mais árdua a tarefa de colocar um ponto final no trabalho, arrematá-lo, tantas são as possíveis frentes de problematização que insistem em emergir do material coletado/produzido, algumas das quais aprofundadas na tese, outras apenas esboçadas, outras ainda sequer enfrentadas, e que, quem sabe, alimentarão trabalhos futuros, meus e de outros.

De todo modo, alguns dos muitos fios analíticos puxados ao longo dos Capítulos e Entremeios esperam por ser minimamente alinhavados, e não me furtarei a fazê-lo, destacando, de antemão, não ser possível - nem necessário - reconstruir as muitas reflexões e argumentos já apresentados ao longo do trabalho. Assim, intento fazê-lo reforçando aquele caráter indutivo da reflexão: justamente porque as questões e temas foram decorrendo do campo, da investigação das trajetórias, justamente por não haver uma única teoria ou conceito a sustentar todo o trabalho, talvez disso decorra a dificuldade em compor diagramas analíticos mais sintetizadores. Nesse sentido, e em consonância com o diálogo teoria-empiria que foi se construindo por dentro das armaduras da pesquisa (e não a priori), mais do que se encerrar em conclusões, a tese - e a experiência etnográfica da qual ela é parte - aqui se abre a um mapeamento de questões, sem pretensão de resolvê-las, mas, sim, de explicitálas e trazê-las ao debate.

À medida que a pesquisa se desenvolvia, a dimensão dos deslocamentos habitacionais em torno dos quais gravitam as trajetórias e experiências urbanas narradas se mostrou central em termos analíticos, não apenas por ter emergido como uma espécie de polarizador dentre os múltiplos vetores que o campo empírico vinha mobilizando, mas por seu potencial heurístico, por colocar muitas dimensões 
(individuais, familiares e sociais; concretas e simbólicas; e, sobretudo, espaciais) em dinâmica e relação frente ao universo das periferias: a contínua busca por um lugar na cidade (e as vicissitudes, inseguranças e violências aí implicadas), assim como sua dialética com os pontos de fixação destas trajetórias em determinadas casasvizinhanças-bairros-territórios orientam significativamente a relação de meus interlocutores com a cidade e a construção, desconstrução e reconstrução de relações com pessoas, espaços e políticas.

A experiência urbana de meus interlocutores está, portanto, absolutamente entramada a essa dinâmica de deslocamentos habitacionais sucessivos, migrações intraurbanas cuja regularidade demarca uma certa condição de 'nomadismo' ${ }^{1}$ que parece ser parte estruturante dos processos simultâneos de produção de subjetividades e territorialidades para os quais a pesquisa atentou. Esse nomadismo, em alguma medida involuntário (mas não de todo), configura-se mesmo como aspecto banalizado - embora, como visto, nada banal - das condições de habitação e inserção urbana das camadas populares e tem o "mercado informal de aluguel" como espécie de dispositivo dessa errância, parte indelével dessa transitoriedade constituinte das trajetórias urbanas analisadas.

Essa talvez seja a principal dimensão a estruturar uma experiência urbana comum dentre meus interlocutores, moradores das periferias de São Carlos: aquela de, em algum momento da vida (ou em toda ela), "não ter lugar", "não ter para onde ir", "morar de favor", em que se vislumbra uma forte marcação de gênero (da qual a figura da mãe é emblemática, por ocupar lugar decisivo como definidora dos rumos das trajetórias familiares e das concepções de cidade que constroem e nas quais se pautam). Trajetórias marcadas por sequências de rupturas e recomeços²,

1 Enquanto escrevia estas considerações, deparei-me - por um desses acasos que, antes da 'era digital', um antigo professor costumava chamar de "o anjo da biblioteca" - com um artigo em que Lindón (2007:92), remetendo a trabalhos anteriores (Hiernaux e Lindón, 2003), elabora o conceito de "nomadismo residencial" para tratar de "trayectorias biográficas integradas por numerosos desplazamientos": "El nomadismo residencial es un conjunto de prácticas residenciales por las cuales las familias van desplazando periódicamente su lugar de residencia hacia las nuevas periferias, es un delocalizarse y relocalizarse periódico". Em artigo anterior, do qual já havia me valido ao longo da produção da tese, a autora já havia destacado, ao tratar do "mito da casa própria" e sua articulação com os "modos de habitar a periferia", o quanto as trajetórias de vida dos moradores das periferias da Cidade do México são marcadas por "alta mobilidade espacial": desde a migração campo-cidade (ou a migração México-Estados Unidos), até a mobilidade espacial cotidiana no presente, com destaque para a intensa mobilidade residencial ao longo da vida ("mobilidade espacial biográfica”), reiterando o caráter estruturante desse 'nomadismo' urbano. Também Rizek (2014) detecta tal dimensão estruturante em trajetórias de moradores das periferias paulistanas.

2 Guardadas as enormes distinções com as questões enfrentadas nesta tese, os trabalhos de Veena Das $(1995,1999,2007,2011)$ me possibilitaram apreender as inúmeras rupturas presentes nas trajetórias - e as violências e vulnerabilidades de que decorrem -, bem como sua atualização na vida cotidiana, no âmbito da construção de subjetividades e narrativas, concepção que foi de grande valia para as reflexões desenvolvidas. 
desenraizamentos sucessivos vividos muitas vezes como traumas ${ }^{3}$, em que a ausência de moradia se vincula à presença do estado como ator de violências múltiplas no campo do urbano, apontando para a coexistência de mecanismos históricos de gestão das diferenças sociais na cidade 4 e processos contemporâneos de "gestão diferencial de territórios" 5 .

E, se tal dimensão 'nômade' se faz presente nestas trajetórias como condição de vida, mostra-se também elemento estruturante dos processos de produção da cidade: a partir das trajetórias se evidencia o quanto a expansão urbana se produz, em grande medida, para e pelas camadas populares, num contínuo "fazer cidade em suas margens" ${ }^{\prime 6}$. Como atestam Lindón (2005) e Hiernaux e Lindón (2002), os habitantes dessas sucessivas "novas periferias" não seguem passivamente as pautas de especuladores, mercados ou políticas: "Estes atores também produzem valorações, tomam decisões, perseguem objetivos, (...) são ativos neste processo que não se reduz a estender os limites da cidade, mas que implica construí-lo em um 'lugar'"7.

À experiência comum dos deslocamentos habitacionais se soma, portanto, aquela da ausência do urbano - o viver em bairros por fazer, o morar em casas inacabadas, o contínuo refazer de relações e espaços. Disso decorrem concepções de casa, vizinhança, bairro, cidade, vividos como processo (sempre inacabado), entendidos como constructos dinâmicos, e não como estruturas fixas no tempo, pautados

3 Embora acredite que a tese tenha deixado evidente, nunca é demais destacar que, muito além de um 'elogio ao nomadismo' (presente em diversos estudos que têm seu foco na mobilidade e nos deslocamentos contemporâneos), os deslocamentos de que falam as trajetórias na minha pesquisa têm uma dimensão bastante trágica e falam ora da ausência de lugar na cidade, ora de uma espécie de detenção em lugares (limiares) indefinidos e incertos (aproximando - com as devidas mediações a concepção de desenraizamento às de "desplazamientos" ou à de "destierro", que, apesar de referirem-se primordialmente a refugiados de conflitos armados extremos, também estão presentes na literatura latino-americana acerca da pobreza e das periferias urbanas, cf. pe. Lindón, 2007), apontando para a violência imanente aos processos de urbanização (Sampaio, 2011) e às dinâmicas relativas ao acesso à moradia. Para uma abordagem instigante das demolições, "desplazamientos", perda de paisagens familiares, expulsões urbanas como "trauma" não apenas para os "desplazados", mas para toda a sociedade, ver Fullilove (2004).

4 Chalhoub (2006).

5 Leite (2013).

6 Agier (2011). Ou, "em termos Arendtianos", como aponta Rizek (2014), "de uma trajetória de moradia em que vislumbra um 'produzir mundo' ali mesmo onde existe apenas espaço precário".

7 Lindón (2005:4), tradução a partir do original: “Estos actores también hacen evaluaciones, toman decisiones, persiguen fines, (...) son actores activos en este proceso que no se reduce a extender los limites de la ciudad sino que implica construirlo en un 'lugar'." Em trabalho anterior em que exploram tal perspectiva, Hiernaux e Lindón (2002:31) esclarecem que a mesma "no pretende negar la importancia de las forzas económicas y de los intereses especulativos en el proceso de expansión de la periferia. Aunque es nuestro objetivo poner en evidencia dimensiones relevantes que operan em los procesos de expansión de la ciudad y qye sólo en muy pocas ocasiones son consideradas. Asimismo, estamos intentando pensar a la periferia y sus actores fuera de las visiones ingenuas y románticas, según las cuales los sectores populares solamente son pasivos frente a las habilidades especulativas de otros atores que los manipulan, o solidários entre sí." 
sempre por um horizonte de melhoria progressiva, aquela mencionada "imaginação do futuro" 8 . Ou, como quer Lindón (2005), a produção de "utopias espaciais": um "projeto otimista (o de viver melhor)" que "se constrói sempre sobre a base de um 'onde', que, em essência, é um 'espaço'."'

El nomadismo, aunque sea hacia zonas de mayores carencias en sentido urbano, desde una subjetividad colectiva es visto como una práctica que permite alguna forma de mejoría en las condiciones de vida: es el dejar todo y volver a empezar en otro territorio que promete mejorar las condiciones de vida a pesar del alto costo personal/cotidiano de empezar nuevamente. Cabe subrayar que esa mejoría en las condiciones materiales de vida no es algo evidente para el etnógrafo. Sólo es posible reconstruir esta interpretación a la luz de la narrativa de vida del habitante de esta periferia, en la cual refiere a distintas experiências residenciales. (Lindón, 2007:93)

E esse é um dos pontos de vista a partir dos quais se deve compreender a centralidade da casa (como presença ou ausência) nessas trajetórias: articulada às experiências anteriores de deslocamentos - e de, por vezes, "não ter pra onde ir" -, a "casa própria" se configura não apenas como horizonte de melhoria, mas como possível ponto de repouso (ainda que não, necessariamente, de fixação), como desejo de permanência frente a esse nomadismo continuado. A construção dos sentidos de ter uma casa se faz em íntima relação com a experiência vivida dos múltiplos deslocamentos, das vicissitudes e sofrimentos decorrentes de não ter casa. De modo complementar, as vivências anteriores da casa como lócus de violências dão lugar ao ideal da casa como abrigo; as inseguranças e incertezas nas demais esferas da vida fazem depositar na casa (própria) a dimensão mais ontológica de segurança - ainda que tais dimensões ideais (dentre outras) estejam em contínua tensão com a realidade cotidiana, com outras esferas de vulnerabilidade que a atravessam, mesmo quando o acesso à moradia se concretiza de alguma maneira. A casa como abrigo, como segurança, ou o "sonho da casa própria" são, por certo, construções sociais (em alguma medida ideológicas); são, entretanto, reapropriadas e ressignificadas no contexto de experiências urbanas como as descritas nesta tese.

Como contraponto às dinâmicas cambiantes em diversos aspectos da vida (trabalho, renda, arranjos familiares, vínculos sociais etc), a perspectiva de fixação em uma casa e um território é um dos principais horizontes das trajetórias, ao qual se articula a dimensão fundamental de construção de redes de relações situadas, de uma

8 Cavalcanti (2007).

9 Lindón (2005:4), tradução de: “Estas utopías son 'espaciales' porque esa visión optimista de una vida mejor se construye siempre sobre la base de un 'donde', que en esencia es un 'espacio'." 
territorialidade propriamente dita ${ }^{10}$. Dos momentos em que alguma fixação se faz possível decorre a atualização daquela "imaginação do futuro", daquelas "utopias espaciais"; nesses momentos se constroem, ou se refazem, os sentidos de vizinhança, bairro e território que, em diálogo com a experiência dos deslocamentos habitacionais, conformam "a espacialidade da vida cotidiana" nas periferias urbanas.

Una vez que las personas se instalan en el lugar de alguna forma (aun improvisada), dichas utopías siguen presentes - aunque reconstruyéndose constantemente - como un marco de referencia desde el cual se toma contacto con el mundo, y en particular como un marco desde el cual se construyen formas de habitar. La reconstrucción de las utopías espaciales a partir del momento que se anclan en un "lugar" es algo inevitable, ya que el lugar en un principio no tiene rasgos claros y evidentes que aseguren la "vida mejor". Por eso, la utopía espacial inicial tiene que reconstruirse a partir de su aterrizaje en un lugar. (Lindón, 2005:5)

Por outro lado, a "casa própria" parece já não configurar, necessariamente, horizonte de estabilidade das camadas populares (como ideal, talvez; mas na prática, não), não representa o ponto final de condensação das trajetórias habitacionais. Mesmo em um contexto em que as políticas sociais e habitacionais se direcionam, cada vez mais, a territorializar a pobreza - ao que se associa o aprofundamento da circunscrição territorial da experiência urbana observada em algumas trajetórias - a persistência, a renovação ou o acirramento de certas condições e vulnerabilidades impulsionam outros deslocamentos, pondo em xeque a própria questão da fixação.

De fato, o 'nomadismo' evidencia-se como força estruturante que vai além, inclusive, do atendimento pelas políticas habitacionais, numa dinâmica que não necessariamente se interrompe pela conquista da "casa própria". Dentre os diversos vetores observados a incidir sobre a continuidade desses deslocamentos mesmo após a consecução de uma casa - para além das dimensões financeiras aí implicadas (dificuldades em arcar com os custos das novas moradias e da infraestrutura urbana formalizada, aumento nos gastos com transporte em função da localização da nova moradia, distância em relação a possibilidades de obtenção de trabalho e renda, para citar alguns exemplos) -, ou, em outro sentido, dos projetos de mobilidade socioespacial (em que a mudança de casa é apreendida ora como espécie de 'conversão', visando a distanciar-se das marcas da pobreza, dos estigmas territorializados, ora como perspectiva de negócio futuro, tendo em vista um novo deslocamento socioespacial 'ascendente') -, dois merecem destaque, por terem se mostrado, em maior ou menor grau, também dimensões constituintes daquela

10 Lindón (2005:4) irá destacar a importância, para as camadas populares, de "ter alguma certeza territorializada". 
mencionada experiência urbana comum, aspectos estruturantes das trajetórias em foco.

O primeiro trata daquelas dinâmicas familiares cambiantes e seus rearranjos constantes: os movimentos de constituição, destituição e restituição das famílias, assim como o caráter plástico das mesmas, que permite que se conciliem modelos nucleares e conjugais com modelos de família extensa, imersos nas relações de vizinhança ou parentesco por afinidade, acabam sendo responsáveis por pautar, em grande medida, direções, escalas e intensidades dos deslocamentos, bem como por tensionar significativamente os processos de fixação nos novos territórios e nas novas casas.

O segundo refere-se ao atravessamento das trajetórias por dinâmicas inerentes à "expansão do mundo do crime nas periferias"11: sua maior ou menor presença, concentração e capilaridade em um determinado território são fatores a motivar deslocamentos mais recentes (voluntários e involuntários), seja pela intenção de fugir dessas dinâmicas, muitas vezes sob a perspectiva de "poder criar um filho de forma decente, com segurança"; de desvincular-se dessa proximidade, corporal inclusive; de tentar escapar ao estigma e à suspeição dirigidos a determinados territórios; de tirar a família dos limites imediatos de ação e domínio do crime; ou mesmo de tentar eliminar os efeitos de tais dinâmicas de dentro da própria casa, entre outros fatores, a depender do envolvimento, direto ou não, com tal universo. Trata-se de uma dimensão mais ampla de vulnerabilidade que, inclusive, desestabiliza famílias relativamente enraizadas em um certo território, como visto.

Há, portanto, uma relação de tensão e complementaridade entre o lugar da casa nas trajetórias urbanas e os múltiplos trânsitos (territoriais, sociais) que as configuram que parece ser central nessas experiências urbanas 'periféricas': de um lado, as dimensões de territorialização e fixação presentes na concepção mesma de moradia, mas, sobretudo, historicamente, nas políticas habitacionais (e sociais) no país; de outro, o caráter dinâmico e transumante inerente às trajetórias investigadas, que tem como cerne arranjos familiares e redes de relações cambiantes que não se pautam pela estabilidade e rigidez dos vínculos ${ }^{12}$. Tal complexa relação é

11 Feltran (2011).

12 Como acredito ter ficado evidente já no Capítulo 1 da tese, em que remeto a diversos autores, não sendo necessário retomá-los aqui. 
sistematicamente ignorada pelas políticas públicas ${ }^{13}$ (e, em certo sentido, também pelos estudos urbanos), e é constituinte do que denomino 'cidades outras'.

Dos meandros da regularidade dos fluxos das camadas populares pelos sempre expandidos territórios periféricos da cidade ${ }^{14}$ decorre a configuração daquelas já mencionadas "tranças de relações entre geografias mais ou menos distantes"15: trânsitos que atravessam e alinhavam as periferias, produzindo redes de relações e interconhecimento que conectam os vários territórios populares. Ao perscrutar que cidades se configuram do ponto de vista de tais deslocamentos habitacionais e seus pontos de fixação (casas, vizinhanças, bairros), deparei-me com uma dimensão indelével dessas trajetórias, qual seja, o fato de conformarem experiências urbanas absolutamente mediadas pelas redes de relações estabelecidas no tempo e no espaço, por trânsitos e deslocamentos no espaço físico e no espaço social, entre mundos sociais e territorialidades (Graffmeyer, 1995).

Assim, mesmo em meio a uma inegável intensificação da territorialização da pobreza, a cidade que emerge da pesquisa empírica se apresenta como campo de trânsitos e mediações, em que se articulam temporalidades, espacialidades e universos sociais distintos (mundo do crime, religião, trabalho, família, políticas públicas, instituições etc). Os trânsitos empreendidos pelos moradores das periferias, compulsórios ou voluntários (e aqui me refiro aos deslocamentos não apenas físicos, já que envolvem também dimensões simbólicas), parecem se configurar como um elemento fundamental para a reflexão em termos da produção - contraditória - do espaço urbano contemporâneo, e trazem consigo a ideia de liminaridades, que creio ser útil para uma aproximação à complexidade socioespacial das periferias urbanas.

Os sujeitos da pesquisa são operadores de conexões de mundos, "figuras de fronteira"16: suas identidades e ações são situacionais, compõem-se de uma superposição de estados situados. Os dispositivos acionados, as instâncias mobilizadas, os espaços atravessados evocam relações e mediações que configuram simultaneamente territórios e experiências urbanas pautadas sob ordenações e normativas múltiplas (muito além das dicotomias formal/informal; legal/ilegal), em movimento, muitas vezes em disputa, e quase sempre coexistentes (quiçá

13 No sentido em que pautam-se por uma imagem fixa de família (e de casa), ignorando a plasticidade (e a diversidade) presente nas experiências de família e casa nas camadas populares, associadas que estão às experiências de deslocamentos.

14 Que Rizek (2014) avalia terem se tornado, mesmo, normalizados e rotinizados, daí sua "quase" invisibilidade.

15 Cunha (2002).

16 Foote-Whyte (2005). 
superpostas), acionadas conforme dinâmicas cotidianas que evidenciam espécies de 'saberes de deslocamentos': rituais cotidianos de atualização dos conflitos, das violências, das rupturas, dos descaminhos como modos de reconstruir cotidianamente a própria vida ${ }^{17}$ na cidade, bem como os espaços onde ela transcorre.

Esse conhecimento acumulado de dinâmicas urbanas específicas articula-se às redes de relações (locais e expandidas) e é composto e recomposto a partir da intensa circulação de informações entre os pares: quem está morando onde, quem mudou para onde, quem tem ou não tem casa própria, quem recebe ou não benefícios sociais, quem está ou não envolvido no mundo do crime... - mesmo a fofoca e o boato, nessa perspectiva, desempenham papel central na construção desses saberes indispensáveis aos moradores das periferias.

Os lugares de moradia influenciam sobremaneira as extensões, dimensões e capilaridades de tais trânsitos e dos saberes deles decorrentes, e vice-versa. Vistos no tempo, trânsitos e saberes mostram-se mesmo indissociáveis das motivações que poderão produzir novos deslocamentos pela cidade. Paradoxalmente, a casa - ponto de fixação - é também um polo irradiador dessas tramas e mediações de que se faz a cidade. É a partir do lugar da casa (ou das várias casas pelas quais já passaram) que se tecem redes de conhecimento e relações que interconectam bairros, territórios e as 'cidades outras' que aí se tramam. Os 'saberes de deslocamentos' são, portanto, eminentemente territoriais: o pleno domínio sobre certos territórios, seus vários espaços, seus recônditos, suas fronteiras, os modos de ultrapassá-las, a que se associam aquelas concepções do ser conhecido e ter conhecimento, tão caras a meus interlocutores. Nas palavras de Lindón (2007): “el conocimiento espacial que articula las trayectorias de vida nómadas".

Nesse sentido, as periferias são vividas, pensadas e narradas a partir de territorialidades múltiplas e superpostas: mercados imobiliários, hip-hop, mundo do crime, religião, políticas habitacionais... - conforme marcadores acionados e posições situadas dos sujeitos, emergem das trajetórias distintas configurações territoriais, que por vezes se sobrepõem ou se contrapõem, em movimentos de construção, desconstrução e reconfiguração que apontam para uma dimensão absolutamente relacional do território. A essas delimitações físicas e simbólicas que conformam tais territorialidades se associam também outras classificações e linhas de clivagem internas às camadas populares e a seus territórios, como visto, em que uma série de critérios morais, econômicos e simbólicos são acionados, de modo que resultam em dinâmicas de aproximação e de distinção socioespacial, de acordo com as 
circunstâncias, em identificações ou oposições situacionais (ou seja, situadas em um espaço, um tempo e uma trama social específica).

Joseph (1999:33-39), conferindo importância "à tomada de partido rigorosamente descritivo de uma etnografia do deslocamento", a qual possibilitaria apreender a própria "urbanidade em operação", fornece algumas pistas para pensar essa dimensão dos trânsitos e mediações a que me refiro: seria possível pensar a cidade a partir das categorias da liminaridade, da passagem, da instabilidade, do espaçamento e da contiguidade? Ou, ainda, a partir da ideia de "um espaço descontínuo constituído de várias regiões de significação, com seus recursos cognitivos e normativos próprios", articuladas entre si por eventos de mobilidade, cursos de ação singular?

Não se pretende afirmar, com isso, a inexistência de fronteiras socioespaciais a delimitar os territórios, as trajetórias e as experiências em foco: mesmo uma rápida incursão pelas trajetórias urbanas investigadas seria suficiente para refutar tal afirmação, como evidenciam também as próprias hierarquizações do espaço processadas por meus interlocutores. De todo modo, talvez fosse possível pensar, classicamente com Foote-Whyte (2005) ou contemporaneamente com Segura (2006:21), em tais fronteiras (simultaneamente físicas e simbólicas) como algo que existe efetivamente, mas que são passíveis de serem cruzadas (ou, ao menos, deslocadas) por motivos, condições e em situações variadas: entretanto, "o fato de cruzá-las - não sempre, nem para todos - não significa a sua abolição"18.

Ni límites insalvables, ni ausencia de límites. No alcanza, pues, con celebrar - o cuestionar - la ambigüedad de las fronteras, que separan y unen. Se trata, por el contrario, de ver qué, cuándo, quiénes y para qué las atraviesan - y en qué direcciones. (Segura, 2006:22)

Buscando apreender formas mais complexas do desenho das desigualdades (e sua reprodução) no espaço urbano para além das surradas dicotomias e categorias autoexplicativas e sob a perspectiva de que há dinâmicas socioespaciais em constante movimento, produzindo e disputando a cidade em suas margens e, portanto, deslocando-as continuamente, a pesquisa propôs refletir sobre um modo de interrogar o espaço urbano contemporâneo a partir, simultaneamente, de sua capacidade de aproximar e de seu efeito de discriminar e distanciar ${ }^{19}$ : uma abordagem das fronteiras socioespaciais a partir dos cruzamentos e contradições que elas ensejam.

18 Segura (2006:21), tradução de: "las fronteras, territoriales y simbólicas, existen, y el hecho de cruzarlas - ni siempre, ni para todo - no implica su abolición".

19 Joseph (1999). 
E aqui nos aproximamos da noção de "limiar" tal como proposta por Rizek (2012) a partir de leituras de Benjamin e seus comentadores. Ainda menos definidos e materializáveis que as fronteiras, os "limiares" remetem a fluxos e contrafluxos, lugares e tempos indeterminados e de extensão indefinida, "um entre, uma zona cinzenta que funde categorias e mistura oposições". Situam-se entre a possibilidade de um futuro em aberto - "zonas de transição" - e o achatamento gestionário da vida - "zonas de detenção": estas últimas corresponderiam ao progressivo encolhimento do potencial que o limiar encerra, a que corresponderiam as reconfigurações contemporâneas das relações entre legalidade e ilegalidade, formalidade e informalidade - as "fronteiras incertas entre o ilegal, o informal e o ilícito" 20 - e do lugar da pobreza nesse contexto. Ou, em outras palavras, entre o estado e suas margens, entre a cidade e suas periferias: também dentre as concepções de margem, tal como sintetizadas por Das e Poole (2008), emerge uma dimensão de "indeterminação", propondo repensar os limites entre o centro e a periferia, o público e o privado, a norma e a transgressão, e permitindo aproximá-la também, portanto, dessa concepção de 'liminaridade' apreendida mesmo como inerente às trajetórias, às experiências e aos espaços urbanos sobre os quais a pesquisa se debruçou.

Os capítulos da tese evidenciaram o quanto os deslocamentos habitacionais, os usos da cidade, as experiências urbanas de meus interlocutores se relacionam com diversos outros processos sociais, como as transformações nos arranjos familiares, nas redes de relações, nas dinâmicas de vizinhança e amizades, no mundo do trabalho, nas perspectivas de mobilidade social e - mais amplamente - na política e na economia. Cabe destacar o quanto os vínculos sociais e afetivos, sobretudo as dinâmicas familiares, influenciam tais deslocamentos e são influenciados por eles.

As motivações dos deslocamentos habitacionais e do viver na periferia, como visto, são muito mais complexas do que o imediatismo das explicações socioeconômicas ou de categorias como "segregação" ou "exclusão" podem fazer parecer ${ }^{21}$ e mostraramse dados fundamentais para se repensar os sentidos de cidade, bairro, casa e as políticas que a eles se entrelaçam: a própria atenção a tais motivações - e suas limitações -, bem como aos trânsitos e mediações aí implicados talvez se configurem, mesmo, como uma das contribuições desta tese. A despeito dos bloqueios e

20 Telles e Hirata (2007).

21 Grafmeyer (1995:62) destaca, precisamente, que as questões da habitação e das mobilidades situam-se no cruzamento desses dois registros: o das "estruturas urbanas" e o das "decisões individuais dos cidadãos", sendo o "campo das possibilidades" destas últimas delimitados pelas primeiras, mas não completamente. Em outra ocasião, se referirá também ao cruzamento das “lógicas econômicas" e das "lógicas familiares" (p.94). 
constrangimentos, as 'cidades outras' que emergem das trajetórias não se pautam exclusivamente pela "lógica da necessidade", sendo mesmo possível dizer que há, sim, alguma dimensão de escolha, numa permanente tensão entre destino e projeto.

Como ensina Das (2011:18): "as vidas individuais são definidas pelo contexto, mas são também geradoras de novos contextos". Mesmo considerando-se que, a despeito de melhorias nas condições econômicas das camadas populares nos últimos anos (que fizeram a pobreza ainda mais heterogênea, como visto), mantém-se a "experiência da cidade sob o signo da vulnerabilidade" (Telles, 2009:9), evidenciando dimensões de "produção da vida nua nas circunstâncias concretas de vida e trabalho dos que habitam e transitam por esses territórios" (Telles, 2013:361), levar a sério as trajetórias e suas narrativas implica constatar que também se desvelam horizontes de projetos - a partir de determinados "campos de possibilidades" 22 , é verdade -, que podem reconfigurar experiências urbanas atravessadas por variadas formas de violência e vulnerabilidade. Ou, nas belas palavras de Agier (2011:172): "é a partir daqui que falamos, de um espaço de reflexões e de ações entre o vazio e o cheio, entre uma cidade nua e uma cidade densa".

Essa condição - liminar - constitui um campo de experiência e significação da cidade (a um só tempo comum e diverso, como visto): considerando a prática de habitar como uma ação produtora de sentidos ${ }^{23}$, a tese distancia-se daquela já referida concepção da "lógica da necessidade", ou do que Marcelin (1999:31) denominou "concepção miserabilista das classes populares", isto é, abordagens que as consideram "incapazes de produzir um mundo e habitá-lo simbolicamente".

Se, como aponta Grafmayer ${ }^{24}$ (1995:23), as "tensões entre a territorialidade e a mobilidade, entre a proximidade e a distância nas interações cotidianas, entre a afirmação da identidade e a experiência do outro" subsistiriam como "uma condição própria do cidadão" - e, portanto, da própria ideia de cidade -, parece-me inevitável a constatação de uma inegável dimensão de urbanidade (ainda que 'outra') decorrente das dinâmicas socioespaciais como as que a tese procurou evidenciar.

E aqui dialogo, uma vez mais, com as proposições de Agier (2011:41), para quem existiriam diferentes "regimes de urbanidade", o que demandaria aos estudos urbanos uma atenção às "múltiplas maneiras de 'fazer cidade'".

A vida social dos slums de Bangcoc, o imaginário de Água Blanca em Cali, a violência da Rocinha no Rio de Janeiro não são menos da cidade que La Defense ou o Marais de Paris, a Quinta Avenida em Nova York ou os subúrbios residenciais de Los Angeles. Uns e outros designam diferentes

22 Velho $(1987,1994)$.

23 Ingold (2000).

24 Retomando proposições seminais de Louis Wirth em "O urbanismo como modo de vida". 
'regimes de urbanidade'. A sua comparação revela uma desigualdade antes mesmo que se possa interrogar sobre as diferenças. Mas depende de cada um atribuir-Ihes plena igualdade epistemológica, no que se refere aos processos de criação e transformação do espaço comum, as situações e os lugares onde a cidade se faz (...). (Agier, 2005:44)

Dessa perspectiva, em se considerando a liminaridade constitutiva das trajetórias e das experiências urbanas que elas evidenciam, ao transformarem reiterada e insistentemente "deserto" em "mundo" 25 , não seria possível pensarmos as periferias em termos de 'urbanidades liminares', uma vez que, tornando-se processualmente cidade, as margens fazem "mover as fronteiras da ordem social até ao limite do qual se transplantou" 26 ?

\section{- Cidades Outras: alteridades socioespaciais em foco}

Extraindo consequência de sua própria metodologia, a pesquisa promoveu uma espécie de inversão epistemológica, a partir da qual se fez inevitável aquele questionamento da ideia de cidade como totalidade a priori ${ }^{27}$ : o percurso da investigação se deu da experiência e da significação em direção à materialidade ou, em outras palavras, dispôs-se a pensar a cidade como "categoria nativa", como referência prática, considerando os vários repertórios correntes sobre a cidade entre meus interlocutores e colocando-os em relação com a cidade tal qual pensada pelas teorias e ciências humanas e sociais (e pelo senso comum) ${ }^{28}$. Tratou-se, então, de uma opção analítica pautada pelo questionamento dos pressupostos normativos que orientam tais concepções de cidade (e daquilo que seria o seu "avesso"), colocandoas em perspectiva.

Se, como nos ensina Bourdieu (2008), não é possível pensar mundo social, territórios e significação de forma dissociada e, do ponto de vista da investigação, não basta apenas ir a campo, sendo necessário desnaturalizar o "olhar estrangeiro" sobre ele, buscando compreender como se produz a distinção (nesta pesquisa, em especial aquela relativa a cidade/periferia, mas não apenas), a proposta aqui foi inverter o olhar comumente lançado às periferias, tanto direcionando-o a "prospectar a cidade

25 Conforme proposição - arendtiana - de Agier (2011:39) e também de Rizek (2014), já mencionada.

26 Parafraseando Agier (2011:42).

27 Reitero que não se trata de desconsiderar a existência de processos totalizantes que atravessariam as dinâmicas socioespaciais envolvidas na produção das cidades; trata-se, porém, de encará-los de maneira relacional, colocando-os também em perspectiva: aqui, novamente, invoco o procedimento analítico da variação da escala, a partir da qual "a cidade" ganha reflexividade, em especial ao ser pensada como "categoria da prática social" (Roncayolo, 1978; Lepetit, 2001).

28 Devo a assunção de tal perspectiva à provocação feita pelo professor Luís Antônio Machado da Silva aos pesquisadores presentes no seminário "Território, crime e ordenamento social nas margens da cidade", realizado em maio de 2012, no CEBRAP - Centro Brasileiro de Análise e Planejamento. 
a partir de suas margens"29, quanto - e principalmente - propondo uma aproximação etnográfica às cidades cravadas nas trajetórias urbanas, nas quais se articulam práticas, espaços e significações classicamente considerados "à parte" da cidade-totalidade.

Assim perspectivadas, as periferias não aparecem mais como "desvio" ou expressão da "falta de ordem" urbana, mas evidenciam-se como constituintes - e mesmo como "condições necessárias" - de uma dada concepção (à qual corresponde uma produção) de cidade, de urbanismo, de urbanização e - por que não dizer? - de estado $^{30}$. Não se trata, portanto, de inverter a valoração sobre esses processos e fenômenos urbanos e suas dinâmicas socioespaciais - da negatividade para a positividade - mas de mudar a perspectiva de leitura sobre eles, desnormatizando seu campo de significação: sem desconsiderar sua construção como "problema urbano" ou "questão social", a intenção foi produzir reflexividade sobre as periferias, evitando reificar tal dimensão "problemática" como um dado objetivo que estaria presente qualquer que fosse a situação ou o ângulo de análise (o que meu próprio campo pôs em cheque todo o tempo).

Dessa forma, a tese moldou-se também enquanto crítica da racionalidade gestionária e aprioristicamente interventora que orienta pesquisas e práticas no campo da arquitetura e do urbanismo ${ }^{31}$, estabelecendo um contraponto à abordagem das periferias em termos de sua valoração ou transformação. O olhar, aqui, não teve como destino prévio a 'necessidade de intervenção', mas a busca de conhecimento: tratou-se de compreender como se constituem, como funcionam, como são vividos e significados os processos e as dinâmicas socioespaciais em foco, e não de pensar exclusivamente 'como transformá-los?' (ou 'como ordená-los?').

Os capítulos permitiram evidenciar ordenamentos socioespaciais nas margens da cidade e os modos pelos quais se produzem, se disputam, são vividos e significados

29 Telles (2013).

30 Cf. Das e Poole (2008:22): "Dado que es imposible pensar a los sistemas políticos en el mundo contemporâneo comprendidos por cualquier forma de sociedad sin estado, ¿es que estamos observando formas de estado incompletas - o frustradas - en dichas situaciones circunstancias? ¿O acaso son las formas de ilegalidad, pertenencia parcial y desorden que parecen habitar los márgenes del estado, las que constituyen las condiciones necesarias para el estado en tanto objeto teórico y político?"

31 Tal perspectiva também estaria fortemente presente em pesquisas filiadas à chamada sociologia urbana, conforme esclarece Hirata (2010). O autor, em reflexão sobre a prática de pesquisa nas cidades e suas complexas relações com a gestão das populações urbanas, desenvolve uma crítica à postura gestionária frente aos chamados "problemas urbanos", a partir de uma revisão dos primeiros estudos da Escola de Chicago, nos quais se construiu a noção da cidade como laboratório e clínica do humano: "Ela parte da representação da cidade como laboratório social, onde seria possível identificar as variáveis que constroem o urbano como um meio, e tem como perspectiva a construção de uma estrutura pragmática, a cidade como artefato, em vista de um ordenamento ou um campo de intervenção possível do homem sobre o homem" (Hirata, 2010:11,12). 
pelos moradores desses territórios periféricos. Há, desse ponto de vista, uma clara disjunção entre, de um lado, saberes e dispositivos técnicos de planejamento e gestão urbana (e social) e, de outro, as práticas de produção do urbano em ato (e suas representações). Parece-me que não há como pensar 'a cidade', ou, ainda mais, intervir em suas 'margens', sem levar em consideração algumas dimensões que a tese procurou descrever e analisar, e que são apenas parte destas 'cidades outras', ainda por conhecer.

Em que pesem as estratégias de conhecimento adotadas nesta pesquisa, a consideração, a partir das trajetórias urbanas de moradores de periferias, da transumância que seria constituinte das cidades parece possibilitar novos campos de reflexão e problematização sobre o espaço urbano e seus modos de produção processual, considerando práticas cotidianas, deslocamentos e narrativas como aspectos legítimos, fundamentais e mesmo fundadores (para retomar Certeau) de tais processos. O autor, invocando a fenomenologia de Merleau Ponty, reitera que "existem tantos espaços quanto experiências espaciais distintas" 32 : considerando espaços, práticas, experiências e representações como inextrincáveis, cartografar essas "cidades transumantes" implicou, portanto, apreender múltiplas dimensões do urbano nessas trajetórias periféricas, atentando aos conflitos, aos constrangimentos, às disputas, às relações, aos afetos, aos medos, às escolhas a elas inerentes. Desse ponto de vista, as trajetórias

(...) nos hablan de formas de vincularse con la ciudad, de modos diferentes de vivirla. En efecto, si dirigimos nuestra mirada y nuestro cuerpo hacia la periferia para conocer otras vidas, con lo que nos encontramos es con otras ciudades, las cuales remiten a experiencias, trayectorias y territorialidades distintas. Nos desplazamos de la inadecuación entre dibujos y ciudad a los modos - diferentes y desiguales - de estar y de hacer en la ciudad, de experimentar un lugar: 'fabricaciones de espacio', como bellamente las denominó de Certeau. (Segura, 2000: 134)

Chegando ao final desta tese, espero ter mostrado que as trajetórias e narrativas, constantemente deslocadas, de meus interlocutores não dizem apenas de seus dramas individuais ou familiares: dizem muito mais das cidades em que vivem, que conhecem, por onde transitam, que experienciam ${ }^{33}$ enfim, revelando-as. Sob o enfoque etnográfico aqui apresentado, trajetórias e narrativas urbanas 'periféricas' permitem não apenas pontuar inflexões, diferenças e desigualdades no campo do urbano, mas produzir inteligibilidade sobre perspectivas múltiplas e conflitantes, colocando no centro da análise a alteridade que elas encerram e que são produtoras, também, de alteridades socioespaciais a serem levadas a sério enquanto tais.

32 Certeau (2003:202).

33 Telles (2009:10). 


\section{REFERÊNCIAS BIBLIOGRÁFICAS .}

ABRAMO, Pedro. A cidade caleidoscópica. Rio de Janeiro: Bertrand, 2007.

. Mercado e ordem urbana. Do caos à teoria da localização residencial. Rio de Janeiro: Bertrand, 2001.

(org.) A cidade da informalidade. O desafio das cidades latino-americanas. Rio de Janeiro: Sette Letras, FAPERJ, 2003.

(org.). Favela e mercado informal: a nova porta de entrada dos pobres nas cidades brasileiras. Porto Alegre: ANTAC, 2009 (coleção Habitare, no10).

ACSELRAD, Henri (org.). Cartografias sociais e território. Rio de Janeiro: Instituto de Pesquisa e Planejamento Urbano e Regional - UFRJ, 2008.

AGIER, Michel. Antropologia da cidade: lugares, situações, movimentos. São Paulo: Terceiro Nome, 2011.

. L'invention de la ville: banlieues, townships, invasions et favelas. Paris: Éditions des Archives Contemporaines, 1999.

ALCANTARA, Danilo Marcondes de; MELAZZO, Everaldo Santos. "Dinâmica imobiliária e produção do espaço urbano nas cidades médias: articulando velhos dilemas a novas estratégias". Anais XVII Encontro Nacional de Geógrafos, Belo Horizonte, 2012.

ALCÂNTARA, Edinéa; MONTEIRO, Circe. "Em que a vida na favela é melhor do que em um conjunto de apartamentos? O caso de Abençoada por Deus, Recife." Anais $V$ Encontro Nacional da Anppas, Florianópolis, 2010.

ALMEIDA, Ronaldo de; D'ANDREA, Tiaraju. "Pobreza e redes sociais em uma favela paulistana". Novos Estudos CEBRAP, n. ${ }^{\circ}$ 68, março de 2004, p. $94-106$.

ALMEIDA, Ronaldo. "Religião e desigualdade urbana". Interseções, v. 13, n. 1, Rio de Janeiro, 2011, p. 126-135.

ALMEIDA, Ronaldo; D'ANDREA, Tiaraju ; DE LUCCA, Daniel. "Situações periféricas: etnografia comparada de pobrezas urbanas". Novos Estudos Cebrap, São Paulo, 2009.

ALVITO, Marcos. "A honra de Acari". VELHO, G. Cidadania e violência. Rio de Janeiro: Ed. UFRJ, 1996.

ALVITO, Marcos. "Um bicho de sete cabeças". Zaluar, A.; Alvito, M. (org.). Um século de favela. Rio de Janeiro: Fundação Getúlio Vargas, 1998, p. 181-208.

ANGELIN, Paulo Eduardo. Mulheres migrantes no contexto das fronteiras de gênero $e$ arranjos familiares. Tese (Doutorado em Sociologia), UFSCar, São. Carlos, 2012.

ANSAY, Pierre. Penser La Ville. Paris: Archives d'Architecture Moderne, 1998.

ARANTES, Pedro; FIX, Mariana. "Como o governo Lula pretende resolver o problema da habitação". Correio da Cidadania, 30/07/2009. (Disponível em: www.correiocidadania.com.br, consulta em maio de 2014) 
ARAUJO, Ana Cristina da Silva. Programa Minha Casa Minha Vida: antigos e novos dilemas da habitação de interesse social e o caso de Marília-SP. Tese (Doutorado em Arquitetura e Urbanismo), Instituto de Arquitetura e Urbanismo - USP São Carlos, 2013.

ARAÚJO, Mayara M. S.; MOURA, Rosa; DIAS, Patricia C. "Cidades médias: uma categoria em discussão". Pereira, R. H. M.; Furtado B. A.(orgs.). Dinâmica urbano-regional, rede urbana e suas interfaces. Brasília: Ipea, 2010, pp. 53-72.

AUGÉ, Marc. El sentido de los otros: actualidad de la antropologia. Barcelona: Paidós, 1996. ÁVILA, Milene Peixoto. Periferia é periferia em qualquer lugar? Antenor Garcia: estudo de uma periferia interiorana. Dissertação (mestrado em Ciências Sociais), USFCar, São Carlos, 2006.

AZEVEDO, Sérgio de; ARAÚJO, Maria Bernadette. "Questões metodológicas sobre o 'déficit habitacional': o perigo de abordagens corporativas". Cadernos Metrópole, ํ17, 1ㅇs. sem. 2007, p. 241-255.

BALTRUSIS, Nelson. "Transformações do modo de morar nas metrópoles contemporâneas: novos discursos, velhos problemas". Cadernos CRH, vol.23, n.59, Salvador, 2010, pp. 235-253.

. A dinâmica do mercado imobiliário na RMSP. Um estudo de caso nas favelas de Paraisópolis e nova Conquista. Dissertação (Mestrado em Arquitetura e Urbanismo), Pontifícia Universidade Católica de Campinas, 2000.

. O mercado imobiliário em favelas e o processo de estruturação do espaço. Tese (Doutorado em Arquitetura e Urbanismo), Universidade de São Paulo, 2005.

BARBON, Ângela Luppi. "Mobilidade residencial intra-urbana em grandes centros: Região Metropolitana de São Paulo - estudo de caso." Anais XIV Encontro Nacional de Estudos Populacionais, Caxambu, 2004.

BARNES, John A. "Redes sociais e processo político". FELDMAN-BIANCO, B. (org.). Antropologia das Sociedades Contemporâneas. São Paulo, Global, 1987.

1954.

. "Class and Committees in a Norwegian Island Parish". Human Relations, n. 7,

BARON, Cristina M. Perissinotto; ANELLI, Renato L. Sobral. "Projeto de Urbanização em Área Subnormal - São Carlos - SP". Revista Tópos, Vol. 3, No 2, 2009, p. 126-144.

BECKER, Howard. Métodos de Pesquisa em Ciências Sociais. São Paulo: Hucitec, 1994.

BIONDI, Karina. "'Quebrada largada': considerações sobre ausência de Estado, desejo de Estado e efeitos de Estado". 35 Encontro Nacional da Anpocs, Caxambu, 2011. . Junto e misturado: imanência e transcendência no PCC. Dissertação (Mestrado em Antropologia), UFSCar, 2009.

BIRMAN, Patricia. "Apresentação". Cunha, N. V. da; Feltran, G. de S. (orgs). Sobre periferias: novos conflitos no Brasil contemporâneo. Rio de Janeiro: Faperj/Lamparina, 2013.

BÓGUS, Lúcia Maria Machado. "Segregação Urbana”. In: Fortuna, C.; Leite, R. P. (Orgs.). Plural de Cidades. Coimbra: Ed. Almedina/CES - Coimbra, 2009, p. 115-126.

BOLAFFI, Gabriel. "Habitação e Urbanismo: o problema e o falso problema". In: Maricato, E. A produção capitalista da casa (e da cidade) no Brasil Industrial. São Paulo: Ed. Alfa Ômega, 1979.

BONATES, Mariana Fialho. "O Programa de Arrendamento Residencial - PAR: acesso diferenciado à moradia e à cidade". Revista Risco, no 7, 2008. 
. Ideologia da casa própria... sem casa própria. O Programa de Arrendamento Residencial na cidade de João Pessoa-PB. Dissertação (mestrado em Arquitetura e Urbanismo), Universidade Federal do Rio Grande do Norte, 2007.

BONDÍA, Jorge Larrosa. "Notas sobre a experiência e o saber de experiência". Revista Brasileira de Educação, Jan-Abr 2002, no 1, p 20-28.

BONDUKI, Nabil. "Do Projeto Moradia ao Programa Minha Casa Minha Vida". Teoria e Debate, v. 82, maio/jun. 2009, p. 8-14.

. "Depoimento". Revista Espaço \& Debates, São Paulo, n. 42, 2001.

BONDUKI, Nabil. Origens da Habitação Social no Brasil. São Paulo: Estação Liberdade/FAPESP, 1998.

; ROLNIK, Raquel. "Periferias: ocupação do espaço e reprodução da força de trabalho". Caderno de Estudos e Pesquisas Fupam. São Paulo: FAU-USP, 1979.

BORNHOLDT, Suzana Ramos Coutinho. "Proclamadores do Reino de Deus": Missão e as Testemunhas de Jeová. Dissertação (mestrado em Antropologia Social), Universidade Federal de Santa Catarina, 2004.

BOTT, Elisabeth. Família e rede social. Rio de Janeiro: Francisco Alves, 1976.

BOURDIEU, Pierre (org.). A miséria do mundo. Petrópolis: Vozes, 2008.

BOURDIEU, Pierre. A Distinção. Crítica Social do Julgamento. São Paulo: Edusp; Porto Alegre: Zouk, 2007. . Coisas ditas. São Paulo: Brasiliense, 2004.

"A ilusão biográfica". Amado, J.; Ferreira, M. de M. (orgs.). Usos e Abusos da História Oral. Rio de Janeiro: Editora FGV, 1998.

BRAIDOTTI, Rosi. Sujetos nómades. Buenos Aires: Paidós, 2000.

BRASIL. Ministério das Cidades. Secretaria Nacional de Habitação. Déficit habitacional no Brasil 2007. Brasília, 2009.

BRASIL. Ministério das Cidades. Secretaria Nacional de Habitação. Programa Minha Casa, Minha Vida. Brasília, 2013.

BRITES, Jurema. "Afeto e desigualdade: gênero, geração e classe entre empregadas domésticas e seus empregadores." Cadernos Pagu, n. 29, 2007, p. 91-109.

Afeto, Desigualdade e Rebeldia: bastidores do serviço doméstico. Tese de Doutorado, Programa de Pós-Graduação em Antropologia Social, UFRGS, Porto Alegre, 2001.

BRUN, Jacques. "Essai critique sur la notion de ségrégation et sur son usage en géographie urbaine". Brun, J.; Rhein, C. (Eds.) La ségrégation dans la ville: concepts et mesure. Paris: L'Harmattan, 1994, p. 21-58

; RHEIN, Catherine (Eds.). La ségrégation dans la ville: concepts et mesure. Paris:

L'Harmattan, 1994.

CABANES, Robert. "Qual dialética é possível entre o espaço público e o privado?" In: Cabanes, R.; Georges, I.; Rizek, C. e Telles, V. (orgs.). Saídas de Emergência: ganhar/perder a vida na periferia de São Paulo. São Paulo: Boitempo, 2011.

. "Espaço privado e espaço público: o jogo de suas relações". In: Telles, V.; Cabanes; R. (orgs.). Nas tramas da cidade: trajetórias urbanas e seus territórios. São Paulo: Humanitas, 2006.

CALDEIRA, Teresa Pires do Rio. Cidade de Muros: crime, segregação e cidadania em São Paulo. São Paulo: Editora 34/Edusp, 2000. 
. A política dos outros: o cotidiano dos moradores de periferia e o que pensam do poder e dos poderosos. São Paulo: Brasiliense, 1984.

CARDOSO, Adauto L. et al. Habitação social na Região Metropolitana do Rio de Janeiro. Coleção Habitare: Habitação Social nas Metrópoles Brasileiras, 2007.

CARDOSO, Adauto Lúcio; ARAGÃO, Thêmis Amorim. "Do fim do BNH ao Programa Minha Casa, Minha Vida: 25 anos da política habitacional no Brasil". In: Cardoso, A. L. (org). O Programa Minha Casa, Minha Vida e seus efeitos territoriais. Rio de Janeiro: Letra Capital, 2013.

; ARAUJO, Flavia de Souza. "Habitação de Interesse Social: política ou mercado? Reflexos sobre a construção do espaço metropolitano". Anais XIII Encontro Nacional da ANPUR, Rio de Janeiro, 2011.

CARDOSO, Adauto (Org.). O Programa Minha Casa Minha Vida e seus efeitos territoriais. Rio de Janeiro: Letra Capital, 2013.

CARMAN, María; VIEIRA, Neiva; y SEGURA, Ramiro (Org.) Segregación y diferencia en la ciudad. QUITO: FLACSO Ecuador, 2013.

CARNEIRO, Daniel Marostegan. A construção das cidades: processos educativos em uma transformação urbana. Dissertação (mestrado em Educação), CECH - UFSCar, São Carlos, 2008.

CARRARA, Amanda Camargo H. A adoção da abordagem de empreendimentos para a gestão ambiental de cidades. Monografia (graduação em Engenharia Ambiental) EESC - USP, São Carlos 2010.

CASTELLS, Manuel. A questão urbana. Rio de Janeiro: Paz e Terra, 1983.

CAVALCANTI, Mariana. "S/morro, varandão, salão, 3dorms: a construção social do valor em mercados imobiliários "limiares"'. Antropolítica, n28, p. 19-46, Niterói, 2010.

. "Do Barraco à Casa: tempo, espaço e valor(es) em uma favela carioca". Revista Brasileira de Ciências Sociais, 2009.

"Tiroteios, Legibilidade e Espaço Urbano: notas etnográficas de uma favela carioca". Dilemas: revista de estudos de conflito e controle social, n.1, 2008, pp.35-59.

Of shacks, houses, and fortresses: An ethnography of favela consolidation in Rio de Janeiro. Tese (Doutorado). Departamento de Antropologia, University of Chicago, 2007.

CERTEAU, Michel de. A invenção do cotidiano: artes de fazer. Petrópolis: Vozes, 2003.

CHALHOUB, Sidney. Cidade Febril. Cortiços e Epidemias na Corte Imperial. São Paulo: Cia das Letras, 2006.

. Trabalho, lar e botequim. Campinas: Editora da Unicamp, 2005.

CHUMILLAS, Isabel Rodríguez. "La clonación del paisaje de la exclusión". In: Méndez, E.; Chumillas, I. R. (orgs). Paisajes y arquitecturas de la exclusión. Madrid: Ediciones UAM, 2007.

CORDEIRO, Graça Índias; FRÚGOLI Jr., Heitor. "Prefácio". AGIER, M. Antropologia da cidade: lugares, situações, movimentos. São Paulo: Terceiro Nome, 2011, p. 9-30.

CUNHA, Gabriel Rodrigues da. O Programa Minha Casa Minha Vida em São José do Rio Preto/SP: Estado, Mercado, Planejamento Urbano e Habitação. Tese (Doutorado em Arquitetura e Urbanismo), Instituto de Arquitetura e Urbanismo - USP São Carlos, 2014.

CUNHA, Manuela Ivone P. da. Entre o bairro e a prisão: tráfico e trajectos. Lisboa: Fim de Século, 2002. 
"Do tráfico retalhista em Portugal: as redes da semi-periferia". Themis: Revista da Faculdade de Direito da Universidade Nova de Lisboa. 2:4, 2001, p.41-60.

CUNHA, Neiva Vieira da; FELTRAN, Gabriel de Santis (orgs). Sobre periferias: novos conflitos no Brasil contemporâneo. Rio de Janeiro: Faperj/Lamparina, 2013.

DA MATTA, Roberto. "O ofício do etnólogo ou como ter Anthropological Blues". In: Nunes, E. de O. (org.). A aventura sociológica. Rio de Janeiro: Zahar, 1978.

DANTAS, Luísa M. S. "Destino ou escolha? Narrativas e memórias acerca do trabalho a partir das experiências intergeracionais de domésticas em Porto Alegre/RS". Iluminuras, Porto Alegre, v. 14, n. 33, p. 306-326, jul./dez. 2013

DAS, Veena. "O ato de testemunhar: violência, gênero e subjetividade". Cadernos Pagu, n.37 , 2011, p. 9-41.

. Life and words: violence and the descent into the ordinary. California: University of California Press, 2007.

"Fronteiras, violência e o trabalho do tempo: alguns temas wittgensteinianos". Revista Brasileira de Ciências Sociais, vol.14, n.40, 1999, p. 31-42.

POOLE, Deborah. El estado y sus márgenes. Etnografías comparadas. Cuadernos de Antropología Social № 27, 2008, pp. 19-52.

(eds.). Anthropology in the Margins of the State. Santa Fe: School of American Research Press, 2004.

DAVIS, Mike. Planeta Favela. São Paulo: Boitempo, 2006.

DE PAOLI, Tercia Pilomia. Favela Código Cidade: o muito falar e o não fazer é suar em vão. Assembléia do Povo - 1980 a 1986. Tese de Doutorado. IFCH / Unicamp, Campinas, 2000.

DELEUZE, Gilles; GUATTARI, Félix. "Acerca do Ritornelo". Mil Platôs: Capitalismo e Esquizofrenia. Vol. 4. São Paulo: Editora 34, 2002.

Mil Platôs: Capitalismo e Esquizofrenia. V.1. São Paulo: Editora 34,

1996.

DEVESCOVI, Regina C. Balieiro. Urbanização e Acumulação. Um estudo sobre a cidade de São Carlos. São Carlos: Arquivo de História Contemporânea - UFSCar, 1987.

DIAS, Sharon Darling de A. "Política habitacional e desigualdades sócio-espaciais em Fortaleza-CE: da remoção ao cotidiano no conjunto habitacional Maria Tomásia". Anais XIII SIMPURB, Rio de Janeiro, 2013.

DOS ANJOS, Kainara Lira. Mercado imobiliário de aluguel em áreas pobres $e$ as transformações urbanas e ambientais. Tese (Doutorado em Desenvolvimento Urbano), Universidade Federal de Pernambuco, 2013.

DOSSIÊ sobre a atual situação de violência vivenciada no Estado de São Paulo, especificamente nos municípios da região de São Carlos, Araraquara e Ribeirão Preto. São Carlos, 2012. (mimeo).

DOZENA, Alessandro. São Carlos e seu 'desenvolvimento': contradições urbanas de um pólo tecnológico. Dissertação (mestrado em Geografia). FFLCH - USP, São Paulo, 2001.

DUARTE, Luiz Fernando Dias; GOMES, Edlaine de Campos. Três famílias: identidades e trajetórias transgeracionais nas classes populares. Rio de Janeiro: Editora FGV, 2008.

DUARTE, Luiz Fernando Dias. Da vida nervosa nas classes trabalhadoras urbanas. Rio de Janeiro: J. Zahar Editor, 1988.

DUARTE, Rosália. "Pesquisa qualitativa: reflexões sobre o trabalho de campo". In: Cadernos de Pesquisa, n.115, março, 2002. p. 139-154. 
DURHAM, Eunice. "A sociedade vista da periferia". Revista Brasileira de Ciências Sociais, no 1, v.1, São Paulo: Anpocs, 1986.

. A caminho da cidade. São Paulo: Ed. Perspectiva, 1973.

ELIAS, Norbert e SCOTSON, John L. Os estabelecidos e os Outsiders. Sociologia das relações de poder a partir de uma pequena comunidade, Rio de Janeiro, Zahar, 2000.

ENNE, Ana Lúcia S. "Conceito de rede e as sociedades contemporâneas". Comunicação $e$ Informação, v. 7, n², jul./dez. 2004, p. 264 - 273.

FELTRAN, Gabriel de Santis. "Governo que produz crime, crime que produz governo: o dispositivo de gestão do homicídio em São Paulo (1992 - 2011)". Revista Brasileira de Segurança Pública, v. 6, n. 2, São Paulo, 2012, p.232-255.

Fronteiras de tensão: política e violência nas periferias de São Paulo. São Paulo: Editora Unesp/CEM/CEBRAP, 2011.

"Transformações sociais e políticas nas periferias de São Paulo". In: Kowarick, L; Marques, E. (Org.). São Paulo: novos percursos e atores - sociedade, cultura e política. São Paulo: Editora 34/CEM, 2011a, p. 360-380.

"Debates no 'mundo do crime', repertórios da justiça ns periferias de São Paulo". Cabanes, R.; Georges, I.; Rizek, C.; Telles, V.. (Org.). Saídas de Emergência: ganhar/perder a vida na periferia de São Paulo. São Paulo: Boitempo, 2011b, p. 215-237.

"Periferias, direito e diferença: notas de uma etnografia urbana". In: Revista de Antropologia, v.53, n.2, FFLCH-USP, São Paulo, 2010.

"Crime e castigo na cidade: os repertórios da justiça e a questão do homicídio nas periferias de São Paulo", Cadernos CRH, vol. 23, no 58, jan/abr. 2010a

. (org.). Dossiê Margens. Lua Nova, 79, São Paulo: CEDEC, 2010b

"O legítimo em disputa: as fronteiras do "mundo do crime" nas periferias de São Paulo". Dilemas. Revista de Estudos de Conflito e Controle Social. v. 1, n. 1, Rio de Janeiro: UFRJ, 2009, p. 93-126

"Trabalhadores e bandidos: categorias de nomeação, significados políticos". Revista Temáticas. Campinas: Unicamp, v.15, 2008. p. 11-50.

"Isolamento, solidão e superfluidade: sobre abismos cotidianos", In: Kofes, Suely. (org.). Histórias de vida: biografias e trajetórias. Cadernos do IFCH, Campinas: UNICAMP, 2004. pp.173-196.

Desvelar a política na periferia: histórias de movimentos sociais em São Paulo. São Paulo: Humanitas/FAPESP, 2005.

et al. As margens da cidade: grupos urbanos 'marginais', política e violência no estado de São Paulo. Relatório parcial de pesquisa. São Carlos, UFSCar, 2011 (mimeo).

; CUNHA, Neiva Vieira da. "Dossiê Fronteiras Urbanas". Contemporânea - revista de sociologia da UFSCar, v. 3, n. 2, 2013.

FERNANDES, Maria Esther (coord.). A Cidade e seus limites: as contradições do urbano na "Califórnia Brasileira". São Paulo: Annablume, FAPESP; Ribeirão Preto: UNAERP, 2004.

FERREIRA, João Sette Whitaker (coord). Produzir casas ou construir cidades? Desafios para um novo Brasil urbano. Parâmetros de qualidade para a implementação de projetos habitacionais e urbanos. São Paulo: LABHAB; FUPAM, 2012.

FERREIRA, Maria Inês Caetano. Trajetórias urbanas de moradores de uma favela de um distrito de elite na Capital paulista. 2003. Tese (Doutorado em Sociologia), Faculdade de Filosofia, Letras e Ciências Humanas da USP, São Paulo. 
FONSECA, Carolina Ferreira da. "Impasses sobre a prática cartográfica: aproximações teórico - metodológicas". In: Anais do VII ENECULT, UFBa, Salvador, 2011.

. "Cartografias: produção de saberes, subjetividades e cidades". Anais do I ENANPARQ, Rio de Janeiro, 2010.

FONSECA, Claudia. "Desigualdades cerca y lejos: adopción Internacional desde la perspectiva de las Favelas brasileñas". Rodríguez, P.; Mannarelli, M. E. (orgs). Historia de la Infancia en América Latina. Bogota: Universidad Externado de Colombia, 2007, pp. 503-534.

. $O$ anonimato e o texto antropológico. Dilemas éticos e políticos da etnografia 'em casa'. VI RAM, Mesa Redonda Trayectorias y diversidade: las estrategias en investigación etnográfica, Montevideo, 2005.

. Família, fofoca e honra: etnografia de relações de gênero e violência em grupos populares. Porto Alegre: Editora da UFRGS, 2004.

FOOTE-WHYTE, Willian. Sociedade de Esquina. Rio de Janeiro: Zahar, 2005.

FORTUNA, Carlos; LEITE, Rogerio Proença. (Org.). Plural de cidade: novos léxicos urbanos. Coimbra: Almedina, 2009.

FOUCAULT, Michel. Vigiar e punir. Petrópolis: Vozes, 1987.

. "Espacios otros". Versión, no 9, Mexico: UAM, 1999, pp. 15-26 [publicado originalmente em Architecture, Movemente, Continuité, 5, 1984].

FREIRE, Letícia Luna. Tecendo as redes do Programa Favela-Bairro em Acari. Dissertação (mestrado em Psicologia Social). Instituto de Psicologia - UERJ, Rio de Janeiro, 2005.

FRIDMAN, Luis Carlos. "Morte e vida favelada". Anais 32 Encontro Anual da ANPOCS, Caxambu, 2008.

FRÚGOLI Jr., Heitor. "A cidade no diálogo entre disciplinas”. In: Fortuna, C.; Leite, R. P. (Org.). Plural de cidade: novos léxicos urbanos. Coimbra: Almedina, 2009, p. 53-67.

"O urbano em questão na antropologia: interfaces com a sociologia". Revista de Antropologia, v.48, n.ำ, São Paulo: USP, 2005. . Centralidade em São Paulo. São Paulo: Cortez/Edusp, 1999.

FULLILOVE, Mindy THOMPSON. Root Shock: How Tearing Up City Neighborhoods Hurts America, and What We Can Do About It. NY: Ballantine, 2004.

FUNDAÇÃO JOÃO PINHEIRO. Centro de Estudos Políticos e Sociais. Déficit habitacional no Brasil. Convênio PNUD/Secretaria de Política Urbana, Ministério do Planejamento, Belo Horizonte, 1995.

GALDEANO, Ana Paula. "A gestão social da violência: de como ativistas de direitos humanos, líderes de associação de bairro e evangélicos se mobilizam". Cunha, N. V. da; Feltran, G. de S. (orgs). Sobre periferias: novos conflitos no Brasil contemporâneo. Rio de Janeiro: Faperj/Lamparina, 2013.

GASPAR, Waldir José. Análise do Processo Erosivo do Loteamento Social Antenor Garcia. Proposta para Expansão do Bairro. Dissertação (mestrado Engenharia Urbana). UFSCAR, São Carlos, 2000.

GEERTZ, Clifford. A Interpretação das Culturas. Rio de Janeiro: Zahar Editores, 1978.

GEORGES, Isabel. "Entre discriminação e reconhecimento: as trabalhadoras domesticas de São Paulo". In: Cabanes, R.; Georges, I.; Rizek, C.S.; Telles, V. da SILVA. (Org.). Saídas de emergência. Perder/ganhar a vida em São Paulo. São Paulo: Boitempo, 2011, v. 1, p. 95-113.

GIDDENS, Anthony. As consequências da modernidade. São Paulo: Unesp, 1991. 
GODOI, Emília Pietrafesa de. O Trabalho da Memória: cotidiano e história no sertão do Piauí. Campinas: Editora da Unicamp, 1999.

GONÇALVES, Rafael Soares. "O mercado de aluguel nas favelas cariocas e sua regularização numa perspectiva histórica". GEOgraphia [online], v. 13, n. 26, 2011. (Disponível em: www.uff.br/geographia, consulta em maio de 2014).

GRAFMEYER, Yves. Sociologia urbana. Mira-Sintra: Publicações Europa-América, 1995.

; JOSEPH, Isaac. L'Ecole de Chicago: naissance de l'écologie urbaine. Paris: Champs, Flammarion, 2004.

GUATTARI, Felix. Espaço e poder: a criação de territórios na cidade. Espaço e Debates, n. 16, ano V. São Paulo: Cortez, 1985.

; ROLNIK, Sueli. Micropolítica - cartografias do desejo. Petrópolis: Editora Vozes, 2000.

GUEDES, Simoni Lahud. "Redes sociais urbanas: casa, família e vizinhança". Anais $26 \underline{a}$ Reunião Brasileira de Antropologia, Porto Seguro, 2008.

"Redes de parentesco e consideração entre trabalhadores urbanos: tecendo relações a partir de quintais". Caderno CRH, Salvador, n. 29, 1998.

; LIMA, Michelle da Silva. "Casa, família nuclear e redes sociais em bairros de trabalhadores". Barros, M. L. (org.). Família e gerações. Rio de Janeiro: FGV Editora, 2006.

HAESBAERT, Rogério. "Da desterritorialização à multiterritorialidade". Anais $X$ Encontro de Geógrafos da América Latina, Universidade de São Paulo, 2005.

O mito da desterritorialização: do "fim dos territórios" à multi-territorialidade.

Rio de Janeiro: Bertrand Brasil, 2004.

HANNERZ, UIf. Exploring the City. Inquiries toward an Urban Anthropology. New York and Guildford, Surrey: Columbia University Press, 1980.

HERNÁNDEZ, María Teresa Esquivel. "Conformando un lugar: narrativas desde la periferia metropolitana". Kuri, P. R.; Díaz M. A. A. (orgs). Pensar y habitar la ciudad: afectividad, memoria y significado. Barcelona: Anthropos, 2006, p. 33-50.

HIERNAUX, Daniel; LINDÓN, Alicia. “Pratiques et stratégies résidentielles dans l'expansion de la périphérie de Mexico: la Vallée de Chalco". Autrepart, n. 25, 1,L'Aube/IRD, Paris, 2003.

; . "Modos de vida y utopías urbanas". Ciudades, Procesos de Metropolización, n. 53, México: Red Nacional de Investigación Urbana, 2002, pp. 26-32.

HIRATA, Daniel Veloso. Sobreviver na adversidade: entre o mercado e a vida. Tese de Doutorado em Sociologia (FFLCH/USP), 2010.

. O futebol varzeano: práticas sociais, disputas pelo espaço e violência em São Paulo. Dissertação (mestrado em Sociologia). FFLCH-USP, 2005.

INGOLD, Tim. The perception of environment: essays on livelihood, dwelling and skill. London/New York: Routledge, 2000.

IVO, Anete Brito Leal (coord). "Dossiê: A Periferia em Debate". Cadernos CRH, Vol. 23, N 58, 2010.

IVO, Anete Brito Leal. Viver por um fio: pobreza e política social. Annablume, 2008.

Pobreza e desigualdades sociais. Bahia: Secretaria de Combate à Pobreza e às Desigualdades Sociais: Superintendência de Estudos Econômicos e Sociais da Bahia, 2003.

Metamorfoses da questão democrática. Conselho Latino-Americano de Ciências Sociais, 2001. 
JOSEPH, Isaac. "A Respeito do Bom Uso da Escola de Chicago" in Valladares, Lícia. A Escola de Chicago. Belo Horizonte: Editora UFMG, 2005.

40, jan./dez. 1999.

"Paisagens urbanas, coisas públicas". Caderno CRH, Salvador, n. 30/31, p. 11-

KESSLER, Gabriel; TELLES, Vera da Silva (orgs.). "Dossiê llegalismos Urbanos". Tempo Social, revista de sociologia da USP, v. 22, n. 2, 2010.

KOFFES, Suely. "Os papéis de Aspern: anotações para um debate" In: KOFFES, Suely (org.). Histórias de vida, Biografias e trajetórias. Unicamp: Cadernos IFCH, 31, 2004. pp. 5-16.

KOPPER, Moisés. A invenção da "Nova Classe Média". Etnografia dos Processos de Mobilidade Econômica e Espacial no Brasil Contemporâneo. Memorial de Qualificação (Doutorado em Antropologia Social), IFCH - UFRGS, 2014.

. “Da 'Nova Classe Média' ao Mercado da Casa Própria: Etnografia dos processos de mobilidade social e espacial no Brasil Contemporâneo". Anais X RAM, Córdoba - Argentina, 2013.

KOWARICK, Lúcio. Viver em risco - sobre a vulnerabilidade socioeconômica e civil. São Paulo: Editora 34, 2009.

"Viver em risco: sobre a vulnerabilidade no Brasil urbano". Novos Estudos Cebrap, nํ63, 2002, p.9-30.

. A espoliação urbana. Rio de Janeiro: Paz e Terra, 1979.

; BRANT, Vinícius Caldeira (coord). São Paulo, 1975: crescimento e pobreza. São

Paulo: Loyola, 1975.

KRAUSE, Cleandro; BALBIM, Renato; LIMA NETO, Vicente Correia. "Minha Casa Minha Vida, nosso crescimento: onde fica a política habitacional?" Texto para Discussão, 1853. Brasília/Rio de Janeiro: IPEA, 2013.

KURI, Patrícia Ramírez.; DÍAZ, Miguel A. Aguilar (orgs). Pensar y habitar la ciudad: afectividad, memoria y significado. Barcelona: Anthropos, 2006, p. 33-50.

LACERDA, Norma. "Mercados imobiliários em áreas pobres: singularidades, particularidades e universalidades". GEOgraphia (UFF), v. 14, 2012, p. 40-62.

Mercado imobiliário de aluguel e Teoria das Convenções. Recife: Centro de Estudos Avançados da Conservação Integrada, 2011.

; et al. "Mercado imobiliário de aluguel em áreas pobres: normas de funcionamento e sentidos da informalidade". In: Leal, S.; Lacerda, N. (Orgs.). Novos padrões de acumulação urbana na produção do habitat: olhares cruzados Brasil - França. Recife: Editora Universitária UFPE, 2010, p. 241-269.

; et al. "Mercado imobiliário de aluguel em áreas pobres e suas escalas de representação socioespacial”. Anais XIII Encontro Nacional da Anpur, Florianópolis, 2009.

LAGO, Luciana Corrêa do. "Favela-loteamento: re-conceituando os termos da ilegalidade e da segregação urbana". Anais X Encontro Nacional da ANPUR. Belo Horizonte, 2003.

. "Estruturação urbana e mobilidade espacial: alterações no quadro de desigualdades socioespaciais na Metrópole do Rio de Janeiro". Anais XI Encontro Nacional de Estudos Populacionais, 1998, Caxambu.

LAISNER, Regina C. Entre formas autoritárias e possibilidades democráticas: uma análise das representações de moradores da periferia de São Carlos/SP. Dissertação (mestrado em Ciência Política). IFCH-UNICAMP, Campinas, 1999.

LEEDS, Anthony. "Poder local em relação com instituições de poder supra-local". LEEDS, A.; LEEDS, E. Sociologia do Brasil Urbano. Rio de Janeiro: Zahar, 1978. 
LEFEBVRE, Henri. La prodution de l'espace. Paris: Anthropos, 1974.

Espaço e Política. Belo Horizonte: Editora UFMG, 2008

LEITE, Márcia Pereira. "De territórios da pobreza a territórios de negócios: dispositivos de gestão das favelas cariocas em contexto de pacificação". BIRMAN, P.; LEITE, M. P.; MACHADO, C.; CARNEIRO, S. (org.). Dispositivos Urbanos e Trama dos Viventes. RJ: Ed. FGV (no prelo).

; MACHADO DA SILVA, Luiz Antonio. "Circulação e fronteiras no Rio de Janeiro: a experiência urbana de jovens moradores de favelas em contexto de 'pacificação'". Cunha, N. V. da; Feltran, G. de S. (orgs). Sobre periferias: novos conflitos no Brasil contemporâneo. Rio de Janeiro: Faperj/Lamparina, 2013.

LEPETIT, Bernard. Por uma nova história urbana. São Paulo: Edusp, 2001.

LEVI, Giovanni. "Comportamentos, recursos, processos: antes da 'revolução' do consumo" In: REVEL, J. (org.). Jogos de Escalas. A experiência da microanálise. São Paulo: Editora FGV, 1998.

LEWIS, Oscar. Five Families. Mexican case studies in the culture of poverty. New York: The New American Library; Toronto: Mentor Book, 1959.

LIMA, Michelle da Silva. "Casa Própria e Família: um estudo etnográfico em uma Cooperativa Habitacional em São Gonçalo, RJ". Anais 26ㅁ Reunião Brasileira de Antropologia, Porto Seguro, 2008.

LIMA, Renata Priore. O Processo e o (Des)controle da Expansão Urbana de São Carlos (18571977). (Mestrado). Dissertação (mestrado em Arquitetura e Urbanismo), EESC-USP, São Carlos, 2007.

LINDÓN, Alicia. “Espacialidades, desplazamientos y trasnacionalismo." Papeles de Población, vol. 13, núm. 53, 2007, pp. 71-101.

. "La territorialidad y el significado de la casa: una visión in-disciplinada de la periferia metropolitana". Ortega, R. R., Ramírez, S. G., Franco, J. L. T. (orgs). La interdisciplina en las ciencias sociales. Barcelona: Anthropos, 2006, p. 89-104.

"El mito de la casa propia y las formas de habitar". Scripta Nova, Revista Electrónica de Geografía y Ciencias Sociales, vol. IX, núm. 194, 2005.

LONARDONI, Fernanda Maria. Aluguel, Informalidade e pobreza: o acesso à moradia em Florianópolis. Dissertação (Mestrado em Urbanismo, História e Arquitetura da Cidade), Universidade Federal de Santa Catarina, 2007.

LYRA, Diogo. A República dos Meninos: valores éticos e morais dos garotos armados do morro. Rio de Janeiro: UCAM/ IUPERJ, 2010.

MACHADO DA SILVA, Luiz Antonio. (Org.). Vida sob cerco: violência e rotinas nas favelas do Rio de Janeiro. Rio de Janeiro: Nova Fronteira, 2008.

. "A política na favela". Cadernos Brasileiros, 41, 1967, p. 35-47.

; LEITE, Márcia Pereira. "Violência, crime e polícia: o que os favelados dizem quando falam desses temas?" Sociedade e Estado, v. 22, n. 3, Brasília, set./dez. 2007, p. 545591.

MACHADO, Igor José de Renó. "Reordenações da casa no contexto migratório de Governador Valadares, Brasil." Etnográfica, vol. 14 (1), 2010, p. 5-26.

MACIEL, Lidiane M. "Arranjos, desarranjos e rearranjos familiares: um estudo sobre famílias de trabalhadores rurais migrantes do interior paulista". VII Congresso Latinoamericano de Sociologia Rural (Anais), Porto de Galinhas, 2010. 
MAGALHÃES, Alex Ferreira; et al. "O mercado imobiliário de aluguel em favelas do Rio de Janeiro: "informalidade" ou outras formas de formalidade?" In: Anais XV Encontro Nacional da Anpur, Recife, 2013.

MAGNANI, José Guilherme C. "Etnografia Urbana”. In: Fortuna C.; Leite, R. P. (Orgs.). Plural de cidade: novos léxicos urbanos. Coimbra: Almedina, 2009, p. 101-114.

. "Trajetos e trajetórias: uma perspectiva da antropologia urbana" [entrevista]. Revista Sexta-feira, no8, São Paulo: Editora 34, 2006, pp. 30-43.

"Os circuitos dos jovens urbanos". In: Tempo Social - revista de sociologia da USP, v. 17, n. 2, 2005, pp. 173-205.

. "De perto e de dentro: notas para uma etnografia urbana". In: Revista Brasileira de Ciências Sociais, no49, 2002, pp.11-29.

. Festa no pedaço: cultura popular e lazer na cidade. São Paulo: Brasiliense, 1984.

MALLART, Fábio. Cadeias dominadas: Dinâmicas de uma instituição em trajetórias de jovens internos. Dissertação (mestrado em antropologia social), Universidade de São Paulo, 2011.

MALVASI, Paulo. Interfaces da vida loka: Um estudo sobre jovens, tráfico de drogas e violência em São Paulo. Tese (Doutorado em Saúde Pública), Universidade de São Paulo, 2011.

MANSO, Bruno Paes (entrevistador). "Um debate sobre o PCC: Entrevista com Camila Nunes Dias, Gabriel de Santis Feltran, Adalton Marques e Karina Biondi". R@U, Revista de Antropologia Social dos Alunos do PPGAS-UFSCar,v.1,n.2, 2009.

MARCELIN, Louis Herns. "A linguagem da casa entre os negros no recôncavo baiano". Mana 5(2):31-60, 1999.

MARCUS, George E. "Etnografía en/del sistema mundo. El surgimento de la etnografía multilocal”. In: Alteridades, año/vol. 11, no22, UAM - Mexico, 2001, pp.111-127.

MARICATO, Erminia. "O 'Minha Casa' é um avanço, mas segregação urbana fica intocada". Carta Maior, 27/05/2009. (disponível em www.cartamaior.com.br, acesso em novembro de 2013).

(org.). A produção capitalista da casa (e da cidade) no Brasil industrial. São Paulo: Alfa-Omega, 1979.

MARQUES, Adalton. Crime, proceder, convívio-seguro: um experimento antropológico a partir de relações entre ladrões. USP, dissertação de mestrado, 2010.

MARQUES, Eduardo, TORRES, Haroldo. (orgs.). São Paulo: segregação, pobreza e desigualdades sociais. São Paulo: Editora SENAC, 2005.

; BICHIR, Renata. "Estado e espaço urbano: revisitando criticamente as explicações sobre as políticas urbanas". Revista de Sociologia e Política, n. 16, Curitiba, 2001.

. "Investimentos públicos, infra-estrutura urbana e produção da periferia em São Paulo" Espaço e Debates. São Paulo: NERU, ano XVII, no 42, p.9-30, 2001a.

MARTINEZ, Mariana M. Andando e parando pelos trechos: uma etnografia das trajetórias de rua em São Carlos. Dissertação (mestrado em Antropologia Social), UFSCAR, 2011.

MARTINS, Maria Lucia Refinetti. "Globalização, Informalidade e Regulação em Cidades Latino-Americanas". Cadernos PROLAM/USP, ano 5, vol. 1, 2006, p. 31-49.

MAURÍCIO, José Gaspar Lima. Cidade Aracy: história de um bairro periférico da cidade de São Carlos - SP. Trabalho de Conclusão de Curso (Licenciatura em História), Unicep, 2008.

MAUTNER, Yvonne. "A periferia como fronteira de expansão do capital". In: DEAK, C.; SCHIFFER, S. (Org.). O processo de urbanização no Brasil. São Paulo: Edusp, 1999. 
MAYOL, Pierre. "Morar". Certeau, M.; Girard, L.; Mayol, L. A invenção do cotidiano. Morar, cozinhar. Petrópolis: Vozes, 1996.

MCCALLUM, Cecilia; BUSTAMANTE, Vania. "Parentesco, gênero e individuação no cotidiano da casa em um bairro popular de Salvador da Bahia". Etnográfica [Online], vol. 16 (2) | 2012. (Disponível em http://etnografica.revues.org/1476, consulta em dezembro de 2013).

MELO, Natália. "L'inclusion et la formation de ses limites: une étude de l'assistance aux sans domicile fixe". Seminário Latinassist . Nogent sur Marne, 2014.

MERLEAU-PONTY, Maurice. Fenomenologia da percepção. São Paulo: Martins Fontes, 1999.

MISSE, Michel. "Crime, sujeito e sujeição criminal: aspectos de uma contribuição analítica sobre a categoria 'bandido'". Lua Nova, 79, 2010, p. 15-38.

. (org). Acusados \& Acusadores - Estudos sobre ofensas, acusações e acusações e incriminações. Rio de Janeiro: Revan, 2008.

. Malandros, marginais e vagabundos: a acumulação social da violência no Rio de Janeiro [Tese de Doutorado em Sociologia], Instituto Universitário de Pesquisas do Rio de Janeiro, IUPERJ/UCAM, 1999.

NAKANO, Kazuo; CAMPOS, Candido Malta, ROLNIK, Raquel. "Dinâmicas dos subespaços da área central de São Paulo". EMURB, PMSP, CEBRAP, CEM. Caminhos para o Centro: Estratégias de desenvolvimento para a região central de São Paulo. São Paulo, 2005, p.123158.

NASCIMENTO, Denise Morado; BRAGA, Carvalho de Queiroz. "Déficit habitacional: um problema a ser resolvido ou uma lição a ser aprendida?" Risco - Revista de Pesquisa em Arquitetura e Urbanismo, São Carlos, n.9, 2009. p.98-109.

; TOSTES, Simone Parrela. “Programa Minha Casa Minha Vida: a (mesma) política habitacional no Brasil”. Arquitextos - Vitruvius, 12.133, São Paulo, jun 2011. (Disponível em www.vitruvius.com.br, consulta em maio de 2014).

NERI, Marcelo. A Nova Classe Média: o lado brilhante da base da pirâmide. São Paulo: editora Saraiva, 2011.

A Nova Classe Média: o lado brilhante dos pobres. Rio de Janeiro: CPS/FGV, 2008.

NEVES, Delma Pessanha. "Nesse terreiro galo não canta. Estudo do caráter matrifocal de unidades familiares de baixa renda". Anuário Antropológico, Fortaleza, UFCE/Tempo Brasileiro, n.83, 1984, p.199-221.

NPD/UFSCar - NÚCLEO DE PESQUISA E DOCUMENTAÇÃO. Condições de vida em São Carlos: a questão da pobreza. Uma abordagem multidisciplinar. Relatório de Pesquisa, São Carlos, 1994.

OLIVEIRA, Francisco de. A economia brasileira: crítica à razão dualista. Petrópolis: Vozes, 1972.

OLIVEIRA, Joana D'arc. Depois da senzala: trajetória social e espacial de negros libertos no município de São Carlos. Memorial de Qualificação (Doutorado em Arquitetura e Urbanismo), IAU - USP, 2012.

PANDOLFI, Dulce Chaves; GRYNSZPAN, Mario (org). A favela fala. Rio de Janeiro: Editora FGV, 2003.

PAOLI, Maria Célia; SADER, Eder. "Sobre 'classes populares' no pensamento sociológico brasileiro: notas de leitura sobre acontecimentos recentes". Cardoso, R. (org). A aventura antropológica. São Paulo: Paz e Terra, 1986. 

trabalhadores sujeitos ao imaginário acadêmico". Revista Brasileira de História, vol. 3, ㄲo6, 1983, p.129-149.

PASSOS, Eduardo; KASTRUP, Virgínia; ESCÓSSIA, Liliana da (orgs.). Pistas do método da cartografia: pesquisa-intervenção e produção de subjetividade. Porto Alegre: Sulina, 2010.

PEDRAZZANI, Carla Eleonora; PEDRAZZANI, Paula Andrea. "Reconstrucción de los efectos territoriales de las políticas de vivienda a partir de la cartografía social". 8o Congresso Internacional Cidade Virtual e Território, Rio de Janeiro, 2012.

PEDROSIAN, Eduardo Álvarez; LATIERRO, María Verónica Blanco. "Componer, habitar, subjetivar. Aportes para la etnografía del habitar." Bifurcaciones - revista de estudios culturales urbanos, n. 015, 2013.

PERLONGHER, Nestor. O negócio do michê: a prostituição viril. São Paulo, Ed. Brasiliense, 1987.

PICCOLO, Fernanda Delvalhas. "Memórias, histórias e representações sociais do bairro de Vila Isabel e de uma de suas favelas (RJ, Brasil)". Etnográfica (Lisboa), v. 13, p. 77-102, 2009.

"A gramática nativa: reflexões sobre as categorias morro, rua, comunidade e favela". Frúgoli jr., Heitor; Andadre, L. T.; Peixoto, F. A. (Org.). As cidades e seus agentes: práticas e representações. Belo Horizonte: PUC MINAS/EDUSP, 2006, p. 330-352.

POCHMANN, Marcio. O Mito da Grande Classe Média: capitalismo e estrutura social. São Paulo: Boitempo, 2014.

Boitempo, 2012.

Nova Classe Média? O trabalho na base da pirâmide social brasileira. São Paulo,

PORTAL, María Ana. "Espacio, tiempo y memoria. Identidad barrial en la ciudad de México: el caso del barrio de la Fama, Tlalpan". Kuri, P. R.; Díaz, M. A. A. (orgs). Pensar y habitar la ciudad: afectividad, memoria y significado. Barcelona: Anthropos, 2006.

PORTUGAL, Sílvia. Contributos para uma discussão do conceito de rede na teoria sociológica. Oficina do CES: publicação seriada do Centro de Estudos Sociais, n. 271, Universidade de Coimbra, PT, 2007.

PREFEITURA MUNICIPAL DE SÃO CARLOS (PMSC); IAU-USP. Revisão do Plano diretor do município de São Carlos. Etapa 1: atualização da leitura técnica do município. São Carlos, 2011. (Disponível em: http://www.saocarlos.sp.gov.br/index.php/noticias/2011/160392revisao-do-plano-diretor-encerra-1o-fase.html, consulta em agosto de 2013)

PREFEITURA MUNICIPAL DE SÃO CARLOS (PMSC). Plano Local de Habitação de Interesse Social de São Carlos. Relatórios Fases 2 e 3. São Carlos, 2010.

. Plano diretor do município de São Carlos. São Carlos, 2005.

Plano diretor do município de São Carlos. Levantamentos (CD-Rom). São Carlos,

2003.

São Carlos, 2002.

"Projeto de Urbanização Integrado - Gonzaga e Monte Carlo". Volumes 3 e 5.

PRETEICELLE, Edmond; VALLADARES, Lícia do Prado. "A desigualdade entre os pobres: favela, favelas". HENRIQUES, Ricardo (org). Desigualdade e pobreza no Brasil. Rio de Janeiro: Ipea, 2000.

Caxambu, 1999. "Favelas no plural". Anais XXIII Encontro Anual da ANPOCS, 
PREUSS, Mirian Raja G. "Patroas e empregadas: relações de proximidade e oposição". Coletâneas da ANPEP - Associação Nacional de Pesquisa e Pós-graduação em Psicologia, 01(7), 1997, p. 53-65.

PREVOT-SCHAPIRA, M. (2001). "Fragmentación espacial y social: conceptos y realidades". Perfiles Latinoamericanos, 19, pp. 33-56.

PULHEZ, Magaly Marques. "Plano de habitação, produção de habitação: as fronteiras de conflito da política pública. Considerações a partir do caso da cidade de São Carlos (SP)." Revista Brasileira de Estudos Urbanos e Regionais, v. 14 , n. 1, 2012, pp 99-117.

. Espaços de favela, fronteiras do ofício: história e experiências contemporâneas de arquitetos em assessorias de urbanização. Dissertação (mestrado em Arquitetura e Urbanismo), EESC-USP, São Carlos, 2007.

QUIJANO, Aníbal. "Redefinición de la dependencia y proceso de marginalización social". In: WEFFORT, F., y QUIJANO, A. Populismo, marginalización y dependencia. Ensayos de interpretación sociológica, San José, Costa Rica, Universidad Centroamericana, 1973, pp. 180213

RAMOS, Geraldo Vinicius; CARDOSO, Alvaro Azevedo. “Análise do programa Minha Casa Minha Vida - Carta de Crédito FGTS como capital para produção de moradias para famílias de baixa renda". Anais XXXI Encontro Nacional de Engenharia de Produção, Belo Horizonte, 2011.

REVEL, Jacques (org.). Jogos de Escalas. A experiência da microanálise. Rio de Janeiro: Ed FGV, 1998.

RIBEIRO, Ana Clara Torres; CAMPOS, Andrelino de Oliveira; SILVA, Catia Antonia da (orgs.). Cartografia da ação social e movimentos da sociedade: desafios das experiências urbanas. Rio de Janeiro: Lamparina, 2011.

RIBEIRO, Luiz César de Queiroz. "Segregação, Desigualdade e Habitação: a metrópole do Rio de Janeiro". Anais IX Encontro Nacional da ANPUR, Rio de Janeiro, 2001.

; CARDOSO, Adauto Lúcio; LAGO, Luciana Corrêa do. Necessidades habitacionais. Déficit habitacional \& inadequação habitacional. Relatório do Observatório de Políticas Urbanas e Gestão Municipal, IPPUR/UFRJ/FASE, 2003. (Disponível em www.observatoriodasmetropoles.ufrj.br, acesso em julho de 2014)

RIZEK, Cibele Saliba. "Cotidiano, cidade e experiência. Questões e apontamentos de pesquisa." Anais XIII Seminário de História da Cidade e do Urbanismo, Brasília, 2014.

. "Limites e limiares/Corpo e experiência". Revista Dobra, v.3, no10, UFBa, 2012, p.33-39.

. "Discutindo cidades e tempos". Revista Dobra, v.3, no9, UFBa, 2012a, p.72-74.

"Pequenas provocações". Caderno de provocações. Corpocidade: debates em estética urbana. Salvador, Rio de Janeiro: UFBa, UFRJ, 2010.

"Trabalho, moradia e cidade. Zonas de indiferenciação?" Anais 340 Encontro Anual da Anpocs, Caxambu, 2010a.

. "Comunidade e violência nas fronteiras da cidade". Anais XXV Reunião Brasileira de Antropologia, Goiânia, 2006.

Os sentidos da cidade brasileira: figurações da ordem e de seus avessos. Relatório Cenedic. São Paulo, 2003.

ROCHA, Lia. Uma favela diferente das outras? Rotina, silenciamento e ação coletiva na favela do Pereirão, Rio de Janeiro. Tese (Doutorado em Sociologia), Instituto de Pesquisas do Rio de Janeiro, 2009. 
. "Território, política e criminalidade violenta em uma favela carioca: limites e possibilidades para a atuação das associações de moradores". Os Urbanitas - Revista de Antropologia Urbana. Ano 5, v. 5, no8, dez 2008. (Disponível em www.osurbanitas.org, consulta em janeiro de 2014)

ROCHA, Sônia. Pobreza no Brasil: afinal, de que se trata? Rio de Janeiro: FGV, 2010.

ROLNIK, Raquel; NAKANO, Kazuo. "As armadilhas do pacote habitacional". Le Monde Diplomatique, no 2, São Paulo, 2009, p. 4-5. (disponível em www.diplomatique.org.br/artigo.php?id=461, consulta em janeiro de 2014).

ROLNIK, Suely. Cartografia Sentimental. Transformações contemporâneas do desejo. São Paulo: Editora Estação Liberdade, 1989.

RONCAYOLO, Marcel. La ville et ses territoires. Paris: Gallimard, 1978.

ROSA, Thaís Troncon. "Planejamento urbano e política habitacional no Brasil: institucionalização, dicotomização, municipalização. Reflexões a partir do caso de São Carlos - SP". Risco, no 16, 2012, p. 17-34.

"Urban trajectories and production of 'poor housing spaces': the construction of a research". II ISA Forum of Sociology - Research Committee on Regional and Urban Development, Universidad de Buenos Aires, Buenos Aires, Argentina, 2012a.

" "Experiência, espaço urbano, pobreza: construindo algumas questões". URBANA - revista eletrônica do CIEC, v. 4, no 5, 2012b.

. "Favelas, periferias: uma reflexão sobre conceitos e dicotomias". Anais 33.은 Encontro Anual da ANPOCS, Caxambu/MG, 2009.

. Fronteiras em disputa na produção do espaço urbano: a trajetória do 'Gonzaga' de favela a bairro de periferia. Dissertação (mestrado em História). IFCH - UNICAMP, Campinas, 2008.

. Fronteiras e Pontes: diálogos e disputas na produção do espaço urbano. O caso da consolidação da Favela do Gonzaga na periferia de São Carlos - SP. Qualificação Mestrado, IFCH-UNICAMP, Campinas, 2007 (mimeo).

- "Produção e apropriação do espaço em periferias urbanas: construindo algumas questões". XXV Reunião Brasileira de Antropologia (Anais), Goiânia, 2006.

ROYER, Luciana de O. Financeirização da política habitacional: limites e perspectivas. Tese (doutorado em Arquitetura e Urbanismo), FAU-USP, São Paulo, 2009.

RUGGIERO, Vincenzo; SOUTH, Nigel. "The late-modern city as a bazaar". British Journal of Sociology, v. 48, n. 1, 1997.

RUI, Taniele. Corpos abjetos: etnografia em cenários de uso e comércio de crack. Tese (doutorado em Antropologia), IFCH - Unicamp, Campinas, 2012.

SADER, Eder. Quando novos personagens entram em cena. Experiências, falas e lutas dos trabalhadores da grande São Paulo (1970-80). Rio de Janeiro: Paz e Terra, 1988.

SAMPAIO, Maria Ruth; LEMOS, Carlos. Habitação popular paulistana: autoconstrução. FAUUSP, 1978.

SAMPAIO, Renata Alves. Da noção de violência urbana à compreensão da violência do processo de urbanização: apontamentos para uma inversão analítica a partir da Geografia Urbana. Dissertação (Mestrado Geografia Humana), FFLCH USP, 2011.

SARAIVA, Camila Pereira. A periferia consolidada em São Paulo: categoria e realidade em construção. Dissertação (mestrado em Planejamento Urbano), Universidade Federal do Rio de Janeiro, Instituto de Pesquisa e Planejamento Urbano e Regional, 2008. 
; MARQUES, Eduardo. "A dinâmica social das favelas da região metropolitana de São Paulo". Seminário sobre estrutura social e segregação espacial - São Paulo, Rio de Janeiro e Paris (Anais), São Paulo, 2004.

SARTI, Cynthia Andersen. A familia como espelho: um estudo sobre a moral dos pobres na periferia de São Paulo. Tese (Doutorado). Departamento de Sociologia, FFLCH - USP, 1994.

.É sina que a gente traz: ser mulher na periferia urbana. Dissertação (mestrado), São Paulo: FFLCH - USP, 1985.

SEGURA, Ramiro. "Los pliegues en la experiencia urbana de la segregación socio-espacial. Análisis comparativo de dos etnografías urbanas". CARMAN, María; VIEIRA, Neiva; y SEGURA, Ramiro (Org.) Segregación y diferencia en la ciudad. QUITO: FLACSO Ecuador, 2013.

. "Elementos para una crítica de la noción de segregación residencial socioeconómica: desigualdades, desplazamientos e interacciones en la periferia de La Plata". Quid 16. Revista del Área de Estudios Urbanos; Buenos Aires; 2012 p. 106 - 132

. "Estigmas, temor e inseguridad en la periferia de la ciudad de La Plata". In: Second ISA Forum of Sociology, Buenos Aires, 2012a.

. "La trama relacional de la periferia urbana en la ciudad de La Plata. La figuración establecidos-outsiders revisitada". Revista Publicar en Antropología y Ciencias Sociales; Buenos Aires; 2011 p. 85 - 106.

. "Paisajes del miedo en la ciudad. Miedo y ciudadanía en el espacio urbano de la ciudad de La Plata". Cuaderno Urbano. Espacio, Cultura, Sociedad, v. 8 - no 8, 2009, p. 59 91.

. "Segregación residencial, fronteras urbanas y movilidad territorial. Un acercamiento etnográfico". Cuadernos del IDES, no 9, Buenos Aires, 2006.

"Territorios del miedo en el espacio urbano de la ciudad de La Plata: efectos y ambivalências". Question, v. 1, no12, Buenos Aires, 2006a.

- "Cartografías Discrepantes. La ciudad de La Plata vista y vivida desde la periferia". Revista Periferia, vol. 2, no1, Rio de janeiro, 2000.

SENNETT, Richard. A cultura do novo capitalismo. Rio de Janeiro: Record, 2006.

SHIMBO, Lucia Zanin. "La construction de l'habitat social: une politique publique liée au marché immobilier". Bresil(s), 2014.

. Habitação social, habitação de mercado: a confluência entre estado, empresas construtoras e capital financeiro. Tese (doutorado em Arquitetura e Urbanismo). IAU - USP, São Carlos, 2010.

- Do servente ao investidor, do mutirante ao gestor: configurações contemporâneas da produção habitacional. Memorial de Qualificação (doutorado em Arquitetura e Urbanismo), Departamento de Arquitetura e Urbanismo - EESC/USP, São Carlos, 2009.

; LOPES, João Marcos de Almeida. "Mucho mercado, poca política: el papel de las grandes empresas de la construcción en el programa 'Mi Casa, Mi Vida' en las ciudades no metropolitanas en Brasil". Studia Politicae, 2014.

SILVA, Ariadne Paulo. "Mercado imobiliário informal de locação no Recife: um estudo das relações socioeconômicas à luz da Teoria do Dom". Anais Alas, 2013.

SILVA, Virgínia Ferreira da. Migração e redes sociais: trajetórias, pertencimentos e relações sociais de migrantes no interior de São Paulo. Tese (Doutorado em Ciências Sociais), Universidade Federal do Rio de Janeiro, 2006. 
SILVA, Eliane Alves da. Nas tramas da "cidade ilegal": atores e conflitos em ocupações de terra urbana. Dissertação (mestrado). Departamento de Sociologia, FFLCH - USP, São Paulo, $2006 a$.

SIMMEL, Georg. Questões Fundamentais da Sociologia: indivíduo e sociedade. Rio de Janeiro: Jorge Zahar Editor, 2006.

SMITH, Neil. "Geografía, diferencia y las políticas de escala". Terra Livre. São Paulo, Ano 18, n. 19,2002 , p. 127-146.

SOUZA, Jessé. Os Batalhadores Brasileiros. Nova classe média ou nova classe trabalhadora? Belo Horizonte: editora UFMG, 2010.

. A Ralé Brasileira: quem é e como vive. Belo Horizonte: editora UFMG, 2009.

SPOSITO, Eliseu Savério; SPOSITO, Maria Encarnação Beltrão; SOBARZO, Oscar (orgs.). Cidades médias: produção do espaço urbano e regional. São Paulo: Expressão Popular, 2006.

SPOSITO, Maria Encarnação Beltrão. "Novos conteúdos nas periferias urbanas das cidades médias do Estado de São Paulo, Brasil". Investigaciones Geográficas. Boletin Del Instituto de Geografia - UNAM, no 54, 2004, PP. 114-139.

. (org.). Cidades médias: espaços em transição. São Paulo: Expressão Popular, 2007.

TARRIUS, Alain. La mondialisation par le bas: les nouveaux nomades de l'economie souterraine. Paris: Balland, 2002.

TASCHNER, Suzana Pasternak. "Espaço e população nas favelas de São Paulo". XIII Encontro da Associação Brasileira de Estudos Populacionais (anais), Ouro Preto, 2002.

TEIA - casa de criação. Histórias do Água Quente. São Carlos, 2005. (mimeo).

Relatório geral urbanístico - Jardim Gonzaga e Vila Monte Carlo. Programa Habitar Brasil Bid/Prefeitura Municipal de São Carlos, São Carlos, 2002.

Relatório de levantamentos preliminares - Jardim Gonzaga. Prefeitura Municipal de São Carlos, São Carlos, 2001.

TELLES, Vera da Silva. "Prospectando a cidade a partir de suas margens: notas inconclusas sobre uma experiência etnográfica." Contemporânea - Revista de Sociologia da UFSCar. São Carlos, v. 3, n. 2, 2013, p. 359-373.

. "Ilegalismos e gestão (em disputa) da ordem". A cidade nas fronteiras do legal e ilegal. Belo Horizonte, Argvumentvm, 2010, p. 207-262.

"Prefácio". In: Kowarick, Lúcio. Viver em risco - sobre a vulnerabilidade socioeconômica e civil. São Paulo: Editora 34, 2009.

“Ilegalismos urbanos e a Cidade". Novos Estudos Cebrap, n.84, 2009a, pp.152163.

. "Nas dobras do legal e ilegal: ilegalismos e jogos de poder". Dilemas: revista de estudos de conflito e controle social, no. 5-6, 2009b, p.97-126

"Debates: a cidade como questão". ; Cabanes, R. (orgs). Nas tramas da cidade: trajetórias urbanas e seus territórios. São Paulo: Humanitas, 2006.

. "Trajetórias urbanas: fios de uma descrição da cidade". In: ; Cabanes, R. (orgs). Nas tramas da cidade: trajetórias urbanas e seus territórios. São Paulo: Humanitas, 2006a.

Pobreza e cidadania, São Paulo, Ed.34: Curso de Pós-Graduação em Sociologia: Departamento de Sociologia da Faculdade de Filosofia, Letras e Ciências Humanas da Universidade de São Paulo, 2001. 
; CABANES, Robert (orgs). Nas tramas da cidade: trajetórias urbanas e seus territórios. São Paulo: Humanitas, 2006.

; HIRATA, Daniel. "Ilegalismos e jogos de poder em São Paulo". Tempo Social, v.22, n.2, 2010, p.39-59.

"Cidade e práticas urbanas: nas fronteiras incertas entre o ilegal, o informal e o ilícito". Revista Estudos Avançados da USP, v. 21, n. 61, 2007.

TORRES, Haroldo. "A fronteira paulistana". In: Marques, E.; Torres, H. (Org.). São Paulo: segregação, pobreza e desigualdade. São Paulo: Editora Senac, 2005.

; et al. "Pobreza e espaço: padrões de segregação em São Paulo". Estudos Avançados, no 17 (47), 2003, p. 97-128

; MARQUES, Eduardo. "Reflexões sobre a hiperperiferia: novas e velhas faces da pobreza no entorno metropolitano". Revista Brasileira de Estudos Urbanos e Regionais, nำ4, 2001.

VALLADARES, Lícia do Prado. A invenção da favela: do mito de origem à favela .com. Rio de Janeiro: Editora FGV, 2005. . (org). Habitação em Questão. Rio de Janeiro: Zahar, 1980.

. (org). Repensando a Habitação no Brasil. Rio de Janeiro: Zahar, 1983.

. Passa-se uma casa: análise do Programa de Remoção de Favelas do Rio de Janeiro. Rio de Janeiro: Zahar, 1978.

VEKEMANS, Roger; VENEGAS, Ramon. Marginalidad, incorporación e integracion. Santiago: DESAL, 1966.

VELHO, Gilberto. Projeto e Metamorfose: antropologia das sociedades complexas. Rio de Janeiro: Jorge Zahar Editor. 1994. . Individualismo e cultura. Rio de Janeiro: Jorge Zahar Editor. 1987.

Janeiro: Zahar, 1978.

"Observando o Familiar". Nunes, E. de O. (org.). A aventura sociológica. Rio de

VEYNE, Paul. Como se escreve a história. Foucault revoluciona a história. Brasília: Editora UnB, 1998.

VIDAL, Dominique. "A afetividade no emprego doméstico: um debate francês à luz de uma pesquisa realizada no Brasil". In: Georges, Isabel; Leite, Marcia de Paula (orgs.). Novas configurações do trabalho e economia solidária. São Paulo: Annablume, 2009.

VIEIRA, Danielli. "Histórias sobre homicídios entre jovens: 'Mundo do crime' e comensurabilidade". DILEMAS: Revista de Estudos de Conflito e Controle Social, Vol. 4, n 2, 2011, pp. 281-308

VILLAÇA, Flávio. O que todo cidadão precisa saber sobre habitação. São Paulo: Global, 1986.

WACQUANT, Loïc. "La estigmatización territorial en la edad de la marginalidad avanzada". Ciências Sociais Unisinos, 43(3), 2007, p. 193-199. . Os condenados da cidade. Rio de Janeiro: Revan Editora, 2001.

WOORTMANN, Klaas. Casa e Família Operária. Anuário Antropológico/80. Rio de Janeiro: Tempo Brasileiro, 1982.

ZALUAR, Alba. Integração perversa: pobreza e tráfico de drogas. Rio de Janeiro: FGV, 2004. . A máquina e a revolta: as organizações populares e o significado da pobreza. São Paulo: Brasiliense, 1985. ; ALVITO, Marcos. Um século de favela. Rio de Janeiro: Editora FGV, 2003. 
ANEXO | mapas . 


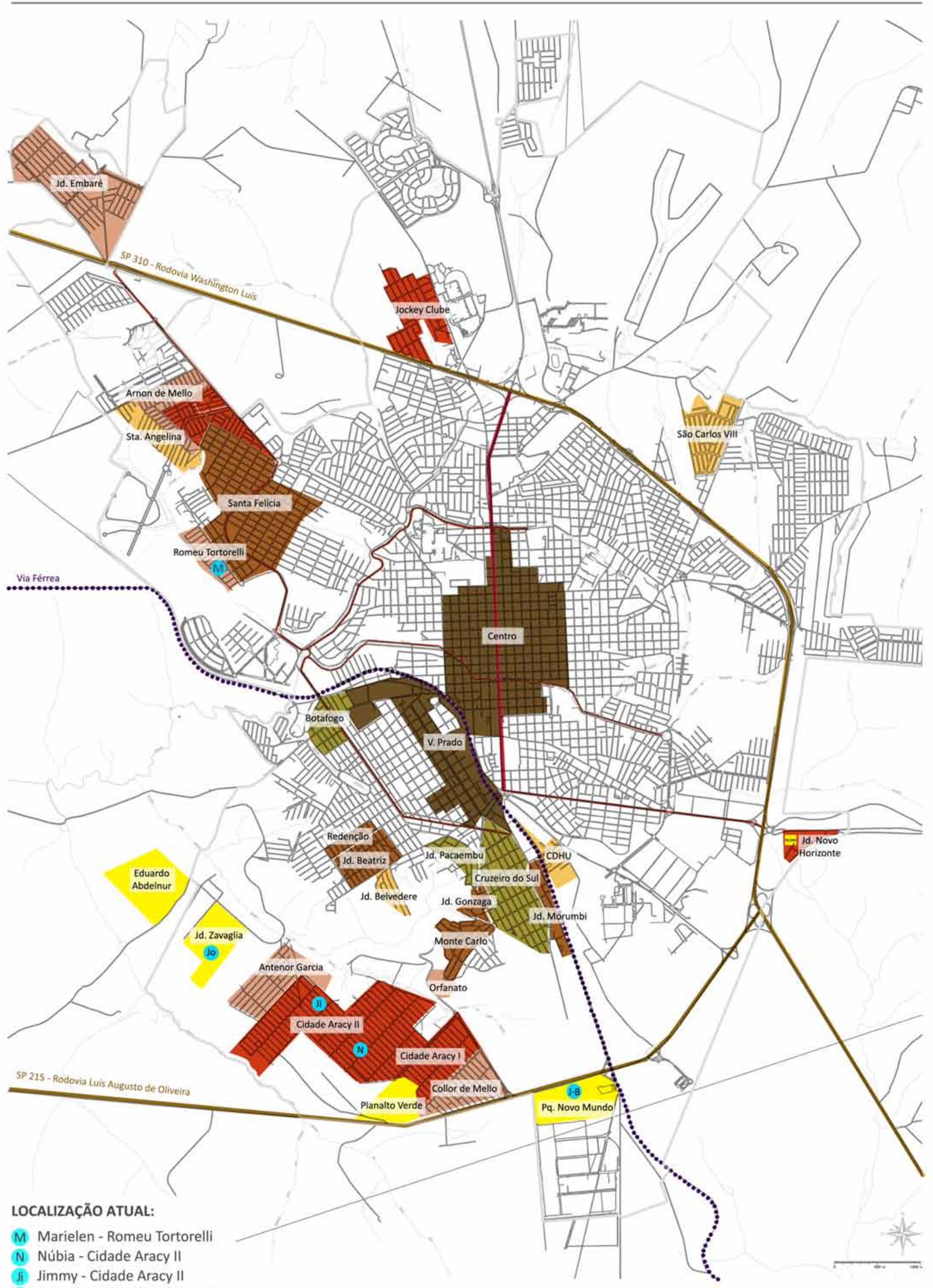

J.B Jefferson e Beatriz - Pq. Novo Mundo

(Jo) Joana-Jardim Zavaglia

\begin{tabular}{|l|l|l|l|l|l|l|}
\hline ATÉ 1940 & $1950-60$ & 1970 & 1980 & 1990 & 2000 & 2010 \\
\hline
\end{tabular}


Mapa de Trajetória: Núbia e Jimmy

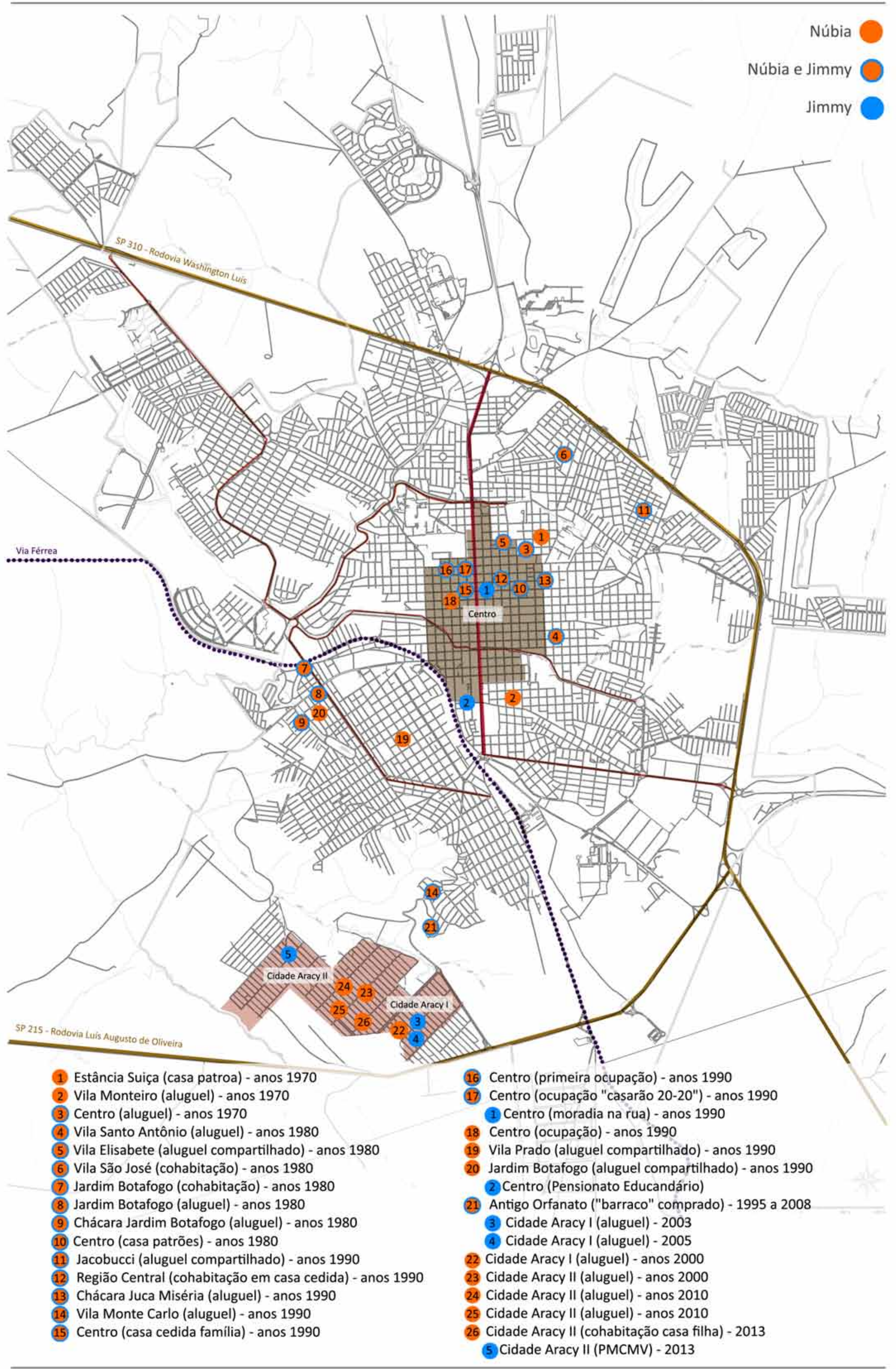


Mapa de Trajetória: Joana

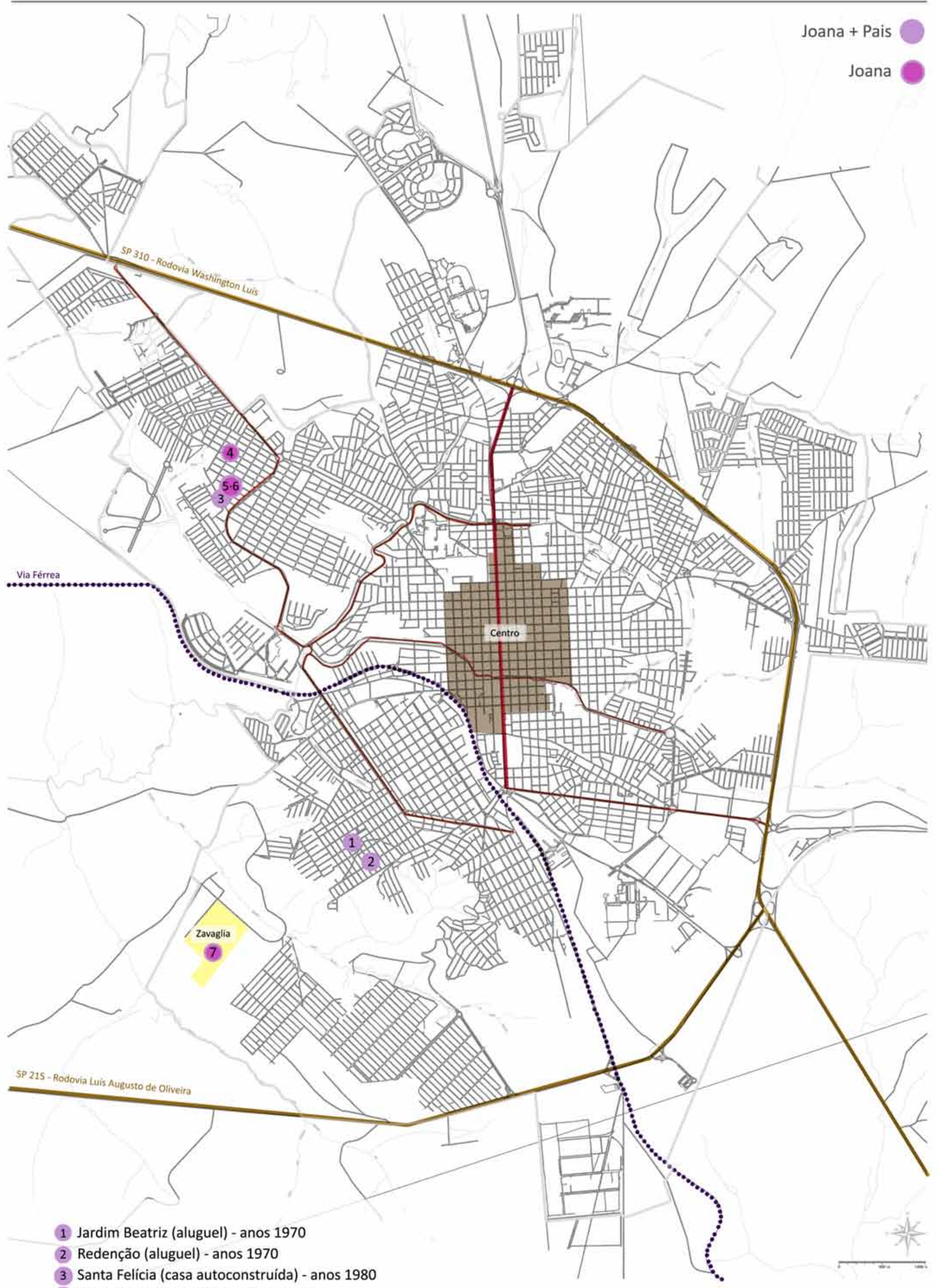

4 Santa Felícia (casa sogra) - anos 1990

5 Santa Felícia (cômodo casa mãe) - anos 1990 -2005

[Mudança para Novo Horizonte 2005 - 2008]

6 Santa Felícia (cômodo casa mãe) - anos 2008 - 2010

(7) Jardim Zavaglia - anos 2011 
Mapa de Trajetória: Jefferson e Beatriz

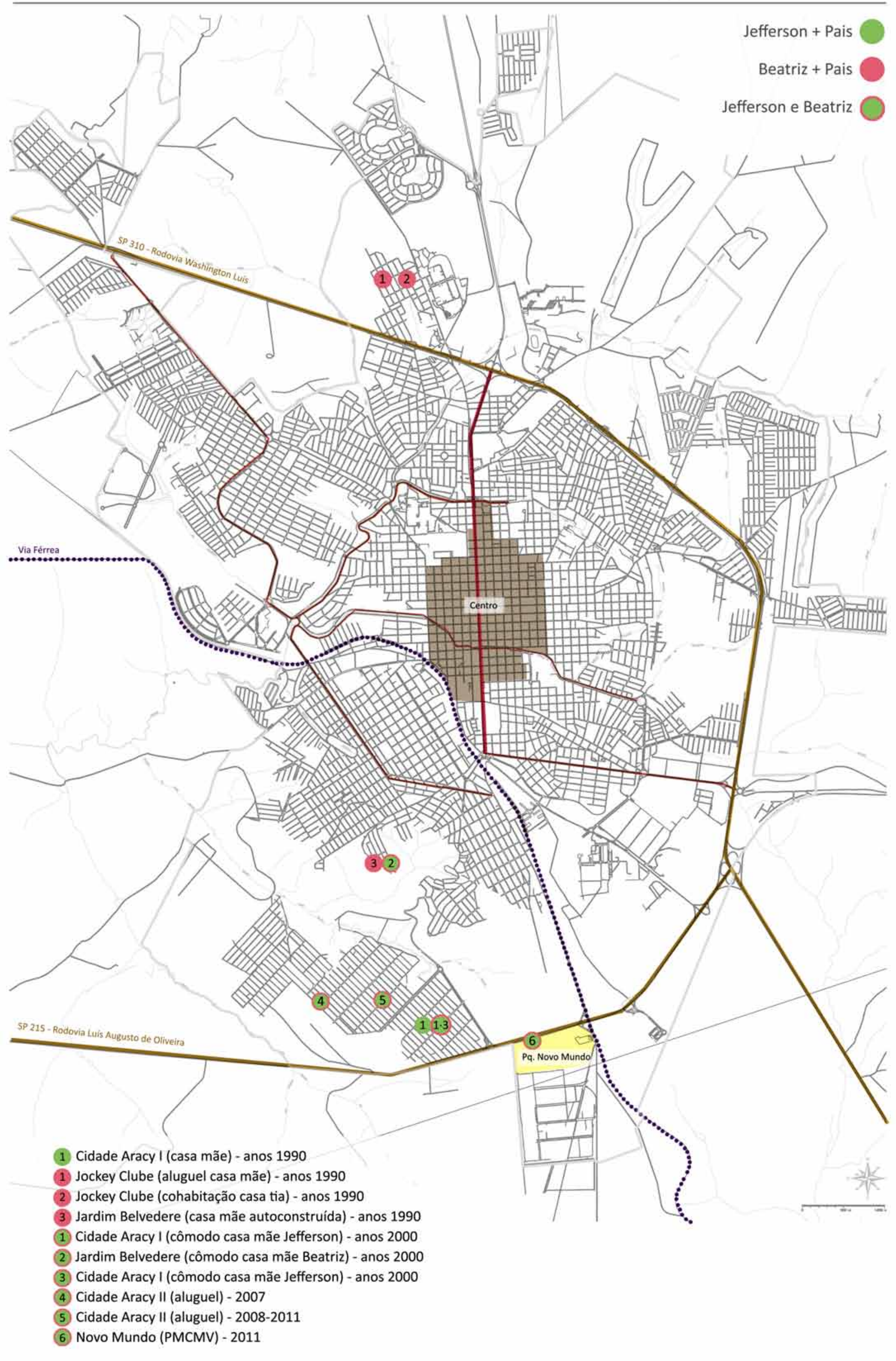


Mapa de Trajetória: Marielen

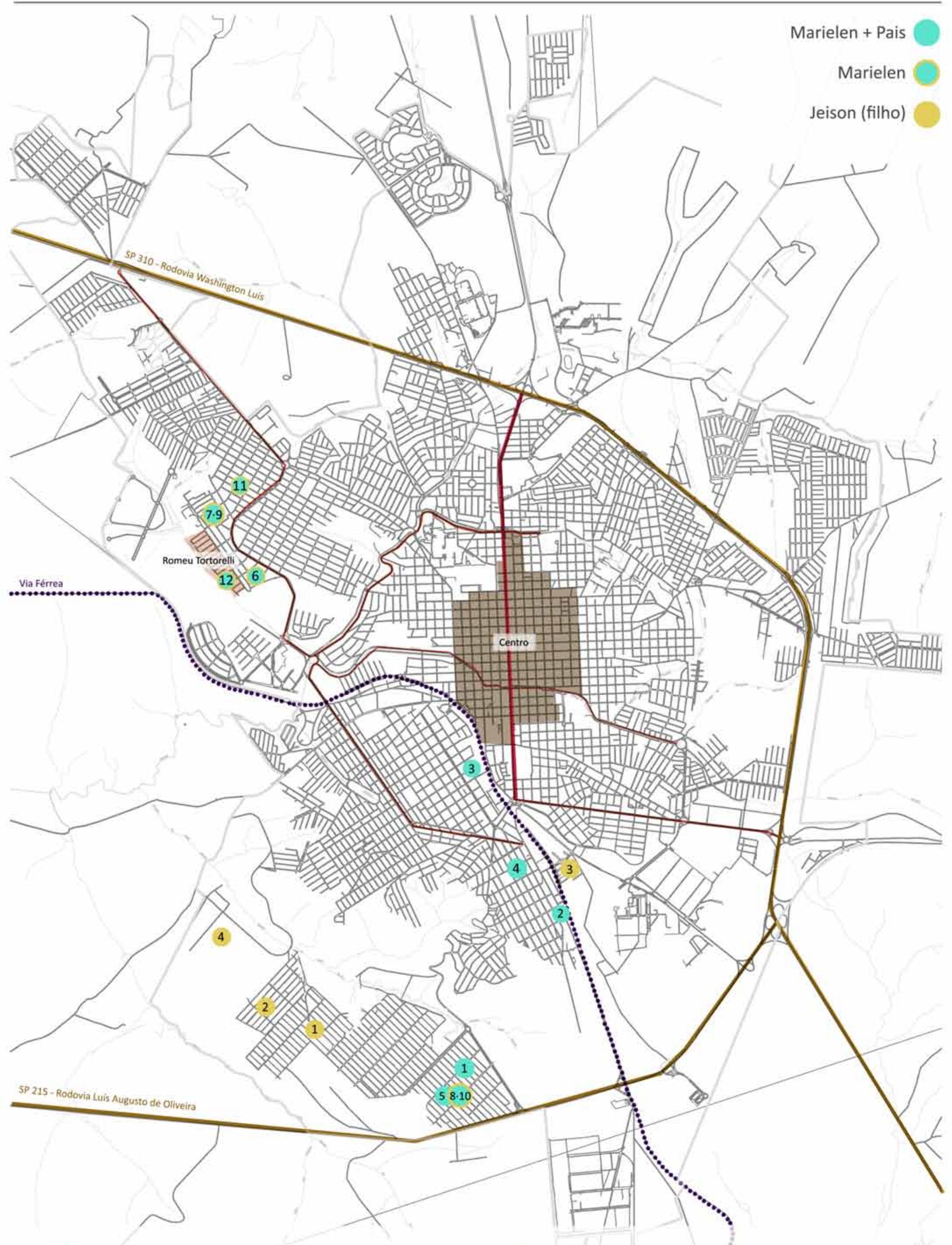

1. Cidade Aracy I (casa abandonada) - anos 1980

(2) Jardim Morumbi (barraco em quintal cedido) - anos 1980

(3) Vila Prado (aluguel) - anos 1980

4. Cruzeiro do Sul (aluguel) - anos 1980

5 Cidade Aracy I (casa autoconstruída) - anos 1980 - 1990

6 Santa Felícia (cohabitação) - anos 1990

7 Santa Felícia (cohabitação casa sogra) - anos 1990

8 Cidade Aracy I (cohabitação casa madrasta) - anos 1990
9 Santa Felícia (casa sogra) - anos 1990

10 Cidade Aracy I (cohabitação casa madrasta) - anos 2000

1 Jeison e Jairo - Cidade Aracy II (casa avó)

11 Santa Felícia (3 casas de favor) - anos 2000

12 Romeu Tortorelli (casa cedida / depois própria) - anos 2000

2. Jeison - Antenor Garcia (casa pai) - 2007

(3) Jeison - CDHU (casa pai) - 2011/2012

4 Jeison-Jardim Zavaglia (casa tio) - 2013 